
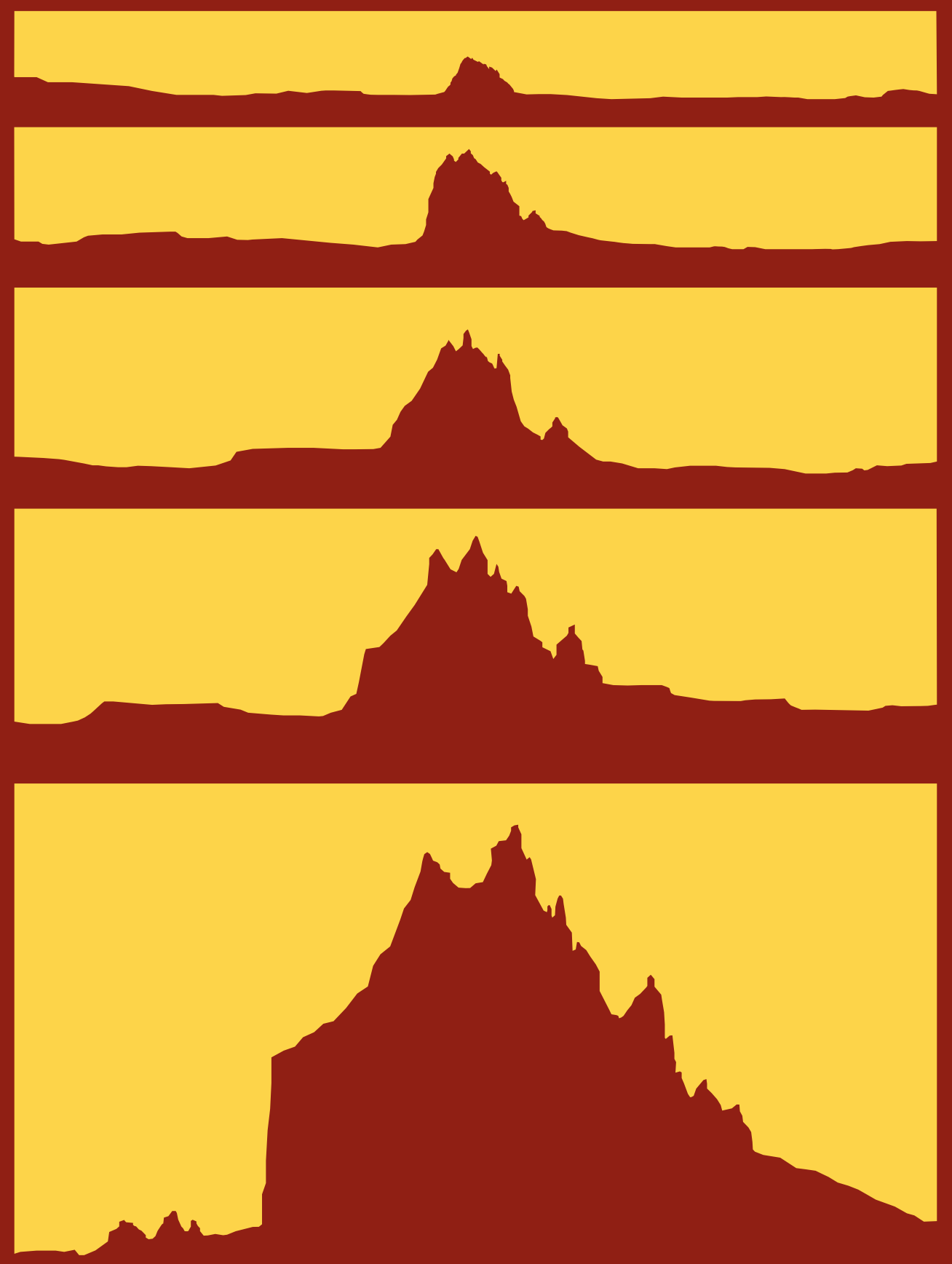

\title{
MECANISMO E PAISAGEM Reyner Banham e a América
}

\author{
Luiz Ricardo Araujo Florence \\ Universidade de São Paulo \\ Faculdade de Arquitetura e Urbanismo \\ São Paulo, 2014
}


MECANISMO E PAISAGEM

Reyner Banham e a América 


\section{MECANISMO E PAISAGEM \\ Reyner Banham e a América}

\section{Luiz Ricardo Araujo Florence}

Dissertação apresentada a Faculdade de Arquitetura e Urbanismo da Universidade de

São Paulo para obtenção do título de Mestre em Arquitetura e Urbanismo Área de Concentração História e Fundamentos da Arquitetura e do Urbanismo Orientador Prof. Dr. José Tavares Correia de Lira

São Paulo, 2014

Exemplar revisado e alterado em relação à versão original, sob responsabilidade do autor e anuência do orientador. O original encontra-se disponível na sede do programa.

São Paulo, 23 de julho de 2014. 


\section{AUTORIZO A REPRODUÇÃO E DIVULGAÇÃO TOTAL OU PARCIAL DESTE TRABALHO, POR QUALQUER MEIO CONVENCIONAL OU ELETRÔNICO, PARA FINS DE ESTUDO E PESQUISA, DESDE QUE CITADA A FONTE.}

e-mail do autor: luizflorence@usp.br

Florence, Luiz Ricardo Araujo

F632m Mecanismo e Paisagem: Reyner Banham e a América / Luiz Ricardo Araujo Florence.-- São Paulo, 2014. 303 p. : il.

Dissertação (Mestrado - Área de Concentração: História e Fundamentos da Arquitetura e do Urbanismo) - FAUUSP. Orientador: José Tavares Correia de Lira

1.Historiografia - Estados Unidos 2.História da arquitetura Estados Unidos 3.Arquitetura moderna - Estados Unidos 4.Arquitetura vernacular 5.Cultura de massa 6.Banham, Peter Reyner, 1922-1988 I.Título 


\section{Agradecimentos}

À FAPESP, pela bolsa de estudos concedida, indispensável para a realização desta pesquisa;

Ao professor José Lira, pela generosidade de se envolver com o tema de pesquisa e pela orientação que transcendeu este processo, e se tornou fundamental para a minha formação;

Ao professor Alexandre Delijaicov, pela inspiração inicial.

Ao Getty Research Institute, pelo acesso concedido aos valiosos materiais arquivados em sua biblioteca, em especial para Wim de Wit e Ann Harrison, pelo valioso apoio durante o período de pesquisa nos manuscritos de Reyner Banham.

À professora Fernanda Fernandes, pela contribuição em conselhos e motivação para a pesquisa; Às professoras Fernanda Peixoto e Ana Luiza Nobre, pela contribuição tanto em conversas quanto na banca de defesa desta dissertação.

À Mary Banham, pela cortesia concedida de apresentar nessa pesquisa imagens do acervo de seu marido;

Aos professores entrevistados para esta pesquisa, Kenneth Frampton, Gabrielle Esperdy, Gwendolyn Wright, Anthony Vidler, Thomas S. Hines, Joe Day e Paul Groth; À Anne Massey, pela contribuição decisiva nos últimos momentos de redação;

Aos meus colegas de atelier, André Sant'Anna, Gabriel Manzi, Ivo Magaldi, Lucas Girard, Luís Pompeo, Moreno Zaidan e Tiago Oakley, pelo apoio essencial; Aos colegas do grupo de estudos, Clévio Rabelo, Diego BIS, Mariana Guardani, Raquel Schenkman, Samira Chahin, Eduardo Costa, Felipe Contier, Mina Warchavchik, Raíssa Oliveira e Felipe Pissardo, pelo intercâmbio de ideias; Aos amigos próximos ou distantes, Vanessa Grossman, Carolina Leonelli, Anna Gomes, Ciro Miguel, Mariana Wilderom, Jess Reynolds, Marcelo Eid, Alfonso Simelio, Sandra Jávera, Pedro Saito, Diego Matos, Celso Reeks, João Yamamoto e Iris Pena pelo apoio durante a pesquisa;

Ao meu companheiro de pesquisa e debates, Rafael Urano Frajndlich. Aos queridos João Clark, Juliana Braga e Paula Dedecca, pelos conselhos, dicas, e apoio fundamental na reta final;

À incrível Gabriela Tamari, amiga talentosa e querida.

Ao meu irmão, Luiz Guilherme Florence, por cumprir o papel de irmão mais velho quando eu mais precisei;

À Nina Jacobi, meu amor, pela motivação. Te dedico este trabalho. 
FLORENCE, Luiz R. A. Mecanismo e Paisagem: Reyner Banham e a América.

Dissertação de Mestrado - Faculdade de Arquitetura e Urbanismo, Universidade de São Paulo, 2014.

Peter Reyner Banham (1922-1988) foi um dos críticos e historiadores de arquitetura responsáveis pela revisão crítica do movimento moderno e importante comentador do design e arquitetura americanos. Esta dissertação pretende abordar o olhar do autor em direção às expressões vernaculares modernas na arquitetura, design na paisagem dos Estados Unidos. Este olhar seria amparado pela relação entre arquitetura e tecnologia e pela apropriação singular desta tecnologia pelo cidadão americano. O Primeiro Capítulo consiste em um estudo historiográfico dos deslocamentos intelectuais da Europa aos Estados Unidos da América. A formação das instituições de ensino de arquitetura americanas será investigada, bem como a trajetória de arquitetos, críticos e historiadores de arquitetura europeus, dando destaque a geração de intelectuais ingleses à qual Banham pertence. O Segundo Capítulo investigará a obra de Reyner Banham sobre as relações entre arquitetura moderna e tecnologia, focando em seu estudo crítico a respeito dos historiadores modernos e suas posturas em relação à arquitetura americana. O Terceiro Capítulo é um estudo teórico sobre o olhar de Banham sobre as paisagens culturais dos Estados Unidos, e dos objetos da arquitetura cotidiana, da cultura de consumo de massa, e das expressões anônimas no espaço urbano.

Palavras Chave: Reyner Banham; Historiografia; História da Arquitetura; Arquitetura Moderna; Estados Unidos da América; arquitetura vernacular; Cultura de massa; 
FLORENCE, Luiz R. A. Mechanism and Landscape: Reyner Banham and América. Dissertation (Master Degree) - Faculdade de Arquitetura e Urbanismo, Universidade de São Paulo, 2014.

Peter Reyner Banham (1922-1988) was one of the architectural historians responsible for the critical revision of the modern movement and a fundamental critic to American design and architecture. This dissertation aims on the approach on the author's view of the modern vernacular expressions in architecture, design in the United States landscape. This specific view have been supported by his experience in the relationship between architecture and technology, and by its singular seizing by the American citizen. The first chapter consist in a historiographical survey on the intellectual displacements from Europe to the United States of America. The formation of the American architecture teaching institutions will be investigated, as the trajectory of the European architects, critics and architectural historians, outlining Reyner Banham's generation of British intellectuals. The second chapter visits Reyner Banham's works, regarding the relationships between modern architecture and technology, focusing his critical study on the modern historians and how they stand towards American architecture. The third chapter is a theoretical study on Banham's view on the cultural landscapes of the U.S., and the objects of everyday architecture, mass consumption culture, and the anonymous expressions in urban spaces.

Keywords: Reyner Banham; Historigraphy; History of Architecture; Modern Architecture; United States of America; vernacular architecture; Cultura de massa; 


\section{Sumário}

Introdução - 11

Capítulo 1: Deslocamentos na Historiografia: migrações e trocas EUA-Europa - 1930-1988

$-24$

América Beaux-Arts - 29

Americanismo: uma agenda de formação - 32

Os alemães e os usos da História nos EUA - 37

O popular 'as found' na Inglaterra - 43

Os ingleses e a renovação historiográfica - 50

Reyner Banham 'travelling light' - 56

A estrada americana de Banham - $\mathbf{6 1}$

\section{Capítulo 2: Vers Une Architecture Autre - 66}

Era da Máquina - 70

Americanismo, Futurismo e Expressionismo - 77

Le Corbusier e a Superfície da Máquina - 97

Walter Gropius e a Terra-mãe da Indústria - 107

Arquitetura e tecnologia: do Brutalismo ao High-Tech - 115

O inventor do clima temperado - $\mathbf{1 3 0}$

O descartável e o limite da arquitetura - 145

\section{Capítulo 3: As Paisagens Americanas - 154}

Jovens ruínas industriais - $\mathbf{1 5 8}$

América Deserta - 174

Mega-estruturas trouvée - $\mathbf{1 8 7}$

A Home is Not a House - 196

Ambientes feitos para você, Estadunidense - 210

\section{Conclusão - 220}

\section{Bibliografia - 230}

\section{Anexo 1}

Manuscritos de Reyner Banham no Getty Research Institute - 236

Anexo 2

Entrevista com Kenneth Frampton - Agosto 2011 - 280

Anexo 3

Entrevista com Gabrielle Esperdy - Agosto 2012 - 286 
Introdução 
Esta dissertação aborda a produção intelectual do historiador, crítico, jornalista e professor de história da arte e arquitetura, Peter Reyner Banham ${ }^{1}$. Ela não se exime de remontar a seu contexto acadêmico: recentemente, a obra do autor vem sendo revisitada por historiadores, docentes, e em especial por estudantes de arquitetura, principalmente nas faculdades de arquitetura dos Estados Unidos e Europa ${ }^{2}$. O fato é que pesquisadores interessados em se apropriar de ferramentas de análise sobre as práticas projetuais e discursivas vem recuperando narrativas de figuras das gerações anteriores como Reyner Banham, reconhecido como teórico da modernidade e das projeções para o futuro da civilização tecnológica. Nesta dissertação, Buscaremos entender como essa crítica foi moldada por anos de interesse acadêmico e residência física do autor nos Estados Unidos. O recorte desta dissertação passa pelo seu interesse pelas expressões do vernacular moderno americano, em suas apropriações da tecnologia nos moldes da promessa das vanguardas modernas de arquitetura. ${ }^{3}$

Mesmo sendo um crítico e historiador de arquitetura cuja produção literária fomentou a formação de gerações de acadêmicos no hemisfério norte, especialmente na Inglaterra e nos Estados Unidos, sua obra ainda é parcamente difundida dentro dos círculos internacionais, e sobretudo brasileiros de arquitetura ${ }^{4}$. Dentre os inúmeros

1 Nascido em 1922 em Norwich, Inglaterra, com dupla formação como engenheiro mecânico British Airplane Company em Bristol, e como historiador de arte pelo Courtauld Institute of Art em História da Arte em Londres, onde obteve seu título de doutor no ano de 1958. Professor de História da Arquitetura na Universidade de Londres entre 1969-76; professor assistente na Bartlett School of Architecture entre 1964 e 69; pesquisador contemplado pela Grahan Foundation de Chicago entre 1964 e 66; Professor de História na Universidade da Califórnia em Santa Cruz durante 2 períodos, entre 1980-83, e 1987 a 88; diretor do Departamento de Arquitetura e Desenho Ambiental (Environmental Design) e da State University of Buffalo entre 1972 e 1976; não chegou a assumir a posição na cátedra Sheldon H. Sollow no Institute of Fine Arts de Nova Iorque, a que foi nomeado em 1988, vítima de complicações causadas por um câncer de pâncreas. 2 Muitas publicações recentes se preocuparam com a remontagem historiográfica da obra do autor: o professor inglês Nigel Whiteley produziu Reyner Banham: Historian of the Immediate Future (2002), uma obra compreensiva sobre a produção de Banham, separando em temáticas como arquitetura pop e vernacular, estética da máquina, expansão do campo da arquitetura e limites entre o moderno pop e pós-moderno; o professor Anthony Vidler apresentou em Histories of the Immediate Present (2008) o estudo das narrativas de quatro teóricos do modernismo durante a segunda metade do século XX - Emil Kaufmann, Colin Rowe, Reyner Banham e Manfredo Tafuri; Jeremy Ainsley e Harriet Atkinson organizaram The Banham Lectures: Essays on Designing the Future (2010) uma compilação de ensaios e palestras póstumas em homenagem ao legado acadêmico de Reyner Banham; desde 2009 a professora americana Gabrielle Esperdy publica experiências no estudo da paisagem americana, com ampla influência de Reyner Banham em meio digital, no American Road Trip: Gabrielle Esperdy explores built \& natural landscapes in the U.S.

3 Na conclusão de seu primeiro livro, Theory and Design in the First Machine Age, publicado originalmente em 1960 a partir de sua tese de doutorado, entregue em 1958 e orientada por Nikolaus Pevsner, Banham apresenta a crítica ao funcionalismo modernista de autores como Le Corbusier, Walter Gropius, e Alberto Sartoris. Para Banham, a estética da máquina não deve ser confundida com abstracionismo geométrico: a estética industrial, derivada da tecnologia e do raciocínio industrial, deveria ser considerada um objeto em constante mutação.

4 No Brasil, a professora Ana Luiza Nobre foi uma das responsáveis pela publicação em português de Los Angeles: The Architecture of Four Ecologies (Martins Fontes, 2013, Tradução de Marcelo Brandão Cipolla. Tradução da biografia e dos anexos: Karina Jannini. Revisão técnica e prefácio à edição brasileira: Ana 
artigos e livros publicados pelo autor, vários são os que se destacam como leitura essencial dos cânones da arquitetura moderna, do Brutalismo - pelo menos em sua vertente escandinava / inglesa - ao movimento Futurista italiano ${ }^{5}$, às Paisagens Culturais americanas - as 4 "ecologias" de Los Angeles ${ }^{6}$ e as cenas do deserto americano, seu "desert book"7, como o próprio se referia - e à arquitetura High-Tech ${ }^{8}$ passando da Werkbund à Throw-away Aesthetics ${ }^{9}$, fazendo incursões pelas imagens da indústria norte-americana no ideário da vanguarda moderna em A Concrete Atlantis e investigando fenômenos da arquitetura americana ${ }^{10}$, seja ela "alta" ou "baixa", em diversos artigos, palestras e seminários ${ }^{11}$.

Malgrado sua produção literária ter investigado narrativas de projeto e narrativas teóricas pertinentes dentro do contexto de revisão da arquitetura moderna brasileira, o trabalho traduzido para a língua portuguesa foi o seu primeiro trabalho intelectual, Teoria e Projeto na Primeira Era da Máquina, de $1960^{12}$. O livro foi frequentemente lido de maneira equivocada como um manual de arquitetura moderna e localizado no final de uma linhagem de publicações já tidas como clássicas ou

Luiza Nobre).

5 Ver Banham, “Itália: Manifestos e Projetos Futuristas, 1909-1914”, em Teoria e Projeto na Primeira Era da Máquina. O capítulo sobre o movimento Futurista italiano é reconhecido por intelectuais como Anthony Vidler, Alan Colquhoun e Kenneth Frampton como uma das grandes contribuições desta publicação.

6 Reyner Banham, Los Angeles: The Architecture of Four Ecologies. London: Harper \& Row, 1971.

7 Reyner Banham, Scenes of America Deserta. Cambridge: The MIT Press, 1989. Publicado originalmente em 1982.

8 Livro não publicado, cujo interesse inicial foi inicialmente expresso em artigos e correspondências a partir de 1978. Banham chegou a colocá-lo em processo produtivo e investigativo, entregando-o em 1989, para a editora alemã Ernst \& Sons, com o último título provisório Making Architecture: The Paradoxes of High-Tech. As complicações do câncer que acarretou seu falecimento em 1988 deixaram essa obra por entregar. Seu material manuscrito pode ser acessado na coleção especial da Biblioteca do Getty Research Institute, em Los Angeles, Califórnia. O registro da última obra publicada de Reyner Banham é de $A$ Concrete Atlantis: American Industrial Building and European Modern Architecture, de 1986, publicada pela MIT Press.

9 Tema e título de um artigo escrito em 1955 e publicado em 1960 no periódico inglês Industrial Design, originalmente sob o título "Industrial Design and Popular Art". Foi reproduzido na compilação Design by Choice, editada por Penny Sparke, em 1981.

10 O termo 'americano' é utilizado costumeiramente na língua inglesa para se referir a cidadãos dos Estados Unidos. Uma das crenças dessa pesquisa é explorar os limites e a possibilidade de ampliação do conceito de 'Americanismo'. Nas traduções das notas de rodapé, a fidelidade com o termo original foi respeitada, utilizando a palavra 'americano' no lugar de 'estadunidense', termo geograficamente correto.

11 Banham contribuiu de maneira constante para periódicos populares de arquitetura, design e tecnologia, como New Society, Industrial Design, e New Statesman; ministrou palestras a respeito dos temas relacionados a sua pesquisa, principalmente em instituições de ensino americanas. Ver A Critic Writes, publicado pela University of California Press e compilado por Cedric Price, Paul Barker, Sutherland Lyall e Mary Banham em 1999; e Design By Choice, publicado por Penny Sparke em 1981 pela editora americana Rizzoli.

12 Publicado pela editora Perspectiva em 1970, tradução de A. M. Goldberger Coelho. Título original, Theory and Design in the First Machine Age. 
datadas ${ }^{13}$, atrelando a obra de seu autor a uma imagem superficial de um "apologista da vanguarda moderna", ou de "historiador do futuro imediato", como numa "gag" teleológica ${ }^{14}$. Mesmo Peter Eisenman, outro entusiasta de elementos da arquitetura americana, encontrou na obra de Banham um positivismo ético e uma idealização da tecnologia, que o aproximaria a "neofuncionalistas", com Cedric Price e o Archigram ${ }^{15}$. O fato é que a compreensão sobre a obra de Banham ficou amarrada ao termo "estética da máquina" e seu engajamento com temas como a expressão popular ${ }^{16}$, a arte pop e a cidade de Los Angeles ${ }^{17}$ levando-o ter diálogos mais rarefeitos no meio acadêmico ortodoxo, especialmente em temáticas ligadas à historiografia eurocentrista da arquitetura. De fato, Banham nunca foi uma unanimidade. Sua popularidade entre estudantes e intelectuais vinculados ao pop o marcaria como populista entre os meios mais intelectualizados da academia, assim como entre os críticos e historiadores comprometidos com e revisão da arquitetura moderna ${ }^{18}$.

Esta dissertação não se propõe a ser uma biografia crítica. Investigações muito mais estruturadas já cobriram essa lacuna historiográfica, sobretudo a pesquisa do inglês Nigel Whiteley, que teve acesso aos principais bancos de dados sobre o autor O Getty Institute of Research de Los Angeles, cujos arquivos mantém os manuscritos

13 Desde os manuais produzidos pelos engenheiros-arquitetos André Lurçat, Gustav Platz e Adolf Behne, comprometidos com suas genealogias modernas, passando pela atuação da geração que influenciou Banham e seus contemporâneos: Emil Kaufman, Siegfried Giedion, Nikolaus Pevsner se destacam por fornecer as bases primárias necessárias para a tese de doutorado de Banham.

14 Ver Anthony Vidler, Histories of the Immediate Present. Cambridge: The MIT Press, 2005, para descrições sobre a apreciação da obra do autor pela geração de arquitetos e historiadores formados por ele. Ver também Nigel Whiteley, Reyner Banham: Historian of the Immediate Future. Cambridge: The MIT Press, 2002.

15 Eisenman comenta a produção de Banham brevemente em "Pós-Funcionalismo", dentro da compilação Uma Nova Agenda para a Arquitetura, organizada por Kate Nesbitt e publicada em português pela Cosac Naify em 2006. No capítulo historiográfico sobre a trajetória de Reyner Banham discutiremos a trajetória do deslocamento intelectual de Reyner Banham dentro da geração de historiadores ingleses com os quais Eisenman teve contato direto. Vale salientar que suas narrativas encontraram uma audiência mais amigável e interessada na costa oeste americana, enquanto as instituições da costa leste engajavam em modalidades diferentes de revisão crítica do moderno.

16 Seus temas recorrentes incluem a estética de filmes como "Barbarella", o desenho de carros como o Mustang e os grafismos de pranchas de surf. A compilação de Penny Sparke, por exemplo, se divide em dois movimentos: o primeiro apresenta as abordagens do autor a respeito da arquitetura moderna, enquanto o segundo reúne exemplos da crítica de objetos da cultura de massa e do design do cotidiano. 17 Em especial, historiadores de vertente marxista, como Kenneth Frampton, o alinharam com Robert Venturi como um apologista da cidade capitalista - ver entrevista com Kenneth Frampton no trabalho programado n.3, em anexo nesta dissertação.

18 Concentrados em Londres, Paris, Veneza e na costa Leste Americana, intelectuais como Manfredo Tafuri, Peter Eisenman, Colin Rowe, Kenneth Frampton, Mario Gandelsonas, Georges Teyssot, Joan Ockman, Aldo Rossi, entre outros, tomaram parte de publicações como o periódico Oppositions e de outros títulos seminais da arquitetura contemporânea. Colin Rowe influenciou uma geração de arquitetos com suas publicações sobre a cidade-colagem e o maneirismo em arquitetura; Alan Colquhoun investigou o conceito de histoiricismo e classicismo, tendo na obra de Le Corbusier seu tema mais frequente. Aldo Rossi discute a relação da cidade histórica e suas tipologias históricas com a produção dos eventos urbanos. 
de suas últimas publicações; a biblioteca da Royal Institute of British Architects, que detém boa parte das fotos tiradas pelo autor; e o contato direto com Mary Banham, artista plástica e viúva do autor. O objetivo dessa pesquisa foi encontrar maneiras de ler a obra do autor na perspectiva específica de um arquiteto em São Paulo, isto é, duplamente distanciado, em relação à matriz europeia e os horizontes norteamericanos descortinados pelo autor. Com isso, se espera de um modo próprio, desvencilhado de vícios e com a vantagem da perspectiva externa, poder contribuir com o debate acadêmico e crítico a respeito da obra de Banham e de seus rebatimentos sobre e historiografia de arquitetura moderna. Ao mesmo tempo, é uma possibilidade de fornecer ao debate acadêmico local novos elementos a respeito da produção arquitetônica e os produtos da modernidade e da sociedade de consumo.

Muitos trabalhos serviram de apoio bibliográfico para minha pesquisa, mas também trouxeram o alívio de não impor a responsabilidade de traçar uma trajetória panorâmica e infalível. Percorrendo seu amplo volume de artigos, sua filiação ao Independent Group ${ }^{19}$, compilações recentes, além de revisões críticas póstumas - como The Banham Lectures: Essays on Designing the Future ${ }^{20}$ - Banham constituiu sua pesquisa como revisão completa da bibliografia do autor e sobre o autor. Nigel Whiteley, professor da Universidade de Lancaster, Inglaterra, desfruta de grande familiaridade com as escolas de arquitetura e as culturas construtivas inglesas e norte-americanas, e abordou a tarefa de traçar um panorama atento e consciente de sua ambição panorâmica. Para conseguir abordar as diversas facetas que ele encontrou na obra de Banham, Whiteley, todavia, analisou cada uma delas em separado, fragmentando e compartimentando sua obra em conceitos um tanto quanto desconectados uns dos outros: a estética popular; a estética da máquina; o americanismo; o populismo e o pós modernismo. Tal escolha, de segmentar a obra de Banham em temáticas, ao mesmo tempo que fortalece conceitos ao isola-los, os faz perder força, e também levam o leitor interessado a impressão equivocada de que existem em Banham diversas abordagens claramente separadas. Essa dissertação se propõe a ler a obra de Banham como fruto de uma só abordagem, e uma só linguagem sobre a arquitetura, ampla o suficiente para abarcar um léxico ampliado de expressões.

Segundo investigações de gerações mais recentes, existem algumas narrativas

19 Para uma bibliografia interessante e polifônica sobre esse movimento, e o engajamento de Banham, ver o as publicações de Anney Massey: The Independent Group: Modernism and mass culture in Britain - 1954-1959. Manchester: Manchester University Press, 1995; e o artigo The Independent Group: Towards a Redefinition, publicado em The Burlington Magazine, Vol. 129, No. 1009 (Abril 1987), pp. 232-242; e pela publicação que lida com o conceito "as found" (como encontrado) que pode ser compreendido isoladamente na publicação homônima de Claude Lichtenstein e Thomas Schregenberger, publicada originalmente em 2001 pela Lars Muller Publishers, As Found: the Discovery of the Ordinary.

20 The Banham Lectures: Essays on Designing the Future. Oxford: Berg, 2009. Uma somatória de artigos compilados por Jeremy Aynsley e Harriet Atkinson, completou a lacuna de uma revisão póstuma de suas linhas de pesquisa. Foi uma coletânea que recebeu a contribuição de Beatriz Colomina, Tomás Maldonado, Cedric Price, e Paul Barker, Peter Cook, entre outros. 
e a presença de certas continuidades e desvios na sua pesquisa que valem a pena serem analisados em específico. Gabrielle Esperdy, professora na escola de arquitetura do New Jersey Institute of Technology, interessada no cruzamento entre arquitetura, modernidade e sociedade de consumo na paisagem urbana americana, aborda a leitura dos modernos vernaculares e os diversos genius loci americanos sob o olhar de Banham ${ }^{21}$. Christophe Cornubert, apoiado na referência de Rem Koolhaas, confronta as 'ecologias' de Los Angeles com os delírios de Nova Iorque, e apresentou, pelo Instituto Berlage, uma investigação bibliográfica e de projeto revisando as 4 ecologias de Banha, através de 4 projetos conceituais ${ }^{22}$. Kazys Varnelis, coordenador do Infrastructural Lab na Universidade de Columbia em Nova Iorque, retomou a cidade lida por Banham 40 anos depois, sob a atmosfera de medo perante um possível colapso de infraestrutura ${ }^{23}$. Desde 2000 a SUNY Buffalo - State University of New York at Buffalo - vem proporcionando uma bolsa de pesquisas anuais (a "Reyner Banham fellowship") para pesquisadores engajados em novas abordagens acerca do discurso do autor. Atualmente, após um momento de relativa ausência no meio acadêmico, que veio acompanhado por um certo isolamento de alguns campos de discussão, Banham vem sendo finalmente reinserido no debate através de abordagens híbridas e múltiplas. ${ }^{24}$

Com o objetivo de contribuir na revisão crítica desse autor, o recorte da presente dissertação é a discussão desencadeada pelo encontro de Reyner Banham com a paisagem construída norte-americana entre o final da década de 1960 e o final da década de 1980. Nesse período de deslocamento e mudança de ambiente, a dissertação pretende encontrar as referências, anseios, conceitos e preconceitos do autor de formação inglesa, referentes à imagem das paisagens americanas.

Inglês que lutou na Segunda Guerra Mundial como engenheiro mecânico montando e reparando aeronaves, Reyner Banham conviveu com a geração de Peter Cook, Peter e Alison Smithson, James Stirling, e colaborou com o periódico Architectural Review sob a direção J. M. Richards e Nikolaus Pevsner, seu tutor de PhD no Courtald Institute of Fine Arts. Nos Estados Unidos, não só entrou em contato com o ambiente construído americano, da cultura popular, da estética da indústria, como mudou de ambiente intelectual e acadêmico, o que para ele parece ter lhe permitido se movimentar com maior liberdade do que na Inglaterra, calcada pela tradição e pelo

21 Seu projeto para um novo livro, American Road Trip, está embebebido de referências a produção de Banham, especialmente seu livro sobre Los Angeles e seu livro sobre as paisagens desertas americanas. 22 Publicado pela editora do Instituto Berlage como LA: Stranger than Fiction, a partir do trabalho de um grupo de pesquisa de pós-graduação da instituição.

23 Kazys Varnelis, The Infrastructural City: networked ecologies in Los Angeles, Los Angeles: Actar, 2008.

24 Jeremy Ainsley e Harriet Atkinson, The Banham Lectures: essays on designing the Future. Cambridge: The MIT Press, 2008, uma das mais recentes e polifônicas releituras de sua obra. 
academicismo, na produção de arquitetura, e pela extratificação social, que demarcava relações sociais e encontrava seus ecos na academia. Nesse contexto, o livro de 1960, que será analisado mais a fundo, assinala o começo de uma trajetória intelectual marcada pelo interesso das relações entre ética e estética da arquitetura moderna, no caso representadas pe o conflito entre a engenhosidade técnica da "era da máquina" e a tradição clássica da academia de radical Beaux-Arts.

Sua migração para o contexto americano e sua inserção no meio acadêmico local liga-se ainda a um deslocamento espacial e intelectual interno em direção ao Oeste daquele país, onde o autor encontraria novos objetos e novos interlocutores, como também uma nova rede de relações sociais e pessoais. Sua estadia na California o aproximou a teóricos mais abertos a novas investigações, a qual o próprio conceito de ensino de arquitetura estava posto em cheque em seu formato ortodoxo. Em instituições como Berkeley e o campus de Santa Cruz da Universidade da Califórnia, o ensino de arquitetura era substituído pelo ensino de desenho do ambiente, ou Environmental Design. Dentre as referências da arquitetura na Califórnia destacam-se os estudos do que se começave a chamar de "paisagem cultural", então capitaneados por John Brinckerhoff Jackson, intelectual de formação híbrida entre Estados Unidos e Europa ${ }^{25}$. Esta pesquisa acreditou na possibilidade de referências como a de J. B. Jackson ter de fato reverberado na guinada nos rumos da pesquisa de Reyner Banham, e seu reencontro com a arquitetura moderna a partir de outros sub-produtos da modernidade. $\mathrm{O}$ interesse por abrir o espectro dos estudos de arquitetura permeavam o lugar. As discussões em torno das noções de americanismo e modernismo alinhavamse em narrativas de geógrafos, historiadores e arquitetos. O naturalismo americano, o interesse pelo vernacular moderno e a recém-difundida idéia de ambientalismo impregnavam o meio acadêmico. Todavia, Banham não abandonou a sua pesquisa e sua crítica ao modernismo em arquitetura, retornando sistematicamente a persistência da arquitetura moderna no meio urbano contemporâneo.

Neste sentido, esta dissertação se propõe também a investigar a fundo a leitura de Reyner Banham a respeito da estética da máquina, e como ela se transformou a partir da interface entre o historiador inglês e a paisagem construída norte-americana, das fábricas e silos às freeways. Acredita-se que tal investigação pode contribuir para o amadurecimento do debate a respeito das inúmeras derivações e desvios da arquitetura moderna emergentes a partir dos anos 1960; e mais além, para o entendimento das relações e referências recíprocas entre a produção dos mestres da arquitetura moderna e a produção anônima, corriqueira, instintiva e pragmática.

Os processos sociais ocorridos no começo do século XX, que mudaram o formato e a função social da profissão de arquitetura, e que concomitantemente

25 Paul Groth organizou uma compilação de artigos que demonstram seu legado na academia Americana em Everyday America: Landscape Studies after J. B. Jackson. Berkeley: University of California Press, 2003. 
trouxeram a expressão arquitetônica para o campo da arte moderna e da vida social, desencadearam também, como processo secundário, uma reaproximação da produção erudita de arquitetura com a criação anônima e corriqueira das grandes cidades. Renegando a faceta elitista do Neo-Classicismo, os mestres do modernismo valorizavam não só a indústria como também a ciência do produto do dia-dia. $\mathrm{O}$ advento da máquina de guerra da era dos conflitos globais engendrou uma rede de desenvolvimentos tecnológicos que logo permeou a produção arquitetônica ${ }^{26}$. A demanda social por reconstrução nos territórios de conflito, e por expansão dos assentamentos humanos em áreas prósperas abasteceu gerações de arquitetos não só de ânimo - materializado em comissões, concursos, grandes contratos e agências de construção - mas também trouxe uma nova relevância para a prática de arquitetura.

Banham é testemunha particularmente sensível a essas circunstâncias e mudanças de atitude, inclusive historiográficas, que pela primeira vez começaram a levantar questionamentos sobre os perigos da ingenuidade da agenda moderna. Em sua fé na máquina e na produção industrial, e em sua tecnocracia sócio-espacial, não só as gerações contemporâneas, mas também retroativamente os mestres do modernismo foram duramente criticados, da década de 1950 em diante. De fato, o modernismo em arquitetura não poderia cumprir com sua própria dimensão utópica. Mas sua negação também trouxa à tona outros riscos, entre os quais o da cisão entre a arquitetura produzida e comentada pela academia, e a produção de arquitetura nas metrópoles, resultando na percepção do alcance limitado do debate arquitetônico em relação às expressões da cultura construtiva contemporânea. É um dos objetivos desta pesquisa encontrar o papel da produção de Reyner Banham na tentativa de chamar atenção para os objetos mundanos, de estradas e autopistas, carros, caminhões e furgões, restaurantes de beira de estrada, abrigos de bicicleta, feiras populares, estacionamentos, shopping-centers, drive-ins, bancas de cachorro-quente, propaganda e imagens da televisão e afins para o domínio dos arquitetos.

Malgrado a maioria da população mundial hoje habita as cidades, a noção sobre a produção anônima, cotidiana, popular e vernacular é ainda pouco difusa entre os arquitetos e os historiadores da arquitetura. A expressão 'vernacular', inclusive, é reservada a fenômenos tidos como alheios aos processos de industrialização e urbanização, muitas vezes evocando atributos bucólicos e rústicos ${ }^{27}$, normalmente uma operação de intelectuais da grande cidade que aplicam termos a fenômenos alheios à esfera metropolitana. Os mesmos historiadores de arquitetura que manipulam o

26 Ver Jean-Louis Cohen, Architecture in Uniform: Designing and Building for the Second World War. Paris, Hazan, 2011 para uma análise da relação entre arquitetura e os preparativos e decorrências da Segunda Guerra Mundial.

27 A discussão sobre o lugar da arquitetura vernacular na cultura capitalista moderna gerou polêmica entre os críticos e historiadores da segunda metade do século XX. Dentre eles se destacam, nem sempre com posições próximas: Frank Lloyd Wright, Reyner Banham, Kenneth Frampton, Robert Venturi, Denise Scott-Brown, Christopher Alexander, Charles Correa, Bernard Rudofsky, Lina Bo Bardi, Gwendolyn Wright, Charles Jencks, e Paul Groth. 
termo original renegam veementemente o termo 'vernacular moderno', o tachando de apologia da produção de cidade voltada para o consumo ${ }^{28}$. Mas as grandes metrópoles contemporâneas há séculos não são mais feitas de casas de pescador ou de antigas unidades produtivas como engenhos ou casamatas. Mesmo no campo da literatura, da história e das ciências sociais, aparentemente muito mais interessada em tais expressões da vida urbana contemporânea, pouca atenção se dá aos objetos e espaços criados pelas mesmas atividades sociais e familiares, as quais são foco dos estudos da arquitetura e de Banham. Até mesmo a produção literária de J. B. Jackson sobre a paisagem cultural americana, casas, paragens, estradas e outros lugares mundanos foram tratados apenas como receptáculos ds atividades humanas, foco dos estudos em questão, enquanto Banham se interessa pelos objetos em si, em seu processo de projeto e produção ${ }^{29}$. Por outro lado, poucos historiadores e críticos tomaram o caminho de enfrentar as questões da arquitetura e do vernacular moderno, saindo do círculo da arquitetura oficial. De fato, Banham em sua atitude de ampliação do vocabulário da arquitetura moderna, assumiu uma postura de vanguarda na historiográfica.

Em novembro de 2007, a Faculdade de Arquitetura e Urbanismo da USP recebeu o historiador francês de arquitetura, Jean-Louis Cohen, que ministrou palestras temáticas a respeito da formação das metrópoles contemporâneas ${ }^{30}$. A palestra de Cohen sobre a metrópole de Los Angeles teve como base bibliográfica, além de obras de autores como Richard Longstreth ${ }^{31}$ e Mike Davis $^{32}$, o livro de Reyner Banham, Los Angeles: the architecture of four ecologies, publicado em 1971. O livro, mesmo que uma narrativa sobre uma cidade já não mais existente hoje, chamou a atenção pela sua eloquência e por propor questões ainda válidas para o debate urbanístico e para os estudos da paisagem cultural.

Influenciada por sua leitura, comecei a elaborar o projeto da pesquisa de base a esta dissertação, com foco na tentativa de encontrar, no discurso de Reyner Banham, evidências que suportassem a hipótese de uma narrativa específica sobre as expressões vernaculares de arquitetura. Amostras de interesse por expressões populares de design e estética não escapavam de sua análise. Com o ingresso no mestrado e o andamento da pesquisa registrou-se que esta postura de associação descompromissada entre arte erudita e cultura de massa não chegou exatamente a ser uma bandeira levantada

28 Ver a entrevista com Kenneth Frampton, em anexo na presente dissertação.

29 Ver a entrevista com Gabrielle Esperdy, em anexo na presente dissertação.

30 As cidades levantadas neste ciclo de palestras foram Nova Iorque, Los Angeles, Paris, Tóquio. O evento "Crises e retorno à urbanidade - de 1980 até hoje", aconteceu na sede de pós-graduação da FAUUSP (FAU-Maranhão), de 21 a 23 de novembro de 2007.

31 Richard Longstreth, City Center to Regional Mall: Architecture, the Automobile, and Retailing in Los Angeles, 1920-1950. Cambridge: The MIT Press, 1998.

32 Mike Davis, City of Quartz: Excavating The Future in Los Angeles. New York: Verso, 1990. 
por Banham. Tampouco foi um mote reconhecível em sua obra, indissociável da narrativa sobre os produtos e propagadores da arquitetura moderna. A busca por uma lacuna no discurso de seus comentadores ${ }^{33}$, algo que delatasse um momento ainda não registrado, mostrou-se um beco sem saída nesta linha de investigação. Por isso a eleição como foco da dissertação de dois grandes temas que se associam em sua obra de múltiplas maneiras: a tecnologia e a paisagem.

A dissertação se organiza de maneira a localizar a produção de Banham dentro do meio da historiografia da arquitetura, e investiga as especificidades de sua produção como também suas transformações no processo de deslocamento intelectual da Europa para os Estados Unidos, e a trajetória acadêmica de Banham no interior do país. Esta é a proposta do primeiro capítulo da dissertação, cujo formato escolhido é o de uma análise retrospectiva da migração de mais de uma geração de críticos e historiadores europeus para o meio norte-americano de arquitetura. Para tal foram escolhidos figuras de relevo na historiografia do moderno e cuja obra mantém relações cronológicas, temáticas e teóricas com Reyner Banham e com o contexto intelectual no qual ele se formou na Inglaterra. Com efeito, a cisão com a história estabelecida pelos modernistas alemães, que se fundamentou na Bauhaus e que se proliferou por escolas norte-americanas como Harvard, o Armour Institute, a Black Mountain College of Design, e mais tarde os cursos de arquitetura de Cornell, Columbia e Georgia Tech ${ }^{34}$, logo depois da primeira geração de migração européia, estava sendo revista pelos jovens estudantes ingleses em atividade após a Segunda Guerra Mundial. A geração de Banham, por outro lado, era formada por agentes da revisão dos preceitos do movimento moderno, e alguns dos quais viriam a se tornar figuras centrais de grupos identificados com a crítica dos Congressos Internacionais de Arquitetura Moderna - CIAMs - e com a aproximação a elementos da vida cotidiana, anteriormente descartados em prol da abstração social e artística. Tal retomada era representada por figuras como John Summerson, James Stirling e Colin Rowe, passando por Kenneth Frampton, até Peter Cook e o grupo do Archigram. Banham fazia parte do grupo de estudantes do Institute of Contemporary Arts da Universidade de Londres, que reunia Nigel Henderson, Richard Hamilton, Lawrence Alloway, Eduardo Paolozi e os Smithsons - o Independent Group - desde sua fundação, em 1952, até seu esvaziamento em $1956^{35}$. Essa geração também contava com críticos do moderno ligados à crítica de radical materialista-tectônico, como Kenneth Frampton;

33 Na coletânea de palestras em homenagem póstuma, reunidas em The Banham Lectures: Essays on designing the Future, que tem Jemery Aynsley e Harriet Atkinson como organizadores, bem como os já mencionados Nigel Whiteley e Anthony Vidler.

34 Ver Joan Ockman, The Architecture School: Three Centuries of Educating Architects in North America. Cambridge: The MIT Press, 2012, pp. 20. Na introdução da organizadora, e no artigo de Anthony Alofsin no mesmo livro, "1920-1945: Challenges to Beaux-Arts Dominance", descrito mais detalhadamente, pp. 90-119.

35 Anne Massey, The Independent Group: modernism and mass culture in Britain, 1945-1959. Manchester, Manchester University Press, 1995. 
críticos dos limites do modernismo como estética, como Colin Rowe; e pesquisadores da historiografia do moderno, como Anthony Vidler.

O segundo capítulo lida com a reconstrução historiográfica de sua pesquisa sobre a estética da máquina, em suas múltiplas figurações, e muito particularmente sobre as relações de troca entre os arquitetos e teóricos europeus e a cultura da tecnologia americana. Neste capítulo é abordado seu material publicado em formato de artigos e livros, tirando o foco da figura do autor e suas relações acadêmicas, abordados no primeiro capítulo. Neste capítulo abordaremos uma das principais linhas críticas de Banham: o suposto fracasso da vanguarda moderna em abarcar o conceito da máquina em toda sua dimensão.

O terceiro capítulo tem a forma de um ensaio teórico sobre a visão de Banham sobre as paisagens americanas, do ponto de vista da apropriação da tecnologia como realização da promessa moderna em sua escala cotidiana. O objetivo é encontrar como seu discurso foi afetado pela referência americana, em sua narrativa, bem como sua contribuição para o feixe de narrativas da academia local. Alguns interlocutores americanos tem maior presença nesse capítulo, como J. B. Jackson, Tom Wolfe, Michael Sorkin, entre outros. As paisagens dos desertos americanos, das tipologias habitacionais, das ruínas industriais, das autopista, e automóveis, e a cultura urbana americana foram elementos selecionados de seu discurso para entender o legado de Banham na escola de estudos da paisagem cultural americana, da cultura de consumismo, do descarte imediato, e encontrar a construção da figura do cidadão americano, como protagonista do vernacular moderno de massa.

Espera-se situar de maneira historiográfica a obra de Reyner Banham nesse contexto, como uma das peças chave da exploração acadêmica dos acontecimentos descritos. Muito mais do que um entusiasta ingênuo da máquina e de suas éticas e estéticas, como foi tachado durante os anos 1970, com o declínio do quadro de entusiasmo da arquitetura com a tecnologia, na verdade Banham foi um dos primeiros profissionais da academia a fazer menção à importância cada vez maior da ação difusa, não-projetada das novas expressões espaciais; da importância cada vez maior da apropriação dos espaços e consumo dos objetos, em relação aos processos de concepção e execução que os desencadearam; dos modelos tecnológicos na Europa e nos Estados Unidos que geraram maneiras diferentes de controle do ambiente construído; da emergência de outras ciências ao campo de interesse dos arquitetos, como a psicologia, genética e antropologia; da leitura respeitosa e desmistificada da expressão popular como algo maior do que uma ação populista e anedótica dentro da historiografia contemporânea; e finalmente, na expansão do campo de estudos da história da arquitetura. 
Um dos maiores desafios encontrados no processo de pesquisa foi o deslocamento necessário para a investigação, tanto intelectual quanto físico ${ }^{36}$. Não somente as fontes primárias bibliográficas encontram-se na Califórnia, mas também os interlocutores e críticos que já se debruçaram sobre a obra de Reyner Banham ou o meio acadêmico e profissional da arquitetura nos Estados Unidos atuam em sua maioria atuam naquele país. Mostrou-se mandatório a investigação bibliográfica junto aos arquivos americanos de fontes tanto primárias quanto secundárias. Durante os meses de agosto e setembro de 2012, foi realizada uma pesquisa junto a instituições de ensino e pesquisa de arquitetura com a finalidade de completar o levantamento bibliográfico realizado em 2011 e 2012 na biblioteca da FAU-USP e nas bases de dados disponibilizadas pelo meio acadêmico geral ${ }^{37}$.

A bibliografia disponível sobre a trajetória dos autores é predominantemente composta por artigos e ensaios. A publicação americana Journal of Society of Architectural Historians é o maior espaço para discussão e revisão da obra critica desses autores, isto feito através de ensaios a respeito de ensino de arquitetura. Dentro de recentes antologias sobre história e teoria de arquitetura, como os tomos de Kate Nesbitt, Joan Ockman e K. Michael Hays encontramos descrições sucintas sobre a trajetória dos autores. Entrevistas, como a concedida para José Lira, editada na revista Desígnio 11/12, por Kenneth Frampton, que também concedeu uma entrevista a Hal Foster e Stan Allen, são tipologias de texto normalmente mais reveladoras sobre as relações entre teoria e circunstância na obra dos autores selecionados: suas razões para atitudes passadas, revisões dotadas de maior sinceridade, e em geral um tom mais personalista. E as entrevistas realizadas durante a viagem de pesquisas à Nova Iorque e Los Angeles, junto a Gabrielle Esperdy, Paul Groth, Gwendolyn Wright e Thomas Hines, malgrado variadas em seus formatos, apresentaram um panorama do ponto de vista de uma geração de interlocutores e arquitetos formados pela geração de Banham - especialmente no caso de Groth e Esperdy.

A pesquisa de material documental e bibliográfico no acervo do Getty Research Institute de Los Angeles foi crucial para a sedimentação de conceitos e conteúdos apreendidos em pesquisas bibliográficas no Brasil, bem como orientou a pesquisa para um caminho menos incerto a respeito da biografia do autor. Foram levantados materiais que apresentam o processo de montagem das disciplinas e palestras ministradas por Banham na América. De tais fragmentos documentais percebeu-se o

36 O acervo documental e bibliográfico a respeito de Reyner Banham encontra-se dividido em dois grandes bancos de dados: o material fotográfico encontra-se nos arquivos da Royal Institute of British Architects (RIBA) junto com manuscritos relacionados ao período Britânico de sua produção, enquanto o material documental e bibliográfico americano encontra nos arquivos do Getty Research Institute. 37 Atráves das bases de dados Jstor e Art-Index, das quais a FAU-USP faz parte até o momento de depósito da presente dissertação. 
forte entrelaçamento entre a produção de artigos e livros publicados e o conteúdo das disciplinas e projetos acadêmicos. De fato, Banham tinha sua produção bibliográfica como carro-chefe de sua atividade acadêmica, ao mesmo tempo que era reconhecido como palestrante e professor carismático - para alguns, inclusive, um crítico e historiador "populista".

Outra barreira intelectual é a língua: para além das dificuldades tradicionais de tradução, se destaca a característica única da escrita de Banham: jocoso, engenhoso, e complexo, Banham se faz valer de neologismos e gírias, e as combina com o mais refinado argumento acadêmico. Evitando o risco de perda substancial do argumento pela traição que acompanha a tradução, foi optado pela manutenção do original em inglês nas notas de rodapé, para a manutenção não só do conteúdo técnico como também da semântica e estilo de escrita do autor. Os interesses culturais recentes têm foco nas produções das universidades americanas - Princeton, Harvard, Columbia, Cornell, Pratt, Cooper Union, Yale e MIT - na costa leste, e as universidades de Berkeley e a UCLA, na costa oeste - bem como as escolas de arquitetura inglesas, como a Architectural Association (AA) e a Universidade de Londres. A referência compreensiva à academia inglesa e americana desta pesquisa demonstra esse câmbio na referência acadêmica para minha geração. Neste sentido, espera-se que a escolha pela valorização da língua inglesa no original preste à maior acessibilidade à obra de Banham, ainda com pouquíssima penetração no país. Recentemente, o livro Los Angeles: the Architecture of Four Ecologies foi traduzido para a língua portuguesa (2013), somando de maneira significativa à historiografia do autor ${ }^{38}$. Este material, contudo, foi publicado quando a presente pesquisa já se encontrava em estágio avançado de desenvolvimento. Por isso, na versão original, a grande maioria das traduções foi traduzida originalmente pelo autor tomando a liberdade de interpretação. A presente versão - revisada após a banca de defesa da dissertação - efetuou traduções livres, com a expectativa de publicação futura com a substituição pelos trechos Los Angeles: a Arquitetura de Quatro Ecologias, publicada pela Editora Martins Fontes. Ao menos que apontado pelo texto, todas as traduções são de minha autoria.

38 Reyner Banham, Los Angeles: a Arquitetura de Quatro Ecologias. São Paulo: WMF Martins Fontes, 2013. 
Capítulo 1 - Deslocamentos na Historiografia:

migrações e trocas EUA-Europa - 1930-1988 
O primeiro capítulo da dissertação propõe lançar algumas questões sobre a cena acadêmica americana e a participação local de historiadores ingleses a partir da década de $1930^{1}$. Dentro desta paisagem acadêmica, a figura de Reyner Banham se destaca pela sua postura diferenciada em relação à tecnologia, expressões populares de arquitetura e design, e uma apreciação diferenciada da paisagem americana. ${ }^{2}$ Inevitavelmente a problemática da historiografia da arquitetura se impõe, bem como seus desdobramentos, usos e narrativas no decorrer do século XX. Apesar de não ser este o foco do trabalho de pesquisa dessa dissertação de mestrado, não podemos nos furtar a recorrer aqui também à construção histórica da genealogia do moderno, proposta por essa geração de historiadores a que pertence Banham³. Também

1 Dois grandes feixes de pesquisa bibliográfica foram tomados para esta parte da dissertação. Primeiramente, o registro da migração intelectual aos Estados Unidos, ocorrida em diversas ocasiões no decorrer do século XX, no qual a obra de Donald Fleming e Bernard Bailyn, The Intellectual Migration: Europe and America, 1930-1960. Cambridge, Harvard University Press, 1969, cobre de maneira competente. Deve-se ter o cuidado de ler seu conteúdo como um documento histórico, contudo. No campo da pesquisa histórica sobre o ensino de arquitetura nos Estados Unidos, foram utilizadas como bases primárias os seguintes trabalhos: Kenneth Frampton e Alessandra Latour, "Notes on American Architectural Education from the End of the Nineteenth Century until the 1970s." in Lotus No. 27 (1980), pp. 9-15; a compilação de Gwendolyn Wright e Janet Parks, History of History in American Schools of Architecture, publicada em 1990 e que foi acompanhada por uma exposição histórica de trabalhos dos estudantes de arquitetura, da qual podemos destacar o próprio artigo de Wright, History for Architects, que se dedica em remontar o à história do ensino de história de arquitetura; e Joan Ockman, Architecture School: Three Centuries of Educating Architects in North America, publicado em 2012, e formado por duas partes - uma revisão cronológica do ensino de arquitetura nos Estados Unidos, e uma série de artigos dedicados a discussão de aspectos do léxico temático do ensino de arquitetura. Muito deve sobre a remontagem do percurso histórico dos cursos de história da arquitetura nas instituições de ensino de arquitetura nos EUA a esses dois livros, mas outros trabalhos foram importantes para criar a rede de informações e organizar o conteúdo crítico: Stanford Anderson relata sobre momentos mais recentes do ensino de arquitetura em Architectural History in the Schools of Architecture; e o artigo de Mark Swenarton, The Role of History in Architectural Education, base para pesquisa sobre as instituições inglesas. Além da pesquisa bibliográfica, apresentada no decorrer do capítulo através das notas e citações, fazem parte da pesquisa entrevistas com acadêmicos ingleses e americanos, e os levantamentos bibliográficos e documentais nas bibliotecas do Getty Research Institute, da Faculdade de Arquitetura e Urbanismo da USP, e da biblioteca Avery da Universidade de Columbia. Os resultados das pesquisas documentais e entrevistas estão dispostos nos trabalhos programados entregues como parte do memorial de qualificação, e uma seleção deste material é apresentada nesta dissertação na seção de anexos. Os trabalhos de Anthony Vidler, Histories of the Immediate Present. Cambridge: the MIT Press, 2008, e Panayotis Tournikiotis, The Historiography of the Modern Movement. Cambridge: The MIT Press, 1999, fizeram parte da bibliografia da disciplina de historiografia da arquitetura moderna, ministrada pelo professor José Lira no curso de pós-graduação no primeiro semestre de 2011.

2 O entendimento da obra de Banham foi concretizado de fato a partir da pesquisa documental e de bibliográfica realizada nos arquivos do Getty Research Institute (GRI), e pela obra biográfica de Nigel Whiteley, publicada em 2005, e pelas entrevistas realizadas, principalmente com Paul Groth e Gabrielle Esperdy.

3 Como primeiro movimento da presente dissertação, espera-se localizar entre a geração de intelectuais ingleses que migraram para as instituições americanas de ensino e pesquisa de arquitetura a trajetória específica de Reyner Banham. 
trataremos de diferentes conceitos de história, historicismo e pós-modernismo, acerca dos quais as posições tomadas pelos autores abordados traz fundamento ao debate acadêmico na época ${ }^{4}$.

Não existem pretensões de esgotar nenhum dos campos de pesquisa nem tampouco de chegar a conclusões sobre a participação e contribuição de cada um desses acadêmicos migrantes, seja no campo do estudo, ou ensino de arquitetura nas instituições americanas. $\mathrm{O}$ interesse é justamente situar a polifonia que os envolve, e, sobretudo, salientar as peculiaridades da trajetória de Banham. Não importa, portanto, encontrar apenas as qualidades e eventos que aproximam as trajetórias individuais destas figuras, nem tampouco escrever uma biografia coletiva de uma geração de historiadores da arquitetura, pelo contrário: estruturado em temas e recortes pontuais, este capítulo constrói sua narrativa de forma pendular; tangenciando por vezes eventos que constroem o processo histórico de formação das instituições de ensino nos Estados Unidos; e em outra perspectiva, focando-se nas atividades acadêmicas de Banham inserido em contexto inglês, e, posteriormente, estadunidense ${ }^{5}$.

As trajetórias individuais dos historiadores serão apresentadas a partir da informação coletada durante o período de pesquisa bibliográfica e documental, realizada nas bibliotecas no Brasil e nos Estados Unidos 6 . Diversos apontamentos e encaminhamentos apareceram após entrevistas com professores e historiadores americanos e ingleses - inclusive alguns dos historiadores pesquisados: a primeira entrevista realizada teve como interlocutor o professor Kenneth Frampton, em Julho de 2011; ; no verão norte-americano de 2012 foram realizadas as demais entrevistas, todas

4 Ver o artigo de George A. Kubler, What Can Historians do for Architecture; o artigo de Alan Colquhoun, Três Tipos de Historicismo, publicado pela coletânea em português pela Cosac \& Naify, Modernidade e Tradição Clássica; e o livro publicado por Anthony Vidler, derivado de uma pesquisa historiográfica sobre as narrativas de revisão do moderno em arquitetura, Histories of the Immediate Present: Inventing Architectural Modernism, publicado em 2008 pela MIT Press.

5 A ideia é se debruçar sobre as narrativas e trajetórias pessoais de arquitetos e historiadores de arquitetura modernos formados na Inglaterra, especialmente a geração formada pela migração de professores alemães, como Wittkower, Pevsner e Giedion (este a caminho dos Estados Unidos), de modo a tecer as relações entre profissionais e instituições e localizar as discrepâncias e rupturas entre práticas e narrativas, bem como as derivações a partir de uma formação inglesa em comum para um leque de experimentações no meio acadêmico americano.

6 No conjunto, os historiadores abordados foram Anthony Vidler, Colin Rowe, Kenneth Frampton e Reyner Banham. O critério de seleção passou inicialmente pela questão geracional e de nacionalidade, porém ao final da pesquisa esta tenha se tornado a menor das questões. Somente as aproximações de formação intelectuais devem ser relevadas. Entende-se que esta geração tem uma agenda coletiva de revisão da arquitetura moderna e seus movimentos e respectivas genealogias: da construtividade do Abade de Laugier, passando pela extravagância de Henri Van de Velde e o moralismo de Bruno Taut, ou pelos delírios futuristas de Marinetti e Boccioni, a arquitetura moderna posou de diversas maneiras, e atentou para diversos recortes históricos.

7 Outras duas entrevistas com o professor Frampton, junto a Hal Foster e Stan Allen, para o periódico October; e por José Lira, para o periódico Desígnio, edição 11/12, cujo tema abordado foi a questão da historiografia na cultura arquitetônica, também foram materiais importantes para a amarração de fatos e conceitos historiográficos. 
com professores da academia estadunidense ${ }^{8}$; em setembro de 2012, foi realizada a última entrevista da presente pesquisa, com o professor Anthony Vidler.

Após o hiato causado pela máquina de guerra entre 1939 e 1945, o recente campo estabelecido de revisão crítica da arquitetura moderna olhava pela primeira vez para as produções da primeira geração de modernos no século XX, com um distanciamento histórico e temporal sem precedentes. Os principais manuais de arquitetura moderna tinham sido publicados no período entre Guerras, e seu conteúdo começava a se tornar historicamente datado9. Durante as décadas de 1940 e 1950, os trabalhos de reconstrução das economias após a Segunda Guerra Mundial na Europa, e a onda de expansão econômica nos Estados Unidos colocavam a arquitetura moderna a serviço da máquina desenvolvimentista, e forjava um casamento sem precedentes entre os arquitetos, o mercado imobiliário e o governo nacional. Concomitantemente, o cânone moderno estava fragilizado por revisões críticas que questionavam sua agenda de reforma social, colocando-a como ingênua. Já o outrora bem visto entrosamento entre arquitetura e as ditas "ciências duras"10 estava sendo questionado, em favor das novas relações forjadas entre o campo da arquitetura e as ciências avançadas - genética, biologia, astrofísica, neurociência - e humanas - geografia, história, antropologia, sociologia, filosofia e psicologia. O próprio Banham, em 1960, escreve no artigo "Stocktaking" no periódico Architectural Review, sobre o ultimato dado à arquitetura moderna quanto a permanência em seu modelo de tecnologia estabelecido historicamente ou a partida para novas experimentações em outros campos do conhecimento $^{11}$. Focalizaremos aqui as continuidades e rupturas entre o campo de ensino da arquitetura e a história, no decorrer do século $X X^{12}$.

8 Ver material anexo à dissertação. Os profissionais americanos entrevistados foram (em ordem cronológica) Gabrielle Esperdy, professora do New Jersey Institute of Technology, cuja transcrição encontra-se nos anexos; Gwendolyn Wright, professora da Graduate School of Architecture, Planning and Preservation; Thomas Hines, professor da University of California - Los Angeles; Joe Day, professor da Southern California Institute of Architecture; e Paul Groth, professor em Berkeley.

9 Após as publicações de Lurçat, Frankl e publicação do suíço Siegfried Giedion, Space, Time and Architecture foi publicada em 1941, cuja genealogia traça as Charles Eliot Norton Lectures, apresentadas em Harvard em 1938; o manual do alemão Nikolaus Pevsner, Pioneers of the Modern Movement: from William Morris to Walter Gropius foi publicado em 1936.

10 Segundo Joan Ockman e Avigail Sachs em "Modernism Takes Command", in Architectural School: three centuries of educating architects in America: Cambridge: The MIT Press, 2012, pp. 135136, o matrimônio entre modernismo e técnica seria posto em discussão ao mesmo momento em que se questionavam o pensamento positivista no qual o racionalismo e a técnica estavam impregnados, abrindo espaço para outros campos do conhecimento.

11 Recentemente (julho 2013) o periódico de arquitetura Log publicou uma versão especial dedicada para o artigo de Banham de 1960. Nesta edição, que contou com a editoração conjunta de Peter Eisenman e Anthony Vidler, lida com a revisão histórica do entrosamento entre tecnologia e arquitetura, situando a revolução digital na arquitetura, a partir da exposição "Archelology of the Digital”, organizada no Canadian Centre for Architecture com a curadoria do arquiteto Greg Lynn. Ver o capítulo 2 desta dissertação para maiores informações sobre a relação entre arquitetura e tecnologia.

12 Ver Joan Ockman e Avigail Sachs, "Modernism Takes Command” em Joan Ockman, Architecture 
O ensino de história, posto de lado pelos formadores do currículo de arquitetura nas décadas 1920, 1930 e 1940, em favor do ensino focado em projeto e na reprodução do ambiente do ateliê ${ }^{13}$, voltava ao currículo das principais instituições de ensino nos Estados Unidos no começo da década de 1950. A reaproximação entre o ensino de arquitetura e a história demandava um novo quadro de pesquisadores e professores de arquitetura. Foi neste contexto que o foco dos reitores das universidades e diretores das escolas de arquitetura se voltou para uma geração de profissionais cuja formação em arquitetura e história da arte, como no caso de Reyner Banham, os habilitava para assumir tal responsabilidade ${ }^{14}$.

Refúgio de intelectuais exilados de outras regiões da Europa como Erwin Panofsky, Ernst Gombrich, Rudolf Wittkower, Nikolaus Pevsner e Emil Kaufmann, a Inglaterra era palco de constantes discussões a respeito da relevância da história e da tradição cultural arquitetônica ${ }^{15}$. De fato, o cânone moderno e a abstração formal destacada do curso da história era questionado em sua genealogia entre os ingleses. Formados em Liverpool, ou em Londres, pela Architectural Association ou em artes liberais pela Universidade de Londres - i. e. no Courtauld Institute of Contemporary Arts (ICA) ${ }^{16}$ - os arquitetos e historiadores de arte formados na década de 1950 sob a tutela de historiadores como Nikolaus Pevsner, Siegfried Giedion ${ }^{17}$ e Erwin Panofsky ${ }^{18}$, e leitores de obras seminais como a de J. M. Richards, recebiam tanto influências modernas do continente europeu, quanto anti-modernas. Entre elas, destaca-se a figura de Sir Reginald Blomfield, arquiteto da Imperial War Graves Commission e membro da mesa de preservação de monumentos históricos do país ${ }^{19}$. O repúdio de Blomfield ao modernismo é simbólico de um sentimento de soberania nacional que se fortaleceu principalmente nos anos de Segunda Grande Guerra na Inglaterra. Nessa época, o modernismo continental, assumidamente de raiz germânica, era tanto atraente quanto ameaçador. A herança histórica inglesa, em uma postura defensiva, raramente sucumbiu ao elogio pelo abstracionismo de raiz moderna que tomava conta do

School pp. 135-136.

13 Ver o artigo de Anthony Alofsin, “1920-1945: Challenges to Beaux-Arts Dominance”, in Joan Ockman, Architecture School, 2012, pp. 95-111.

14 Ver Alina Payne, "Architectural History and the History of Art: A Suspended Dialogue" in Journal of the Society of Architectural Historians, Vol. 58, No. 3, (Setembro 1999), no qual as relações entre história da arte e história da arquitetura são remontadas às origens da sua profissionalização, na virada do século XIX para o XX.

15 Ver Nigel Whiteley, "Modern Architecture, Heritage and Englishness", publicado no Jornal da Sociedade de Historiadores de Arquitetura da Grã-Bretanha (SAHGB), Vol. 38, 1995, pp. 220-237.

16 Ver Denis Farr, "A Student at the Courtauld Institute", in The Burlington Magazine, Vol. 147, No 1229 (Agosto 2005), pp.539-547.

17 Giedion foi Secretário geral do CIAM, professor convidado no ICA, e professor em Harvard e no Massachussetts Institute of Technology (MIT).

18 Professor no Warburg Institute, em frente ao Cortauld Institute, lugar que Banham e os demais membros do Independent Group frequentavam durante os anos 1950.

19 Ver Nigel Whiteley, "Modern Architecture, Heritage and Englishness", pp. 224-226 
continente, especialmente da França e Alemanha, que rapidamente se difundiu pelos demais países do continente.

Em suma, no momento em que a academia tomou de maneira generalizada o retorno da história como fator fundamental ao ensino, esta geração de arquitetos e historiadores ingleses possuía uma formação diferenciada. Somaram-se as narrativas entusiásticas daqueles que construíram a narrativa moderna como Pevsner e Giedion, narradores de eventos do seu presente, que materializaram um passado imediato, uma genealogia moderna que possuía tanta carga histórica, em tom de apologia aos seus heróis, quanto o seu passado mais distante, vitoriano, 'arts and crafts' e pré-moderno. O rompimento com o ensino de história na Inglaterra, ao contrário do que acontecia no continente europeu e americano, nunca fora completo.

A respeito da estrutura, seguirá a proposta cronológica de análise da situação das escolas americanas prévia às levas migratórias (1890-1930); da primeira geração de migração europeia (1930-1940), tendo como protagonistas os arquitetos Walter Gropius e Ludwig Mies van der Rohe, e a estruturação dos cursos modernos de arquitetura nos Estados Unidos; e o retorno à história, com a presença dos acadêmicos ingleses, tendo como protagonista Reyner Banham, e sua trajetória americana, em destaque ${ }^{20}$. As citações foram mantidas em sua língua original, inglês, em sua grande maioria.

\section{América Beaux-Arts}

Segundo Anthony Alofsin, durante o boom dos anos 1920, quando a BeauxArts Institute of Design (BAID) estaria no auge de sua influência, a prática e ensino de arquitetura operavam uma variedade de estilos que cairiam na categoria de 'ecletismo' ${ }^{21}$. No interim, na Europa, o movimento moderno teria consolidado seus desenvolvimentos formativos, amalgamando as abstrações plásticas da De Stjil, o vocabulário pós-cubista de Le Corbusier, e o idioma racionalista da Neue Sachlichkeit. Inicialmente esses desenvolvimentos penetrariam pouco na América, mas ao final da década seu impacto foi crescentemente sentido, justo como teria acontecido uma década ou duas atrás, quando a próspera atividade de construção americana levou à produção de mais edifícios na linguagem da Belas-Artes do que era produzido na França. O Art-Deco teria se difundido amplamente no país, das metrópoles aos subúrbios em crescimento. $\mathrm{O}$ "estilo do momento" foi traduzido rapidamente em projetos de estúdio em escolas de arquitetura, como um idioma em projetos de

20 Esse método de modo algum é experimental: a proposta foi se apropriar da metodologia que escrita que o próprio Banham utiliza em diversos de seus livros, como Teoria e Projeto na Primeira Era da Máquina e Los Angeles: the Architecture of Four Ecologies. Frampton também faz menção desse sistema de narrativa em suas bases bibliográficas em História Crítica da Arquitetura Moderna; Anthony Vidler identifica esse movimento pendular e sua genealogia na bibliografia de Le Corbusier, em especial Vers Une Architecture, no qual o foco passa dos elementos simbólicos da indústria para a arquitetura clássica de radical grego.

21 Ver Anthony Alofsin, em Ockman, Architectural School, pp,93. 
estudantes, em um processo de mimese que ainda ocorreu por muitos anos. ${ }^{22}$

Para entendermos a contribuição dos historiadores ingleses no campo da formação de arquitetura nos Estados Unidos, precisamos entender quais eram as condições por eles encontradas quando ali chegaram a partir de 1950, e até a década de 1970. Segundo Gwendolyn Wright ${ }^{23}$, para os professores de arquitetura em universidades americanas foi o currículo de história que elevou seus programas acima das escolas de engenharia e minas, onde estavam originalmente alocadas. O estudo de história teria lhes dado autonomia e legitimidade dentro do quadro da academia. $\mathrm{Na}$ virada do século XIX para o XX, as escolas de arquitetura nos Estados Unidos estavam sendo abertas dentro de universidades ou como instituições autônomas. ${ }^{24}$ As primeiras escolas eram inevitavelmente calcadas no exemplo europeu ${ }^{25}$, um rastro do senso de inferioridade colonial, talvez. As grandes referências de ensino eram a Ecole des BeauxArts, de Paris, a Bauakademie de Berlin, gerida por Schinkel, e a King's College, de Londres, desfiada pela Architectural Association, formada por jovens projetistas em 1847.

Nesse momento na Europa o estudo de história da arquitetura se confundia com o ensino de repertório estilístico, e valorização do patrimônio construído.

Nesse ambiente acadêmico, a cultura arquitetônica estava atrelada à valorização dos monumentos do passado. Nas escolas de arquitetura americanas, a cultura e a história arquitetônicas eram claramente fixadas no ideal e patrimônio europeu. De início, poucos textos tinham tradução para a língua inglesa. Autores como Julien Guadet, Viollet-le-Duc e Otto Wagner teriam suas obras traduzidas pela atividade de intelectuais como Nathan Ricker. ${ }^{26}$ Essa atitude permaneceria até a virada de século ${ }^{27}$. Os primeiros livros de referência para ensino de arquitetura escritos sob o ponto de vista americano surgiriam ao final do século. A. D. F. Hamlin publicou o seu manual, Textbook on the History of Architecture já em 191528, uma obra compreensiva de diversos períodos da arquitetura mundial, ainda com inegável foco na produção européia ${ }^{29}$. O

22 Idem, p.94.

23 Em "History for Architects", em The History of History..., pp. 13-52.

24 A primeira instituição a instalar um programa profissional de arquitetura foi o MIT, em 1865, logo seguida por outras instituições como em Ilinois, Cornell, Syracuse e Columbia, até chegar a soma de mais de 80 instituições e universidades nos anos 1890. Ver também Dell Upton, "Defining the Profession", in Joan Ockman, The Architectural School, 2012, pp. 36-65, e Michael J. Lewis, “The Battle between Polytechnic and Beaux-Arts in the American University", Idem, pp. 66-89.

25 Gwendolyn Wright, pp.14.

26 Idem, pp.17.

27 Segundo Gwendolyn Wright, o recurso à história foi aplicado pelos arquitetos em busca de credenciais que os distinguissem dos carpinteiros e construtores comuns, pp.18.

28 A. D. F. Hamlin, A Text-Book of the History of Architecture. New York: Longmans, Green and Co., 1915.

29 Idem. A proposta da publicação original de 1896, por parte de Hamlin, professor na Universidade de Columbia, era fornecer um manual amplo e embasado para os estudantes de arquitetura. A predominância do material europeu é visível - apenas um capítulo é dedicado aos Estados Unidos, e outro para a arquitetura oriental (China, Índia e Japão), sintomática da postura de assimilação de seu 
livro de Russel Sturgis, European Architecture: A Historical Survey (1896) se destacaria pelo uso de fotografias, pioneiramente utilizadas por Ruskin em seu livro publicado algumas décadas antes, The Stones of Venice ${ }^{30}$.

Alguns livros europeus ainda teriam grande influência sobre o ensino na América, como o Eléménts et Théorie de l'Architecture, de Guadet, de 1902, e o livro de Auguste Choisy, professor da Escola Politécnica de Paris, Histoire de l'Architecture, publicado em 1899, que introduziria no debate acadêmico, tanto na América quanto na Europa, alguns fatores interessantes no questionamento da hegemonia da abordagem formal na arquitetura ${ }^{31}$. Este último, por meio de suas representações gráficas em perspectiva axonométrica dos monumentos da arquitetura histórica, valorizaria a estrutura e a tridimensionalidade das construções, colocando o jogo de proporções clássicas das fachadas em segundo plano ${ }^{32}$. Também existe em Choisy um tom de moralismo e um ideal místico de arquitetura como expressão pura de uma sociedade e de um tempo. Mais à frente essa mudança de comportamento apontará para a postura receptiva por parte dos alunos das faculdades de arquitetura na América à doutrina modernista de genealogia alemã, baseada na apropriação da dialética hegeliana e do conceito de Zeitgeist.

No campo de ensino de projeto, o MIT, em Massachussets, e mais tarde (1865) a Universidade de Columbia, em Nova Iorque, ambas capitaneadas por William R. Ware foram as primeiras instituições a aplicar o método francês de pedagogia formal de arquitetura. A partir daí o método se proliferou pelo país. No momento da Primeira Guerra Mundial o Beaux-Arts Institute of Design (BAID) tinha sido estabelecido nos Estados Unidos, mais especificamente em 1916 em Nova Iorque, tomando a responsabilidade de gerir um sistema nacional de concursos de arquitetura que começou em 1894 com a Society of Beaux-Arts Architects, e organizar cursos não só de arquitetura, como também de pintura e escultura e outras artes decorativas ${ }^{33}$.

A centralização das discussões através dos eventos promovidos pela BAID encontrou desafios na relação com o vasto território americano e as particularidades de suas diversas paisagens acadêmicas e culturais. $\mathrm{O}$ entusiasmo pelos concursos de arquitetura organizados pela BAID não eram unanimidade entre as escolas americanas. Em Harvard, por exemplo, o sentimento de emancipação era claro. Dadas as suas especificidades locais - como em outras regiões - arquitetos locais acreditavam na capacidade de organizar eles mesmos sua própria cena. ${ }^{34}$

O reconhecimento da cultura nacional de construção viria somente mais tarde, com o

partido arquitetônico por parte das instituições de ensino da costa leste dos Estados Unidos nesse período, especialmente Columbia.

30 Gwendolyn Wright, "History for Architects", p. 19

31 Idem, pp. 22-23

32 Ver o capítulo sobre Choisy em Reyner Banham, Teoria e Projeto na Primeira Era da Máquina, de 1960.

33 Gwendolyn Wright, "History for Architects",pp. 20-21

34 Anthony Alofsin, in Joan Ockman, p. 93. 
estabelecimento de uma produção intelectual impressa por parte dos historiadores de arquitetura americanos assim como por observadores estrangeiros, fascinados pelos desenvolvimentos técnicos e programáticos da arquitetura local. O input inicial viria pelo reconhecimento da importância da preservação do patrimônio histórico nacional, paradoxalmente evocado pela valorização de regionalismos. Não por acaso, a arquitetura vernacular e as influências hispânicas e orientais seriam a referência da primeira geração de arquitetos modernos na Califórnia, como Irving Gill e os irmãos Greene. Motivos abstratos e referências de arte africana seriam aplicados por Wallace Harrison, que ensinaria na Universidade de Columbia nos anos 1920, em alguns dos mais famosos arranha-céus de Nova Iorque. A modernidade embebida dos arranha-céus comporia o quadro em transição da arquitetura moderna americana ao final da década de 1920, junto com casas Georgianas e com o conjunto construído da escola de Chicago, na publicação inclusiva de Fiske Kimball, um breve ensaio publicado como American Architecture, de 1928. Uma nova atitude a respeito do legado americano estava em voga, junto com o reconhecimento do americanismo na arquitetura ${ }^{35}$. Arquitetos europeus em visita ou como imigrantes permanentes se interessaram em relatar as novas expressões da arquitetura americana. Amerika: Bilderbuch Eines Architekten (1929), de Erich Mendelsohn e Wie Baut Amerika, 1927, de Richard Neutra são exemplos dessas publicações ${ }^{36}$. Neutra, especialmente, relataria sobre as obras da costa oeste americana em uma das seções do CIAM ${ }^{37}$. A publicação de Henry-Russel Hitchcock, Modern Architecture: Romantism and Reintegration, de 1929, substituiria muitas das raízes européias por referências aos pioneiros da arquitetura moderna norte-americana. Profissionais como Richardson, Sullivan e Wright, arquitetos já estabelecidos entre a recém inaugurada crítica da arquitetura moderna, seriam elevados por Hitchcock ao patamar dos pioneiros do movimento moderno enquadrados por Nikolaus Pevsner em Pioneers of the Modern Movement de 1936.

\section{Americanismo: uma agenda de formação}

Para Anthony Alofsin, arquiteto e historiador de arquitetura formado em Harvard e professor em Austin, Texas, a visão do período entre as duas guerras mundiais mira demonstrar que bem antes da chegada dos celebrados imigrantes modernistas na década de 1930 um número de escolas norte-americanas já teriam feito importantes tentativas de atualizar seus programas ajustando-se a condições sociais em transformação, novas demandas econômicas, e tecnologia em evolução. ${ }^{38}$ Ele coloca a

35 Ver Gwendolyn Wright, pp. 28. Ver Scènes de la vie future (Flammarion,1995), de Jean-Louis Cohen.

36 Ver o capítulo 3 desta dissertação para uma discrição mais profunda da publicação de Eric Mendelsohn.

37 Na edição de 1929 do CIAM em Frankfurt que Neutra apresenta os exemplares da arquitetura americana para o público de arquitetos modernos europeus.

38 Anthony Alofsin, em Joan Ockman, pp.92. 
transferência do idioma adotado pelos americanos da escola parisiense de Belas Artes para o idioma moderno recém inaugurado como um processo de experimentações, que também indicavam o "interesse contínuo da escola americana por emancipação".

Alofsin traça um paralelo entre a Bauhaus e escolas de vanguarda americanas como instituições de liderança a busca de um alinhamento entre arquitetura e produção industrial ${ }^{39}$. Em Cincinnati, Herman Schneider, diretor da escola de arquitetura local, propôs em 1922 o engajamento de alunos ingressantes em atividades externas aos muros da escola, as quais abrangiam trabalho em companhias de construção, estágios em escritórios de arquitetura e colaborações com indústrias em geral. Na University of Southern California, em 1930, o reitor Arthur Weatherhead incorporou o uso de modelos físicos nos métodos de ensino, além de ensaios de representação tridimensional. Em meados de 1920, a Association of Collegiate Schools of Architecture, fundada em 1912, promoveu a organização do currículo de arquitetura que culminou na padronização do curso de 4 anos para arquitetos, feito não alcançado pela BAID. A Universidade de Oregon foi a primeira a abandonar o sistema de concursos de projeto no começo da década de 1920. Seu diretor, Ellis F. Lawrence, propôs um novo sistema no qual o aluno seria avaliado pelo desenvolvimento de sua investigação individual em ateliê. $\mathrm{O}$ valor da apresentação diminuiu, e o plágio ou reinterpretação foi desencorajado, em benefício à exploração da expressão individual. ${ }^{40}$

A partir de 1919, Everett Meeks instaurou em Yale um sistema de intercâmbio entre os departamentos de arquitetura, pintura e escultura, com igualdade de importância. Em Cornell, sob influência de F. H. Bosworth, o primeiro ano foi inteiramente revisado e, a partir de 1929, os alunos receberam como tarefa curricular o desenho completo de um edifício ${ }^{41}$. A abordagem de Emil Lorch em Michigan pode ser lida como uma das mais heterodoxas. Sua promoção do desenho baseado na abstração formal livre da rigidez do sistema Beaux-Arts foi um grande avanço em direção à "verdadeira arquitetura americana" ${ }^{42}$, como também, paralelamente, se aproximava da linguagem modernista europeia ${ }^{43}$. No aprofundamento de seu currículo protomodernista, Lorch convidou o arquiteto Eliel Saarinen para lecionar em Michigan em 1923. Saarinen transferiu-se para a Cranbrook Academy após dois anos e uma grande exposição de seu trabalho. Nesse interim, Lorch também traria o arquiteto escandinavo Knud Lönberg-Holm para a instituição. Holm, nascido na Dinamarca, trouxe conteúdo construtivista e produtivista soviético para o vocabulário da escola.

A necessidade de valorização do lugar deu ao regionalismo a capacidade de trazer o pensamento moderno para a prática arquitetônica nos EUA. A preocupação

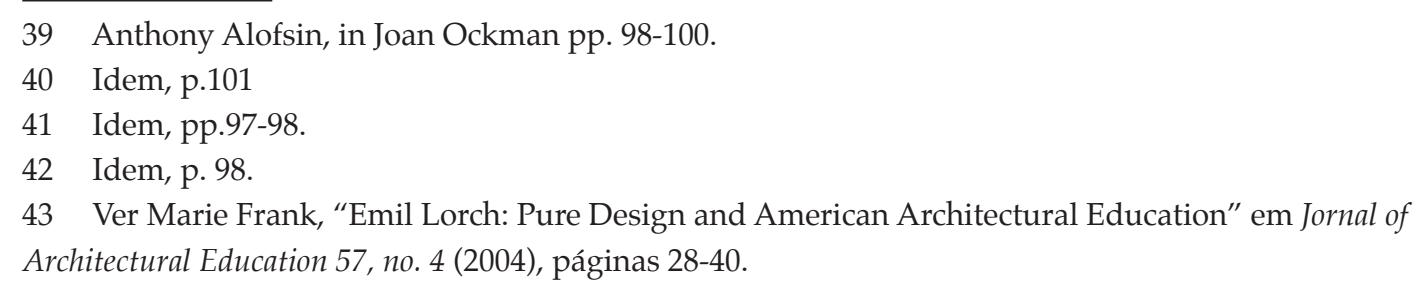


deixaria de ser com o tempo e com a história, e sim com o presente e com as particularidades da cultura e do local ${ }^{44}$. O clima de afirmação do americanismo na arquitetura, paradoxalmente, era interpenetrado pela ampla aceitação da arquitetura moderna de origem européia.

O livro de Le Corbusier, Vers Une Architecture, havia sido recentemente traduzido para a língua inglesa em 1927, e estava presente no interesse geral dos alunos de arquitetura no país ${ }^{45}$. A famosa exposição de 1932 no MoMA de Nova Iorque sobre o Estilo Internacional (International Style), curada por Hitchcock e Philip Johnson, divulgaria a polêmica expressão que cunhou o movimento moderno por anos. Nessa denominação não estão presentes as sementes da discórdia no discurso moderno que viriam a ser interpretadas pelos críticos do pós-guerra na década de 1950.

Foi neste contexto que se deu a primeira onda de migração intelectual européia aos EUA, na qual ali chegariam os antigos mestres da Bauhaus, Gropius e Mies Van der Rohe e muitos outros arquitetos e historiadores, para disseminar um novo uso de história respectivamente em Harvard e em Ilinois.

Em paralelo com o desenvolvimento de grandes instituições, experiências menores e menos ortodoxas tomaram forma durante a década de 1930. A Black Mountain College na Carolina do Norte, fundada por John Andrew Rice, Theodore Dreier, e outros membros do corpo docente de Rollins College. Seguindo o legado de John Dewey, seu currículo era baseado no estudo de arte no centro da formação. Essa postura atraiu Anni e Josef Albers, ex-membros do corpo docente da Bauhaus, no começo de 1933. Buckminster Fuller chegou a lecionar na instituição na década de 1940. A escola fechou em $1957^{46}$. A abordagem ainda mais radical em seu pragmatismo e totalmente moldada no ambiente do atelier do arquiteto foi a Taliesin West, capitaneada por Frank Lloyd Wright. Sua postura pedagógica envolvia o estudante em todo o processo produtivo, colocando-o na posição de construtor de seus próprios projetos. Paolo Soleri, um arquitetos formados pela instituição, e foi talvez o aluno de Wright que mais despertou interesse para Reyner Banham. Esse pragmatismo também se encontra na tentativa de curta duração de Richard Neutra e seu colega vienense Franz K. Ferenz, A Practical Course in Modern Building Art, realizada em Los

44 Nesse contexto, a iniciativa gorvernamental de programas da Era Roosevelt como o Tenesse Valley Authority, o Public Works Administration eram práticas no campo da experimentação moderna.

45 Segundo Willian H. Jordy, na compilação sobre migração intelectual editada por Fleming e Bailyn, a leitura corbusiana da metrópole o do arranha-céu, apropriada de sua própria matéria-prima urbana, seria o olhar estrangeiro que estimularia aquela geração de estudantes de arquitetura: "To interested Americans, as bystanders experiencing this exhilarating episode from a double distance of time and geography, Le Corbusier became the fervent apostle of the modem movement. Gropius' Bauhaus was its collegium."

46 Anthony Alofsin, p. 109. 
Angeles, durante o ano de 1928, com apenas 12 alunos participantes, que teve pontos de tangência com a formação de uma geração de arquitetos californianos como Harwell Hamilton Harris e Gregory Ain ${ }^{47}$.

Segundo Dell Upton, em seu estudo sobre a relação entre ensino de arquitetura e produção vernacular (entre 1890 e 1990), a Society of Architectural Historians (SAH) teve participação decisiva na consolidação de um estudo das formas cotidianas de arquitetura ${ }^{48}$. Segundo Upton, teriam existido duas grandes linhas de pesquisa acadêmica do vernacular nos Estados Unidos: a histórica - focada em elementos sócio-econômicos e técnicos - e a cultural - focada em elementos antropológicos, geográficos e tipológicos. Neste panorama, os arquitetos e historiadores de arquitetura se alimentavam de ambas as fontes. Os primeiros pesquisadores do vernacular Morisson Isham, Irving Whitall Lyon e Henry Chapman Mercer - teceram ligações visuais entre a teoria estética do "pitoresco", muito difundida na Inglaterra, fato conflitante com o caráter nacionalista dado à arquitetura vernacular nos Estados Unidos $^{49}$. De fato, a primeira geração de pesquisadores não emancipou o vernacular de uma tradição de radical britânico Somente após a Primeira Guerra Mundial que este emerge como tradição autônoma ${ }^{50}$. Autores como Fiske Kimball introduziram de maneira mais profunda o estudo das tipologias domésticas nacionais no âmbito da academia. O livro Domestic Architecture of the American Colonies and the Early Republic não só consolidou uma massa crítica sobre a arquitetura colonial, mas também fundamenta o vernacular como linha emancipada de pesquisa ${ }^{51}$. Uma geração de historiadores como John Kouwenhoven, autor de Made in America ${ }^{52}$, Siegfried Giedion, que publicou em 1948 Mechanization Takes Command, se apropriariam do método de abordagem cultural de Kimball para tecer comentários sobre os produtos anônimos da era industrial nos Estados Unidos. Upton considera que Giedion teria aplicado a noção de Zeitgeist para encontrar o ethos do país, uma nova nação mecanizada. ${ }^{53}$ Já John Brinckerhoff Jackson teria entendido que a paisagem vernacular fornecia os valores coletivos que Kouwenhoven e Giedion viam na tecnologia. Para Jackson, a noção de consciente coletivo e tradição cultural eram claros ${ }^{54}$.

Alofsin credita a maior quebra de paradigma de ensino de arquitetura aquela

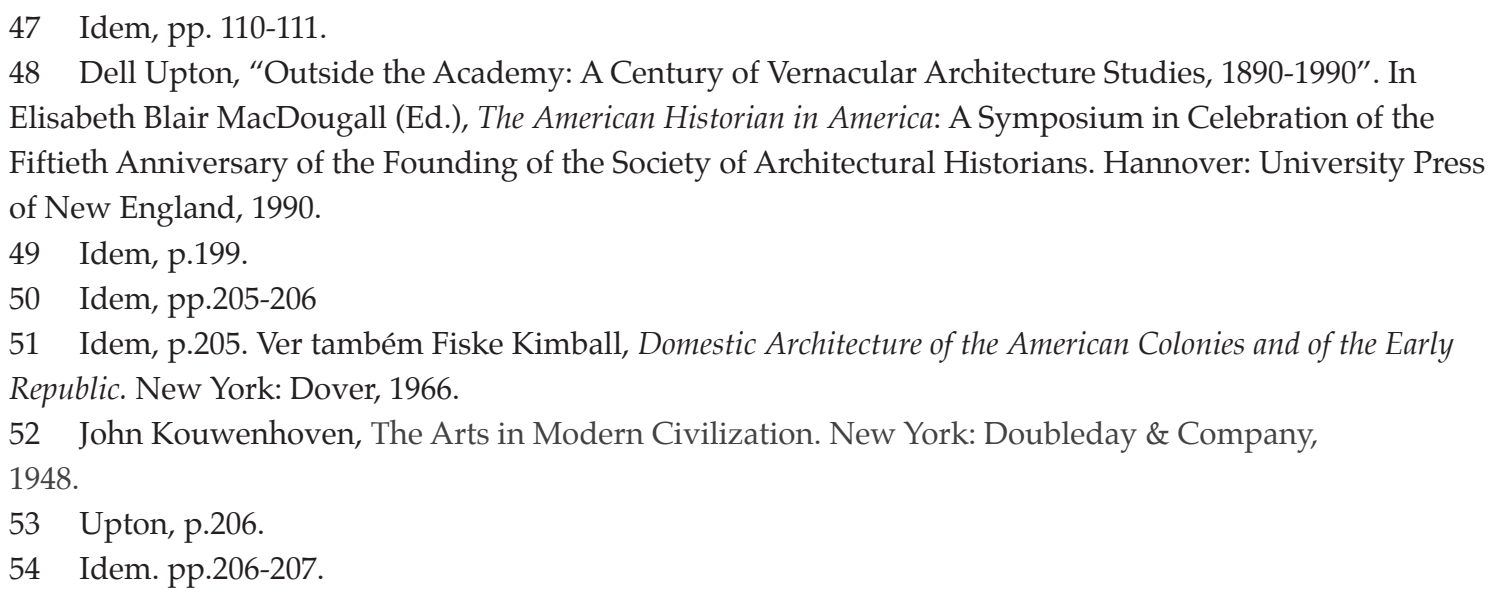


que se deu na Universidade de Columbia, durante a gestão de Joseph Hudnut ${ }^{55}$. Nascido em 1884, Hudnut pertenceu a uma das primeiras gerações de docentes americanos formados no século XX. Em 1926, Hudnut assumiu uma cadeira como professor de história da arquitetura, para tornar-se reitor em 1934. Acreditando que a arquitetura seria tomada no futuro não por beleza e conforto, mas por desejos de melhorias sociais e avanço tecnológico, Hudnut defendeu embeber a arquitetura de uma atitude científica, similar a de um químico, ou engenheiro ${ }^{56}$. Devemos notar, contudo, que diferentemente da admiração que Corbusier nutria e expunha em suas publicações, Hudnut e seus compatriotas eram dotados de um pragmatismo e de uma aproximação muito maior para com o fato da industrialização enquanto processo, a partir da lógica da linha de produção, e não como estética a ser emulada.

Hudnut não somente levantava a questão a respeito da noção de realismo na técnica construtiva, e da necessidade por parte dos estudantes de arquitetura em projetar apenas o que fosse possível construir, como também reforçava a importância do aspecto comercial da profissão: ao invés de projetar catedrais e palácios, caberia aos arquitetos se engajarem com as instituições humanas de importância para a sociedade $^{57}$. Para tal, ele montou um arcabouço de ensino que reproduzia o ambiente do escritório de arquitetura dentro do ciclo de ensino de projeto. É notável, segundo Alofsin, que a abordagem de Hudnut sobre ensino de arquitetura parta do estudo de história da arquitetura. Ele considerava o conteúdo importante para o arquiteto, ainda que não devesse fazer parte do corpo de disciplinas primordiais do ciclo de graduação, e sim do ciclo básico ou undergraduate ${ }^{58}$. O ensino de história, portanto, não foi incorporado no currículo de Columbia durante a gestão de Hudnut, fato que repercutiu no circuito de ensino de arquitetura por décadas nos Estados Unidos.

Malgrado o pioneirismo creditado a Columbia, foi em Harvard que a proposta de Hudnut teria tido maior impacto. Sua performance em Nova Iorque atraiu o interesse do reitor James Bryant Conant e em 1935 Hudnut foi chamado para assumir o cargo de diretor da escola de arquitetura de Harvard. O objetivo era ambicioso, e Hudnut foi incumbido de fundir as escolas de arquitetura, desenho da paisagem e planejamento urbano em uma só instituição. ${ }^{59}$ Ao contrário da prática nos primeiros 40 anos de existência da escola de arquitetura em Harvard, o foco não seria mais em história da arquitetura, mas na prática de projeto.

Alofsin credita a grande repercussão do programa de Harvard a Hudnut. Já na chegada de Walter Gropius a seu cargo na escola, o arcabouço pedagógico

\footnotetext{
55 Anthony Alofsin, pp.102-103.

56 Idem, pp. 101

57 Idem, pp. 102-103.

58 No sistema americano de ensino, os anos undergraduate se referem ao college, um ciclo básico de ensino das universidades que precede o ciclo de graduação. Sua duração pode variar de 2 a 4 anos, dependendo da instituição.

59 Ver Alofsin, p. 103.
} 
estava construído. Tampouco o processo pode ser lido como monolítico. A polifonia de modernismos, desde o abstracionismo miesiano e suas vertentes californianogermânicas, à arquitetura orgânica de Frank Lloyd Wright, a referência de um só movimento não existe.

\section{Os alemães e os usos da História nos EUA}

Segundo Gwendolyn Wright, quando Hudnut trouxe Walter Gropius para Harvard em 1937, ele também teria olhado para além da história das ciências sociais. Como um notório intelectual europeu e social-democrata, Gropius teria estabelecido ligações com cientistas sociais notáveis, incluído o sociologista Talcott Parsons, a quem ele trouxe para o conselho do Departamento de Planejamento Regional, e o economista político Charles Merriam, que se juntou ao Comitê Visitante. Mais tarde, Giedion também foi trazido por Gropius, para assumir a cadeira Charles Eliot Norton de professor de poesia em Harvard, em 1938 ${ }^{60}$. Gropius reconhecia que outras disciplinas também exploravam teorias de percepção psicológica e interação social que transcendiam a história. Ao invés de desvalorizar a história, como é dito frequentemente, Gropius a estendeu através das conexões com as ciências sociais. ${ }^{61}$

Após um ano de atividades dentro do novo sistema de ensino, o novo currículo da escola de arquitetura, paisagismo e planejamento urbano de Harvard estava estabelecido. No verão de 1936 Hudnut viajou para a Europa para localizar alguém capaz de assumir o cargo de diretor do departamento de arquitetura da escola. Walter Gropius foi selecionado entre uma pequena lista na qual estavam também Ludwig Mies Van der Rohe e J. J. P. Oud, outros mestres do Estilo Internacional. Gropius se encontrava em uma situação precária, recentemente exilado da Alemanha, sua terra natal, vivendo na Inglaterra com futuro profissional incerto. Era, entretanto, uma figura reconhecida, com status de arquiteto-estrela de grande reputação, mesmo nos Estados Unidos ${ }^{62}$. Enquanto a gestão de Gropius estava cercada de interesse e polêmica dentro do meio acadêmico americano, Mies van der Rohe seguiu um caminho com diversos pontos de tangência com o de seu ex-colega de corpo docente na Bauhaus. Em 1938, Mies assumiu o cargo de chefe do Departamento de Arquitetura do Armour Institute em Chicago, mais tarde rebatizado de Illinois Institute of Technology. Além de deixar sua marca através da propagação do sistema de ensino de arquitetura segundo sua visão - e baseado em sua experiência prévia como diretor da Bauhaus Mies também projetou o novo campus da instituição, deixando sua marca de maneira

60 As series de palestras (Norton Lectures) ministradas entre 1938 e 1939 dariam origem ao seu mais importante livro publicado, Space, Time and Architecture: the Growth of a New Tradition. Cambridge: Harvard University Press, 1941.

61 Gwendolyn Wright, 1990, pp.31.

62 Margret Kentgens-Craig, The Bauhaus and America: First contacts 1919 - 1936. Cambrigde: The MIT Press, 1999. 
ainda não alcançada quando em solo europeu, tanto em escala quanto em liberdade de apropriação do conceito de projeto. ${ }^{63}$

O interesse de Gropius pelos Estados Unidos teria começado antes de sua chegada como professor em Harvard, e demonstraria a valorização mútua entre o público americano e os profissionais europeus recém-exilados. Gropius já havia realizado o projeto da fábrica de sapatos Fagus Werk, muito marcada pela referência à arquitetura industrial americana ${ }^{64}$; já teria publicado um relatório sobre o conjunto construído industrial americano, Die Entwicklung moderner Industriebaukunst, no anuário da Werkbund alemã ${ }^{65}$. Marcel Breuer, que acompanharia Gropius como professor em Harvard, também nutria admiração pela intimidade dos americanos com os processos de construção e da técnica:

"O americano tem um instinto para eficiência. Eu não digo "know-how", e eu não gosto da frase. A eficiência Americana vai além de 'know-how'. Eu vejo essa qualidade no menor empreiteiro. É a maneira como ele planeja cada movimento; a maneira como ele encomenda materiais; a maneira que ele os armazena e os posiciona ao redor do canteiro. Americanos tem um instinto para construção. Cada dona de casa na América sabe o que uma caixa 'quatro-por-dois' é. Mulheres europeias não sabem tais coisas." 66

O reconhecimento de Breuer da produção americana apontava para o novo uso da história pelo método moderno de ensino. Muitos educadores americanos acreditavam que uma nova era na história da arquitetura estava em sua iminência ${ }^{67}$. Se era necessário legitimar sua própria genealogia e a canonização de seus próprios santos, os historiadores europeus partidários do movimento moderno já o tinham feito. Entre outros, Siegfried Giedion, diretor-geral do CIAM publicara em 1941 o seu Space Time and Architecture, todavia já teria sido apresentado em Harvard em uma série de palestras em 1938-39. Giedion, tal como Pevsner, e até certo ponto Emil Kaufmann, teriam construído cada um sua genealogia da arquitetura moderna, fazendo uso de

63 Anthony Alofsin, pp. 106-108.

64 Ver o capítulo 2 desta dissertação para detalhes da relação entre Gropius e a paisagem industrial americana.

65 Uma das mais detalhadas análises da relação entre o conjunto construído americano e a arquitetura moderna da vanguarda de 1920 e 1930 na Europa foi escrita por Reyner Banham, em A Concrete Atlantis, de 1986, publicado pela MIT Press.

66 Citação de Marcel Breuer extraída do ensaio de William H. Jordy, em Intellectual Migration: Europe and America 1930-1960, editado por Donald Fleming e Bernard Bailyn em 1969. Original: “The American has an instinct for efficiency. I don't say 'know how,' and I don't like the phrase. American efficiency goes deeper than 'know how.' You see this quality in the smallest contractor. It's the way he plans every move; the way he orders materials; the way he stacks them and places them around the job. Americans have an instinct for building. Every housewife in America knows what a two-by-four is. European women don't know such things."

67 Ver Gwendolyn Wright, pp. 33. 
exemplos da história para legitimar sua versão de arquitetura moderna. De fato, em duas décadas, os Estados Unidos assumiram um novo lugar na historiografia do moderno, já distante da situação registrada pela geração de historiadores nativos como Hamlin, e presente também, como vimos, nas obras de Giedion, como também na obra de Bruno Zevi, que estudou em Harvard, sob a gestão de Gropius, durante a Segunda Guerra Mundial.

A presença dos mestres da Bauhaus em Harvard afetaria também as outras intituições. O esforço por construir uma tradição que legitimasse a prática moderna reforçou o papel de Le Corbusier, Gropius, Mies, Wright e Breuer como mestres da arquitetura moderna. $\mathrm{O}$ passado eclético tornou-se mal visto nos meios acadêmicos renovados. Com isso, o ensino de história também foi de certa maneira reduzido ou banido das instituições americanas durante duas décadas, sob o argumento de que a imposição de formas do passado coibiria o aluno de arquitetura em sua busca do projeto original, baseado na abstração cubista e na forma pura. ${ }^{68}$ Bruno Zevi, aluno de Gropius na Bauhaus, teria relatado com tom crítico a ausência deliberada do curso de história da arquitetura do currículo da Bauhaus ${ }^{69}$. Para apoiar seu argumento, Zevi teria parafraseado Gropius em seu ensaio sobre educação em arquitetura publicado em inglês, "Blueprint of an Architect's Education", em 1949:

“Estudos em história da arte podem aferir princípios encontrados pelo estudante através de seus estudos prévios em superfície, volume, espaço e cor; eles não podem desenvolver por si mesmos, contudo, um código de princípios válidos para a presente criação em projeto. Princípios devem ser estabelecidos para cada período a partir de novos trabalhos criativos. Os estudos em história são dessa maneira melhor oferecidos para alunos mais velhos, os quais já encontraram sua auto-expressão. Quando um inocente iniciante é introduzido às grandes realizações do passado ele muito é muito facilmente desencorajado de tentar criar por si próprio." ${ }^{70}$

Gropius se defendia das acusações de Zevi, quanto ao abandono da disciplina de história, apontando a evidente tradição de Schinkel em seu trabalho, inclusive na Bauhaus. De fato, a atitude de Gropius em relação à história mudaria, de Dessau

68 Gwendolyn Wright, pp. 36 e Winfried Nerdinger, em seu artigo "From Bauhaus to Harvard: Walter Gropius and the Use of History", dentro da coletânia de Gwendolyn Wright, pp. 89.

69 Winfred Nerdinger, pp. 89-90.

70 Gropius, apud Winfried Nerdinger, "From Bauhaus to Harvard: Walter Gropius and the Use of History", in Gwendolyn Wright, History od History in American Schools of Architecture, 1865-1975, pp.91. Original: Studies in the history of art and architecture can verify principles found by the student through his own previous exercises in surface, volume, space and color; they cannot by themselves, however, develop a code of principles to be valid for present creation in design. Principles have to be established for each period from new creative work. History studies are therefore best offered to older students who have already found self-expression. When the innocent beginner is introduced to the great achievements of the past he may be too easily discouraged from trying to create for himself. 
a Boston, mas a história que emerge vem como legitimação da prática moderna, chamada de "busca pela essência". Segundo Nerdinger, a migração inicial de Gropius a Inglaterra teria mudado sua atitude em relação à História de maneira decisiva. Cerceado de sua própria tradição e confrontado com um campo onde as pessoas nutriam um forte apego à história, Gropius teria refletido sobre a relação da arquitetura moderna com a mesma. Nerdinger cita o próprio Gropius: seu foco é a busca de processos; sua postura, moralista e idealista em relação à técnica.

"A nova arquitetura é de forma alguma em oposição à "tradição" propriamente dita. O respeito pela tradição não significa ... a aceitação ou dominação das formas estéticas do passado. Significa e sempre significou a preservação da essência dos processos de esforço para conseguir chegar ao que se encerra em cada material e em cada técnica. ."71

Ludwig Mies Van der Rohe construiu seu arcabouço histórico para legitimar sua prática de ateliê, tal qual Gropius. Mas ao contrário de Gropius, Mies, interessado em difundir o conceito de espírito da época traduzido em espaço. Segundo Kevin Harrington, se Gropius acreditava que o ensino dos antigos esquemas endureceria o aluno em sua criatividade, Mies usava a história para determinar um padrão de qualidade, deixando o desafio de superar os antigos modelos aos alunos e suas ambições. ${ }^{72}$

Mas o ensino de história na concepção de Mies estaria mais próximo de outras áreas do conhecimento, como filosofia e matemática. Seria mais focado no próprio ensino de teoria do que na descrição histórica, paradoxalmente com a exposição de exemplos da antiguidade. Mies buscava o eterno no passado através do estudo da história e na sua inscrição espacial no presente. Por trás do ensino de arquitetura de Mies, refletidos tanto no currículo quanto na prática no Illinois Institute of Tecnology (IIT), estava a tensão entre o impessoal, e as formas que definem uma era, e o papel do arquiteto em entender e dar forma a essas forças. Ao enfatizar a ideia de Zeitgeist, Mies encorajou o estudo de história como método para entender as relações intrínsecas aos elementos que davam à cada era sua característica particular:

“Tal como em seu famoso aforisma, "Menos é Mais", se juntaram dois conceitos

71 Walter Gropius, citado por Nerdinger, pp. 91. Texto original: The New Architecture is nowhere and in no sense in opposition to "tradition" properly so called. Respect for tradition does not mean. . . the acceptance or domination of bygone aesthetic forms. It means and always has meant the preservation of essentials in the process of striving to get at what lies at the back of all materials and every technique

72 Kevin Harrington, “Aphorisms, Axioms, \& Anonymous Heroes: The History of Architecture in Mies's Curriculum at the Illinois Institute of Technology, in Gwendolyn Wright, History od History in American Schools of Architecture, 1865-1975, pp.99-110. 
opostos com equivalência linguística, o currículo de Mies era simultaneamente preocupado com o abstrato e o concreto, com o Zeitgeist e com o tijolo."73

Para coordenar os cursos de história no Armour Institute, a partir de 1938, Mies chamaria seu colega alemão Walter Peterhans ${ }^{74}$. Sua formação em filosofia e matemática o qualificaria para suas atribuições e o desafio de ensinar história como diferencial, acentuando o sentido da Zeitwille (vontade de uma era) de Mies e afirmando o presente. Peterhans teria colaborado na construção das famosas fotomontagens de Mies, as quais foram usadas primeiramente no ensino de história.

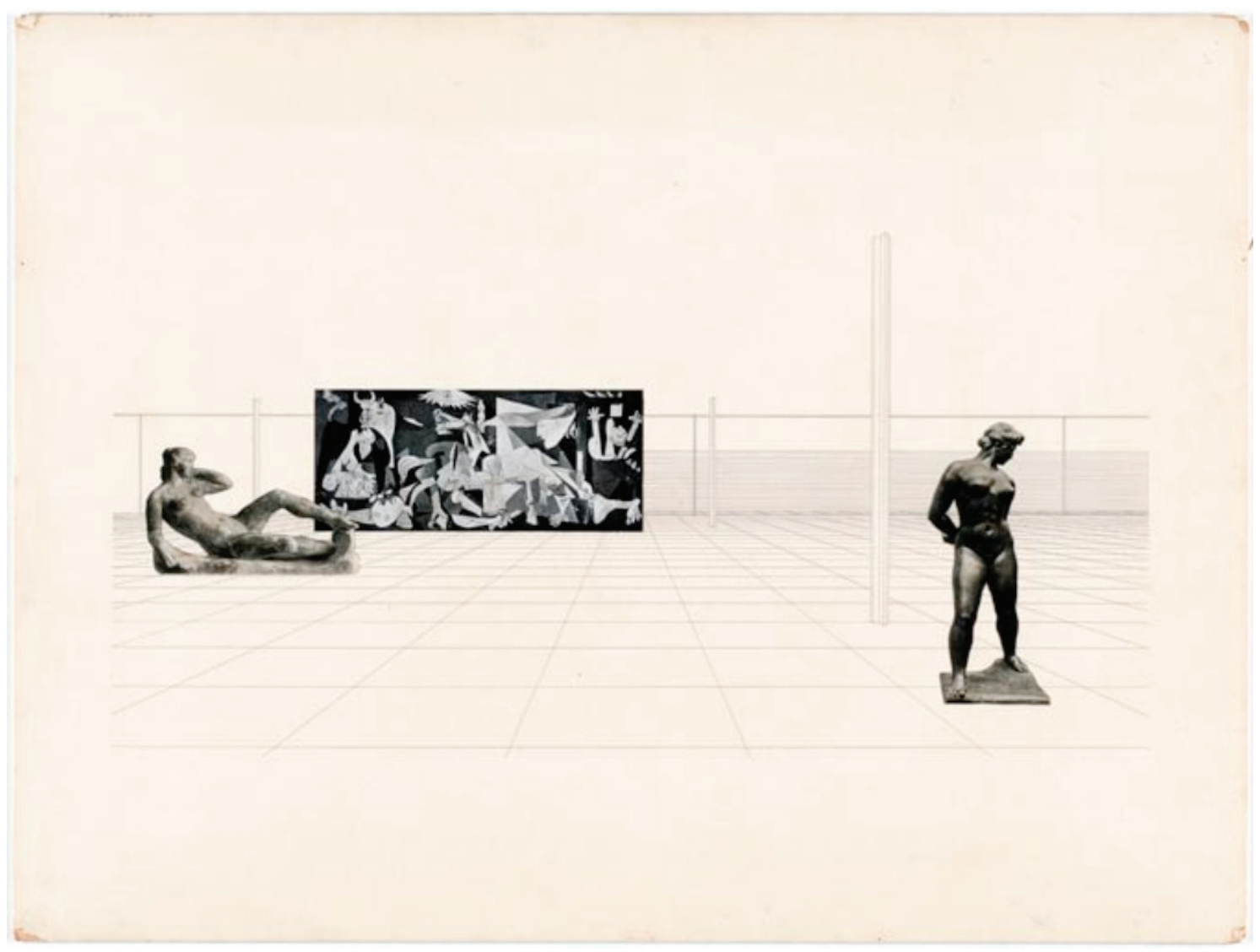

Ludwig Mies Van der Rohe, Museu para uma cidade pequena, 1941-43, perspectiva em fotomontagem. Fonte: Arquivos MoMA.

Segundo Harrington, o problema de como se poderia alcançar o Zeitgeist

73 Idem, p. 100. Texto original: Just as his most famous aphorism, "Less is more," joined two opposed concepts with linguistic equivalence, Mies's curriculum was simultaneously concerned with the abstract and the concrete, the Zeitgeist and the brick

74 Ver Kevin Harrington, "Aphorisms, Axioms \& Anonymous Heroes: the history of Architecture in Mies's curriculum at the Illinois Institute of Technology", em WRIGHT, The History of History in American Schools of Architecture, 1990. 
seria pensado da seguinte maneira: assume-se a presença do espírito da época, para produzir uma forma arquitetônica que expresse sua vontade - Zeitwille. $\mathrm{O}$ papel do individual é considerar e articular tendências correntes e redirecionar seus pensamentos ao longo das linhas dessas tendências. Através de colagem e fotomontagem, Peterhans pôde oferecer novas formas justapostas de maneira crítica às formas caóticas dos trabalhos anteriores, mal-orientados, do passado. ${ }^{75}$

No paradigma moderno de ensino, o estudo de história da arquitetura, quando não abandonado, seria colocado à serviço do ensino de ateliê. Em alguns casos, no entanto, alunos interessados no estudo de história da arquitetura se voltaram aos departamentos e institutos de história da arte e arqueologia ${ }^{76}$. No caso das universidades americanas, os estudantes transitavam entre campos do conhecimento. Dessa maneira, as disciplinas - e seus paradigmas em relação ao estudo da forma compositiva - se deixaram interpenetrar. Durante os anos 1920, 1930 e 1940, a história da arquitetura, ausente dos debates dentro do ciclo de historiadores da arte, reaparece. Nessa trilha podemos observar a reconciliação entre não somente arquitetura e história, mas também entre o racionalismo e a sensibilidade aguçada pelos estudos das ciências humanas, como Earl C. Kelley, que sintetizou, em seu discurso de 1947, o interesse por reconciliação com as humanidades, bem como a crítica à tecnocracia que permeava tanto academia quanto produção profissional americanas:

"A civilização deve significar mais do que ferramentas, mais do que banheiros azulejados e bombas atômicas. Deve implicar no alinhamento às éticas mais elevadas daquelas mantidas pelos incivilizados. Deve significar o encontro de grande bondade pessoal pela realização de um bem coletivo. Para a educação, deve significar um novo esquema de padrões, construídos pelo cooperativismo, ao invés do ponto de vista da punição e da competição." 77

Discípulo de John Dewey, teórico do pensamento pragmático americano e professor em Columbia, Kelley propunha o retorno ao realismo concreto, dotado de uma carga de informações de experiências prévias, que afloram no observador da arquitetura e da paisagem construída. O conceito Deweyano era compartilhado por pesquisadores também focados em psicologia como Adalbert Ames. Siegfried Giedion, após assistir a uma apresentação de Ames em Princeton, em 1938-39, teria,

\footnotetext{
75 Kevin Harrington, pp. 104.

76 Kevin Harrington, pp. 104-106

77 Earl C. Kelley, apud Ockman e Sachs, em Ockman, 2012, p. 136. Texto Original: Civilization must mean more than gadgets, more than tiled bathrooms and atomic bombs. It must imply attainment of ethics higher than those held by the uncivilized. It must mean the finding of the greatest personal good by the achievement of the greatest good for all. For education, it must mean a new set of patterns, built from the cooperative, rather than the punitive and competitive, point of view.
} 
segundo Joan Ockman, trazido conceitos a respeito do ato de 'sentir' e 'pensar' para o campo das problematizações da modernidade arquitetônica ${ }^{78}$. A partir da exposição a tais questões, Giedion teria criticado a ilusão do progresso e o risco da tecnocracia, e atentaria para a necessidade de equilíbrio entre ambientes naturais e artificiais, especialização e universalização, quase como profetizando questões chave do debate arquitetônico para décadas a frente ${ }^{79}$.

A segunda onda de migração intelectual no campo da arquitetura, a qual nos interessa, também tem a Segunda Guerra mundial como referência, malgrado começa posteriormente ao final do conflito. $\mathrm{O}$ descompasso entre a ascenção da economia americana e a reconstrução das economias europeias é pano de fundo para a nova postura das instituições americanas de ensino.

\section{O vernacular "as found" na inglaterra}

"A ênfase e também grande parte do conteúdo desta cultura [inglesa] era mericana porque não havia nada mais. Uma vez que nós não conseguíamos adquirir quadrinhos americanos, nos comprávamos uma cópia de Punch por engano e nunca mais, somos culpados disso? Essa era nossa cena. E pensar que isso era verdade para muitos de nós, especialmente aqueles que formaram o Independent Group, que marcavam o ritmo do começo da década de 1950 em Londres. Daí que nós viemos, e nos deixou em uma situação peculiar, visto as divisões comuns da cultura britânica. Porque nos tínhamos essa inclinação à América, ainda assim muitos de nós era de certa maneira de esquerda. ${ }^{"} 80$

Segundo a historiadora inglesa e crítica de arte Anne Massey, a Segunda Guerra Mundial foi um divisor de águas para a história da arte britânica ${ }^{81}$. Dividindo dois momentos da crítica e do ensino de arquitetura no país, a partir da Segunda Guerra Mundial, destaca-se a hegemonia da referencia americana parace suplantar

\footnotetext{
78 Segundo Ockman, questões que percorreram sua publicação de 1941, Space, Time and Architecture. Ver também a dissertação de PhD de Reto Geiser, “Giedion in Between” ETH Zurique.

79 Também segundo Ockman, agora mais claramente expostos no livro Mechanization Takes Command, de 1948, pp. 714-723

80 Reyner Banham, "The Atavism of the Short Distance Mini-cyclist", in Penny Sparke (org.), Design By Choice, p.85.othing else. Once when we couldn't get American comics we bought a copy of Punch by mistake and never again, do you blame us? This was our scene. And to think this is true for a great many of us, specially those who made up the Independent Group, who were the pacemakers of the early and middle fifties in London. Now this is where we came from, it left many of us in a very peculiar position, vis-à-vis the normal divisions, of English culture. Because we had this American leaning and yet most of us are in some way Left-oriented

81 Para uma das mais profundas pesquisas em torno da geração moderna britânica de 1950 e o Independent Group, ver Anne Massey, The Independent Group: Modernism and Mass Culture in Britain, 1945-59. Manchester: Manchester University Press, 1995
} 
o modernismo do continente, especialmente durante a década de $1950^{82}$. No entanto o modernismo se manteve como uma linguagem comum antes e depois da Guerra, malgrado a discussão se tenha se mantido em torno de sua relevância social, e que deveria dar espaço a um novo tipo de expressão estética. Neste contexto, os fundadores do Institute of Contemporary Arts (ICA), berço do grupo inglês Independent Group, formaram a geração responsável por uma das primeiras revisões críticas marcantes do modernismo. O objetivo dessa sessão é descrever essa geração, mais especificamente o Independent Group, do qual Reyner Banham fez parte, e do qual podemos identificar o surgimento de questões que se tornariam recorrentes de sua obra, especialmente o apreço pelo vernacular moderno de origem americana.

Anne Massey estabelece uma ligação entre os jovens artistas, Arquitetos e escritores do Independent Group (IG) com os surrealistas pré-Guerra dos anos 1930. A negação da lógica abstrata para a avaliação. Segundo Massey, a historiografia do IG revela, erroneamente, que as raízes provincianas e "working-class", ou seja, as origens dentro da classe trabalhadora proveram um território comum para o início das atividades do grupo. Massey apresenta que membros proeminentes do grupo como Nigel Henderson, William Turnbull, Eduardo Paolozzi e Richard Hamilton têm em comum uma formação economicamente privilegiada na Slade School of Art em Londres. Henderson, especialmente, vinha de uma linhagem de elite artística britânica: sua mãe Wyn Henderson, era editor da Nancy Cunard's Hours Press, e relacionava-se em Paris com membros do grupo surrealista. ${ }^{83}$

“Inspirados pela filosofia do positivismo lógico e existencialismo, o Grupo chegou ao entendimento do modernismo que enfatizava a história da ciência e da tecnologia e glorificava a desordem da existência humana em oposição ao preciosismo da arte metafísica." ${ }^{84}$

Segundo Massey, durante os anos 1930 o modernismo veio a ser crescentemente identificado com a esquerda socialista. Após 1950, o equilíbrio começou a mudar: a ala radical, mais antiga e rígida do ICA começa a abrir espaço para uma nova ala, mais liberal e mais atrelada à referencia americana - principalmente cinema, mídia impressa e outros elementos da cultura popular. Essa mudança gradual teria refletido na segunda sessão do Independent Group, focada principalmente em cultura americana. Em 1956, quando o grupo interromperia em definitivo seus encontros, o modernismo estava francamente identificado com a América, e a Europa teria perdera a liderança da vanguarda em arquitetura e nas artes. ${ }^{85}$

82 Idem, pp.1-2

83 Ver Anne Massey, pp.33-34.

84 Ver Anne Massey, p.33. Texto original: Inspired by the philosophy of logical positivism and existentialism, the Group arrived at a new understanding of modernism which emphasised the history of science and technology and gloried in the disorder of human existence as opposed to the preciousness of metaphysical art.

85 Idem, p.2. 
“Os significados da cultura modernista na Grã-Bretanha antes da Segunda Guerra Mundial eram claramente definidos. A cultura Modernista era elitista. Ela excluía as massas por conta de sua própria obscuridade. Ironicamente, alianças com políticos de esquerda eram também um fator do modernismo pré-guerra." ${ }^{\prime 6}$

O Independent Group desempenhou a revisão do modernismo através da erosão da fronteira entre alta e baixa cultura, e a reavaliação do consumo e sua importância para a expressão cultural ${ }^{87}$. No campo estético, o abstracionismo geométrico das formas platônicas, preconizadas por Le Corbusier e Loos daria lugar à abordagem iconográfica. Elementos como as propagandas, embalagens de produtos de consumo de massa e revistas em quadrinhos serviam de matéria-prima para colagens, sejam como as de Eduardo Paolozzi (ver imagem abaixo), ou Richard Hamilton, ou como em montagens de Peter e Alison Smithson, nas quais a referência miesiana se combina com elementos da cultura pop.

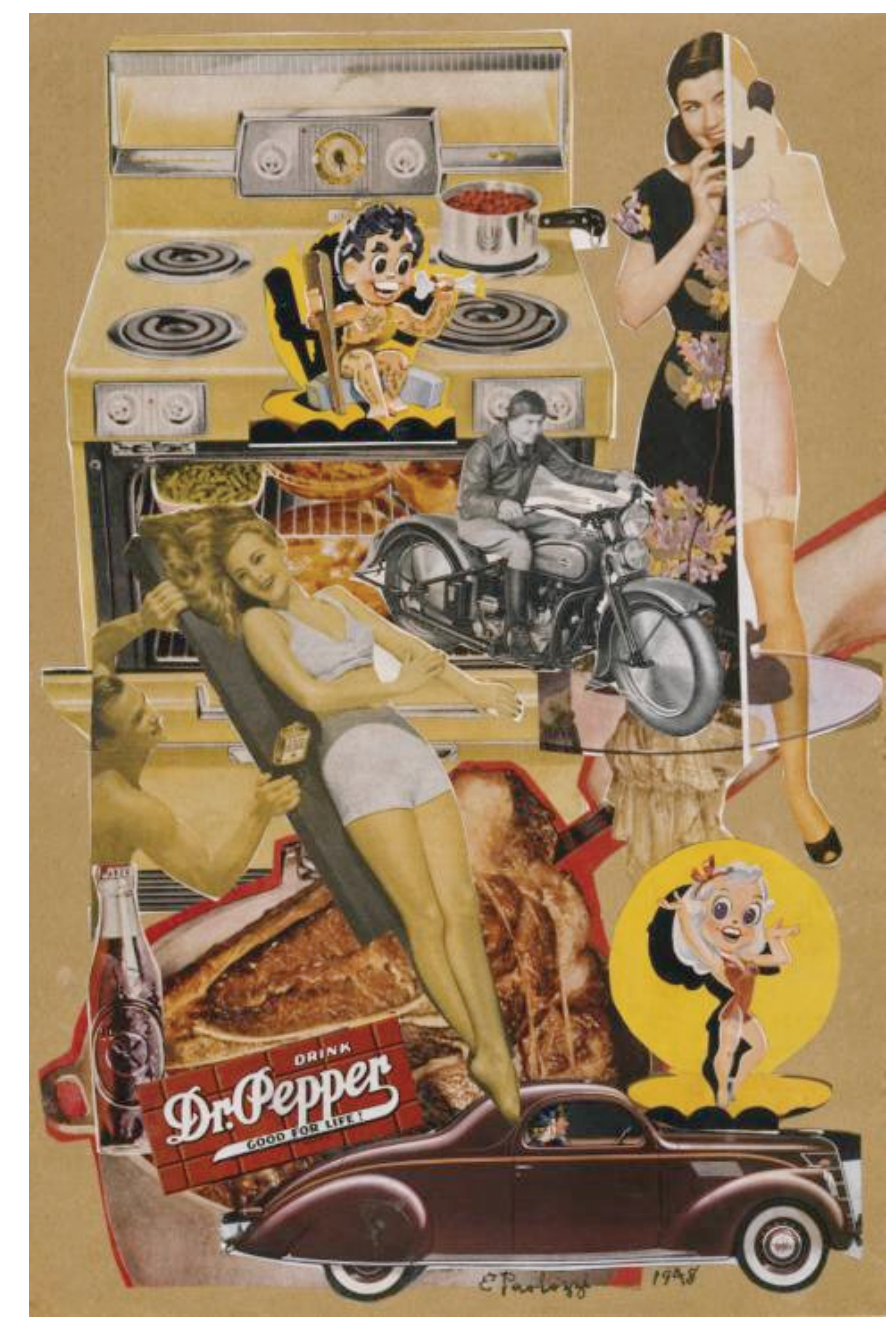

Eduardo Paolozzi, Dr. Pepper

(colagem), acervo Tate London, 1948.

86 Idem, p.4. Texto original: The meanings of modernist culture in Britain before the Second World War were clear cut. Modernist culture was elitist. It excluded the masses by its very obscurity. Ironically, allegiances with left-wing politics were also a key feature of pre-war modernism.

87 Idem, p.3. 
Para Massey a razão para o enfraquecimento da posição britânica no campo da historiografia estaria ligada à ascenção americana no cenário internacional. A Inglaterra estava destruída pela Guerra e com a economia enfraquecida, dedicada à reconstrução: A crise teria gerado uma atmosfera de xenofobia, e a necessidade de reafirmação da cultura nacional. Instituições como o Ministério da Informação que sobreviveu ao período de guerra, divulgava elementos da cultura oficial; em paralelo, a cultura de massa americana, impulsionada pelos sucessos de Hollywood, se espraiva pela sociedade inglesa através dos filmes, propaganda, televisão e música. ${ }^{88}$

No campo bibliográfico, a leitura do livro Growth of Form, de D'Arcy Wentworth Thompson teria sido referencia para a geração de artistas britânicos no pós-guerra, particularmente entre os construtivistas ${ }^{89}$. A ligação crucial entre a tese de Thompson e o IG foi a rejeição do universalismo do homem e do meio, e a crítica à hierarquia cultural, entre cultura erudita e cultura popular, imposta na entre os acadêmicos na Inglaterra ${ }^{90}$. Na introdução de Growth of Form Thompson criticou Charles Darwin, entre outros, por conta de seu conceito teleológico de fim, pelo qual a raça humana tenta explicar o mundo. O abandono da filosofia aristotélica, do estoicismo, e da lógica abstrata foram fundamental para o modo como o IG entendia a arte, design e cultura de massa.

Essa visão seria, segundo Massey, reforçada pelos escritos do professor do Warburg Institute, Ernst Gombrich. No livro que acompanhava a exposição homônima Aspects of Form (1951), Gombrich teria críticado a aplicação de valores universais aplicados à arte, base da proposta de um "continuum" de valores próprios para cada expressão artística, do vernacular moderno ao modernismo acadêmico ${ }^{91}$, e advocaria pelo uso da iconologia para o entendimento da cultura visual, e para criar uma aproximação mais rigorosa e científica que estava negada na análise formal alemã.

“O modelo de contínuo de cultura visual foi, de fato, uma mudança radical do sistema piramidal convencional, e se igualava ao que o IG interpretava como a guinada em relaçnao aos valores universalistas aristotélicos para valores nãoaristotélicos. A adoção do modelo também marca o momento chave de mudança de valores tradicionais ou Modernistas para interesses pós-modernos. Mas há dois fatores do modelo contínuo que o diferenciam das versões tardias pós-modernas. $\mathrm{O}$ primeiro é que sua linearidade tem implicações. Nas "bordas" de cada discurso, existe uma interconectividade ou sobreposição, mas cada discurso é ainda pensado como mantenedora de uma identidade distinta." ${ }^{92}$

88 Idem, p.5.

89 Anne Massey, The Independent Group: Modernism and Mass Culture in Britain, 1945-59. Manchester: Manchester University Press, 1995, p.42

90 Anne Massey, p.44. A palavra "meio" teve sua tradução retirada do termo original environment.

Outras traduções da palavra para o português são ambiente ou campo (no sentido abstrato).

91 Nigel Whiteley, Reyner Banham: Historian of the Immediate Future. Cambridge: The MIT Press, 2002, pp.101-106.

92 Idem, p. 104. Texto original: The continuum visual culture model was, indeed, a radical shift from the 
A apropriação da iconologia pode ser melhor compreendida pela especificidade da criação individual - através do reconhecimento da arte popular e de sua retirada do anonimato. O ponto de tangência entre Gombrich e Thompson é que ambos compartilhavam do rompimento com o conceito de universalidade do Iluminismo, em favor de uma metodologia empírica de análise da forma, na qual os símbolos aplicados aos objetos traçam relações com demais símbolos ligados a outros objetos. A contribuição de Giedion, principalmente em Mechanization Takes Command (1948), estabeleceu precedentes históricos para os artistas amparados por conceitos nãoaristotélicos e pelo uso de 'ready-mades', base para o conceito inglês do 'as found' - como encontrado. Marcel Duchamp e os demais artistas dadaístas representavam o começo de uma linhagem na qual o IG seria historicamente encaixado ${ }^{93}$. Massey cita o elogio de Lawrence Alloway ao Dada, feito em uma das sessões do grupo, em 1956:

“[o Dada] não insiste sobre a abstração de aspectos fixos da vida por questões de tratamento estético. Ele remete a arte aos canais entremeados da comunicação cotidiana. Uma obra de arte pode ser feita de bilhetes de ônibus ou pode parecer com propaganda. Arte pode ser um anúncio. " 94

Segundo Anne Massey, a estética do descartável foi uma das principais contribuições do IG para a revisão dos valores culturais das décadas de 1950 e 1960. O estilo não seria atemporal, mas rompia com o modernismo ortodoxo tanto quanto o gesto de elevar a cultura de massa ao patamar da alta-cultura academicista ${ }^{95}$.

Banham, bem como a maioria dos membros do IG evitavam repetir a atitude de seus predecessores ingleses na necessidade de estabelecer leis e valores, o que eles chamariam basicamente de 'acadêmico' ${ }^{96}$. $\mathrm{O}$ artigo New Brutalism, escrito por Banham, mas motivado por boa parte do IG, principalmente por Peter e Alison Smithson e Eduardo Paolozzi, publicado em 1955, foi um dos primeiros enfrentamentos abertos em relação à estética modernista tradicional. ${ }^{97} \mathrm{Na}$ exposição Parallels of Life and Art, a

conventional pyramidal model, and equates with what the IG interpreted as the shift form universalist, Aristotelian values to non-Aristotelian ones. The adoption of the model also marks a key moment of a change from traditional or Modernist values to postmodern concerns. But there are two features of the continuum model which differentiate it from later postmodern versions. The first is that its linearity has implications. At the "edges" of each discourse, there may be an interconnectedness or overlap, but each discourse is still thought of as retaining a distinct identity.

93 Anne Massey, pp.44-45.

94 Lawrence Alloway, “Dada 1956”. Architectural Design, November 1956, p.374, apud Anne Massey, p.45. Texto original: it does not insist upon the abstraction of fixed aspects of life for aesthetic treatment. It effectually consigns art to the tangled channels of everyday communications. A work of art may be made of bus tickets or it may look like an advertisement. It may be an ad.

95 Anne Massey, p.72.

96 Idem, p.74. O método acadêmico de Paul Klee teria sido amadurecido por gerações de seguidores, nos quais gerações de jovens artistas entravam em um embate com as gerações de artistas estabelecidos: seja entre Boccioni e os futuristas e as leis do academicismo de Alberti; seja na rejeição do IG em assumir o legado de críticos ingleses da antiga geração, como Herbert Read ou Roger Fry.

97 Reyner Banham, New Brutalism: Ethic or Aesthetic? Publicado em 1964, para o resgate histórico 
proposta de manipulação da fotografia de Henderson, a distorção expressionista de Paolozzi somaram-se ao interesse dos Smithsons pelo "as found" - o objeto do cotidiano tal como encontrado.

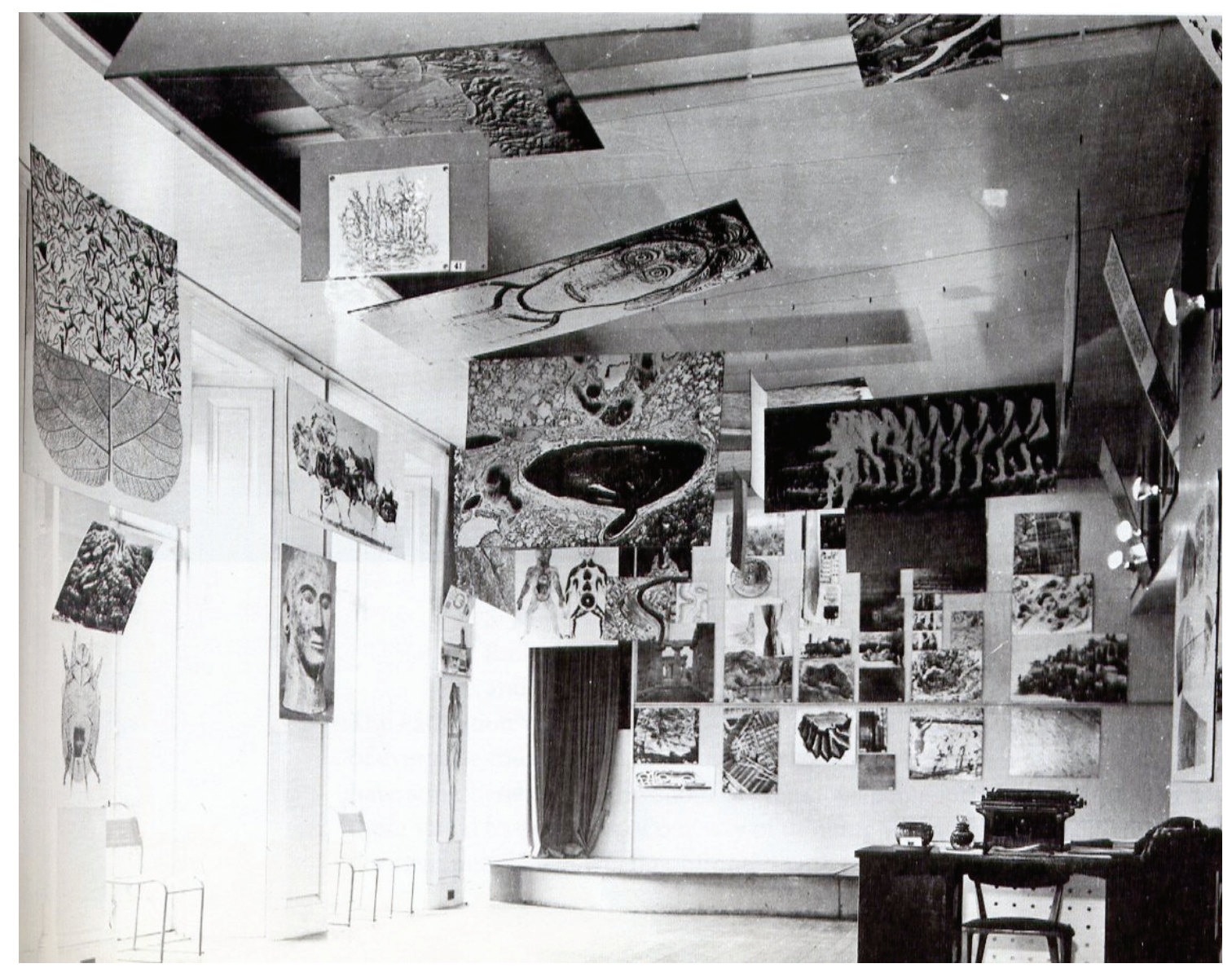

Nigel Henderson, Eduardo Paolozzi, Peter e Alison Smithson: Exposição Parallel of Life and Art, Whitechapel Gallery, Londres, 1953.

O Independent Group não dividia o entusiasmo de alguns acadêmicos pela cultura popular tradicional britânica, baseada no artesanato, e a distinguiam da cultura de consumo de massa para a qual se cunhou o termo 'pop art'. ${ }^{98}$ Gillo Dorfles, crítico e teórico italiano, forneceu matéria para o entendimento do objeto industrial. Dorfles trabalhou com o editor da revista Stile Industria, Alberto Rosselli, e designers como

das movimentações políticas e estéticas desencadeadas pela operação do IG na formação do movimento Brutalista inglês. Neste livro, Banham remonta seu artigo de 1955, no qual escrevia sobre um projeto de um sobrado no bairro de Soho, em Londres, de autoria do casal Smithson. A partir deste projeto, e de muitos outros do grupo - muitos deles sequer construídos - foi-se tecendo a crítica aos valores aristotélicos em arquitetura, e a valorização da simbologia e da iconografia, despertada também na exposição Parallels of Life and Art, de Paolozzi, Henderson e dos Smithsons, apresentada na Whitechappel Gallery do ICA, em 1954.

98 Anne Massey, p. 77. 
Marco Zanuso, na trienal de 1954. E sua palestra para o público inglês, no momento em que Dorfles visitava Londres para uma exposição sobre design industrial no Instituto Italiano, propiciou um encontro foi agendado com o IG, motivada pela referência para o jovem grupo inglês de seus estudo de objetos da vida cotidiana, como frigideiras, instrumentos musicais e aspiradores de pó:

"Banham aplicou o conceito surrealista de fantasia e realização de sonho nestes produtos tipicamente americanos. Simbolismo sexual foi um segundo tema a ser explorado. Banham afirmou em seu artigo, "Machine Aesthetic", que foi por meio de "contexto simbólico que design de automóveis poderia ser analisado. " 99

Para Nigel Whiteley, os artigos "Vehicles of Desire" e "Machine Aesthetic", artigos escritos em 1954, e derivados do seminário "Man, Machine and Motion"100, teriam muitos pontos de tangência: além de terem sido publicados em um curto intervalo de tempo, ambos trabalham com a noção da constante renovação tecnológica e estética da indústria dos objetos de massa. No caso de "Vehicles of Desire", termos como "iconologias simbólicas" demonstram o tom acadêmico que Banham atribuiu ao estudo de tais objetos da cultura popular ${ }^{101}$. As razões para tal seriedade no tratamento acadêmico de objetos mundanos se explicaria pela formação dos membros do IG. Se levarmos em conta os apontamentos de Anne Massey, podemos cruzar a naturalidade com a qual os membros do IG se relacionavam com elementos da cultura popular americana, com a revisão crítica desses elementos, alimentados por trabalhos como o de Thompson e Gombrich. Massey e Whiteley compartilham a opinião de que, a despeito da mitologia sobre as origens proletárias do grupo que distorce a realidade sobre a formação de Nigel Henderson, William Turnbull, Toni Del Renzio, e em parte sobre os Smithsons ${ }^{102}$, é possível reconhecer claramente no IG uma inversão de valores, e a quebra de algumas divisões entre alta e baixa cultura na Inglaterra.

O entusiasmo de Banham pela cultura de massa americana o levaria a debater sobre alguns argumentos: a crítica à cultura popular americana, e do modo como se amparava sua imagem democrática, enquanto em um processo exploratório e de ilusão de bem-estar provida pelo consumismo, reforçava dinâmicas de exploração capitalistas $^{103}$. Durante a década de 1960, em palestras sobre as origens intelectuais do IG, Banham admitiria o potencial exploratório da cultura de massa, mas negaria que

99 Idem, pp.81-82. Texto original: Banham applied the Surrealist concept of fantasy and dream fulfilment to these all-American products. Sexual symbolism was a second theme to be explored. Banham asserted in his article, "Machine Aesthetic", that it was by means of the 'symbolic content that car styling could be analysed".

100 Exposição realizada na Lower Gallery do ICA em Londres, sob a curadoria de Richard Hamilton, em 1955.

101 Nigel Whiteley, Reyner Banham: Historian of the Immediate Future, p.57.

102 Idem, p.94.

103 Idem. P.95. 
esse efeito invalidasse a legitimidade do vernacular moderno:

“Que existe exploração commercial na cultura pop ninguém em sã consciência pode negar, mas deve existir algo por baixo, algum substrato de sentimento genuíno, um desejo genuíno pela coisa, o qual deve ser encontrado antes do Mercado começar a agir." 104

Mais do que acreditar em uma horizontalidade de valores culturais, Whiteley entende que Banham acredita que existia algo de genuino na apropriação e expressão de design do vernacular moderno, algo que teria reverberações para a construção de uma nova ponte entre arquitetura e tecnologia, e o cumprimento de uma promessa não realizada por completo na primeira metade do século XX. Esses valores culturais, e essa elevação da cultura de massa se encontraria na América, para onde Banham se deslocaria com mais frequência a partir da década de 1960.

\section{Os ingleses e a renovação historiográfica}

Na década de 1960, em ambos os lados do Atlântico, as escolas de arquitetura já tinham passado pelo processo de assimilação da proposta moderna. O cânone moderno já passaria por um amplo processo de revisão, do qual propostas historicistas, contextualistas e desconstrutivistas emergiam. A agenda de renovação social, proposta abstracionista de estudo do espaço, e a noção de homem universal, bases do modernismo na arquitetura, deixavam de ser valores inquestionáveis e passavam a ser objeto de críticas duras por intelectuais como Robert Venturi e Aldo Rossi publicavam trabalhos de revisão crítica ao modernismo e aos seus métodos ${ }^{105}$. Um aspecto era compartilhado pelas propostas: o retorno da disciplina de história de arquitetura à prática e ao ensino era iminente. Neste panorama, a escola inglesa de arquitetura, que há muito se dedicaria à elaborar seu repertório, fomentado por uma escola de história da arte, forneceria não apenas uma proposta de retomada da teoria de investigação histórica da arquitetura e do urbanismo. Do outro lado do Atlântico, as escolas de arquitetura da costa leste buscavam uma nova geração de intelectuais capacitados para reintroduzir o ensino de história Esta sessão se dedicará a entender como as gerações de historiadores de arquitetura ingleses próximos a Banham tiveram suas carreiras afetadas pelo deslocamento para os Estados Unidos, e qual foi o impacto de sua presença nas instituições americanas de ensino de arquitetura.

104 Ver Banham, "The Atavism of the Short-Distance Mini-Ciclist", apud Whiteley, p.95. Texto original: That there is comercial exploitation in pop culture nobody in his right mind would deny, but there has to be something else underneath, some sub-stratum of genuine feeling, a genuine desire for the thing, which has to be touched off before the market will really move.

105 Robert Venturi, Complexidade e Contradição em Arquitetura. São Paulo, Martins Fontes, 1995; Aldo Rossi, Arquitetura da Cidade. São Paulo, Martins Fontes, 2001. 
Colin Rowe obteve sua primeira formação como arquiteto na Universidade de Liverpool em na qual entraria em 1938, e a qual interromperia para cumprir serviços militares na Segunda Guerra Mundial. A escolha pelo mestrado em história da arte o levou a estudar no recém transferido Warburg Institute na Universidade de Londres ${ }^{106}$. Antes de fazer 33 anos, Colin Rowe já havia publicado dois de seus mais influentes artigos. The Mathematics of the Ideal Villa traria a discussão de tratadística de Wittkower e o método comparativo de Wölfflin para o debate, estabelecendo inéditas comparações entre a Villa Malcontenta de Palladio com a VIlla Garches de Le Corbusier. Foi também a transposição do Palladianismo de Wittkower para a análise moderna, a qual ele investigaria com mais rigor em seu artigo posterior, Mannerism and Modern Architecture, de 1950. A metodologia analítica dos artigos tem referência no campo de intelectuais de língua alemã, Ernst Gombrich, Erwin Panofsky e Karl Popper, com quem Rowe teria contato no Instituto Warburg.

A obra de Rowe é vista por alguns historiadores, como Banham, como o retorno do formalismo ao discurso de história de arquitetura. De fato, a experiência de Rowe baseia-se em experimentos formais, alimentados pelo ímpeto de compreender as raízes ocultas do desenho moderno - o qual Rowe trabalharia junto com alunos de Austin, onde lecionou durante a década de 1950, após ter estudado em Yale, a convite de Henry-Russel Hitchcock, e Josef Albers, exilado da Bauhaus, seria um dos seus professores.

Após seu período no Texas ao final de 1959, Rowe voltaria para a Inglaterra, e encontraria um clima aquecido de discussões, envolvendo jovens arquitetos recémformados como Peter Smithson e James Stirling, numa cena de embate de gerações em Londres. Alunos da Architectural Association, Frampton e Colquhoun eram colaboradores do periódico Architectural Design; Banham seguiria seu orientador Nikolaus Pevsner na edição da Architectural Review, contribuindo para a difusão das propostas do Independent Group, formado por artistas e estudantes do Instituto Courtauld de artes, da Universidade de Londres; em Cambridge, Rowe conheceria Peter Eisenman, um ex-aluno de Cornell, e seria tutor de Anthony Vidler. Rowe convenceria o reitor, Sir Leslie Martin, a fundar o Center for Land Use and Built Form Studies, junto com Lionel March. Nele, Rowe introduziria sistemas matemáticos e proporcionais de cidade. Nesse momento, Rowe fortaleceria sua amizade com Stirling, com quem estudou em Liverpool, e cuja obra construída junto com James Gowan, os laboratórios de Engenharia de Leicester, seria referência perene no trabalho de revisão da arquitetura moderna de Rowe. Sua colagem estética, suas referências à engenharia do século XIX, e a conceitualização espacial desses edifícios foram elevadas

106 O Warburg Institute, cujas dependências incluem a famosa biblioteca Mnemosyne, extrato da obra de compilação de imagens (o Atlas homônimo) e textos que abrem um leque entre renascimento a culturas indígenas norte-americanas, teria sido transferido de Hamburg, com o consentimento de sua família, por seus discípulos, Panofsky e seu colaborador Fritz Saxl. 
por Rowe como "implementações de uma visão arquitetônica altamente seletiva"107. Pevsner, voz que representava a opinião geral da redação da Architectural Review, não compartilhava da opinião de Rowe, ao chamar o edifício de "banheiro vitoriano revestido de azulejos". ${ }^{108}$ Banham e o grupo Brutalista do IG também não desfrutavam da mesma opinião do fim de uma ideologia moderna.

Em sua volta aos Estados Unidos, já reconhecido por sua obra difundida no país, Rowe assumiria uma cadeira em Cornell, em 1962, onde Stephen Jacobs redirecionado o curso de volta à prática histórica ${ }^{109}$, e precedido também pelo impacto de sua obra escrita no ambiente acadêmico americano. Em Cornell Rowe ensinaria projeto, porém com a abordagem que colocava o estudo da história no centro do processo criativo, ao invés de servir como repertório como era anteriormente concebido por Jacobs. Para Rowe, desenho, história e teoria eram inseparáveis, e constituíam um único processo de aprendizado. O reitor Dean Burnham reagruparia em Cornell os Texas Rangers, grupo de acadêmicos anteriormente reunidos na Universidade de Austin - Robert Slutzky, Werner Seligmann, Bernard Hoesli e Jerry Wells. No grupo original dos Rangers estava presente John Hejduk, que junto com Eisenman, Michael Graves, Charles Gwathmey e Richard Meier formariam o New York Five, sobre o qual Colin Rowe escreveria um artigo de grande repercusão, presente no livro que divulgaria o grupo de arqutetos americanos ao grande público, mas que também ligaria de certo modo a imagem de Rowe a do pós-moderno na arquitetura. Ademais, nesse artigo Rowe escreveria uma de suas mais célebres frases, a qual, junto com A Collage City e The Architecture of Good Intentions formariam a fase mais madura do autor em sua revisão do projeto moderno e as aspirações de uma arquitetura que explorasse o legado formal por ele deixado.

"Pode a arquitetura que processa um experimento contínuo e objetivo se tornar congruente com a idéia de arquitetura que almeja ser popular, inteligível e profunda?"110

Kenneth Frampton é categórico em afirmar que a América o politizou ${ }^{111}$.

107 Ver o obituário de Colin Rowe, escrito D. G. Shane, pp. 192. Ver Também o brilhante discurso de Anthony Vidler sobre Colin Rowe em Histories of the Immediate Present (2008), certamente um dos mais inclusivos e incisivos artigos sobre a trajetória de Colin Rowe; e o artigo de Joan Ockman, Form Without Utopia: Contextualizing Colin Rowe, de 1998.

108 D. G. Shane, pp. 192.

109 Ver artigo de Christian F. Otto a respeito do ensino em Cornell a partir da década de 1940, na coletânea de Gwendolyn Wright, pp. 115.

110 Colin Rowe, Collage City, p.210. Texto original: Can an architecture which professes an objective of continuous experiment ever become congruous with the idea of an architecture which is to be popular, intelligible, and profound?

111 Não sabia, na ocasião, que essa fala já havia sido reproduzida em ocasiões anteriores, como a conversa de 2003 com Hal Foster e Stan Allen, e de maneira mais sutil a José Lira em 2009. 
O encontro com a cultura norte-americana, segundo a metáfora do próprio Frampton, na qual, ao contrário da Inglaterra, as "garras estão expostas" em época de propagandística de Guerra-Fria teria demandado dele, como de todos os jovens arquitetos de sua geração, um posicionamento político ${ }^{112}$.

Formado em 1956 na Architectural Association, Frampton praticou arquitetura junto a colegas durante algum tempo, enquanto produzia peças de crítica e teoria publicadas em periódicos como a Architectural Design. O contato com Peter Eisenman, que o levaria em 1965 para lecionar em Princeton, recém reformada em sua estrutura curricular e em seu edifício. Detonou o primeiro influxo de migração inglesa em Princeton, precedido apenas nos EUA por algumas visitas esporádicas e pela curta permanência de Colin Rowe em Austin, que lecionava em Cornell no momento em que Frampton junto com Vidler chegavam a Princeton para ensinar história da arquitetura - Vidler daria o curso de história de arquitetura de 1500-1900, enquanto Frampton seria responsável pelo ensino de arquitetura no século $X X^{113}$.

A saída da Inglaterra para Frampton representaria busca por campos de discussão que não estivessem saturados pelo revivalismo. Para ele, a história não poderia ser um peso, e sim um território de referências para a construção de novas alternativas para o movimento moderno. Para alguém da geração de Frampton, dez anos mais novo do que Colin Rowe, e formado já em tempos de progressismo e bem-estar-social, o alinhamento da arquitetura moderna às esferas de poder já estava consolidado. Diversas experimentações formais em arquitetura já haviam sido construídas pela LCC e por arquitetos como Stirling e os Smithsons, como os apartamentos em Han Common e a escola Brutalista em Hunstanton, respectivamente.

O campo da arquitetura inglesa se dividia entre os Revivalistas das tipologias modernas da pré-guerra; e os Brutalistas cuja cúpula era formado pelo Independent Group, liderado pelos Smithsons, e Banham. Malgrado Frampton valorizasse a sensibilidade dos grupo frente a situação da classe operária inglesa na época principalmente no trabalho do fotógrafo Nigel Henderson - para ele o interesse no pop e na monumentalidade americana por parte dos brutalistas levava a experimentações infrutíferas enquanto apolíticas.

“Os Estados Unidos me politizaram de uma maneira... (...) Primeiramente através de meu contato com os estudantes, em Princeton e em outros lugares, em direção a 1968. É um período curto, na verdade, entre 1965 e 1968, mas o movimento estudantil foi muito importante para mim. Banham não parece ter sido tocado por essa experiência. Ele se esquivou dessa questão. Além disso, eu suponho, eu nunca vi produção e consumo em tal escala antes de vir aos Estados Unidos - gasolina, energia elétrica, todo o pa cote. Isso me tornou ciente dos riscos, os quais de alguma maneira estavam disfarçados na

112 Ver entrevista com Kenneth Frampton, em anexo na presente dissertação.

113 Hal Foster e Stan Allen, Conversa com Kenneth Frampton, p. 39. 
Europa naquela época, ao menos para alguém ingênuo como eu. Outro fator é que eu me tornei mais e mais interessado nos Russos. É interessante que, em Teoria e Projeto na Primeira Era da Máquina, os russos foram deixados de fora. Banham virtualmente negou toda a vanguarda russa tal qual Giedion e outros historiadores o fizeram."114

Em Princeton Frampton fortaleceria suas convicções políticas ao entrar em contato com o trabalho de Hannah Arendt, Heidegger, com a presença de Tomás Maldonado, ex-diretor da escola de Ulm, e Camila Gray, cujo livro The Great Experiment: Russian Art 1863-1922 teria sido a entrada de Frampton ao trabalho das vanguardas russas em arquitetura.

Ao mesmo tempo em que Peter Eisenman sai de Princeton, em 1971, depois de perder a cadeira de professor para Michael Graves, Frampton aceitaria a encomenda de Robin Middleton para escrever História Crítica da Arquitetura Moderna, para a editora Thames \& Hudson ${ }^{115}$, o qual demoraria dez anos para terminar. Em 1972, Frampton abdicaria de sua cátedra vitalícia em Princeton para ensinar em Columbia, tendo que percorrer o processo acadêmico do zero. Michael Graves, junto com Robert Venturi, cujos livros Complexidade e Contradição (1968) e Aprendendo com Las Vegas (1971) representava o pensamento cuja ênfase imagética era uma expressão pós-moderna de pensamento em arquitetura a ser combatido por Frampton, através de suas publicações sobre a tectônica e sobre o regionalismo crítico, os quais ele desenvolveu em artigos para Oppositions, Casabella, Architecture d'Aujourd'hui, entre outras, desde a década de 1970 até hoje.

De todos os arquitetos pesquisados, Anthony Vidler certamente é quem mais se dedicou a discutir os efeitos do pensamento pós-moderno na conceituação de história. Formado em Cambridge, sob a orientação de Colin Rowe, sua relação com o estudo de história o levou a uma carreira de pesquisas interessadas na relação entre o estudo histórico e a prática contemporânea. Por seu orientador teria acesso, ainda em sua formação, à pesquisa de Wittkower e a uma abordagem mais atenta à história. Vidler, muito mais jovem do que Banham e Colin Rowe, teve o trabalho deles como referência em sua formação.

Após um curto espaço de prática profissional, Vidler foi convidado por Peter Eisenman a lecionar em Princeton, onde ficaria até transferir-se em 1998 para

114 Ibid, pp.39. Texto original: The United States politicized me in a way... (...)Primarily through my contact with students, at Princeton and elsewhere, moving toward 1968. It's a short period really, 1965 to 1968 , but the student movement was very important to me. Banham seems not to have been touched by that experience; he evaded that question. Also, as you suggest, I'd never seen production and consumption on such a scale before coming to the States-gasoline, electrical energy, the whole lot. That made me very aware of the stakes, which could somehow be concealed in Europe then, at least to someone as naive as myself. Another factor is that I became more and more interested in the Russians. It's interesting that, in Theory and Design in the First Machine Age, the Russians are left out. Banham virtually neglects the entire Soviet avant-garde just as Giedion and other received modern histories had done.

115 Entrevista a José Lira, pp. 129. 
a Universidade da California, após um breve período em Cornell, entre 1997-1998.

Transfere-se da Costa Oeste para Cooper Union em 2001, e torna-se reitor da instituição em 2002, cargo que abandonou recentemente.

Em Princeton Vidler estabelece suas relações acadêmicas mais duradouras e marcantes. Através do ensino de história da arquitetura no período revolucionárioiluminista, entre 1750-1900, Vidler entrou em contato com a obra de Emil Kaufmann, um de suas maiores referências. Após a saída de Eisenman de Princeton e a criação do IAUS - Institute of Architecture and Urban Studies - Vidler passou a participar do círculo em torno da Oppositions, um grupo internacional, nem europeu, tampouco americano, formado por Gandelsonas e Agrest, de formação acadêmica francófila e interessados na semiótica; Aldo Rossi e Manfredo Tafuri, da escola de Veneza, os quais exerceriam grande influência em seu trabalho futuro; além de Eisenman, Frampton e Colquhoun. ${ }^{116}$

No momento em que o IAUS produzia com mais intensidade era acirravase também o debate entte os "brancos" - Gwathmey, Graves, Eisenman, Hejduk e Meier - e a linha americanista-populista de Robert Venturi. A campanha de Vidler era romper com a idéia pós-moderna de fim da história ${ }^{117}$. As diferenças entre a prática de história e que concerne especificamente à arte demandavam a ruptura epistemológica com a história. De fato, Vidler reconhece os perigos do retorno do historicismo sem a recuperação do conceito de história.

Vidler também demonstraria sua formação em história cultural a partir de seus recentes ensaios: The Architectural Uncanny e Warped Space demostram o domínio de Vidler de algumas das principais fontes de história cultural com Benjamin e Schorske, e da história da arte alemães puro-visibilistas e a literatura de Allan Poe, Oscar Wilde e Mark Twain.

Através da trajetória destes três historiadores, fica patente o quanto entrelaçada se torna o processo histórico pelo qual passam as escolas inglesas e estadunidenses de historiografia. Um intercâmbio intenso é forjado, e perdura até hoje, entre universidades como Columbia, Yale, e Harvard, nos Estados Unidos, e a Architectural Association, a Universidade de Londres, Oxford e outras na Inglaterra. O que veremos ao nos debruçar na trajetória de Banham não é mais do que um desvio desta curva. Banham, mais do qualquer outro historiador da arquitetura inglês, se expôs sem restrições ao repertório americano. Ele rompeu com o limite da costa leste, e se relacionou com aspectos da cultura americana mais distantes da academia.

116 Entrevista a José Lira, pp. 130.

117 Ibid, 130 


\section{Reyner Banham “Travelling Light”}

“O que nós arquitetos tendemos a esquecer é que não somente donas-de-casa, políticos e o público em geral nas ruas têm vidas cotidianas. Nós também temos vidas cotidianas, e todos nós temos tivemos uma vida normal antes de nos tornarmos acadêmicos, e antes de nos tornarmos arquitetos. Uma das coisas mais estranhas sobre tornar-se um acadêmico é lembrar como era não ser um. Eu acho que é importante nos lembrarmos disso. Ou seja, pensarmos como que as pessoas vão experienciar o morar, por exemplo, ou os prédios públicos, fora das experiências que nós somos treinados para ter. Não é que exista uma maneira certa ou errada, mas elas não estão em conflito uma cou a outra, e não há razão porque nós não podemos expandir e tirar algo disso." ${ }^{118}$

Se para Frampton a América teria o efeito politizante por reação ao choque com a monumentalidade da metrópole, para Reyner Banham a presença no novo continente o imbuiu de estímulos pelas mesmas paisagens. Na América Banham não somente encontrou uma nova modalidade de metropolização amparada nos elementos da Segunda Era da Máquina, mas também encontrou estudiosos - sociólogos, antropólogos, historiadores e escritores - igualmente interessados nos fenômenos da paisagem construída pelo homem americano. O meio acadêmico americano da arquitetura já havia passado pelo processo de crítica às ditas 'ciências duras' e em processo de aproximação com outros campos da ciência, como sociologia, antropologia, geografia e psicologia ${ }^{119}$.

Ao contrário dos demais historiadores ingleses mencionados anteriormente, Banham não tinha formação em arquitetura, e sim num curioso binômio engenhariahistória, focado em história da arte. Formado em engenharia aeronáutica e oriundo de uma família de engenheiros de Norwich, Banham muda radicalmente de rumo - provavelmente durante os anos de guerra - e entra no final da década de 1940 no Cortauld Institute da Universidade de Londres, para cursar história da arte ${ }^{120}$. No

118 Gwendolyn Wright, em entrevista para a presente pesquisa, sobre Reyner Banham e o conceito de vernacular moderno americano, realizada no Buell Hall da Universidade de Columbia, em agosto de 2012. Texto original: What we architects tend to forget is that not only housewives, the politicians, and the general people on the streets have everyday lives. We have everyday lives, and all of us have a life before we became scholars, and before we became architects. And one of the strangest things about becoming a scholar is remembering what was like not to be one. I think is important to remind our selves about this. To say, how was that the people is going to experience housing, per instance, or public buildings, outside this experiences that we are prime to have. It is not that there is a right one and a wrong one, but they aren't in conflict with each other, and there is no reason why we can't expand and draw from that. 119 Joan Ockman, pp.135-136, para referências sobre o campo ampliado do engajamento do ensino de arquitetura com outros campos científicos; ver Vidler, Histories of the Immediate... sobre a mudança de paradigmas sobre as ciências e a estética da máquina no discurso de Banham.

120 Para descrições mais detalhadas da biografia de Reyner Banham, ver Nigel Whiteley, Reyner Banham: Historian of the Immediate Future. 
Cortauld, Banham estabeleceu contato com seus futuros parceiros intelectuais do Independent Group, que

"estava interessado em decodificar os artefatos culturais, antes de aferir quais eram bons e quais eram ruins. A contribuição perene deixada para o estudo e prática de cultura foi a negação da hierarquia que posicionou as artes acima da cultura de massa." 121

Mas também nutriam interesse sobre a história da arte de matriz germânica - o Warburg Institute estava situado do outro lado da rua dentro do campus da Universidade de Londres - tomado contato com a obra de Aby Warburg, Erwin Panofsky, Ernst Gombrich, Rudolph Wittkower e Heinrich Wölfflin, entre outros: através da contribuição destes historiadores e teóricos da arte, a matriz iconográfica e simbólica pode vir a ser assimilada ao currículo de uma geração de jovens artistas, críticos e arquitetos, conforme previamente analisado através do trabalho de Anne Massey e Nigel Whiteley.

Uma tensão entre grupos de intelectuais pairava no campo da crítica de arquitetura inglesa. A apreciação do vernacular moderno e da cultura de massa era mal vista tanto pelos defensores ortodoxos da arquitetura moderna, quanto pelos teóricos da revisão crítica do moderno, cujo viés se encerraria na crítica ao engajamento da arquitetura moderna nos meios de produção capitalista.

"Até certo ponto eu acredito que fomos vítimas da Guerra Fria. Algo muito estranho aconteceu entre 1946-1947 quando as linhas foram desenhadas pela Guerra Fria. Repentinamente veio um momento em que era muito difícil ler o [New York] Times ou qualquer revista americana, simplesmente por causa de lealdades políticas. Naquele período emergiu a situação na qual as inclinações naturais para o mundo do entretenimento eram os Estados Unidos, mas as filosofias políticas aparentavam requerer que se virasse as costas aos EUA. Eu lembro de mentes curiosamente divididas ouvindo discos Pop na Rádio Luxemburg à noite e imaginava em que lado eu estaria." 122

121 Anne Massey, “The Independent Group: Towards a redefinition”, em The Burlington Magazine, No. 1009, pp. 232-242. Texto original: The Independent Group was concerned with decoding cultural artifacts, rather than ascertaining which were good and which bad. The lasting contribution which it made to the study and practice of culture was the negation of the hierarchy which placed fine art above mass culture. 122 Reyner Banham, "The Atavism of the Short-distance Mini-Cyclist", in Penny Sparke, p.85. Texto original: To some extent I think we were the victims of the Cold War. Something very weird happened around 1946-1947 when the lines were being drawn for the Cold War. Suddenly there came a moment when it was very difficult to read Times or any American magazine at all, simply because of one's political loyalties. In that period arose a situation where one's natural leanings in the world of entertainment, and so on, were the States, but one's political philosophy seemed to require one to turn one's back to the States. I remember the curiously divided mind in which one listened to Pop records on Radio Luxembourg in the evenings and wondered just whose side you were on. 
Sob a tutela de Pevsner, Banham publicou sua tese de PhD, Theory and Design in the First Machine Age, em $1960^{123}$. Muitos críticos entendem o trabalho como uma resposta ao livro de seu orientador Nikolaus Pevsner, Pioneers of Modern Design, de $1936^{124}$. Contudo não é apenas na correção de algumas genealogias e na inclusão de lacunas sobre o Futurismo italiano que a obra de Banham se destaca. É importante ressaltar que acima de tudo, Banham deixaria claro suas intenções a respeito da revisão do moderno a partir de sua primeira publicação, ao questionar a suposta ruptura moderna em se desvencilhar do peso do classicismo acadêmico - postulado do qual Colquhoun também partiria, malgrado sem a oposição tácita de Banham ao academicismo.

“O que é perturbador sobre Teoria e Projeto na Primeira Era da Máquina - isso se relaciona com Colquhoun novamente, quem fez uma importante crítica ao livro, contudo isso era evidente para mim através de minhas experiências na Architectural Design - é a total defesa de Buckminster Fuller, uma posição que considerei insustentável, e ainda considero. Banham termina com Fuller como seu novo deus ex machina da cena. Ademais os efeitos dos EUA em Banham e em mim foram completamente diferentes." 125

Para Banham, fica claro que uma nova estética estava ainda por ser construída. E o primeiro foco dessa nova arquitetura seria a produção de seus colegas Brutalistas - Peter e Alison Smithson, e com algumas restrições, James Stirling ${ }^{126}$. Após a publicação de sua tese, Banham subiria ao status de prodígio intelectual, e se tornaria editor assistente na Architectural Review e professor em Bartlett. Sua posição pode ser entendida naquele momento como a de um revisionista interno do movimento ${ }^{127}$. A partir de sua posição privilegiada de insider, publicaria o relato dessas experimentações no livro New Brutalism: Ethic or Aesthetic? em 1966.

Seu interesse afetivo pela produção americana seria alimentado pelo contato com John Entenza, da Grahan Foundation, o qual the encomendaria um livro sobre a arquitetura moderna e o desenvolvimento tecnológico no qual a produção americana

123 Publicado em 1987 em português pela editora Perspectiva.

124 Ver a compreensiva pesquisa biografia de Nigel Whiteley, Reyner Banham: Historian of the Immediate Future, para uma das mais profundas pesquisas sobre a relação profissional e pessoal entre Banham e seu tutor Pevsner.

125 Conversa com Kenneth Frampton, pp. 39. Texto original: What is disturbing about Theory and Design in the First Machine Age - this relates to Colquhoun again, who made an important critique of the book, but it was also evident to me through my experiences at Architectural Design - is its total advocacy of Buckminster Fuller, a position I found untenable, and still do. Banham ends with Fuller as the new deus ex machina of the scene. Also the effects of the States on Banham and on myself were completely different. 126 Sobre a valorização do trabalho de Stirling, ver XXXX

127 A biografia de Nigel Whiteley descreve a mudança de postura de Banham em suas diversas investigações na Europa e América. Ver a conclusão de Reyner Banham: Historian of the Immediat Future, pp. 364-410. 
tivesse espaço maior do que em publicações anteriores ${ }^{128}$. Banham passa então a visitar regularmente os Estados Unidos durante o período de 1966 a 1968. Nessas visitas, entra em contato com a cidade de Los Angeles, que viria a ser objeto de uma de suas mais difundidas obras, Los Angeles: The Architecture of Four Ecologies, publicada em $1970 \mathrm{e}$ amplamente comparada com a obra do casal intelectual Venturi-Scott Brown sobre Las Vegas ${ }^{129}$. Segundo Vidler, sua abordagem inusitada de ecologias humanas deve às fontes da publicação Los Angeles: Werden, Leben und Gestalt der Zweimillionstadt in Südkalifornien, do geógrafo alemão Anton Wagner; e à estrutura de ensaios separados do manifesto de Le Corbusier, Vers Une Architecture, um método de retórica que podemos traçar até a raiz Wölffliniana, mas na qual Le Corbusier definitivamente colocaria novas cores ${ }^{130}$. A metodologia de ensaios separados e abertura para as narrativas dos autores citados já havia sido experimentada por Banham em Teoria e Projeto na Primeira Era da Máquina, e teria influenciado Frampton a organizar seu manual sobre arquitetura moderna de maneira semelhante.

Malgrado a análise de Vidler sobre o livro de Banham ser precisa, falta acrescentar o papel da mudança de postura de Banham como historiador a partir de seu contato na América. Enquanto inglês em seu próprio país, Banham era insider, um narrador de questões da arquitetura no olho do furacão ${ }^{131}$. Praticou o revisionismo crítico do moderno. Enquanto expatriado nos EUA, Banham tornous-se outsider, tomando distância dos objetos e relacionando-os com sua memória do velho continente. Como indica Whiteley, Banham gostava de se considerar um historiadorobservador $^{132}$. Sua crítica à bibliografia anterior sobre o movimento moderno, como expõe em seus textos sobre a leitura da Fagus Werk de Gropius, o fez distanciar-se do meio acadêmico paulatinamente ${ }^{133}$. Se Frampton, Vidler e Colquhoun estavam publicando em periódicos acadêmicos como a Oppositions, Assemblage e Perspecta, Banham publicaria em revistas populares como a New Statesman em solo Britânico, e na Scientific American e New Society, nos EUA. Seria um exagero dizer que Banham viraria suas costas para a academia, todavia é fácil perceber quais debates ele queria manter e como isso o afastou do centro do debate da Costa Leste Americana Princeton, Harvard, Yale e Columbia - e dos demais acadêmicos dessas instituições.

128 Reyner Banham, The Architecture of the Well-Tempered Environment, produto publicado da pesquisa comissionada pela Grahan Foundation e John Entenza.

129 Sobre comparações sobre Aprendendo com Las Vegas e Los Angeles: the Architecture of Four Ecologies, ver o artigo de Nigel Whiteley. "Learning from Las Vegas... and Los Angeles, and Reyner Banham”, publicado originalmente no periódico Visible Language 37.3, em 2003.

130 Ver no ensaio de Anthony Vidler sobre Reyner Banham, "Reyner Banham Futurist Modernism” in Histories of the Immediate Present, pp. 149-155.

131 Termo utilizado por Banham em New Brutalism: Ethic or Aesthetic?, na conclusão sobre os eventos relacionados ao Independent Group e a sua roda de contatos no campo da arquitetura e arte na Inglaterra da década de 1950.

132 Whiteley, pp. 400.

133 No capítulo The Factory Aesthetic, em Theory and Design in the First Machine Age, traduzido para o português pela editora perspectiva em 1986. 
Outra maneira de colocar a diferença entre Banham e sua geração diz respeito ao conteúdo. Conforme apontado por Gwendolyn Wright ${ }^{134}$, Banham teria sido chamado para inicialmente por John Entenza, para o debate sobre arquitetura americana junto aos teóricos e críticos nativos, inicialmente em viagens regulares, para a produção de The Architecture of the Well-Tempered Environment, somente para se firmar como professor em Buffalo, em 1972. Sua atitude passa a ser a de um Cowboy, um desbravador de um novo primitivismo autóctone. O que se verifica em eus livros subsequentes, quando Banham já tinha se transferido para Buffalo, a convite de Magda Cordell, casada com John McHale ${ }^{135}$, antigo colega de Banham no IG. Tanto em Scenes of America Deserta ${ }^{136}$, no qual Banham aplica um método de comparação mnemônica entre a escala monumental do deserto, o "anti-arranha-céu" em contraposição com suas memórias da urbanização europeia, como em A Concrete Atlantis: : U.S. Industrial Building and European Modern Architecture, 1900-1925, Banham baseia seus ensaios em impressões pessoais através da presença física do edifício. Seria um exagero afirmar que ao contrário de seus compatriotas, os quais foram mobilizados para reportar às gerações de estudantes norte-americanos sobre a revisão crítica do moderno, Banham viria 'sem bagagem' intelectual prévia. Mas ele soube se desvencilhar de vícios, e soube se apropriar dos novos objetos de pesquisa sem dogmas definidos, no que diz respeito à produção americana. Veio sem nenhuma responsabilidade de trazer notícias de sua terra natal, nem tampouco de reafirmar críticas em cima de obras consagradas, no que diz respeito a conteúdos europeus. Sua contribuição mais significativa era sobre as produções americanas, malgrado seu interesse pela arquitetura moderna continuasse presente. E mesmo quando trazia à luz objetos da vanguarda moderna, o fazia de maneira a desestabilizar certezas da historiografia européia sobre a estética da máquina, dos mecanismos de propaganda e auto-afirmação do movimento moderno, e das raízes e polifonias ocultas dessa geração.

Mais especificamente em Buffalo, onde Banham recorre ao estudo comparativo de suas impressões pessoais defronte ao conjunto construído industrial, com o material divulgado pelos arquitetos da vanguarda moderna - Mendelsohn, Gropius e Le Corbusier - para questionar a construção da memória coletiva dos arquitetos em relação à estética da máquina, talvez o mais recorrente de seus temas. ${ }^{137}$

134 Em entrevista, agosto de 2012.

135 Colegas de Banham no Independent Group, e responsáveis pela introdução do discurso de interesse pela produção vernacular moderna na State University of New York in Buffalo (SUNY Buffalo).

136 Publicado em 1982 originalmente, e depois amplamente difundido pela publicação de 1989 pela MIT Press.

137 A análise crítica do livro A Concrete Atlantis se divide nos próximos capítulos da presente dissertação, separando os temas da técnica e do mecanismo, de um lado, e da paisagem construída, de outro. 

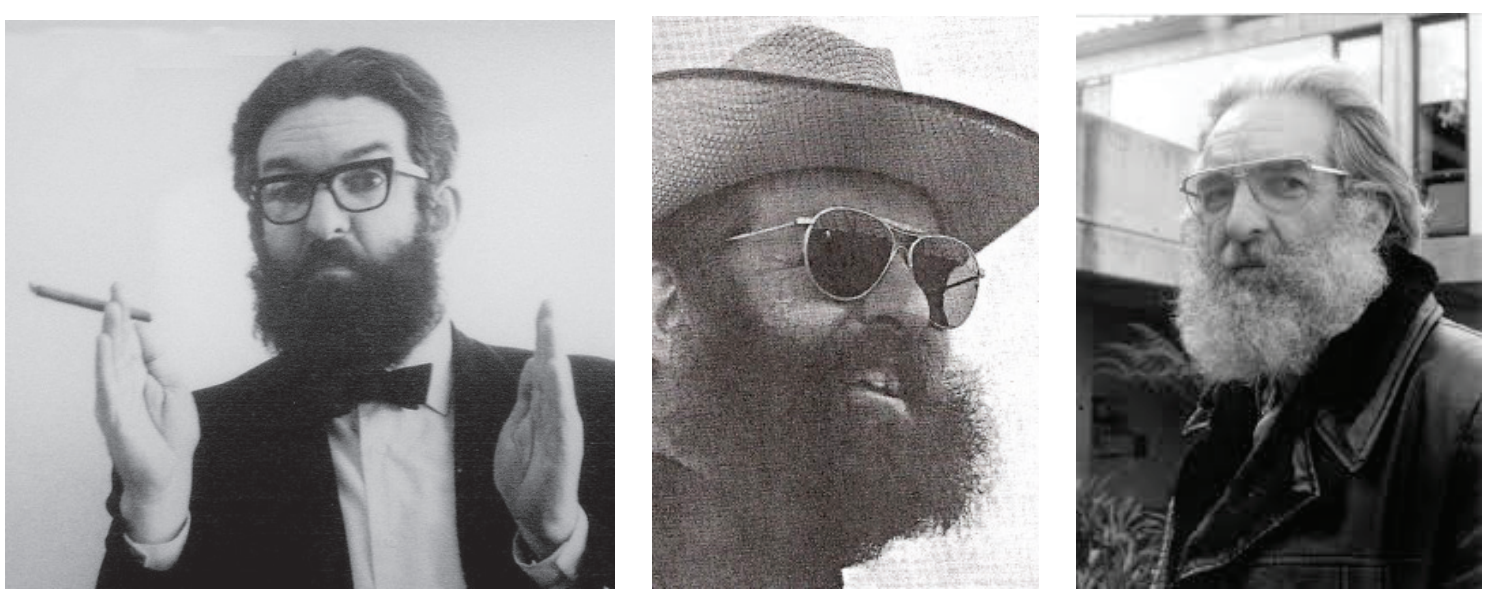

Três retratos distintos de Reyner Banham: Década de 1960 (sem data definida); 1982, e 1987-88. Sem autor identificado.

Após um curto período de 5 anos em Buffalo, entre 1972 e 1976, ensinando em uma cadeira de arquitetura na escola de Environmental Design, Banham transfere-se para a costa oeste, na Universidade da Califórnia de Santa Cruz, na faculdade de artes onde desenvolve seus trabalhos sobre a história do design - Penny Sparke o considera um dos pais da investigação histórica em design nos EUA ${ }^{139}$.

Muitas coisas são relevantes sobre sua curta passagem pela pequena cidade de Buffalo. Em primeiro lugar, Banham lecionara em Buffalo na cadeira de história da arquitetura. Este fato só ocorreria outra vez caso Banham tivesse assumido a vaga no Instituto de Belas Artes de Nova Iorque ${ }^{140}$. Essa experiência o reaproximou do vocabulário de projeto, e o trouxe mais próximo aos métodos de construção americanos. Por outro lado, sua experiência com a cultura popular americana até então tinha sido através do contato com elementos ativos da cultura popular - televisão, expressões do vernacular moderno como carrinhos de hot-dog, pranchas de surf, carros sport $^{141}$ - mas o que estava na frente de Banham eram ruínas de expressões

138 Para a formação das informações dispostas nessa parte da dissertação, a pesquisa documental e bibliográfica nos arquivos do Getty Research Institute foi fundamental. Pouco material publicado demonstra interesse pelas últimas publicações de Reyner Banham, e pelos movimentos finais de sua trajetória acadêmica, malgrado sua notoriedade estaria voltando a crescer, após o ostracismo experienciado no meio acadêmico, dada a polêmica e o caráter heterodoxo de suas últimas publicações.

139 Penny Sparke editou a coletânea de textos de Banham sobre o Design, Design By Choice, de 1981.

140 Banham faleceu vítima de câncer logo depois de ter sido convidado a assumir a cadeira Sheldon $\mathrm{H}$. Sollow, no Institute of Fine Arts anteriormente ocupada por Henri-Russel Hitchcock na Universidade de Nova Iorque.

141 Ver Penny Sparke, Design by Choice, na seção dedicada à cultura popular, artigos como "A Horse of a Different Color", "The Great Gizmo", e "Design by Choice". Também soma-se como contribuição importante para o entendimento da leitura de Banham a respeito da cultura popular o ensaio de Adrian Forty, "Of Cars, Clothes and Carpets: Design Metaphors in Architectural Thought", publicado na Journal of Design History, No. 1, 1989, pp. 1-14 
populares do passado. Essa experiência o fez retomar questões pertinentes à estética da máquina que remontavam a seu primeiro livro, porém desta vez destacando as realizações americanas, e relegando obras como a Fagus Werk a um segundo plano. A busca por seus próprios pioneiros e heróis, em meio à arquitetura pragmática industrial americana, era uma das construções de Banham ${ }^{142}$. Além disso, a experiência de crítica observacional foi aperfeiçoada para a produção de seu livro de 1982, Scenes of America Deserta, o livro que mais aproximou Banham do meio acadêmico do Oeste americano. ${ }^{143}$ Banham refinou seu discurso sobre o vernacular moderno, nesse período. Essa aposta foi assimilada por gerações posteriores de historiadores americanos e suas pesquisas sobre elementos da paisagem cultural.

“De repente, na sociedade industrializada o vernacular iria deixar de existir? Isso é absurdo. Este apenas se transforma. Eu penso que Banham entendia isso de alguma maneira. Mesmo que ele não trazia a arquitetura para esse tema, Banham entendia que os produtos de consumo de massa estavam lá. Não é que seja impossível contornar esse fato. (...) Não é surpresa para mim que Frampton negaria isso, por conta de sua aproximação problemática em relação ao regionalismo crítico: é predicado nesta noção o vernacular não modernizado, e não industrial. De alguma maneira, o regionalismo em si parte da noção de autenticidade, que é próprio de um lugar préindustrial. Desta maneira ele acaba sendo tão elitista quanto os outros. Qualquer projeto intelectual pode ser estruturado como elitista, mas eu acho que Banham teria entendido a noção de um vernacular moderno que abarcasse a arquitetura. Bom, é onde ele estava chegando, nos capítulos do livro de Los Angeles que olham para essa outra arquitetura. Não importa se ele não a descreve como arquitetura da mesma maneira como o programa das Case Study Houses. Eu acho que ele estava começando a entender isso." ${ }^{144}$

142 Arquitetos até então desconhecidos do meio europeu de arquitetura como Ernest L. Ransome, mencionado com o mesmo destaque que Albert Kahn em A Concrete Atlantis.

143 Para essa investigação, a entrevista junto a professora Gabrielle Esperdy, realizada em agosto de 2012 na Universidade de Columbia, em Nova Iorque, foi de vital importância.

144 Trecho extraído da entrevista com a professora Gabrielle Esperdy, agosto 2012. Texto original: Suddenly, in the industrialized society the vernacular would cease existing? That's absurd. It's just that it transforms itself. I think Banham understood that in some way. Even though he didn't pulled architecture into that, Banham understood that the products of mass production were there. It's not that he couldn't get around to that. (...) But it's not surprising for me that Frampton would reject that, because of his problematic approach to critical regionalism: it is predicated on this notion of the vernacular that is not modernized, and not industrial. That somehow, regionalism itself taps into some other notion of authenticity, which is entitled to a pre-industrialized place. It's the way he ends being just as elitist as the next guy. Any intellectual project can be structured as elitist, but I think Banham would have understood a notion of a modern vernacular that embraces architecture. Well, that's where he's getting at, in chapters of the Los Angeles book that looks at this other architecture. Doesn't matter if he does not describe it as 'architecture' in the same way as the Case Study program. I think he was beginning to understand that. 


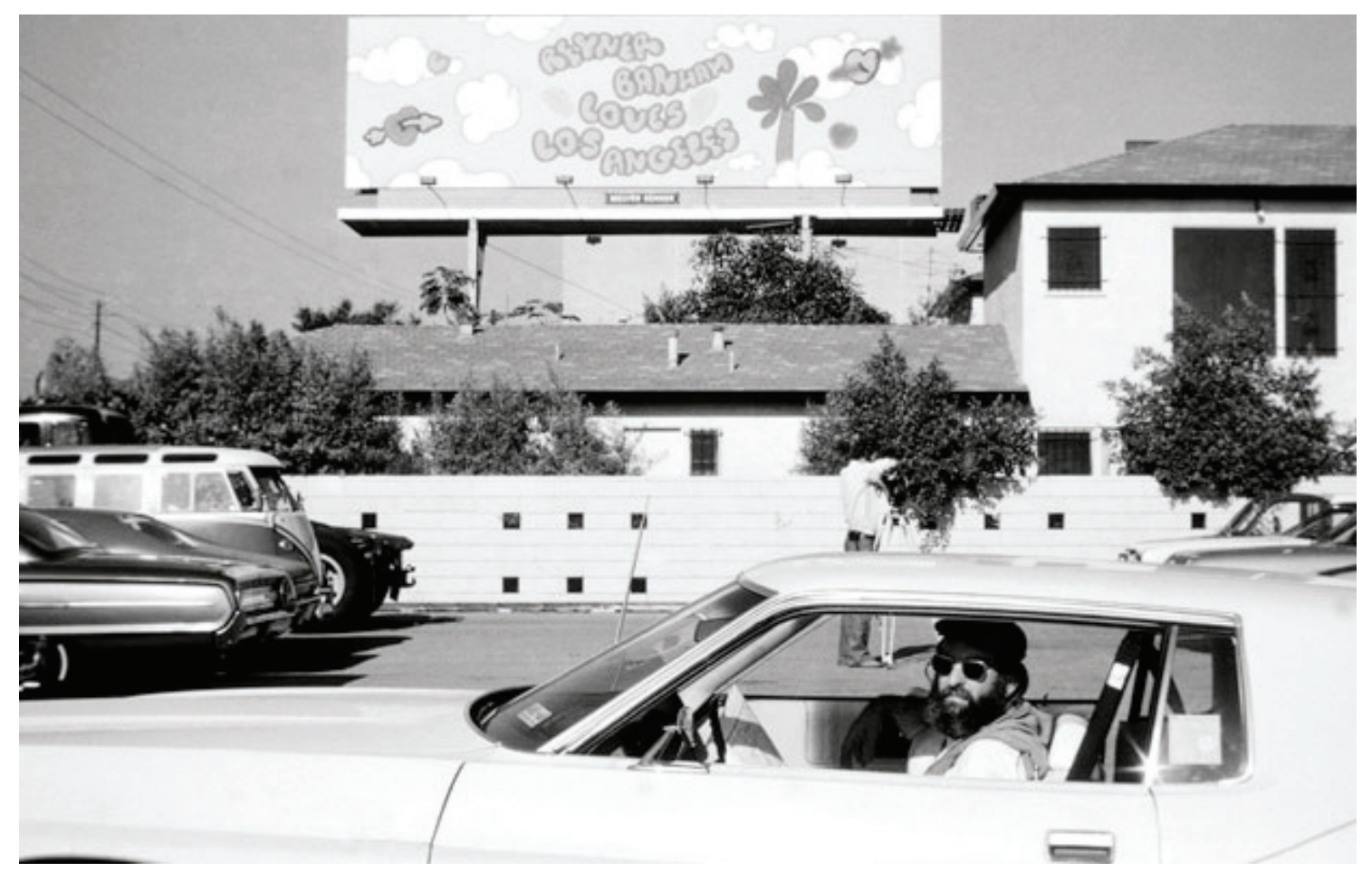

Still do documentário de 1972 da BBC, "Reyner Banham Loves Los Angeles"

Embora Banham tenha escrito sobre Los Angeles, ele nunca residiu na cidade. Tornou-se um constante visitante. Neste processo de investigação e crítica observacional, os temas do vernacular moderno e da paisagem cultural tornaram-se constantes em sua produção. E em Santa Cruz, a mais de 500 quilômetros de distância de Los Angeles, porém a menos de 300 quilômetros de Berkeley, Banham se engajaria com o meio acadêmico da região. Em Berkeley estava Spiro Kostoff, com o qual Banham se alinharia e trocaria experiências e impressões. Seria através de Kostoff que chegaria à J. B. Jackson, intelectual americano e figura paterna dos estudos de paisagem cultural. ${ }^{145}$

Jackson, americano cuja formação fora obtida na Europa, seria uma das figuras mais importantes e notórias do corpo docente de Berkeley na época. Seu interesse pelas expressões populares da paisagem construída americana fez com que ele pudesse aproximar de profissionais e acadêmicos de campos distintos da arquitetura, do design, geografia e da antropologia. Seu ciclo de palestras em Berkeley, em 1976, foi acompanhado por figuras como Reyner Banham, bem como Denise Scott-Brown. Sua pesquisa sobre as paisagens construídas pelo homem em território americano tomaram corpo na revista Landscape, periódico fundado em 1956 que perdurou por

145 Informações coletadas em conversa com o professor Paul Groth, membro do corpo docente de Berkeley e autor de uma série de publicações e compilações a respeito dos estudos de paisagem cultural, paisagens ordinárias e cotidianas, e o legado de J. B. Jackson. Ver também Paul Groth e Chris Wilson (Ed.), Everyday America: Cultural Landscapes Studies After J. B. Jackson. Berkeley: University of California Press, 2003; 
mais de 3 décadas, publicando artigos sobre a valorização não só do folk amparado no artesanato, mas também dos elementos do vernacular moderno - as estradas, os automóveis, os postos de gasolina e os mercados de esquina. Para seus discípulos, Jackson foi o pai da ciência que somava geografia, arquitetura e sociologia, a ser intitulada de 'estudos da paisagem cultural'. Uma das principais contribuições de Jackson não somente em conteúdo, mas em ferramentas de estudo. Seu interesse pela terminologia e pela etimologia dos elementos da paisagem forneceram toda um repertório de análise para as gerações futuras de pesquisadores, arquitetos e geógrafos americanos. Talvez o mais importante termo de seu trabalho seja o termo original do latin cunhado de genius loci, ou o espírito do lugar, ${ }^{146}$ com o qual Jackson trabalharia a idéia dos lugares formados eminentemente por contribuições anônimas, espaços nos quais a vida cotidiana exerce a experiência estética.

Dentro desta atmosfera, seu livro sobre a paisagem cultural do deserto americano estava embebido no entusiasmo sobre o genius loci americano e sobre a metodologia de investigação das paisagens americanas. O livro do deserto, sem notas de rodapé, dificilmente rotulável pela academia, e claramente uma alegoria de outros livros do deserto como o de Charles Doughty, tornou-se mais um atestado de que Banham estava cada vez mais distante do meio acadêmico da Costa Leste. ${ }^{147}$ Dentro da paisagem cultural americana de Banham, expressões do vernacular moderno, e práticas arquitetônicas eruditas encontravam um lugar comum. Esta operação, contudo, foi vista por muitos de seus interlocutores da costa Lesta como populista, e apologética de uma sociedade de consumo em rota de desastre ${ }^{148}$.
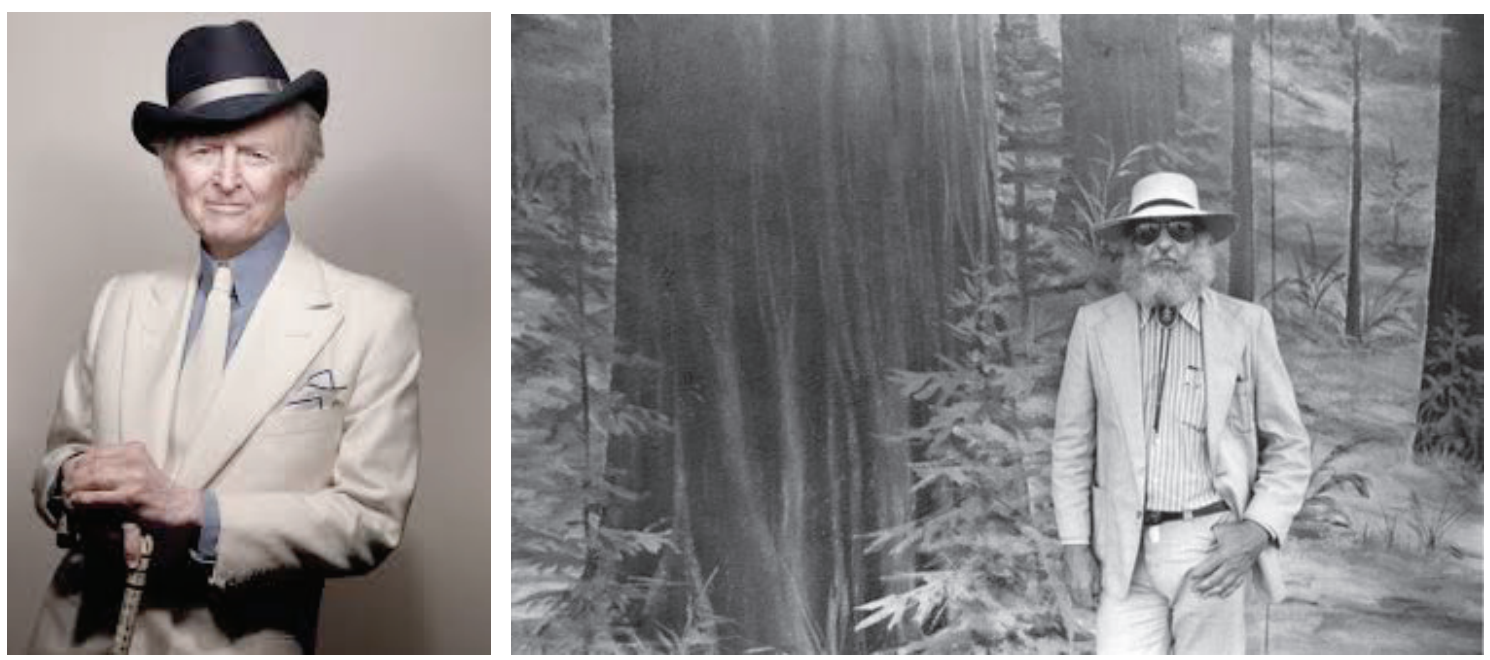

Vestidos à caráter: Tom Wolfe e Reyner Banham, vítimas da moda Americana. Fonte: Revista Log.

146 Sobre o termo genius loci americano, ver Gabrielle Esperdy, em artigo publicado para o Design Observer, "Banham's America", publicado em formato digital em 12 de março de 2012 - http:/ / places. designobserver.com / feature / reyner-banham-in-america /32698/

147 Charles Doughty, Travels in Arabia Deserta, Oxford, 1888.

148 Ver entrevista com Kenneth Frampton, agosto de 2011. 
Outro interlocutor de Banham foi Tom Wolfe, escritor, jornalista e crítico cultural inglês. Considerado um membro da geração beatnik, a qual Banham fazia menção em seus textos, Banham tinha em Wolfe um parceiro em narrativas espirituosas da cultura americana: From Bauhaus to Your House ${ }^{149}$, no qual Wolfe critica a frieza do partido da escola alemã de arquitetura e a rigidez da Neue Sachlichkeit, identificando a rejeição da cultura americana a certos conceitos 'espartanos' europeus; em KandyKolored Tangerine-Flake Streamline Baby, Tom Wolfe disseca a cultura da customização americana, desde o automóvel até as vestimentas e cortes de cabelo, e aponta para a massificação inserida em suas entrelinhas ${ }^{150}$. Wolfe tinha a qualidade de ser ao mesmo tempo um crítico e foco de atenções: sua notoriedade foi muito maior do que a de Banham (bem como seria se compararmos qualquer escritor de romances com críticos de arquitetura), em parte por conta de seu culto à personalidade, o que demonstrava o quanto Wolfe - e em certa medida Banham também - estavam embebidos na cultura americana da auto-afirmação.

De fato, Banham estava em um ostracismo, mas somente ponto de vista eurocêntrico da academia de arquitetura. Seu interesse pelos temas do modernismo, malgrado estivessem permeados pela leitura da arquitetura popular, mereciam igual importância. De 1978 a 1988, Banham construiu o argumento de seus últimos 3 livros em paralelo, dedicando-se a cada momento a cada um deles, conforme a oportunidade apresentada. Seu argumento para o livro sobre arquitetura High-Tech, no qual a genealogia inglesa de arquitetura moderna seria a protagonista na historiografia contemporânea através da obra de Richard Rogers e Norman Foster foi o primeiro a ser concebido ${ }^{151}$. Este projeto, porém, teve que ceder lugar primeiramente ao livro do deserto, finalizado em 1981, e publicado em 1982; e posteriormente a produção do livro sobre o conjunto construído industrial americano, cujos trabalhos intensos tiveram início em 1983 e terminaram em 1986. Somente em 1987, em meio ao processo de transferência para assumir a cadeira Sheldon H. Sollow de história da arquitetura no Institute of Fine Arts da Universidade de Nova Iorque, Banham começou a pesquisa que construiria o seu argumento sobre a arquitetura high-tech. Apesar de ter publicado alguns de seus artigos e entrevistas - inclusive com Renzo Piano e Rogers - o projeto manteve-se inacabado, dadas as complicações do câncer que tomou a vida de Banham em 1988.

149 Tom Wolfe, From Bauhaus to Our House. New York: Picador, 2009.

150 Tom Wolfe, The Kandy Kolored Tangerine Flake Streamline Baby, publicado originalmente em 1963.

New York: Bantam, 1999,

151 Conforme comprova material documental - correspondências e atas de reunião - dentro dos arquivos do GRI. 
Capítulo 2 - Vers Une Architecture Autre 


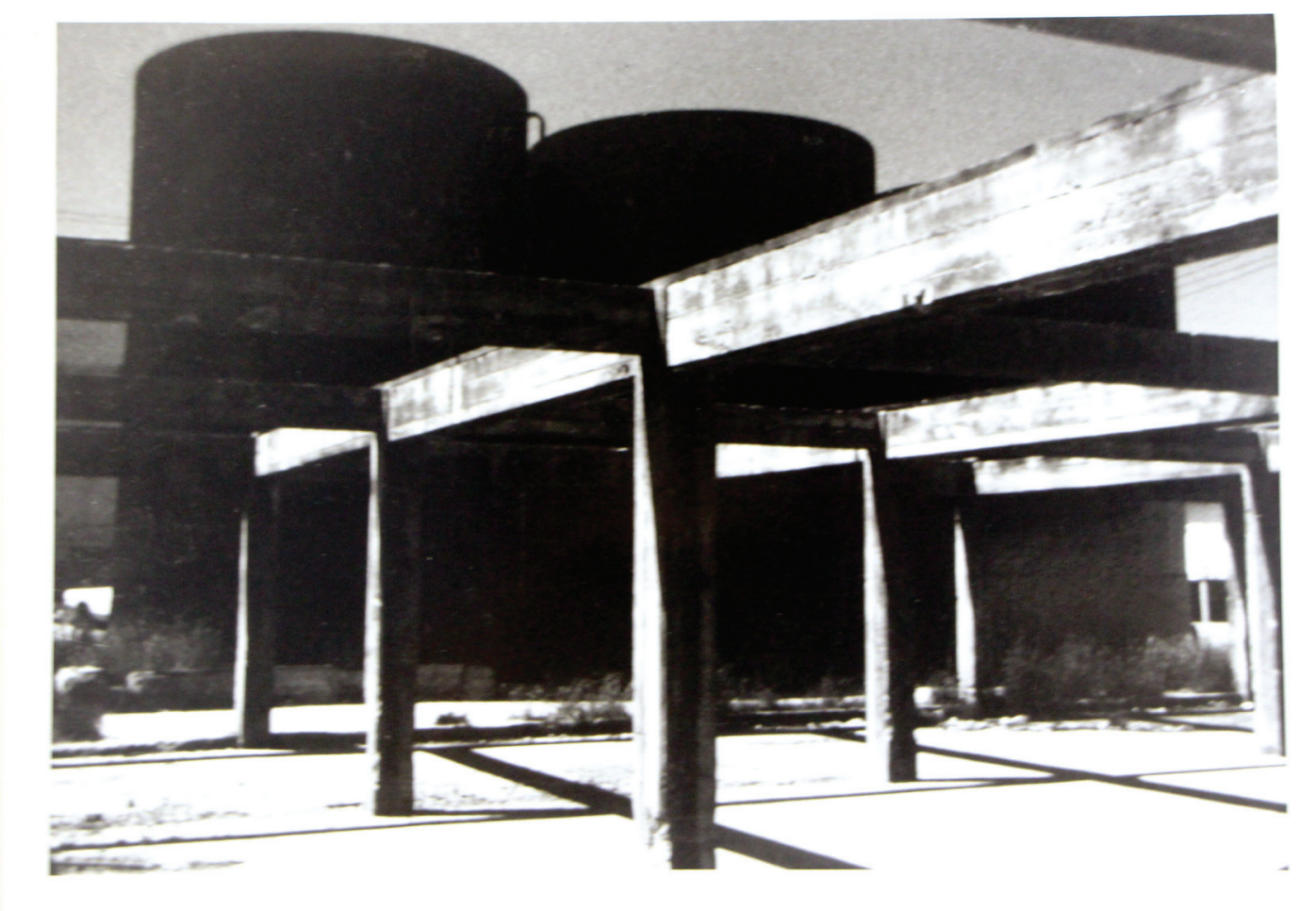

Estrutura em concreto e tanques abandonados, Cannery Row, Monterey, California. Fonte: A Concrete Atlantis: U.S. industrial building and European modern archnitecture. Cambridge: The MIT Press, 1986. p.5

Reyner Banham abre a introdução de seu último livro publicado em vida, $A$ Concrete Atlantis: U.S. industrial building and European modern architecture 1900-1925 com a fotografia que abre também esse capítulo. A imagem sintetiza enquanto alegoria o arco teórico e historiográfico de Reyner Banham sobre a estética da máquina, e sua relação com a arquitetura moderna européia. Muitos dos críticos que investigaram a obra de Banham não conseguiram escapar do rótulo corriqueiro de "historiador do futuro imediato" ${ }^{1 "}$, ou historiador da "estética da era da máquina". A partir da verdade parcial que esse rótulo encerra, e mesmo com a oportunidade de acrescentar alguns novos elementos da cultura construtiva americana, assume-se que em Banham houve um meta-projeto historiográfico perene sobre o tema da estética da máquina, bem como da relação entre arquitetura e engenho humano, tema que teria permeado a modernidade. Tal tema foi inicialmente apresentado em sua revisão crítica da historiografia da arquitetura moderna e a atitude da indústria americana, em Teoria e Projeto na Primeira Era da Máquina²: inicialmente, enquanto ainda residia na

1 Ambos os historiadores Nigel Whiteley e Anthony Vidler se apropriaram do termo para cunhar suas recentes obras historiográficas: Reyner Banham: historian of the immediate future. Cambridge: The MIT Press, 2002; e Histories of the Immediate Present: inventing architectural modernism. Cambridge: The MIT Press, 2008.

2 Reyner Banham, Theory and Design in the First Machine Age. Cambridge: The MIT Press, 1980. Originalmente publicado pela Architectural Press em 1960. Ver os capítulos “The Factory Aesthetics"e "Germany: Industry and the Werkbund". 
Inglaterra, Banham identifica predisposições e preconceitos de seus antecessores da historiografia moderna em relação às fábricas americanas e a produção moderna. O eurocentrismo e o fetiche da máquina foram apontados por Banham sobre obras como a Fagus Werk, de Walter Gropius. Mas Banham tardou quase toda sua carreira, cerca de 30 anos, para consumar sua postura, quando finalmente se encontra defronte destes elementos da paisagem industrial americana ${ }^{3}$. Banham criticava os historiadores europeus de tecer comentários sobre obras que sequer foram visitar em pessoa. $\mathrm{Na}$ posição de historiador observacional, restaria a Banham encontrar com tais elementos do pragmatismo americano.

A grande contribuição da cultura dos Estados Unidos para a fundamentação da estética da máquina, bem como para o engajamento com a tecnologia na arquitetura moderna é também um distúrbio deste modelo pré-estabelecido ${ }^{4}$. As fontes dessa contribuição - e deste distúrbio - estão em duas grandes características, presentes na raiz do pensamento produtivo americano (buscaremos neste capítulo abordar alguns tópicos que explicitem essas duas fontes). Primeiro, o resultado do fácil acesso à tecnologia, fomentada pelo franco desenvolvimento da industrialização em território americano após a Guerra Civil, cuja exposição de seu potencial ao resto do mundo teve sua temporalidade encerrada na primeira metade do século $X X^{5}$. No processo de ocupação do território, a cultura construtiva norte-americana assimilou o espírito de investigação e invenção humano em seu ethos moderno ${ }^{6}$. Carros, eletrodomésticos, soluções construtivas não só pré-fabricadas mas transformadas em objetos de consumo são algumas das manufaturas desta cultura produtiva7, absorvidas pelo modo de produção de consumo de massa e disponibilizadas ao vasto mercado consumidor americano $^{8}$. Encerrada na crítica de Banham a respeito dos teóricos do funcionalismo

3 Nigel Whiteley, em Reyner Banham: historian of the immediate future, malgrado não tenha se dedicado especificamente em analisar a obra de Banham sobre o conjunto fabril Americano da virada do século, percebe o fechamento do arco teórico iniciado em 1960.

4 Para o argumento a seguir, consideramos as diversas tradições do movimento moderno, que malgrado sua polifonia, lograram fomentar o arcabouço teórico do Estilo Internacional, na primeira metade do século XX, representados por Le Corbusier, Walter Gropius, Mies Van der Rohe, elevados ao patamar de figuras centrais do modernismo em sua fase heróica por Nikolaus Pevsner, Siegfried Giedion, Adolf Behne e Walter Curt Behnrendt.

5 Gwendolyn Wright, “Modern Consolidation, 1865-1893” in Wright, G., USA: modern architectures in history. London: Reaktion Books, 2008, pp. 17-46.

6 Idem, p.19-27. Gwendolyn Wright indica que a arquitetura moderna nos Estados Unidos foi profundamente afetada pelos resultados da Guerra Civil que terminou em 1865. O avanço industrial dos estados do norte do país alavancaram a reconstrução de toda a nação. Os efeitos da recém estabelecida igualdade racial e a ampliação do mercado consumidor transformaram o país e sua arquitetura em fenômenos modernos. O crescimento da malha ferroviária foi seguido pela criação de uma rede de cidades pioneiras, o que permitiu a expansão da malha rodoviária e a viabilização do automóvel como produto de consume.

7 Aqui o termo 'produtiva' substituiu o termo 'construtiva', como sugestão da relação entre indústria do objeto e da construção como possuidoras de um mesmo radical.

8 Penny Sparke, "From Production to Consumption in Twentieth Century Design" in Ainsley, Jeremy, 
moderno - principalmente Alberto Sartoris, Le Corbusier e Siegfried Giedion ${ }^{9}$ - está a fascinação destes intelectuais, por objetos como transatlânticos, aviões e automóveis (e como a idéia criada por estes teóricos, malgrado mantivesse uma "certa nobreza, era simbolicamente empobrecida"10). Foi principalmente com o grupo de historiadores e artistas como Richard Hamilton, Banham e os Smithsons ${ }^{11}$ que tais elementos, e outros da cultura produtiva americana foram tomadas em sua carga simbólica plena. Lawrence Alloway, outro participante do Independent Group (IG), descreveu as predisposições do grupo, afirmando justamente o interesse em comum pela cultura vernacular, o qual teria persistido para além de qualquer outro interesse do grupo no campo das expressões artísticas. Os objetos de cultura a serem produtos de consumo de massa descartáveis, como filmes, propagandas, ficção científica e música pop eram não só aceitos, como também analisados em detalhe, e consumidos esteticamente ${ }^{12}$. A geração de Banham estava portanto inserida, já na Segunda Era da Máquina, expostos aos produtos de uma cultura de consumo e comunicação de massa. Banham olhava para trás, e tentava entender os fenômenos da Primeira Era da Máquina, na tentativa de reabrir as narrativas modernas, que em seu entendimento ainda apresentavam lacunas.

A segunda fonte deste distúrbio foi a aplicação do engenho humano no controle do ambiente imediato, em seus atributos climáticos, sociais e econômicos, através do consumo elevado dos meios de produção e recursos naturais. Em The Architecture of the Well-Tempered Environment, Banham confere à cultura construtiva dos Estados Unidos o papel de protagonista no desenvolvimento de mecanismos de controle climático que suprimiriam a necessidade de uma tectônica mais robusta, desde as lareiras dos pioneiros desbravadores, até o empreendedorismo de Willis Carrier no desenvolvimento dos mecanismos de ar-condicionado ${ }^{13}$. No presente capítulo será apresentada a trajetória do desenvolvimento tecnológico norte-americano, suas relações e trocas com a produção de arquitetura nos Estados Unidos, da escala do objeto industrial à produção da paisagem construída pelo homem, bem como seus espelhamentos e confrontos com a cultura tecnológica e arquitetônica moderna - de radical europeu. $\mathrm{O}$ eixo condutor desta investigação, cujo foco se desloca de maneira pendular entre as genealogias da cultura modernista na Europa e Estados Unidos é a

Atkinson, Harriet (ed.). The Banham Lectures: essays on designing the future, Cambridge: The MIT Press, 2009, pp.127-128.

9 Reyner Banham, "Conclusion: Functionalism and Technology" in Theory and Design in the First Machine Age, pp. 320-322

10 Idem, p.322

11 Formados dentro do Institute of Contemporary Arts da Universidade de Londres, e membros fundadores do Independent Group - ver capítulo 1 para a descrição biográfica do grupo e a trajetória específica de Banham dentro do métier inglês de crítica da arte.

12 Nigel Whiteley, p. 91.

13 Reyner Banham, The Architecture of the Well Tempered Environment. Chicago: University of Chicago Press, 1984 
produção bibliográfica de Reyner Banham, selecionando as narrativas que abordam a relação entre engenho humano e produção (e controle) dos ambientes adequados para as atividades humanas ${ }^{14}$.

\section{Era da Máquina}

Para entender as diferenças nessas duas genealogias do modernismo (europeu e norte-americano), é necessário entendermos o contexto intelectual, econômico e cultural nos quais os profissionais de arquitetura e seus clientes se inserem. Também é fundamental, se considerarmos um espectro mais amplo, entender as relações entre homem e máquina nos dois panoramas. Para o historiador alemão Siegfried Giedion, autor de Mechanization Takes Command ${ }^{15}$, seu livro seminal cuja temática é o efeito da era de mecanização total sobre as relações humanas desde o século XVII até os primórdios do século $X X$, há uma diferenciação entre os modelos de industrialização nos Estados Unidos e Europa. De fato, o processo de desenvolvimento tecnológico para substituição do trabalho manual pela máquina fora acelerado, em ambos os continentes. Contudo, a inserção social do processo de criação de novas tecnologias teria sido diferente nos dois lados do Oceâno Atlântico Norte: a apropriação dos meios de produção para a invenção e aprimoramento de sistemas que Giedion chama de "mecânicos complexos"16 teria se democratizado na América. Enquanto a oportunidade de criação se reservava a um extrato social específico e privilegiado na Inglaterra e Alemanha - a aristocracia e a jovem burguesia industrial em 1800; e em 1900, através de uma já fortalecida e proeminente burguesia industrial, com expoentes do mercado de construção civil, especulação imobiliária e financeira - já na América, a genealogia da tradição de pioneirismo tecnológico seguiria caminhos mais abertos. O empreendedorismo teria sido compartilhado entre artesãos, industriais, cientistas auto-didatas; técnicos e acadêmicos, que buscavam soluções para aprimoramento de seus ofícios, focando em certa medida na manutenção da qualidade do produto, mas principalmente na produtividade da linha industrial, e por extensão, na possibilidade de consumo massivo de seus produtos.

14 Tradução para o português do recorrente termo do autor, "fit environments for human activities". Presente em muitos textos de Banham, o termo 'environment', cujo significado transcende sua tradução, ambiente, era um substituto recorrente para o ensino de arquitetura nos Estados Unidos, como visto no capítulo I. O presente argumento passa pela discussão sobre o campo ampliado da arquitetura, tema de algumas narrativas de Banham. Sobre esse assunto, ver o capítulo "The Expanded Field", em Whiteley, Historian of the Immediate Future, pp. 186-243

15 Siegfried Giedion, Mechanization Takes Command: a contribution to anonymous history. Norton \& Company, New York, 1969.

16 Ver "The simple and the Complicated Craft"na monografia de Siegfried Giedion, Mechanization Takes Command", pp.39-40; e o capítulo "The Mechanization of the complicated Crafr", idem, pp. 51-76. 
“Um fervor coletivo por invenção parece ter seguido curso durante este período. No século XVII a vontade inventive foi poss de um grupo limitado de intelectuais - filósofos e letrados como Pasqual, Descartes, Leibnitz, Huygens, ou mais para trás, o homem universal de Leonardo [Da Vinci]. A orientação era de distribuir posteriormente às massas o que se delineou nas mentes de poucos. Até o final do século XVIII, a atividade de invenção, enquanto encontrado nos arquivos de patentes ingles, era um pouco mais do que um punhado de numerous. Até o meio do século XIX esse processo se difundiu entre as massas, talvez mais na América dos anos 1860 do que em qualquer lugar." ${ }^{\prime 17}$

Já para Reyner Banham, um dos aspectos relevantes não seria apenas a maior familiaridade da população americana com inventos e produtos industriais em geral, mas diz sobre o input popular na apropriação da modernidade, fortemente baseado no materialismo, no acesso fácil e amplo à tecnologia, e ao espírito empreendedor embebido na cultura americana ${ }^{18}$. Como veremos no decorrer deste capítulo, nos Estados Unidos da América o espírito do arquiteto teria seguido o mesmo padrão do empresário em geral: oportunismo, empreendedorismo e capacidade de buscar respostas a demandas de mercado. Embora não tenha sido um dos primeiros estudiosos do fenômeno do "Americanismo" - processo de apreciação da referência americana pelos intelectuais europeus, ou filão específico da modernidade regional nos Estados Unidos ${ }^{19}$ - Banham se destaca por dedicar-se a escrutinar os produtos construídos da relação entre progresso e tradição na cultura construtiva industrial nos Estado Unidos, de modo a evidenciar as diferenças ideológicas entre o pioneirismo

17 Idem, p. 191. Texto original: A collective fervor for invention seems to course through this period. In the seventeenth century the inventive urge was possessed by a limited group of scholars - philosophers and savants like Pasqual, Descartes, Leibnitz, Huygens, or further back, the universal man of the Leonardo type. The orientation that was later to sway the masses of the people first takes shape in the minds of the few. Until late in the eighteenth century, inventive activity, so far as it found record in the British Patent archives, was no more than a trickle. Toward the mid-nineteenth century it gained its hold over the broad masses, and perhaps nowhere more strongly than in the America of the 'sixties [1860].

18 Dentro da bibliografia de Banham alguns artigos se destacam no tema do engajamento entre tecnologia e arquitetura nos Estados Unidos: "Art and Necessity: Inmos and the Persistence of Functionalism", Architectural Review, Dezembro 1982, vol.172: pp.34-41, 93-100; “A Throw-Away Aesthetics", Industrial Design, Março 1960, Vol, 7: pp.45-58; e um dos mais conhecidos artigos do autor, publicado na maioria de suas compilações, "1960 - Stocktaking of the Impact of Traditions and Technology on Architecture Today", Fevereiro 1960.

19 Para Jean-Louis Cohen, em Scenes of the World to Come: Architecture and American Challenge 1893-1960, a América jamais deixou de assumir o papel designado pela imaginação européia: tanto em sua faceta urbana quanto rural, a América que outrora não adotava o modelo de urbanização que acompanhou a sua industrialização, tornou-se exemplar do urbanismo movido pelo capitalismo, formado por cidades marcadas por grelhas ortogonais rigorosas, arranha-céus e contrapartidas em uma vastidão de subúrbios. Cohen indica que o arranha-céus é seu principal objeto de pesquisa neste livro, e que o abordará entendendo que este fenômeno, malgrado não restrito aos Estados Unidos, encontra sua forma mais eloquente por lá. Para Cohen, citando o êxito da tipologia em Chicago e Nova Iorque, e o fracasso em Paris - bairro de Defense - não é o arranha-céu que faz a cidade, mas sim a cidade quem faz o arranha-céu. 
europeu e americano. Mas também se destaca por se lançar em corpo físico na paisagem americana ${ }^{20}$. O leque de referências entre inventores buscava ampliar a historiografia da arquitetura moderna americana, elencando figuras como Ernst Ransome, engenheiro e inventor de técnicas construtivas em concreto, como integrante de uma genealogia alternativa de modernismo:

“Modernistas europeus, olhando através de todo o Atlântico, e em quase total ignorantes da antiga tradição, podem ter acreditado que o que eles viram era radical, sem precedentes e revolucionário: mas no seu território e contexto, isso parece não mais radical, não mais inovador que o necessário para garantir, passo a passo, as economias competitivas para seus clientes. Patrões de nariz empinado e os arquitetos que os serviam conservavam usos tradicionais que eram meramente práticos. Eles não tinham nenhum eixo ideológico para se agarrar, nenhuma postura revolucionaria para manter, mesmo que eles soubessem - como sabia Ransome ao final de sua vida - que a revolução na arquitetura industrial tinha chegado. Paulatinamente, as dinâmicas dos edifícios na economia de mercado em uma época de avanços tecnológicos velozes produziriam cada aspecto de uma revolução arquitetônica exceto seu conteúdo revolucionário. A racionalidade do sistema de economia industrial para o qual esses arquitetos serviam requeria deles, como inovações diárias e costumeiras, eram as mesmas que os futuristas europeus exigiam como pré-requisitos para uma utopia distante e desejada." ${ }^{21}$

De maneira elogiosa ao campo americano de arquitetura e construção daquela época, Banham coloca no mesmo patamar a produção europeia e americana. Podemos ver claramente sua agenda política, que remonta ao capítulo da estética da fábrica, em Teoria e Projeto na Primeira Era da Máquina22. Dessa vez, contudo, Banham está imerso no ambiente acadêmico americano, e embebido de entusiasmo frente ao pragmatismo e engenhosidade da cultura construtiva local. Por outro lado, no ambiente acadêmico europeu racionalismo e neoclassicismo nunca foram apartados, e os marcos da

20 A qual iremos abordar no Capítulo 3: Paisagens Americanas

21 A Concrete Atlantis, pp. 52-53. Texto original: European modernists, looking across the full width of the Atlantic and in almost complete ignorance of the former tradition, might have believed that what they saw was radical, unprecedented, and revolutionary; but on its territory and in context, it looks no more radical, no more innovative than was needed to ensure, step by step, competitive economies for the clients. Hard-nosed patrons and the architects who served them conserved traditional usages that were still serviceable. They had no ideological axes to grind, no revolutionary postures to maintain, even if they knew - as Ransome did at the end of his life -that revolutions in industrial architecture had been wrought. Piecemeal, the dynamics of building in a market economy at a time of rapid technological advance would produce every aspect of an architectural revolution except the revolutionary intent. The rationality of the economic industrial system that these architects served required of them as a daily commonplace innovations as constant as any European futurist of the day could demand as prerequisites for some distant but, desired utopia.

22 Reyner Banham, "The Factory Aesthetic"em Theory and Design in the First Machine Age, pp.79-87 
arquitetura moderna foram construídos pelo engenho de arquitetos intelectualizados, alguns dos quais instalados em escolas de arquitetura proeminentes, radicais e renovadoras; enquanto os feitos na América, em sua maioria, passavam pelas mãos de engenheiros e arquitetos em ambientes profissionais significativamente diferentes dos europeus, distribuídos pelo vasto território dos Estados Unidos, em pequenos assentamentos urbanos, quase sempre distantes de qualquer ambiente universitário. Para a geração de Giedion, o Taylorismo e o Fordismo eram os objetos de estudo mais recorrentes, visto o impacto de tais fenômenos na Primeira Era da Máquina. Tanto a influência da indústria quanto da arquitetura no ideário dos arquitetos europeus foi posteriormente cunhada de americanismo ${ }^{23}$. Mas o entendimento ainda não era consolidado. Os termos "linha de produção", "americanismo" "fordismo", entre outros, ainda não tinham tomado domínio no senso comum da historiografia européia.

“O sintoma da mecanização total é a linha de montagem, na qual a fábrica inteira é consolidada em um organismo sincronizado. Desde sua primeira aparição no século XVIII até sua decisiva elaboração entre duas guerras mundiais, a linha de montagem é uma instituição americana. O que devemos dizer sobre ela está ainda esboçado. Até onde sabemos, nenhum aporte histórico cobre o mais significativo fator da capacidade produtiva americana." 24

Para Jean-Louis Cohen, mais do que imagens de fábricas difundidas por meio de fotografias que se espalharam pela Alemanha, Paris e Moscou, foi a organização de trabalho Fordista e Taylorista que enraizou o americanismo na Europa em meados da primeira grande Guerra. A biografia do industrialista de Detroit, Frederick Winslow Taylor, se disseminou em traduções pelo continente europeu. Muitos desenvolvimentos prévios ao taylorismo, ocorridos durante os 30 anos finais do século XIX permitiram a introdução da doutrina dentro das plantas industriais na cultura ocidental..$^{25}$

Dentre os métodos científicos de organização de trabalho introduzidos por Taylor, destaca-se a introdução das mulheres nas plantas industriais e escritórios. O taylorismo, segundo Cohen amparado por Olivier Pastré, define-se por separações de esferas de trabalho tanto horizontais - divisão de tarefas - quanto verticais - separação entre projeto e execução, seja de arquitetura, indústria ou qualquer produção digna

23 Ver Antonio Gramsci, Americanismo e Fordismo (tradução Gabriel Bogossian; introdução Ruy Braga). São Paulo: Hedra, 2008

24 Siegfried Giedion, Mechanization Takes Command, p. 5. Texto original: The Symptom of full mechanization is the assembly line, wherein the entire factory is consolidated into a synchronous organism. From its first appearance in the eighteenth century down to its later and decisive elaboration between the two world wars, the assembly line is an American institution. What we shall have to say about it is but roughly carved out. As far as we know, no historic account yet covers this most significant factor in America's productive capacity.

25 Jean-Louis Cohen, Scenes of the World to Come: European Architecture and American Challenge 1893-1960. Canadian Centre for Architecture, Paris, Flammarion, 1995 
de controle e gestão ${ }^{26}$ Já o Fordismo opera de maneira diferente, porém em diversos momentos os dois modelos gerenciais se confundiram historicamente:

“Frequentemente confundido com Taylorismo, o Fordismo é um modo de organização de trabalho baseado na introdução da linha de montagem e produção em massa de um lado, e do outro, uma generosa política de remuneração que cria um mercado de consumo de massa para produtos manufaturados. A difusão do Fordismo na Europa e no mundo foi em grande extensão devido às traduções dos livros de Ford, os quais foram sucesso de vendas imediato e duradouro. Ademais, registros de experiências americanas, como as Standards por Hyacinthe Dubreil, que se tornou amigo próximo de Le Corbusier, acelerou a disseminação do mito para o qual Rene Clair prestou um tributo cinematográfico no filme de 1932, 'A nous fa liberte'." ${ }^{27}$

A diferença entre os modelos industriais claramente se remete ao conceito de modernidade. Como a citação de Gertrude Stein apresentada no ensaio do arquiteto Rem Koolhaas sobre a modernidade baseada na congestão materializada em Nova Iorque - Nova Iorque Delirante - enquanto na Europa a indústria se forma como conceito, enquanto "os americanos são os materialistas do abstrato" 28 . Neste momento Koolhaas traça o perfil do arquiteto responsável pela expressão dos motivos da modernidade americana, em destaque, o arranha-céus; o arquiteto em específico, o autor do projeto do Rockefeller Center, materialização da ambição da família de John D. Rockefeller, Raymond Hood.

Dessa simplificação relacionada principalmente à matriz econômica do uso da tecnologia, podemos tirar não só as diferenças entre os modelos de industrialização, bem como posturas em relação ao papel da indústria no cotidiano dos distintos modelos produtivos, subjugados a diferentes contextos de clima, recursos naturais, quadros sociais e ambições estéticas e econômicas. No plano ideológico, onde o posicionamento político era tão distinto entre arquitetos europeus e americanos, confundia-se radicalismo com pragmatismo. Em A Concrete Atlantis ${ }^{29}$, Banham resgata as ruínas do curto ciclo de industrialização que precedeu o modelo de industrialização predominante da máquina de Guerra americana: entre 1900 e 1925, o parque industrial nos Estados Unidos passou por rápidas e profundas transformações, modernizações

\footnotetext{
26 Idem. p. 69

27 Idem. p. 70. Texto original: Frequently confused with Taylorism, Fordism is a mode of labor organization based on the introduction of the assembly line and mass production on the one hand, and on the other, a generous wage policy that creates a mass consumer market for manufactured goods. The spread of Fordism in Europe and the world was to a large extent due to translations of Ford's own books, which were immediate and lasting bestsellers. Moreover, accounts of direct American experiences, such as Standards by Hyacinthe Dubreuil, who became a close friend of Le Corbusier, hastened the dissemination of a myth to which Rene Clair paid a cinematographic tribute in his 1932 film 'A nous fa liberte'.

28 Ver Rem Koolhaas, Delirious New York: a Retroactive Manifesto for Manhattan, pp. 161-205

29 Reyner Banham: A Concrete Atlantis: US Industrial Building and European Modern Architecture - 1900-

1925. Cambridge, The MIT Press, 1986.
} 
fomentadas por um frenético ritmo de desenvolvimento tecnológico que tirou o país da tradição escandinava, importada de unidades industriais erigidas em blocos de pedra e madeira, para sistemas complexos de concreto armado e estrutura metálica que, conforme defendeu Banham, rivalizavam com o processo de industrialização de construção na Europa ${ }^{30}$. Mais do que isso: tais inovações na paisagem industrial americana despertou a sensibilidade dos formadores de opinião entre os heróis do modernismo nas décadas de 1920 e 1930 - ou seja, Le Corbusier, Walter Gropius, Eric Mendelsohn, Moizei Ginzburg. Estes arquitetos americanos, heróis alternativos da formação do estilo internacional, homens cujo espírito empreendedor e pragmatismo teriam substituído o interesse intelectual dos seus contemporâneos europeus, cuja menção histórica lhes teria sido renegada, têm em seu âmago uma diferente genealogia do engenho humano de controle ambiental e respostas rápidas à demanda do progresso industrial.

Nigel Whiteley identifica a diferenciação entre "Máquina" e "Indústria" no discurso de Banham ${ }^{31}$. Ele afirma que a revolução industrial americana teria mudado o cotidiano coletivo e doméstico com o aquecimento mecanizado e a luz elétrica; na primeira era da máquina, entre a segunda metade do século XIX até a Segunda Guerra Mundial, as mudanças no cotidiano pessoal e social foram profundas, com a produção de eletrodomésticos, com os avanços da química sintética. gramofones reproduziram a música no ambiente doméstico, esta outrora reservada aos grandes salões, bares, ruas e outros espaços sociais; a máquina de escrever ampliou o espectro literário; e as máquinas reduzidas em seu tamanho chegaram ao domicílio e passaram a ser manuseadas por mulheres, como o telefone, o aspirador de pó e forno á gás. ${ }^{32}$ O automóvel, reservado às elites que podiam sustentar esse luxo, foi o símbolo da Primeira Era da Máquina.

Se nos debruçarmos sobre a Segunda Era da Máquina, mais especificamente sobre o fenômeno do consumismo, através de Banham perceberemos que o impacto do avanço tecnológico galga de patamar ao tornar-se mais democrático e expansivo. Os domicílios das classes médias e abastadas deixaram de ser os únicos campos afetados pelo desenvolvimento da máquina. Enquanto o cinema fora, na Primeira Era da Máquina, o único veículo mecanizado de cultura de massa, o símbolo desta era (a Segunda, na qual se insere o Banham de 1960) é a televisão. ${ }^{33}$

Uma decorrência deste pragmatismo e fácil acesso aos meios de produção, é a popularização da apropriação da tecnologia - e da arquitetura - nos Estados Unidos. Esse tipo de aproximação entre público consumidor as formas do urbano, concomitantemente ao progresso tecnológico, fomentou o nascimento de um tipo de

30 Generosamente registrado pela historiografia da geração de Pevsner e Giedion, em Pioneers of Modern Design e Space, Time and Architecture, respectivamente.

31 Nigel Whiteley, Reyner Banham: the historian of the immediate present, pp.53-54

32 Reyner Banham, Theory and Design in the First Machine Age, p. 10.

33 Idem, p.13 
modernidade dotado de uma genealogia (e um radical) diferentes de seu correlato do velho continente. Cidades energizadas pela luz elétrica, pela multidão, mas também um território de experiências e desbravamentos onde empreendedores encontravam à sua mão meios para criar, inventar e transformar o ambiente. Uma modernidade distópica, aos olhos Europeus, pela promiscuidade para com o modo de produção capitalista, e por seus protagonistas, cujos interesses não eram, aos olhos dos Europeus, nobres como os de seus pensadores de sua modalidade de modernismo.

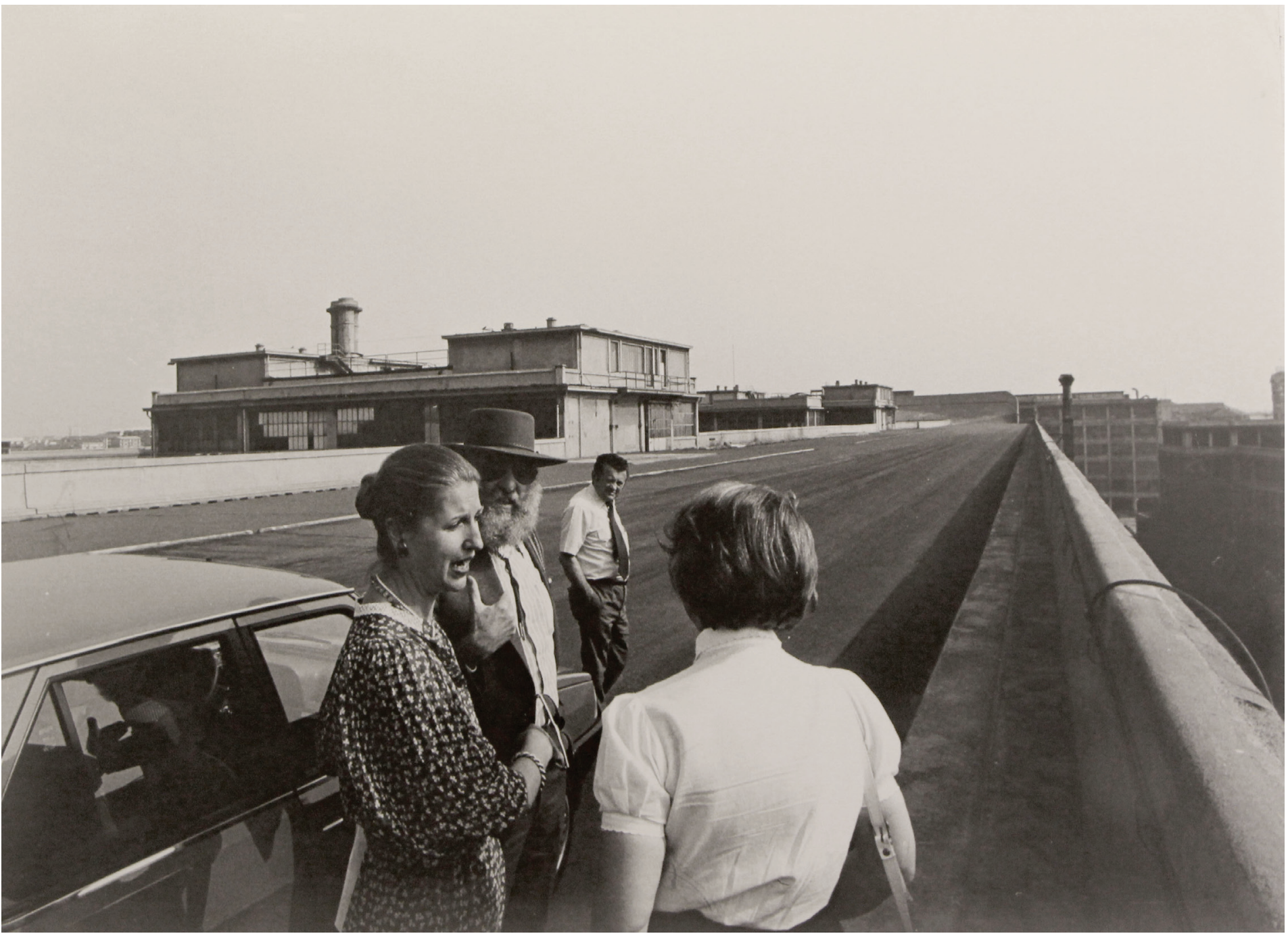

Reyner Banham em visita à fábrica Fiat-Lingotto, acima da pista de testes da cobertura. Data: 1984. Fonte: Arquivo Getty 


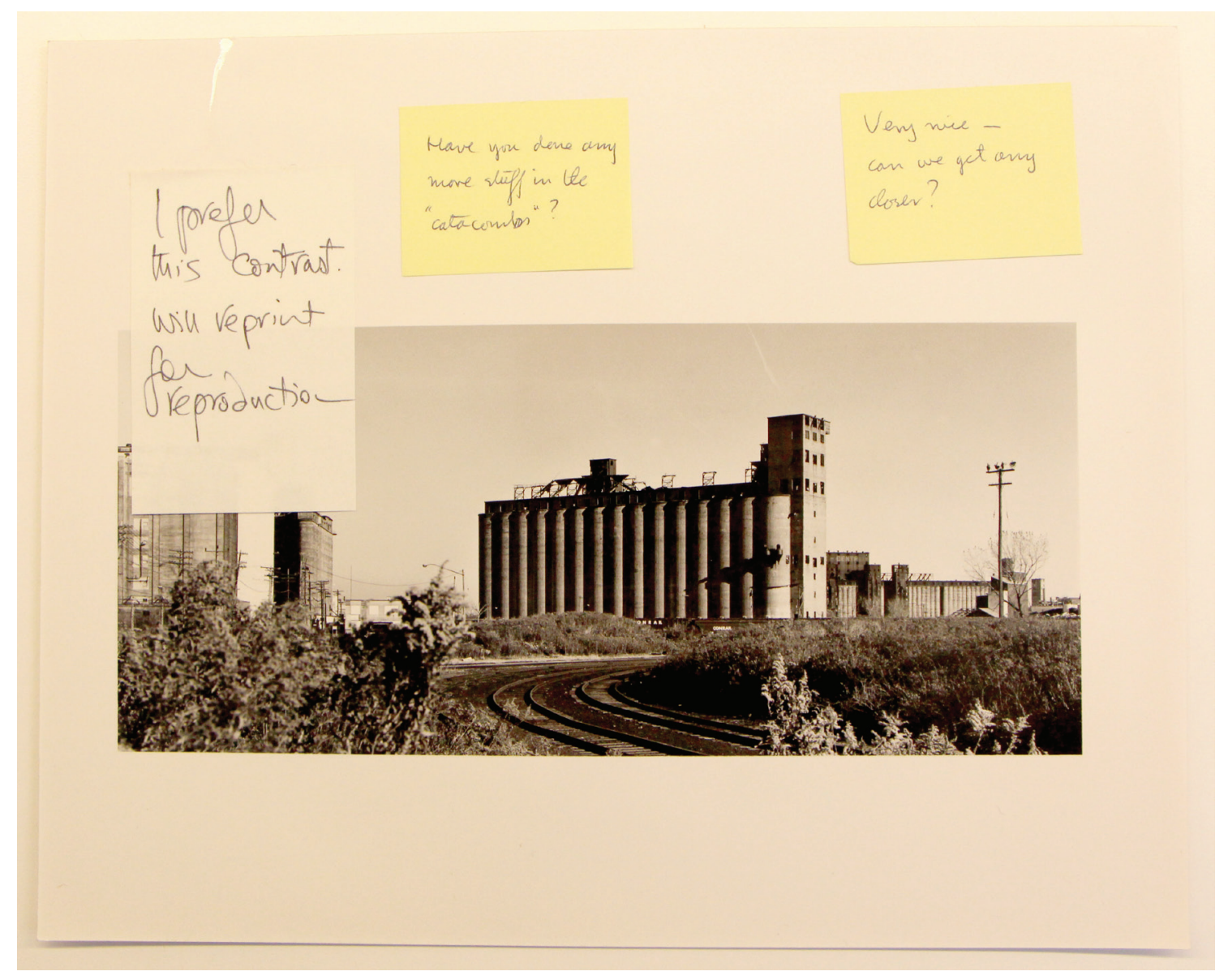

Silo de Grãos: teste para foto de ilustração de A Concrete Atlantis. Patricia Bazelon, 1986.

Fonte: arquivo Getty

\section{Americanismo, Futurismo e Expressionismo}

"Pode ser que aquilo que até aqui entendemos como arquitetura e aquilo que começamos a entender como tecnologia sejam disciplinas incompatíveis. O arquiteto que se proponha acertar o passo com a tecnologia sabe agora que terá a seu lado uma companheira rápida e que, a fim de manter o ritmo, pode ser que ele tenha que seguir os futuristas e deixar de lado toda a sua carga cultura, inclusive a indumentária professional pela quale le é reconhecido como arquiteto. Se por outro lado, decidir não fazer isto, pode vir a descobrir que uma cultura tecnolófica decidiu ir à frente sem ele. Trata-se de uma escolha que os mestres da década de 20 deixaram de observar até que a fizeram por acidente; este entretanto, é um tipo de acidente ao qual a arquitetura pode não sobreviver pela segunda vez - podemos acreditar que os Arquitetos da Primeira Era da Máquina estavam errados, mas nós, da Segunda Era da Máquina, ainda não temos razões para sermos superiores a eles." ${ }^{34}$

34 Reyner Banham, Teoria e Projeto na Primeira Era da Máquina, p.515. 
Em Teoria e Projeto na Primeira Era da Máquina, temos a imagem mais difundida do acadêmico e pesquisador Reyner Banham ${ }^{35}$. O livro também é fonte de uma das principais leituras equivocadas sobre o autor, ao mesmo tempo que uma das mais honrosas homenagens a um historiador de arquitetura com apenas 32 anos de vida: o enquadraram seu trabalho na linhagem de uma tradição de manuais de arquitetura que buscavam encontrar, cada um com sua respectiva agenda, uma genealogia do Movimento Moderno na arquitetura ${ }^{36}$. De fato, Teoria e Projeto não foge desta tradição inteiramente. Mas Banham na verdade se faz valer da já consagrada tipologia da literatura de arquitetura para apresentar sua crítica à historiografia estabelecida. Segundo Banham, uma das grandes confusões geradas pelo academicismo foi a substituição do termo 'racional'por 'funcional: a primeira menção ao termo foi a partir do livro Gli Elementi dell'architecturea Funzionale, inicialmente cunhado por Alberto Sartoris como Architettura Razionale.

O funcionalismo segundo Reyner Banham, como credo ou programa, poderia ter uma certa nobreza austera, mas era simbolicamente empobrecido. A grande falácia da historiografia moderna a partir da década de 1930 fora ignorar a carga simbólica da produção dos arquitetos ativos durante a década de 192037. Na geração de Pevsner e Giedion, cúmplices e relatores do período heróico da arquitetura moderna, Banham identifica efeitos da proximidade temporal e social do historiador para com seu objeto de pesquisa ${ }^{38}$. Teria existido na historiografia anterior à geração de Banham a omissão de algumas narrativas, as quais, segundo Banham, não se encaixavam na narrativa consagrada da arquitetura moderna, fruto de um processo seletivo e classificador. Nigel Whiteley indica que as omissões teriam feito parte da chamada 'Zona de Silêncio'. Mesmo dentro das próprias biografias pessoais dos principais arquitetos da narrativa seletiva da historiografia moderna teriam existido omissões parciais de suas trajetórias profissionais:

"As omissões de Gropius eram sintomáticas do que Banham descreveu como "Zona de Silêncio", mesmo que tenha sido o "período no qual a maioria dos mestres da

35 Conforme previamente mencionado na introdução, é a única obra do autor traduzida para a língua portuguesa até então. O segundo livro de Banham a ser publicado em português, Los Angeles: The Architecture of Four Ecologies, traduzido pela Profa. Ana Luiza Nobre, da PUC-RJ, encontra-se no prelo. 36 Desde Walter Curt Behrendt: Der Sieg des Neuen Baustils, 1927; GustaPlatz, Die Baukunst der Neuensten Zeit, 1930; Emil Kauffman, Von Ledoux bis Le Corbusier, 1930; até a geração de seus professores e tutores: Nikolaus Pevsner: Pioneers of Modern Movement, 1936; Siegfried Giedion: Space, Time and Architecture, 1941; e Henry-Russel Hitchcock: Architecture: Nineteenth and Twentieth Centuries, 1958; outras obras da mesma tipologia literária foram publicadas ou revisadas após Banham, como Leonardo Benevolo: História da Arquitetura Moderna, 1976; Kenneth Frampton: Modern Architecture, a Critical View. 1980; e Alan Colquhoun: Modern Architecture, 2002.

37 Reyner Banham, Teoria e Projeto na Primeira Era da Máquina, 321-322

38 Reyner Banham "History and Psychiatry" publicado originalmente em Architectural Review, maio 1960, e republicado em Design by Choice, pp. 20-22. 
arquitetura moderna estavam aperfeiçoando seus estilos pessoais, como indivíduos, e o Estilo Internacional, como um grupo. ${ }^{\prime 39}$

Para Nigel Whiteley, o papel dos historiadores da Segunda Era da Máquina na qual Banham se inseria - seria diferente da agenda de seus antecessores: converter descrentes no movimento moderno em seguidores, traçando as trajetórias de seus heróis. Banham, bem como muitos de sua geração, deveria ser o mais objetivo possível, mesmo que isso significasse desfazer o que a historiografia moderna tinha construído. Era uma responsabilidade que nem Banham nem os demais tinham consciência. E esses processos tomaram conta das décadas de 1950 e 1960 na Europa. ${ }^{40}$

Para Reyner Banham, as grandes omissões da narrativa pré-estabelecida da historiografia do modernismo faziam parte da criação da 'Zona de Silêncio', momento no qual os então pioneiros da arquitetura moderna estavam aperfeiçoando seus estilos pessoais, individualmente, e construindo a imagem do Estilo Internacional, enquanto grupo $^{41}$. Não havia distanciamento temporal suficiente para identificar, dentre a somatória de acontecimentos cotidianos e extraordinários, quais seriam marcantes para a arquitetura moderna. De fato, Giedion foi um dos autores os quais teriam se preocupado dessa prerrogativa: como narrar a história da arquitetura do seu tempo. Para ele, somente quando o historioador estivesse permeado pelo espírito de sua época (Zeitgeist), pode este detectar traços do passado que gerações anteriores teriam deixado passar. Nesse sentido, ao se reportar ao presente, o historiador deve embeber-se da riqueza de informações da vida cotidiana e registrar os aspectos dos fatos históricos que de outra maneira se perderão para gerações futuras. ${ }^{42}$ Segundo Banham, o livro de Pevsner, Pioneiros do Desenho Moderno, que finaliza com a exposição da Deutscher Werkbund de 1914, uma confusão se traça entre a figura de 'pioneiro' e mestre: ao final, os pioneiros se tornariam os próprios mestres, anos depois. Em Bauen in Frankreich, Giedion leva a origem do moderno ainda mais para trás, o que resulta de uma operação de "seleção e exclusão" que deixaria de fora diversos aspectos da polissemia moderna, os quais Banham chamaria de 'escombros' ${ }^{43}$.

Os 'escombros' mencionados por Banham em seu artigo de 1960"4, “History and Psychiatry", referiam-se às evidências históricas de como estas tendências amadureceram. De fato, pouco fora discutido no momento em questão, talvez por ser demasiadamente óbvio no momento em que os eventos tomavam espaço, ou

39 Nigel Whiteley, Reyner Banham: Historian of the Immediate Future, Cambridge, The MIT press, 2002, p. 69. Texto original: The Gropius omissions were symptomatic of what Banham described as a "Zone of Silence," even though it was "the period when most of the Masters of Modern Architecture were perfecting their personal styles, as individuals, and the International Style, as a group.

40 Idem, p.69.

41 Reyner Banham, "History and Psychiatry” pp.20-22.

42 Giedion, Space, Time and Architecture, pp. 5-6.

43 Reyner Banham, "History and Psychiatry" p.20.

44 Idem, p.20 
porque a historiografia não estaria disposta a levar à luz do julgamento crítico alguma incoerência de algum de seus colegas e contemporâneos. Ademais, com o objetivo de forjar uma narrativa única para o Movimento, livre dos escândalos, conflitos e sujeiras em seu passado, omissões propositais foram cometidas. Até a geração de Banham rever essa linha, a narrativa oficial vigente do Modernismo o definia como uma continuação direta do Racionalismo e do Funcionalismo do século XIX. As principais narrativas dos manuais de arquitetura moderna, de autoria de Pevsner e Giedion assim o difundiram. Foi um mecanismo de auto-afirmação do movimento e uma defesa contra ataques da ala 'filistina'. Era, acima de tudo, uma maneira de vender a idéia da arquitetura moderna aos indecisos, em termos passíveis de serem entendidos e aceitados honestidade sobre forma e função, materiais, estrutura, respeito pela higiene (mental ou física), economia e racionalização da construção ${ }^{45}$.

A geração de Banham, atuantes a partir do Pós-Guerra, tinha como agenda uma nova proposta: a revisão de tais mitos do movimento moderno. Para além de ampliar o espectro de estudo para homenagear os Grands Constructeurs do século XIX, o desafio principal foi a de preencher as lacunas deixadas pela 'Zona de Silêncio'. Uma geração de historiadores, pesquisadores e arquitetos se engajaram em rever as trajetórias dos mestres do modernismo heroico ${ }^{46}$ - Walter Gropius, Mies van der Rohe e Le Corbusier - revisitando momentos mais ‘sombrios' e apagados de suas trajetórias, como a residência Sommerfeld, de Gropius, um chalé expressionista construído em 1921, cuja existência em si apresentava uma incoerência com a já consagrada trajetória do autor ${ }^{47}$.

Dentro dessa proposta de revisão da historiografia moderna (de Teoria e Projeto), dois trechos se destacam por serem reconhecidos como contribuições significativas para o preenchimento dessa lacunas: a cobertura do grupo Futurista Italiano e seu manifesto ${ }^{48}$; e a atenção dedicada à escola expressionista de Berlim, representada pelos arquitetos Erich Mendelsohn, Bruno Taut e o escritor Paul Scheerbart49.

45 Idem, p.20.

46 Podemos destacar desse grupo, além de Banham, Peter Smithson, Anthony Vidler, Colin Rowe, John Summerson, Bruno Zevi, entre outros.

47 Idem, p.21.

48 Reyner Banham, “Sant’Elia”, publicado originalmente na Architectural Review em maio de 1955.

49 Ver as seções "Expressionism: Amsterdam and Berlin"e "The Berlin School" em Theory and Design in the First Machine Age. 


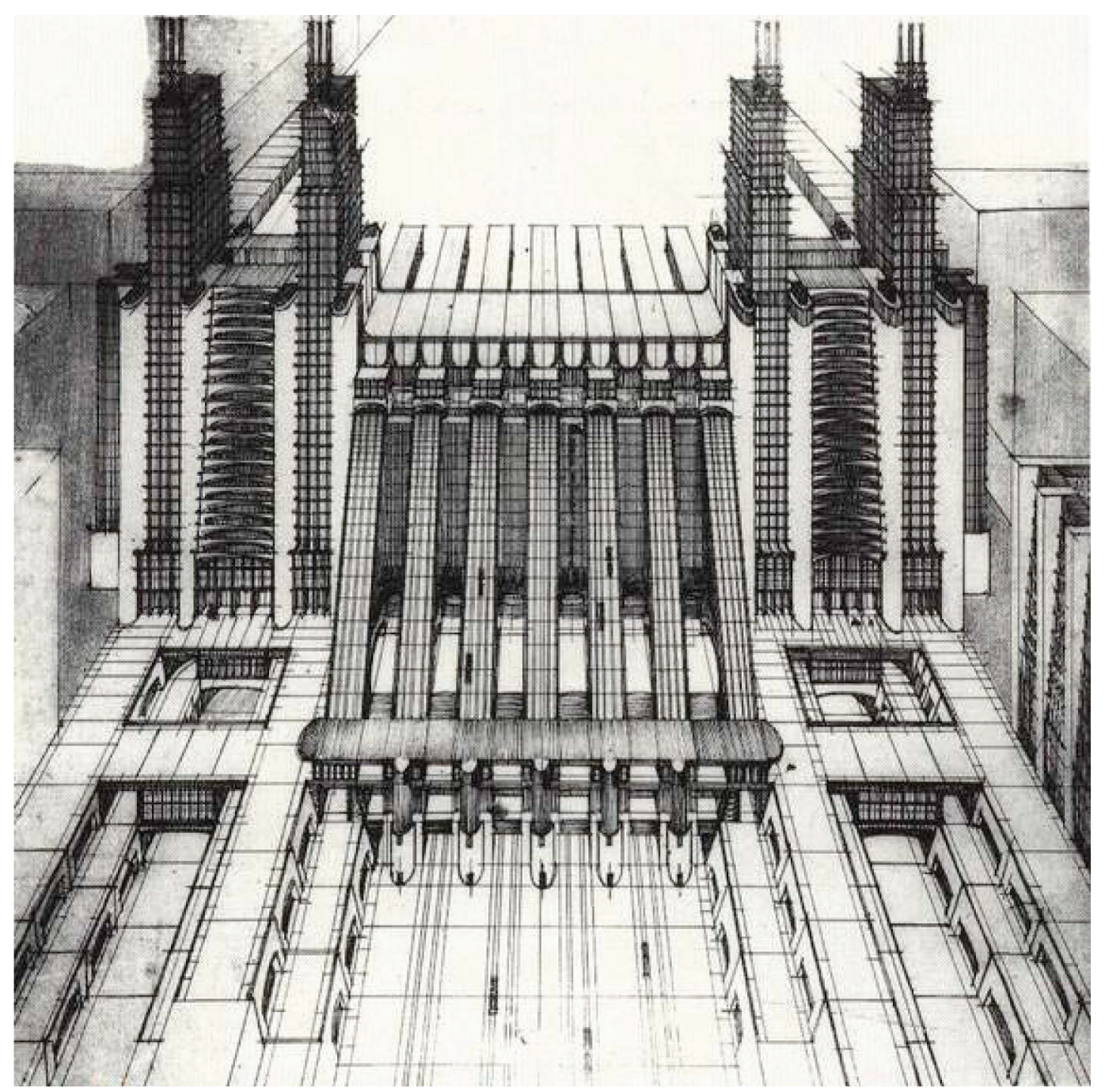

Antonio Sant'Elia, Estação Central da Cittá Nuova, 1913-1914. (fonte: Theory and Design in the First Machine Age, p.116)

Conforme diagnosticado por Reyner Banham no artigo "Sant'Elia”, publicado em 1955, as monografias que antecederam a sua investigação prestaram pouca atenção ao movimento Futurista italiano: algumas citações em nota de rodapé por parte de Pevsner em Pioneers of Modern Design; quatro parágrafos em Space, Time and Architecture, de Siegfried Giedion; duas páginas na publicação Belvedere, de Pietro Maria Bardi; dois artigos na revista Casabella, no começo dos anos 1930; seis páginas focalizadas na avaliação do Manifesto Futurista, em Storia dell'Architettura, de Bruno Zevi; a maior cobertura do grupo teria se dado pela publicação de Alberto Sartoris. Para Banham, malgrado Antonio Sant'Elia não teria construído nenhum de seus projetos, fora parco, antes de 1960, o registro das atividades do grupo Futurista Italiano, liderados pelo artista plástico F. T. Marinetti e o também artista Sant'Elia ${ }^{50}$,

50 Reyner Banham, “Sant'Elia”em Design by Choice, pp. 23-28, originalmente publicado em Architectural Review, maio 1955; e os capítulos da seção 2 de Theory and Design in the First Machine Age, Italy: Futurist Manifestos and Projects, 1909-1914. 
cuja contribuição para a formação da atitude moderna foi a proposta de adoção da máquina como símbolo, mais presente em outras expressões artísticas do que na arquitetura. Banham analisa, em seu artigo de 1955, as razões para a negação a uma leitura mais atenta a obra Futurista, focando-se na figura de Sant'Elia: o principal obstáculo para o entendimento do Futurismo, segundo Banham, seria a imagem de que o Futurismo seria um sistema estético fixo com um único objetivo, a ilustração e elogio do movimento. Mas mesmo que estudos do movimento constituam uma grande contribuição futurista à arte do século XX, o movimento não permaneceria apenas ligado à elevaçãoo das máquinas. O que foi apresentado nos manifestos de 1909 e 1910 foram revistos nos manifestos de 1912 e 1914. Após a fusão do grupo original com os cubistas florentinos, o grupo teria emergido em um processo revisionista de seus próprios passos. ${ }^{51}$

A proposta de apropriação da máquina em seus próprios termos e condições é uma das qualidades mais presentes do discurso Futurista na obra de Reyner Banham. A estética da velocidade, abordada também por Giedion ${ }^{52}$ e Pevsner em menor escala de importância, encontra sua glorificação no discurso Futurista, o qual estava disposto a libertar a máquina das amarras do abstracionismo academicista, considerado por eles reacionário e um risco ao franco desenvolvimento da relação entre homem e tecnologia.

A força pode ter interessado Marinetti, nobreza e monumentos não, analisa Banham, nos capítulos futuristas de Teoria e Projeto: Sua descoberta teria sido que as máquinas poreriam ser uma fonte de realização e gratificação pessoal, que telefones e máquinas de escrever, máquinas de soda e cinemas, aviões e automóveis tinham estendido enormemente a experiência humana em um nível pessoal, e não social. Máquinas trabalhavam para o homem, um homem comanda suas próprias máquinas, ele dirige o seu carro, não mais tem que divider um trem com milhares de outros homens. Marinetti teria sido, segundo Banham, um dos primeiros intelectuais de sua geração a desfrutar dessas experiências, bem como teria conseguido articular o entusiasmo de sua geração. ${ }^{53}$

Em Courtald, Banham produziu sua tese sob a orientação de Nikolaus Pevsner, que deu origem a seu primeiro livro, Theory and Design in the First Machine Age, no qual o primeiro e último capítulos foram anexados após a tese. Whiteley considera a maior contribuição do livro a sua leitura do Movimento Futurista de Giacomo Balla e Umberto Boccioni. ${ }^{54}$ Whiteley contudo credita o engajamento de Banham com a sensibilidade Futurista a uma experiência de velocidade em uma estação de trem em Londres - na Willesden Junction:

51 Idem, p.23.

52 Siegfried Giedion, Mechanization Takes Command, pp.17-29.

53 Reyner Banham, Theory and Design in the First Machine Age, p.102.

54 Nigel Whiteley, p.10 
“De pé na plataforma, uma vez por semana e até certo ponto... o Flying Scot ou alguma coisa costumava chacoalhar por baixo, e o edifício inteiro parecia sacudir, e vapor sairia através da plataforma. ao mesmo tempo, algo elétrico rasgaria a névoa e subiria ao céu... e de repente eu entenderia... sobre que tipo de experiência seria o Futurismo, e como isso perdura até hoje." 55

Segundo ele, ao descobrir sensibilidade Futurista, sua atitude não só em direção ao Movimento Moderno, mas à arquitetura em geral, teria se transformado. Um certo exagero, mas Whiteley coloca de maneira sintética uma série de atitudes que permearão a obra de Banham a partir de sua formação e dos anos de produção de sua tese: a crença nos "monumentos de fato" ${ }^{56}$, sejam construídos ou não, que reforçam o aporte do pensamento moderno; o compromisso com a história da arquitetura como uma disciplina ativa e vital; e seu entusiasmo pela cultura popular americana. ${ }^{57}$

Embora não seja obra dos arquitetos do movimento futurista, a fábrica da Fiat em Lingotto, idealizada pelo engenheiro de produção Giacomo Matté-Trucco, e projetada pelo Eng. Vittorio Bonadé Bottino ${ }^{58}$, representa uma das mais bemsucedidas materializações dos preceitos Futuristas. Em Lingotto, a elevação espiritual da indústria como religião que tem como seu messias o automóvel, simbolo da independencia pessoal e, principalmente, da velocidade. Sem dúvida, o automóvel particular é um dos protagonistas de suas narrativas, e seu cronista encontrou na América panos de fundo mais ricos para suas histórias.

Enquanto a Fagus projetada por Walter Gropius seria um primeiro enfrentamento da construção industrial na europa após o advento da construção industrial americana ${ }^{59}$, a fábrica da Fiat em Lingotto representaria o segundo movimento de leitura das construções fabris, na qual a presença do raciocínio americano é muito mais clara. Banham atribui esse fato às raízes modestas da Fiat, e à necessidade de uma economia de escala, que permitisse à empresa dispor de instalações que pudessem abarcar seu empreendimento. A partir de uma tradição de

55 Ver entrevista com John Maule McKean, “The Last of England? - Part 1" em Building Design (Agosto 13, 1976). Texto original: Standing on the platform, one night a week, and at a certain point. . . the Flying Scot or something used to hurtle through underneath, and the whole building would shake and steam would come up through the platform. And at the same time an electric would come through at the high level, bursting, through the steam. .. And suddenly I got the message. . about the actual kind of experience that Futurism was all about, and it suddenly began tohang together from then on.

56 Tradução: "set of actual monuments", em Nigel Whiteley, p.10. Banham se referia às construções pragmáticas e fabris das quais os modernistas em arquitetura extraíram seu vocabulário construtivo.

57 Nigel Whiteley, p.10

58 Mesmo sendo claro que Matté-Trucco não fora o arquiteto do projeto, e a única assinatura nas pranchas de projeto seja do presidente da FIAT no momento, Giovanni Agnelli, a referência de autoria é difusa. O nome de Bottino é o único nome na folha de pagamento da empresa que estivesse relacionado com o projeto da fábrica. Banham sugere fortemente a presence de consultores Americanos na equipe de projeto. Ver A Concrete Atlantis, pp.236-253.

59 A ser discutido mais a frente neste capítulo. 
construções em alvenaria de tijolo, a Fiat-Lingotto representaria um salto de escala, comparável às obras de Albert Kahn para a Ford em Highland Park ${ }^{60}$.

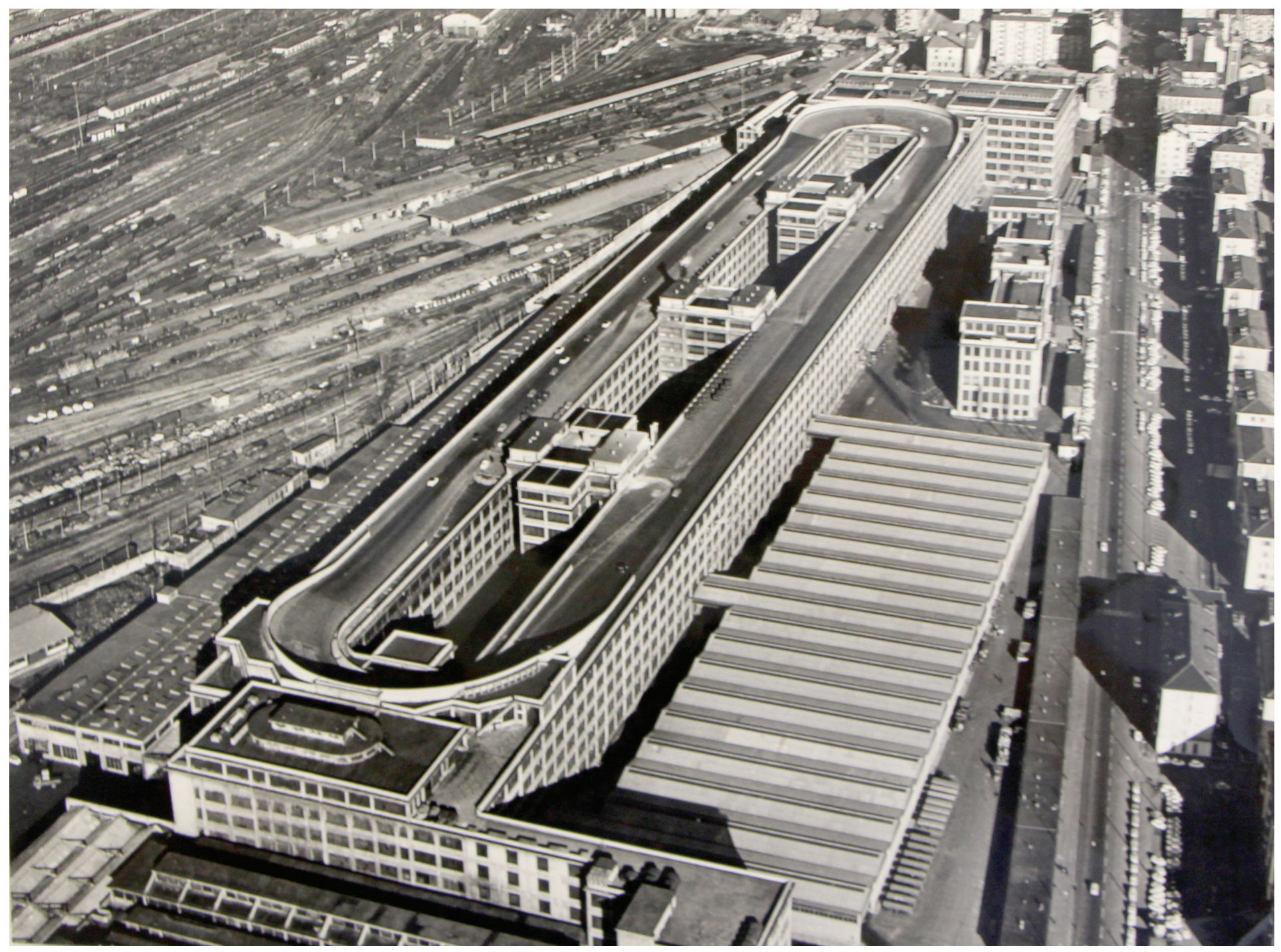

Matté Tucco, Fiat-Lingotto, vista aérea, s/ data. Fonte: arquivo Getty.

60 Reyner Banham, A Concrete Atlantis, p.7. 


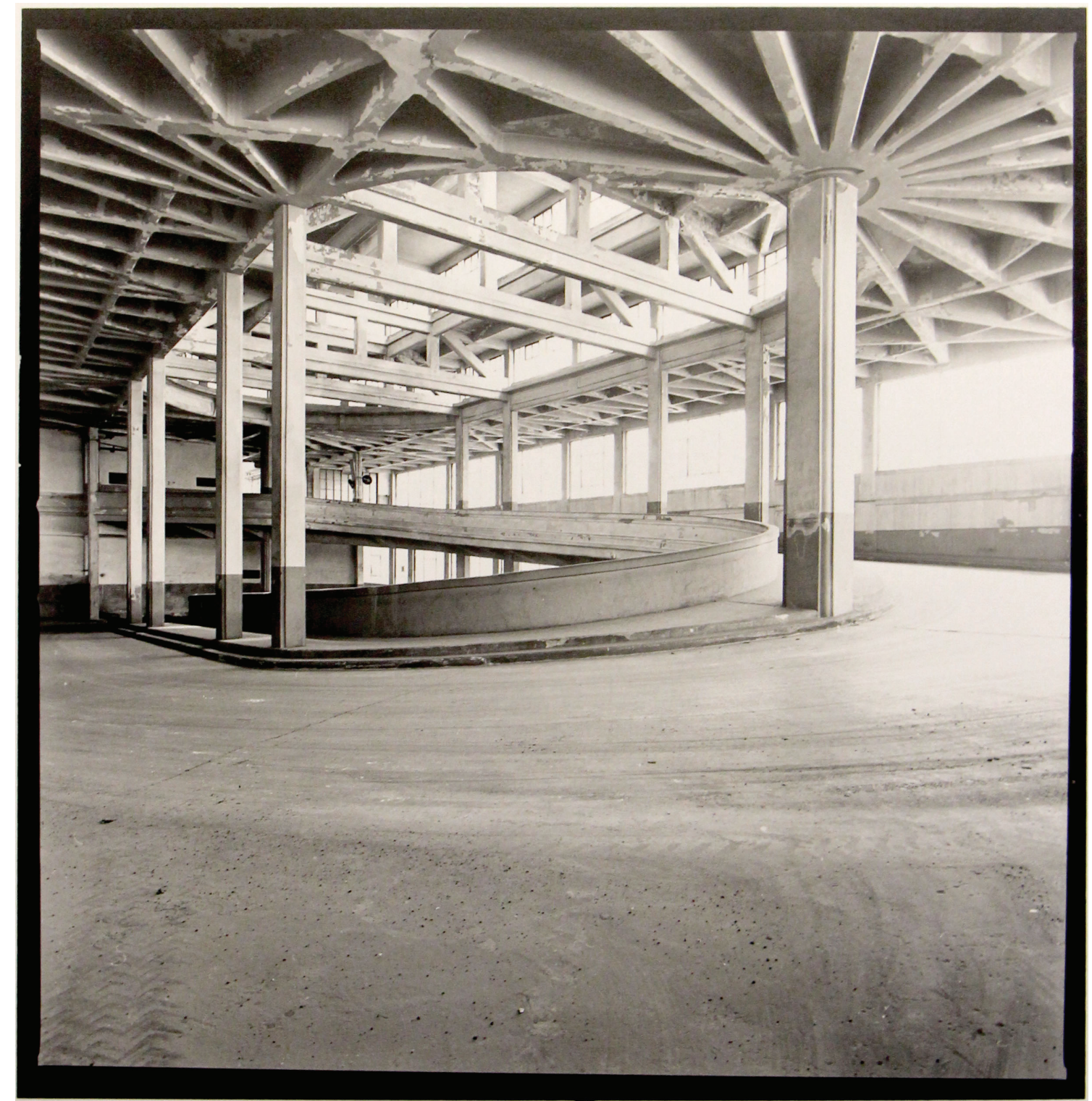

Matté Tucco, Fiat-Lingotto, vista da rampa de acesso à cobertura. Foto: Reyner Banham, s / data. Fonte: arquivo Getty.

De fato, é o caso em que se deve comparar não somente métodos construtivos, mas também filosofias industriais. Se a Fagus representa seu potencial através da elevação do trabalho mental encapsulado em seus escritórios, em Lingotto, assim como em Highland Park a experiência espacial deveria evocar a glória da produção em série. Devemos estender então a responsabilidade sobre a obra não só ao projetista, mas também ao mestre-engenheiro de produção, Giacomo Matté-Trucco. Contudo a experiência italiana seria lida como antiquada por olhos experientes americanos: enquanto a Fiat-Lingotto era erguida em diversos andares, a produção das novas instalações da Ford já se encontravam transferidas para um grande complexo térreo: era a produção fordista já revisada. 
"Foi de fato muito estranho experienciar o americanismo antiquado de Lingotto pela primeira vez. Em 1984 eu atravessei seus pisos de produção e senti que eu tinha sido transportado para alguma lendária "Lontane Americhe", tão familiar eram quase todos seus detalhes e dimensões. Aqui estavam colunas quadradas de concreto aproximadamente em perfis padrão de 14 polegadas, com cantos chanfrados, que podiam ser vistos em qualquer lugar do noroeste industrial [americano]. Eu poderia estar de volta em Buffalo, mas o fato de que o grafite que persistia nas paredes e as pin-ups eram italianas, sem dúvida, e por conta de um detalhe que seria difícil de se reproduzir em construções fabris americanas - a perfuração horizontal das vigas com furos retangulares para passage de dutos e conduítes elétricos. Foi uma experiência motivante e perturbadora para mim, um tipo de retorno à casa para um europeu parcialmente americanizado cujo principal objeto de estudo foi o Estilo Internacional." ${ }^{61}$

Todavia, não seria pelo americanismo inerente ao edifício que a Fiat-Lingotto obteve sua notoriedade internacional na história da Itália moderna, alerta Banham: seria a pista de testes na cobertura do edifício que tornaria a fábrica "magnífica, européia" e com um sabor de Auguste Perret em seu detalhamento.

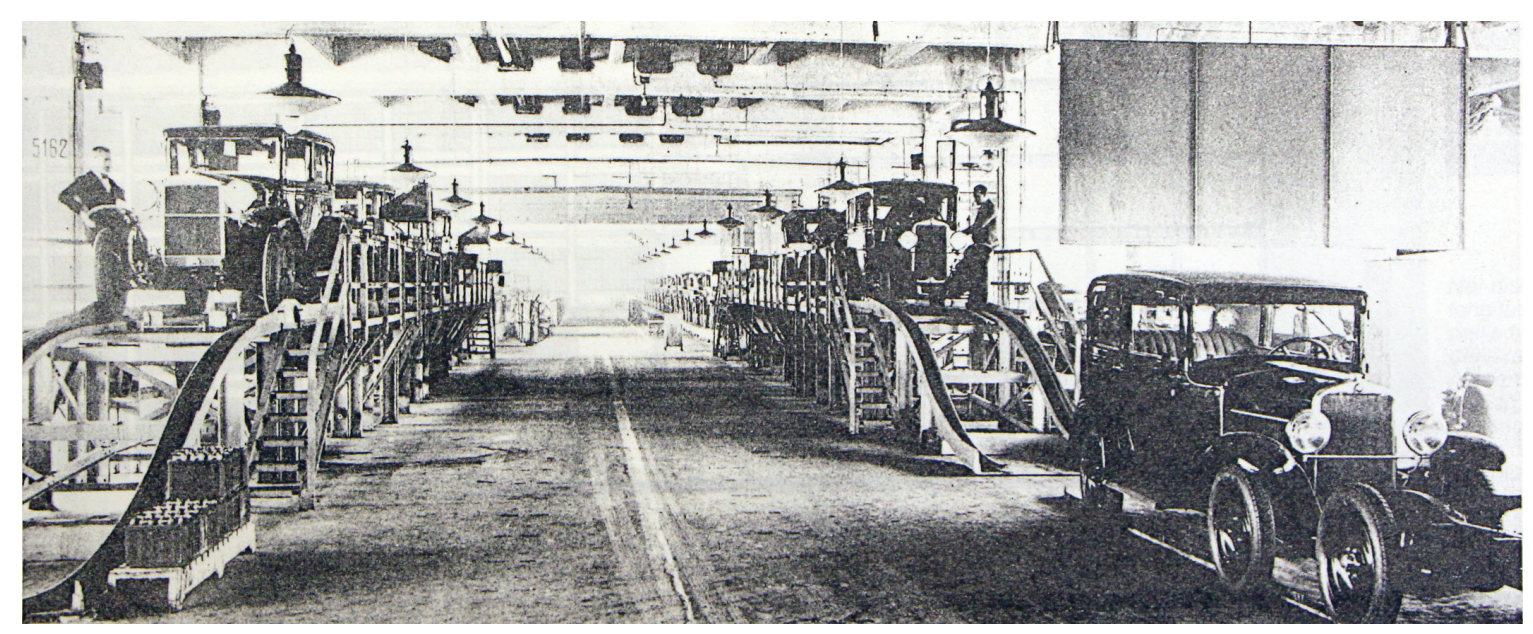

Matté Tucco, Fiat Lingotto, linha de montagem, s/ data. Fonte: arquivo Getty.

61 Reyner Banham, A Concrete Atlantis, pp.241-242. Texto original: It is very strange indeed to experience the antiquated Americanism of Lingotto at first hand. In 1984 I walked through its deserted production floors and felt that I must have been transported to some legendary 'Lontane Americhe', so familiar were nearly all the details and dimensions. Here were square concrete columns approximating the standard fourteen-inch sections with chamfered edged that could be anywhere in the industrial northeast. (...) I could be back in Buffalo, but the fact that the surviving graffiti and pin-ups were unmistakably Italian, and but for one detail that would be hard to parallel in common American factory construction - the perforation of the horizontal beams with regular rectangular holes to accept the passage of piping and electrical conduitry. It was strangely disturbing and moving experience for me, a kind of historian's homecoming for one partially Americanized European whose prime subject of study has been the International Style. 
"Quando se sobe, todavia, as rampas deixam o veículo em um espaço apertado abaixo da sombra de uma das curvas, que permanecem como parte essencial da imagem do edifício. Espremido entre o parapeito e a curva, surge de repente sobre a pista, que se estende por meio quilômetro, até onde outra curva se ergue e vira à esquerda para devolver o veículo novamente à pista. Ver isso pela primeira vez, como fiz, através do do pára-brisa de um carro em movimento, é um uma experiência que mexe com os nervos. Ao se entrar em um dos lugares sagrados do Modernismo Europeu, santificado e certificado pela presença documentada em fotografia por futuristas, modernistas e outros espíritos progressistas através dos anos 1920 e começo dos 1930. E o choque do reconhecimento é reforçado pelo fato de que ainda parece exatamente como nas fotos históricas." ${ }^{2}$

62 Idem, p.243. Texto original: Wherever one ascends, however, the ramps deliver the rolling vehicle into a cramped and awkward space under the shadow behind one of the banked turns that remain an essential part of the image of the building. Squeezed between the flank of the banking and the parapet on the edge of the building, one emerges suddenly on to the track, which extends half a kilometer to where the other banking rises and turns to the left do deliver the vehicle to the return straight of the track. Too see it for the first time, as I did, through the widescreen of a moving car is a nerve-tingling experience. One is entering one of the sacred places of European Modernism, sanctified and certified by the photographically documented presence of practically every European Futurist, modernist, or other progressive spirit of note throughout the twenties and early thirties. And the shock of recognition is reinforced by the fact that it still looks exactly as it did in those historic photographs. 


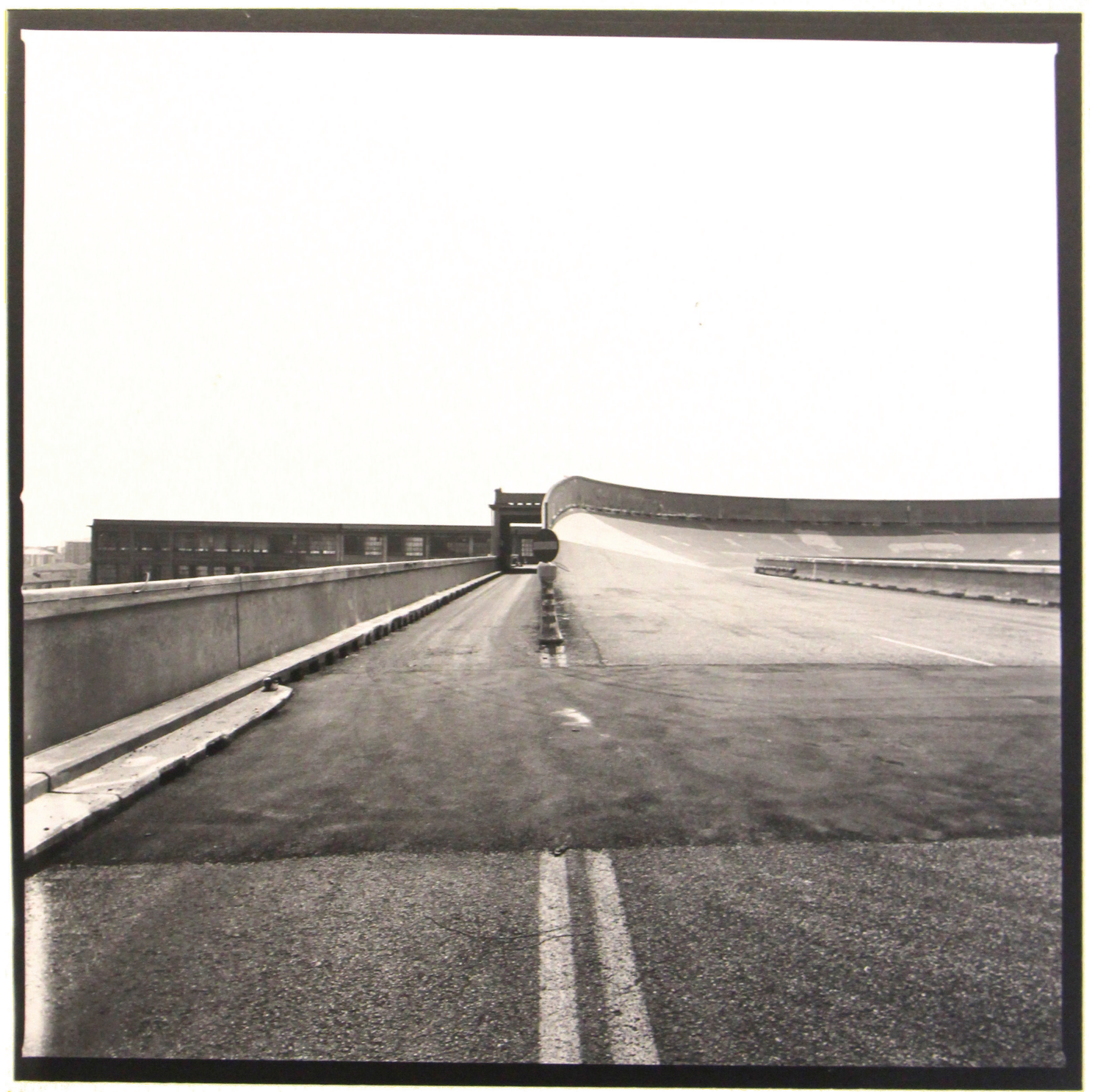

Matté Tucco, Fiat-Lingotto, Vista da pista de testes, 1984. Foto: Reyner Banham. Fonte: arquivo Getty, 
A decisão de construir uma pista de teste no nível da cobertura, para além de um desejo impulsionado pelo futurismo, fazia parte da organização de produção concebida por Matté-Trucco. Banham compara a lógica da Fiat com o Fordismo na fábrica de High-Land Park. Ao contrário da produção que acompanha a força da gravidade - onde os materiais mais leves entram pelo topo da fábrica e são combinados até montarem produtos finalizados na parte inferior da fábrica (uma lógica que atualmente não faz mais sentido, já que grande parte das fábricas funcionam em um só nível) - a produção na Fiat-Lingotto segue o caminho inverso:

“Partes e materiais entram a loja ao nível do solo e se movem ao final da linha de montage no ultimo andar. De lá os recém-nascidos emergem na corbertura à luz do sol da esfumaçada Turim, para serem postos à prova na pista de testes antes de retornarem ao nível térreo nos pátios entre a fábrica e a via Nizza." ${ }^{63}$

Poéticas do automóvel a parte, e para além da destreza de Banham em descrever suas experiências visuais nas obras, suas descrições úteis dão intensidade à experiência estética tecnófila-futurista, baseada captura da estética da velocidade. No caso da modernidade italiana, a velocidade era o maior valor estético em voga. Uma nova religião, amparada pela idéia da máquina, na velocidade e no progresso, encontrava no automóvel a sua divindade. Erguer os automóveis ao céu pode ser comparado, em nossa modernidade ocidental, a posicionar os sagrados afrescos nas cúpulas das basílicas italianas. Banham coloca o relativo "fracasso" econômico devido a problemas de projeto da pista, a qual não permitia que os carros chegassem à sua velocidade máxima, mas principalmente à curta sobre-vida do conjunto em operação, típico desse momento da indústria - como menor que o triunfo simbólico para a cidade e para o país: A Fiat em Lingotto teria colocado a Itália nos tempos modernos, apresentou o norte da Itália como uma potência industrial, e teria dado aos italianos uma crença que rivalizou a religião católica ${ }^{64}$. Essa crença teria seus profetas, como o crítico napolitano Edoardo Persico, que escreveu sobre Lingotto - cuja citação de 4 páginas finaliza o livro A Concrete Atlantis, sem comentários posteriores de Banham ${ }^{6}$. Dentre as inúmeras citações que marcam o estilo de Banham de dar 'voz' aos seus heróis, Persico ganhou as últimas palavras de seu último livro publicado, demonstrando o quanto da referência Futurista Banham carregou consigo durante sua trajetória. Note-se que para além de um elogio à arquitetura, o manifesto futurista remete à uma nova ordem, apoiada na indústria e no automóvel como arcabouços de

63 Idem, p. 243. Texto original: Parts and materials enter the plant at ground level and move to the final assembly lines on the top floor. From there the "neo-nato" would emerge into Turin's smoggy sunshine on the roof, there to prove itself on the test track before finally returning to ground level in the parking yards between the plant and the via Nizza.

64 Idem, p.246-247

65 Idem, p.247-253. 
uma nova era de progresso e disciplina coletivos, apagando o passado impregnado de imperfeições e egoísmo. É, sem dúvida, um tom característico do seu tempo na Itália, dividida entre o Facismo e a os grupos anarquistas. Curiosamente, hoje o automóvel representa muito mais a negação de um espírito coletivo, e uma busca pela expressão pessoal de liberdade, contrariando os desejos expressos de Persico:

“(....) um trabalho de inteligência que encontrou a ligação entre graça e necessidade por pura dedução. Essa grandeza alcançada é como a imagem do Homem e suas preocupações. Em sua aparência simples onde combinações de curvas e linhas retas formularam um momento de Eternidade, existe uma manifestação da busca humana que resolveu algumas incertezas na obediência da Lei, tal como o estilo das catedrais (...) em sua própria estrutura, a pista é uma imagem concreta de velocidade. Ela expressa a idéia do automóvel em um conceito claro: nada deve ficar parado lá. Das bordas das parabolas que definem as curvas deriva uma linha ideal que cruza as grelhas para retornar à sua origem, onde ela volta a descer e subir, até a eternidade (...) Apenas a pista é livre sob os céus e perante Deus. Isso significa que através dela os trabalhadores podem alcançar, encerrado na fábrica, é uma inspiração perpétua. $\mathrm{O}$ significado dessas duas espirais [as rampas de acesso à pista] é obediência: pisar nelas significa entender o motivo secreto da disciplina que conecta cada parte dos trabalhos ao seu ápice, que é, o fim supremo de tudo. (...) E se acontecer de você passar por baixo dessas paredes enquanto anoitece e a alma é pesada com insuperável melancolia do crepúsculo nórdico, talbez você verá as amplas sombras das lâmpadas que ainda estão acesas como diversas medusas flutuando em um imenso aquário... e você saudará a Fiat como um sinal inegável colocado em seu caminho para te ensinar a rebaixar seu egoism e viver em boa ordem." ${ }^{\prime 6}$

66 Idem, pp. 247-253. Texto original: (...) A work of intelligence that has found the link between grace and necessity by pure deduction. This accomplished grandeur is like an image of Man and of his concerns. In its simple appearance where combinations of curves and straight lines have fashioned a moment of Eternity, there is manifested a human quest that has resolved its uncertainties in obedience to the Law, as with the style of the cathedrals. (...) In its own structure, the track is a concrete image of speed. It expresses the idea of the car in a clear concept: nothing may stand still here. From the crests of the parabolas that define the curves there derives and ideal line that crosses the grids to regain its origin, where it resumes the rise and fall, to eternity. (...) Only the track is free beneath the heavens and before God. This means by which the workers can reach it are concealed within the factory like a perpetual, buried aspiration. The meaning of these two rising spirals [as rampas de acesso à pista] is obedience: to set foot upon them means to understand the secret motiv of discipline that connects every part of the works to its summit, that is, the supreme end of everything. (...) And if it should happen that you are passing under its walls as evening falls and the soul is weighed down with insuperable melancholy of the Nordic twilight, perhaps you will see the broad shades of the lamps that are still lit as so many medusas floating in an immense aquarium... And you will salute Fiat as an undeniable sign placed in your way to teach you to subdue your egoism and to live in good order. 


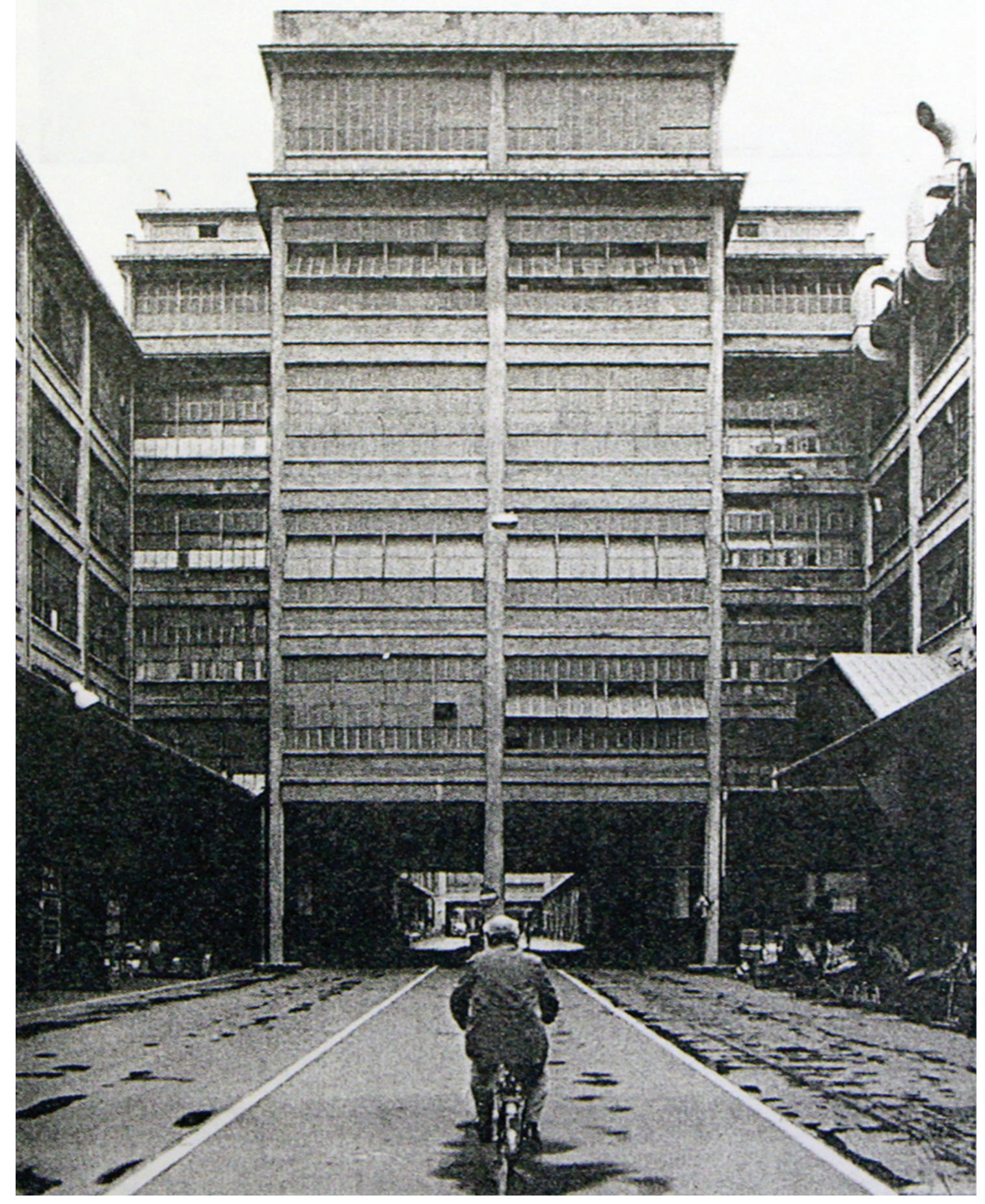

Matté Tucco, FIAT-Lingotto, vista da entrada da fábrica, s/ data - recorte de revista. Fonte: arquivo Getty. 
Para além da introdução do Futurismo nos anais da historiografia do moderno, outro mérito da obra de Banham passa pela abordagem detalhada e cuidadosa do movimento expressionista na arquitetura moderna. Em trechos de Teoria e Projeto ${ }^{67}$, e em artigos publicados na revista Architectural Review, o autor faz menção à escola de Berlin, às figuras dos arquitetos alemães Erich Mendelsohnn ${ }^{68}$, Bruno Taut e o intelectual, poeta e escritor Paul Sheerbart ${ }^{6}$.

Detalhando sua contribuição para a apropriação dos elementos simbólicos e a força expressiva do vidro para os arquitetos modernos de Berlim, com destaque para Mies Van Der Rohe e seu conhecido projeto para o concurso para um arranha-céu na Friedrichstraße, a narrativa da contribuição do expressionismo de Sheerbart e Taut se sumariza pela manipulação do vidro com outras predisposições. Este material, enquanto tratado como o fechamento sem materialidade, para Taut e os expressionistas da escola de Berlin - como também para Wright - o vidro possui suas próprias características enquanto matéria: cor, espessura, opacidade, expressividade. Em suma, elementos ativos de uma cultura nova, esta que abandonava a escuridão insalubre das edificações do passado fabril.

De fato, a narrativa de Scheerbart em seu livro intitulado Glasarchitektur, de 1913, antecipou muito dos acontecimentos e proposições a ocorrer durante a década de $1920^{70}$. Banham observa essa relação curta entre Taut e Scheerbart - ambos se conheceriam em 1913, e Scheerbart morre em 1915 - como a referência romântica à cultura do vidro na arquitetura moderna. Em oposição à proposta do vidro desmaterializado preconizado pelos arquitetos da Bauhaus, a arquitetura de vidro do expressionismo alemão pensava em cores, no efeito da luz elétrica filtrada pelo vidro colorido, e por uma noção de higiene pública impulsionada pela adoção sistemática de ambientes totalmente envidraçados, abertos ao céu e ao sol. Mais do que transparência, para os expressionistas de Berlim o vidro significava luz e cor, a negação dos ambientes fechados, insalubres dos cortiços das cidades europeias do século XIX. Segundo o romantismo de Scheerbart, o vidro era, em si, um redentor para as más práticas da arquitetura do século anterior.

\footnotetext{
67 Nas seções "Expressionismo: Amsterdam e Berlin" e "A Escola de Berlin"

68 Reyner Banham "Mendelsohn”, publicado originalmente na Architectural Review, vol. 116, 1954, pp.8493.

69 Reyner Banham, “The Glass Paradise" originalmente publicado em fevereiro de 1959 na Architectural Review e republicado em 1981 na compilação Design By Choice e na coletânea póstuma A Critic Writes, em 1996. Neste artigo, Banham reconhece o débito da geração expressionista ao pavilhão de vidro de Taut e à literatura de Scheerbart, e alerta para como a historiografia moderna ignorou os aspectos vitais da evolução deste material, em especial Le Corbusier no argumento do projeto da Ville Radieuse, no qual o vidro aparece como um elemento quase etéreo, dispojado de corpo aparente e efeito imagético e sensorial. 70 Reyner Banham Theory and Design... pp.266-268.
} 
“Das Glas bringt uns de neue Zeit

Backsteinkulture tut uns nur leid"71

Mesmo que sua estética e detalhamentos cuja referência era o Art-Nouveau, era inegável na literatura de Scheerbart a noção de progresso e aceitação (Futurista, segundo Banham) da era da máquina, dos Zeppelins, dos transatlânticos e trens de alta velocidade, das cidades iluminadas e do automóvel (talvez seja possível associar esse interesse pelos mecanismos de luz, transparência e cor, assim como pelas simbologias de velocidade ao elogio de Banham às paisagens de Los Angeles e Las Vegas, nos Estados Unidos) $)^{72}$.

Malgrado a historiografia da arquitetura moderna tê-lo relegado a menções periféricas, era de interesse de Reyner Banham dar destaque para Scheerbart na historia do vidro na arquitetura moderna. Não era o caso de negar a importância da manipulação do vidro por parte de Mies, Breuer ou Le Corbusier, mas de ampliar o espectro de genealogias da utilização do material. Como um engenheiro e historiador de arte, é de se esperar que a combinação de sensibilidade mecânica e estética de Banham despertasse seu interesse em direção à utopia tecno-pictórica de Scheerbart.

Foi em sua relação com o arquiteto Bruno Taut, e principalmente na referência que este convívio apresentou ao arquiteto, que a obra de Scheerbart poderia ter sua mais fiel materialização, como parte do Stadtkrone de Taut. Epítome da negação das paredes opacas de alvenaria, o Pavilhão de Taut talvez seja, para ele, a alegoria da cidade das luzes, antecipando em décadas as cenografias urbanas de Las Vegas, Atlantic City, a transparência dos domos geodésicos de Buckminster Fuller e a transparência da arquitetura High-Tech.

71 Paul Scheerbart, Apud Banham, p. 269. Tradução: O vidro nos tráz os novos tempos. A cultura da alvenaria nos traz apenas sofrimento.

72 A análise crítica das paisagens das cidades do deserto Americano sera parte da narrative do capítulo

3. Ver Reyner Banham, Scenes of America Deserta, publicado em 1982; Tom Wolfe, The Kandy-Kolored

Tangerine-Flake Streamline Baby, publicado em 1965. 


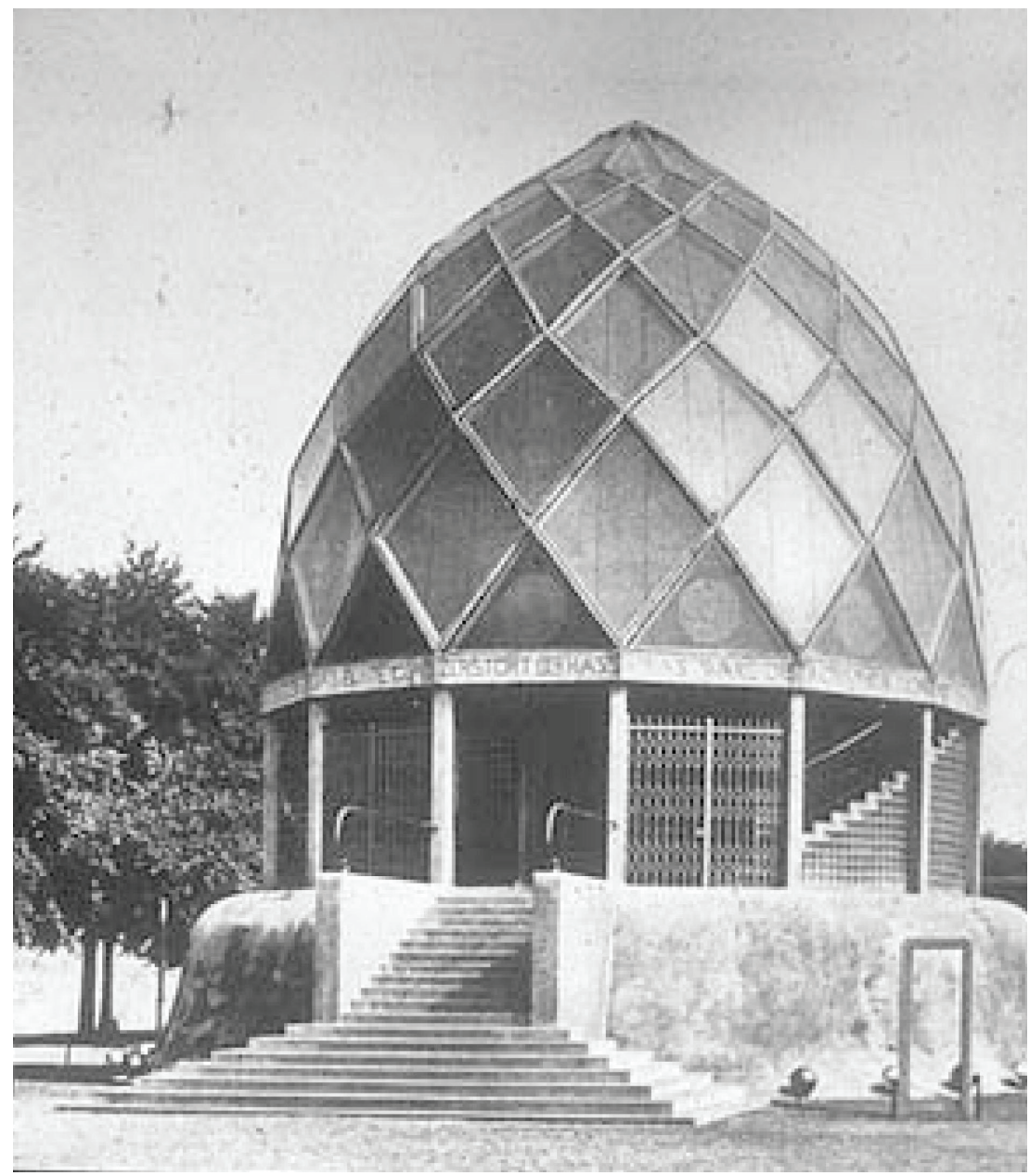

Bruno Taut, Pavilhão de Vidro para a Exposição Deutsche Werkbund, 1914.

Fonte: Mary Banham, Peter Hall e Sutherland Lyall, Design by Choice, p.31

Para Banham, o Pavilhão de vidro, ou Glass Pavillion, obra de Bruno Taut, ultrapassava qualquer outro projeto de sua autoria. Seria devido ao diálogo com Scheerbart, e sua obra, literarischer Vorläufer und Anreger moderner Glasarchitektur. Segundo Banham, Scheerbart seria o intigador e padrinho do conceito modern de arquitetura de vidro, malgrado o desconhecimento geral de sua obra entre leitores ingleses e alemães. Apenas em Baukunst der neuesten Zeit, de Giedion, e em alguns textos perdidos de Taut, faz-se menção a Scheebart; mas não há menção alguma sobre ele Space Time and Architecture, tampouco nos escritos de Walter Gropius. ${ }^{73}$ Banham se pergunta sobre a dramaticidade da afirmação, e se é realmente necessário reescrever a história do movimento moderno - mais uma vez atentando para a seletividade do discurso da historiografia moderna. Para que a história da arquitetura fizesse sentido, conforme o modelo intelectual forjado pela historiografia da geração de Pevsner e Giedion, era necessário deixar de lado aquelas expressões dissonantes dentro do

73 Reyner Banham, "The Glass Paradise", em A Critic Writes, p.34. 
movimento. Nigel Whiteley interpreta a crítica de Banham pelos conceitos de seleção e classificação. Neste processo, o simples reporte da arquitetura moderna, composta por uma polifonia de grupos, indivíduos com agendas pessoais e dissidências. A narrative moderna buscou criar uma narrative coerente, com uma espinha dorsal na qual os futuristas, expressionistas e outros não têm lugar. Essa questão se faria clara em Bauen in Frankreich, de Giedion, mas não seria justo acusar apenas a ele: esta foi uma escolha da historiografia do movimento como um todo. Repentinamente, todos os arquitetos modernos que antes mantiveram referências em futuristas e expressionistas dariam lhes dariam as costas. ${ }^{74}$

De fato, essas omissões são mais patentes na obra de Pevsner (Pioneiros do Movimento Moderno) do que no manual de Giedion. Contudo, não podemos entender a proposta de Banham apenas como uma leitura ampliada das polifonias modernas, depois de tomar conhecimento de seu interesse historiográfico, demonstrado inicialmente em Teoria e Projeto de reescrever a genealogia do movimento moderno segundo a apreciação dos conceitos da primeira era da máquina ${ }^{75}$. Se existe uma agenda por trás dessa publicação, não é a de uma leitura panorâmica. Notamos a ausência patente de algumas narrativas modernas - a vanguarda russa, as contribuições da arquitetura do leste europeu - as quais seriam abordadas futuramente por Jean-Louis Cohen $^{76}$, Alan Colquhoun ${ }^{77}$ entre outros. Para Anthony Vidler, em Histories of the Immediate Present (2008), a natureza deste funcionalismo e dessa estética da máquina, e seu papel em relação à arquitetura moderna parece supremo: era a maneira de ignorar as diferenças formais e estilísticas de diversas vanguardas e fornecer um álibi, ou uma fundação definitiva para a modernidade em arquitetura. ${ }^{78}$

"Banham está colapsando a polarização entre "racionalistas" e "anti-racionalistas" promovida por muitos historiadores da feixe central, inclusive Pevsner, argumentando que existem estéticas da máquina potencialmente similares baseadas em crenças e ideais similares - uma posição que ele manteve durante sua vida e aplicou a todas as Eras da Máquina. Os reais inimigos do Movimento Moderno, ele sentia, não eram os “anti-racionalistas" Expressionistas porque, segundo sua avaliação, eles deveriam ser

\footnotetext{
74 Nigel Whiteley,p.119

75 Anthony Vidler, Histories of The Immediate Present, 2008, pp.117. Segundo Vidler, a revisão do conceito de funcionalismo por parte de Banham não mais seria parte de conceitos da arquitetura, mas domínio das ciências reais. "In search of what He called 'une autre architecture,' Banham turned to the authority of military and Corporate engineers, biological researchers, and social scientists, while Summerson outlined a new concept of the program as the foundation of a "Theory of Modern Architecture". pp117. Tradução: "Na busca de o que ele chamava 'une architecture autre', Banham tornou-se para a autoridade dos engenheiros militares e corporarivos, pesquisadores em biologia, e cientistas sociais, enquanto Summerson delineou um novo conceito do programa como a fundação da "Teoria da Arquitetura Moderna".

76 Jean-Louis Cohen, The Future of Architecture Since 1889. New York: Phaidon, 2012.

77 Alan Colquhoun, Modern Architecture. New York: Oxford University Press, 2002.

78 Anthony Vidler, pp.117-119.
} 
vistos como uma parte e parcela do mesmo movimento, mas aqueles que se opuseram ou tiveram pouca simpatia com as características e valores da Primeira Era da Máquina." 79

É importante identificar que Banham faz ressalvas sobre o julgamento do processo seletivo de narrativa moderna, já na publicação de 1960, Theory and Design in the First Machine Age. Com o ostracismo político do Estilo internacional na Alemanha e Rússia, alejado financeiramente na França, os reminicentes do front do Modernismo europeu tinham que traçar uma narrativa convincente para uma Itália facista, uma Inglaterra esteticamente indiferente, e uma América afundada na crise de 1930. Malgrado uma interpretação equivocada de funcionalismo, a supressão de elementos simbólicos e estéticos, em favorecimento a um discurso de ordem racionalista e de base econômica foi uma maneira de fazer sobreviver o movimento. E inclusive, de fazer com que o movimento moderno se difundisse mesmo nesse campo desfavorável, tornandose o estilo vigente do imediato pós-guerra. ${ }^{80}$

79 Nigel Whiteley, pp.120-121. Texto original: Banham is collapsing the polarization of "rationalists" and "anti-rationalists" promoted by many mainstream historians, including Pevsner's arguing that there are potentially equally valid alternative machine aesthetics founded on similar beliefs and ideals-a position he maintained throughout his life and applied to all Machine Ages. The real enemies of the Modern movement, he felt, were not the "anti-rationalists" Expressionists because, following his revaluation, they ought to be regarded as part and parcel of the same Movement, but those who opposed or were out of sympathy with the characteristics and values of the First Machine Age.

80 Reyner Banham, Theory and Design, p.321. 


\section{Le Corbusier e a Superfície da Máquina}

Como Anthony Vidler identificou em seu ensaio sobre Banham ${ }^{81}$, uma das características mais interessantes e menos relevadas em sua obra é a apreciação da obra de Le Corbusier, principalmente a sua produção acadêmica, manifestos, dogmas e postulados, os quais serviram para a construção do arcabouço de idéias do Movimento Moderno.

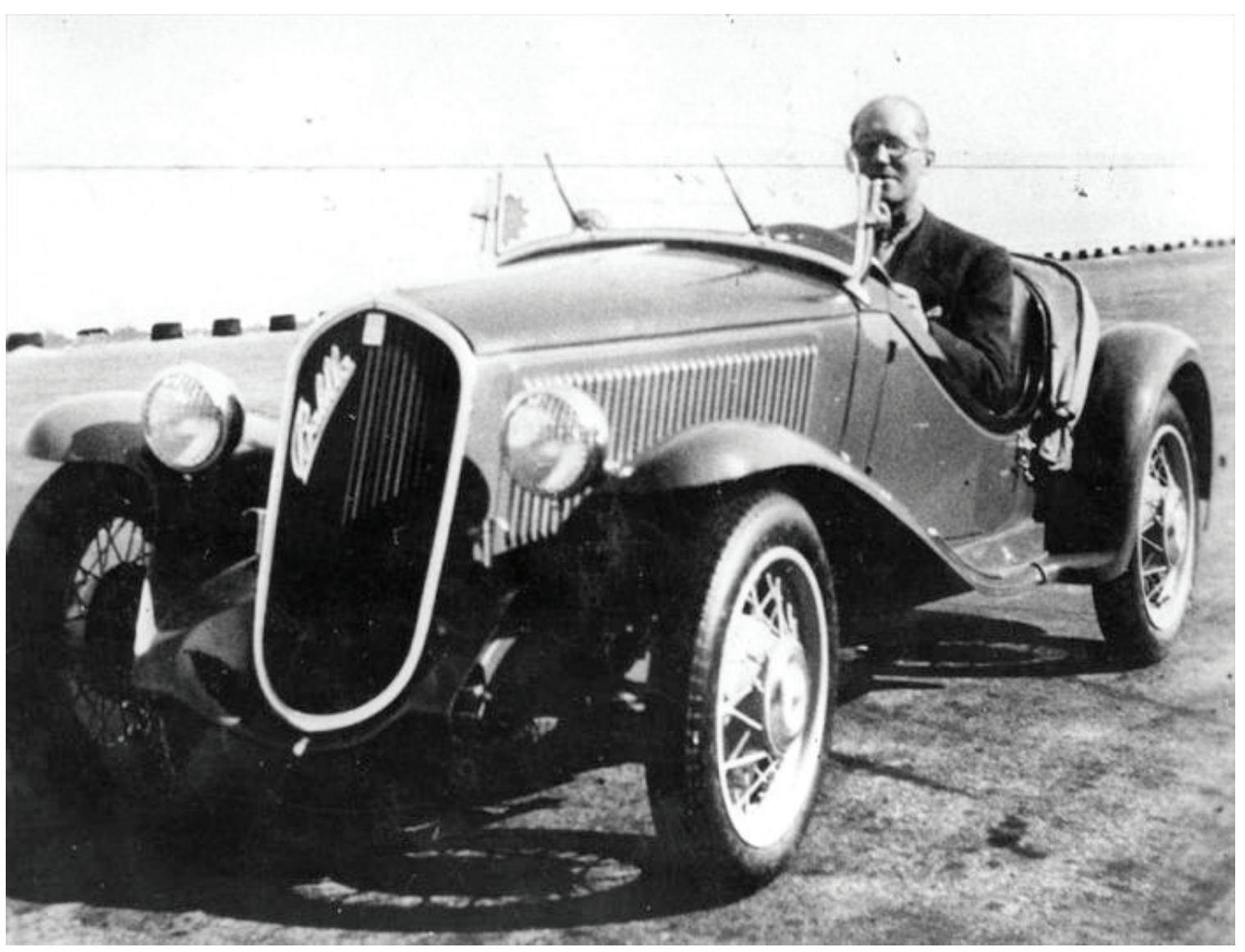

Le Corbusier atrás do volante, recorte de jornal da FIAT, s/ data. Fonte: arquivo Getty

Já em Teoria em Projeto Banham dedica uma sessão completa ao arquiteto franco-suíço. Dentre os 4 ensaios (o primeiro lida com a tradição cubista na arquitetura francesa; sobre a tradição da escola progressista de Auguste Perret; e a última é dedicada ao partido urbanístico e estético de Le Corbusier), uma das sessões se dedica integralmente ao arcabouço teórico do arquiteto, originalmente assentado nas páginas do periódico L'Esprit Nouveau durante a década de 1910 até 1922, e consolidado

81 Em Histories of The Immediate Present, 2008, Vidler apresenta as genalogias predominantes do moderno na arquitetura e seus autores, os quais moldaram o arcabouço intelectual não só do autor, como de uma geração de intelectuais do campo da historiografia da arquitetura. Maiores comentários encontram-se no capítulo I. 
historicamente na publicação Vers Une Architecture ${ }^{82}$. O interesse de Banham pela ativivade literária de Le Corbusier se expressa em duas vertentes, as quais estão presentes pela trajetória profissional de Banham. A primeira, segundo Anthony Vidler, é a influência da estrutura narraiva que Banham encontra em Vers Une Architecture. O manifesto fora estruturado em um formato de narrativa pendular entre os fenômenos da tecnologia e do raciocínio industrial, e das tradições clássicas a serem resgatadas pelo processo de seleção histórica da historiografia moderna ${ }^{83}$. A segunda vertente é o entusiasmo compartilhado pelos objetos da modernidade industrializada: aviões, transatlânticos e automóveis. Também é notável a narrativa sobre os monumentos da modernidade fabril americana, os quais ainda serão abordados mais a frente, mas vale adiantar que sobre o conjunto construído industrial americano, a postura de Banham mudará substancialmente após sua estadia em Buffalo, e sua exposição direta de alguns dos exemplares das obras apresentadas por Le Corbuiser em $1923^{84}$.

Banham se reserva o direito (dado à gerações posteriores) de criticar seus antecessores, e expõe as contradições e minúcias encerradas no discurso de Le Corbusier. Primeiramente, identifica a presença do discurso Futurista dentro da narrativa de Le Corbusier, que compara aeronaves, frutos da produção serializada, a 'pequenas casas, capazes de voar e resistir à chuva e tempestade' ${ }^{85}$. Para Banham, a referência de casas fabricadas como aeronaves nada mais seria do que uma alusão ao discurso de Sant'Elia. Contudo, as duas ideologias (Corbusiana e Futurista) divergem em relação ao homem arquetípico a habitar tais construções: enquanto o homem futurista expõe um desejo pela velocidade e apetite pelo novo, frenético e veloz; o homem corbusiano demonstra a placidez do sábio, do monge. Sua rigidez moral e física é necessária para conviver no mundo das máquinas industriais. ${ }^{86}$

Outra questão se refere ao culto à máquina, e à busca de um denominador comum entre produção industrial e a matriz abstrato-purista do pensamento moderno Corbusiano. Ao contrário do que clamava Le Corbusier, Banham enxergava um certo receio difundido entre os arquitetos em relação à máquina. A proposta de analogia traçada por Corbusier entre estética da máquina e arquitetura moderna encerrava, segundo Banham, um dos mais difundidos equívocos da historiografia moderna: de que os produtos da modernidade industrial seguiriam os valores da geometria pura

82 Reyner Banham, Theory and Design in the First Machine Age, pp.220-246

83 Segundo Vidler (2008), Banham identifica em sua leitura o que ele chama de abordagem acadêmica na arquitetura - arquitetura concebida como uma arte formal e derivada de modelos romanos e gregos, como ensinado na academia de Beaux-Arts ao final do século XIX; o segundo é o que ele identifica como tópicos "mecanicistas" - a estética da engenharia, os transatlânticos, os aviões, e os automóveis. Essa estrutura formal foi utilizada por Banham para compor os ensaios entrecruzados de Los Angeles: the architecture of four ecologies. Para acessar a fonte do argumento de Vidler, ver Banham, Theory and Design in the First Machine Age, pp.222-223.

84 Reyner Banham, A Concrete Atlantis, 1986.

85 Reyner Banham, Theory and Design in the First Machine Age, p.222.

86 Idem. p.222. 
das formas platônicas, e que compartilhariam dos mesmos valores de permanência e equilíbrio, através da preferência por superfícies simples e formas baseadas na geometria euclidiana, 'massa (volume) e superfície's7. Esses dois elementos são justamente o mote de 2 capítulos de Vers Une Architecture. É no início do primeiro capítulo, 'Volume', que Corbusier cunha uma de suas mais difundidas frases, reproduzidas em Theory and Design:

"L'Architecture est le jeu savant, correct et magnifique des volumes assemblés sous la lumière." 88

Banham identifica a proximidade do discurso de Corbusier para com os princípios da acadêmicos de Guadet, cuja contribuição para o ideário moderno é abordada no início do livro ${ }^{89}$. Em "Machine Aesthetes" publicado em 1958, Banham trabalha a relação entre a atitude do pintor e do arquiteto moderno ${ }^{90}$, e a diferença de entendimento acerda da estética da máquina entre a geração de arquitetos da década de 1930 e da chamada 'arquitetura branca', e a geração dos brutalistas ingleses de 1950, os quais esperavam uma atitude mais honesta em relação aos materiais. Para Banham, os jovens escultores do meio intelectual de Banham teriam rejeitado ambas as formas e teorias dos anos trinta, e a teoria que eles aceitaram em sua dimensão moral, racional e funcional, era a verdade dos materiais, estrutura e forma. Também apontariam para o fato de que a "arquitetura branca" dos anos 1930 fracassou nesta proposta. ${ }^{91}$ Banham claramente favorece sua geração, e particularmente seu círculo de relações. Mas em seu argumento, permite-se tomar o tempo necessário para explicar as conexões entre ideologia moderna, construtibilidade baseada no concreto armado cuja genealogia se traça ao raciocínio plástico de Auguste Perret. A arquitetura branca teria sido amplamente produzida em uma doutrina que preconizaria: (a) a idéia de viver na Era da Máquina; e (b) a idéia do concreto aermado como material simbólico dessa era. Em algum lugar ao longo da linha estética preconceitos foram lidos na equaçãoo com resultados que poderiam ser descritos desta maneira:

“This is a Machine Age.

Machine surfaces are smooth and plain

Machine Forms are of rule-and-compass simplicity.

Reinforced concrete is the Machine Age material

Therefore

Reinforced concrete has a smooth surface and must be used in rule-and-

87 Idem. pp. 224-225.

88 Idem. p.224. Tradução: A arquitetura é o jogo sábio, correto e magnífico de volumes dispostos sob a luz.

89 Idem. pp.14-22.

90 Reyner Banham, "Machine Aesthetes", publicado originalmente em New Statesman, no. 55, (16 de Agosto,1958), pp.192-193, e republicado em Design by Choice, em 1981, pp.26-28.

91 Idem, p.27. 
compasss shapes." ${ }^{92}$

Nem mesmo Banham poderia imaginar a magnitude da referência da narrativa corbusiana para a formação do Estilo Internacional, baseado em superfícies lisas erigidas em concreto armado e cobertas por massa corrida, esta a receber pintura branca; e suas reproduções históricas, releituras e revisões. Contudo, Banham consegue captar um dos motes da contradição da estética da máquina para a vanguarda modernista em arquitetura. Toda a somatória de elementos que visavam o controle da forma industrializada era nada mais do que indício do temor compartilhado pelos arquitetos em relação ao potencial destrutivo e agressivo da produção industrial. Já em um de seus primeiros artigos, "Machine Aesthetics", de 1955, Banham acusa: "architects are frightened of machinery" ${ }^{33}$ Para Banham, a proposta de 'descoberta do velho no novo', em Vers Une Architecture e no discurso de Le Corbusier em geral, é uma das predisposições intelectuais que corroboram uma ideologia que tente a impor uma forma (e um ritmo) à máquina. Mesmo não tendo dedicado mais do que algumas menções em 2 páginas de Theory and Design, Banham já tinha se debruçado com certo interesse sobre o capítulo Superfície, de Vers Une Architecture. Os silos de grãos, os quais serão analisados em sua paisagem no capítulo 3 desta dissertação, eram o mote da relação de formas platônicas, genealogias da antiguidade clássica grega e os "novos monumentos" da arquitetura moderna. Para Banham, admirar tais cilindros de grãos, alinhados em séries de 8,10, ou até 20 unidades, não era uma grande surpresa estética para quem foi treinado a aceitar o ritmo estrutural dos templos gregos:

“A 'estética da máquina' dos pioneiros mestres do movimento moderno era portanto seletiva e classicizante (...) esse tipo de aceitação teria que esperar pelos poetas, especialmente Marinetti, cujo Manifesto Futurista de 1909 não apenas abre com o primeiro acidente de carro da literature européia, mas contém o pioneiro julgamento de valor '...um ruidoso carro de corrida, rangendo como uma metralhadora, é mais bonito que a Vitória Alada de Samotracia. Tal opinião somente poderia ser expressada na rara atmosfera de pura poesia enquanto eminências pardas da arquitetura continuavam a se aproximar do problema vagarosamente, avançando com cuidado. Eles tinham se comprimissado à Estética da Máquina, e as palavras de Marinetti parecem ter prendido como arame farpado na pele, mas aceitar seu ponto de vista seria abandonar

92 Idem. p.27. Tradução:

Esta é a Era da Máquina.

Superfícies das máquinas são lisas e planas

Formas das máquinas são de simplicidade típica de régua e compasso.

Pontanto

O Concreto armado tem uma superfície lisa e deve ser utilizado em formas baseadas na régua e no compasso.

93 Reyner Banham, "The Machine Aesthetic", em Design by Choice, p.44, originalmente publicado em Architectural Review, abril 1955. 
a arquitetura tal qual eles a entendiam." ${ }^{94}$

Da mesma maneira que dentro do círculo da L'Esprit Nouveau, na Bauhaus essa abordagem teria se propagado, ainda que disfarçada em formas complexas e abstratas, definindo um padrão de aceitação das formas retangulares e prismas puros como representantes legítimos da Estética da Máquina..$^{95}$ Banham considera, contudo, a presença de um argumento mais nítido sobre a concepção de uma estética da máquina dentro do discurso dos autores do periódico francês. Em diversos artigos da L'Esprit Nouveau Banham encontra a manipulação superficial de termos da engenharia para validar uma concepção particular de arquitetura.

De maneira a buscar compreender a genealogia da estética da máquina entre os Puristas, Banham sugere o exercício de estudo biográfico de seu maior expoente, Le Corbusier: sua formação inicial como relojoeiro em Chaux-de-Fonds, embebido em um ambiente cuja técnica remetia ao século XVIII; sua formação profissional como arquiteto junto a Auguste Perret e Behrens, expoentes auto-assumidos do classicismo, cujo modelo para a plasticidade do concreto era o frame de madeira; e sua experiência junto à indústria Voisin, cuja produção aeronáutica ainda não havia abandonado a lógica aerodinâmica da pipa. ${ }^{96}$ Para Banham, esse panorama de formação explicaria a ingenuidade de Le Corbusier em relação ao funcionamento das máquinas, e explicaria a leitura equivocada do mesmo em relação ao automóvel, em Por Uma Arquitetura. Le Corbusier comete um erro de interpretação, ao comparar o automóvel, um dos temas preferidos de Banham como também de Le Corbusier, com elementos do passado clássico, como o Parthenon:

"Nenhum dos carros ilustrados era um modelo de produção em massa; todos eram modelos únicos, caros, especializados, feitos à mão, que poderiam com justice ser comparados ao Partenon, porque, como ele, são peças únicas de manufatura. Modelos produzidos em massa como o modelo Ford T não eram permitidos nessas páginas classicistas.Ingenuidade? Prática afiada? Ou pensamento positive? Uma certa 'partipris' estética definitivamente está lá; um desejo que certos pedidos deveriam se tornar realidade; que arquitetos deveriam na verdade serem capazes de assumir a estatura

94 Idem. p.44. Texto original: The 'Machine Aesthetic' of the Pioneer Masters of the Modern Movement was thus selective and classicizing. (...) That kind of acceptance had to wait upon the poets, and particularly Marinetti, whose Futurist Manifesto of 1909 not only opens with the first car-crash in European literature, but contains the pioneering value judgment ' ... a roaring racing car, rattling like a machine gun, is more beautiful than the Winged Victory of Samothrace.' Such an opinion could only be expressed in the rare atmosphere of pure poetry and the grey eminences of architecture continued to square up to the problem slowly, picking their ground with care. They had committed themselves to a Machine Aesthetic of some sort, and the words of Marinetti must have stuck like barbs in the flesh, but to accept his viewpoint would have been to let go of architecture as they understood it.

95 Idem. p.44.

96 Idem. p.44 
dos engenheiros aos quais, no primeiro capítulo, Le Corbusier deseja as virtudes do artesão gótico e do nobre selvagem: "Engenheiros são saudáveis, viris, ativos e úteis, morais e felizes"." "'97

Em La Peinture Moderne, em L'Esprit Nouveau, Ozenfant define a idéia de "tipo" como resultante da evolução de formas em consonância com as demandas de produção e o ideal de máxima produtividade. Essa dicotomia resultaria na criação de uma série de objetos que podem ser chamados de standardized (industrializados) ${ }^{98}$. Esse imagem idealizada da máquina, mais do que um entendimento profundo dos funcionamentos da cadeia industrial, era uma maneira de criar grilhões para domesticar a máquina por meio da moral abstrato-moderna. Para Banham, a vanguarda moderna na arquitetura não teria mais potência para controlar o ciclo industrial. Para os engenheiros, "nobres selvagens" da produção industrial, Banham oferece uma leitura desmistificada: para eles, a utilidade, no sentido racionalista no qual os autores claramente pretendiam, era um fator marginal - apenas um entre uma série de fatores que influenciam as vendas. Quando a companhia Ford emitiu um questionário, afirmou Banham, para descobrir quais qualidades seus consumidores buscavam em um carro, muitas respostas no topo da lista eram de ordem utilitária, como alinhamento e consumo de combustível, enquanto outros descreveriam detalhes cromados e padrões cromáticos. Para os fabricantes, utilidade seria um tema complexo, e em diversos momentos a resposta seria dada pela adição de um ornamento, para ostentação ou prestígio social. Em resumo, Banham descreve como um veículo mais complexo, mais detalhado, passa a ser um produto mais interessante, ao ser um resultado de vendas mais bem sucedido do que um automóvel simplificado. ${ }^{99}$

Após 20 anos, Banham retornaria à temática da estética da máquina Corbusiana, dessa vez informado pela produção industrial Americana. Citados e representados por Le Corbusier, os silos de grãos foram (literalmente) revisitados, tanto fisicamente quanto historiograficamente. Em A Concrete Atlantis, publicado em 1986, mas cuja pesquisa se iniciou desde 1976 100 , Banham analisa os fatores técnicos constituintes do processo de adoção e abandono da tecnologia de concreto armado para a construção

97 Idem, p.44. Texto original: ...none of the motor cars illustrated is a standarzied mass-produced model; all are expensive, specialized, handicraft one-offs which can justly be compared to the Parthenon because, like it, they are unique works of handmade art. Mass produced vehicles like the Model T Ford are not allowed to sully these classicist pages.

"Naivety? Sharp practice? Or wishful thinking? A certain aesthetic parti-pris is undoubtedly there; a desire that certain wishes should come true; that architects should in reality be able to assume the moral stature of engineers to whom, in the opening chapter, Le Corbusier had wished the virtues of the Gothic Craftsman and the Noble Savage: 'Engineers are healthy, virile, active and useful, moral and happy'.

98 Idem. p.45.

99 Ibid. p.45.

100 Segundo registros nos manuscritos de Reyner Banham arquivados na biblioteca do Getty Research Institute, caixas 3 a 6. O indício sobre o início da pesquisa direta sobre a produção do livro e a investigação sobre silos de grãos foi encontrada em correspondências com editores e colegas pesquisadores. 
dos cilindros monumentais que chamaram a atenção dos arquitetos modernos Mendelsohn, Gropius, Le Corbusier e Moizei Ginsburg - e sua parte na formação do ideário da estética da máquina no modernismo das décadas de 1920 e 1930. Seguindo o padrão historiográfico do capítulo "Modernism and Americanism"do livro, Banham parte para um de seus textos mais constantemente abordado, o manifesto modernista de Le Corbusier, Vers Une Architecture, mais especificamente, "Rappel a MMs. Les Architectes".

Dentro da lógica persuasiva de Le Corbusier, a fábrica Fagus, projetada por Gropius, seria destaque no panorama da arquitetura protagonizada pelas obras de engenharia - em relação com as práticas dos arquitetos americanos. Banham parte primeiramente para a avaliação das diferenças entre o posicionamento de Gropius para e Le Corbusier, sobretudo no que se refere à eleição por este último do concreto como o material do futuro. Não existe nos textos de Gropius anteriores à Vers Une Architecture qualquer menção tão afirmativa em prol de uma técnica ou de um material. A relação com a publicação de Gropius passaria pelo ampla manipulação retórica da imagem ${ }^{101}$. Como já mencionado anteriormente (tanto quanto em Theory and Design), nos três lembretes (Rappels) aos arquitetos, destaca Banham, dirigem-se ao volume, à superfície e ao plano, formando 3 seções independentes do livro. Contudo estas são precedidas por um capítulo que atenta para a estética dos engenheiros, destacando com o mesmo misto de admiração e distanciamento os empreendimentos da indústria americana. A menção de Banham a Worringer aparece novamente, malgrado Banham não confirme a conexão direta com Le Corbusier ou Gropius, e a existência de relações marcantes com o abstracionismo e primitivismo contido nos textos de Gropius. Em seguida, as imagens 'tratadas' de Le Corbusier são cotejadas e apresentadas ${ }^{102}$.

Em seguida os 3 lembretes são analisados sob a luz da referência industrial:

"Massa, superfície, e plano são de fato os temas desses três apelos, mas o tratamento dado ao "plano" é eminentemente diferente dos outros dois temas. Nenhuma estrutura moderna, primitive industrial aparece entre as ilustrações. Ao invés, existem axonométricas e planos da Histoire de Choisy que carregam o fardo de serem as primeiras do capítulo, enquanto os arranjos gerais e perspectivas da visionária Cité Industrielle de Tony e dos próprios projetos urbanísticos de Le Corbusier, ao trabalho visual na muito mais longa segunda parte de seu argumento, q ue é inteiramente focado nas soluções aplicáveis para os problemas correntes do urbanismo. Os dois apelos "industriais" não têm "aplicação"; são afirmações puras sobre a natureza da arquitetura, mas bem diferentes das que ele queria dizer sobre plano. “103

101 Reyner Banham, A Concrete Atlantis, p. 217.

102 Idem. pp.218-221.

103 Idem. p.222. Texto original: Mass, surface, and plan are indeed the topics of the three rappels, but the treatment of "plan" is strikingly different from that of the first two topics. No modern, primitive industrial 
Banham analisa o capítulo sobre massa (volume), considerando um dos mais ressonantes e lembrados discursos de Le Corbusier. A famosa frase (transcrita por Banham para o inglês) que inicia o capítulo é parafraseada - "Architecture is the masterly, correct and magnificent play of masses brought together in light." Banham continua a citação: "Our eyes are made to see forms in light; light and shade reveal these forms: cubes, cones, spheres, cylinders or pyramids are the great primary forms which light reveals to advantage (...)"104. Mais a frente, Banham destaca a relação entre a citação e as imagens:

"Se o leitor olha para a confirmação visível dessas reinvidicações fundamentalistas, tudo que sera visto são imagens de elevadores de grãos, mais notadamente o Government 1 em Montreal e o Dakota em Buffalo, os quais ocupam toda a página seguinte." ${ }^{105}$

Eram estas, segundo Banham, evidências visuais de validação do argumento de Le Corbusier, evidências das formas platônicas encontradas no mais simples e pragmático engenho humano. Banham constrói o argumento em cima do texto de Le Corbusier para chegar à sua apoteose, a frase que resume a postura corbusiana frente à arquitetura industrial:

"Portanto nós temos o elevador de grãos e fábricas americanas, os magnificos PRIMEIROS FRUTOS da nova era. OS ENGENHEIROS AMERICANOS ESMAGAM COM SEUS CÁLCULOS NOSSA ARQUITETURA ASPIRANTE." 106

Após comentar jocosamente o uso da fonte em caixa alta - por Le Corbusier Banham critica o uso de instrumentos de desenho técnico - régua, compasso, esquadro na produção de formas platônicas. Para ele, o choque por parte dos arquitetos

\footnotetext{
structures appear among its illustrations. Rather, there are axonometrics and plans from Choisy's Histoire to carry the burden of the first part of the chapter, while layouts and perspectives from Tony Garnier's visionary Cité Industrielle and from Le Corbusier's own urbanistic projects do the visual work in the much longer second part of the argument which is entirely concerned with applicable solutions to current city-planning concerns. The two preceding "industrial" rappels have no "applications" content of this sort; they are pure statements about the nature of architecture, but of a quite different order from what he is trying to say about the plan.

104 Tradução: nossos olhos foram feitos para enxergar formas na luz; luz e sombra revelam essas formas: cubos, cones, esferas, cilindros e pirâmides são as grandes formas primárias nas quais a luz releva vantagem.

105 Idem, 224. Texto original: If the reader looks for visible confirmation of these resounding fundamentalist claims, all that will be seen are pictures of grain elevators, most notably Government I in Montreal and the Dakota in Buffalo, which between them occupy a whole of the facing page. 106 Idem, p.224. Texto original: Thus we have the American grain elevators and factories, the magnificent FIRST FRUITS of the new age. THE AMERICAN ENGINEERS OVERWHELM WITH THEIR CALCULATIONS OUR EXPIRING ARCHITECTURE.
} 
modernos europeus em se deparar com formas construídas que validassem as mesmas leis "infalíveis" da geometria euclidiana em construções modernas, mesmo que exóticas e selvagens:

"Para ser franco, o choque não passou completamente até agora. Existe ainda algo perturbadoramente franco sobre essa confluência do cruamente functional e do universalmente abstrato" 107

Para Banham, o primeiro rappel tornou-se o ponto máximo de toda a nova Atlântida de Concreto. Tudo depois do manifesto de Le Corbusier teria, para ele, um sentido de anti-climax, mesmo se consideramos a visita de Mendelsohn à America em 1924. Vincent Scully, meio século depois, também optaria por utilizar a mesma imagem emprestada de Gropius por Corbusier, ao invés de outras fotografias, de maior qualidade, as quais ele teria acesso na época. Banham coloca nessa conta inclusive os próximos lembretes, nos quais, segundo ele, os tópicos de abordagem eram de certa maneira menores ou mais superficiais. ${ }^{108}$

De modo geral, para Banham o texto de Le Corbusier era muito mais radical do que o de Gropius, que seria abordado em seguida, em suas assertivas sobre o papel da arquitetura industrial americana dentro do ideário moderno:

“Enquanto para Gropius elas [as construções fabris americanas] têm sido simples exemplars para uma arquitetura moderna industrial melhor, para Le Corbusier elas se tornaram - como o Tempietto de Bramante - exemplares para toda a arquitetura, para sempre, tal como o livro é intitulado "Towards an Architecture" sem nenhum epiteto de causa subsidiária para qualificar a palavra "arquitetura". Le Corbusier aqui se coloca como mais do que um simples modernista; ele reivindica falar pela arquitetura de todos os tempos." ${ }^{109}$

107 Idem, p.225. Texto original: To be frank, the shock has not completely worn off even now. There is still something disturbingly bold about this conflation of the crudely functional and the universally abstract.

108 Idem, pp.225-226.

109 Idem, pp.227-228. Texto original: Whereas for Gropius they [as construções fabris americanas] had been simply exemplars for a better modern industrial architecture, for Le Corbusier they had become - like the Tempietto of Bramante - exemplars for all architecture, forever, much as the book in entitled simply "Towards an Architecture", without any epithet of subsidiary cause to qualify the word "architecture." Le Corbusier here stands as more than a simple modernist; his claims is to speak for the architecture of all time. 


\section{Walter Gropius e a Terra-mãe da Indústria}

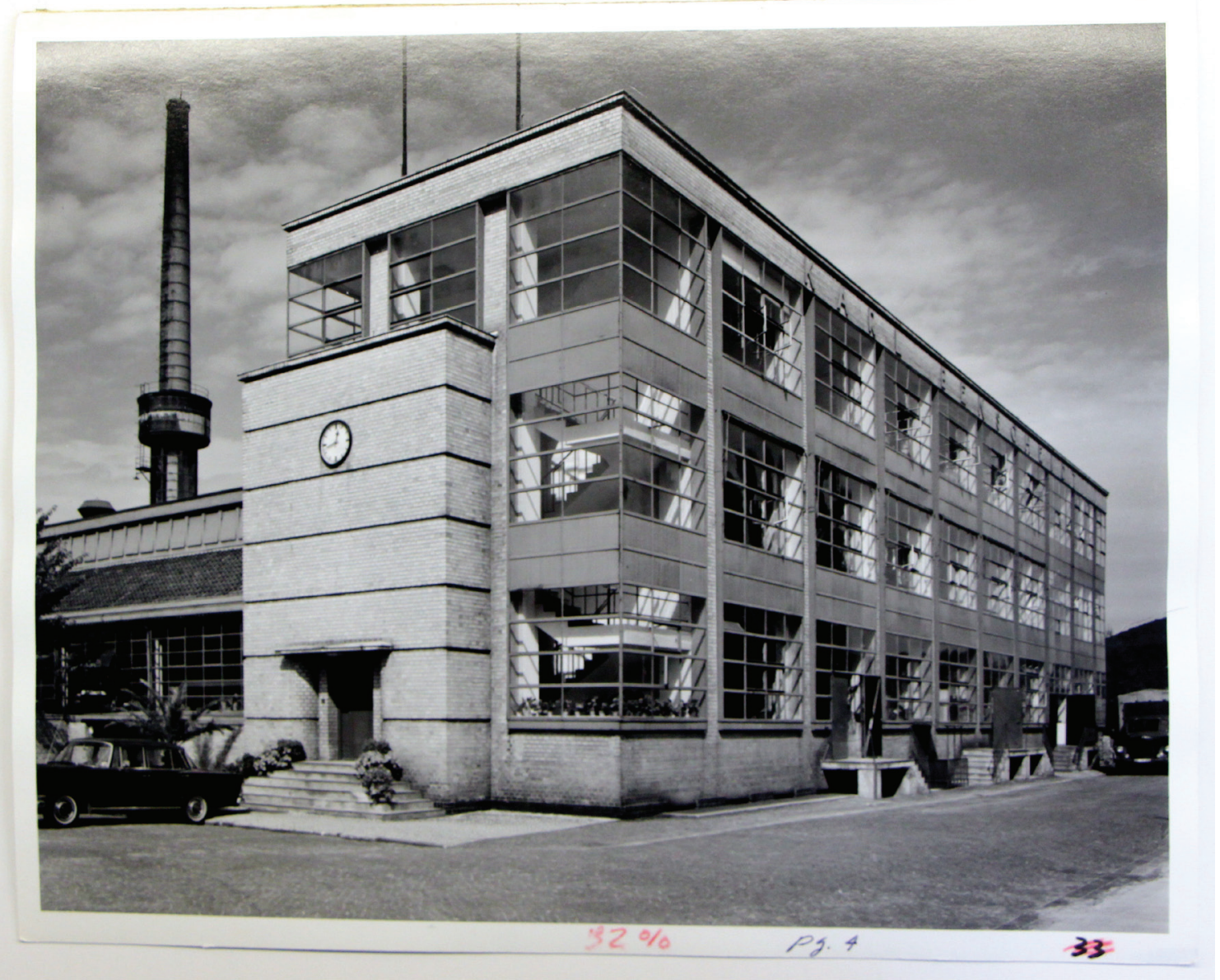

Walter Gropius e Adolf Meyer, Fagus Werk. Foto: Reyner Banham, s / data. Fonte: Arquivo Getty.

A Concrete Atlantis fecha, conforme já mencionado, um arco temático sobre a relação entre a arquitetura anônima, pragmática, industrial americana e a geração modernista de arquitetos europeus. O recorte temporal proposto foi definido entre $1900 \mathrm{e}$ 1925, e os profissionais levantados pela narrativa são arquitetos europeus que estabeleceram, em diversas proporções e intensidades, relações com o conjunto construído americano - Eric Mendelsohn, Walter Gropius, Le Corbusier e Moizei Ginzburg. Sua leitura pode ser reconstruída como pertencente ao final de uma investigação a respeito da estética da máquina e a construção da estética moderna a partir do funcionalismo rudimentar industrial. Essa investigação foi iniciada nos capítulos sobre a Werkbund e a estética industrial européia, de Teoria e Projeto na Primeira Era da Máquina, de 1960 Germany: Industry and the Werkbund; The Factory aesthetic ${ }^{110}$.

A Concrete Atlantis é dividido em 3 capítulos precedidos por uma introdução onde o autor apresenta seu método investigativo e a gênese de seu interesse sobre o tema; No primeiro e segundo capítulos, Banham apresenta as tipologias mais recorren-

110 Reyner Banham, Theory and Design, pp. 68-98 
tes e significativas da construção industrial americana - a Day Light Factory ${ }^{111}$ e o Silo de Grãos. No terceiro capítulo, Banham tece comentários mais abrangentes sobre as raízes canônicas do modernismo europeu e sua relação com o 'americanismo em arquitetura', identificando as especificidades da expressão moderna na arquitetura americana, relacionando consumo, produção e estética.

Já no primeiro parágrafo da introdução Reyner Banham apresenta os parâmetros de pesquisa e as fontes de inspiração para a publicação, e desde o princípio deixa clara sua postura de pesquisador de campo: a motivação inicial do livro não teria vindo de uma fonte publicada, nem de um texto específico sobre o assunto, mas da presença acidental do autor em uma instalação abandonada da Baía de Monterey, na Califórina. Banham busca referências bibliográficas para tecer relações entre a estrutura abandonada de concreto e a "metafísica da forma", tal como expressa pelo estilo internacional e por Le Corbusier. Contudo, é em uma referência literária; como em sua última publicação, Scenes of America Deserta, ${ }^{112}$ que Banham se ampara na literatura de língua americana para construir sua narrativa, evocando elementos da arquitetura vernacular americana, no caso, o romance de John Steinbeck Cannery Row. ${ }^{113}$

Na introdução, Banham também apresenta sua tese: a existência de uma conexão causal, cultural e consciente entre as grandes obras da arquitetura moderna, como a Cité de Refuge ou a Ville Savoye e as estruturas utilitárias de um certo período e tipologia da indústria norte-americana ${ }^{114}$. Banham atenta para a procedência de tal assertiva em narrativas publicadas no decorrer do século XX, como Learning from Las Vegas, de Robert Venturi e Denise Scott-Brown ${ }^{115}$. No caso de Venturi, ao se remeter ao uso das

111 A tradução direta do termo é "fábrica da luz do dia", mas o significado mais próprio é a fábrica dependente da luz do dia para amparo da produção manufatureira. O desenvolvimento tecnológico das construções em tijolo e concreto favoreceu a ampliação gradual do tamanho das janelas, permitindo que mais luz entrasse no ambiente, minimizando a utilização de luz elétrica proporcionando mais horas de trabalho.

112 Publicado em 1982, Scenes of America Deserta é um extenso trabalho de literatura de avaliação presencial por parte de Banham. O material deste livro será mais aprofundadamente analisado no capítulo 3.

113 John Steinbeck, Cannery Row. New York, Penguin, 1993. texto original: Cannery Row in Monterey in California is a poem, a stink, a grating noise, a quality of light, a tone, a habit, a nostalgia, a dream.

Cannery Row is the gathered and scattered, tin and iron and rust and splintered wood, chipped pavement and weedy lots and junk heaps, sardine canneries of corrugated iron, honky tonks, restaurants and whore houses, and little crowded groceries, and laboratories and flophouses. Its inhabitant are, as the man once said, "whores, pimps, gambler and sons of bitches," by which he meant Everybody. Had the man looked through another peephole he might have said, "Saints and angels and martyrs and holymen" and he would have meant the same thing. A imagem traçada por Steinbeck é de monolitos negros, enferrujados porém ainda refletindo a luz de um fraco sol de outono. Esses monolitos seriam máquinas industriais, confundidas com prismas mitológicos, aludindo à uma civilização perdida, para Banham.

114 Idem, p.3

115 No artigo Relearning from Las Vegas... and Los Angeles, and Reyner Banham, publicado originalmente em Visible Language 37.3, Nigel Whiteley aponta para aproximações e discrepâncias entre o discurso de Banham sobre Los Angeles e o vernacular moderno e o discurso do casal Venturi e Scott-Brown sobre Las Vegas e a arquitetura e urbanismo da Commercial Strip. 
formas puras da construção industrial americana, aponta para a aplicação não-consciente do jogo de formas que seria usado décadas a frente pelos arquitetos modernos europeus. Para Banham, tal explicação encerra apenas uma parcela da questão, ao se reportar apenas à investigação de forma por parte dos arquitetos europeus. E isto ainda de maneira unilateral. Banham também considera incompleta a análise orçamentária sobre a arquitetura pragmática funcionalista. Segundo ele, não são apenas em fórmulas econômicas que cruzam dados de investimento material, e retorno financeiro em produção e faturamento que se encerram as decisões projetuais, tecnológicas e construtivas de tais obras, dentro do conjunto construído industrial americano.

Banham também aborda os critérios seletivos dos arquitetos europeus para valorizar ou desconsiderar alguns exemplares de arquitetura pragmática industrial. Os adereços que figuravam em treliças de pontes e torres, por exemplo, eram considerados sinais de atraso. Utilizando a referência recorrente da laje plana de concreto, Banham apela para a faceta meramente estética desses critérios seletivos. Banham apresenta, através desse estudo de caso, os limites do conhecimento dos arquitetos de vanguarda acerca das soluções construtivas da construção fabril americana.

“E isso nos evoca o assunto de extraordinária importância histórica que vai muito além de qualquer escândalo sobre telhados infiltrados: na medida que o Estilo Internacional foi copiado pelos protótipos industriais americanos, deve ser o primeiro movimento de arquitetura da história da arte baseado exclusivamente em evidência fotográfica ao invés das técnicas ancestrais e previamente inevitáveis de inspeção pessoal e desenho dotado de medidas." 116

Fechando um arco temporal desde a genealogia da frame estrutural de concreto, Banham chega nas obras que receberiam a alcunha de 'frutos de uma nova era' por Le Corbusier em Vers Une Architecture, os edifícios Packard, em Detroit, e Pierce Arrow, em Buffalo, ambos relacionados com o nome de Albert Kahn ${ }^{117}$. Seriam os primeiros edifícios a apresentar uma "pureza nua e desinibida". Em tais obras o encontro entre os métodos e materiais simples e despojados, porém com detalhamento atencioso e bom desempenho estrutural e ambiental, estimularam Banham a trazer tais obras para o patamar de grandes realizações na história da arquitetura:

116 Reyner Banham, A Concrete Atlantis, p.18. Texto original: And this brings up a matter of extraordinary historical importance that goes well beyond any scandals about leaking roofs: insofar as the International Style was copied from American industrial prototypes and models, it must be the first architectural movement in the history of the art based almost exclusively on photographic evidence rather than on the ancient and previously unavoidable techniques of personal inspection and measured drawing. 117 A autoria da obra de Pierce Arrow gera muita polêmica, até o tempo presente. Nos arquivos municipais de Buffalo está registrado o nome da firma de arquitetura local, Lockwood Greene and Co. 
"Aos meus olhos, isso é arquitetura mais uma vez, ao menos isso. Vai de fato mais além da mera provisão de abrigo. Habilidades especiais parecem ter retornado, mas em novas formas sóbrias que descobriram o refinamento e graça necessários para fazer tal arquitetura minimalista ser sustentável e prática." ${ }^{118}$

Logo em seguida, Banham apresenta a ruptura de imagem e significado ocorrida entre esses objetos-símbolos, os 'frutos de uma nova era', e seus leitores, os arquitetos modernos europeus, admiradores do outro lado do Oceano Atlântico:

"As ilustrações de revista de tais trabalhos vistas por modernistas europeus era normalmente muito mal definidas para tais detalhes como chanfros de uma polegada em cantos de colunas serem visíveis; nunca tendo visto os edifícios originais, eles tiveram que descobrir tais usos por eles mesmos, a duras penas, normalmente muito tarde, e costumeiramente às custas dos clients (muito a ver com os telhados planos discutidos anteriormente). Tal comportamento seria suicídio para um arquiteto industrial americano." ${ }^{119}$

Banham apresenta a fábrica Faguswerke como o mais apropriado exemplo para exame da influência das exóticas estruturas industriais americanas no meio da arquitetura moderna na Europa. Banham indica que um dos fatores principais para essa relação seria o fato de que os contratantes de Walter Gropius nutriam admiração prévia não só pela arquitetura americana, mas também pela expertise industrial do novo mundo. Não obstante, rapidamente Banham problematiza a questão. Para ele, a Fagus Werke emana claramente ambições e intenções americanas para seu visitante. Suas origens, contudo, não são tão claras. São contradições de seu desenho híbrido entre elementos europeus e americanos, malgrado de inegável qualidade, que o aproxima tanto de uma catedral gótica, quanto de uma fábrica americana. ${ }^{120}$ Poderíamos resgatar o capítulo “The Factory Aesthetics” de Theory and Design in the First Machine Age para entendermos o conteúdo da crítica da Banham acima ${ }^{121}$. Contudo, nesse segundo enfrentamento do tema, Banham apresentará diferenças entre

118 Idem, p.86. Texto original: To my eyes, this is architecture again, if only just. It does go one step beyond the mere provision of safe shelter. Traditional skills appear to have returned, but in some new and chastened forms that have rediscovered the refinements and graces needed to make such minimalizing architecture bear able and workable.

119 Idem, p.87. Texto original: The magazine illustrations of such works seen by European modernists were usually too small and too coarse-screened for details as fine as an inch-wide chamfer on the edge of a column to be visible; having never seen the original buildings, they had to discover such usages for themselves, painfully, often too late, and usually at the clients' expense (much as they had with the flat roofs discussed earlier). Such behavior would have been professional suicide for an American industrial architect.

120 Idem. p.181.

121 Reyner Banham, Theory and Design, mais precisamente o "Factory Aesthetics". 
os radicais intelectuais da indústria alemã e americana que se encerram na comparação entre a Fagus e os exemplos posteriormente citados em A Concrete Atlantis.

No primeiro movimento de descrição da Fagus, Banham se concentra em avaliar as condições de conservação do edifício. Vale notar que em diversos momentos no decorrer do livro, ele apresenta impressões pessoais a partir de visitas diretas aos sítios. No caso da Fagus, Banham relativisa sua dita 'modernidade' por levantar detalhes inspirados no Art Nouveau e no estilo Vitoriano. Em seguida discorre sobre a narrativa da historiografia moderna a respeito do edifício. Banham acredita que dificilmente qualquer um dos propagandistas do Estilo Internacional viram a fábrica Fagus senão em fotografias. O historiador italiano Leonardo Benevolo, apenas ele, teria visto o edifício com seus próprios olhos, dada a clareza de suas descrições do sítio. Banham identifica, também no discurso de Benevolo, o entendimento que a Fagus não poderia ser considerada interiamente moderna. A Fagus estaria confinada em um passado imediatamente pré-moderno. ${ }^{122}$

Notamos a predileção de Banham sobre o método de crítica arquitetônica fundamentado na visita direta à obra e na experiência sensorial e pessoal em detriment da pesquisa na bibliografia historiografia disponível. Em seguida, ele cita Benevolo, a quem Banham abre uma exceção de validação em seu argumento:

"A escolha de detalhes, particularmente neste famoso edifício de vidro, revela inúmeras incertezas: o ideam de fazer o vidro se projetar da parede, o vidro contínuo nas quinas. $\mathrm{O}$ acesso principal, e o bloco do edificio no qual ele se instala, delineado por faixas horizontais de tijolo mais escuro, são referentes ao estilo de Behrens, feito com um certo grau de embaraço... neste edifício um fugaz momento de transição é cristalizado, e isso pode ser a explicação de sua atração particular. ${ }^{123}$

Banham se atém ao termo "momento de transição", no qual ele encaixa a obra de Gropius. Ele considera a Fagus como uma obra-de-arte característica de um momento de transição, comparando-o à Escola de Arte de Charles Mackintosh, na sua clareza de propósito, mesmo sendo este um momento transitório e híbrido, típico da

122 Reyner Banham, A Concrete Atlantis, p.182.

The Italian historian Leonardo Benevolo, however, clearly had seen the plant with his own eyes, because he describes its site as only an eyewitness could have done. He too observes that it is not conventionally "modern" but looks back in many parts to the immediate pre-modern past

123 Leonardo Benevolo, apud Reyner Banham, in A Concrete Atlantis, p.111. Texto original: The choice of details, particularly in the famous glass building, reveals numerous uncertainties: the ideal of making the glass protrude from the wall, the continuous glass at the corners. The main doorway, and the block of the building in which it is set, lined with darker horizontal bands of brick, are plainly references to Behrens' style, made with a certain amount of embarrassment. . .

In this building an extremely fleeting moment of transition is crystallized, and this may be the explanation of its particular attraction. 
história primitiva da arquitetura moderna. ${ }^{124}$

Banham discorre sobre a história da Fagus, focando na importância dos clientes, Carl e Karl Benscheidt (pai e filho) no estabelecimento de um elo com a indústria americana na construção de sua fábrica de sapatos. Através do contato com a United Shoe Machinery, com a qual a Fagus estabeleceria parceria, os industriais alemães entrariam em contato com o método produtivo americano. Contudo, Banham aponta para o fato de que os industriais alemães não teriam entrado em contato com a planta fabril da United Shoe Machinery, projetada por Ransome. De fato, a Fagus estaria completamente construída antes que Gropius realizasse sua primeira viagem aos Estados Unidos. Seria possível, no entanto, que o real efeito da conexão de Benscheidt com os Estados Unidos tenha sido a contratação do jovem Walter Gropius, em 1910. O arquiteto teria mantido como hábito o envio de cartas para diversos empreendedores alemães, oferecendo seus serviços, e apresentando as credenciais de participação nas obras da sede da empresa de eletrodomésticos AEG - Allgemeine Eletrizitäts Gesellschaft - enquanto funcionário de Peter Behrens. ${ }^{125}$

Mesmo sob condições adversas, visto que Benscheidt tinha já um arquiteto de confiança, Eduard Werner, e quando Gropius foi contratado, as fundações da fábrica já tinham sido concretadas, amarrando o projeto - o jovem Gropius, a princípio encarregado apenas de tocar o projeto de acabamentos, tratou de reorganizar o projeto para além do esperado. Talvez a experiência de Benscheidt na América o tenha convencido de encarregar uma mente mais jovem e progressista na definição da imagem de sua empresa. No processo de desenho e redesenho das fachadas da fábrica, a mando de Benscheidt, Gropius e Adolf Meyer chegaram à forma final da famosa fachada de vidro composta com a escada na esquina do bloco de entrada, já na segunda fase de implantação da fábrica. Para Banham, esta decisão de empreender tanto esmero na fachada menos visível do complexo fabril era perturbadora. Uma das hipóteses era de que o bloco seria utilizado como escritório para projeto e desenhistas, e nesse sentido a generosidade luminosa proporcionada pela fachada de vidro teria uma aplicação direta. Somava à essa hipótese a vontade de Benscheidt em assimilar uma atmosfera americanizada para o espaço de trabalho, provavelmente como referência à sua experiência na United Shoe Machinery Corporation. ${ }^{126}$

Banham desenvolve seu argumento sobre as relações genealógicas da Fagus com as fábricas naturalmente iluminadas, as Day-light-Factories americanas. Como em primeira mirada, os grandes planos de vidro causam a sensação de familiaredade. Mas Banham também se dedica a apontar as diferenças entre o pragmatismo americano, ancorado nas capacidades técnicas das soluções oferecidas pelo construtor, e as manipulações da estética fabril por Gropius e Meyer, distantes da lógica de

124 Ver A Concrete Atlantis, pp.184-185.

125 Ibid. p.186.

126 Idem. p.190. 
aproveitamento de luz das Day-Light. Ademais, notemos que Gropius se dedicou muito mais ao projeto do bloco de escritórios do que outras áreas de trabalho, diferentemente dos arquitetos americanos, conforme apontado por Banham ${ }^{127}$. Suas fachadas, visualmente impressionantes, permeadas por inúmeros detalhes, demonstram ser frutos de um esmero de projeto e de uma forte influência da arquitetura fabril e na estética da máquina. $\mathrm{O}$ ritmo dos pilares alinhados na fachada remontam à estética das fábricas americanas, conforme o desejo de Benscheidt. Para Banham, é um dos melhores e mais notáveis exemplos de arquitetura da Deutscher Werkbunb, momento primitive da arquitetura moderna alemã. $\mathrm{O}$ esmero no detalhamento era para Banham sintomático da ligação entre disciplina e espiritualização que emolduravam não só a arquitetura industrial mas também toda a indústria alemã. Isso se perceberia nos trabalhos de Wagner, Hoffman, e principalmente nos trabalhos de Behrens, como arquiteto e desenvolvedor de produtos para a AEG, referências para Gropius no projeto da Fagus. ${ }^{128}$

Malgrado não seja a obra de Gropius um exemplo em si do processo de americanização da indústria alemã, apenas de sua arquitetura - e com algumas ressalvas a serem feitas - a Fagus, junto aos acontecimentos que envolveram sua concepção e construção, contribui para a aproximação das duas culturas construtivas. O principal acontecimento nessa época, envolvendo Gropius e possivelmente seus interesses estéticos, seria segundo Banham um artigo de 1913 publicado em Jarbuch des Deutschen Werkbundes, o anuário da liga industrial americana sobre a construção fabril dos Estados Unidos, país que Gropius se refere como "terra-mãe da indústria".

Os objetos em questão são as fotografias que ilustram o artigo, muitas delas da Atlas Portland Cement Company, figurando trabalhos como os do escritório do Americano Albert Kahn. Segundo Banham, as fotos eram de péssima qualidade, e em alguns registros pessoais e depoimentos, Gropius se remetia a essas fotografias como "recortes de jornal". De fato, é difícil localizar a importância de tais imagens para a construção do ideário industrial da Werkbund. A dívida com Worringer a respeito da relação entre arte egípcia e industrialização americana, mencionada na introdução de A Concrete Atlantis, é questionada: o artigo de Worringer, que lida diretamente com o tema da estética egípcia - Ägyptische Kunst - foi publicado somente em 1927, muito depois do artigo de Gropius ${ }^{129}$. Mesmo assim Banham aposta na referência ao trabalho de Worringer, mas em seu primeiro livro, Abstraktion und Einfühlung, de $1908^{130}$. Banham cita então Gropius a respeito de suas fontes, não só Worringer mas

127 Idem. pp.190-193.

128 Idem, p.193.

129 Ver os manuscritos de Reyner Banham no Getty Research Institute, 'Banham Papers', Caixa 2, pasta 3.

130 Ver Wilheim Worringer, Abstraction and Empathy: A Contribution to the Psychology of Style. New York: Ivan R. Dee, 2007. 
também Riegl. É natural a referência: a geração de Gropius foi educada pela geração que desenvolveu os estudos de puro visibilismo e a história cultural da arte, ambas desenvolvidas na Alemanha e Áustria.

"Arte é feita pelo homem e para o homem; ela é uma contradição da natureza. Ela busca mudar a beleza absoluta própria da natureza, em beleza relativa e consciente. Esse diálogo é mantido pela força de vontade. O que não tem intenção na natureza, o homem intencionalmente busca afetar. No centro da força de vontade do homem estão duas intenções: de conhecer e criar. Com elas o homem toma conta do sensual e trancedental mundo dos fenômenos, enquanto o impulso criativo responde aos limitadores mecânicos das coisas e fenômenos, este sendo afirmativo do impulso de viver, criar e construir, também responde ao conhecimento da condição do mundo em negar a vida, crítica e destruição. Os dois impulsos lutam, em uma resolução final ideal, para se aproximarem." 131

Gropius foi mais incisivo na relação entre material, ideais abstratos de transformação e indústria. Banham cita seu discurso na conferência e exposição da Werkbund de 1911. Atributos de estados mentais e espirituais elevados são colocados à frente dos materiais, como símbolos da modernidade. A arquitetura, como resultado dessa vontade e consciência, devia refletir a pureza de propósito da nova sociedade alemã: industrializada, porém atenta à necessidade de valores elevados. A recusa a formulas passadas - lida algumas vezes como rompimento com a história - pelo menos como ela tinha sido abordada até então - também é evocada:

"A vida moderna necessita de novas construções que expressem a vida e a forma de nossos tempos - estações, lojas de departamento, fábricas, todas elas demandam uma expressão moderna unívoca, que não pode se satisfazer com os estilos de séculos passados, sem cair em esquemas vazios de modas passageiras. Ao invés de aplicar fórmulas superficiais, uma modelagem de dentro para fora desses novos problemas da arquitetura é necessária, bem como pensamento fora da rotina, e considerações estéticas das formas básicas dos tempos passados, sem adicionarmos decorações. "132

131 Aloïs Riegl, apud Reyner Banham, in A Concrete Atlantis, pp.197-198. Texto original: Art is made by man and for man; it is a contradiction of nature. It seeks tho change the absolute beauty proper to nature, into conscious relative beauty. This conversation is wrought by the will. What is without will in nature, man strives to affect by means of the will. At the power center of mam's will stand two innate drives: to know and to create. With these he takes hold of the sensual and transcendental world of phenomena. While the creative drive responds to the mechanical constraints of things and phenomena, it being lifeaffirming, generative, and constructive, but directs that the drive to knowledge of the phenomenal world be life-denying, critical, destructive. Both strive, in a final ideal resolution, to come together (...) 132 Walter Gropius, apud Reyner Banham, in A Concrete Atlantis, p.200. Texto original: Modern living needs new building organisms expressing the life forms of our times - stations, department stores, 
A forma do edifício, neste contexto, seria a principal tarefa do arquiteto. $\mathrm{O}$ ornamento, segundo Gropius, não era negado, mas era colocado em um patamar inferior de detalhamento, e obediente ao ritmo do edifício ${ }^{133}$. Segundo Banham, Gropius, mesmo ao encontrar na indústria um ponto de tangência com o pensamento americano, se furtava a analisar as questões sob o ponto de vista do progesso e indústria juntos, e analisava design e produção industrial como duas coisas separadas, sendo a função daquele que pensa o desenho das formas - Behrens, Poelzig, Stoffregen, Martin Wagner, entre outros - aplicar o senso do bom design para o melhoramento da indústria. Citando novamente Gropius, Banham aponta para a visão de "nobre selvagem" e as comparações com o egito antigo, com a finalidade de destacar a maneira como os alemães - através do discurso de Gropius - viam a cultura industrial americana como um misto de selvageria, rusticidade, barbarismo e progresso, criatividade, monumentalidade ${ }^{134}$. Diferentemente de Le Corbusier, Gropius elevaria os arquitetos americanos a patamares superiores, valorizando a obra de Frank Lloyd Wright entre todos.

Banham destaca a essa nova percepção da figura dos engenheiros nas narrativas do escritor futurista italiano F. T. Marinetti, que os chamaria de "homens do povo, sem cultura ou educação, que não obstante foram abençoados com o dom da profecia mecânica e o domínio dos metais". Mas os engenheiros de Gropius teriam a autoridade de terem suas origens na 'terra-mãe da indústria'. Seriam verdadeiros autóctones da cultura da indústria de massa. Esses "nobres selvagens", como teriam sido vistos pelos europeus, teriam as virtudes perdidas dentre os arquitetos europeus, daí justificando o jogo de palavras com a "Atlântida de concreto". ${ }^{135}$

É interessante notar a presença de Marinetti e do pensamento futurista a respeito dos conceitos de progresso e modernidade, e como Banham opõe duas visões, italiana e alemã - se é que podemos falar do pensamento nacional - duas leituras distintas de relações entre modernidade e tradição. Fica claro que para Banham, Gropius nutria um misto de admiração e distanciamento, enquanto que para Marinetti os valores impregnados na cultura americana deveriam solapar os cânones ultrapassados da alta cultura européia. Nos próximos movimentos, a noção de abstração primitiva americana e egípcia, objeto de estudo por parte dos teóricos alemães, é examinada por Banham. Nas sete páginas que Gropius teria dedicado aos elevadores de grãos, Banham viu o interesse em construir a imagem do construtor americano como herói primitivo. Em seguida, Banham reflete sobre outro efeito da

factories all demand a uniquely modern expression that cannot be satisfied in the styles of centuries past without falling into empty schematics of period fancy-dress. Instead of the application of superficial formulas, an inward shaping of these new architectural problems is required, non-routine thinking, an aesthetic consideration of the basic forms of former times, not added decoration.

133 Reyner Banham, A Concrete Atlantis, p.200.

134 Reyner Banham, Concrete Atlantis. pp.201-203.

135 Idem, p.204. 
publicação:

"O que é poco notado, contudo, foi o efeito paralelo que os novos projetos Americanos, particularmente os elevadores, causaram em engenheiros europeus, presumidamente por suas razões funcionais "objetivas", que supostamente não envolviam retórica tampouco estética. "136

A partir da revisão historiográfica de Banham, formulada em A Concrete Atlantis, e apresentadas nas últimas páginas do livro, podemos verificar como, a partir dos anos de estudo dos autores do pré-guerra - Pevsner, Giedion, Le Corbusier e Walter Gropius - ele constrói seu argumento acerca da arquitetura contemporânea. A aceitação da máquina em seus próprios termos ${ }^{137}$; da histoiricização do abstracionismo da 'arquitetura branca' de 1930; a manipulação do projeto e dos artifícios mecânicos disponíveis para controle do ambiente. O entendimento sobre tecnologia e industrialização, e a revisão da postura profissional do arquiteto em relação à técnica serão os aspectos priorizados para traçar as semelhanças, interrelações e rupturas entre as produções dos arquitetos dos dois lados do Atlântico.

\section{Arquitetura e Tecnologia: do Brutalismo ao High-Tech}

Após a publicação de Theory and Design in the First Machine Age, e de uma série de artigos publicados nos periódicos britânicos New Statesman e Architectural Review, Reyner Banham consolidava sua crítica acerca do fracasso da arquitetura moderna das décadas de 1920 e 1930 em se apropriar da estética da máquina em todo o seu potencial. Já abordamos suas pautas iniciais em defesa de figuras esquecidas da arquitetura moderna como Mendelsohn, Scheerbart, Marinetti e Sant'Elia, entre outros. A partir de 1960, Banham teria o espaço (e a notoriedade necessária) para ampliar seu campo de questões, e aprofundar a sua pesquisa sobre o engajamento dos arquitetos com a tecnologia durante o século XX, buscando encontrar caminhos para compreender os fenômenos da arquitetura moderna na segunda metade do século, do Brutalismo de origem britânico-escandinava e o movimento da arquitetura High-Tech.

Segundo Nigel Whiteley, no capítulo 3 de sua biografia sobre Banham, "Science for Kicks: an architecture for technology for the second machine age", era necessário formar um novo corpo de teorias próprias para uma nova Era da Máquina. A relação desse corpo teórico com uma arquitetura dotada de sensibilidade tecnológica, sujeita a referências da cultura pop, e que, tal qual a art autre de Michel Tapié, rejeitasse a abstração teórica em favor da carga simbólica e imagética eram os elementos para

136 Idem, p. 214. Texto original: What is little noted, however, was the parallel effect that the new American designs, particutarly for elevators, was having on European engineers, presumably for "objective" functional reasons that supposedly did not involve rhetoric or aesthetics.

137 Nigel Whiteley, Reyner Banham, Historian of the Immediat Future, p.142. 
a formação de uma outra arquitetura, une Architecture autre. Essa nova arquitetura poderia estabelecer um diálogo mais profundo e duradouro com a técnica. ${ }^{138}$ Em sua explanação, Whiteley define três correntes de abordagem da tecnologia, que geraram três ramificações da apropriação da mesma: pragmática, simbolizada pela apropriação de objetos 'as found', ou diretamente da prateleira, representados pelo CLASP (Consortium of Local Authorities Special Programme) ${ }^{139}$ e pelo casal Eames e sua casa em Pacific Palisades ${ }^{140}$; radical, representado por Buckminster Fuller ${ }^{141}$; e pop, sem um estandarte que representasse o movimento, pelo menos por parte dos arquitetos ${ }^{142}$.

A investigação de Banham enveredava para encontrar arquitetos cuja atitude em relação à tecnologia. Seria apenas através de uma mudança de postura em relação às possibilidades abertas pela Primeira Era da Máquina que Banham visualizava um meio de "manter o ritmo" de desenvolvimento da tecnologia no século XX. O arquiteto deveria se 'despir das indumentárias' da arquitetura e se livrar do peso do academicismo ${ }^{143}$. Para Banham, tradição e tecnologia eram antagônicos, em grande parte das situações.

O primeiro grande herói de Banham é, nesse sentido, o arquiteto americano Buckminster Fuller. Na conclusão do livro de 1960, Fuller já emerge, através das palavras de Banham, como um deus ex machina, cuja prática era sintomática de que a arquitetura moderna ainda tinha alternativas para manter-se em dia com a tecnologia ${ }^{144}$. Em comparação com os arquitetos da geração anterior, Fuller teria acrescentado mais do que um verniz de funcionalismo na arquitetura academicista, a qual já cometia o erro, segundo Banham, de confundir funcionalismo dotado de lastro técnico na matemática e geometria com sensibilidade mecânica. Fuller, no entanto, oferecia o grau de comprometimento com a tecnologia de que o mundo pós-guerra precisava ${ }^{145}$.

\footnotetext{
138 Nigel Whiteley, p.143.

139 Idem, p.151. O grupo inglês, dedicado à praticas de provisão de habitação, Segundo Whiteley, é uma referência na apropriação de elementos disponíveis na indústria para o enriquecimento de suas práticas de arquitetura. Malgrado tivessem muitas semelhanças com a metodologia construtiva do casal Eames na Califórnia, estes últimos foram considerados por Whiteley como experimentais, em comparação com os primeiros.

140 Ibid, pp.152-153. Banham se refere à Case Study House \#8, a qual Banham considera única, entre a série de casas do programa, dada sua aplicabilidade de elementos 'off-the-shelf", (saídos da prateleira). 141 Ibid, pp.155-159.

142 Ibid, p.162. Whiteley deixa identificado que a apropriação da tecnologia pela vertente pop desafia a sua classificação dentre o campo da arquitetura, e é melhor representada pelos exemplos do design popular de consume de massa - carros, eletrodomésticos e filmes de ficção científica.

143 Theory and Design in the First Machine Age, 1960, pp.329-330. Tradução livre do autor.

144 Whiteley afirma que a inclusão da menção a Fuller somente se deu na publicação do livro, enquanto anteriormente, na entrega da tese de doutorado, não havia menção ao Americano. Whiteley sugere que foi por mediação de John McHale que Banham teria se entusiasmado com a obra de Fuller. Ver Whiteley, p. 156.

145 Reyner Banham, “The Dymaxicrat", em A Critic Writes, p. 95. O artigo, uma resenha da publicação de John McHale, R.Buckminster Fuller, da série "Makers of Contemporary Architecture", foi publicado originalmente em Arts Magazine, 38, outubro 1963, pp.66-69
} 
Para Banham, enquanto os Modernistas europeus se distanciavam dos aspectos filosóficos do Futurismo, na esperança de atingir um patamar de respeitabilidade enquanto arte da "Era da Máquina", os heróis modernos não somente se isolariam de suas origens históricas, mas também de seu lugar no mundo da tecnologia, o qual não seria cunhado por valores perenes, mas sim por elementos voláteis em mudança acelerada. ${ }^{146}$ Em contraponto, a obra e posicionamento de Fuller são apresentados como capazes de falar a língua da produção industrial. O entusiasmo de Banham com a recente descoberta da obra do autor é evidente, e é um dos poucos pontos do livro em que percebemos que seu autor tinha o entusiasmo de um jovem de menos de 30 anos quando o escreveu ${ }^{147}$. Enquanto a reação de Le Corbusier à derrocada da abundância tecnológica teria sido o retorno ao primitivismo das paredes de barro e dos telhados de madeira, e enquanto outros se dedicariam a criar espaços habitacionais minimalistas, informalmente apresentando uma renovação cosmética do partido de Adolf Loos - que perdura até hoje - Fuller teria investigado mecanismo de aprimorar a qualidade dos elementos de habitação, e seus serviços - água, climatização, iluminação, ventilação. A Dymaxion House, projeto de 1927, chegaria, segundo Banham, a ser uma zombaria a seus contemporâneos - a residência Lange em Krefeld, de Mies Van der Rohe; a Villa Garches, de Le Corbusier; A residência Lowell, em Los Angeles, de Richard Netra. Era, para Banham, um projeto que apresentava algo que os demais não teriam prometido mas não teriam alcançado: uma maneira radical de ambiente para a vida doméstica. Seria uma proposta de um ambiente completamente controlado e climatizado, e uma proposição estética que apenas Le Corbusier (anos depois) conseguiria alcançar (Banham não menciona qual seria esse projeto).

"Como solução técnica, ela propôs um espaço totalmente controlado e condicionado, e como proposição estética ofereceu o que apenas o que Corbusier prometeu e (anos depois) entregou parcialmente - uma perspectiva idílica de um mundo longe da lama e da sujeira. Ao oferecer ambas as promessas, a Dymaxion House foi - e ainda é - de uma liga na qual ninguém mais está jogando."148

Reyner Banham se encontrava em um campo de revisão do movimento moderno na verdade muito mais amplo do que sua atuação individual. Na posição privilegiada de porta-voz do Independent Group, no interior do qual a ideologia do movimento Brutalista inglês foi formulada.

\footnotetext{
146 Reyner Banham, Theory and Design, p.327.

147 Idem, pp. 325-326:

148 Idem, p.94. Texto original: As a technical proposition it proposed fully controlled and conditioned living space, and as an aesthetic proposition it offered what Corb alone (and years later) was to promise and half-deliver - a idyllic prospect of the world from the damp and dirt. In offering both, the Dymaxion House was - and still is - in a league where no one else is playing.
} 
“A definição de edifício Neo Brutalista derivou de Hunstanton e do centro de arte de Yale, (...) deve ser modificado para excluir o formalismo como qualidade se vamos cobrir desenvolvimentos futuros, e deve ser lida propriamente: 1, capacidade de memória como imagem; 2, clara exibição da estrutura; e 3, valorização de materiais 'as found' [tal como encontrados] (...) Mesmo que seja verdade que os Brutalistas dialogam apenas com eles mesmos, o fato de que eles pararam de dialogar com Mansart, Palladio, e com Alberti faria dos Neo-brutalistas, mesmo que no sentido privado, uma grande contribuição para a arquitetura de hoje." ${ }^{\prime 19}$

Banham registrou, entre 1952 a 1955, as atividades de sua geração na formação de uma nova atitude em relação à arquitetura, que encerrava o desafio à tradição cubista da arquitetura moderna ${ }^{150}$. Abraçando as contribuições do radical Futurista do movimento moderno - evidentemente por conta da influência de Banham dentro do grupo - esboçando interesse pela produção de arte que questionava os ideais de beleza clássicos - cujas referências eram Michel Tapié, Jean Dubuffet e Jackson Pollock - e revisitando os vernaculares modernos e as expressões de design de cultura de massa, críticos - John McHale, Richard Hamilton, Lawrence Alloway e o próprio Reyner Banham - arquitetos - Peter e Alison Smithson - artistas - Eduardo Paolozzi, Nigel Henderson - entre outros buscaram ampliar o vocabulário da arquitetura e romper com a tradição cubista-abstrata ${ }^{151}$.

Um dos movimentos mais representativos desse grupo foi a formulação dos conceitos do Brutalismo em arquitetura. Em duas ocasiões, tanto en 1955, quando o movimento se desenhava no círculo de arquitetos britânicos, principalmente pelas atividades do casal Smithson: um projeto de sobrado no bairro do Soho, em Londres, que caso fosse construído o seria a partir de técnicas rudimentares, utilidades expostas e estrutura aparente; e a escola pública de Hunstanton, projetada em 1954, e construída apenas em 1958, dada a escassez de metal na Inglaterra pós-guerra. No caso específico de Hunstanton, o caminho estava apresentado para o ciclo de experimentações do Brutalismo, tendo em seu passado, a referência de Mies van der Rohe, Louis Kahn e Le Corbusier - pelo menos em sua fase mediterrânea - e no futuro a revisão da estética da máquina, cujas referências eram,

149 Ver Banham, "New Brutalism”, in Architectural Review, Dezembro 1955, p.15. Texto original: The definition of a New Brutalist building derived from Hunstanton and Yale Art Centre, (...) must be modified so as to exclude formality as a basic quality if it is to cover future developments and should more properly read: 1, Memorability as an Image; 2, Clear exhibition of Structure; and 3, Valuation of Materials 'as found'. (...) Even if it were true that the Brutalists speak only to one another, the fact that they have stopped speaking to Mansart, to Paliadio and to Alberti would make The New Brutalism, even in its more private sense, a major contribution to the architecture of today.

150 Reyner Banham, "New Brutalism", originalmente publicado em Architectural Review, dezembro de 1955, republicado na compilação A Critic Writes: Essays by Reyner Banham, pp.7-15.

151 Para uma biografia coletiva ampla do grupo, ver Anne Massey, The Independent Group: modernism and mass culture in Britain, 1945-1959. 
segundo Banham, o Futurismo italiano, o conceito de "as found", a estética da indústria de consumo de massa, e a arte bruta de Jean Dubuffet.

Para a narrativa de Banham, a principal contribuição do Movimento Brutalista, em sua curta duração, foi o amadurecimento do conceito de une architecture autre. O enfrentamento da arquitetura como um organismo vivo, e a proposta de 'naturalizar' seus sistemas de utilidades, bem como a adoção do aspecto de 'ruínas' que a arquitetura moderna do pré-guerra passara a incorporar. O Brutalismo teve como mérito o questionamento do conceito de beleza clássica, superfícies lisas e planos perfeitos configurando objetos geométricos perfeitamente herméticos. Em 1966, ao escrever New Brutalism: Ethic or Aesthetic?, Banham retoma a reflexão sobre o movimento, se aproveitando de sua posição de expectador privilegiado, e fala sobre a origem do termo une architecture autre:

“Como já foi sugerido, anteriormente, o termo foi cunhado por uma analogia com o conceito de 'une art autre' de Michel Tapié, e sua intenção era de ser algo igualmente radical. Isto é, uma arquitetura cuja veemência transcenderia as normas da expressão de arquitetura tão violentamente quanto as pinturas de Dubuffet transcendeu as normas da arte pictórica; uma arquitetura cujos conceitos de ordem foram removidos da 'composição arquitetônica' tal como Pollock removeu-se das rotinas de pintura compositiva (i. e. equilíbrio, congruência de contraste de formas dentre um formato retangular predominante - nós questionamos se Pollock prestava atenção às margens de sua tela quando derramada a tinta em seus quadros); uma arquitetura sem inibições em sua resposta aos materiais 'as found', como eram os compositores da 'musique concrete' em sua resposta aos sons naturais 'como recorded' [como gravados]." 152

O processo de despojamento gradual da arquitetura, se livrando de suas indumentárias clássicas era para Banham parte de um processo de questionamento sobre os limites físicos (e práticos) da arquitetura. Uma das primeiras menções ao termo "fit environments for human activities" (ambientes adequados para atividades humanas), surgiu nesse contexto, denotando o interesse em ampliar o conceito de arquitetura, através dos equipamentos que permitiriam o controle ambiental

152 Reyner Banham, New Brutalism: Ethic or Aesthetic?, p.68. Texto original: As has been implied, already, the term was coined by analogy with Tapié's concept of 'un art autre', and was intended to stand for something equally radical. That is, an architecture whose vehemence transcended the norms of architectural expression as violently as the paintings of Dubuffet transcended the norms of pictorial art; an architecture whose concepts of order were far removed from these of 'architectural composition' as those of Pollock were removed from the routines of painterly composition (i.e. balance, congruence of contrast of forms within a dominant rectangular format - we argued much whether Pollock pay any regard to the edges of the canvas when dribbling his action paintings); an architecture as uninhibited in its response to the nature of materials 'as found' as were the composers of 'musique concrète' in their response to natural sounds 'as recorded'. 
ampliado (a ser analisado em seguida) bem como adequar-se aos novos costumes da modernidade. Uma das mais reproduzidas metáforas do design de consumo de massa, paisagens urbanas, ou paisagens naturais desbravadas pelos pioneiros, transformadas em ambientes adequados para atividades humanas, foi primeiramente apresentado neste capítulo de New Brutalism. Segundo Banham, na história humana, tipos de estruturas, ambientes ou espaços conseguiram satisfazer tanto necessidades físicas quanto culturais do homem. Cada vez mais, tais ambientes seriam menos relacionados à ideia clássica de abrigo confinado. Um exemplo moderno dessa ideia seria o cinema drive-in, cuja estrutura da tela define o espaço, sem limites físicos definidos ao redor; outro exemplo, mais primitivo seria o acampamento ao redor de uma fogueira, elemento da cultura nômade. $\mathrm{O}$ fogo seria um forte elemento tanto físico, por seu calor liberado, que substitui o envelope do edifício que controla o clima imediato, tanto quanto cultural e psicológico, por simbolizar claramente a noção de calor humano e reunião, sem a necessidade de uma estrutura física ao redor. ${ }^{153}$

Mas como esse tipo de despojamento em relação ao ambiente construído se relaciona com os exemplares de arquitetura que simbolizam o Brutalismo inglês? De fato, as relações são indiretas, mas a atitude projetual é relativamente similar. No caso da escola de Hunstanton, sendo a obra construída do casal Smithson que expressa seus anseios para com a arquitetura Brutalista. Na época, a produção de Mies van der Rohe em Chicago já estava divulgada pelos periódicos de arquitetura, e de fato é uma das referencias principais do casal inglês; combinação entre elementos metálicos de estrutura definindo as arestas, planos em alvenaria e caixilharias de vidro, cada material preenchendo um plano, a princípio configuram uma experimentação do vocabulário miesiano. Mas ao olhar de perto, ao notar os detalhes (como fez Banham, tanto no acompanhamento de projeto quanto ao visitar a obra executada), nota-se a experimentação com materiais e o jogo de exposição dos sistemas de utilidades. Enquanto a 'arquitetura branca' moderna se baseou em paredes brancas e vidro, mesmo quando fizeram uso de metal, Hunstanton se destaca pela uso irrestrito de materiais em seu estado natural: tijolo, aço, concreto e vidro são o que são. As alimentações de água, eletricidade e esgoto não se escondem em paredes. Segundo Banham, o observador pode ver claramente do que a escola é feita, como funciona, e seu jogo de volumes. ${ }^{154}$ Acima de tudo, Hunstanton sinaliza, junto com a Unité d'Habitacion, em Marselha, para um novo panorama de recursos materiais inaugurado pela empresa de reconstrução do período pós-guerra.

Se rastrearmos outras fontes bibliográficas de Banham em busca das origens de tal franqueza em relação aos materiais, encontramos referências à obras da arquitetura americana. Em especial, a produção experimental da escola californiana, cujo evento simbólico mais difundido na historiografia ocidental fora o programa das

153 Idem, p.68

154 Reyner Banham Banham, “New Brutalism”, pp.9-10. 
Case Study Houses. O advento das Case Study Houses, a rotina de projetos e construções experimentais realizadas no sul da Califórnia e apadrinhadas pelo então editor da revista Arts \& Architecture, John Entenza ${ }^{155}$, significou uma aproximação da arquitetura com outros produtos da modernidade - indústria, tecnologia e modos de vida - por duas perspectivas. Primeiramente, pela apropriação do modo de vida moderno, fomentado pelos fenômenos do período pós-Guerra: explosão de crescimento demográfico; franco processo de industrialização incrementada cio durante a Guerra; novo posicionamento social da mulher, fruto de conquistas relacionadas à sua posição na máquina de Guerra americana ${ }^{156}$; explosão da suburbanização e do desenvolvimento urbano rodoviarista ${ }^{157}$. E não era por coincidência que esse processo aconteceu na costa oeste americana. De fato, a Califórnia, em especial Los Angeles, se tornava um campo de experimentações, já alimentado pela experiência em arquitetura doméstica, comercial e educacional de Frank Lloyd Wright, Irving Gill, Greene \& Greene, Rudolph Schindler, Craig Ellwood, Rafael Soriano e Richard Neutra. ${ }^{158}$

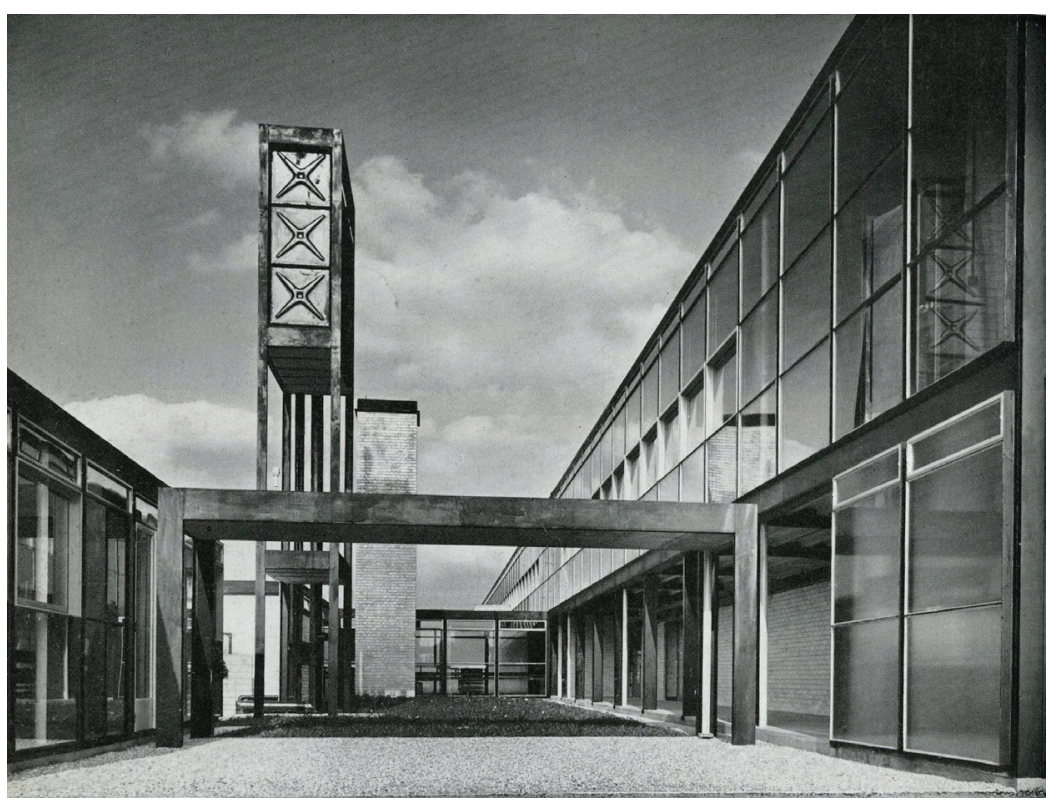

Alison e Peter Smithson, Escola Secundária de Hunstanton, Norflok, Inglaterra, 1949-54. Fonte: Arquivos Architectural Association, Londres.

155 Conforme apresentado no capítulo 1, John Entenza seria futuramente o diretor da Fundação Grahan, responsável pelo financiamento da pesquisa de Reyner Banham para a produção do livro The Architecture of the Well-Tempered Environment.

156 Para melhores aproximações sobre o papel da mulher em relação às novas estruturas sociais do ambiente da residência, e sobre as transformações recorrentes nos modos de produção da habitação nos Estados Unidos, ver Gwendolyn Wright, Building The Dream: A Social History of Housing in America. Cambridge, The MIT Press, 1983.

157 Sobre o processo de suburbanização ligado ao fenômeno das rodovias nos Estados Unidos, ver capítulo III.

158 Ver Thomas S. Hines, “Case Study Trouvé: Sources and Precedents Southern California, 1920 1942", em Smith, Blueprints of Modern Living: history and legacy of the Case Study Houses, 1982, pp.83-87. 

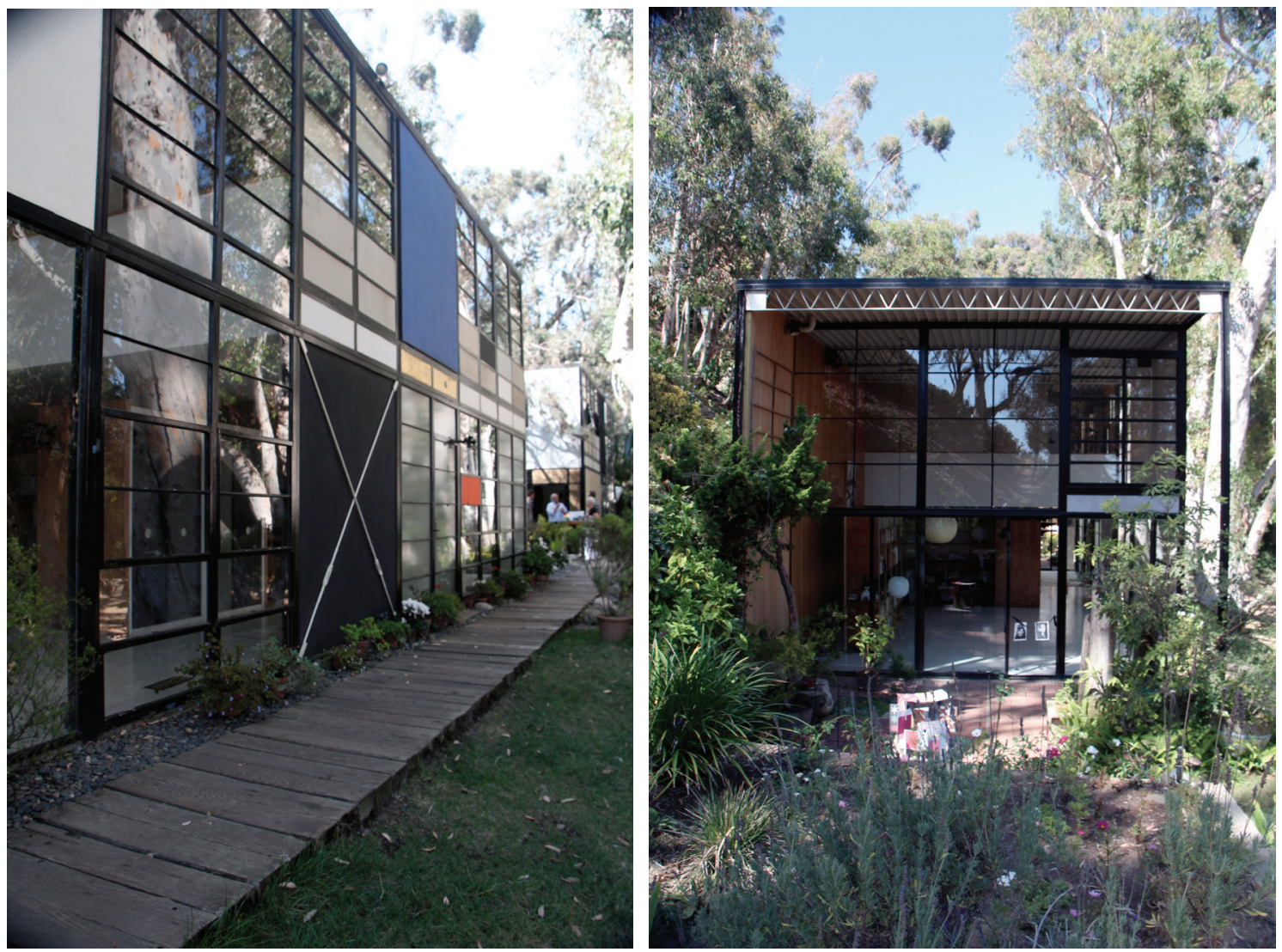

Ray e Charles Eames, Case Study House \#8, Pacific Palisades, 1945-49. Fotos: Luiz Florence, 2012.

Mais do que um programa que se propôs a construir uma série de residências experimentais entre o final da década de 1940, no decorrer da década de 1950 até o começo da década de 1960, o CSH Program de Entenza previa a divulgação de um novo modo de vida que sintetizava o novo quadro social do qual a Califórnia emergia do período de Guerra que sucedeu a crise econômica da década de 1930, através das publicações dos projetos - e de suas premissas programáticas - no periódico editado por Entenza. Devemos lembrar que durante o período que sucedeu a II Guerra, as revistas de arquitetura, ganharam força como veículos de comunicação, e o próprio Banham valorizava sua posição como jornalista da Architectural Review, e seu acesso à recursos de deslocamento e contato com os expoentes da profissão de sua geração. O alcance da A\&A não era de modo algum desconsiderável: pelo contrário, seguia uma tradição de periódicos de arquitetura dedicados ao estilo de vida emergente nos Estados Unidos desde a popularização da residência unifamiliar.

Essa junção de estilo de vida e técnica construtiva atraiu o olhar não só de Banham, mas como também de seus outros arquitetos e pesquisadores. Em especial, o casal Eames, com sua intervenção de projeto em diversas escalas da vida cotidiana: a cadeira Eames, feita em madeira laminada; a tala desenvolvida para o exercito americano, a qual precedeu a cadeira em ousadia tecnologia e abriu caminho para a série de patentes do casal; e a residência $C S H \# 8$ (1949), segundo projeto do casal para 
a residência própria, e vizinho da residência de John Entenza, nas colinas do conjunto de Pacific Palisades, em Los Angeles. A importância desta casa justifica a citação do programa para o desenvolvimento da arquitetura moderna preconizada por Banham:

"Para muitos europeus - e para alguns africanos, australianos, japoneses com quem conversei - a era do programa Case Study começou em meados do natal de 1948. Neste momento a revista Arts \& Architecture conseguiu suficiente grau de penetração em livrarias especializadas, por conta do impacto das primeiras casas em estrutura metálica a despertar o arquiteto Peter Smithson a dizer "um tipo completamente novo de conversa." ${ }^{159}$

No entanto, aponta Banham, a arquitetura da casa do casal Eames não seguia a regra histórica da arquitetura moderna, pelo menos não eram tão inseridas na tradição 'bauhausiana' tanto quanto as cadeiras em laminado de madeira. ${ }^{160}$ As "verdades" sobre arquitetura eram comuns de serem encontradas na mitologia do gótico, mas o temperamento na Europa durante a década de 50 indicou para o racionalismo da tradição clássica. A casa dos Eames foi erigida antes da casa Farnsworth de Mies (1950), e apresentou uma “ocupação" mais humana dos preceitos abstratos visão da arquitetura em estrutura de metal. Todavia, era vista como confirmação de soluções de projeto criadas na Europa, mais do que uma inovação. Para a geração mais jovem (estudantes na época dos últimos CIAMs), as obras do programa CSH representavam outros valores, como o experimentalismo, o improviso, a aplicação prática, rápida de técnicas, diferente dos cânones ensinados nas escolas de arquitetura. ${ }^{161}$

De fato, podemos observar o legado comprometido, e a intepretação preconceituosa das CHS, pela incapacidade da historiografia europeia de assimilar, ou mesmo apreciar o idioma americano em arquitetura. Da mesma forma que a produção de arranha-céus de Mies van der Rohe nos Estados Unidos foi rastreada por Banham até o concurso da Friedrichstraße e à Escola de Berlin ${ }^{162}$, a produção dos Eames, de Ellwood e Koenig foi por ele associada à história da produção industrial de habitações nos Estados Unidos, e à cultura Californiana de arquitetura, fundada por Schindler, Neutra, Irving Gill, Rafael Soriano, e os irmãos Greene ${ }^{163}$. Essa segunda narrativa era

159 Reyner Banham, "Klarheit, Ehrlichkeit, Einfachkeit ... and Wit Too! The Case Study Houses in the World's Eyes", em Smith, Blueprints of Modern Living: history and legacy of the Case Study Houses, 1982, pp.183. Texto original: For most Europeans - and some Africans, Australians, and Japanese to whom I have spoken - the Case Study era began around Christmas 1949. By that time the magazine Arts \& Architecture had achieved a sufficient degree of penetration into specialized bookstores and architectural libraries for the impact of the first of the steel-framed Case Study houses to trigger as British architect Peter Smithson, to said - "a wholly different kind of conversation.

160 Idem, p.185

161 Idem, p.190.

162 Reyner Banham, Theory and Design, pp. 268-269

163 Ver o capítulo "The Style that Nearly..."em Banham, Los Angeles: the architecture of four ecologies. 
mais exótica, pelo menos do ponto de vista europeu, e portanto mais difícil de ser assimilada, principalmente em um momento de revisão crítica dos preceitos modernos. Entretanto, existe, Segundo Banham uma linha genealógica a ser tratada pela historiografia moderna, que teria como uma das fontes a atitude apresentada pelos arquitetos californianos, a qual ofereceria mudança permanente à arquitetura moderna: o surgimento da arquitetura high-tech.

“Uma linha de parentesco das Case Study é razoavelmente direto; vai desde a fábrica da SDS de Ellwood, a qual pode ser encarada como uma de suas casas expandidas em escala industrial, à fábrica Teledyne de 1966 em Northridge, Califórnia (projetada por Cesar Pelli enquanto no escritório de Daniel, Mann, Johnson, e Mendenhall) que pode ser encarada como uma variação da casa Eames. Daí saiu da área de Los Angeles para o idioma comum de lajes planas, paredes de vidro e alta tecnologia de culturas como as do Vale do Silício, ou nos arredores de Boston, Massachussetts. Desde este ponto, por emulação o estilo viajou para o resto do mundo industrializado - e neste senso, as Case Study Houses da fase do aço-e-vidro contribuíram para a criação do vernacular industrial global." ${ }^{164}$

De fato, é difícil traçar algum julgamento sobre a obra inacabada de Banham a respeito do surgimento e posterior estabelecimento da arquitetura high-tech durante as décadas de 1960 e 1970. Seu livro sobre o tema viria a ser publicado em 1990, com base em suas pesquisas publicadas parcialmente no formato de artigos ementas para disciplinas e seminários, restando boa parte do material a ser publicada ${ }^{165}$. Malgrado algumas lacunas do pelo material inconcluso, algumas questões por ele levantadas são relativamente claras: o movimento High-Tech, como Banham o classificou, tem radical inglês, genealogia na qual Richard Rogers e Norman Foster surgem como os grandes expoentes, acompanhados por figuras como Michael Hopkins; Cedric Price reconhecido por seu radicalismo conceitual e técnico, e responsável pela materialização em projeto do conceito de "responsive buildings", incorporados no Fun Palace em Londres ${ }^{166}$; atitudes de gerações anteriores como a de James Stirling, indo até

164 Idem. p. 191. Texto original: One line of Case Study parentage is fairly direct; it goes from Ellwood's SDS plant, which can be construed as one of his houses expanded to industrial scale, to the Teledyne plant of 1966 in Northridge, California (designed by Cesar Pelli while in the office of Daniel, Mann, Johnson, and Mendenhall), which can be construed as a of variation upon the Eames house. Thence it went out of the Los Angeles area and into the common flat-topped, glass-walled architectural idioms of high technology cultures like those of Silicon Valley in central California or around Boston, Massachusetts. From there by emulation it traveled to the rest of the Industrializing world - and in this sense, the Case Study houses of the steel-and-glass phase have contributed to the creation of a global industrial vernacular.

165 Os manuscritos para o livro em questão estão armazenados nos arquivos especiais do Getty Research Insttute, juntamente com o material relacionado aos artigos correlatos. Ver "In The Neighborhood of Art", publicado em Junho de 1987 em Art in America; ver entrevista com Reyner Banham, por Doralice Boles e Susan Doubilet, em Progressive Architecture, março 1986, e o manuscrito resumido para o livro: 166 Ver "People's Palace", originalmente publicado em New Statesman, 68, maio 1964, pp.191-192, e 
a escola de Hunstanton, projetada pelo casal Smithson ${ }^{167}$ também tem o seu lugar nessa genealogia. Banham se dedica a cotejar a obra de Foster, Rogers e Renzo Piano, como os três responsáveis pela persistência do modernismo através do amadurecimento da técnica, tratando edificações como complexas máquinas que recebem atividades humanas. Sua disposição em revisitar a estética da máquina de maneira menos ingênua do que seus antecessores do pré-guerra, valendo-se de elementos industrializados fornecidos pelo mercado de construção civil, tal qual a referência dos americanos, surgiria para como uma fronteira de resistência contra o avanço do histoiricismo nas décadas de 1960 e 1970.

Na introdução do livro que apresenta a obra do escritório inglês de Norman Foster, Reyner Banham afirma que o colapso da arquitetura moderna e a emergência do pós-modernismo em arquitetura, malgrado pluralista, popular em sua participação e auto referente, foi razoavelmente infrutífero em sua produção construída. Coloca a produção de Foster como um dos sobreviventes da arquitetura moderna, e de suas mitologias técnicas, sociais e econômicas. A figura de Richard Rogers e a importância da obra do Centre Pompidou também são levantadas, como o maior dos parcos exemplos de arquitetura de significância nos anos 1970.

“Construir com materiais não convencionais, e em formas não familiares para os olhos destreinados - isto é, construir arquitetura moderna - é ainda praticar a 'arquitetura de risco'. Mas enquanto aqueles que construíram arquitetura moderna nos anos 1920 e 1930 puderam faze-lo em imaculada ignorância de suas consequências, e apoiados pela crença da inevitabilidade do progresso (de qualquer forma), nós não podemos ser mais tão deliberadamente inocentes. Nós sabemos quais são as consequências de abandonar as rotinas e tradições de quatro mil anos de arquitetura, e nós sabemos que o progresso é algo que deve ser feito, e não inevitável, e vai apensa na direção na qual nós estivermos indo, não automaticamente 'para o alto e avante'."'168

republicado em A Critic Writes, pp.105-108.

167 Ver "Interview with Reyner Banham", em Progressive Architecture, Março 1986, p.75 (arquivada junto com os manuscritos do autor nos arquivos do Getty).

168 Reyner Banham (introdução), Foster Associates. London: RIBA Publications, 1979. Texto original: To build in unconventional materials and in forms not familiar to the untutored eye - to build Modern Architecture, that is - is still to practice 'the architecture of risk'. But whereas those who built Modern in the Twenties and Thirties could do so in unsullied ignorance of what the consequences might be, and supported by a belief in the inevitability of progress (of whatever sort), we can no longer be so willfully innocent. We know what are the consequences of abandoning the routines and traditions of four thousands of years of architecture, and we know that progress is something that has to be made, is not inevitable, and goes only in whatever direction we will it, not automatically 'onward and upward' 


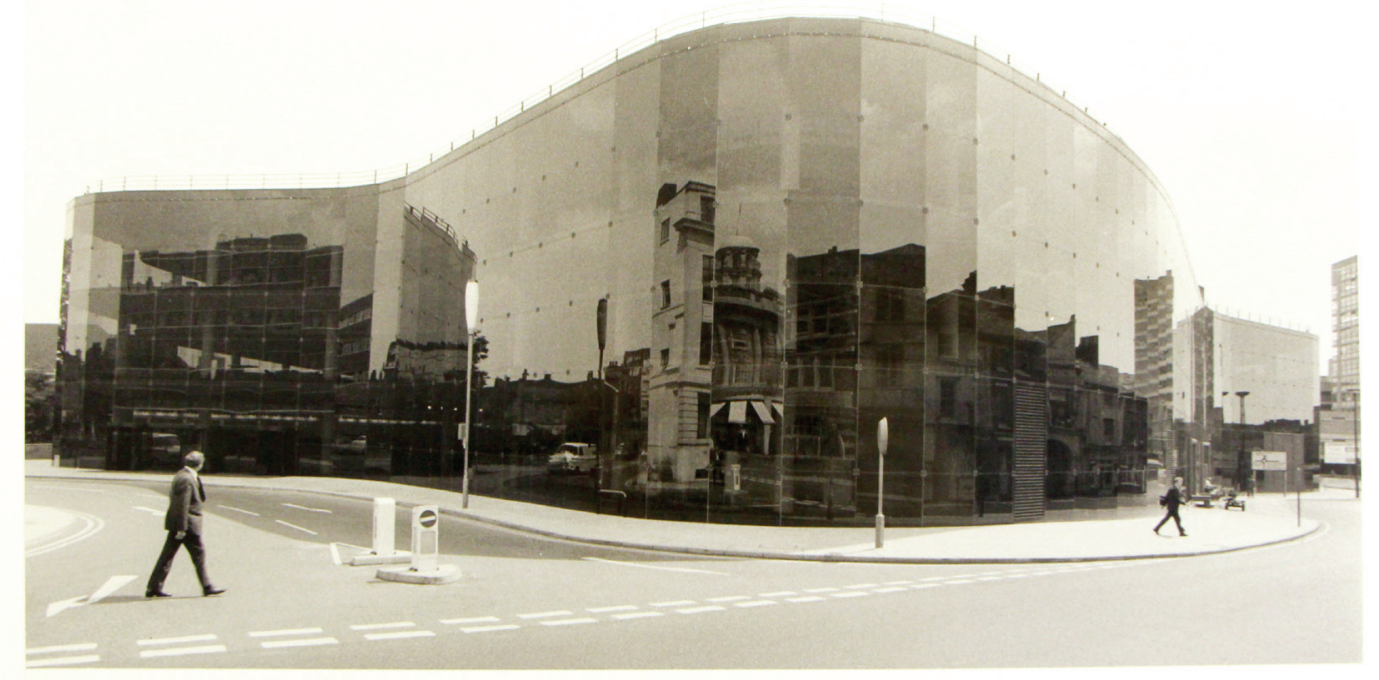

"PLEASE DO NOT USE

THIS ONE!

mestrage from N.F.

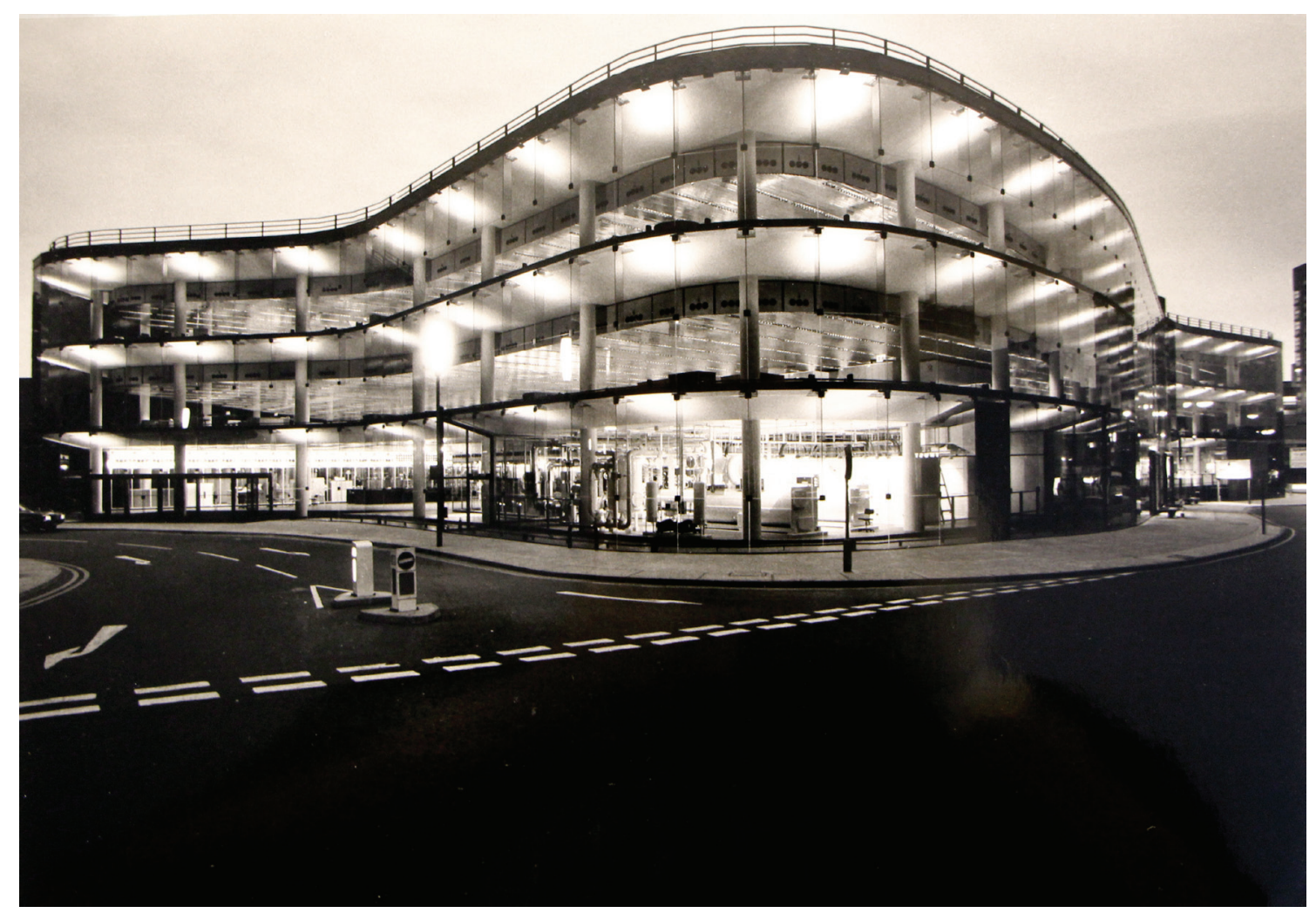


Página anterior: Foster Associates, escritórios Willis Faber. Fotos fornecidas pelo escritório de Norman Foster para figurar no livro de Banham, a ser publicado em 1990 - Making Architecture: the paradoxes of High-Tech (título provisório). A preferência por publicar a foto noturna, que valoriza a transparência do edifício, dificilmente expressível na foto diurna, foi uma pista dos interesses de Foster, posteriormente absorvida na análise de Reyner Banham sobre o edifício em artigos e na introdução do livro monográfico sobre o arquiteto. Fonte: arquivo Getty.

Banham evoca a qualidade de Foster em se exceder na missão de atender aos anseios e demandas técnicas e econômicas outrora menosprezadas pelos arquitetos da fase 'heróica' do modernismo, os quais se compreendiam preferencialmente como artistas, renunciando as responsabilidades técnicas, ambientais e construtivas de suas obras. Com a resposta da 'pergunta' de Buckminster Fuller, afirma Banham “quanto pesa seu edifício?" - Foster não só sabe dizer o quanto sua casa pesa, mas também demonstra controle total da construção. Foster, Rogers, Piano e Price, bem como suas arquiteturas leves são, segundo Banham, desafios a historiadores e críticos fundamentados na tradição da arquitetura de massa e peso ${ }^{169}$. Sua produção desafia técnicas tradicionais de cálculo de eficiência energética, para além das ciências da construção. A tradição de Foster e de sua arquitetura leve viria, então de prosaicos exemplos utilitários, como casas em madeira, celeiros, abrigos, que se combinam com construções maciças - exemplos de arquitetura dotada de atitute 'conservadora' de energia - para formar o campo construtivo vernacular inglês.

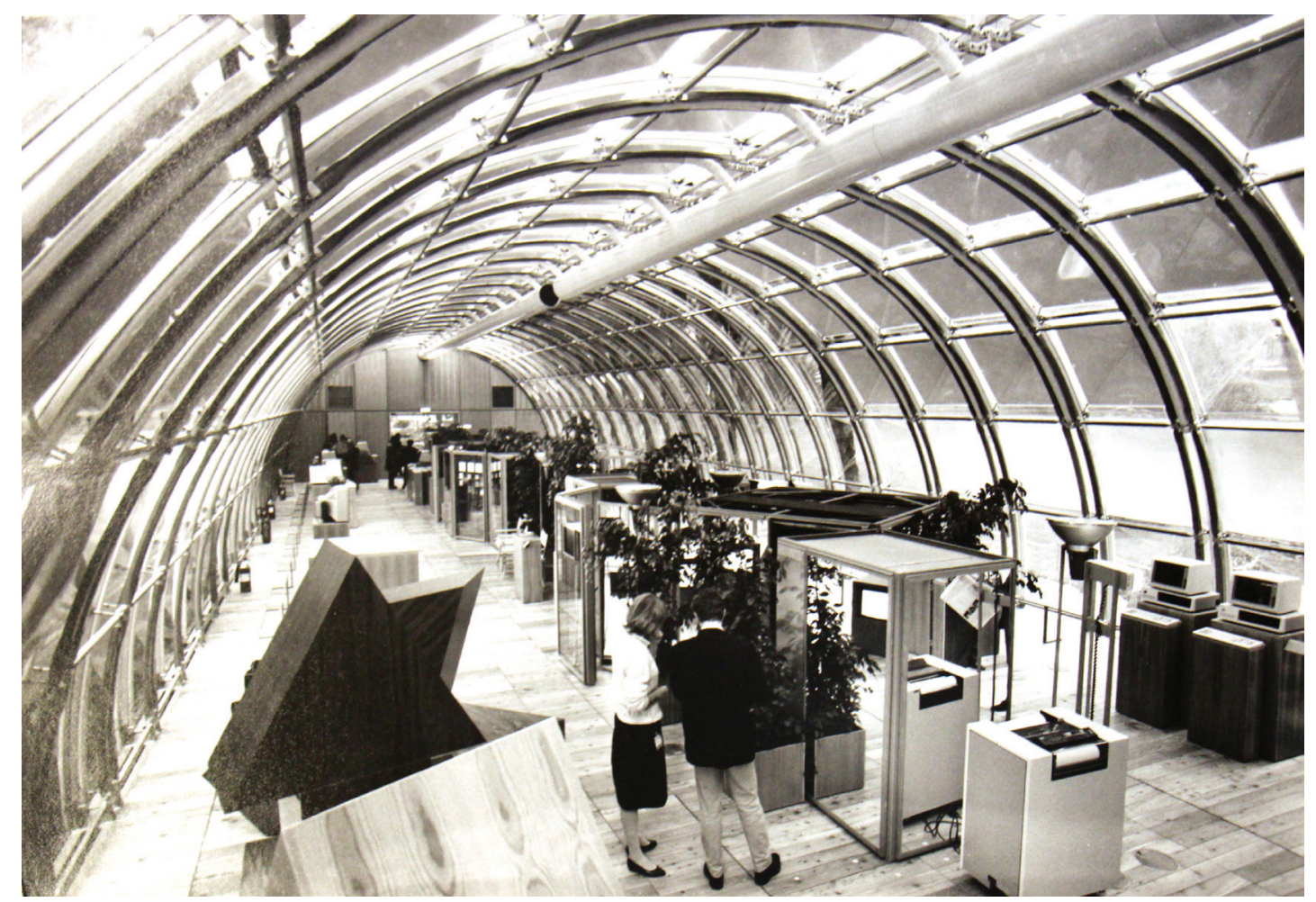

Exposição itinerante da IBM em Paris, Renzo Piano (imagem fornecida pelo escritório do arquiteto). Fonte:

169 Idem, p.5. 
arquivo Getty.

Ainda na introdução do livro de Foster, Banham traça a genealogia do Team 4, grupo que reunia Foster, Piano e Rogers, que teria respondido a novas demandas tecnológicas, enquanto promotores do High-Tech na arquitetura. Banham dobra o termo para "appropriate technology", afirmando o compromisso desse grupo de arquitetos com a realização de projetos tecnologicamente engajados e herdeiros de um funcionalismo de Eames Saarinen e Ellwood, da Califórnia.

Na seção especial da biblioteca do Getty Research Institute estão arquivados os materiais mais interessantes sobre o tema do high-tech, um manuscrito de 30 páginas sobre o argumento geral do livro planejado ${ }^{170}$. Neste manuscrito, Banham traça os limites de sua narrativa a respeito do movimento, e elenca uma obra notável de arquitetura para servir de arcabouço para a definição de seus pontos principais, de maneira propositalmente similar à narrativa de Le Corbusier em Vers Une Architecture. A obra em questão é o museu de artes em Paris, objeto de concurso vencido pelo arquiteto italiano Renzo Piano, o Centro George Pompidou. Banham evoca no projeto do museu os 5 pontos da arquitetura High-Tech:

A Grandes e espaços desobstruídos em todos os andares;

B Alto nível de provisão de serviços mecânicos

C Clara exposição de estrutura metálica

D Clara exposição de infra-estrutura de serviços mecânicos

E Estética oriunda - ou fomentada - pelos itens ' $C$ ' e ' $D$ '

Para Banham, o high-tech é a expressão de que a arquitetura, antes há tempos defasada em relação à tecnologia de controle climático - conforme introduzido em Well Tempered Environment - finalmente recuperava o campo que lhe era devido. Nesse sentido o cânone inaugurado pela obra de Rogers e Piano em Paris carregava um peso de importância simbólica e apreciação popular. A opinião pública, a partir da apreciação do Museu George Pompidou, personifica o high-tech como um recurso estilístico, senão uma roupagem elegante para edificações. De fato, diz Banham, a opinião pública está correta, porque históricamente em estágios cruciais da apropriação de avanços tecnológicos por parte dos arquitetos sempre foi um recurso estilístico.

"Que o triunfo de Behrens em seu trabalho para a AEG e de Gropius para a Fagus - em ambos os casos os elementos de um novo estilo foram descobertos dentre as novas tecnologias de construção." ${ }^{171}$

170 Ver o manuscrito "Making Architecture: the Paradoxes of High-Tech", nos Manuscritos de Reyner Banham no arquivo Getty.

171 Ver o manuscrito de Reyner Banham para o livro High-Tech Architecture: the Beginning of an Argument, . Texto original: That as the triumph of Behrens in his work for AEG and of Gropius for Fagus - in both 


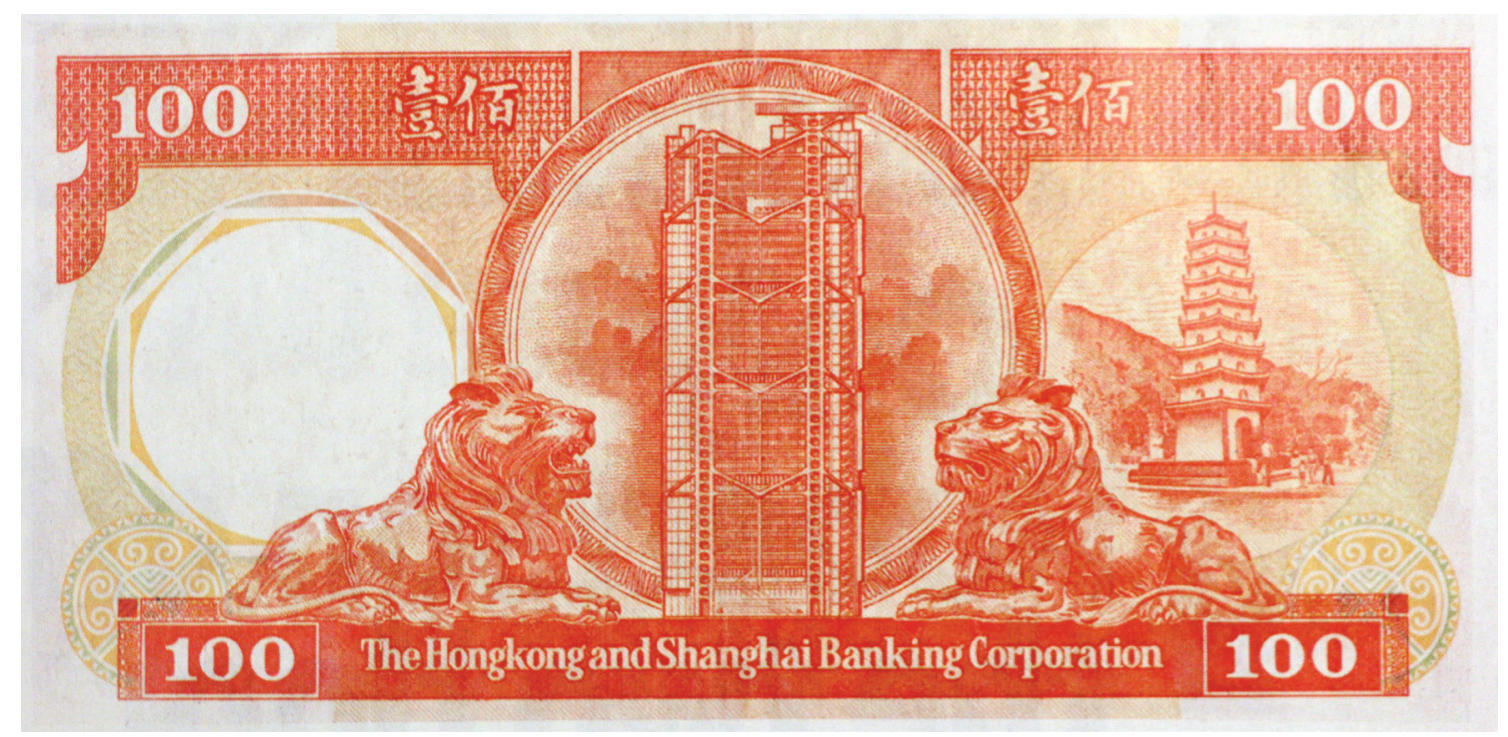

Imagem de cédula de dinheiro de HongKong, contendo a imagem da sede do Banco de Xangai, projetado por Foster. A imagem ilustra a capa da edição de Progressive Architecture, de março de 1986, dedicada à reflexão sobre a arquitetura High-Tech. Fonte: arquivo Getty.

O mesmo poderia ser dito de Perret e Le Corbusier no manejo do concreto armado - onde o primeiro falhou ao aplicar uma estética ultrapassada ao material. O segundo forçou uma inovação estética; Pierre Chareau e Bijvouet chegaram perto de descobrir uma nova estética enquanto Jean Prouvé se aproximou mais ainda - como insistiam Foster e Piano ${ }^{172}$.

"Deve-se pausar e observar que não existe conexão necessária entre arquitetura de nenhum estilo que foi cunhada "high-tech" e a presença de "alta-tecnologia" ou até mesmo engenharia avançada dentro do edifício, seja como função a ser abrigada, ou seja como um auxílio para uma melhor performance ambiental e estrutural do invólucro construído."173

A retórica do high-tech poderia ter fornecido, caso Banham tivesse perdurado para aprofundar seus estudos, na construção de uma crítica de radical tecnológico nas obras dos arquitetos contemporâneos, como Zaha Hadid, Toyo Ito, Rem Koolhaas, como também à geração da arquitetura parametrizada, uma vez que é facilmente perceptível

cases the elements of a new style were discovered withim the new technologies of construcion.

172 Ver o manuscrito de Reyner Banham para o livro High-Tech Architecture: the Beginning of an Argument, p.4.

173 Ver o manuscrito de Reyner Banham para o livro Making Architecture: the Paradoxes of High-Tech, p.11. Texto original: One should also pause to observe that there is no necessary connection between architecture that is in any of the styles that have been termed "high-tech" and the presence of "hightechnology" or even advanced engineering within a building, either as a function to be housed, or as an aid to the better structural and environmental performance of the building-shell. 
as relações entre arquitetura, tecnologia, e projeto (tanto em sua concepção quanto em sua representação) em obras como os manuscritos do High-Tech, na obra Visions of Ron Herron, publicado no começo da década de 1980, e inaugurado na publicação de 1968, The Architecture of the Well-Tempered Environment.

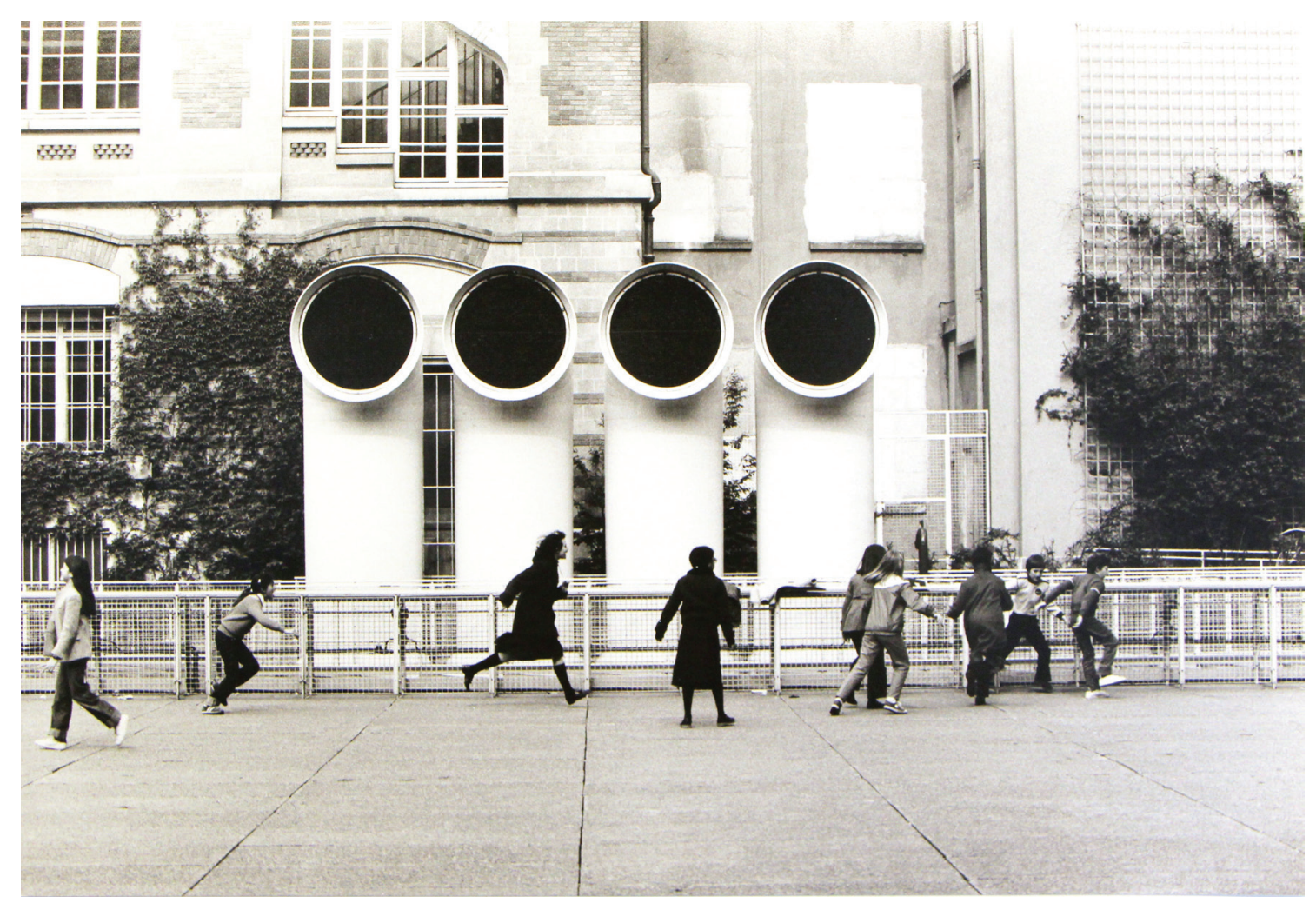

Reforma do IRCAM, Renzo Piano, Paris, s/ data. Crédito: Renzo Piano Building Workshop. Banham demonstra fascinação pelo elementos escultórico dos sistemas de exaustão de ar, comuns dentro da simbologia construtiva da arquitetura de Rogers, Foster e Piano, comparando a mudança de proporção entre o diâmetro dos pilares da estrutura e as tubulações de utilidades entre a Modernidade Heroica (19231939) e o "high-tech". Fonte: arquivo Getty.

\section{O Inventor do Clima Temperado}

"Invenção estava no curso normal das coisas. Todo mundo inventava, seja quem possuísse um negócio buscava maneiras para fabricar mercadorias mais rapidamente, mais apuradamente, e frequentemente, mais bonitas. Anonimamente e desapercebidamente as antigas ferramentas são transformadas em instrumentos modernos. Nunca o número de invenções per capita da populaçãoo excedeu a proporção da América nos anos 1860." ${ }^{174}$

174 Siegfried Giedion, Mechanization Takes Command, p.40. Texto original: Invention was in the normal course of things. Everyone invented, whoever owned an enterprise sought ways and means by which to make his goods more speedily, more perfectly, and often of improved beauty. Anonymously and inconspicuously the old tools were transformed into modern instruments. Never did the number of inventions per capita of the population exceed its proportion in America of the 'sixties. 
Na introdução de Mechanization Takes Command, como já foi discutido no começo deste capítulo, Siegfried Giedion deixa claro o seu interesse pela a figura do inventor dentro do processo de introdução da mecanização das atividades humanas. Ele estabelece uma comparação entre as relações entre sociedade e tecnologia, que pautam o desenvolvimento do senso estético de cada grupo social. Giedon evoca o espírito de empreendedor e a curiosidade no estudo das questões naturais - no caso de Benjamin Franklin, por exemplo - como características intrínsecas da geração de inventores que se confundem com os pioneiros da colonização americana. Os anos "sessenta" mencionados na citação de Giedion, acima, são na verdade os anos 1860, nos qual a sociedade americana se reconstruía da Guerra Civil, impulsionada por um ciclo de desenvolvimento industrial que culminaria na explosão demográfica e econômica. Cidades como Los Angeles se ergueriam a partir de Pueblos, aldeias indígenas, vilarejos e pequenos assentamentos, para se tornarem grandes centros econômicos ${ }^{175}$; outras cidades, como Chicago e Nova Iorque, passariam por explosões demográficas, nas quais novas infraestruturas, técnicas construtivas, especulação imobiliária e metropolização atraíram gerações de arquitetos como Louis Sullivan e Frank Lloyd Wright (em Chicago), e Raymond Hood e Harvey Corbett, em Nova Iorque; sistemas de transporte e logística - como o sistema de correia desenvolvido para os elevadores de grãos por Joseph Dart ${ }^{176}$, e o sistema de produção industrial desenvolvido por Henry Ford - permitiu o desenvolvimento do parque industrial americano, simplesmente inaugurando cidades como módulos produtivos ou entrepostos industriais - Buffalo, Minneapolis, Bayonne, Detroit, Saint Louis, entre outras; e uma rede de infraestruturas conectaria essas cidades, e permitiria a fundação de uma diversidade de assentamentos urbanos de baixa densidade, amparados pelo desenvolvimento dessas tecnologias recentemente inventadas - o sistema de ventilação integrado, calefação, elevadores, e luz elétrica' ${ }^{177}$;

Fazem parte dessa geração de pioneiros as figuras selecionadas por Banham como heróis injustiçados da modernidade em arquitetura, os quais foram selecionados por seu aporte diferenciado em relação à tecnologia, e pela manipulação da mesma para a formação de paisagens urbanas americanas ${ }^{178}$. Os principais inventores da arquitetura americana elencados por Banham não eram necessariamente arquitetos. Ernst Ransome e R. J. Reidpath, construtores, engenheiros, e inventores de patentes foram as figuras dominantes do grupo de construtores americanos, que junto a

175 Reyner Banham, Los Angeles: the architecture of four ecologies. Banham baseia boa parte de sua pesquisa histórica da formação da cidade no trabalho do geógrafo alemão Anton Wagner, autor de Los Angeles: der Zweimillionenstadt in Sudkalifornien.

176 Reyner Banham, A Concrete Atlantis, p.12-16.

177 Gwendolyn Wright, “Modern Consolidation, 1865-1893” em Wright, USA: modern architectures in history, pp. 17-46

178 Objeto de estudo do Capítulo 3. 
arquitetos como Albert Kahn, foram responsáveis pela formação do parque industrial americano, que forneceria a cosmogonia da arquitetura funcionalista do modernismo europeu. A paisagem americana mais frequente, malgrado uma construção coletiva de empreendedores imobiliários, empreiteiros e governantes locais que implantaram uma rede de infraestrutura que permitiu a colonização dispersa do território, somente foi possível através da técnica de controle ambiental que permitiu a construção simplificada e despojada das residências. Dentre os responsáveis pela difusão de técnicas pioneiras, destacou-se a feminista e inventora Catherine Beecher, cuja principal criação foi a residência da mulher moderna, abastecida por um core de infraestrutura, o qual permitiu a adoção ao sistema de construção perimetral leve em madeira, o balloon-frame, técnica oriunda de Chicago; uma das exceções dentre esse panorama é o arquiteto Frank Lloyd Wright, a quem Banham dá significativo destaque logo no início de sua carreira, e ao qual atribuiu o termo "mestre do controle ambiental", acenando para a expansão do conceito de arquitetura para a idéia de ambientes controlados pelo homem através da tecnologiai ${ }^{179}$.

179 Vale a pena lembrar da importância de Buckminster Fuller para a construção da "outra arquitetura" do future imediato. Segundo Nigel Whiteley, Fuller se considerava mais um inventor do que um arquiteto, e a quem Banham atribuíra importância no avanço dos Estudos de controle climático, através do aprofundamento de seu Estudos das cúpulas geodésicas. Ver Whiteley, Reyner Banham: Historian of the Immediate Future, pp.156-157. 


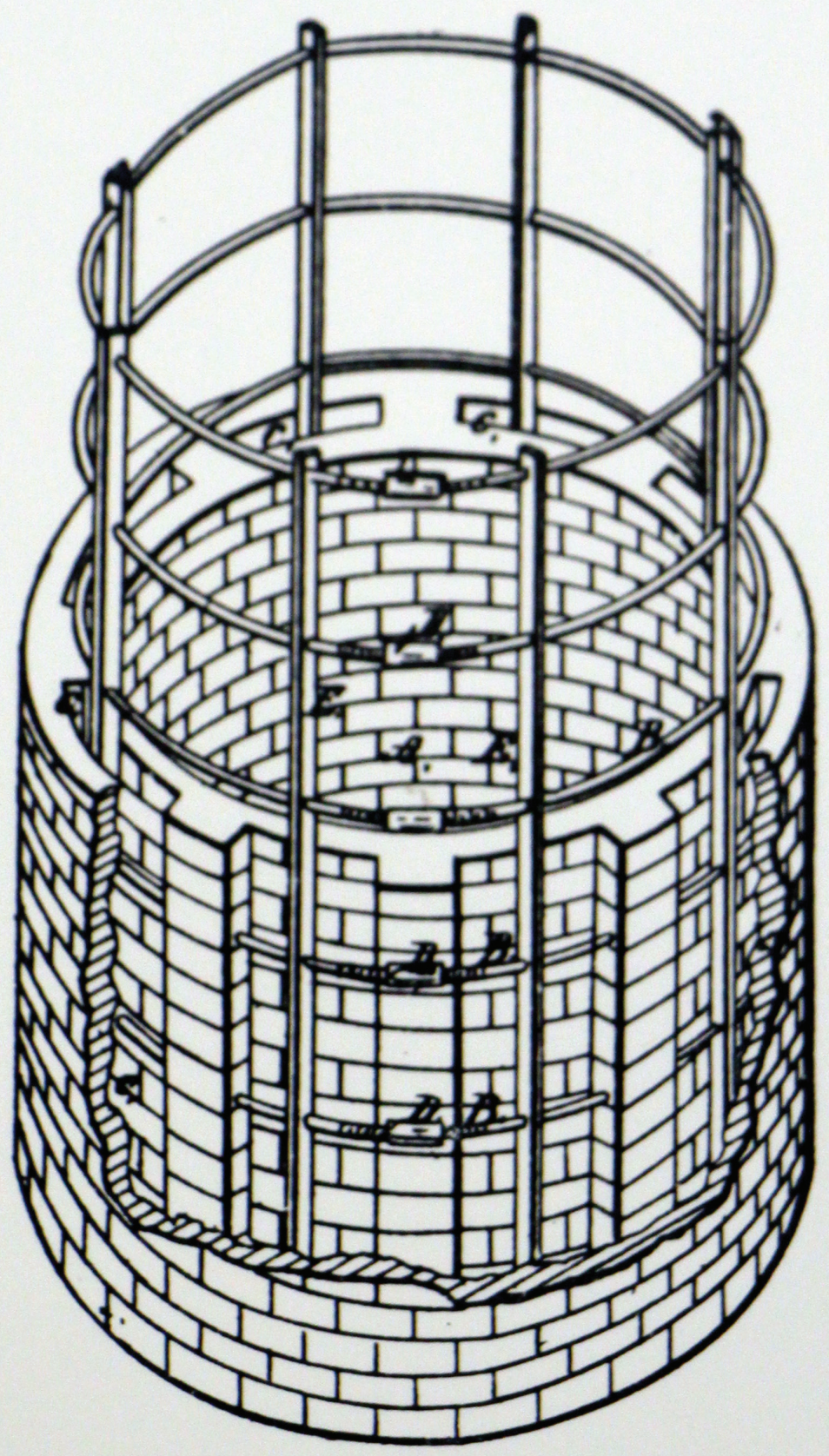

Ernst Ransome, sistema de construção mista em tijolo reforçado com parede de concreto, detalhe construtivo de cimbramento de silo de grãos, s/ data. Fonte: arquivo Getty. 
Em A Concrete Atlantis de 1986, Banham retoma a discussão do campo da produção do parque industrial americano, a fim de consumar sua crítica à historiografia moderna europeia, e fechar o ciclo temporal aberto em Theory and Design, em 1960. Não só era essencial o estudo mais profundo dessas estruturas fabris, bem como a investigação dos pioneiros da construção americana que permitiram o rápido avanço tecnológico que tomou boa parte do território. Continuando a discussão sobre invenção e desenvolvimento tecnológico, mais especificamente da construção de concreto armado, Banham destaca a trajetória de Ernest L. Ransome, engenheiro pioneiro no concreto armado nos Estados Unidos. Em A Concrete Atlantis, Ransome é um dos 'heróis' desconhecidos que ele pretende alçar ao patamar de pioneiro da arquitetura moderna americana. Muitas críticas e resenhas ${ }^{180}$ apontam essa agenda como uma das mais fortes características do livro, como também uma de suas deficiências que o teria desviado a atenção de Banham para questões mais relevantes, focando nas relações com a arquitetura moderna europeia, cuja ênfase somente é dada no terceiro capítulo do livro.

Banham critica a historiografia moderna por classificar Ransome como um pioneiro na exploração de materiais, enquanto muitos historiadores desconhecem a obra construída do arquiteto-engenheiro ${ }^{181}$, dispersa em documentos históricos. São pelas patentes relativas às inovações tecnológicas de Ransome que muitos historiadores guiam sua leitura. Banham se atém a algumas obras, muitas delas construídas na Califórnia, como o depósito da Pacific Coast Borax Company e o armazém da empresa Weed/McNear em Port Costa, no qual o concreto substituiu as paredes externas de tijolo e pedra, ainda seguindo uma tradição do método 'brick and pier' americano ${ }^{182}$. Segundo Banham, as obras de Ransome são exemplares do processo de investigação tecnológica contínua que prevaleceu no final do século XIX e nas primeiras décadas do século XX.

Banham parte para uma reconstrução das origens do sistema de construção das fábricas americanas, remontando suas origens e diferentes genealogias, sejam nativas,

"Parece que a emergência do perfil de cobertura plana era um assunto eminentemente americano e veio com a racionalização geral da indústria e os procedimentos gerais de construção de moinhos - nos anos 1820, junto com o uso de madeira pesada como grelha interna por razões de proteção contra fogo, pode ser aglomeradas como uma

180 Ver a resenha de Elizabeth Cromley, in Journal of Society of Architectural Historians, Vol. 46, No. 3, (Setembro 1987), pp.301-302, e Lindy Biggs, in Technology and Culture, Vol. 29, No. 2, (abril 1988), pp.316317.

181 Reyner Banham A Concrete Atlantis, pp.33-32.

182 "... a system of separate brick columns, connected by thinner membranes of brickwork con taining windows that went almost from pier to pier. In this way the weight of brickwork that had to be supported by the arch or beam that spanned each opening could be reduced to the minimum required for decent weatherproofing, but the stability of the wall as a whole was guaranteed by the thickness of the piers." Ver Reyner Banham, A Concrete Atlantis, pp.4445 
"construção padrão de moinho". Esse termo se aplica, tecnicamente, somente para o quadro interno de madeira, mas pode ser mantido aqui por conta de um significativo desenvolvimento americano de grandes obras industriais. "183

Sejam europeias, como aquelas estudadas por J. M. Richards em Functional Tradiction de 1958, e que remontam a antes de 1700, em Nyhavn, em Copenhage ${ }^{184}$. Lá, a necessidade de verticalização, dada pelo custo do solo ser alto nas margens dos corpos d'água em geral e a ausência de ornamentação formam as características consideradas por Banham como "industriais". Esse conceito de adaptação às necessidades produtivas é o que para Banham justificaria o nascimento e rápido desaparecimento da tipologia construtiva das Day-Light Factories. ${ }^{185}$

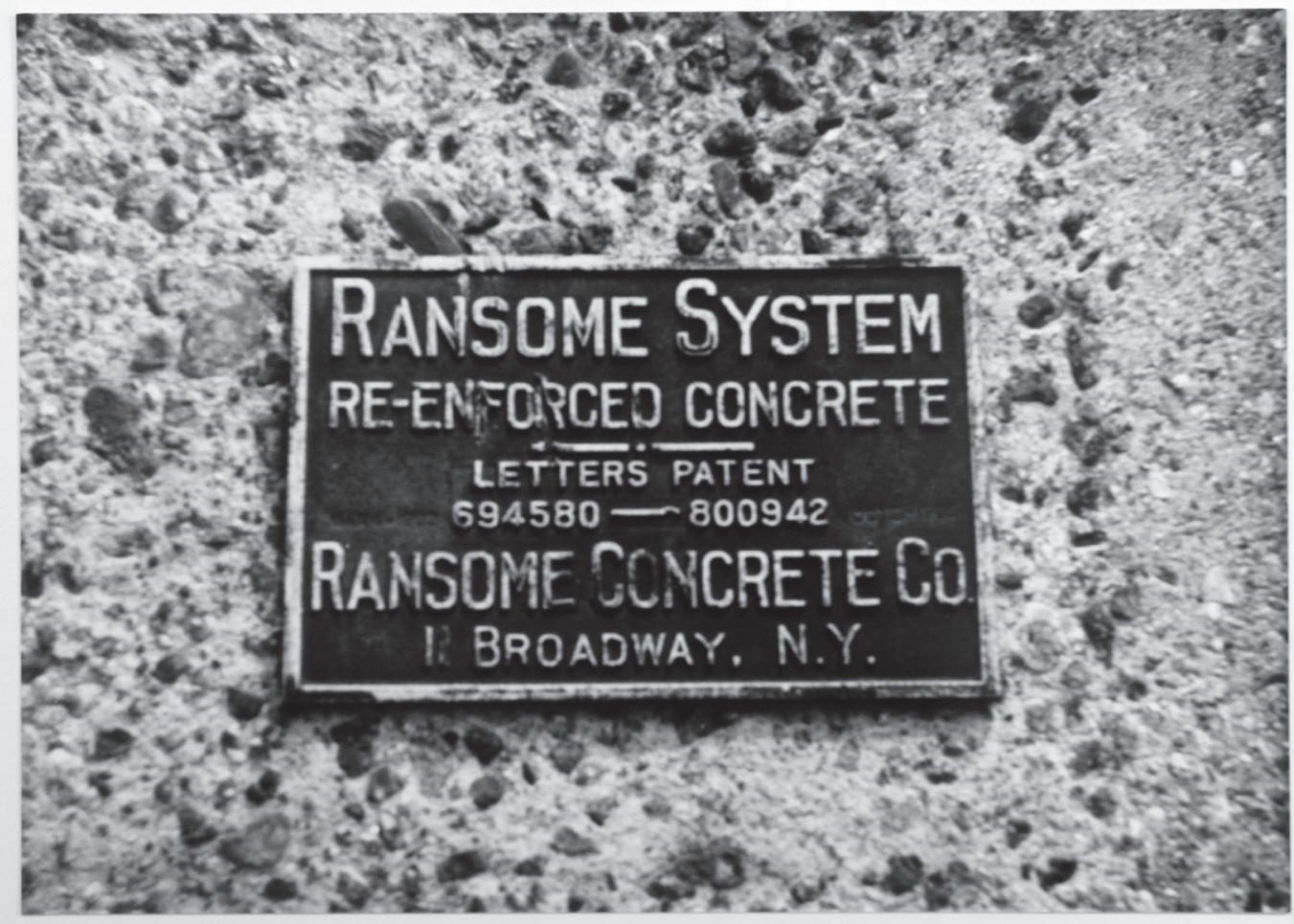

Placa de identificação em construção não identificada, s/ data. Foto: Reyner Banham. Fonte: arquivo Getty.

183 Reyner Banham, A Concrete Atlantis, p. 39. Texto original: It seems clear that the emergence of the flat-topped profile was a mostly American affair and came in with the general rationalization of factory and mill building procedures - in the 1820s that, together with the use of a heavy timber internal frame for fireproofing reasons, can be lumped together as "regular mill construction." That term applies, technically, only to the timber internal frame, but it can stand here for a significantly American development in the construction of large industrial works.

184 Idem, pp.41-42

185 Idem, p.40 
Mais a frente em Concrete Atlantis, Banham demonstra seu apreço pelo conjunto construído dessa tipologia e coloca em xeque a possibilidade de uso do termo 'vernacular' para tais obras. Para Banham, o refinamento no projeto e na execução dos elementos construtivos se comparava ao conjunto construído da antiga Roma. Banham destaca a participação a ser reconhecida de Arquitetos como R. J. Reidpath, e seu filho, que posteriormente trabalhariam como engenheiros calculistas para Frank Lloyd Wright, entre outros trabalhos. ${ }^{186}$

Junto ao parque industrial americano - imagem simbólica da nova América Fordista - a habitação unifamiliar isolada, chamada por Banham como Pioneer Household formava a parte onde as relações pessoais tinham seu espaço reservado, e onde podemos dizer que a sociedade continental americana se fundou. Banham define assim em 1969:

"unidades familiares isoladas, atômicas, auto-suficientes (...) crescentemente armadas com auxílios mecânicos e cada vez menos apoiadas por relações sociais externas do que quaisquer comunidades prévias acima da linha de subsistência." ${ }^{187}$

Em The Architecture of the Well Tempered Environment, fruto de estudo financiado pela Grahan Foundation, então dirigida por John Entenza ${ }^{188}$, e publicado em 1969 e provavelmente ponto de encontro de diversas pesquisas relacionadas ao tema da arquitetura americana, Banham lança mão de argumentos que defendem o estudo do desenvolvimento histórico dos métodos eletromecânicos de controle ambiental das edificações para entendimento das transformações ocorridas na arquitetura moderna ${ }^{189}$. A feminista e educadora Catherine Beecher, malgrado sem formação oficial em arquitetura, foi a responsável pelo desenvolvimento da organização espacial do domicílio e suas utilidades domésticas. Para Banham, parafraseando James Marston Fitch, este processo interno de organização seria essencial para a difusão do modelo de vida suburbano. Para ele, Beecher teria sido "uma das mães do estilo de vida suburban nos Estados Unidos", e suas 'house-types' - casas tipo - em Domestic Economy, de 1842, e American Woman's Home, de 1869, foram o exemplo tardio de diversas transformações encapsuladas do design doméstico. ${ }^{190}$ Banham descreve, novamente citando Fitch

186 Reyner Banham, A Concrete Atlantis, pp. 49-50.

187 Reyner Banham, "The Wilderness Years of Frank Lloyd Wright”, em A Critic Writes, p.139. Originalmente publicado no jornal do RIBA edição 76, Dezembro 1969, pp. 512-518. Texto original: Isolated, atomic, self-sustained family unites (...) increasingly armed with mechanical aids and less supported by outside social relationships than in any previous communities above the subsistence line. 188 Entenza tornou-se o diretor da instituição após deixar seu cargo de editor-chefe do periódico Arts $\mathcal{E}$ Architecture, em 1965. Entenza foi responsável pela criação e gestão do programa das Case Study Houses. 189 Reyner Banham, "Unwarranted apology" em The Architecture of the Well Tempered Environment, pp.9-18.

190 Reyner Banham, The Architecture of the Well Tempered Environment, p. 98. 
“A casa em si - enquanto nominalmente 'gótica' em seu estilo - é agora visualizada como uma verdadeira máquina de morar. Não mais são esses espaços anônimos e generalizados; desde cima até embaixo, cada espaço foi cuidadosamente analisado e organizado para uma destinação. $\mathrm{O}$ armazenamento classificado de cada objeto domestic é agora visto como o primeiro passo em um cuidado do lar eficiente. Na cozinha ele produz um gabinete incrivelmente modern com prateleiras, cristaleiras, gavetas e bancadas que anteciparam a prática atual. "191

Banham, mesmo apontando para o desalinhamento entre a estética antiquada da proposta de Beecher em relação aos avanços técnicos que ela encerra, deixa claro o pioneirismo em relação à conceituação da casa individual americana. Destaca ainda como Beecher foi importante para a formação da cultura da dona-de-casa americana, responsável pelo território doméstico, a mesma cultura que colaboraria de forma essencial para a construção do cotidiano doméstico moderno, fonte de inspiração não só para Wright e suas casas da pradaria, mas também para Buckminster Fuller e sua Dymaxion House de 1927, e para as Case Study Houses na Califórnia de 1936 a 1960, como vimos anteriormente. No ano do nascimento de Frank Lloyd Wright, segundo Banham, Beecher já estava abordando o tema da economia doméstica em novos territórios, e publicando seus resultados em livros e revistas como The American Woman's Home. Nesta revista, em 1869, ela produziria sua mais radical proposta: o 'ballon-frame' envelopando um core de serviços eletromecânicos. ${ }^{192}$

191 Idem, 96. Texto original: The house itself - while still nominally 'Gothic' in style - is now firmly visualized as a true machine for living. No longer are there generalized or anonymous spaces; from top to bottom every cubic inch has been carefully analyzed and organized for a specific purpose. Classified storage for all household objects is now fully realized as the first step in efficient house-keeping. In the kitchen it produces cabinet-York of astonishing modernity with shelving, cupboards, drawers and countertops which anticipate current practice.

192 Reyner Banham, “The Wilderness Years of Frank Lloyd Wright”, em A Critic Writes, p.139. Originalmente publicado em 


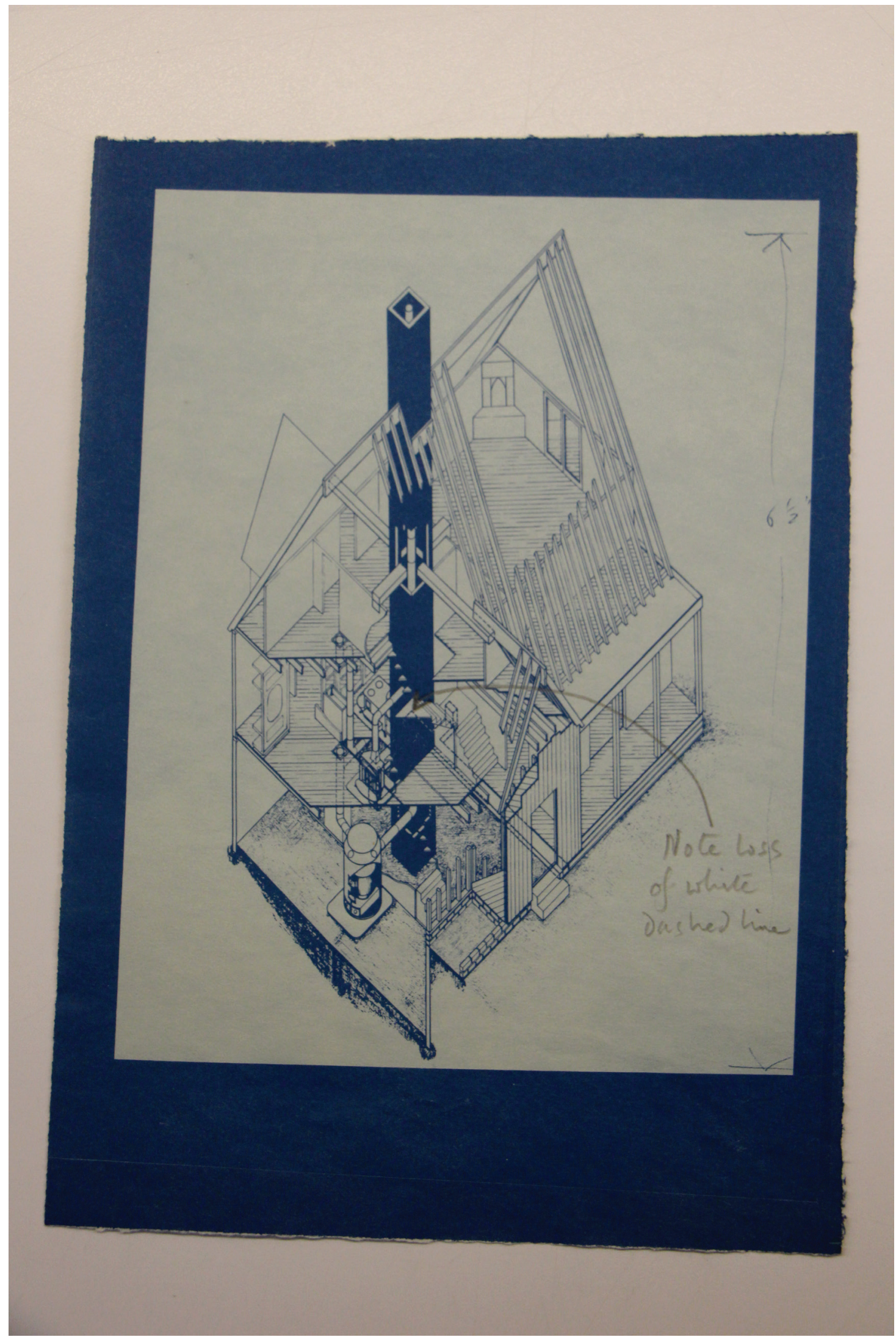

Catherine Beecher, American Woman's House, 1969. Fonte: Arquivo Getty. 
Devemos reconhecer os métodos avançados com os quais Beecher organizou a hidráulica e os sistemas de aquecimento para formar a "environmental tree" - a árvore ambiental - na qual os sistemas de utilidades se concentram em um corpo central da casa, propiciando a redução drástica da espessura das paredes externas, bem como se reduzindo a necessidade de performance de qualquer sistema de isolamento térmico perimetral. Com pouco a desempenhar, senão prevenir que a temperatura interna escape do ambiente, a casca externa da casa americana, tanto na visão precoce de Catherine Beecher, quanto no fato construído pelo território, de costa a costa, perdeu espaço como elemento fisicamente predominante na construção. Em casos como nas casas projetadas por Frank Lloyd Wright, ou pelos irmãos Greene, as paredes externas tornaram-se suscetível a diversificações estilísticas e experimentações estéticas. ${ }^{193}$ Conforme os edifícios se tornaram mais leves, e com a introdução do balloon-frame a partir de 1840, houve um crescimento expressivo na necessidade de aquecer artificialmente os ambientes externos. $\mathrm{O}$ forno de ferro fundido permitiu trazer a fonte de calor para o centro da construção, instalando a chaminé no centro da edificação, conforme preconizou Catherine Beecher. ${ }^{194}$

Além de materializar o ancestral idealizado de cada residência do subúrbio americano, a American Woman's Home é também o antecessor das casas Usonianas de Wright, a casa do casal Eames e a casa de vidro de Phillip Johnson: estruturas leves equipadas com sistemas onerosos de controle climático e tarefas da economia doméstica. ${ }^{195}$

Bem como Le Corbusier, Wright também é uma referência na obra de Banham. Mas ao contrário de sua investigação a respeito da estética da máquina, para Banham a chave da contribuição de Wright reside em sua apropriação do termo ambiente - do inglês environment - uma tradução ao meu ver infeliz por ser incompleta em relação ao original. $\mathrm{O}$ ambiente que Banham descreve através das palavras de Wright encerra uma das propriedades mais importantes da architecture autre: a sua ausência de limites físicos. Não é a toa, visto isso, que o termo environment esteja presente em diversas citações e no título do livro de 1968 - The Architecture of the Well-Tempered Environment.

Banham pinta Wright como um interventor na paisagem do deserto ${ }^{196}$, formador da paisagem da pradaria e um dos poucos arquitetos a questionar o modelo urbanístico Europeu de cidades adensadas nucleares ${ }^{197}$. Malgrado fracassado em sua intuição sobre o ambiente adequado para as atividades humanas em algumas de suas investigações, conseguiu encontrar a medida do ambiente deserto, e trouxe a significação mítica

193 Ver Banham, The Architecture of the Well Tempered Environment, pp.100.

194 Idem, pp.99-101.

195 Ver "The Wilderness Years of Frank Lloyd Wright" , pp.139-140.

196 Ver Banham, Scenes of America Deserta, "Wright as an environmentalist", a ser mais profundamente abordado no capítulo 3.

197 Ver "The Wilderness Years of Frank Lloyd Wright" , pp.140-141. 
imprescindível para a paisagem que Banham buscava. Suas proposta de casa da pradaria, com núcleos rígidos ao redor da lareira e dos sistemas de manutenção da vida humana, em muito consolidavam anseios da arquitetura vernacular em se tornar uma tipologia arquitetônica dotada de lastro cultural:

“Então, o potencial tecnológico correu continuamente na frente da performance arquitetônica. $\mathrm{O}$ abismo entre as duas era comumente ocupado pela experimentação em campos não comumente entendidos como arquitetura - estufas, fábricas, transporte. Quase quatro décadas separam os primeiros usos de ar-condicionado de sua aplicação confiante no tipo de arquitetura desenhada por arquitetos famosos, mas esses longos intervalos envolvem não somente experimentação física, mas muita especulação e troca de ideias, nas quais o clima é gerado para permitir que a exploração da tecnologias tão particulares se tornasse pensável." ${ }^{198}$

Em duas diferentes escalas, Frank Lloyd Wright é alçado ao patamar de mestre da arquitetura do clima controlado e herói de dois capítulos do livro The Architecture of the Well Tempered Environment - um sobre o ambiente interno de grandes edificações, e outro sobre os mecanismos de controle climático na escala residencial. ${ }^{199} \mathrm{O}$ edifício de escritórios da empresa Larkin, em Buffalo, EUA, malgrado tenha sido registrada como uma das primeiras obras-primas de Frank Lloyd Wright, foi por conta de seu alinhamento estético com outros clássicos da primeira Era Moderna, como a produção de Behrens, Gropius e Perret, e não por conta do reconhecimento de sua engenhosidade em solucionar problemas de ordem climática. ${ }^{200}$

A figura de Wright a partir do projeto do Edifício Larkin significava para Banham uma ponte entre a história da arquitetura moderna como costumeiramente escrita - o progresso da estrutura e da morfologia externa do edifício - e a história da arquitetura moderna entendida como o progresso de criar ambientes cada vez mais aptos a abrigar as atividades humanas na era da modernidade, conforme o autor menciona mais a frente em seu argumento ${ }^{201}$, avaliando o desempenho funcional das casas da Pradaria ${ }^{202}$. Reyner Banham discorre sobre as qualidades ambientais dos

198 The Architecture of The Well Tempered Environment, pp.27-28. Texto original: So, technological potential continuously runs ahead of architectural performance. The gap between the two is commonly occupied by environmental experimentation in fields no commonly regarded as architecture - greenhouses, factories, transportation. Almost four decades separate the first industrial uses of air-conditioning from its confident employment in the kind of architecture that is designed by famous architects, but these long intervals involve not only physical experimentation, but much speculation and brainstorming as well, in which a climate of ideas is generated that makes the eventual architectural exploitation of the particular technology become thinkable.

199 Idem, p.71.

200 Reyner Banham The Architecture of the Well Tempered Environment, p.86.

201 Idem, p.92.

202 Ver o capítulo "The Well-tempered Home", in Reyner Banham, The Architecture of the Well-tempered Environment, pp. 93-121. 
projetos residenciais de Frank Lloyd Wright, e de fato pontua o termo "American domestic vernacular". Outro termo peculiar cunhado por Banham, no qual ele agrupa os projetistas americanos da escala residencial, é "Wright and his California Contemporaries" ${ }^{203}$. Ele prossegue ao comparar por confrontamento as casas de Loos e Irving Gill, acusando que

"Apesar de surpreendentes similaridades ocasionais de detalhamento e forma exterior sem ornamentos, as predisposicões culturais subjacentes aos dois arquitetos está a polos de distância." ${ }^{204}$.
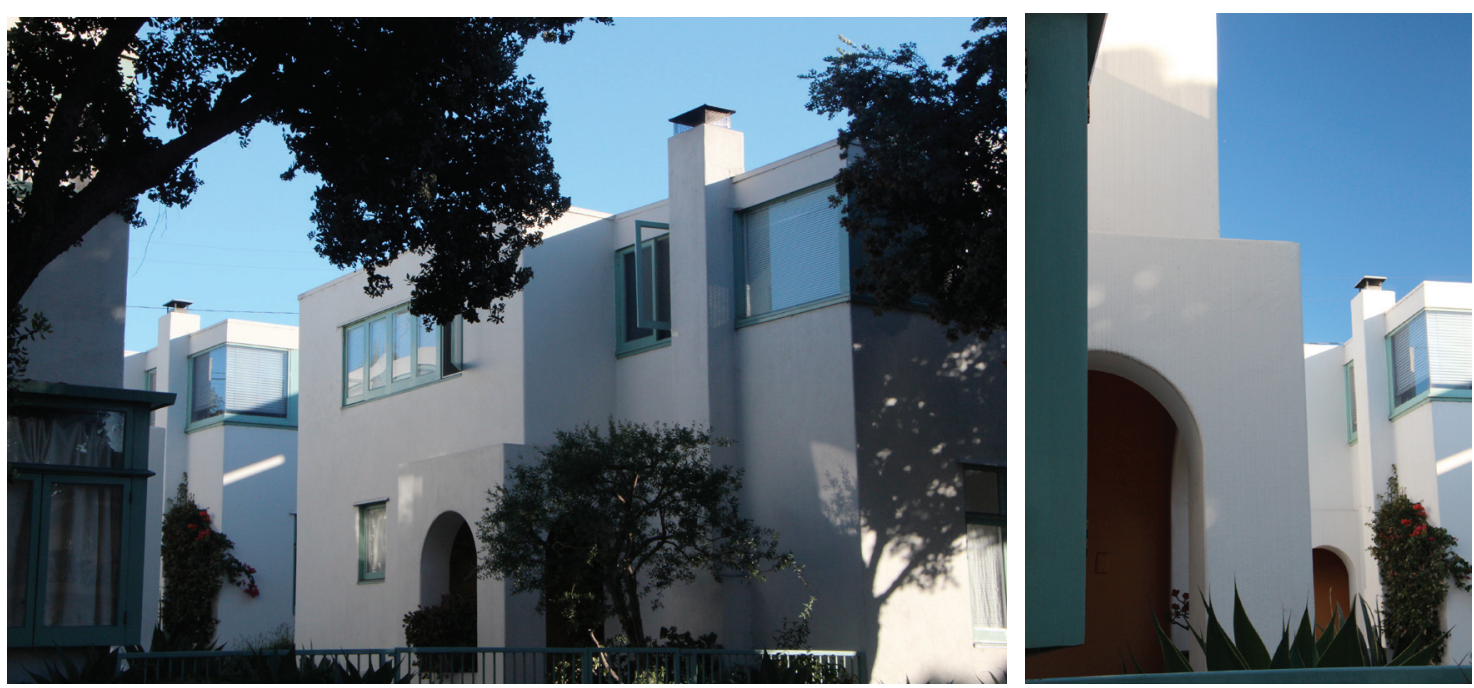

Irving Gill, Horatio West Court apartments, Santa Monica, 1919. Foto: Luiz Florence, 2012.

O idioma wrightiano seria uma maneira de organizar interiores. $\mathrm{O}$ deslocamento de uma mudança de ênfase do exterior para o interior demonstra na arquitetura doméstica a ênfase no conforto ambiental. Essa ênfase poderia ser materializada em uma forma envelopada de diversas maneiras, muito provavelmente porque a embalagem da construção se tornava cada vez mais irrelevante. As coberturas das casas da pradaria e nas construções californianas, segundo Banham, se destaca do resto do envelope. Dentro da tradição abstrato-cubista europeia, principalmente pela arquitetura de Adolf Loos, as paredes são os elementos principais da composição, e os telhados são banidos do visual por platibandas. Mas nos Estados Unidos, mesmo com muito a discorrer sobre paredes, como nas obras de Wright, liberados pela cultura do controle ambiental baseado no consumo de energia fóssil, os arquitetos se orgulham da liberdade em relação às restrições dos fechamentos verticais.

203 como apontado por Banham e por Henry-Russell Hitchcock, no mesmo capílto de Architecture: Nineteenth and Twentieth Centuries.

204 Reyner Banham, The Architecture of the Well Tempered Environment, p.93. Texto original: Apesar de surpreendentes similaridades ocasionais de detalhamento e forma exterior sem ornamentos, as predisposicões culturais subjacentes aos dois arquitetos está a polos de distância. 


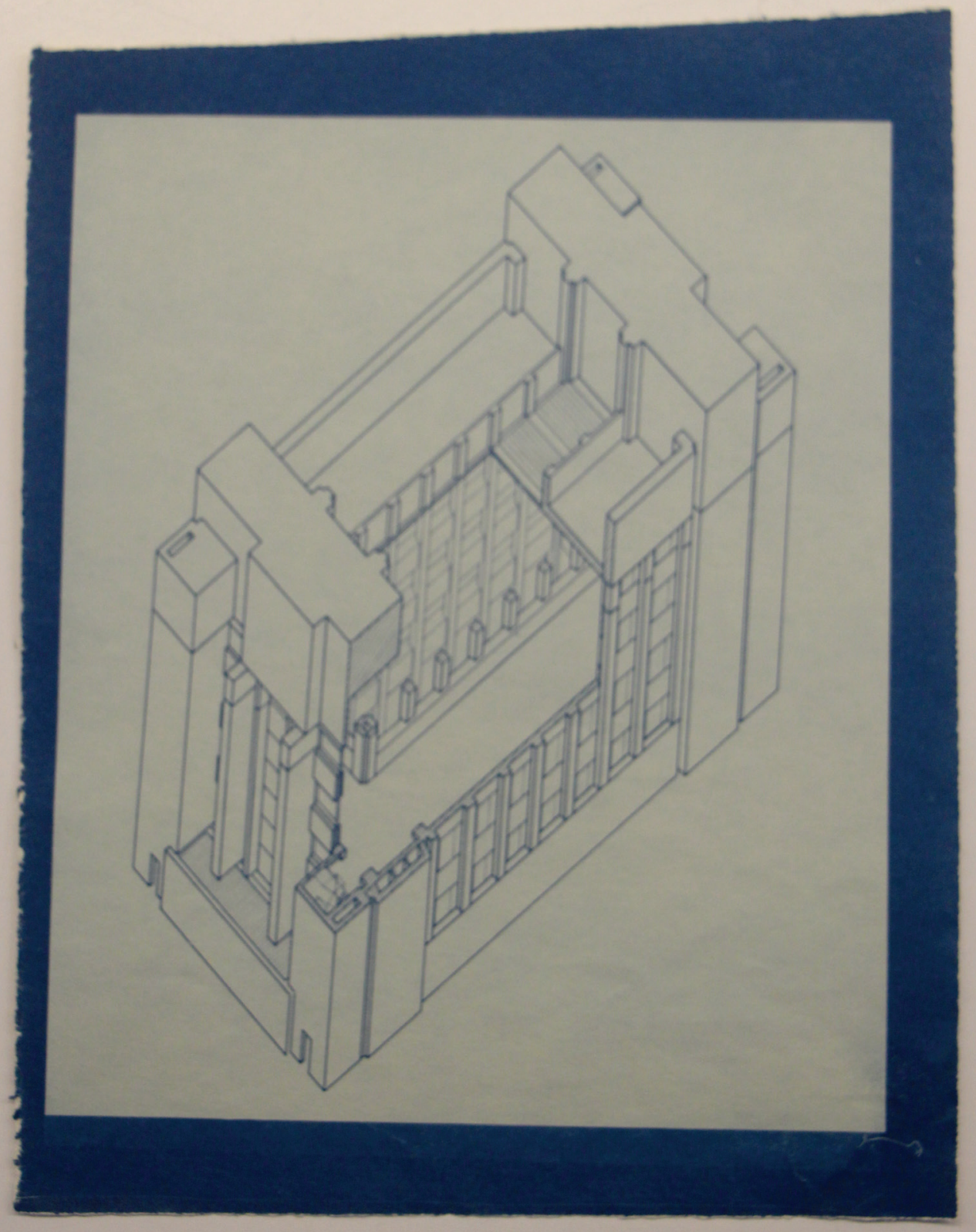

Frank Lloyd Wright, Larkin Building. Desenho esquemático dos sistemas de controle climático, s/ data. Fonte: arquivo Getty. 
"A arquitetura chegou a ser vista como a arte consciente de criar estruturas maciças e perenes, e chegou a se ver profissionalmente como nada mais do que isso, o que é uma das razões para seus problemas e incertezas presentes. As sociedades - através de qualquer órgão cabível, como os clientes ou o mercado - encomendam a criação de ambientes adequados para as atividades humanas; esses profissionais de arquitetura respondem, reflexivamente, propondo espaços encerrados em estruturas maciças, porque é o que os arquitetos foram ensinados a fazer, e é o que a sociedade foi ensinada a esperar dos arquitetos." ${ }^{205}$

Para Banham, a arquitetura do "clima temperado" questionaria o conceito de abrigo baseado na alegoria da caverna e na perduração das estruturas. A mudança de hardware para software, uma transformação baseada no conceito de consumir recursos para manter algo a princípio insustentável sem amparo de consumo de energia, pareceu mais atraente à cultura americana, em contraste às maciças estruturas europeias. Para Banham, a arquitetura americana, malgrado dividisse algumas genealogias em comum com a europeia, teria inaugurado um tipo de raciocínio diametralmente oposto em relação à construção, consumo de energia, e urbanização. As construções americanas, são comparáveis a máquinas e objetos de uso pessoal, como isqueiros, lanternas rádios, televisores, por conta de seu desempenho similar ao de tais objetos, que Banham apelidou de "gizmo" 206 , uma derivação popular de 'mechanism'. Pode ser um exagero comparar as casas de Frank Lloyd Wright à um eletrodoméstico, mas tal análise radical nos permite entender as diferenças intelectuais entre arquitetos nos dois lados do Atlântico.

205 Reyner Banham, The Architecture of the Well Tempered Environment, p.21. Texto original: Architecture came to be seen as the conscious art of creating these massive and perdurable structures, and came to see itself professionally as no more than that art, which is one of the reasons for its present problems and uncertainties. Societies - through whatever organs they see fit, such as patronage or the operation of the market - prescribe the creation of fit environments for human activities; the architecture profession responds, reflexively, by proposing enclosed spaces framed by massive structures, because that is what architects have been taught to do, and what society has been taught to expect of architects.

206 Reyner Banham, “The Great Gizmo”, em Design by Choice, 1981. 


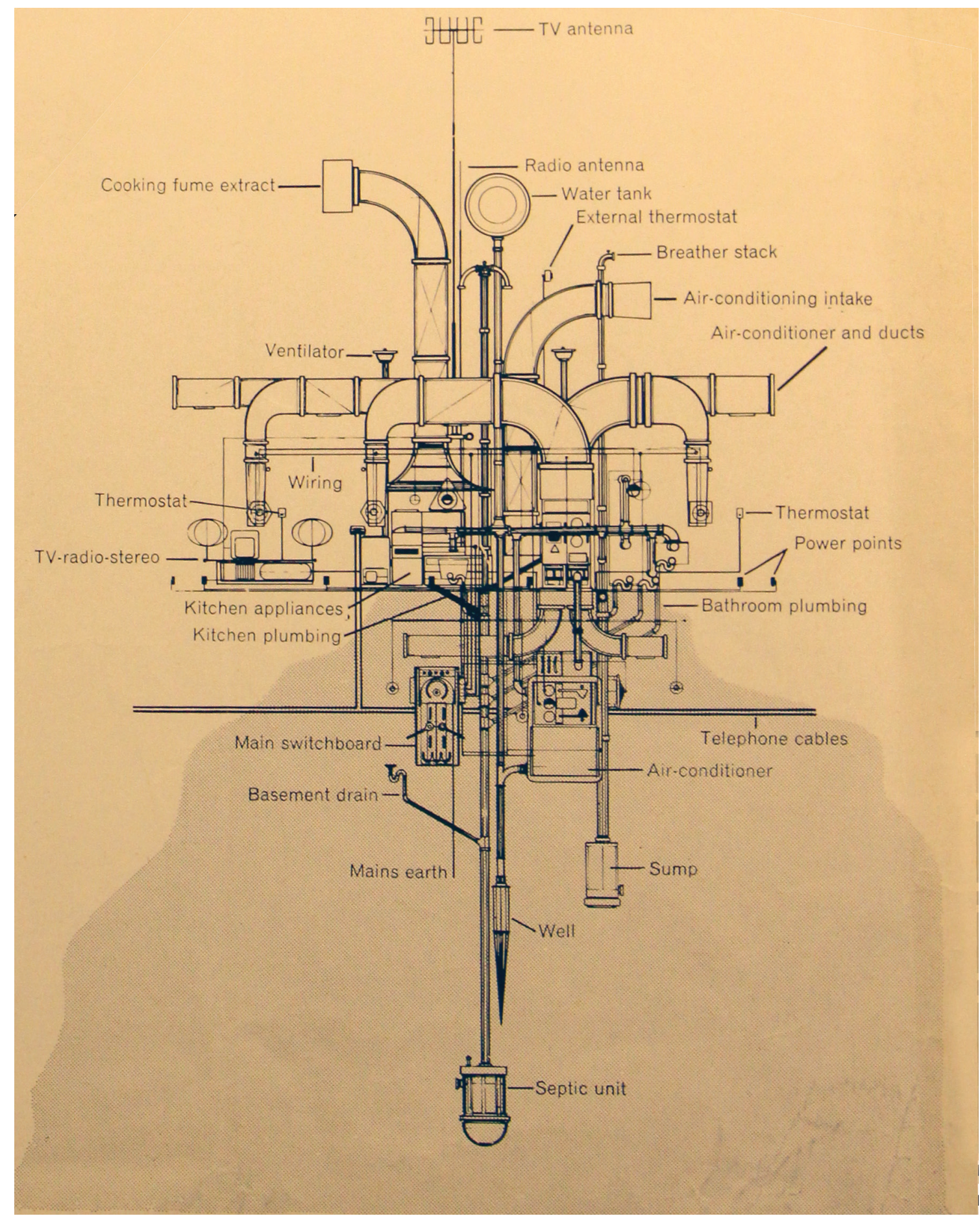

François Dallegret, Ilustração para "Home is Not a House", publicado originalmente em 1965 na revista Art in America, No. 2. Nota-se como Banham passa a isolar o fator climático como element essencial para preservação da vida humana. Indo mais a frente, eliminaria a necessidade por espaços encerrados, se fazendo faler de máquinas e ferramentas eletromecânicas de controle ambiental. A divisão entre externo e interno se dissolveria, como nas residências de Richard Neutra na Califórnia. 


\section{O Descartável e o Limite da Arquitetura}

Conforme foi apresentado nos movimentos anteriores deste capítulo, a formulação da 'outra arquitetura' de Banham passou pela revisão de postura com relação à tecnologia no campo da cultura construtiva. A revisão da noção de abrigo e ambiente dotado de controle climático, bem como a postura em sua face, a aceitação do engenho popular, como referência a ser criticada dentro de seus próprios parâmetros, bem como fonte de trocas de referências com a arquitetura; e o entendimento da cronologia do ciclo industrial, questionando os valores eternos da arquitetura em prol da estética descartável do objeto de consumo de massa.

Durante os primeiros anos de sua carreira, Banham constrói o arcabouço de estudo dos limites da arquitetura, e sua relação com os produtos de design industrial. Em contraponto ao objeto estático que é o produto da arquitetura, nosso autor elege seu anti-herói, o automóvel, como símbolo Futurista da estética da velocidade e do descartável. Inicialmente, a agenda de Banham durante as décadas de 1960 e 1970 é de explorar o abismo entre a arquitetura - como representante de uma elite cultural que remontava à situação do século XIX - e os objetos de consumo de massa, enquanto elemento da cultura popular ${ }^{207}$.

Claramente, Banham demonstra suas predisposições de classe cultural inglesa, e do orgulho de classe, cunhado localmente como working class pride, e seu relacionado fascínio com os produtos da indústria e da cultura americana ${ }^{208}$. Conforme vimos anteriormente neste capítulo, a 'architecture autre' que Banham buscou na arquitetura europeia e americana tinha, em seu arcabouço teórico, a obrigação de envolver com a estética popular e o vernacular moderno, como caminho de apropriação da tecnologia; a flexibilidade e com o descartável do design industrial, como vimos em relação à arquitetura industrial; as transformações pelas quais a tecnologia e o engenho humano passaram - desde o Brutalismo e as experiências do Independent Group com a House of the Future ${ }^{209}$; revisitando pelas experimentações de Cedric Price com o Fun Palace; e com a persistência do moderno nas releituras do high-tech de Piano, Foster e Rogers.

Nigel Whiteley encara essa atitude como uma tentativa de Banham de construir o "campo expandido da arquitetura". Whiteley traça uma comparação com o trabalho de Rosalind Krauss, sobre o campo expandido da escultura, com o intuito de acenar para a proposta de um significado ampliado para o termo 'arquitetura' ${ }^{210}$. De fato, conforme vimos no capítulo 1, a discussão das fronteiras da arquitetura permeavam as escolas americanas, mesmo antes da chegada das gerações de migrações europeias. O termo arquitetura fora, em muitas instituições, substituído pelo termo

207 Ver "A throw-away Aesthetic", publicado originalmente em Industrial Design, 1955

208 Ver "The Atavism of the Short-Distance Mini-Cyclist", publicado originalmente em Living Arts 3, 1964, e republicado em Design by Choice, pp.84-89.

209 Ver Banham, New Brutalism: ethic or aesthetic?, pp.XX-XX

210 Nigel Whiteley, pp.254-280 
"human Environemnts". Malgrado não exista tradução adequada para o termo, já que 'ambiente' não é um sinônimo perfeito, o termo ambiente humano encerra a ideia da apropriação total dos recursos para reconstrução do meio.

Em seu apreço pelo raciocínio projetual de Buckminster Fuller ${ }^{211}$, nas experimentações de condensadores sociais do casal Smithson, e nas utopias do Archigram, Banham deixa transparecer sua predileção por uma arquitetura que é ampla, e ao mesmo tempo, permissiva e inclusiva. Dentro desse raciocínio, o primeiro passo fora conseguir absorver a atitude de projeto nas criações populares no campo semântico da arquitetura. Banham deparou-se com a ampliação do conceito de human environments para environments fit for human activities. Nesta mudança, percebe-se o fortalecimento do plano da mutabilidade do ambiente, em resposta ao estímulo da atividade humana. Nigel Whiteley nomeou esta tipologia de ambiente como "responsive environment" 212 . O plano da mutabilidade, seria traduzido pela mídia, pelo mercado de consumo de massa e pela economia, pela idéia de "fora com o velho, que venha o novo". A ligação entre mutabilidade e o produto descartável estava fortalecido, mas não seria com os objetos de arquitetura que esse fenômeno tomaria sua dimensão mais eloquente.

O artigo entitulado "Vehicles of Desire ${ }^{213}$ " se torna a partir da década de 1960 o mais conhecido material no qual Banham traça comparações entre o ethos da arquitetura e o design de automóveis. O tema da estética do objeto descartável é pela primeira vez aqui esboçado, tendo o Cadillac como a epítome do objeto de desenho industrial, cujos valores não poderiam se distanciar mais dos valores da arquitetura moderna. Banham descreve e analisa os valores embebidos no design de carros como antítese do projeto de arquitetura, e retoma a bibliografia modernista de elogio ao automóvel durante a década de 1920, na qual destaca trechos do manifesto de Le Corbusier, Vers Une Architecture. A proposta do artigo, contudo, não é nada elogiosa: busca encontrar as contradições no discurso de alinhamento entre a ética do produto industrial e a estética abstrata do modernismo, segundo Banham amarrada ao academicismo clássico. É uma história de fracasso, que aponta para os limites da disciplina quando se trata do projeto de objetos da modernidade.

211 Reyner Banham, Theory and Design in the First Machine Age, pp. 320-330.

212 Ver o capítulo de Nigel Whiteley, "Science for Kicks", em Reyner Banham: Historian of the Immediate Future.

213 Reyner Banham, “Vehicles of Desire”, originalmente publicado em Art, setembro de 1954. 


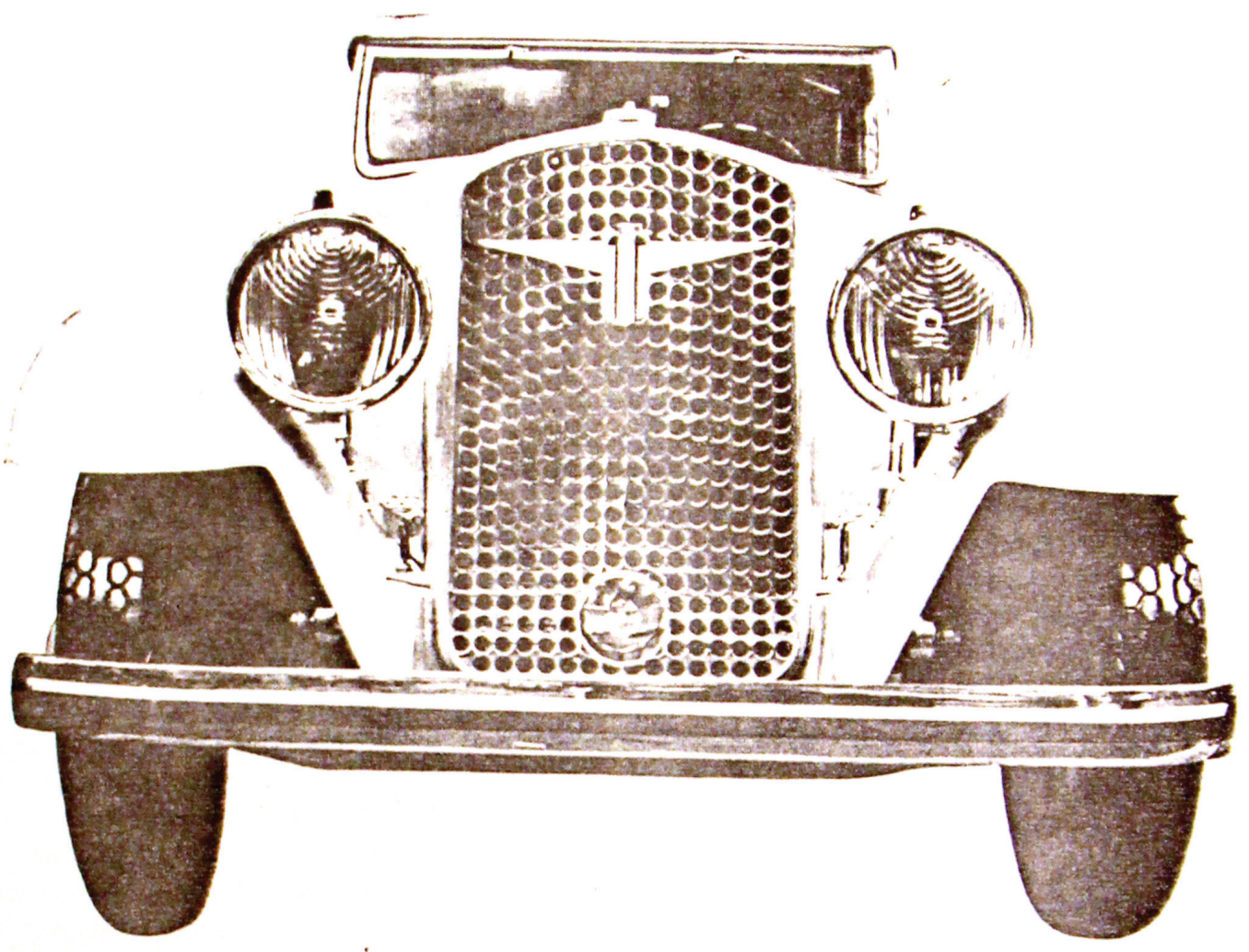

429 W Gropius. The Adler car designed in 1930 (from S. Giedion, W. G., 1954)

Walter Gropius, Adler modelo 1930. Fonte: arquivo Getty

“Longe de ser homens universais os arquitetos são por treinamento, predisposição estética e psicológica, compromissados com o desenho de estruturas únicas e permanentes, e seus esforços são direcionados meramente a grandes e permanentes valores humanos em obras de arte únicas e sem repetição.

“O automóvel não é grande - alguns são da altura de um balcão não são permanentes - o período médio mundial de sucateamento subiu recentemente, repito, para 15 anos - e eles certamente não são únicos. ${ }^{{ }^{214}}$

Banham se envolve na discussão sobre como a cultura arquitetônica de sua época não teria ainda amadurecido um discurso capaz de equacionar a estética do produto descartável. Como historiador da arquitetura, faz uso de figuras do passado clássico - no caso, o desenho das cerâmicas, objetos cotidianos na Grécia antiga -

214 Idem. O artigo foi republicado em A Critic Writes: essays by Reyner Banham, organizado por sua esposa, Mary Banham, em 1995, do qual o trecho foi retirado, p.5. Texto original: Far from being uomini universali architects are by training, aesthetics and psychological predisposition narrowly committed, to the design of big permanent single structures, and their efforts are directed merely to focusing big, permanent human values on unrepeatable works of unique art.

"The automobile is not big - few are even mantel-piece high - it is not permanent - the average world scrapping period has lately risen, repeat risen, to fifteen years - and they certainly are not unique. 
para encontrar sentidos novos para seu tempo (não sabemos se com a intenção de desestabilizar e satirizar o meio):

“Essa é uma situação com a qual a estética pré-industrial nunca deve que lidar: até mesmo as necessidades de Platão, para o vaso grego, malgrado inúmeros e padronizados, tinham desistido de evoluir e não são exatamente descartáveis. Mas ainda continuamos lidando com Platão na estética, como em outras coisas, nós ainda não formulamos atitudes para viver em uma sociedade da economia do objeto descartável. Consumimos vorazmente efemeridades que chegam fazendo barulho, e desaparecem sem que ninguém chore por elas - cinemas, moda de praia, revistas pulp, as notícias dessa manhã e os programas de televisão de amanhã - ainda assim persistimos em uma estética e padrões morais ligados à permanência, durabilidade e perenidade. ${ }^{\prime 215}$

O clima de interesse pelos produtos de origem e consumo populares, que unia a geração de Banham, em especial seus colegas de Independent Group orienta o discurso do artigo. Banham combina esta sensibilidade com sua capacidade de analisar objetos de design através de suas simbologias atribuídas, como o balanceamento entre poder masculino e luxúria feminina que encontrava nas curvas dos automóveis.

Para Nigel Whiteley, o descartável torna-se uma teoria, mais do que um tema para Banham. É uma linha de raciocínio de projeto que corre em paralelo com a

Nenhum ornamento é acidental. Para Banham o profissional que desenha automóveis é de natureza diversa da do arquiteto: mentes anônimas em equipes anônimas, estes se esforçam em dar às suas criações, através de iconografias simbólicas retiradas de filmes, ficções científicas, aeronaves, e outros produtos de consumo já presentes no ideário popular, as qualidades aparentes de velocidade, poder, Brutalismo luxúria, exotismo, extravagância e, é claro, apelo sexual ${ }^{216}$.

215 Idem. pp.4-5. Texto original: This is a situation with which no pre-industrial aesthetic ever had to cope; even Plato's needs, for the Greek pot, though numerous and standardized, had long given up evolving and was not conspicuously expendable. But we are still making do with Plato because in aesthetics, as in most other things, we still have no formulated intellectual attitudes for living in a throwaway economy. We eagerly consume noisy ephemeridae, here with a bang today, gone without a whisper tomorrow - movies, beach-wear, pulp magazines, this morning's headlines and tomorrow's TV programmes-yet we insist on aesthetic and moral standards hitched to permanency, durability and perennity.

216 Idem, p.5. Também em "Horse of a Different Colour", publicado originalmente em New Socitety, Banham oferece, através da análise do Mustang e de suas sutilezas e diferenças em relação aos outros automóveis da época, uma amostra de sua capacidade de ler o objeto de design popular tal como um objeto da arte do Renascimento italiano. Fica a questão sobre as possíveis influências da escola de Aby Warburg, cujo instituto - e a conhecida biblioteca Mnemosine - fora transplantado para a mesma rua do Institute of Contemporary Arts no campus da Universidade de Londres. Sabe-se, inclusive, do contato entre os pupilos de Warburg - Erwin Panofsky em específico - e a geração de Banham. Ver "The art of the well tempered Lecture", em Ainsley, Jeremy, Atkinson, Harriet (ed.). The Banham Lectures: essays on designing the 
Em "Stocktaking", texto revisionista da primeira parte de sua carreira e do estado da arquitetura contemporânea, Banham aborda duas facetas da arquitetura moderna ${ }^{217}$. Um artigo escrito em duas narrativas paralelas, sobre a tradição e tecnologia, revelava a predileção de Banham pelo engajamento com a tecnologia e o repúdio a tradição, esta que levaria o modernismo de volta ao historicismo. Em sua versão original de 1960, o artigo foi diagramado em duas colunas paralelas. O leitor poderia ler qualquer uma das colunas, cada qual levando a conclusões de perspectivas diferentes sobre a arquitetura. Em alguns momentos to texto "Technology" Banham acena para a evolução da arquitetura para uma disciplina que reflitisse sobre o conceito de abrigo se livrando dos grilhões das tradições construtivas de parede, piso e teto. A esperança lançada por Banham em relação à arquitetura é que ela se apropriasse das novas tecnologias, as quais segundo seu entendimento estariam à frente da arquitetura, enquanto esta estivesse presa aos valores da tradição e do academicismo, em detrimento de sua própria relevância social. Segundo Banham, os serviços que os arquitetos se propõem a fazer pela sociedade frequentemente poderiam ser realizados sem chamar um arquiteto. Ao sair da necessidade utilizar apenas as tecnologias do tijolo e da massa, a sociedade poderia se emancipar do monopólio dos arquitetos como provedores de abrigos para a raça humana. Essas alternativas, cuja justificativa seria a performance mesurável, ao invés de valores culturais, extendem a noção de "casa" para algo sem a referencia de chão ou teto, mas simplesmente a integração de serviços mecânicos de sustento à vida. ${ }^{218}$

Em "Home is Not a House", cinco anos depois, Banham refina seu argumento sobre a dissolução do invólucro da arquitetura e a quebra com a estética da máquina preconizada na primeira geração de arquitetos modernos. Com o apoio da pesquisa que estava se iniciando para o livro The Architecture of the Well Tempered Environment, Banham afirma que os serviços eletro-mecânicos providos pela modernidade para o conforto humano, os eletro-domésticos, sistemas de ventilação e condicionamento de ar, etc, tinham redefinido o conceito de funcionalidade, incorporando a mesma o simbolismo próprio do objeto de design e produto para consumo de massa. Essa é a contribuição da cultura construtiva americana, a qual restava apenas a única saída possível: aceitar o conceito de "anti-casa", abandonando de vez a estética moderna prévia, tornando-se une Architecture autre. ${ }^{219}$

Banham retoma a metáfora do design de automóveis, seu anti-herói preferido.

\footnotetext{
future.

217 Reyner Banham "Stocktaking”, publicado originalmente na Architectural Review, 197 Fevereiro 1960, pp.93-100. Republicado em Design by Choice, pp.48-55.

218 Reyner Banham "Home is Not a House" publicado originalmente em Art in America, Vol. 53, pp.7079 - fonte: arquivo Getty, Banham Papers, caixa 8, pasta 8.1.

219 Idem p.56-60.
} 
No trecho abaixo, note-se como ele descreve um projeto (aparentemente de sua autoria) para a customização do automóvel como esfera de vivência:

“O carro, em resumo, já faz muito do trabalho de uma unidade padrão de habitação - um casal beijoqueiro dançando a música do radio no conversível criaram uma pista de baile no meio da natureza (cortesia do departamento de auropistas, claro) e isso tudo é paradisíaco até que chova. Mesmo assim, se não houver vazamento de ar, é necessário muito pouco ar para preencher uma redoma Mylar, o seu caro pode fazelo, com o sem um empurrão, e a redoma, em si, dobrada como um para-quédas, pode ser parte dele. Dentro de um hemistério de 10 metros quadrados, de vivência seca e quente pode-se ter uma vista espetecular do vento sacudindo as árvores, neve, fogo nas floresta acima do morro de Constance Chatterlay, até você sabe quem através do aguaceiro." 220

A relação entre o objeto de consumo e a estética descartável em relação com a arquitetura, em Banham, sempre girou em torno das lições a serem retiradas pelos arquitetos do confronto com esses objetos, e suas evidentes qualidades superiores - a popularização, a aceitação pela cultura de massa e a introdução da discussão de tais fenômenos em rodas nas quais a arquitetura dificilmente figuraria como tópico. Adrian Forty, em uma das palestras em homenagem a Banham, levantou o tema das metáforas entre arquitetura, design e objeto de consumo imediato ${ }^{221}$.

A partir de um certo estágio em sua carreira, Banham reúne alguns argumentos sobre os limites da arquitetura enquanto disciplina, e à luz de sua comparação - e metáforas - com os objetos de consumo e as expressões do vernacular moderno, se questiona sobre se todos os elementos por ele investigados de fato se encaixavam sob o conceito de arquitetura. O tema de seu último artigo publicado, A Black Box: the secret profession of Architecture ${ }^{222}$, lido de maneira retrospectiva o tema do limite da

220 Reyner Banham, "Home is Not a House", in Design by Choice, p.59. Texto original: The car, in short, is already doing quite a lot of the standard-of-living package's job - the smoochy couple dancing to the music of the radio in their parked convertible have created a ballroom in the wilderness (dance floor by courtesy of the Highway Dept. of course) and all this is paradisal till it starts to rain. Even then, you're not licked - it takes very little air pressure to inflate a transparent Mylar airdome, the conditioned-air output of your mobile package might be able to do it, with or without a little boosting, and the dome itself, folded into a parachute pack, might be part of the package. From within your thirty-foot hemisphere of warm dry lebensraum you could have spectacular ringside views of the wind felling trees, snow swirling through the glade, the forest fire coming over the hill of Constance Chatterlay running swiftly to you know whom through the downpour.

221 Adrian Forty, "Of Cars, Clothes and Carpets: design metaphores in architectural thought”, in The Banham Lectures: essays on designing the future, editado por Jeremy Ainsley e Harriet Atkinson, e publicado em 2009.

222 Reyner Banham, “A Black Box: the secret profession of architecture" originalmente publicado em New Statesman and Society, 12 de outubro de 1990, pp.22-25. O artigo, póstumo a seu falecimento em 1988, foi reproduzido em A Critic Writes: essays by Reyner Banham, pp. 292-299. 
disciplina, e de maneira aparentemente contraditória, propôe a redução do espectro da arquitetura enquanto disciplina, tornando-a distinta e menor do que o conjunto das artes construtivas ${ }^{223}$.

Seu argumento principal passa por uma reflexão sobre a profissão do arquiteto e a série de padrões de comportamento, pensamento, exercício da profissão e abordagem em relação às demais ciências da construção, que sugere a regressão da arquitetura a seu radical centro-europeu como apenas uma das artes construtivas. É possível que sua exposição a textos alemães tenham lhe apresentado a distinção, que já era comum na língua entre Baukunst (arte de construir, ou arte construtiva), e Architektur. Talvez tenha sido a sua exposição à paisagem americana a fonte de elementos de comparação para perceber a força desse outro ponto do espectro da arte construtiva - ou chamemos de cultura construtiva - a qual se encontra em um ponto diferente do ocupado pelo domínio da arquitetura.

É neste artigo que encontramos uma das mais expressivas comparações entre duas peças de construção - já admitindo que uma delas não se encaixa na alcunha de arquitetura - a Catedral Lincoln e um abrigo de bicicletas, uma comparação previamente construída pelo seu antigo mestre, Nikolaus Pevsner:

"The tendency has been much muddled by the tendency of the modern movement, since the time of William Morris, to gather up all decent buildings into the rubric of "architecture". This was a warm, friendly and egalitarian thing to do, but it must now seem as historically crude and perniciously confusing as Nikolaus Pevsner's proposition that Lincoln Cathedral is architecture and a bicycle shed is not. The distinction was made on the basis that Lincoln Cathedral had aesthetic pretensions and bike sheds don't." 224

223 Idem, p. 297

224 Reyner Banham, "A Black Box", p. 293. Tradução: A tendência tem sido silenciadas pela tendência do movimento moderno, desde o tempo de William Morris, de juntar todos os edifícios decentes sob a rubric de "aruqitetura". Isso era um gesto amigável e igualitário, mas deve ser visto agora como historicamentr grosseiro e perniciosamente confuso, como a proposta de Nikolaus Pevsner de que a Catedral em Lincoln é arquitetura e que um abrigo de bicicletas não é. Essa distinção foi feita com base de que a Catedral em Lincoln tinha pretensões estéticas e um abrigo de bicicletas não. 

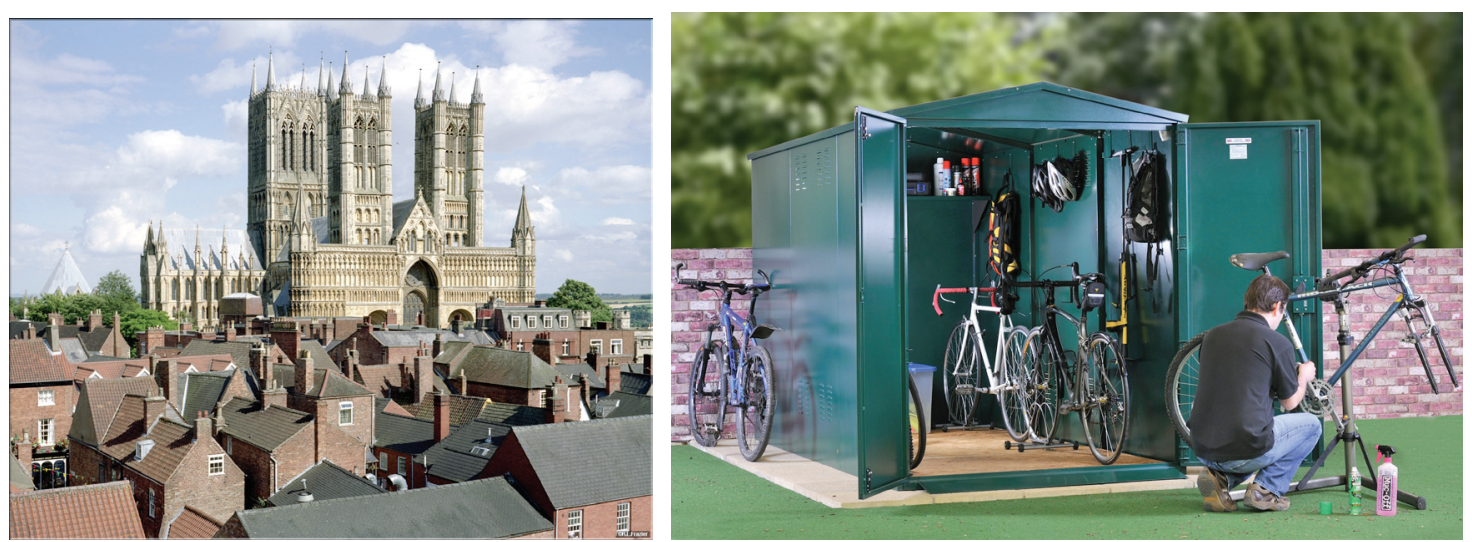

Esquerda: Remigius de Fécamp, Catedral Lincoln, 1092, Inglaterra. Foto: R. L. Frazier. Direita: Asgard Steel Storage, XXL Cycle Storage (abrigo de bicicletas metálico). Segundo o fabricante, Asgard Steel Storage, o abrigo, além de guarder 8 bicicletas, vem equipado com tomada elétrica, kit de manutenção, ganchos para roupas e bolsas, e caixa de ferramentas para bicicletas.

Se a narrativa de Banham parte da procura por uma "architecture autre" enquanto resposta às limitações da arquitetura moderna, a experiência estética das paisagens americanas foi central para o entendimento do campo ampliado das artes construtivas, como esfera de produção de ambientes tecnologicamente engendrados para responder inteligentemente às atividades humanas em constantes variações. Como veremos no próximo capítulo, a partir do momento em que Banham estabelece origens comuns para soluções estéticas e construtivas, aproximando elementos da produção do vernacular moderno e a produção de arquitetura segundo o comportamento da arquitetura em relação à cultura construtiva em geral, elementos mundanos não só receberão a mesma ênfase em seu estudo crítico, como também lhe fornecerão metáforas e comparações para o entendimento da arquitetura contemporânea. 
Capítulo 3 - Paisagens Americanas 
Como vimos na conclusão do capítulo 2, a investigação de uma arquitetura apropriada para o domínio da linguagem tecnológica de Reyner Banham o levou a uma "outra arquitetura", Une Architecture Autre. Com potencial de fornecer uma saída para o impasse da arquitetura moderna e a tecnologia na segunda metade do século XX, essa modalidade de expressão arquitetônica encontrou um topos ideal para a sua reprodução nos Estados Unidos da América, onde a apropriação da tecnologia se daria de maneira supostamente mais democrática, popularizada, desatrelada dos meios intelectuais e das altas rodas sociais; onde a expressão vernacular de design e arquitetura tomou uma importância não só de vanguarda nos processos de criação de novos espaços e formas, mas também no grande impacto desses elementos na construção de um novo estilo de vida urbano. Se Reyner Banham elegeu a América como este lugar, não foi por razões puramente acadêmicas, como vimos no capítulo 1. Este capítulo tratará de abordar a relação indefectível entre arquitetura popular e tecnologia, através das narrativas de Reyner Banham sobre as paisagens construídas, ou conquistadas pelo homem, em território americanoํ.

Foram eleitas quatro paisagens arquetípicas do contexto americano: as ruínas do parque industrial americano; as paisagens do deserto do meio-oeste americano; as megaestruturas de transporte, das quais as autopistas são as protagonistas; as múltiplas facetas do subúrbio residencial americano; Através do estudo das paisagens culturais americanas e dessas "tipologias" específicas, pretende-se rastrear a figura do povo que construiu essas estruturas, objeto da última seção deste capítulo.

O mesmo arquétipo do cidadão americano, pioneiro, embebido no radical Futurista, desbravador, e por vezes cruel conquistador do território previamente ocupado, atraiu a atenção de Banham desde Theory and Design in the First Machine Age 2 . Ainda preso ao vocabulário da historiografia moderna, porém com a predisposição a dela se desvencilhar, Banham elege (como vimos) Buckminster Fuller e a postura

1 Muito do amadurecimento dessas questões se deve à interlocução com os professores americanos Paul Groth, Gwendolyn Wright e Gabrielle Esperdy, durante a viagem de pesquisas em 2012. As transcrições da entrevista com a professora Gabrielle Esperdy encontra-se como anexo dessa dissertação.

2 Banham escreve, em 1980: “Twenty years ago, when this book was first written, most of the beliefs on which the Modern Movement had been based were still standing and in good order, and what appeared to be a second machine age as glorious as the first beckoned us into the 'Fabulous Sixties' - minituarization, transistorization, jet and rocket travel, wonder-drugs and new domestic chemistries, television and the computer seemed to offer more of the same, only better. What had been promised by the First Machine Age, but never properly delivered, now seemed to be at hand."

Tradução: Vinte anos atrás, quando este livro foi primeiramente escrito, muitas das crenças nas quais o Movimento Moderno foi baseado ainda se mantinham e em boa ordem, e o que pareceu ser a segunda era da máquina, tão gloriosa como a primeira, acenou a nós nos “Fabulosos 60's" - minituarização, transistorização, viagens de jatos e foguetes, drogas-maravilha e novas químicas cosméticas, televisão e o computador pareceram oferecer mais do mesmo, somente melhor. O que tem sido prometido pela Primeira Era da Máquina, porém nunca cumprido, agora parece estar à nossa mão.

Todos os fenômenos listados acima são obra de atitudes culturais americanas. O excesso, a apropriação da tecnologia para o prazer e a domesticação da tecnologia são os principais motes do discurso, identificando a diferença de postura para com a Sachlichkeit alemã da primeira parte do século XX. 
Futurista de Marinetti e Sant'Elia como os pioneiros da formação da Architecture autre ${ }^{3}$. Mais tarde, em The Architecture of the Well Tempered Environment, Banham aborda os fenômenos da cultura construtiva americana que permitiram uma maneira alternativa de ocupação do espaço e controle do ambiente humano. O sistema de controle climático por consumo de energia e o condicionamento de ar se reproduziram na cultura americana, através os arranha-céus, casas, e automóveis. É a primeira linha de abordagem de Banham da figura do construtor das paisagens modernas, como uma população dotada de uma cultura construtiva suficientemente coerente para ser objeto de pesquisa. Encarada por Banham como responsável pelo projeto coletivo da paisagem, a população americana - e não somente seus arquitetos - foi objeto de pesquisa, bem como seus hábitos, cultura urbana e posicionamento a respeito da arquitetura moderna, apropriação de tecnologia e consumo de massa.

A propagação desse meio de ocupação do espaço, baseado no consumo expressivo de recursos naturais e no consumo de massa se difundiria pelo território americano, e permitiria a ocupação de territórios anteriormente inabitáveis pelo homem ${ }^{4}$. A ocupação americana atravessou o deserto do meio-oeste americano e colonizou as últimas fronteiras junto à costa do Oceano Pacífico. Em Los Angeles, essa cultura construtiva encontrou, em diversos aspectos, suas apoteoses em uma época de exuberância da economia nacional e costumes eminentemente americanos.

“Los Angeles é o meio-oeste elevado à última potência..." 5

Los Angeles: the Architecture of Four Ecologies tornou-se na comunidade acadêmica de arquitetura um exemplo e anti-exemplo de leitura da cidade moderna: em sua criatividade na manipulação dos termos originalmente apresentados por Anton Wagner ${ }^{6}$, Banham teceu não só uma crítica ao pensamento urbanístico moderno e reconstruiu o conceito de ecologia humana, bem como contribuiu para a formação de uma escola de estudos da paisagem cultural, centrada nas faculdades de Berkeley e UCLA ${ }^{7}$, na qual desde os anos 1950 John Brinckerhoff Jackson trabalhou para sua formação ${ }^{8}$. Em Scenes of America Deserta, o estudo da paisagem cultural se mescla

3 O termo em si surge posteriormente ao livro, publicado em 1960. Apenas em 1964, na publicação New Brutalism: ethic or aesthetic?

4 Ver em especial o capítulo "Towards Full Control", em The Architecture of the Well Tempered Environment, pp. 171-194

5 Reyner Banham apud. Michael Sorkin, “Explaining Los Angeles", in Exquisite Corpse: writing on buildings. London: Verso, 1994. Texto original: "Los Angeles is the Middle West raised to the flash-point...

6 A obra do Geógrafo alemão, conhecido nos círculos da UCLA como "aquele que percorreu Los Angeles a pé" influenciou a estrutura de narrativa de Reyner Banham. Die Zweimillionenstadt von Sudkalifornien estabeleceu o conceito de "ecologia humana" que amparou a estruturação da narrativa de Banham. Ver também o estudo historiográfico de Anthony Vidler, Histories of the Immediate Present (2008), no qual são apresentadas outras fontes literárias de Banham para sua obra sobre Los Angeles.

7 Ver o Capítulo 1 desta dissertação para maiores detalhes da trajetória acadêmica de Banham.

8 Em entrevista com o prof. Paul Groth, da Universidade de Berkeley e pesquisador do legado de J. 
ao confronto com as fronteiras da paisagem humana e os limites claros impostos pela natureza, e culmina no estudo antropológico do homem que insistentemente mantém sua agenda de colonização do deserto. Banham descreve as diversas facetas da ocupação moderna do deserto, citando os arquitetos Frank Lloyd Wright, seu discípulo Paolo Soleri, bem como figuras insólitas de nômades, desert freaks e eremitas reclusos em cavernas, e culturas indígenas ocupantes das escarpadas e cânions de Mesa Verde, as mesmas estudadas por Aby Warburg na virada do século XIX ao XX9. Em uma de suas últimas produções literárias, A Concrete Atlantis, Banham retorna ao tema da arquitetura moderna, desta vez para observa-la de um ponto de vista diametralmente oposto: quebrando o mito da estética vernacular industrial, Banham desvela o processo de apropriação da imagem da máquina original do parque industrial americano por parte dos pioneiros modernos. Le Corbusier, Erich Mendelsohn e Walter Gropius, contudo, são abordados apenas em sua obra intelectual, pois os protagonistas agora são os arquitetos e engenheiros americanos responsáveis pela difusão de tipologias industriais que formaram o ideário moderno sobre a estética produtiva: o silo de grãos e a fábrica de concreto, tijolo e vidro, as Daylight Factories ${ }^{10}$.

Uma das grandes contribuições de Banham para a historiografia é apontar para a necessidade e os meios de se estudar as paisagens construídas pelo homem. Sempre mantendo uma postura clara de historiador da arquitetura, Banham analisa os objetos, ruas, casas, celeiros, carros, fábricas, pontes, píeres e viadutos, não com a postura tradicional do antropólogo ou do geógrafo: conforme afirma Gabrielle Esperdy, para Banham não se trata de investigar os espaços como receptáculos das atividades humanas, mas de observar os objetos em si, como foram produzidos, e como são apropriados, com os critérios próprios da ciência da arquitetura ${ }^{11}$. A cada publicação, fica cada vez mais claramente delineado o perfil do homem americano, responsável pela construção dessas paisagens. Buscaremos encontrar o perfil desse indivíduo, desse cidadão americano de múltiplas origens e modos de construir seu próprio espaço, produto e reprodutor do mercado de consumo de massa que permeou o modo de vida americano por todo o século XX, de modo a entender quais foram as ferramentas criadas por Banham para ampliar o vocabulário da arquitetura moderna, em sua experiência de mais de 20 anos se debruçando sobre o conjunto construído nos

B. Jackson, fica patente a relação entre os dois pesquisadores - Jackson e Banham - nas discussões da academia de Environmental Design da Califórnia sobre arquitetura, paisagem e cultura. Ver o capítulo 1 desta dissertação para maiores detalhes.

9 Ver Scenes of America Deserta, pp.111-131. Argumento desenvolvido na monografia final da disciplina FLS-5365 - Artes da Memória: Espaço Arte e Narrativa, ministrada pela profa. Dra. Fernanda Arêas Peixoto, na Faculdade de Filosofia, Letras, e Ciências Humanas - FFLCH - no Segundo semestre de 2011, "A Memória da Máquina: Fotografia e os Monumentos Industriais da Arquitetura Moderna".

10 Ver os capítulos 1 e 2 do livro, nos quais as tipologias construtivas são abordadas - A Concrete Atlantis, pp. 23-180.

11 Ver Entrevista com a professora Gabrielle Esperdy, contida como anexo desta dissertação. 


\section{Estados Unidos.}

\section{Jovens ruínas industriais}

Ao se falar de arquitetura moderna americana, é importante ter o discernimento sobre as profundas diferenças entre arquitetura moderna nos Estados Unidos e Europa, e como cada expressão observou sua contraparte do outro lado do Oceano Atlântico. Arquétipos, mitologias e manipulações da história da arquitetura, imagens da paisagem construída pelo homem marcaram o período de surgimento das cidades modernas da Cultura Ocidental, desde os últimos anos de século XIX até a SegundaGuerra Mundial ${ }^{12}$. Essa sessão se dedicará a discutir como a ampliação das viagens transoceânicas realizadas por arquitetos, bem como a difusão da utilização da fotografia como ferramenta de pesquisa de arquitetura, contribuíram para a criação e destruição de mitos sobre a modernidade.

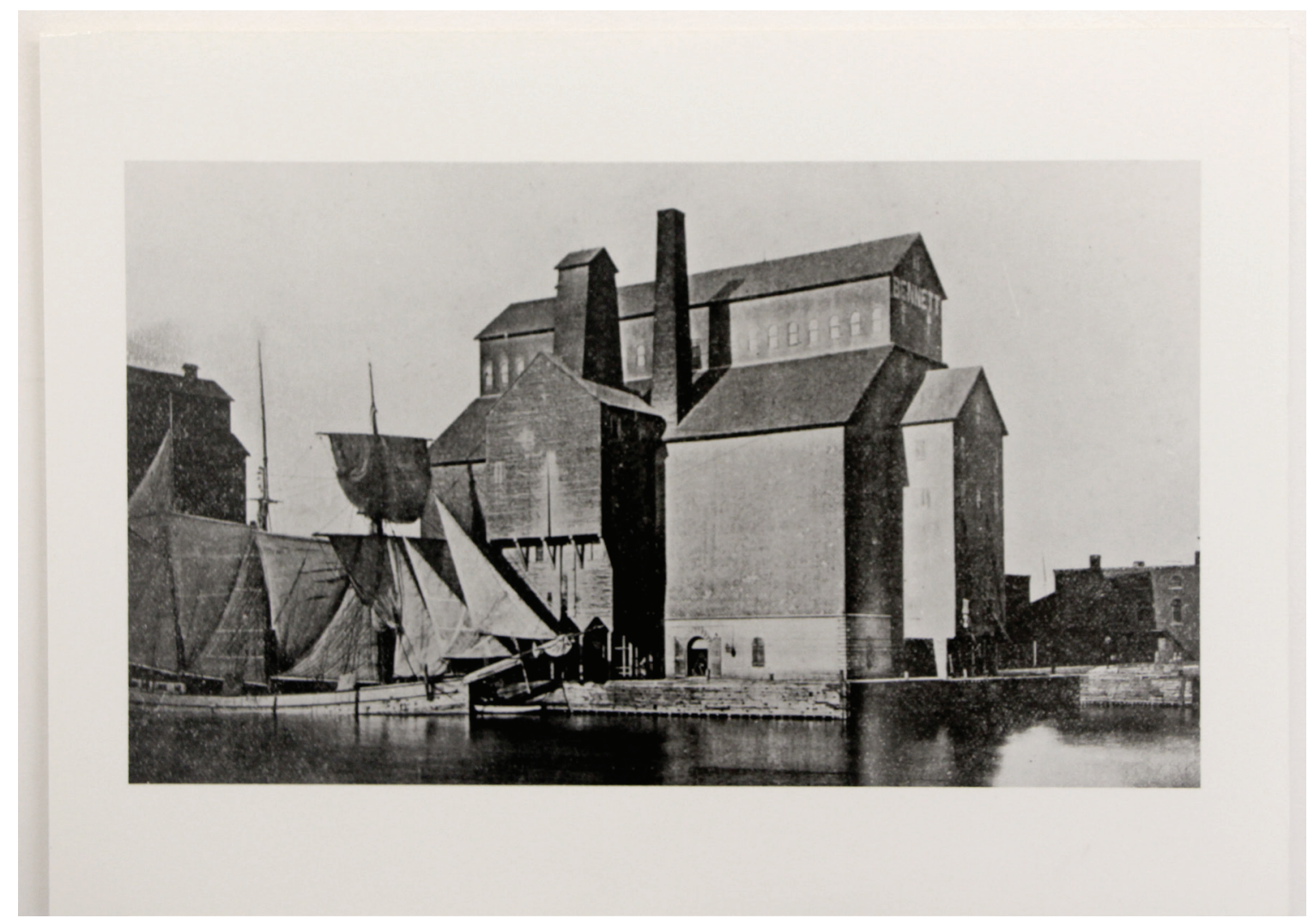

Elevador de Grãos e porto de carga, s/ data - provavelmente século XIX, pela ausência de braços mecânicos e . Nota-se o tipo de embarcação ao lado do elevador de grãos, este feito ainda em estrutura de tijolo e concreto, sem o formato de cilindros (tecnicamente mais econômico do que ambientes reticulados). Todas as imagens de construções industriais americanas foram reproduzidas na época de produção do

12 Menções curtas serão feitas a fatores sociais das diferenças, bem como sobre as relações entre instituições de ensino americanas e europeias. Para descrições mais generosas, ver o Capítulo 1 desta dissertação. 
livro A Concrete Atlantis, entre 1983-1986. São em sua maior parte de autoria de Patricia Layman Bazelon, e eventuais fotos do autor. Fonte: Arquivo Getty.

Nos Estados Unidos, a modernidade se deu pela difusão do espírito empreendedor e inventor oriundos do século XIX, no período de reconstrução pós Guerra Civil Americana ${ }^{13}$. Durante essa época, em cidades como Nova Iorque, Chicago, Boston, Los Angeles, San Francisco e Philadelphia, povos de múltiplas nacionalidades construíam paisagens de maneira diametralmente distintas. Desde sua fundação, até o final do século XIX, a América recebeu um grande contingente de imigrantes. Irlandeses, alemães, italianos, entre outros povos, tiveram participação fundamental na formação das culturas urbanas das cidades americanas. A escravidão terminava junto com a resistência dos confederados do sul, mas as marcas da separação racial são claras ${ }^{14}$. Com a expansão da malha de infraestrutura americana, e a difusão de algumas invenções na segunda metade do século XIX os Estados Unidos puderam modernizar seu parque industrial, bem como afinar as técnicas manuais, mecanizando as mesmas, como registrado por Siegfried Giedion em Mechanization Takes Command, de 1948 ${ }^{15}$. A mecanização do trabalho rural, bem como o aprimoramento da rede de transportes hidrográficos e a profissionalização da especulação imobiliária urbana tornou a prática de condensar unidades de logística em uma única área um negócio rentável. Cidades como Minneapolis, Chicago e Buffalo tornariam-se centros de logística e produção industrial. Os silos de grãos, representativos do patamar tecnológico alcançado pela iniciativa de empreendedores como Joseph Dart, inventor do sistema de transbordo em correia, foram também uma demonstração da capacidade dos construtores do país em alcançar a monumentalidade. Fábricas como tecelagens, onde o trabalho manual foi gradativamente cedendo espaço à mecanização, se desvencilharam dos moinhos movidos pela força da água, e se ampararam gradativamente na energia a vapor e na eletricidade, deixando locais inóspitos e ermos, para se adensarem em pontos de logística facilitada. Nascem as Daylight Factories, ou as "fábricas da luz do dia": plantas industriais dependentes da luz do natural para manter sua produção, em construções onde a massa é distribuída principalmente nas fachadas, em espessas paredes de construção, travadas por sistemas de assoalhos de madeira, ou grelhas de ferro fundido ou aço, cujo interios é iluminado por grandes superfícies de vidro nas laterais, ou pela cobertura. O sistema brick-and-pier foundation é uma evolução desse sistema: reforços estruturais são dados às paredes entre janelas, estas cada vez mais amplas, captando

13 Gwendolyn Wright, “Modern Consolidation, 1865-1893” em USA: Modern Architectures in History. London: Reaktion Books, 2007.

14 Idem. Ademais, como registrado por autores da literatura, a cultura americana foi tão marcada pela Guerra Civil, tanto pela explosão da tecnologia tanto quanto pela explosão demográfica da população negra e sua entrada na sociedade americana pós abolição.

15 Ver o primeiro trecho do Capítulo 1 desta dissertação para maiores discussões a cerca da obra de Giedion e suas relações com a produção americana. 
mais luz para o ambiente externo e permitindo o máximo de economia de luz ${ }^{16}$.

Já na Europa a força motriz permanecia no interesse por rever os conceitos e valores intelectuais e produtivos estabelecidos pelo século passado. A Primeira Era da Máquina imprimiu na memória coletiva europeia a imagem agressiva das paisagens industriais. Os movimentos de renovação do trabalho industrial propunham o retorno a valores do trabalho ligados ao trabalho dos artesões e a manutenção da qualidade do produto industrial, frente à demanda ampliada da sociedade moderna europeia. A Deutscher Werkbund, liga de industriais e intelectuais ligados à produção industrial alemã, da qual Walter Gropius e Peter Behrens eram afiliados, defendiam a recuperação da qualidade do produto industrial alemão a partir da primeira década do século $X X^{17}$.

O conhecimento prévio sobre quais foram seus respectivos pioneiros, construtores, pensadores, críticos, propagandistas, e difusores por si já nos oferece uma diferença inequívoca de vocações e genealogias. Como introduzido pelos primeiros movimentos do segundo capítulo, a cultura americana tem em seu radical elementos fundamentais da modernidade. O conceito de moderno encerra em si, contudo, uma polifonia suficientemente ampla para encontrarmos elementos diametralmente opostos nas pontas do espectro. Para a historiografia moderna, segundo Banham, tal polifonia não permitia a coerência necessária para um discurso necessário à agenda de autodivulgação do movimento moderno ${ }^{18}$. Enquanto Gropius trabalhava em paralelo seus dois aportes em sua carreira, um como arquiteto de prancheta, outro como promotor do ensino e pesquisa de arquitetura conforme os conceitos da Neue Sachlichkeit dentro da Bauhaus, Ernst Ransome, menos conhecido engenheiro de patentes de concreto e construtor de fábricas, foi um dos pioneiros no desenvolvimento de estruturas de concreto para conjuntos fabris, uma contribuição definitiva para a difusão das Daylight Factories pelo país ${ }^{19}$. As duas trajetórias, embora tangentes, são extremamente diferentes. Não obstante, é importante compreender porque a narrativa moderna privilegiou uma trajetória em detrimento da outra.

Modernismo e Americanismo, como descrito por Jean Louis Cohen, são movimentos que afetaram fortemente não só a cultura americana, bem como as demais culturas ocidentais na primeira metade do século $X X^{20}$. Poucas pesquisas, porém, trataram de relacionar os radicais da modernidade americana com a sua lógica industrial tão profundamente focada na simbologia das construções como Reyner Banham o fez para o conjunto construído industrial dos norte-americano.

16 Ver Banham, A Concrete Atlantis, pp.23-50.

17 Ver "Walter Gropius and the German Development" em Siegfried Giedion, Space, Time and Architecture: the growth of a new tradition, originalmente publicado em 1941, e revisado e expandido em sua quinta edição, datada de 1969.

18 Para entendimento da crítica de Banham a respeito do método seletivo e classificatório da historiografia moderna, ver Whiteley, Reyner Banham: historian of the Immediate Future, pp.33-37.

19 Para uma trajetória mais detalhada de Ransome, ver capítulo 2.

20 Ver Jean-Louis Cohen, Scenes of the World to Come: European Modern Architecture and American Challenge, pp.14-18. 


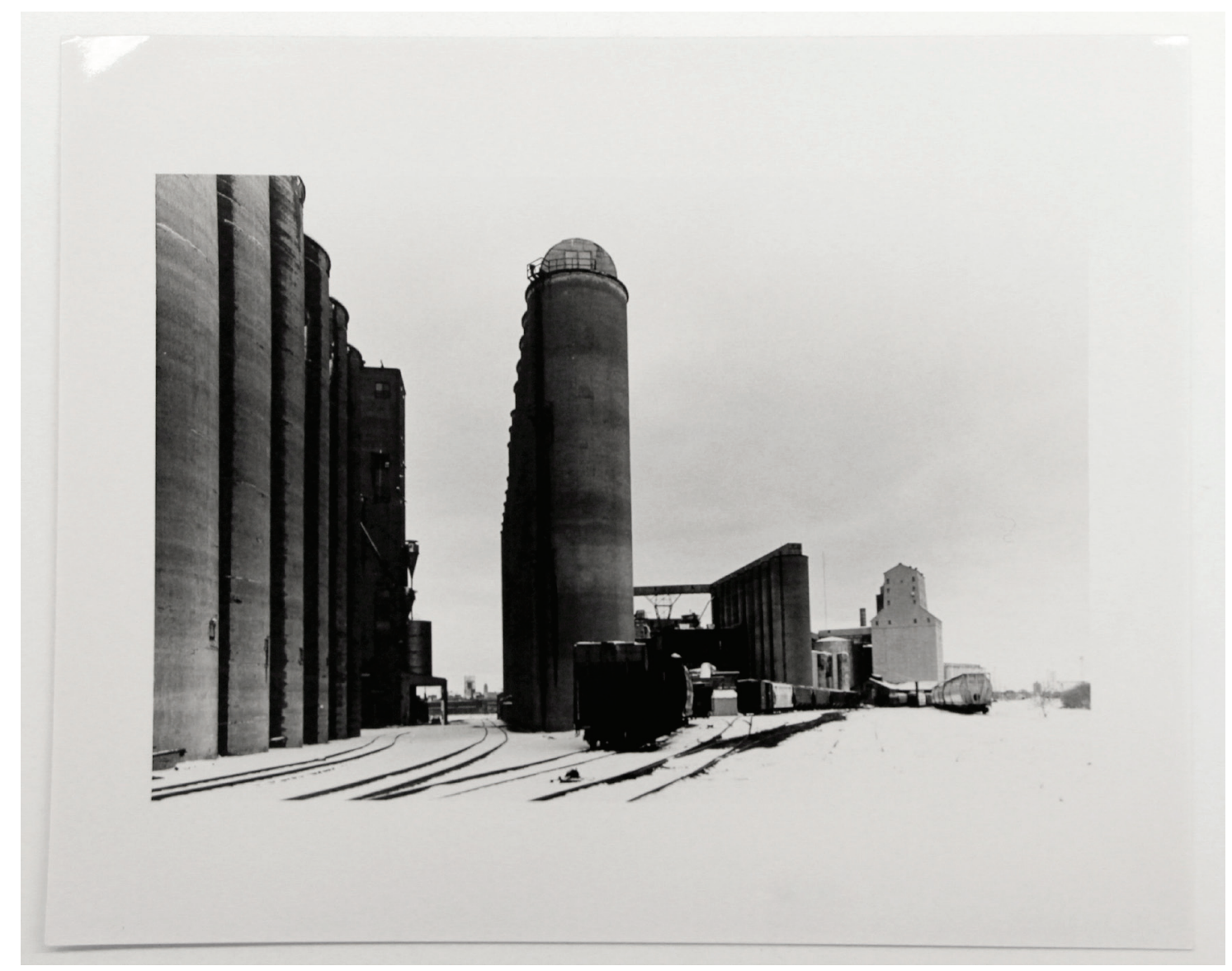

Silos e Elevadores de gãos, Buffalo s/data. Foto: Patricia Layman Bazelon. Fonte: Arquivo Getty. Em alguns casos, o que Banham encontrou foram plantas industriais ainda em funcionamento, como o caso desta unidade. Percebem-se os trilhos localizados entre os silos, e mais ao fundo, percebe-se o lago Eerie e suas instalações de transbordo. 


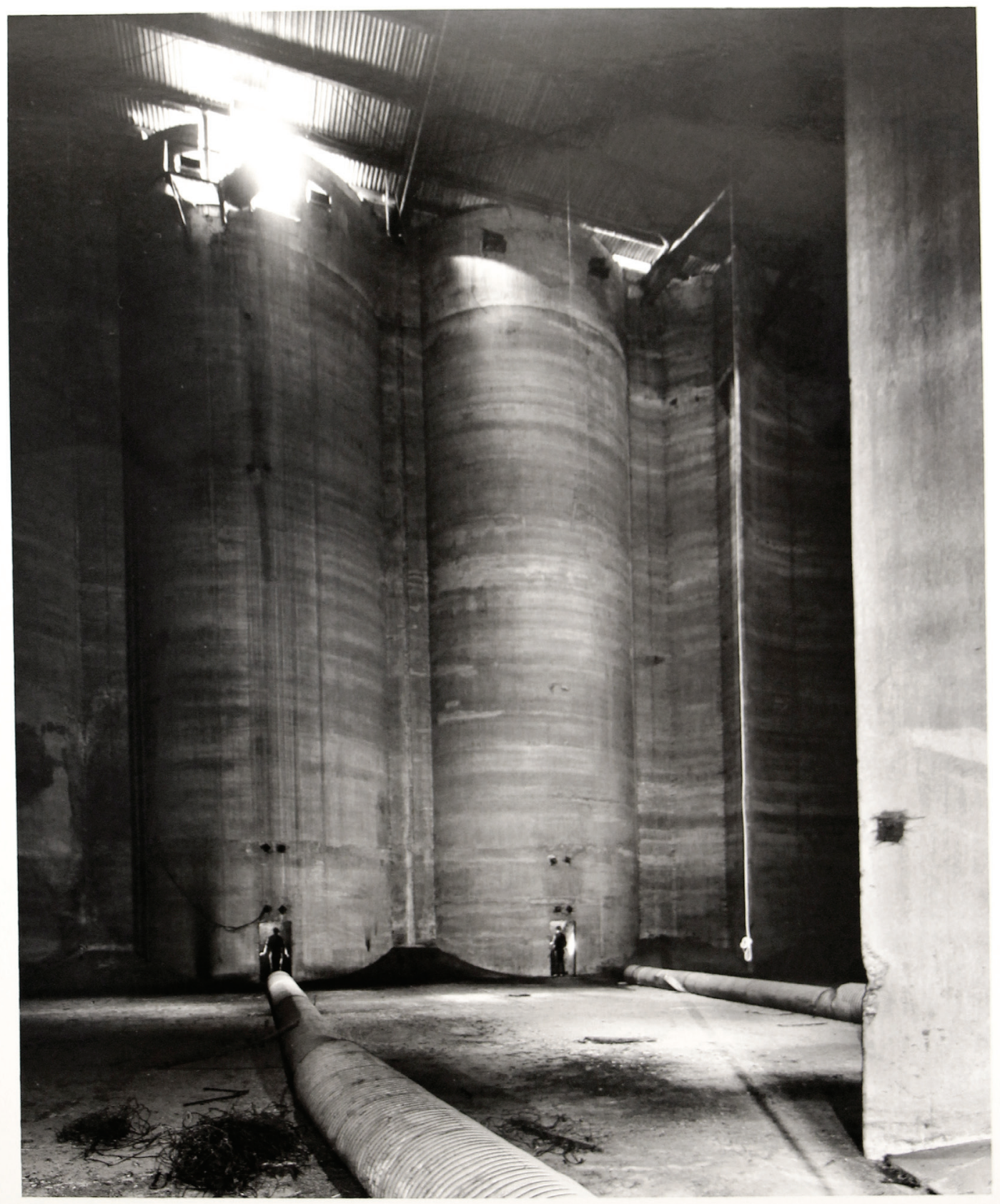

Interior de um elevador de grãos, s/ data. Foto: Patricia Layman Bazelon. Fonte: Arquivo Getty.

Reyner Banham pode não ter sido o primeiro a identificar o radical pragmático da cultura construtiva Americana ${ }^{21}$, mas certamente seus estudos do conjunto construído industrial americano trouxeram uma nova luz à questão da modernidade pela construção industrial. Mais do que isso, também se configura como um estudo

21 O mesmo atribuía muito do pioneirismo na pesquisa da arquitetura moderna Americana a HenryRussel Hitchcock, a quem dedicaria sua palestra de aceite da cadeira homônima no Institute of Fine Arts da Universidade de Nova Iorque, em 1988, meses depois de seu falecimento. O conteúdo do discurso pode ser acessado nos manuscritos de Banham, arquivados na Biblioteca do Getty Institute, de Los Angeles. 
contundente da materialização de uma era da construção civil americana, dentro da Primeira Era da Máquina, descrita em seu primeiro livro (1960). Malgrado de vida curta em seu próprio território, e talvez exatamente por isso, o parque industrial americano, e principalmente sua imagem registrada em fotos, teve um efeito marcante na cultura construtiva americana. Um dos principais elementos desse legado industrial é que o seu ciclo se acabou rapidamente, dando espaço a uma nova tipologia construtiva, por força da especulação imobiliária ao redor das áreas portuárias, e ao desenvolvimento da técnica moderna em construção de galpões de aço. Ao contrário das experiências de Maillart, Freyssinet, das unidades fabris da AEG de Peter Behrens ${ }^{22}$, essa geração de construções logo se tornou ruínas, elementos construídos parrudos e estanques, resistentes à ação do tempo e das intempéries pois assim foram projetados. Abandonados, fortaleceram a ideia de uma civilização perdida, uma Atlantis de concreto.

Como descreve Georg Simmel, em seu artigo "A Ruína” , a ruína da obra arquitetônica representa a vitória das formas da natureza sobre o espírito humano. Por vezes, os próprios homens, os mesmos que agem de acordo com as vontades do espírito, atraídos pela sedução estética da ruína, proporcionada pela força da natureza podem agir de alinhados com essas mesmas forças ${ }^{23}$. No caso da imagem arruinada das fábricas de tijolo e concreto da virada do século, temos de um lado a força da tectônica exposta sem véus das espessas paredes de tijolo, das placas de ferro fundido dos silos e dos maquinários, dos grafismos industriais característicos de cidades como Chicago e Nova Iorque, todos os quais corroboram para uma nostalgia de uma época idílica, na qual a indústria representava a vitória do homem sobre a natureza.

John Brinckerhoff Jackson, intelectual e pesquisador das paisagens culturais americanas ${ }^{24}$, apresenta no artigo "The Necessity for Ruins" como a cultura americana aprendeu a lidar com a nostalgia em relação ao seu passado local. Diferentemente da proposta europeia de preservação de seu patrimônio, e de locais, eventos e objetos específicos, segundo Jackson a cultura americana se preocuparia em preservar a ambientação histórica de um passado vernacular, anônimo e mítico ${ }^{25}$. Nos Estados Unidos, Jackson acusa existir uma proliferação de monumentos a heróis anônimos,

22 Ver Banham, "Germany: Industry and the Werkbund" em Theory and Design in the First Machine Age, pp.68-78

23 Ver Georg Simmel, "A Ruína”, em Simmel e a Modernidade, Brasília, Editora Universidade de Brasília, 1998.

24 A contribuição acadêmica de J. B. Jackson mais conhecida e difundida no Brasil é o periódico Landscape, editado entre as décadas de 1960 e 1970. A revista se dedicou a registrar uma resistência ao agressivo processo de urbanização de gentrificação nos Estados Unidos, recolhendo e registrando as imagens da paisagem cultural vernacular Americana - as quintas, as fazendas e seus celeiros e casamatas, as estruturas industriais, os subúrbios e as estradas e suas modalidades de ocupação do território. Para maiores descrições de sua contribuição para o pensamento da academia Americana, ver Capítulo 1 desta dissertação.

25 Ver J. B. Jackson, The Necessity for Ruins and other Essays, University of Massachusetts Press, 1980, pp. 89-102. 
figuras do passado vernacular, uma "Era de Ouro" perdida e utópica: o carteiro, o soldado, o cowboy, em suma, aqueles que ajudaram a construir a imagem moderna do país. Nesta era de ouro, não existem nomes nem datas, apenas um sentido de moral de "como as coisas deveriam ser", uma ordem natural há muito corrompida da vida cotidiana ${ }^{26}$. Nessa ordem natural, as ruínas industriais, imagens de uma conquista de hegemonia econômica e avanço tecnológico, os casulos abandonados das formas primitivas de industrialização, são necessárias para os americanos como lembretes do esforço coletivo de construção de uma nação. Banham, de alguma maneira, captou não só a maneira como os nativos se ampararam nessa imagem, bem como a operação efetuada pelos europeus. A figura do industrial "nobre selvagem" americano foi o mito principal criado pelo intelectual europeu ${ }^{27}$.

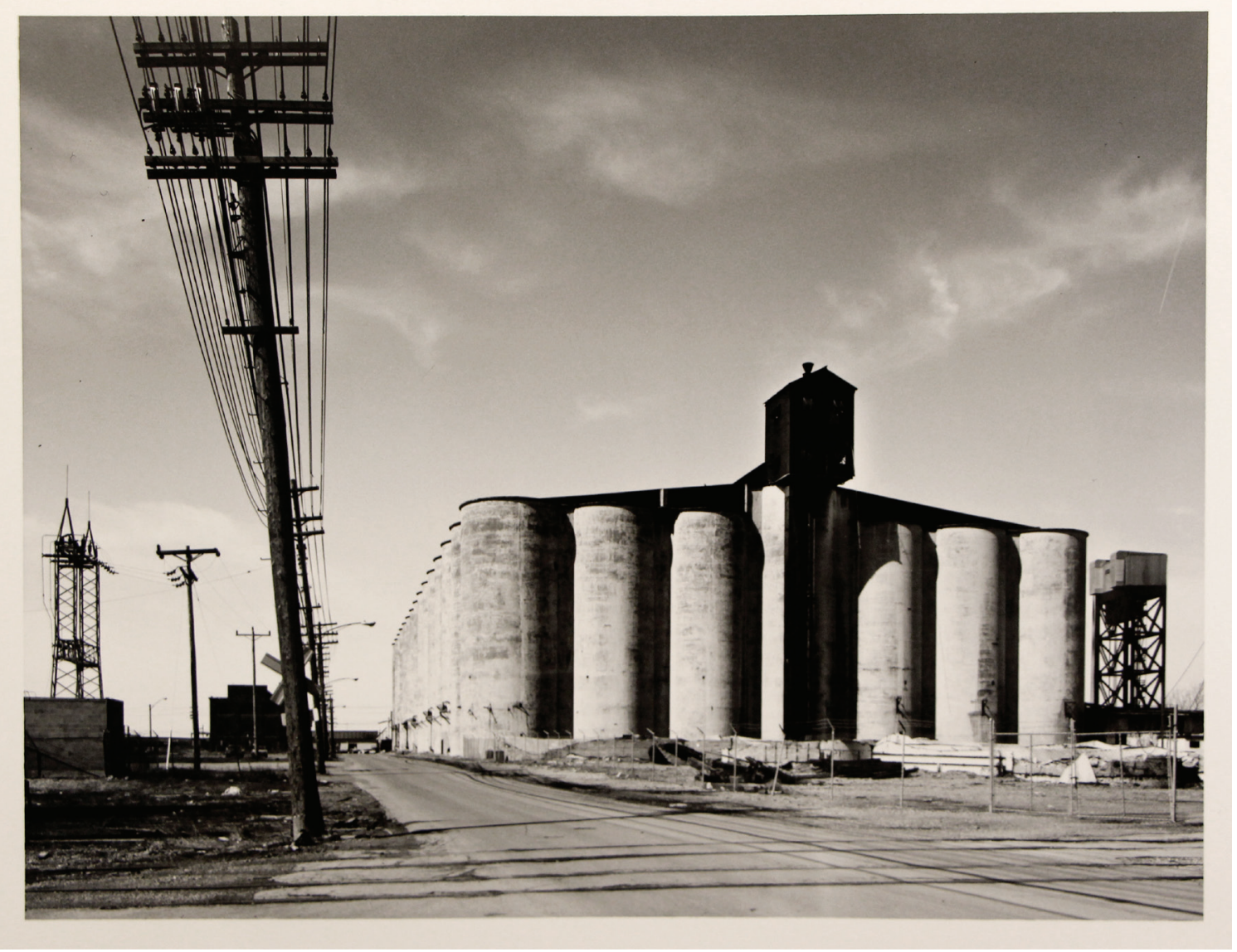

Elevador de Grãos, s/ data. Foto: Patricia Layman Bazelon. Fonte: Arquivo Getty.

“Orem também, poderá se dizer, para que os propagandistas da arquitetura europeia com eixos para destrinchar, e até mesmo para industrialistas monomaníacos europeus com visões de uma "fábrica americana". Nas palavras de Amedee Ozenfant,

\footnotetext{
26 Idem. pp.94-95.

27 Ver capítulo 2 desta dissertação para descrições sobre a figura do construtor americano idealizado pelo intelectual europeu.
} 
parceiro de Le Corbusier na política das artes e co-editor de L'Esprit Nouveau: “Aqueles que professam seu amor pelo maquinário costumeiramente provam ser colecionadores de antiguidades!" Europeus amantes de arquitetura industrial se provariam também próprios de antiquários - não somente os arquitetos modernistas, mas também o chefe da companhia de automóveis FIAT, Giovanni Agnelli, quem, possuído por visões americanas e ambições de produçãoo em massa, comissionou em 1916 uma cópia da fábrica (Old Shop) da Ford em Highland Park, a verdadeira América "arquitetura utilitária colossal de grande forma." Como disse Wilheim Worringer sobre os elevadores de grãos, esta poderia ser, de fato, uma "área da civilização sem mitos." Mas a Europa parece ser a terra-mãe da mitologia moderna." ${ }^{28}$

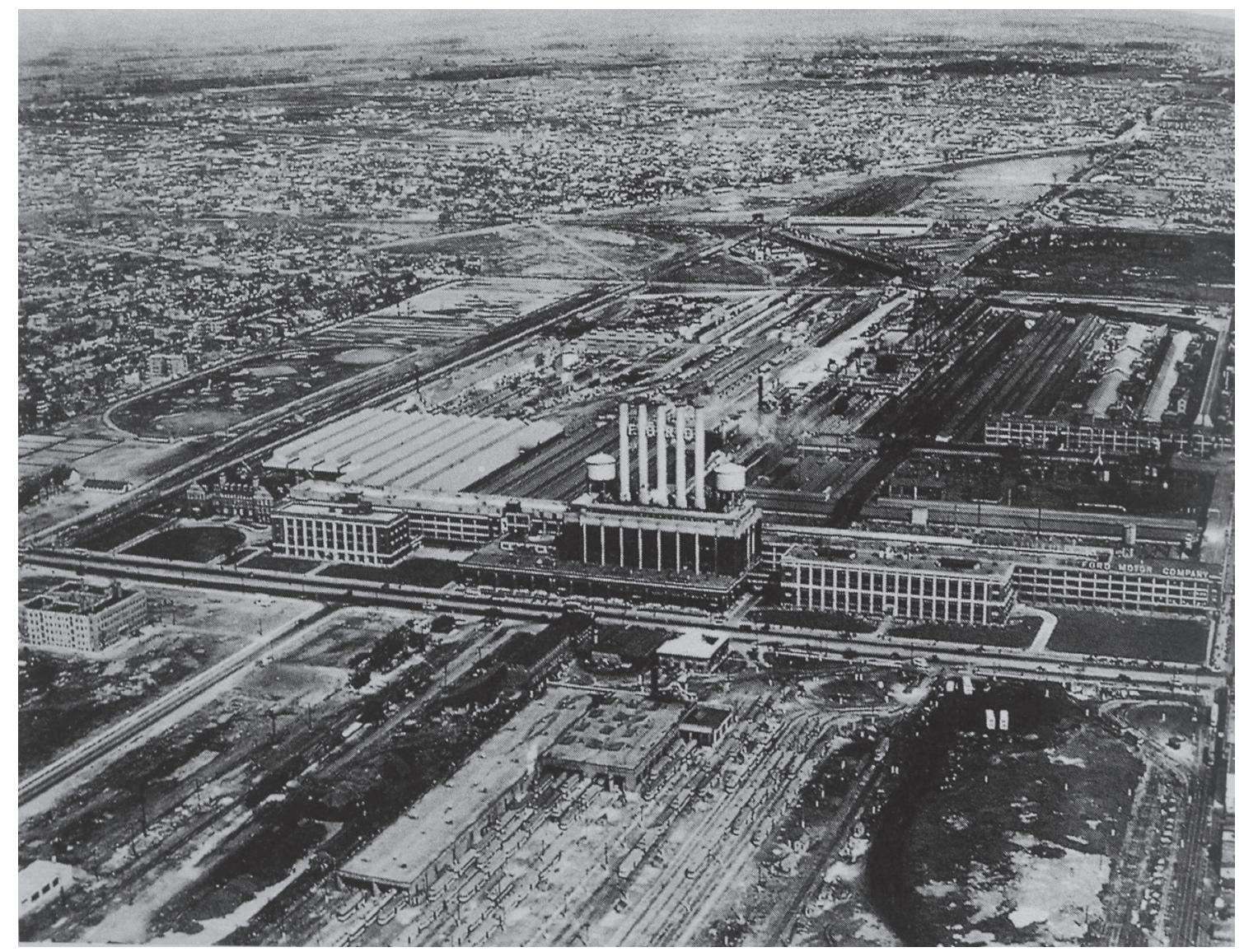

28 Ver A Concrete Atlantis, p.179. Texto original: Prey also, one might say, to European architectural propagandists with axes to grind, and even to monomaniacal European industrialists with visions of "an American factory." In the words of Amedee Ozenfant, Le Corbusier's partner in art politics and co-editor of L'Esprit Nouveau: "Those who profess to love machinery usually prove to be collectors of antiques!" European lovers of industrial architecture were also to prove to be antiquarians - not only the modernist architects but even the boss of the Fiat automobile company, Giovanni Agnelli, who, possessed by American visions and mass-production ambitions, commissioned in 1916 a copy of Ford's Old Shop at Highland Park, the real America of "colossal utilitarian architecture of great form." as Wilhelm Worringer had said of the elevators, might indeed be an "area of civilization without myths." but Europe seems to have been the motherland of modern mythology. Para estudos mais aprofundados da fábrica da Fiat em Lingotto, Turim, ver capítulo 2. 
Página anterior: Albert Kahn, Ford Motor Company: Highland Park, 1909-1918 - foto: Ernest Wilby, 1915. Fonte: Frederico Bucci, Albert Kahn: architect of Ford. New York: Princeton Architectural Press, 2002.

Essa mitologia moderna foi criada pelos arquitetos-idealizadores europeus, amparados pelo arcabouço da modernidade: viagens, fotografias, e publicaçõesmanifestos, nos quais emprestaram e manipularam tais imagens para criar o mito abstrato da industrialização. O fato de que a própria Ford aposentaria o sistema construtivo criado por Albert Kahn para Highland Park em favor de uma arquitetura alinhada com uma nova cadeia industrial contribuiu para criar ruínas com menos de 20 anos de idade. Cunhando de Atlantis moderna, ao contrário de Utopia moderna, Banham emprestou a esse conjunto construído uma genealogia própria, cunhada no saber técnico desvinculado de pretensão estética. Para ele, tais construções mereciam ser abordadas como protagonistas de uma investigação histórica, deixando desta vez as produções europeias como avaliações secundárias. Dessa maneira, Banham teria fechado um arco de crítica à historiografia moderna aberto em 196029.

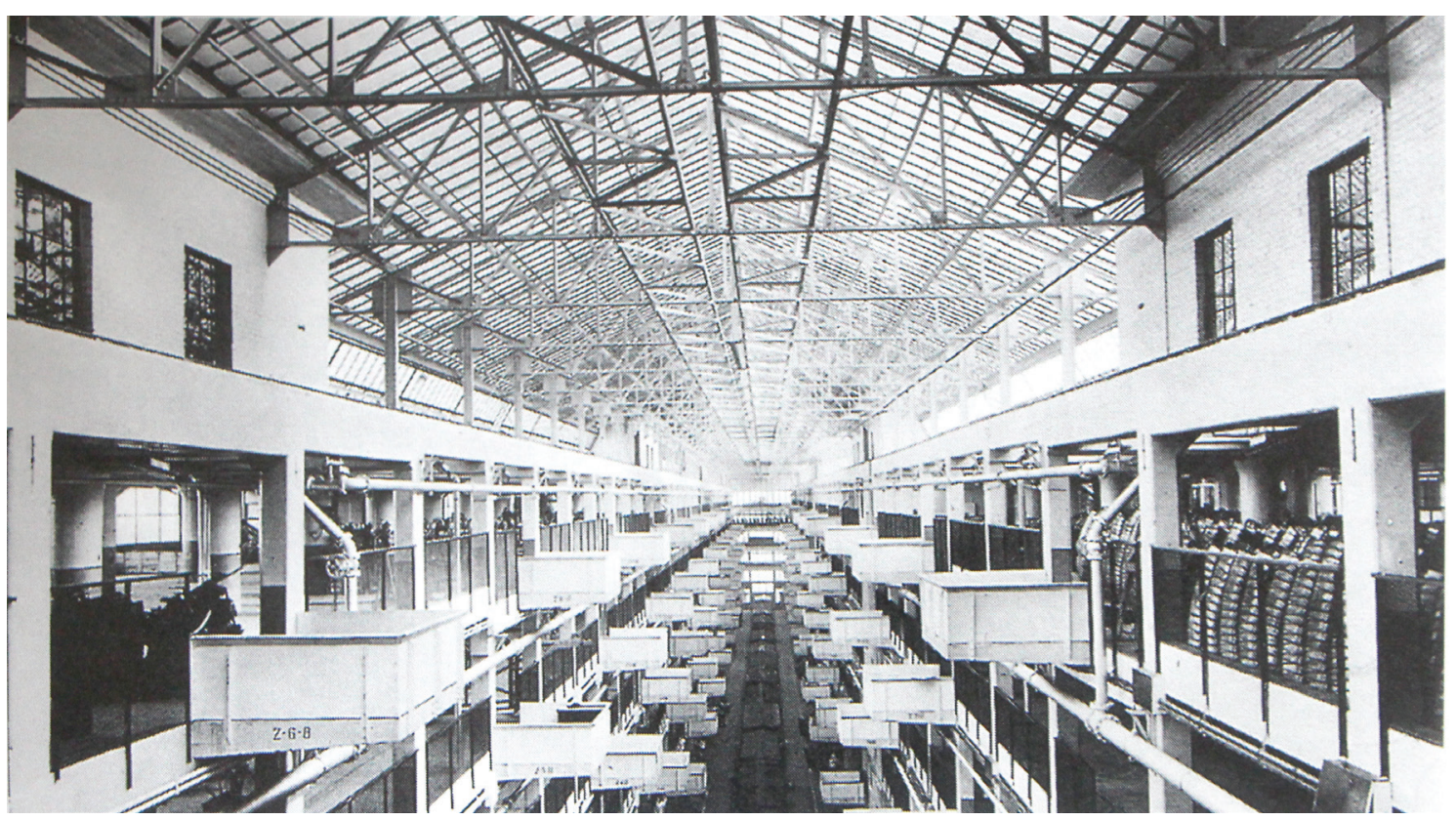

Albert Kahn, Ford Motor Company: Highland Park, 1918 - foto: Ernest Wilby. Fonte: Frederico Bucci, Albert Kahn: architect of Ford. New York: Princeton Architectural Press, 2002.

Eric Mendelsohn, com suas fotos tiradas em sua visita aos Estados Unidos no ano de $1923^{30}$, é a única testemunha ocular dessas construções na época da publicação do livro de Corbusier, Vers Une Architecture, e antes da formação do sistema pedagógico da Bauhaus. É um dos responsáveis pela disseminação das imagens do conjunto construído americano como produto da modernidade. Em pouco tempo, segundo

29 Arco aberto por Banhamcom o livro Theory and Design in the First Machine Age, mais especificamente no capítulo "Estética Fabril"

30 Eric Mendelsohn, Amerika: 82 photographs, editado por Rudolf Mosse. Berlin: Buchverlag, 1926. 
Banham, as imagens das fábricas americanas e dos "Silo Dreams" de Mendelsohn, e das publicações do periódico L'Esprit Nouveau, até a publicação de Vincent Scully, American Architecture e Urbanism, já de 1969, estas imagens tornaram-se quase um lugar comum, dada sua vasta divulgação ${ }^{31}$. As fotografias entraram no ideário moderno, como imagens-símbolo do modernismo. Banham se põe como desafio para a publicação investigar as razões para tão vasta proliferação dessas imagens, e porque os arquitetos europeus modernos as elevaram como símbolos da modernidade, ao contrário de outras edificações da época. O termo "nobre selvagem" é usado por Banham para qualificar esse tipo de modernidade exótica, de mesmo radical que o Jazz, arraigada em um primitivismo semelhante ao que inspirou a arte abstrata das vanguardas. ${ }^{32}$

“(...) tendo chegado às mãos de seus admiradores europeus na forma de novas fotografias, ao invés de uma fotografia "de arte", eles estariam supostamente livres destes elementos de seleçãoo pessoal e interpretação, inevitavelmente infectados por representação artística, ou até por produção tradicional de desenhistas de croquis com arte-final de medidas tomadas em campo. Essas fotografias representavam a verdade como aparentemente objetiva e moderna das estruturas funcionais que elas retratavam." 33

Podemos nos arriscar a dizer que a imagem da arquitetura moderna americana mais madura foi dada anteriormente, por Eric Mendelsohn (1887-1953), que talvez seja aquele dentre sua geração que operou com mais lucidez sobre a paisagem Americana industrial. $\mathrm{O}$ fato fundamental para seu destaque é o simples fato de que ele não só foi um dos poucos autores que visitaram o continente antes de 193034, bem como foi o único que realizou uma viagem mais profunda dentro do continente. Visitou as cidades da costa leste americana, identificando motivos da paisagem urbana que simbolizassem os valores da modernidade. Mendelsohn registra os locais do ponto de vista do cidadão: os arranha-céus são vistos da calçada. A névoa da noite e o ofuscamento das luzes da cidade compõem algumas das imagens. As legendas das fotos e o prefácio da compilação publicada de suas fotos, datada de 1926, são marcantes. Demonstram a maturidade em relação às leituras de seus colegas europeus, e apontam para o risco do romantismo exacerbado em relação ao progresso americano. Também apresenta o reconhecimento de uma modernidade dotada de um histórico e uma genealogia diferente

31 Reyner Banham, A Concrete Atlantis, pp. 11-15

32 Reyner Banham, A Concrete Atlantis: pp.15-18

33 Idem, pp.18. Texto original: (...) Having come into the hands of their European admirers in the guise of new photographs, rather than that of "art" photography, they were supposedly free from those elements of personal selection and interpretation that must inevitably infected by artistic rendering, or even the traditional production by architectural draftsmen of finished drawings from measured field notes. Those photographs represented a truth as apparently objective and modern as that of the functional structures they portrayed.

34 Banham resgata também Moizei Ginzburg, que realizou viagem ao continente Americano em 
da europeia: mais intrínseca ao progresso tecnológico e industrial. Para Mendelsohn, antes de Banham, a arquitetura do mecanismo se realizava na América, sem o peso da tradição inerente ao conflito da modernidade europeia.

"A realidade dos EUA - Os Estados Unidos da América - é costumeiramente vista na Europa por olhos de admiração, ao invés de olhos conscienciosos.

O preconceito romântico é uma das razões para o desconforto com o qual um recémchegado se aproxima de um amplo corte transversal deste país.

Por, onde quer que o velho continente está desistindo de sua até então cultura uniforme, este é forçado a faze-lo assim por conta da influência destrutiva das ciências naturais, mesmo um século de explosão populacional e crescimento de produção baseado na máquina não puderam romper completamente a resistência de mil anos de civilização." ${ }^{35}$

Em corpo presente, sua percepção das obras americanas é muito mais rica que as primeiras impressões de Gropius e Le Corbusier. É acrescentada a percepção de movimento à experiência estética, na percepção do maquinário das fábricas, no movimento dos trens e dos automóveis. As referências futuristas de Giacomo Balla e Umberto Boccioni são claras na percepção dos feixes de luz. A distorção Seguem as descrições das fotos das fábricas americanas capturadas pela camera de Mendelsohn, principalmente do registro dos silos de grãos, em Chicago e Buffalo. Neles, revisamos o americanismo por Mendelsohn: denotamos a capacidade de dicernimento sobre os potenciais de engrandecimento; as estratégias para domesticar os elementos fabris à estética das edificações da época ${ }^{36}$; riscos de uma modernidade barbárica e inconsciente de seu próprio impacto no ambiente e nas cidades:

“A América está ainda tão focada no período de exploração, da função primitiva de necessidades diárias, que não tem tempo para pensar sobre si mesma, sobre o significado de sua vivência cheia de vida.

Esse país dá tudo: o pior estrato da Europa, abortos de civilização, mas também esperanças por um novo mundo." 37

35 Ver Mendelsohn, p.ix. Texto original: The reality of the U.S.A. - the United States of America - is usually seen in Europe through admiring rather than conscientious eyes.

"The romantic prejudice is one of the reasons for the unease with which a newcomer approaches the broad cross section of this country."

"For, whereas the old continent is giving up its hitherto uniform culture, is forced to do so by the destructive influence of the natural sciences, even a century of population explosion and machine-based increase in production cannot completely break the resistance of a thousand years of civilization.

36 Em A Concrete Atlantis, Banham identifica a mesma questão do ornamento, reconhecendo não como uma fraqueza conceitual, mas como um momento de transição, no qual o experimentalismo com a ornamentação foi presente.

37 Ver Eric Mendelsohn, pp IX-X. Texto original: Americans attempt to make this unwieldy largeness 
Mendelsohn capta a poética dos processos logísticos: o transbordo, o transporte, o carregamento. Para ele, formas puramente práticas adquirem beleza abstrata pelo seu desejo latente por organização. Não são ruínas para o que Mendelsohn olha, nem para o passado. É nas apostas do futuro que escolhe por se focar na identificação dos elementos da indústria - disciplina, ritmo, organização - capazes de guiar o desenvolvimento da modernidade americana.

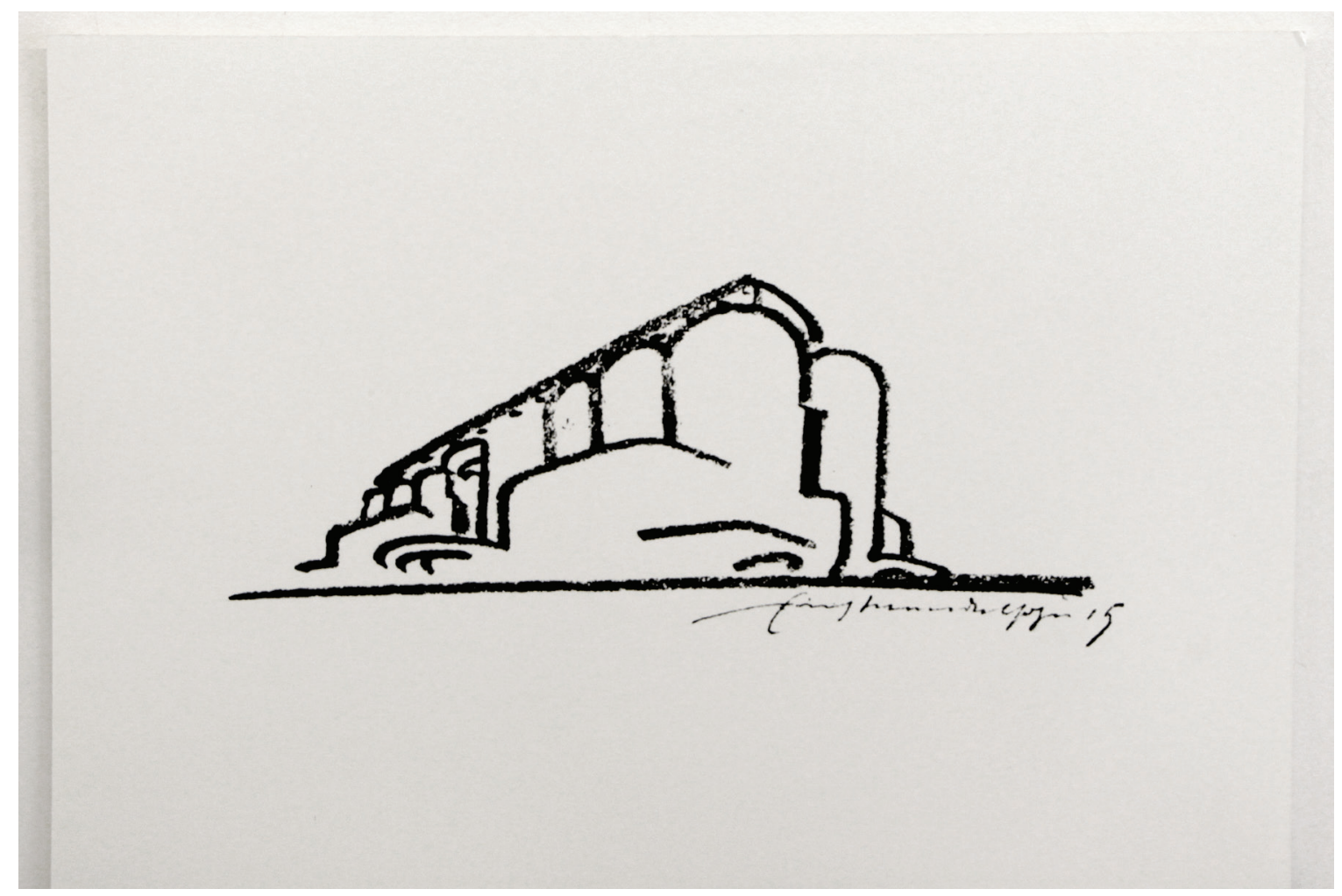

Eric Mendelsohn, croqui dos silos de grãos, s/ data. Fonte: Arquivo Getty.

acceptable to themselves and to us by applying decorative elements on an human scale even to their monstruous creations. But still do not realize that size alone is only one size of the equation, which is worthless when taken alone, and is no solution.

"America is still so mired in the period of exploitation, of the primitive function of daily needs, that it has no time to think about itself, about the meaning of its lively lifelessness."

"This country gives everything: the worst strata of Europe, abortions of civilization, but also hopes for a new world." 


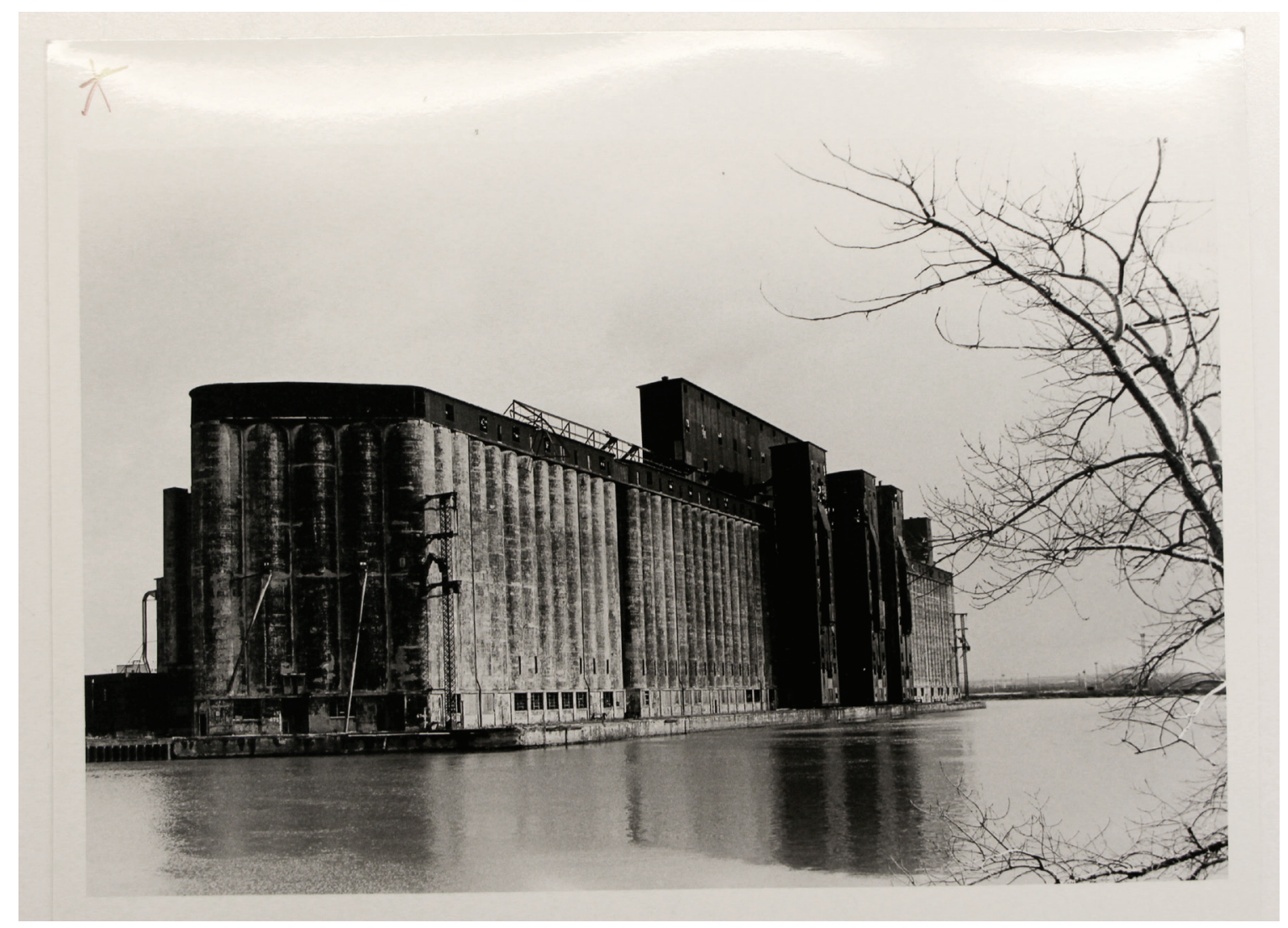

Lago Erie, Cargill Superior Grain Elevator, s/ data. Foto: Patricia Layman Bazelon. Fonte: Arquivo Getty. Elementos metálicos leves já teriam sucumbido à ação do tempo; já o monolito de silos de grãos, erguido em concreto armado, permanece resistente ao processo de ruína.

Não foi pela ausência de precedentes pessoais que Banham se sensibilizou pelo impacto das fotografias difundidas no meio da arquitetura dos anos 1920. O interesse de Banham pela fotografia data do começo de sua carreira, e é uma de suas principais ferramentas de pesquisa. A exposição Parallels of Life and Art, da qual Banham participou juntamente a Eduardo Paolozzi, Nigel Henderson e os Smithsons, em 1953, é uma amostra da força da fotografia na linguagem do grupo de Banham ${ }^{38}$. Tim Benton, um dos autores convidados a contribuir com a compilação póstuma de Ainsley e Atkinson ${ }^{39}$, abordou a importância das imagens no raciocínio histórico-crítico de Banham $^{40}$. Amparado pelo estudo comparativo dos recursos gráficos das palestras de

38 Para maiores detalhes do da geração do Courtauld Institute dos anos 1940 e 1950, do Independent Group e da formação de Reyner Banham no Reino Unido, ver capítulo 1.

39 Ver Tim Benton, "The Art of the Well-Tempered Lecture”, em Ainsley, Jeremy, Atkinson, Harriet (ed.). The Banham Lectures: essays on designing the future, Cambridge: The MIT Press, 2009

40 De fato, uma das constantes nos arquivos de Banham depositados no acervo do Getty Research Institute, em Los Angeles, é a lista de slides que normalmente acompanhava os manuscritos de palestras ministradas. Nota-se como as seleções de imagens selecionadas para uma palestra amadureceram para se tornarem as seleções de imagens de suas publicações. Ademais, nota-se a frequência na qual Banham aplica notas em post-its nas fotografias, acrescentando comentários e referências às imagens registradas, seja por ele, seja por fotógrafos como Tim Street Porter e Patricia Layman Bazelon, que acompanharam Banham em suas últimas pesquisas de campo ligadas a publicações de livros. 
Banham e Corbusier, Benton analisa como a retórica de Banham através das imagens se alimentou da referência corbusiana ${ }^{41}$. Somente através das fotos, fora possível criar o mito.

"A veracidade da camera é proverbial, mas quase todos os provérbios tomam uma perspectiva unilateral da vida. A verdade pode ser mais estranha que a ficção, mas muitos dos depoimentos das câmeras são mais estranhas que a verdade em si. Nos tendemos a esquecer que toda fotografia é um artefato, um documento recordando para sempre uma construção momentânea baseada na realidade. Instantânea, ela zomba do monumental; atemporal, ela monumentaliza o grotesco." ${ }^{42}$

Banham tira a indústria americana do terreno da memória, no qual a fotografia é indiscutível e não dissociada de seus discursos, e nos leva ao campo da história. Não são mais formas belas, frutos de nobres selvagens, e sim obras de empreendedores, capitalistas do ramo da construção civil e da produção industrial, os quais deram formas ao parque industrial americano. Albert Kahn, Reidpath, Ransome, Persico, estes profissionais são alçados ao patamar de "heróis" da modernidade por Banham como parte de sua crítica à historiografia hegemônica da época de sua formação, a qual não teria sofrido uma revisão crítica consistente até o momento da publicação de Concrete Atlantis.

"o que se vê são aquelas 'forma belas, as mais belas formas" exaltadas por Le Corbusier, puras e organizadas porém negras contra o verde da grama e arbustos do verão - ou de maneira mais sensacional - preto contra a neve fresca recém caída do inverno. O conceito de Wilheim Worringer, do geométrico e abstrato como marca do primitivo em todas as culturas e artes - a fonte da crença de Walter Gropius de que os engenheiros americanos retiveram algum sentimento aborígene por große, knapp, gebunden Form (sentimento por formas grandes, esparsas e compactas) fresco e intacto, e que seus trabalhos eram portanto comparáveis aos sobreviventes do antigo Egito - toda aquela superestrutura europeia de estética e sensibilidades culturais

41 Ver Mark Haworth-Booth, "Banham and Photography" in Ainsley e Atkinson, The Banham Lectures: Essays on Designing the Future. New York: Berg, 2009. O fotógrafo Mark Haworth-Booth, outro contribuinte para a compilação de artigos de Ainsley e Atkinson, analisa os três papéis que a fotografia exerceu na carreira de Banham: as fotografias manipuladas por Reyner Banham, e como Banham reinterpreta o uso das fotografias por parte dos arquitetos modernos e críticos modernos - Corbusier, Gropius e Mies, Pevsner, Giedion e Hitchcock; como e em que situações Banham fazia uso de sua própria visão, e dentro de sua dinâmica de crítico-observador, como essas imagens se transformavam em argumentos; e como Banham se colocava como personagem de suas próprias fotos

42 Reyner Banham, "Photography." em Architectural Review, outubro, 1953. Texto original: The Veracity of the camera is proverbial, but nearly all proverbs take a one-sided view of life. Truth may be stranger than fiction, but many of the camera's statements are stranger than truth itself. We tend to forget that every photograph is an artifact, a document recording forever a momentary construction based upon reality. Instantaneous, it mocks the monumental; timeless, it monumentalizes the grotesque. 
começa a fazer sentido quando se vê essas formas francas e abstratas em alto-contraste contra a igualmente abstrata superfície da neve. Se a sarcástica referência tardia de Worringer a alguma 'Metafísica definitiva da Forma' a ser encontrada na América do Norte contém a metáfora de substância para mim, é em vista dessas formas persistentes, rebaixadas sob um pesado céu de inverno, sem amor mas com respeito cativante, da ética de trabalho Protestante monumentalizada." ${ }^{43}$

Além de ter sido celeiro de um grande parque industrial em um curto espaço de tempo, cidades como Buffalo também se tornariam um acervo de ruínas, tendo visto a dificuldade de demolição de tais estruturas robustas. Em pouco tempo, o ar decadente de tais estruturas, fósseis de incríveis vinte anos de idade já percorreriam a memória coletiva como espaços assombrados, melancólicos, soturnos, passiveis de morada de facínoras e espectros. Banham descreve, em correspondências com os editores da MIT Press, sobre seu processo de investigação às unidades fabris americanas ${ }^{44}$. Em algumas ocasiões, Banham navegou pelo lago Eerie, para capturar a paisagem portuária da região dos silos de grãos. Banham não se furta a reconhecer a dramaticidade da cena: grandes blocos de concreto e tijovo, marcados pela ação do tempo, mas ainda predominantemente erguidos frente ao lago. A ação do tempo deixaria marcas nestas fábricas, mas também provaria a perícia dos seus arquitetos e engenheiros. O interesse era desmistificar os monumentos dos "bons selvagens americanos", eternizados nas fotografias da vanguarda moderna. Através de uma leitura mais atenciosa das obras, Banham as tiraria do anonimato e lhes daria lugar na história, mas as tirou também do lugar do mito.

43 Reyner Banham, A Concrete Atlantis, p.136. Texto original: What one sees are those 'beautiful forms, the most beautiful forms' praised by Le Corbusier, pure and uncluttered but black against the green of the summer grass and scrub - or more sensationally yeat - black against white-fresh fallen snow in winter. Wilheim Worringer's concept of the geometrical and abstract as the mark of the primitive in all arts and cultures - the source of Walter Gropius's belief that American engineers had retained some aboriginal Sinn fur grosse, knapp, gebunden Form (feeling for large, sparse, compact form) fresh and intact, and that their work was therefore comparable to that surviving from ancient Egypt - all that European superstructure of aesthetics and cultural sensitivities begins to look like good sense when one sees these blunt abstract forms in high contrast against the equally abstract surface of the snow. If Worringer's later sneering reference to some "ultimate Methaphysic of Form" to be found in North America has a metaphor of substance for me, it is in the sight of these grudging, lowering shapes crouched under a leaden winter sky, unlovable but compelling respect, the Protestant work ethic monumentalized.

44 Correspondências trocadas com Debbi Edelstein e Roger Conover, nas quais Banham descreve o processo de visitas às fábricas, acompanhado, em algumas ocasiões, pela fotógrafa Patricia Layman Bazelon. Ver a ficha descritiva dos manuscritos de Reyner Banham na biblioteca do Instituto Getty, em anexo nesta dissertação. 


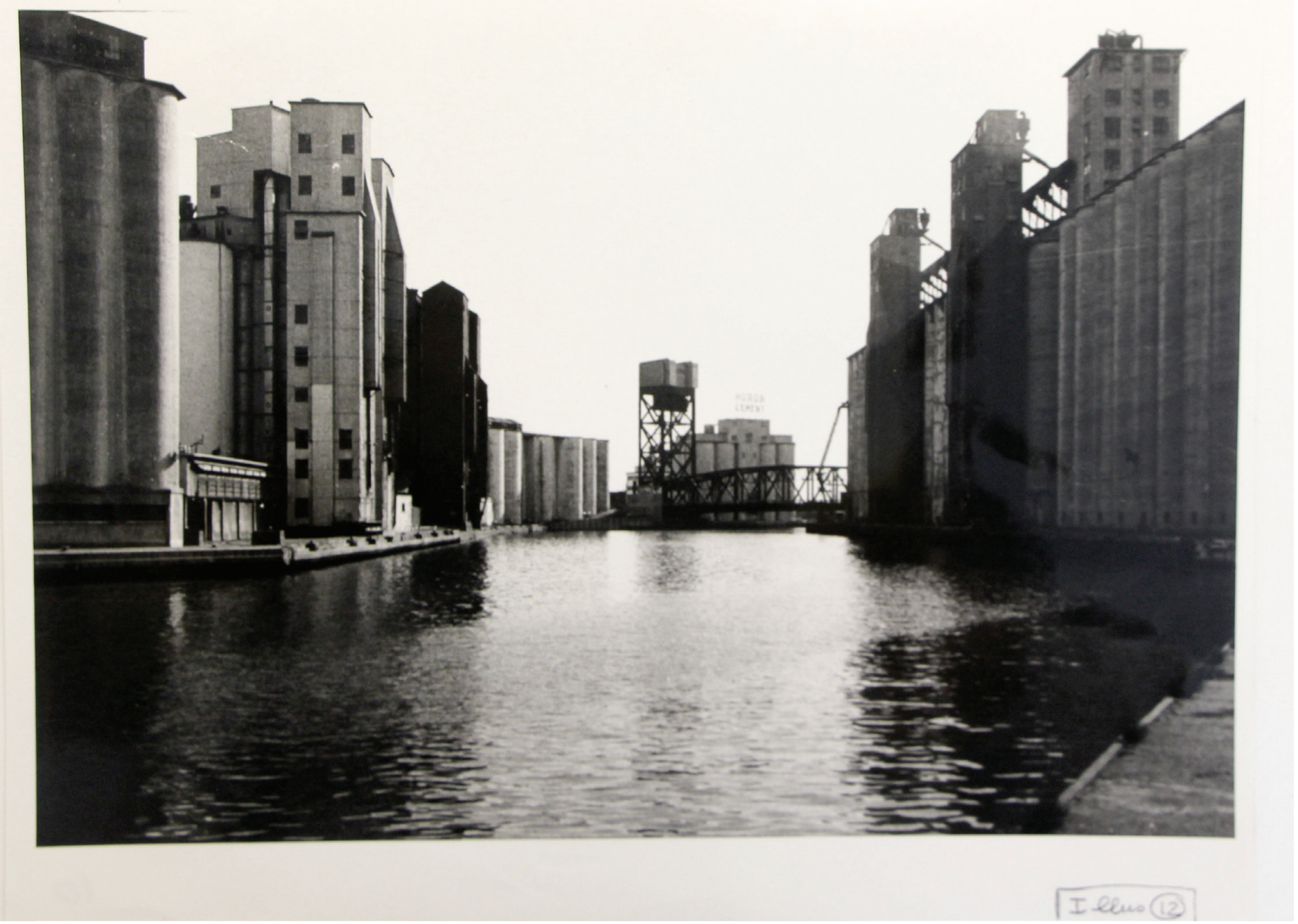

Buffalo, canal do lago Eerie, s/ data. Fonte: arquivo Getty. 


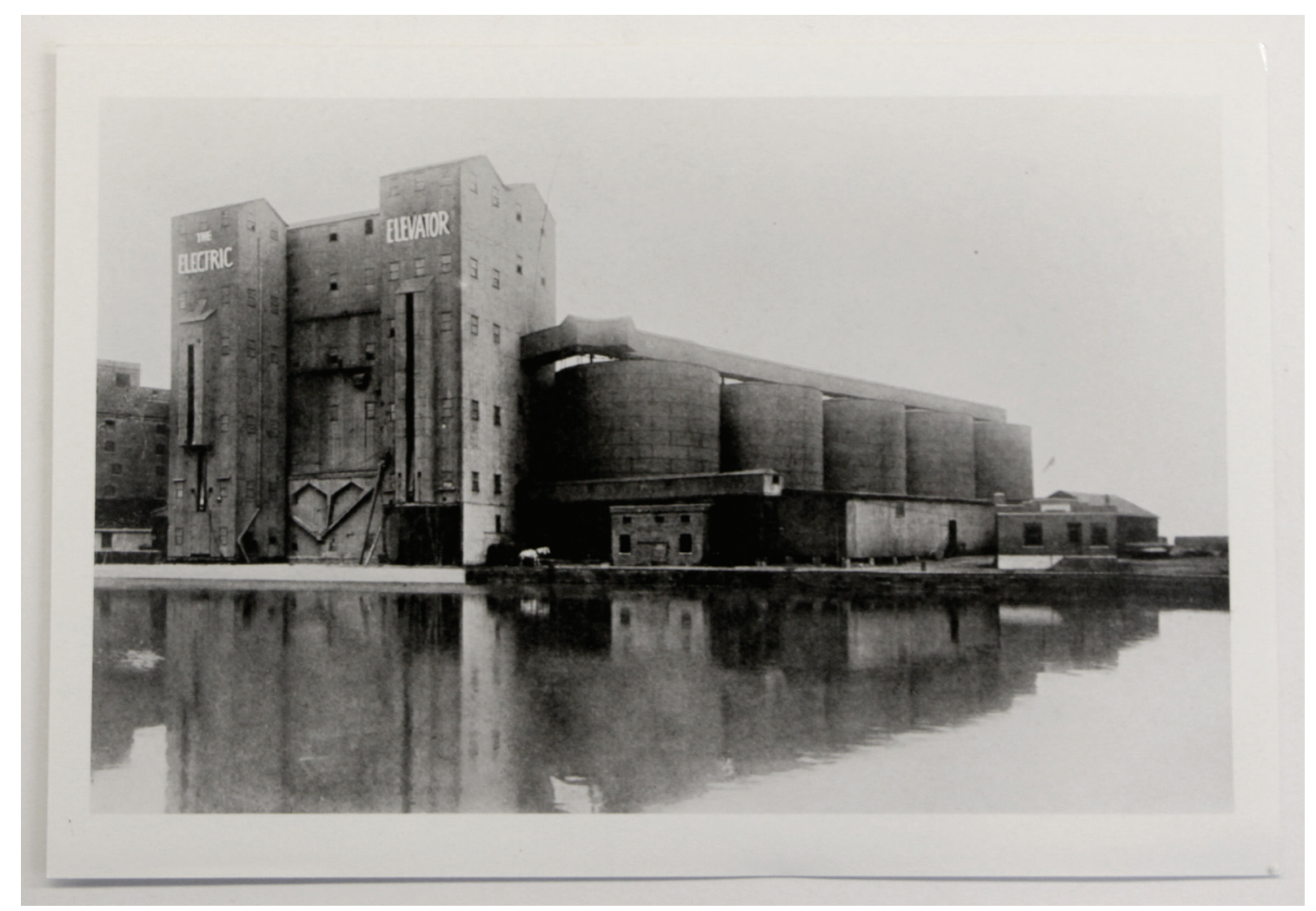

Eletric Elevator, Buffalo, s/Data. Fonte: Arquivo Getty. Provavelmente, uma foto de autoria de Patricia Layman Bazelon.

\section{América Deserta}

A verdadeira e discreta exuberância, no rigoroso ambiente do deserto do Mojave, entre 3 estados do meio oeste americano - Arizona, Novo México e Nevada é o espaço coletivo de clima controlado, para sustentar a permanência do homem no deserto ${ }^{45}$. Agressivo e impiedoso, vasto demais, no deserto não se configura como um cenário propício para a ocupação humana tradicional. A noção de escala do deserto, de concentração populacional, da escala do pedestre, todos estes parâmetros da urbanização europeia moderna perdem seu sentido neste meio. No deserto americano, Banham encontra o limite para a cultura construtiva americana de alto consumo de energia em relação à natureza. A natureza põe a prova a beleza das ruínas americanas, já diria Banham, ao citar a cidade de Las Vegas. Banham se faz valer dos elementos da ocupação do território desértico para abastecer a narrativa de Scenes of America Deserta. Ali seu objetivo é se tornar um 'desert freak,' um andarilho, explorador e admirador das paisagens do deserto, e construir uma narrativa tradicional dos livros de viagem para narrar uma história dos limites da ocupação urbana moderna da natureza agressiva e

45 Outros aspectos da apropriação de tecnologia para controle climático foram debatidos no capítulo 2, cujo um dos eixos é a publicação de Banham, The Architectural of the Well-Tempered Environment, publicada em 1968. 
desprovida de generosidade. Não existe, para Banham experiência humana que não seja espacial e estética.
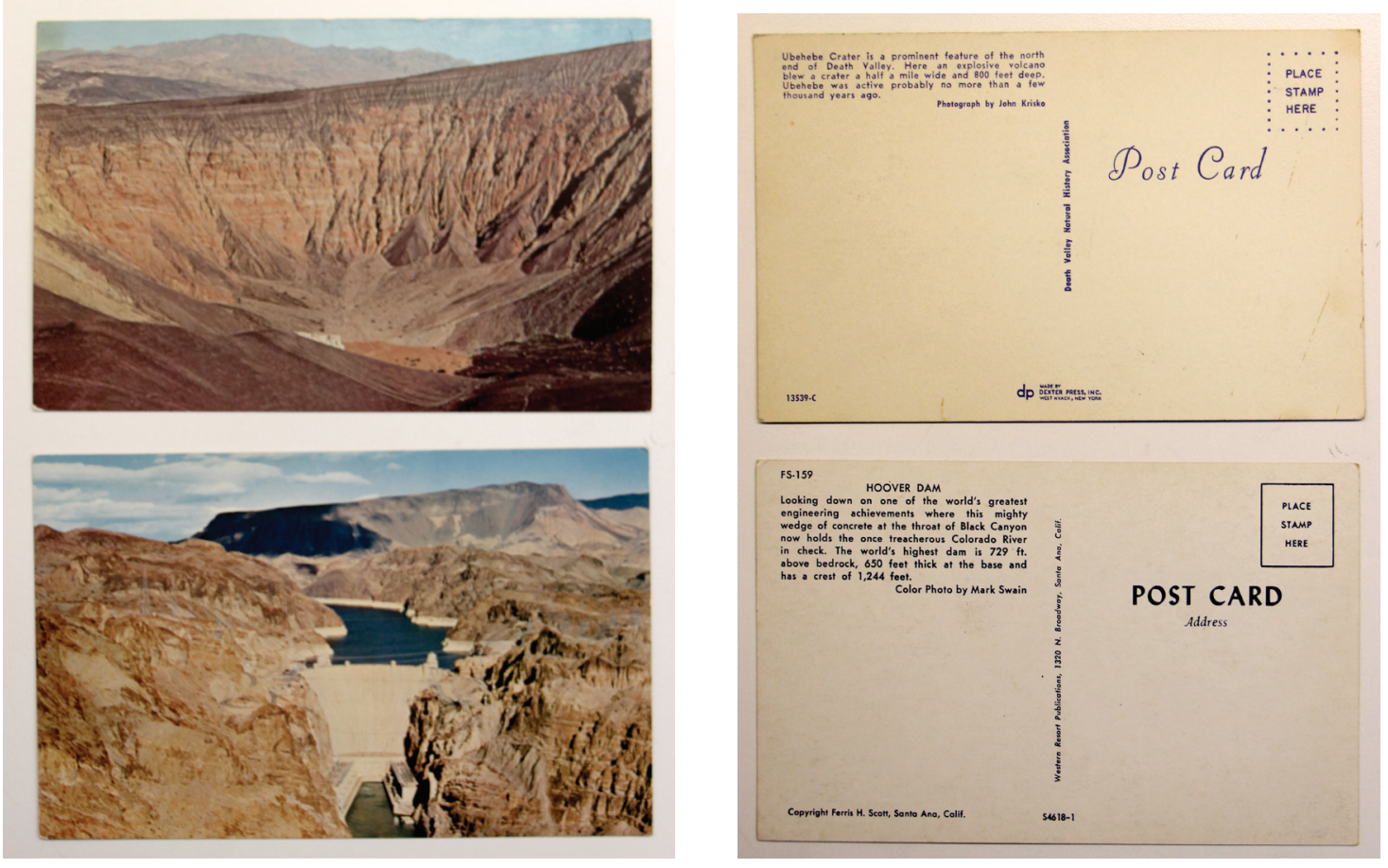

Cartão postal de paisagens do deserto, s/ data. Fonte: arquivo Getty. Nota-se a investigação de Banham sobre a ação do homem na paisagem natural. Podemos perceber também que as fontes bibliográficas, como quase tudo relativo ao livro Scenes of America Deserta, fugia do padrão ortodoxo de pesquisa acadêmica.

Segundo Banham, na história americana, muitos teriam sido aqueles que tentaram ocupar o território do deserto do Vale da Morte. Primeiramente, os índios Navajo e outras tribos que construíram as trilhas indígenas, as aldeias nas escarpas das montanhas e desfiladeiros, antecipando as vilas das falésias do mediterrâneo exaltadas por Le Corbusier ${ }^{46}$; em seguida a conquista do território pela coroa espanhola, suas trilhas de carruagens e suas cidades reticulares e ranchos; por fim, a máquina moderna de urbanização dos Estados Unidos, com suas técnicas modernas de construção, e acima de tudo, com a máquina de transporte de alta-velocidade, o automóvel. Com ele, teria sido finalmente possível apreciar o deserto em sua escala total, a partir da noção de paisagem em movimento em alta velocidade.

Banham apresenta quais estratégias de ocupação foram adotadas para conquistar um ambiente hostil como o deserto. As modalidades de ocupação - resorts, igrejas, fábricas, escolas de arquitetura, comunidades alternativas, abrigos de eremitas, vans, cavernas e outros artifícios dos desert freaks, até mesmo cidades inteiras foram

46 Ver Banham, Scenes of America Deserta, originalmente publicado em 1982. Cambridge: the MIT Press, 1989. 
criadas para conquistar um ambiente que não oferece meios naturais de permanência ${ }^{47}$. A América deserta de Banham traz consigo a lembrança dos registros de viagens ao deserto feitos por escritores europeus como John Van Dyke e Charles M. Doughty ${ }^{48}$, em que ele se apoia, mas enfrenta o desafio de entender um cenário dominado por uma cultura diferente - a cultura americana do controle climático, do automóvel como meio de transporte e do consumo excessivo de energia. Cidades como Baker, o primeiro entreposto na rota Los Angeles - Las Vegas, foram fundadas na dimensão da viagem de automóvel. O que antes era culturalmente impossível torna-se realidade com os mecanismos modernos de controle climático, geração de energia, transporte e fornecimento de água potável. Baker é um verdadeiro oásis moderno, técnico, e sem nenhuma pretensão de eloquência.

"Baker, como vemos, é uma criação de uma longa campanha para tornar mais curta a autopista entre Las Vegas e San Bernardino, uma rota cujo alinhamento não é natural, particularmente no ponto o qual foi meticulosamente evitado por estradas mais antigas - a Trilha Mojave foi mais ao sul, a Antiga Trilha Espanhola separou-se da linha da Interestadual 15 muito a oeste, e passou bem a norte. Apenas as técnicas modernas de construção de estradas, e o automóvel moderno, puderam pensar em passar por esse caminho, e assim que se tornou possível, Baker se tornou um porto-deentrada lógico para o Vale da Morte." 49

Las Vegas é inserida nas narrativas dos oásis do deserto, e se torna seu símbolo máximo da impermanência do homem no deserto ${ }^{50}$. Seu futuro e passado são incógnitas. Ninguém sabe porque a cidade foi originalmente criada. Segundo Banham

\footnotetext{
47 Idem, pp.41-44

48 Idem, pp.153-169. O livro de John Van Dyke, The Desert: Further Studies in Natural Appearances no qual são descritos com riqueza de detalhes e vocabulário os aspectos naturais da fauna e flora do Mojave ao final do século XIX, muito antes da visita de Banham; já o livro de Charles M. Doughty, Travels in Arabia Deserta, forneceu combustível para o imaginário do deserto da cultura ocidental através das imagens do deserto da Arábia Saudita, Síria, Jordânia e Israel. Camelos, dunas e beduínos formaram a paisagem tradicional do deserto para gerações de europeus como Reyner Banham. As cenas do deserto americano, compostas por índios, automóveis e montanhas contrastavam com o que Banham identificou como 'ética Protestante' que permeou narrativas como as de Doughty. Soma-se ao imaginário das arábias a cultura do "Spaghetti Western", seriados de cowboys e índios, grandes assaltos a trens, emboscadas nos vales do Arizona e Texas, e grandes duelos de pistola ao entardecer. Esses seriados permearam a adolescência de Banham, e têm presença constante em seu imaginário, principalmente em seus artigos escritos sobre cultura popular americana.

49 Idem. P.42. Texto original: Baker, as we have it, is a creature of the long campaign to make a shorter highway between Las Vegas and San Bernardino, a route whose alignment is thoroughly "un-natural," particularly at this point which was studiously avoided by earlier roads - the Mojave Trail went further south, the Old Spanish Trail separated itself from the line of I-15 s lot further west, and passed well to the north. Only modern road building techniques, and the modern automobile, could think of passing this way, and once this became possible, Baker also became a logical port-of-entry for Death Valley.

50 Ver Banham, Scenes of America Deserta, pp.41-43
} 
as razões para a sua construção não satisfazem o rigor histórico-técnico. Mesmo sendo possível, não existe registro de uma razão historicamente sustentável que não seja fruto de puro empreendedorismo: seria o resultado da decisão individual de algum empreendedor excêntrico:

“Como eles puderam fazer um lugar como esse? Não é suficiente reviver os fatores históricos, topográficos e econômicos; eles não respondem à questão porque eles não indicam como tais propostas puderam ser sequer concebíveis." ${ }^{51}$

Banham recorre aos critérios de julgamento da cultura pop para justificar a existência de tal oásis impensável. De repertórios da cultura popular foram acessados: música folk; os comentários sobre duas casas de show/hotéis chamados El Sodom e Gomorrah Inn $n^{52}$; ficção científica; aspectos da decadência e ruína; espaçonaves siderais; mas principalmente, da capacidade de identificar elementos visuais, experiências estéticas proporcionadas pela arquitetura e iluminação burlescas da cidade, somente comparáveis a exemplos como Conney Island e Hollywood:

“Eu ouço aquele cantor folk toda vez que estou em Las Vegas cruzando a Strip. Las Vegas é um símbolo, acima de tudo, da impermanência do homem no deserto e não porque nunca se esquece da presença em todos os lugares; onde quer que o homem não tenha construído ou pavimentado, o deserto persiste obstinadamente mesmo em algumas ilhas de pedestres no centro da Strip! A presença de tal enclave de prazeres sem charme em tal meio é tão improvável que apenas ficção científica pode lidar com tal presença; o lugar é como um assentamento de uma raça alienígena, ou uma acampamento-base humano em um planeta hostil. Para capturar essa imagem você precisa ver Las Vegas do ar pela noite, ou melhor, ao final da tarde, tal qual eu a vi pela primeira vez, quando existe apenas luz roxa do pôr-do-sol suficiente no talvegue para capturar os cumes das montanhas ao redor, mas escuro o suficiente para que se perceba o registro de cada lâmpada. Assim, e somente neste momento - a visão não é vulgar, mas sim de um jardim mágico de luzes a florescer, apontando para seu centro em fantásticas fontes de cor em constante mudança. E você vira ao capitão de sua espaçonave e diz, "Olhe Senhor, parece ter vida inteligente lá embaixo," porque era maravilhoso demais para pôr em palavras. E condenado - está já começando a fenecer, na medida em que a energia elétrica tornou-se mais cara e a arquitetura menos criativa. Ela não vai desaparecer com o vento da noite, mas você começa a torcer para isso aconteça, porque ela nunca deixará ruínas nobres, e nunca vai descobrir como

51 Ver Banham, Scenes of America Deserta, p.43. Texto original: How could they have made a place like that? It is not enough to rehearse the historical, topographical and economic factors; they do not answer the question because they do not indicate how such proposals could ever become thinkable.

52 referências às cidades Sodoma e Gomorra, capitais da promiscuidade, punidas por Deus conforme os escritos do Primeiro Testamento da Bíblia Cristã-Católica. 
desaparecer graciosamente. Ela vai se tornar Government Hole ${ }^{53}$ numa escala gigante, enquanto Rock Springs conseguirá sobreviver, e provavelmente, Zzyzx também. " ${ }^{54}$
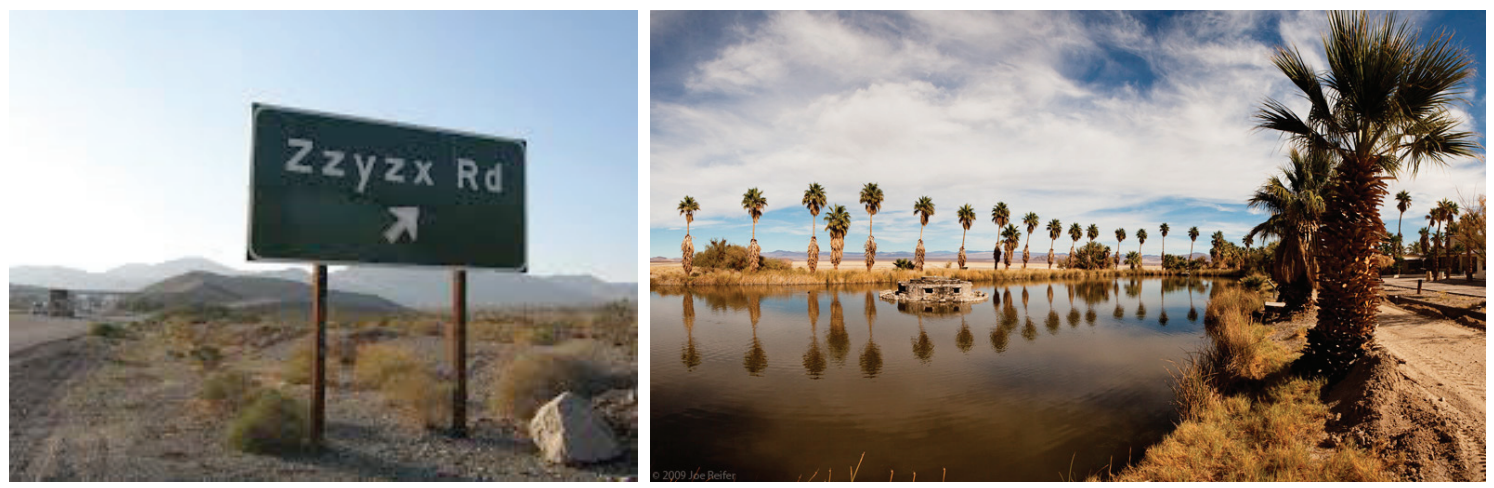

Oásis abandonado de Zzyzx, entre as cidades de Barstow e Las Vegas. Foto: Joe Reifer

Para Banham, o deserto é o anti-arranha-céu, a oposição ao urbanismo da congestão nova-iorquino. Banham admite sua preferencia por essa rarefação humana em relação às multidões das cidades europeias. Nova Iorque seria um exemplo por demais próximo da cultura de urbanização europeia para ser relevante, ou caracteristicamente americano. Banham admite sua predisposição a valorizar as paisagens do deserto. Como ele mesmo diz:

"A beleza pode estar no olho do observador, mas esse olho tem que ter um objeto de visão, uma cena na qual ele pode se amarrar, e eu encontrei essa cena, e

53 Ruína de infra-estrutura pública de manutenção na área do Deserto de Mojave.

54 Ver Banham, Scenes of America Deserta, pp.42-43. Para descrições mais detalhadas de outras modalidades de oásis modernos, como Kelso, Scotty's Castle, o resort de Zzyzx e Rock Springs, das comunidades construtivas de Arcosanti (Paolo Soleri) e Taliesin West, em Scottsdale (Frank Lloyd Wright), no Arizona, o capítulo "Oasis and Resorts" descreve as mais notáveis propostas de ocupação do deserto, e "Frank Lloyd Wright Country" apresenta a interface entre tectônica, estética e paisagem, ensino de arquitetura e o desafio do controle climático. Texto original: I hear that folk singer every time I am in Las Vegas and cruise the Strip. Las Vegas is a symbol, above all else, of the impermanence of man in the desert, and not least because one is never not aware of the desert's all pervading presence; whenever man has not built nor paved over, the desert grimly endures - even on some of the pedestrian islands down the center of the Strip! The presence of such an enclave of graceless pleasures in such an environment is so improbable that only science fiction can manage it; the place is like the compound of an alien race, or a human base camp on a hostile planet. To catch this image you need to see Las Vegas from the air by night, or better still, late on the afternoon, as I first saw it, when there is just purple sunset light enough in the bottom of the basin to pick out the crests of the surrounding mountains, but dark enough for every little lamp to register. Then - and only then - the vision is not tawdry, but is of a magic garden of blossoming lights, welling up at its center into fantastic fountains of everchanging [sic] color. And you turned to the captain of your spaceship and said, "Look Sir, there must be intelligent life down there," because it was marvellous beyond words. And doomed - it is already beginning to fade, as energy becomes more expensive and the architecture less inventive. It won't blow away in the night, but you begin to wish it might, because it will never make noble ruins, and it will never discover how to fade away gracefully. It will become Government Hole on a gigantic scale, whereas Rock Springs will survive and so, probably, will Zzyzx. 
objetos apropriados para escrutiniza-la, e aquela luz e cor. E tudo isso eu sabia (e acredito) desde o primeiro momento em que meu olho foi tomado pela visão da névoa etérea e luminosa daquela primeira manhã no Mojave. O deserto me arrebatou, e eu estou feliz em dizer que eu estou ainda chocado por descobrir que isso é assim. " 55

A experiência estética do deserto desfrutada por Banham é uma exploração de escala de vazios. Mais do que alimentado pela mesma sensação e estímulo com esses vazios desfrutada pelos artistas de land art, Banham se ocupa em analisar os paralelismos entre esse contexto natural e a realidade construída pelo homem da arte e arquitetura modernas:

"A sensação de vasta imensidão não é falso; o deserto oferece de na medida certa espaços imensuráveis. É um meio no qual o "Homem Moderno" deve sentir-se em casa - sua pintura moderna, como nos trabalhos de Mondrian, sugerem um espaço que se estende para além dos trabalhos de Mies van der Rohe, é uma distribuição retangular de um espaço regular porém infinito; seus habitantes, as esculturas de Giacometti espreitando metafisicamente por esse espaço por onde ele se estende infinitamente. E a última fronteira de exploração do homem moderno é um tropeço em paisagens lunares tão desconfortáveis como os desertos da Terra." ${ }^{56}$

No capítulo "Elevations from the Plain ${ }^{57}$ ", Banham identifica os elementos da paisagem que formam a noção de escala do deserto. Sem as cadeias montanhosas, as escarpas e as falésias no deserto, os paredões rochosos e colinas conformam as bacias, desenham as paisagens, e são elementos imprescindíveis para seus habitantes se deslocarem - sejam os brancos, os índios Navajos, primeiros colonizadores da região, ou o turista ocasional (em menor escala) ${ }^{58}$.

“a escala do cenário é crucial - se o vale fosse mais amplo a vista não se sustentaria, e se fosse mais apertada a sequência alternada de amplas colinas perderia

55 Idem, p.228. Texto original: Beauty may indeed lie in the eye of the beholder, but that eye must have an object of vision, a scene on which it can be fasten, and I have found that scene, and appropriate objects of scrutiny within it, and that light and that color, And All this I knew (I believe) from the very moment that my eye was taken by the vision of that ethereal luminous mist on that first morning in the Mojave. The desert hath me in thrall, and I am happy to say that I am still astonished to discover that this is so.

56 Idem, pp.62-63. Texto original: The sense of vast immensity is not phony; the desert measurably offers immensurable space. It is therefore an environment in which "Modern Man" ought to feel at home - his modern painting, as in the works of Mondrian, implies a space that extend beyond the works of Mies van der Rohe, is a rectangular partition of a regular but infinite space; its ideal inhabitants, the sculptures of Giacometti stalking metaphysically through that space as far as it infinitely extends. And modern man's last frontier of exploration be stumbling about lunar landscapes that are uncomfortably like the deserts of the earth.

57 Ver Banham, Scenes of America Deserta, pp.133-152

58 Ver Banham, Scenes of America Deserta, p.133 
o imponente ritmo adagio que a dá tal poder. Eu suspeito que o efeito como um todo precisa também da velocidade do automóvel para trazer as colinas alternadas à vista no ritmo certo - no passo à pé elas estariam muito distantes em tempo para a congruência de lances sucessivos, para que o padrão de colinas seja perceptível. Quaisquer que sejam as sutilezas da experiência visual, contudo, o resultado é algo a saborear em um movimento comparativamente mais fluido, ao contrário de um grito de "Uau!" e o barulho dos freios que tão frequentemente acompanham a repentina revelação de um grande espetáculo da América Deserta." 59

59 Ver Banham, Scenes of America Deserta, p.149. Texto original: The scale of the scenery is crucial - if the valley were wider the view would fall apart, if it were more cramped the alternating sequence of broad slopes would lose the stately adagio rhythm that gives it such power. I suspect that the whole effect needs also the forward speed of the automobile to bring the alternating slopes into view at the right pace - at walking speed they would be too far apart in time for the congruence of the successive sweeps, the pattern of alternating slopes to be perceived. Whatever the niceties of the visual experience, however, the result is something to savor contemplatively and in pondered motion, instead of the cry of "Wow!" and the squeal of brakes that so often greet the sudden revelation of some great spectacle of America Deserta. 


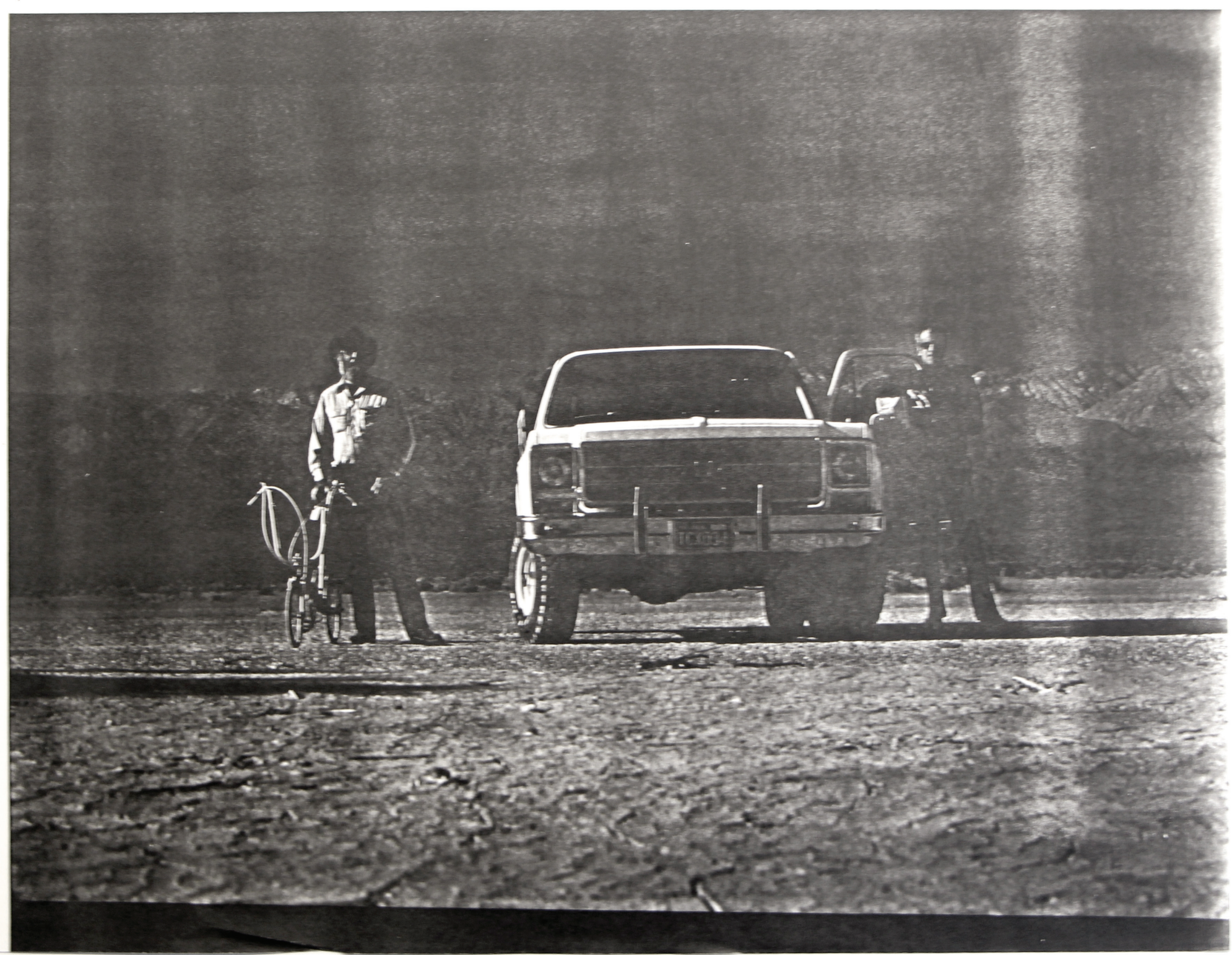

Reyner Banham e Tim Street Porter, Soda Lake (Lago Soda), s/ data. Fonte: Arquivo Getty. 


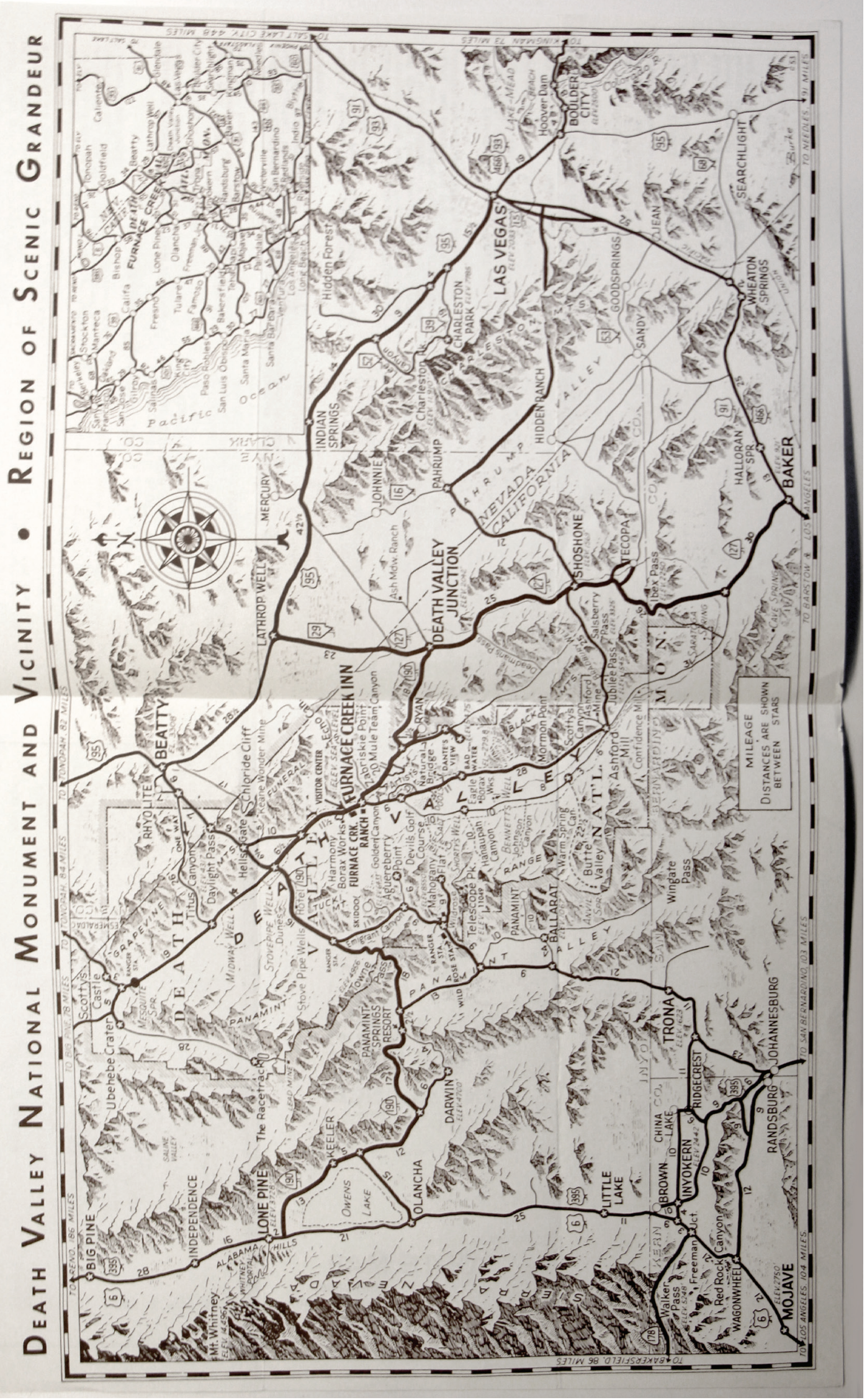

Mapa turístico do Vale da Morte e região, s/ data. Fonte: arquivo Getty. Em linhas mais fortes, estão demarcadas as autopistas. Em linhas mais finas, as antigas trilhas espanholas e indígenas. 
Banham percebe a importância do deslocamento para a apreciação das paisagens do deserto. A antecipação e o suspense entre a placa de aviso de chegada da cidade os primeiros traços de sua paisagem construída estão presentes, subliminarmente, tal qual como diretamente transcrita. As trilhas antigas e novas figuram nos mapas turísticos e nas cartas rodoviárias (ver imagem abaixo). Banham sabia da importância de se conhecer a estrada onde se estava, seus marcos de paisagem, seus momentos, e o ritmo de sua paisagem. Baseado no tempo do automóvel, não conseguiu se aproximar da figura dos índios do Mojave - aparentemente intocados pela cultura moderna, e arautos de um outro tempo histórico. Uma variação individual do Orientalismo analisado por Edward Said é expressada na relação de identificação dos membros da cultura Navajo feita por Banham ${ }^{60}$. Talvez para um britânico fossem muitas camadas de diferenciação cultural. Já para J. B. Jackson, que expressa uma consciência mais profunda dos detalhes históricos da formação do território americano, a idéia de deslocamento não foi criada pelo europeu, mas sim emprestada e retrabalhada do original indígena.

“A jornada do Navajo não é uma peregrinação que resulta em uma experiência transcendente; é a existência diária governada e protegida por ritos e precauções. Ele segue a trilha que seus antepassados seguiram. Elas levam a lugares nos quais existem ervas raras e úteis. Elas evitam qualquer lugar associado com a morte. Elas levam a altares e santuários, para lugares de beleza natural e boa caça. O Navajo retorna de sua jornada - quer ela ocupe um dia ou uma vida - com alimento e recursos para a família. Ele paga tributos para os túmulos de seus ancestrais, obedece as injunções e performa os rituais necessários; acima de tudo, ele se torna familiarizado com sua paisagem natural e se torna um elemento harmonioso com ela. A jornada faz dele um homem mais sábio e com mais conhecimento; ele aprendeu como aceitar a trilha e seus riscos." ${ }^{61}$

60 Edward Said, Orientalism. New York: Vintage Books, 1979.

61 Idem, pp.203-204. Texto original: The path is so much a part of existence that it eventually becomes a metaphor for human life itself. Life is a road, long and unpredictable, and full of danger, that each of us must travel."

To the Navajo, as to many other Indian tribes, the metaphor is almost an article of faith. Spiritual preparation for adult existence emphasizes the journey ahead. "Man's life cycle," Gladys Reichard wrote, "is called a 'walk' through time. He travels a 'trail' repeatedly symbolized in sand painting and ritual. A major purpose of the ritual is to carry him safely and pleasantly along this road from birth to dissolution."

The Navajo journey is not, strictly speaking, a pilgrimage resulting in a transcendent experience; it is everyday existence ruled and protected by rites and precautions. He follows the paths his forebears followed. They lead to places where there are rare and useful herbs. They avoid all places associated with death. They lead to altars and shrines, to places of natural beauty and good hunting. The Navajo returns from the journey - whether it occupies a day or a lifetime - with food and resources for the family. He has paid tribute to the graves of ancestors, obeyed all injunctions and performed all necessary rites; above all, he has become familiar with his native landscape and become a harmonious element in it. The journey has made him a wises and more knowledgable man; he has learned how to accept the path with its hazards. 
Podemos analisar, pela postura de Banham, que a proposta de ocupação do deserto por parte da sociedade moderna nos Estados Unidos não foge muito ao conceito da civilização Navajo. Contudo, a influência e seus predecessores indígenas e coloniais espanhóis, a paisagem moderna do deserto americano se destaca por estar inserida na lógica de urbanização e espraiamento americano. A broadacre city de Frank Lloyd Wright e seu conceito de residência usoniana encontraria sua escala no espraiamento entre assentamentos humanos no deserto ${ }^{62}$. Também em Wright, encontraríamos a revisão do conceito de balloon-frame, do 'core' de serviços da casa da pradaria e dos fundamentos de arquitetura em Taliesin West, e no campo de Ocatillo ${ }^{63}$; dos oásis modernos construídos por empreendedores vaidosos americanos, como Zzyzx ou Scotty's Castle ${ }^{64}$; das armadilhas de turistas localizadas próximas à autopistas; e de monumentos naturais como o Monument Valley e o Soda Lake. Mesmo os cenários naturais poderiam ser usufruídos de maneira diferente. Para além de facilitar o acesso, o advento da viagem de automóvel e da mudança de perspectiva em alta velocidade, tais colinas, paredes e falésias ganhariam tridimensionalidade. É uma nova maneira de apreciação de paisagem, reconhecida e defendida por Banham, desert freak desde então.

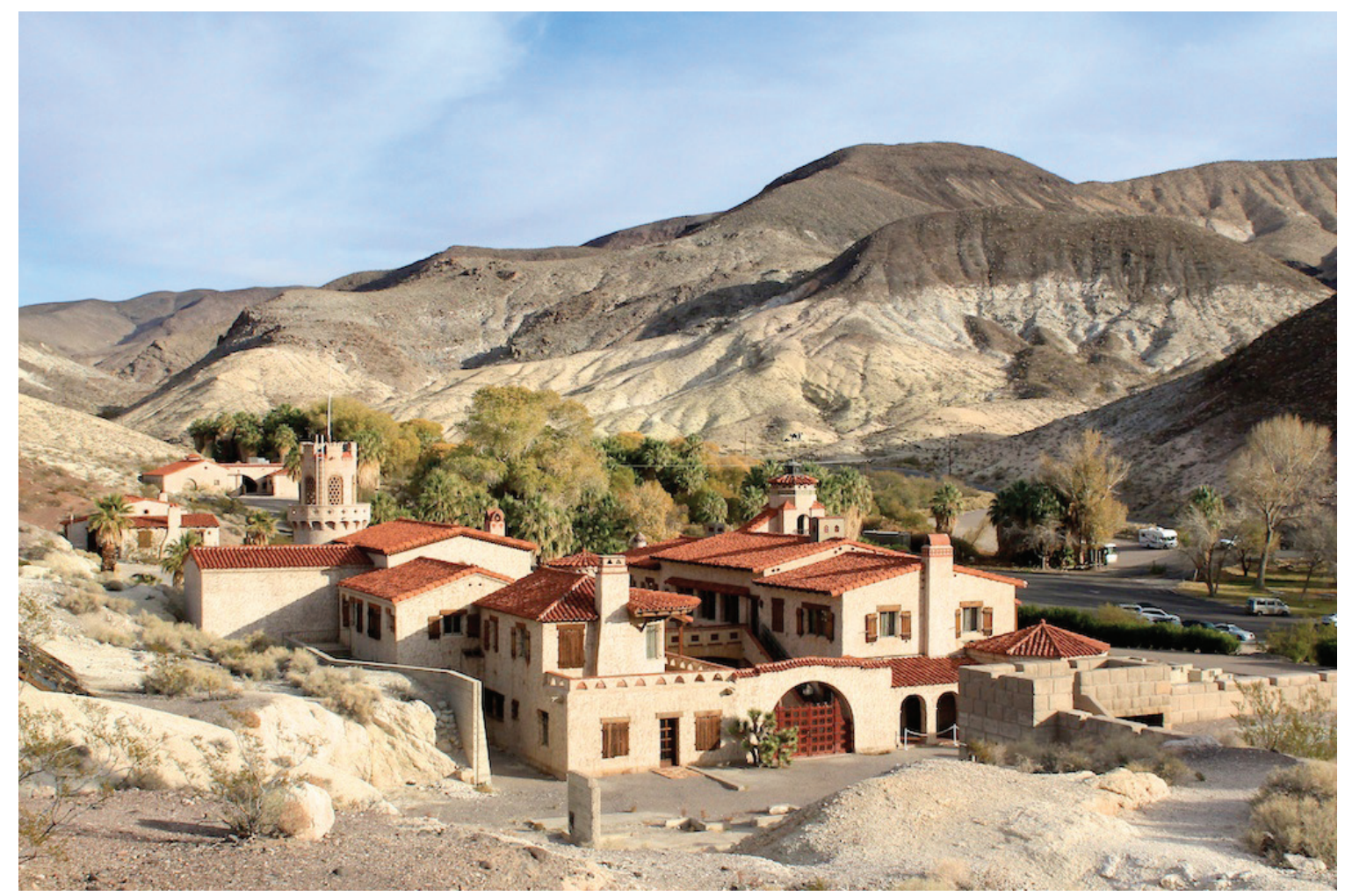

Albert Mussey Johnson, Scotty's Castle, 1922. Foto: Josh McNair

62 Ver Banham, "Frank Lloyd Wright Country", Scenes of America Deserta, pp.69-90

63 Idem, pp.69-72

64 Idem, pp.33-37. 


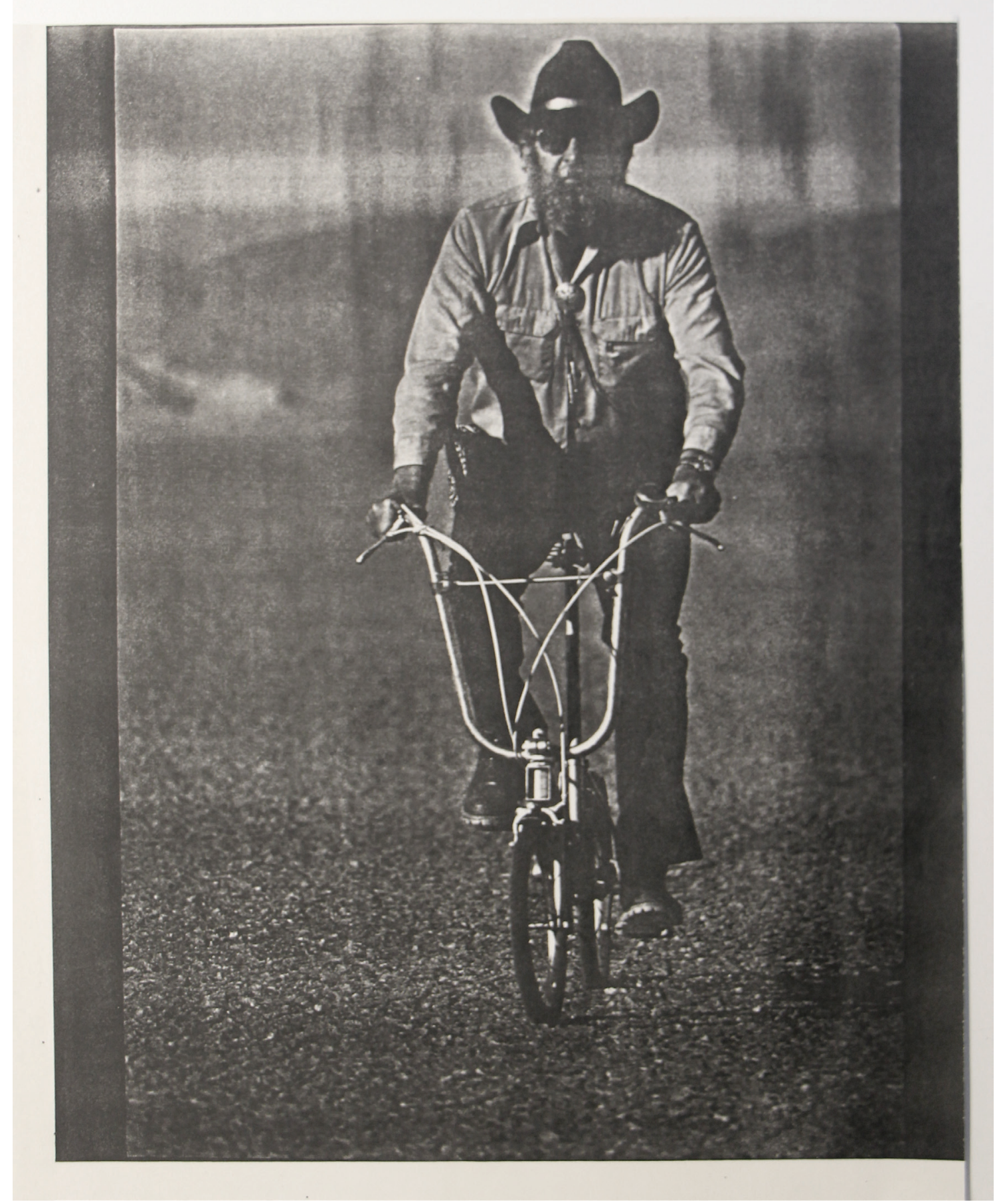

Reyner Banham, o vaqueiro ciclista no Lago Soda, s/ data. Foto: Tim Street Porter. Fonte: Arquivo getty. 


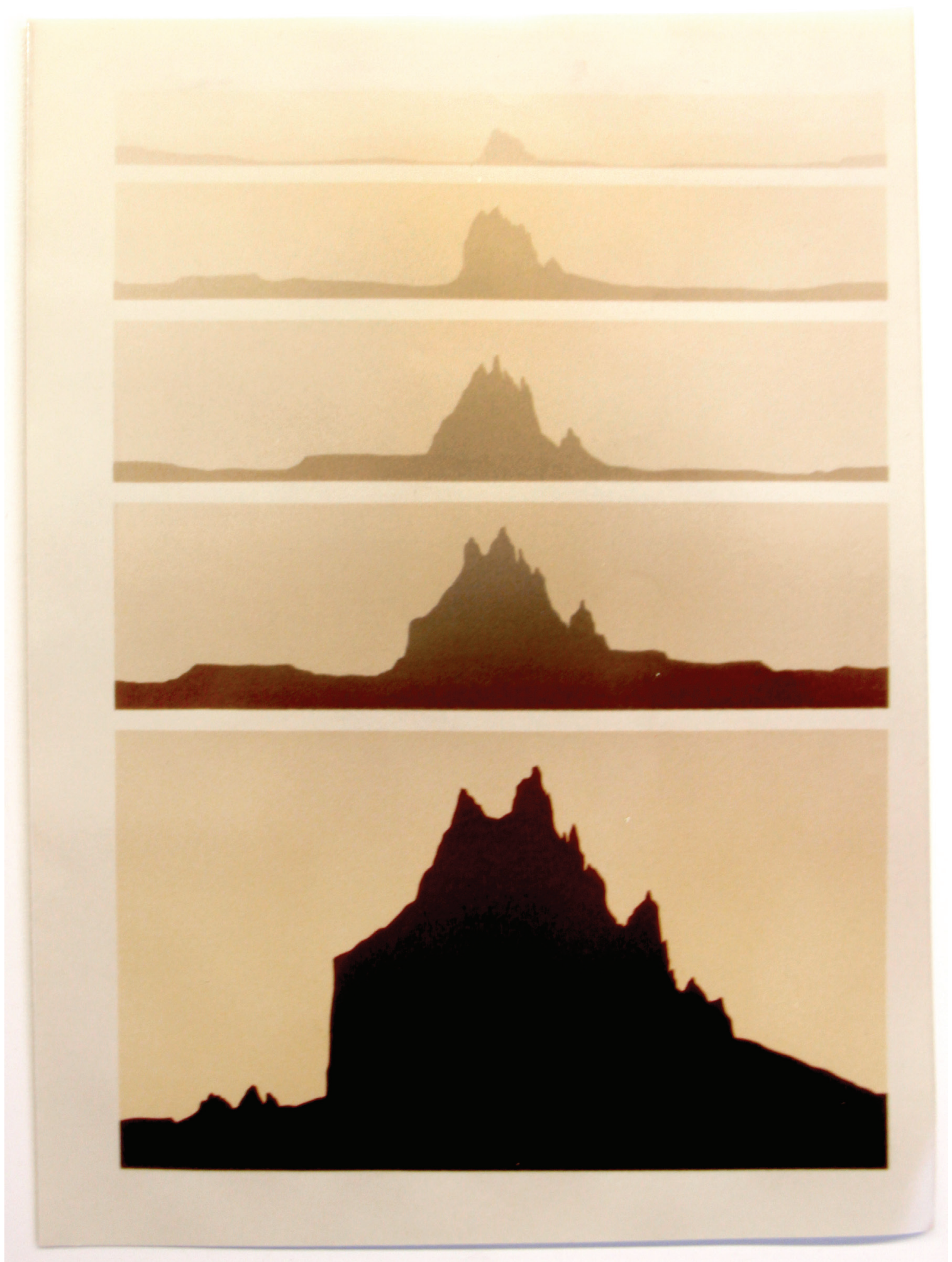

Reyner Banham, vistas do Monument Valley, Arizona. Note-se o sentido de aproximação descrito por Banham. Apenas em uma viagem em alta velocidade, seria possível atribuir movimento à percepção de elementos naturais tão imensos. Fonte: Arquivo Getty. 


\section{Mega-estruturas trouvée}

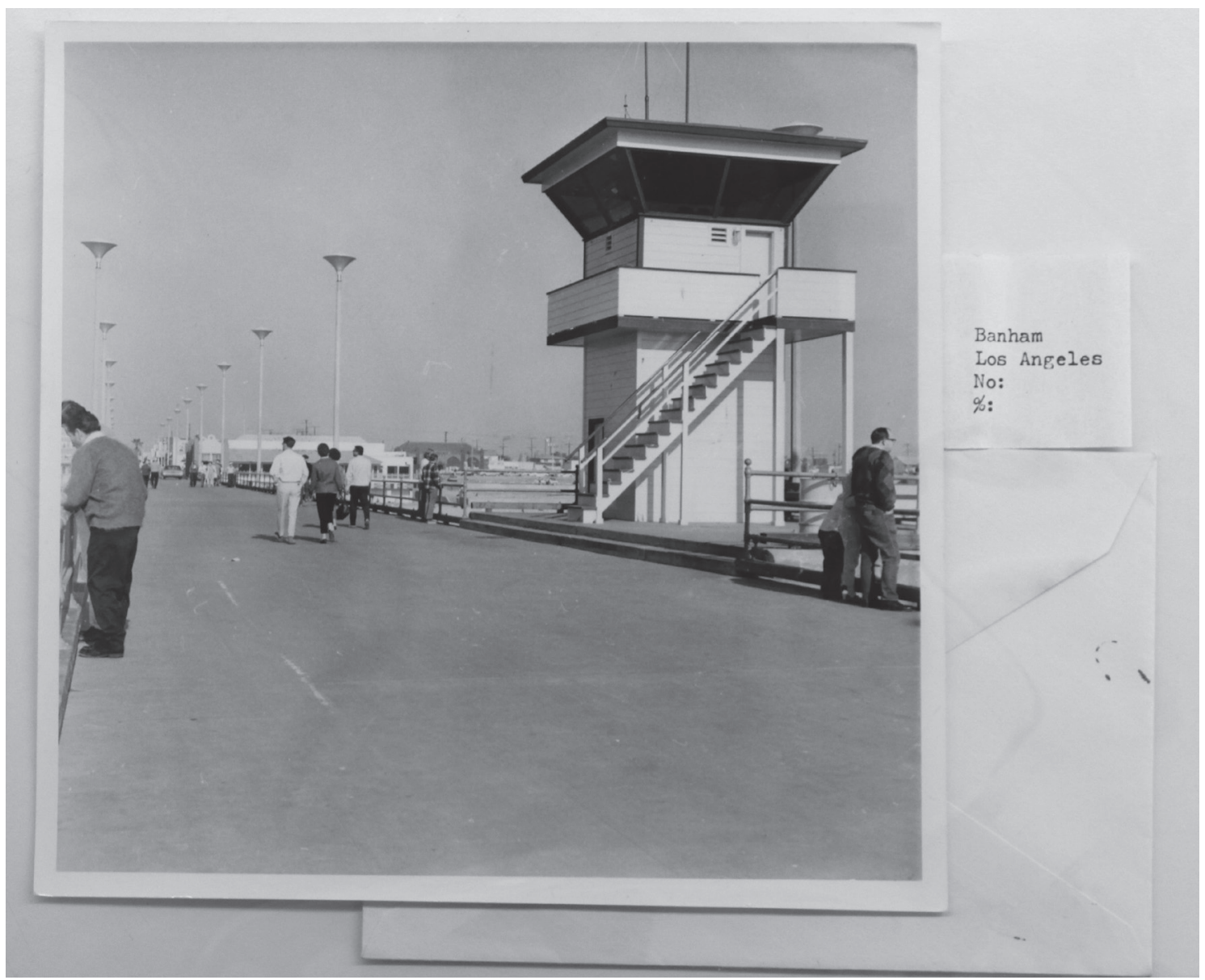

Píer de Santa Monica, s / data. Foto: Julius Schulman. Fonte: arquivo Getty. A mega-estrutura californiana reproduz o asfalto das ruas, levando os automóveis a trafegar por cima do Oceano Pacífico.

Quando Banham escreveu e publicou Megastructure: Urban Futures of the Recent Past $^{65}$, uma de suas primeiras observações recaiu sobre as megaestruturas trouvé, exemplos tal como encontrados. O termo aplica-se ali aos precedentes históricos dos clássicos exemplares metabolistas e high-tech. Banham procurou no conceito 'as found' ${ }^{66}$ estruturas existentes para criar a genealogia da tipologia. O Píer de Santa Monica, na Califórnia, foi descrito por Banham com uma certa carga de surpresa e um questionamento: quando uma estrutura como um píer, uma estrada, ou uma linha ferroviária deixariam de ser um simples elemento da paisagem e passariam a ser uma edificação.

Uma das características da ocupação do território americano seria justamente a presença alastrada, por todos os lugares conquistados pelo homem, dos grandes objetos de infraestrutura. Elementos que ora se fundem no território e paisagem, como

65 Ver Banham, Megastructure: Urban Futures of a Recent Past. London: Thames and Hudson, 1976.

66 Tradução: como encontrado. Para maiores descrições do conceito, ver capítulo 1 da presente dissertação. 
nas estradas que cruzam o deserto, e ora se projetam e se afirmam como arquitetura, tal como o Píer de Santa Monica, na Califórnia. Banham descreveu elementos como a ponte George Washington e o terminal de ônibus, em Nova Iorque, projetada por Pier Luigi Nervi, como uma megaestrutura: cunhando uma nomenclatura retroativa, essas edificações, construções massivas de infraestrutura em concreto e aço, pedra e tijolo seriam chamadas de megaestruturas trouvé. Como tais elementos pré-existentes da paisagem americana poderiam ser 'descobertos', exaltados e analisados por Banham, na construção de uma das principais paisagens americanas: a ecologia humana do deslocamento?

Através da apropriação da tecnologia construtiva e do advento do automóvel, nasce uma tipologia de espaço infinito, em rede, sem uma forma definida, mas segundo J. B. Jackson, com noções de tempo definidas. Um dos temas mais recorrentes dentre os publicados por Jackson na revista americana Landscape é a estrada, e ele a estuda do ponto de vista das dinâmicas humanas dentro dela. A história e ciência das estradas não só fazem parte do estudo de paisagens culturais, bem como é um dos principais fatores que alteraram a paisagem americana nos últimos 150 anos. 


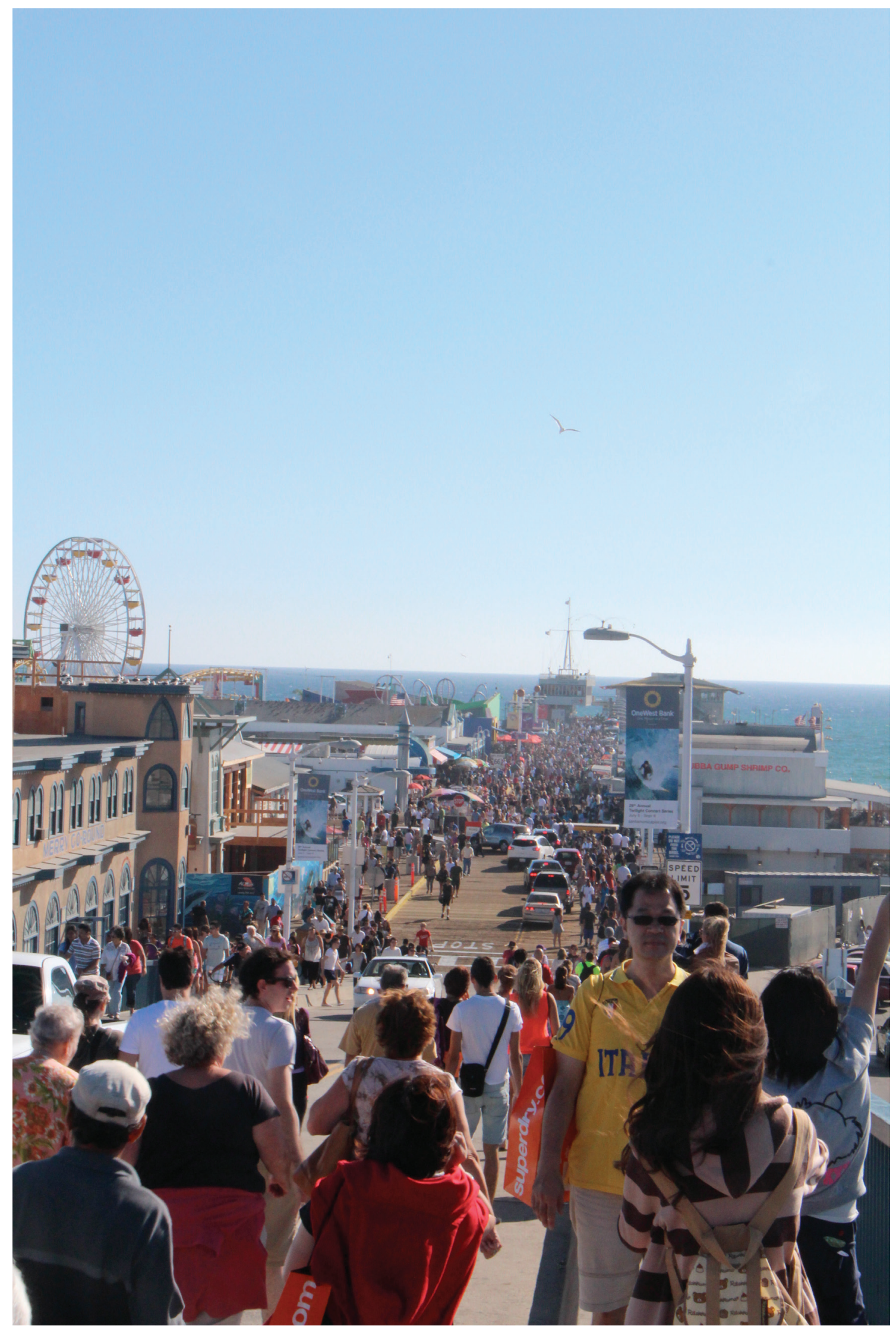

Pier de Santa Monica, agosto 2012. Foto: Luiz Florence 


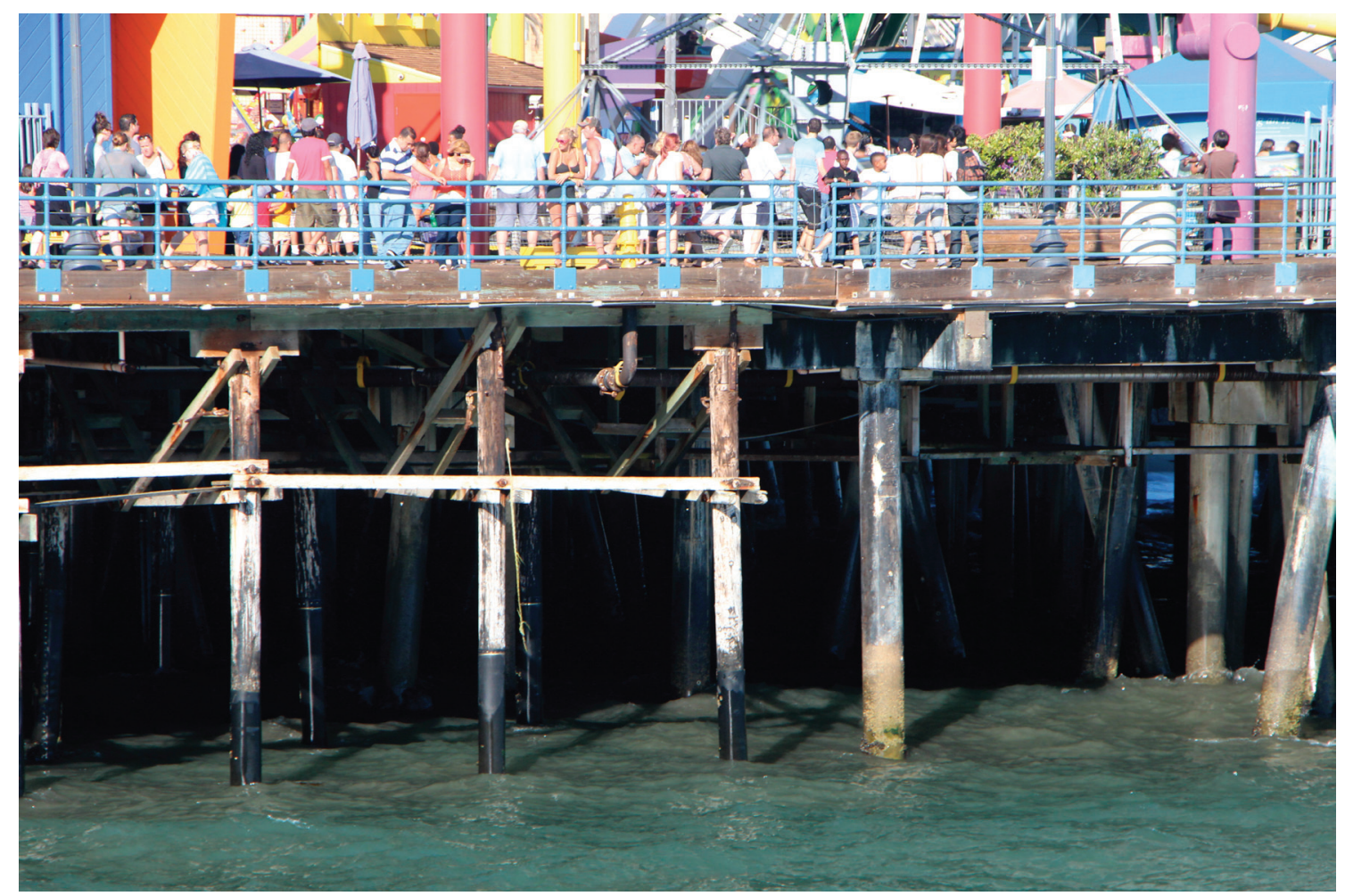

Pier de Santa Monica, agosto 2012. Foto: Luiz Florence

"Falar de uma Ciência de estradas, é insinuar que o aluno de paisagismo deveria se interessar no trabalho do engenheiro e temas de construção, alinhamento, e o movimento eficiente de mercadorias." ${ }^{67}$

Banham de fato não observa as autopistas tal como o engenheiro. Tampouco se priva a analisar a materialidade da qual consiste a megaestrutura. Diferentemente de Jackson, Banham não se atem aos elementos da cultura humana, mas estuda qual o conceito de forma aplicado a tais megaestruturas de movimento. Tal como o automóvel, o pavimento sob ele receberá considerável atenção por parte de seus estudos. E seu principal território de estudos é, mais uma vez, a Califórnia.

É facilmente perceptível seu entusiasmo em falar sobre a estética da velocidade e do estilo de vida angeleno, dedicado a depositar parte de seu tempo - e personalidade - na cultura das freeways, as autopistas. O primeiro parágrafo do capítulo intitulado "Autopia" (um jogo de palavras entre autopista e utopia), demonstra como a retórica de Banham é especialmente detalhista ao falar deste assunto:

67 J. B. Jackson, "Roads", in Jackson, Discovering the Vernacular Landscape. New Haven: Yale University Press, 1984, pp.21-26. Texto original: to speak of a Science of roads, is to imply that the landscape student should be interested in the work of the engineer and matters of construction, alignment, and the eficiente movement of goods. 
"A primeira vez que eu vi acontecer nada registrou em minha mente consciente, porque tudo parecia tão natural - no momento em que o carro à frente desceu a rampa da autopista de San Diego, a garota ao lado do motorista puxou o espelho da viseira para arrumar seu cabelo. Apenas quando eu já tinha visto a cena umas duas vezes mais, eu pude captar seu significado: descer da autopista é como sair para fora de casa. Uma jornada doméstica ou social em Los Angeles não acaba na porta de entrada de seu destino final, como a rampa de descida de uma autopista, uma milha ou duas de ruas ao nível do chão sendo como nada mais do que a estrada de acesso em frente à sua casa." ${ }^{68}$

Muitas das metáforas literárias do livro sobre Los Angeles, principalmente no capítulo que descreve a ecologia urbana das autopistas foram extraídas de impressões pessoais e da dinâmica que Banham se impôs para conhecer a cidade. Comparando àqueles intelectuais que aprendem italiano para ler Dante no original, ele teria aprendido a dirigir para entender Los Angeles. A idéia da bibliografia retrospectiva, toward a drive-in bibliography (bibliografia de drive-in), ou pela metáfora do retrovisor, por exemplo. $\mathrm{O}$ fato das autopistas serem elevadas fornece a imagem de "altar de transporte" ao qual os angelenos devem prestar tributo diário. A imagem do transporte em Los Angeles é, para Banham, mais significativa do que em Paris ou Nova Iorque. Ninguém, diz ele, conhece Paris por seu metrô da mesma maneira que Los Angeles é conhecida por seu sistema de pistas elevadas. É parte integrante e inexpugnável de sua paisagem. Ademais, a experiência de dirigir nas autopistas, segundo Banham, imprime-se profundamente tanto na mente consciente quanto em seu subconsciente. Subliminarmente, os reflexos e os instintos se calibram ao movimento e ritmo da estrada. $\mathrm{O}$ meio ambiente das autopistas de Los Angeles seriam um espaço de condicionamento para o sistema motor do cidadão motorizado; mais do que isso, tornaria em si em um 'transe', um fenômeno místico de hipnose temporária. ${ }^{69}$ Não somente Banham, mas também o escritor Christopher Isherwood descreve, em A Single Man, o efeito:

“E agora, enquanto dirige, é como se um tipo de auto-hipnose se exercesse. Nos vemos a face relaxar, os ombros desencolherem, o corpo relaxar e ceder ao assento. Os reflexos estão tomando conta; o pé esquerdo desce com firmeza, pressionando a embreagem, enquanto o direito prudentemente fornece gasolina. A mão esquerda

68 Reyner Banham, Los Angeles: the Architecture of Four Ecologies, p.195. Texto original: The first time I saw it happen nothing registered on my conscious mind, because it all seemed so natural - as the car in front turned down the off-ramp of the San Diego freeway, the girl beside the driver pulled down the sunvisor and used the mirror on the back of it to pulled down the sun-visor and used the mirror on the back of it to tidy her hair. Only when I had seen a couple more incidents of the kind did I catch their import: that coming off the freeway is coming in from outdoors. A domestic or sociable journey in Los Angeles does not end so much at the door of one's destination as at the off-ramp of the freeway, the mile or two of ground-level streets counts as no more than the front drive of the house.

69 Reyner Banham, "Autopia", in Los Angeles: the Architecture of Four Ecologies, pp.196-197. 
é leve ao volante; a direita desliza a marcha com precisão para a última marcha.

Os olhos, movendo-se sem pressa da estrada ao retrovisor, do retrovisor à estrada, calmamente medindo as distâncias à frente e atrás, ao carro mais próximo. Afinal, esta não é uma corrida - é apenas como parece aos olhos de observadores e novatos - é um rio, fluindo em vazão máxima em direção de sua foz com tranquilizante força. Não há nada a temer, enquanto você deixar-se levar; de fato, você descobre, no meio da correnteza, um senso de indolência e sossego." ${ }^{70}$.

Banham descreve o temperamento das autopistas, comparando-as com suas experiências na Europa - o que é curioso, visto que ele não tinha habilitação de motorista antes de vir para Los Angeles. Também comenta sobre o temperamento dos motoristas locais, aparentemente sempre insatisfeitos com seu próprio sistema de transporte. Segundo Banham, reclamar do trânsito em Los Angeles é como reclamar do clima em Londres. ${ }^{71}$

Seu entusiasmo com o sistema rodoviário chega ao ponto de relevar o trânsito da cidade como um problema urbano - o que atualmente demonstraria ingenuidade, visto o agravamento das condições de transporte na cidade. Ele idealiza o sistema de transporte e seu estilo de vida correlato. Estar preso no trânsito seria para Banham, uma atividade de sociabilização, um paradoxo de liberdade pessoal e disciplina pública que permeia a sociedade mecanizada urbana. O binômio "carro privado / autopista pública" forneceria uma versão ideal (e padronizada) de transporte público: o trânsito em constante fluxo, de porta a porta, na hora em que se desejar, em distâncias consideráveis, que podem passar de 40 quilômetros diários, permitiriam ao angeleno uma sensação, malgrado fabricada, de liberdade. Segundo Banham, a população de Los Angeles dificilmente estaria disposta a sacrificar liberdade por um sistema público de transporte de alto carregamento e alta velocidade. Praticidade não é o ponto final, e sim expressão de estilo de vida. Transporte, contudo, não deixaria de ser um tópico de interesse em conversas por todos os lados da cidade..$^{2}$ Para Banham, como europeu e turista, todo o sistema das autopistas californianas seria exótico. Inclusive, o sistema de comunicação visual - a qual se deve obediência - que diz que para virar à esquerda,

70 Christopher Isherwood, “A Single Man”, apud Michael Sorkin, Exquisite Corpse. London: Verso, 1994, p. 58. Sorkin, no entanto, reage com Texto original: And now, as he drives, it is as if some kind of auto-hypnosis exerts itself. We see the face relax, the shoulders unhunch themselves, the body ease itself back into the seat. The reflexes are taking over; the left comes down with firm, even pressure on the clutch pedal, while the right prudently feeds in gas. The left hand is light on the wheel; the right slips the gearshift with precision into high. The eyes, moving unhurriedly from road to mirror, mirror to road, calmly measure the distance ahead, behind, to the nearest car... After all, this is no mad chariot race that's only how it seems to onlookers or nervous novices - it is a river, sweeping in full flood toward its outlet with a soothing power. There is nothing to fear, as long as you let yourself go with it; indeed, your discover, in the midst of its stream-power, a sense indolence and ease."

71 Reyner Banham,Los Angeles, p.197.

72 Idem, p.199. 
deve-se manter-se a direita. ${ }^{73}$ Também comenta a inteligência das rádios especializadas em relatórios sobre o trânsito, exercendo uma função social necessária para o planejamento diário de rotas. Mas toda essa disciplina não destrói a ilusão e o fetiche do automóvel. O carro particular teria se tornado uma peça artística, e a galeria seria a própria a autopista. ${ }^{74}$
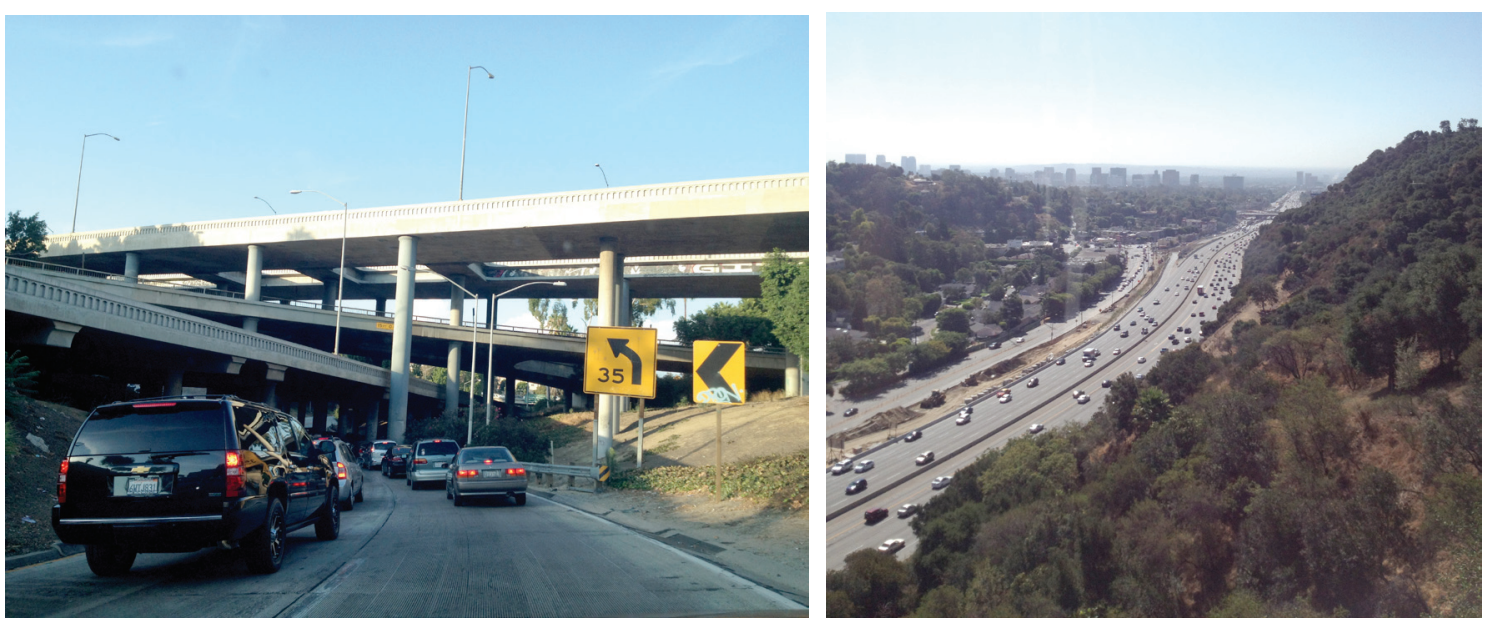

Cenas das autopistas 110 e 405 em Los Angeles, 2012. Não somenta na escala, as formas das estruturas rodoviárias de Los Angeles assumem o caráter monumental: no encontro das autopistas 101, 405 e 110, percebe-se a generosidade especial dada para tais estruturas. Fotos: Luiz Florence

“A via expressa não é dividida pelo tipo de regra de jardim-de-infância que se percebe em autopistas Britânicas, com seu rápido, lento, e de ultrapassagens (onde existem três pistas para usar!). As três, quatro ou cinco pistas de uma via expressa Angelena são virtualmente iguais, o motorista é obrigado a escolher ou mudar de pistas conforme sua velocidade, circunstâncias ao redor e intenções futuras. Se todos fazem isso com uma mistura permitida de espírito público e auto-interesse iluminados, é possível manter um grande fluxo de carros movendo-se surpreendentemente rápido." 75

Como veremos mais a frente, o automóvel teria se tornado o elemento principal da cultura de customização e de apropriação dos elementos do mercado de consumo de massa. Ao final do capítulo "Autopia", o entusiasmo de Banham com o automóvel é tanto, que ele chega a afirmar que a freeway não é o "limbo existencal onde o homem

\footnotetext{
73 Idem, p.201

74 Veremos mais à frente a análise do automóvel como parte importante da paisagem americana.

75 Idem, pp.199. Texto original: The carriage-way is not divided by the kind of kindergarten rule of the road that obtains on British motorways, with their fast, slow, and overtaking lanes (where there are three lanes to use!). The three, four, or five lanes of an Angeleno freeway are virtually equal, the driver is required to select or change lanes according to his speed, surrounding circumstances and future intentions. If everybody does this with the approved mixture of enlightened self-interest and public spirit, it is possible to keep a very large flow of traffic moving quite surprisingly fast.
} 
parte em busca do individualismo ocidental", segundo Brock Yates ${ }^{76}$. É, para ele, um lugar de suspensão, mas não de angústia, onde o angeleno "passa duas das mais calmas e agradáveis horas de seu cotidiano ${ }^{77 \prime \prime}$.

A pesquisa de Banham a respeito das autopistas encontra interlocução na obra de J. B. Jackson, em diversos pontos. As estradas são também para Jackson tema de muito interesse, e percorrem diversos artigos publicados, entre 1950 a 1990. Jackson, ao contrário de Banham, se foca nas estradas para tentar capturar os valores estéticos mais relevantes. O sentido de tempo, para Jackson, se sobressai ao sentido de espaço, ao identificar a relação do americano com o espaço, no sentido em que o espírito do cidadão dos Estados Unidos leva a uma conquista do espaço pelo deslocamento. $\mathrm{O}$ sentido de pertencimento a um local é superado pela possibilidade de conquista do novo. Além disso, para Jackson as relações entre homens seria mais importante do que a relação entre homem e espaço. Essa liberdade de ir e vir, enaltecida por Jackson, é a base do seu questionamento: o que o americano valoriza mais, o sentido de lugar, ou a sensação de liberdade?

"Estamos emergindo de um período de séculos quando a estrada era subserviente do lugar e a ela era dado pouco respeito. Hoje, cem anos depois da invenção do automóvel, a questão seria respondida em favor da estrada - ou sua versão moderna, a autopista - que continua a tecer uma intrincada rede sobre todas as paisagens no mundo ocidental e que reproduziu uma série de espaços similares a estradas - linhas ferroviárias, linhas de energia, linhas aéreas, linhas de montagem. Agora a questão demanda um tipo diferente de resposta: o que valorizamos mais, um sentido de lugar ou um sentido de liberdade?" 78

A rede em geral, mais especificamente a linha de montagem mais uma vez aparece quando se discute a noção de espaço nos Estados Unidos, reforçando a importância destes elementos na modernidade nacional. Jackson utiliza a palavra 'Odologia', do radical grego hodos, que significa "caminho até a casa", para classificar a ciência ou estudo das viagens e das estradas, bem como sua genealogia. É uma ciência

76 É certo que muito dessa exuberância se perdeu atualmente, e provavelmente não só por conta do aumento do trânsito. A virada da década de 1960 para 1970, momento em que Banham escreveu o livro, representava o apogeu de uma sociedade progressista, e a tal "art of doing your own thing" se ampara na prosperidade de seus habitantes. Em tempos de crise financeira e cultura retraída, pouco se vê deste tipo de expressão pessoal. Na verdade, este aspecto da cultura angelena se perdeu um pouco em todas as esferas da vida cotidiana. 77 Idem. pp.200.

78 J. B. Jackson, "Roads Belong in the Landscape", p. 190. Texto otiginal: We are emerging from a centuries-long period when the road was subservient to place and given little respect. Today, a hundred years after the invention of the automobile, the question would be answered in favor of the road - or its modern version, the highway - which continues to weave a tight, intricate web over every landscape in the Western world and has spawned a whole breed of roadlike spaces - railroad lines, pipelines, power lines, flight lines, assembly lines. Now the question demands a very different sort of answer: Which do we value more, a sense of place or a sense of freedom? 
mista entre geografia, urbanismo e engenharia civil. Jackson enxerga riscos nessa fórmula, a partir do momento no qual se aplica regras de construção para leis sociais; ao mesmo tempo, vê com otimismo o futuro da ciência, a partir desse cruzamento entre ciências 'duras' e ciências sociais. ${ }^{79}$

Jackson também atribui uma intimidade única do americano com essa ciência, e um interesse maior pela cultura das estradas (pelo menos do que o interesse europeu). Onde o europeu vê monotonia, seja nas fileiras de celeiros e casas de fazenda, nas plantações infindáveis, nas cidades sem individualidade - em contraste com as cidades europeias, as quais seriam muito mais discerníveis - a ausência de marcos na paisagem é uma constante americana a ser valorizada e estudada, para encontrar a variedade nacional de sentido de lugar - genius loci. ${ }^{80}$

Genius Loci, ou espírito do lugar, é um conceito apresentado por Jackson para explicar sua versão de sentido de lugar. O espírito do lugar, cuja genealogia vem da divindade mitológica que protege um local específico, pode ser tanto atrelada ao espaço, por si, como também pode estar relacionado à história, aos costumes, e ao sentido de tempo. Para Banham, segundo Gabrielle Esperdy, o sentido de lugar estaria completamente atrelado às atividades humanas: como elas moldam o lugar, e como este é adaptado para se tornar um meio adequado para a realização das atividades humanas ${ }^{81}$. Já Jackson vê essa questão de maneira desatrelada do espaço: para ele, o foco está completamente no indivíduo e nos costumes compartilhados. Jackson consegue chegar a um conceito mais abstrato para conseguir emoldurar a imagem das autopistas, e leva mais à frente do conceito futurista de velocidade. $\mathrm{O}$ 'sentido do tempo' ora se soma, ora se contrapõe ao 'sentido de lugar'.

"A autopista nunca parece acabar. Há uma parada para caminhões acesa e as luzes de uma cidade que ficou para trás. Fileiras de caminhões estão parados pela noite em áreas de descanso, e em horas de viagem solitária vem a introspecção. O episódio favorito em romances, filmes e televisão mostram uma viagem solitária no coração da América pela paisagem noturna: uma ocasião para lembrar de outros tempos. Você pena sobre seu passado, pensa sobre seu trabalho, sobre sua destinação e sobre aqueles que você deixou. O painel mostra quão rápido você está dirigindo, diz a hora e quantas milhas faltam ainda. A mesmice da paisagem americana te abarca e libera de qualquer sentido de espaço. Familiaridade faz você sentir em casa em $\mathrm{O}$ sentido de tempo passando faz você gradualmente aumentar sua velocidade." ${ }^{82}$

79 Idem, p.191

80 J. B. Jackson, A Sense of Place, a Sense of Time, p.151.

81 Ver entrevista com Gabrielle Esperdy, em anexo nesta dissertação.

82 Idem, pp.152-153. Texto original: The highway never seems to end. There is an occasional brightly lit truck stop and the lights of a bypassed town. Rows of trucks are parked for the night at rest areas, and with hours of solitary travel there comes a mood of introspection. A favourite episode in novels and movies and television shows laid in the American heartland is that lonesome ride through the night landscape: an occasion for remembering other times. You think back over your past, think about your 


\section{A Home is not a House}

É já um grande desafio descrever de maneira compreensiva e coerente todas as modalidades de morar do cidadão Americano analisadas por Reyner Banham. Este, por sua parte, nunca abordou o tema diretamente: mesmo quando escreveu sobre as ecologias humanas em Los Angeles, Banham não se dedicou a falar da genealogia do habitat americano, e se reservou a narrar variações do tema da habitação ${ }^{83}$.

Há, portanto, o desafio de traçar um fio condutor para o conjunto. $\mathrm{O}$ desafio é válido, e necessário. Malgrado o tema da habitação não ter sido o foco principal de nenhuma de suas publicações, é um tema recorrente de diversos trechos de livros como Well-Tempered Environment, Los Angeles: the Architecture of Four Ecologies, e Scenes of America Deserta, remontando até seu livro de 1960 - Theory and Design in the First Machine Age.
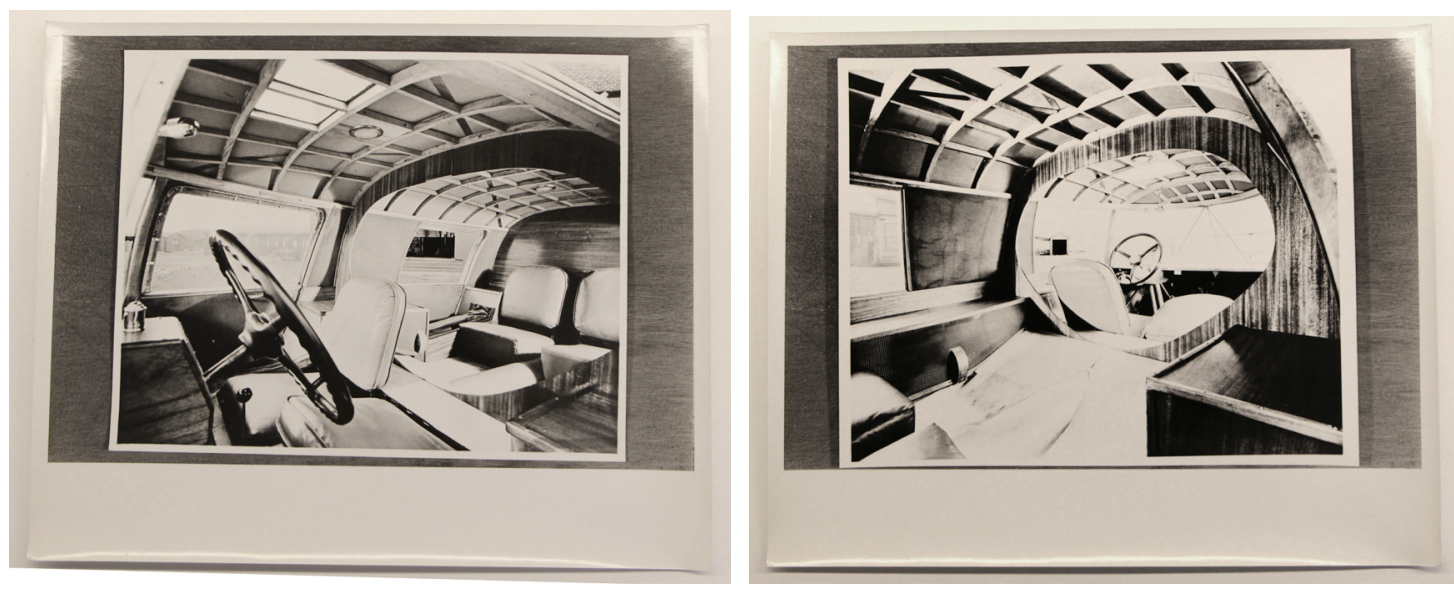

Buckminster Fuller, Dymaxion car, 1933. Fonte: arquivo Getty

Em 1965, quando escreveu o artigo "Home is Not a House" ${ }^{84}$, Banham chegou à conclusão de que os avanços tecnológicos de controle climático recentes permitiriam que o ser humano pudesse romper com a noção tradicional moradia, e se lançar a experimentações sobre o tema do abrigo adequado para atividades humanas. Arquitetos como Buckminster Fuller, Cedric Price e Peter Cook se lançaram a investigações teóricas que transitaram pelo mesmo questionamento. As walking cities do grupo Archigram ${ }^{85}$ exploravam a imagem da tecnologia do plástico, da cápsula

work, think about your destination and about those you have left. The dashboard display shows how fast you are driving, tells you the hour and how many miles you still have to go. The sameness of the American landscape overwhelms and liberates you from any sense of place. Familiarity makes you feel everywhere at home. A sense of time passing makes you gradually increase your speed. qualquer lugar. 83 Ver os capítulos "Surfurbia", "The Exiles", "Foothills" e "Plains of Id" in Reyner Banham, Los Angeles: the Architecture of Four Ecologies.

84 Em Art in America, n.2 (abril 1965).

85 Peter Cook, "Peter Would Enjoy These: Looking at the Edges of the Architectural Vocabulary Plus 
e da ficção científica, para explorar os limites conceituais da arquitetura através de uma vertente pop de megaestruturas urbanas. O edifício multifuncional de Cedric Price, o Fun Palace, foi segundo Nigel Whiteley a versão mais próxima do conceito de "responsive building for human activities" (edifício que responde à atividades humanas) ${ }^{86}$. Buckminster Fuller, herói do primeiro livro de Banham em 1960, explorou a transferência de conceito de arquitetura para desenho do meio - environmental design em seus projetos habitacionais, a partir da Dymaxion House ${ }^{87}$, em 1929.

Durante o período de pesquisa para a produção de The Architecture of the WellTempered Environment, entre 1964 e 1968, Reyner Banham recebeu recursos da Fundação Graham, então gerida por John Entenza, para visitar constantemente os Estados Unidos. Em muitas dessas ocasiões, Banham visitou a Califórnia, e desenvolveu interesse especial não somente por Los Angeles, mas também pela apropriação vernacular da tecnologia de controle climático do meio para expandir o vocabulário habitacional. De posse da tecnologia do automóvel, do ar-condicionado e calefação, do rádio e telefone, o cidadão americano poderia conquistar o território e sua própria individualidade. Um conceito de urbanização tão espraiada como o subúrbio, malgrado tenha surgido como tipologia na Inglaterra da revolução industrial, teria tomado a forma eloquente que povoa o ideário arquitetônico nos Estados Unidos, e atraiu o interesse de Banham. Juntamente com os trailers, as vans, e outras maneiras de se transportar sua própria residência, o subúrbio era sinônimo de privacidade e liberdade - pelo menos dos malefícios da urbanização moderna - para o americano médio.
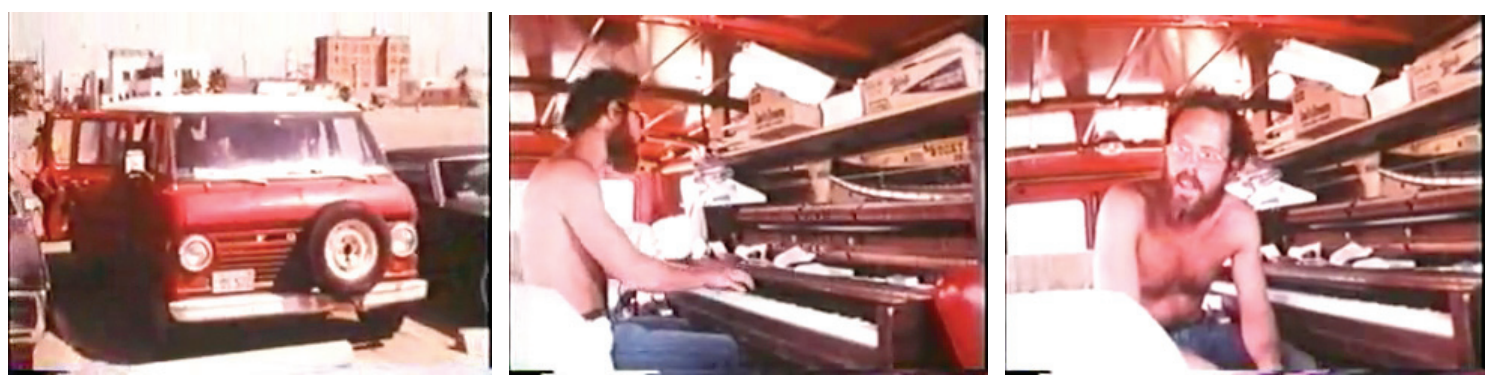

Cenas do documentário especial para televisão de 1972, “Reyner Banham Loves Los Angeles”, do canal Britânico BBC (38"55). O pianista da van, nômade em quatro rodas na Califórnia, seria para Banham a apropriação vernacular moderna e individualista das propostas radicais de moradia da década de 1960 e 1970.

Nos focaremos principalmente na leitura das diversas modalidades de

\footnotetext{
a Description of the Kunsthaus Graz", in Ainsley e Atkinson, pp.74-109. Peter Cook e Reyner Banham, malgrado de gerações ligeiramente diferentes, mantiveram contato ao longo de suas carreiras. Para maiores descrições, ver cap.1.

86 Nigel Whiteley, Reyner Banham: Historian of the Immediate Future. Cambridge: The MIT Press, 2005, pp. 324

87 Reyner Banham, “The Dymaxicrat”, in A Critic Writes: Essays by Reyner Banham. Berkeley: University of California Press, 1996.
} 
subúrbio no território americano, e nas propostas mais radicais de moradia integrada à paisagem. De fato, Banham não demonstrou interesse claro por outras modalidades de habitação que preconizavam uma densidade de ocupação maior, como nas metrópoles densas como Nova Iorque e Chicago, Philadelphia ou Boston. É importante desde já apresentar o argumento de que Banham atrela a ideia de uma liberdade cultural à possibilidade de criação de um espaço próprio para realizar essas atividades com liberdade, mesmo que esse local fosse uma fabricação, fora da cidade criada pela própria economia e cultura urbanas. Cidade e não-cidade juntas, este é o conceito de subúrbio, adotado não somente por Banham, mas como veremos, por muitos outros pesquisadores.

Para Robert Fisherman, em Bourgeous Utopias, o subúrbio é mais do que a reunião de casas, mas sim o local no qual se pode encontrar os monumentos da burguesia. É para as família o refúgio - no caso inglês e americano - tanto dos elementos da cidade que possam colocar em risco a utopia de uma vida perfeita de lazer, valores familiares e saúde, quanto dos próprios malefícios e contradições da cidade burguesa. ${ }^{88}$

“Desde suas origens, o mundo suburbano de lazer, vida familiar e união com a natureza estava baseado no princípio de exclusão. Trabalho era excluído da residência familiar; casas de classe média eram segregadas da habitação da classe trabalhadora; o verde do subúrbio contrastava com o meio urbano, poluído e cinza. Mulheres da classe média eram especialmente afetadas pela dicotomia suburbana de trabalho e vida familiar. O novo meio supostamente enaltecia seu papel na família, mas também as segregava do mundo do poder e produtividade. Essa auto-segregação rapidamente abraçou todos os aspectos da utopia burguesa, a asserção triunfante dos valores da classe média. Isso também reflete a alienação da classe média do mundo industrialurbano que elas mesmas estavam criando." ${ }^{89}$

Para entender melhor a análise de Banham a respeito das variações do subúrbio que encontrou, é importante compreender a idéia de segregação, e como cada cultura encontra seu lugar para a formação de uma cultura local. Jackson rastreia a formação das cidades americanas como uma composição cultural.

88 Robert Fisherman, Bourgeois Utopia: the Rise and Fall of Suburbia. New York: Basic Books, 1987, p. 4

89 Idem, p. 4. Texto original: From its origins, the suburbian world of leisure, family life, and union with nature was based on the principle of exclusion. Work was excluded from the family residence; middleclass villas were segregated from working-class housing; the greenery of suburbia stood in contrast to a gray, polluted urban environment. Middle-class women were especially affected by the new suburbian dichotomy of work and family life. The new environment supposedly exalted their role in the family, but also segregated them from the world of power and productivity. This self-segregation soon enveloped all aspects of bourgeois utopia, the triumphant assertion of middle-class values. It also reflects the alienation of the middle classes from the urban-industrial world they themselves were creating. 
"A população de muitas cidades americanas vêm de todos os cantos dos Estados Unidos, e Europa. Quando cada elemento étnico tem sua própria igreja, seu próprio tipo de emprego, sua própria ideia de vida pública, a praça central significa muito pouco. Um arranjo frequentemente transformado de ruas e espaços, ajustados à valores do mercado imobiliário e um aumento do trânsito, torna-se geral: quadras residenciais, ao invés de se agrupar ao redor de setores comerciais, tentem se mover para onde o futuro imediato é mais previsível." 90

Logo depois, Jackson identifica como essa tendência pela segregação, também encontrada por Fisherman, seria defendida por arquitetos locais como Frank Lloyd Wright - dentro do conceito da Broadacre City - gerando um conceito de espraiamento urbano de escala ainda desconhecida pela humanidade.

Para Jackson, o americano teria sido educado para acreditar que a maneira adequada de ocupação do território é aquela baseada em núcleos compactos e bem definidos, em uma composição compacta de arruamento com algum ponto notável em seu centro (uma praça, igreja, ou monumento), favorecendo o encontro cotidiano e a vida do pedestre. Teoricamente, é claro. Na prática, Jackson observa o contrário. A maioria da população nos Estados Unidos tende a tomar uma distância de seus vizinhos e comunidades. Historicamente, as autoridades urbanas teriam se esforçado para conter o espraiamento. ${ }^{11}$ Já Gwendolyn Wright, em USA: Modern Architectures in History, destaca aspectos relacionados à mídia como força condutora da difusão do estilo de vida suburbano, desde o século XIX. Periódicos direcionados à construção residencial destaca-se o pioneirismo dado no enfoque da dona-de-casa americana como protagonista de sua narrativa. Desde a Guerra Civil, um mecanismo de urbanização extremamente espraiada, que facilitava a manutenção da saúde pública e propiciava a geração de renda teria se popularizado. O paisagismo pitoresco inglês também seria forte influência na modelagem de diversos empreendimentos. A figura do loteador privado, apoiado por incentivos públicos, surgiria e se manteria como força motriz da economia e do urbanismo até então. ${ }^{92}$

"A verdade é os americanos têm duas ideias sobre como viver. Publicamente, dizemos coisas pesadas sobre o espraiamento dos subúrbios, e encorajamos a atividade no coração da cidade. Em teoria, mas somente em teoria, nos queremos duplicar a comunidade compacta tradicional da Europa, na qual todos tomam parte de uma vida

90 J. B. Jackson, A Sense of Place, a Sense of Time, p.156. Texto original: The population of many American towns comes from all over the United States and Europe. When each ethnic element has its own church, its own kind of employment, its own idea of public life, the central square means very little. A flexible and frequently shifting arrangement of streets and spaces, adjusted to new real state values and an increased traffic flow, becomes general: residential quarters, instead of grouping around the business section, tend to move out to where the immediate future is more predictable.

91 J. B. Jackson, A Sense of Place, a Sense of Time, pp.156-157

92 Gwendolyn Wright, USA: Modern Architectures in History. London: Reaktion, 2008, pp.37-38. 
pública rica e diversa. Mas ao mesmo tempo muitos de nós estamos secretamente comsiderando um refúgio, um pedaço de terra, ou uma pequena casa no campo onde podemos levar uma vida intensamente privada e não urbana, se mantendo perto de casa. Eu não estou inteiramente certo de que essa é uma contradição real. Enquanto nós concordamos que o espraiamento e o moribundo centro da cidade são ambos de má aparência e ilógicos, nos também sentimos, eu penso, uma profunda e persistente necessidade de privacidade e independência em nossa vida doméstica. Por isso uma moradia erguida em sua própria parcela de terra, seja em um bairro abastado ou nas franjas urbanas empobrecidas, é uma característica tão persistente de nossa paisagem. É por isso que as áreas centrais, não importa como estejam economicamente, são tão desprovidas de sentido de lugar. " ${ }_{93}$

Em sua investigação pessoal sobre os modos de morar do cidadão americano, Banham encontra as anomalias desse sistema: As suburbanizações à beira-mar, os refúgios na sinuosa estrada Mullholand Drive, as planícies infindáveis ocupadas por um mar de residências, entrecortadas e sobrevoadas por autopistas. Formada por não somente diversas variações sobre o tema, Los Angeles seria a metrópole da suburbanização. Fisherman dedica um capítulo aos comentários sobre a cidade de Los Angeles. Nela, a desconfiguração do centro histórico e descentralização apoiada pelo espraiamento da rede de viária dedicada ao automóvel significou a universalização do subúrbio como forma de urbanização. ${ }^{94}$ A cidade se torna a metrópoles suburbana.

"Não por surpresa, essa nova cidade era incompreensível, pelo menos para forasteiros. Richard Neutra, o grande arquiteto de Los Angeles, descreve a Conferência Internacional de Arquitetura Moderna (CIAM) em Bruxelas de 1931, na qual tentouse prover mapas para as grandes cidades do mundo, utilizando a mesma escala e símbolos para distritos comerciais, zonas fabris, favelas, subúrbios e outros. Não apenas o mapa de Los Angeles deixava os outros parecendo pequenos, virtualmente monopolizando o espaço livre de parede, mas os símbolos pareciam quase

93 Idem, p. 157. Texto original: The truth is, Americans are of two minds as to how we ought to live. Publicly we say harsh things about urban sprawl and suburbia, and we encourage activity in the heart of town. In theory, but only in theory, we want to duplicate the traditional compact European community, where everyone takes part in a rich and diversified public life. But at the same time most of us are secretly pinning for a secluded hideaway, a piece of land, or a small house in the country where we can lead an intensely private nonurban existence, staying close to home. I am not entirely sure that this is a real contradiction. While we agree that scatteration and the dying central city are both of them unsightly and illogical, we also, I think, feel a deep and persistent need for privacy and independence in our domestic life. That is why the freestanding dwelling on its own well-defined plot of land, whether in a prosperous residential neighborhood or in impoverished urban fringes, is so persistent a feature of our landscape. That is why our downtown areas, however may be economically, are so lacking in what is called a sense of place.

94 Fisherman, pp.155-157. 
inaplicáveis.” “95

Em Ecology 1: Surfurbia, Banham vai longe na apologia da cultura do surf e da praia, identificando um sinal de contra-cultura da sociedade de consumo: a cultura da praia seria em muitas maneiras uma rejeição simbólica dos valores da sociedade de consumo, um lugar onde é necessário apenas possuir roupas de banho e óculos de sol.

“Existe um sentido para a praia ser o único lugar em Los Angeles onde todos os homens são iguais e em um lugar comum. Parece existir (e em certo grau existe de fato) uma real alternativa à tendência da vida a se compartimentar nas maçonarias das praias, e malgrado algumas escolas supostamente mantém um sistema de 'domínios' que reconhece algumas praias como território particular, é possível para um homem vestido de bermuda e uma garota de biquíni ir para qualquer praia sem ser molestado - até praias privadas se eles tiverem coragem de entrar. De uma maneira ou de outra, a praia é o que a vida de Los Angeles inteira." 96

95 Fisherman, p.156. Texto original: Not surprisingly, this new city was incomprehensible, at leas to outsiders. Richard Neutra, the great Los Angeles architect, describes the 1931 International Conference for Modern Building (CIAM) at Brussels, where an attempt was made to provide maps for all the world's great cities, using the same scale and standard symbols for business districts, factory zones, slums, suburbs and so on. Not only did the Los Angeles map dwarf all the others, virtually monopolizing the available wall space, but the symbols seemed almost inapplicable.

96 Ver Banham, Los Angeles, p.20-21. Texto original: There is a sense in which the beach is the only place in Los Angeles where all men are equal and on common ground. There appears to be (and to a varying degree there really is) a real alternative to the tendency of life to compartmentalize in this freemasonry of the beaches, and although certain high schools allegedly maintain a 'turf' system that recognizes certain beaches as the private territories of particular schools, it is roughly speaking possible for a man in beach trunks and a girl in a bikini to go to almost any beach unmolested - even private ones if they can muster the nerve to walk in. One way and another, the beach is what life is all about in Los Angeles. 


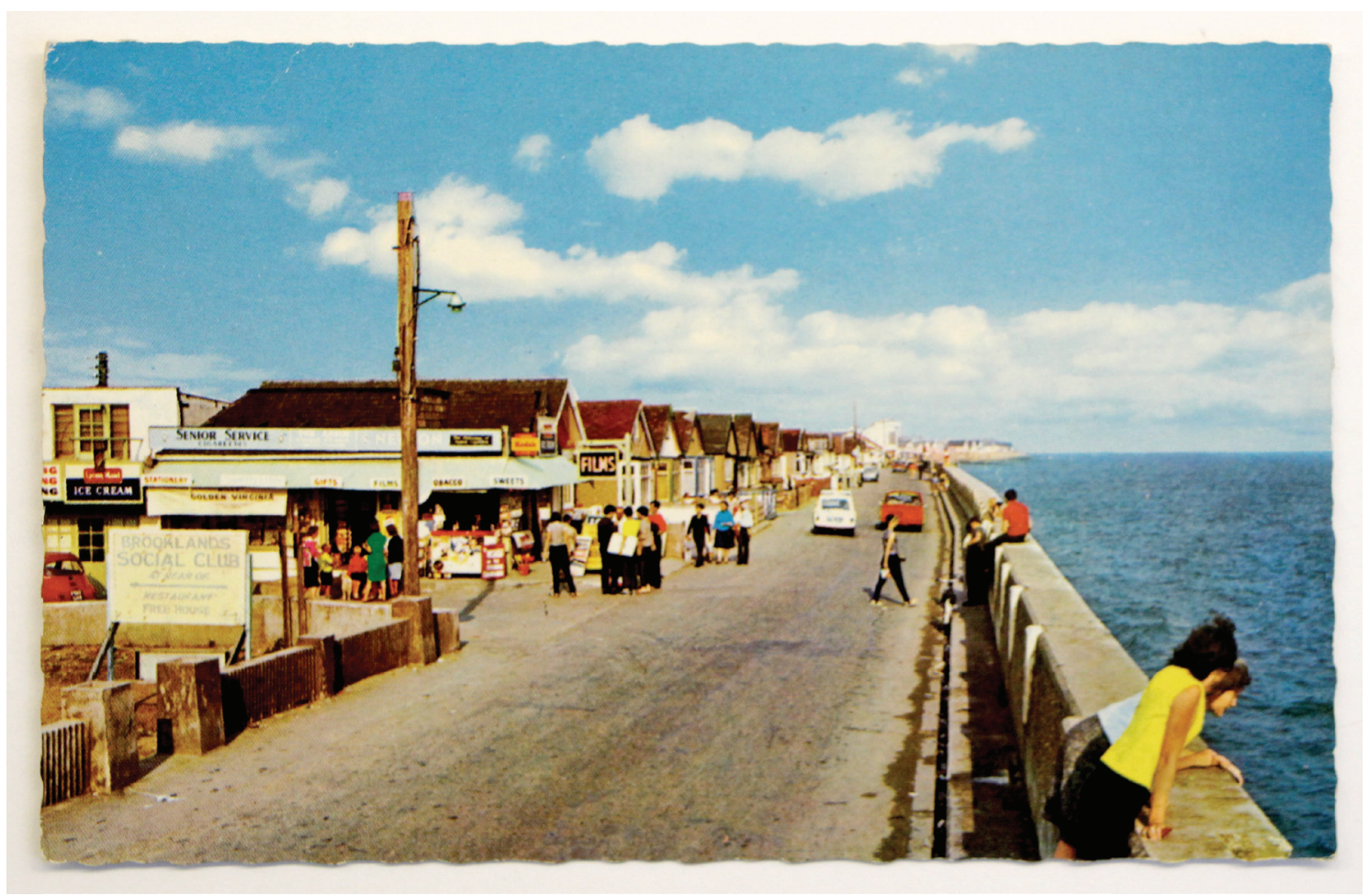

Cartão Postal de Los Angeles (provavelmente Marina Del Rey), s/ data. Fonte: arquivo Getty

Este é um dos trechos em que Banham é mais radical em sua leitura da cidade. Com certeza, essa leitura não é compartilhada por moradores de Pasadena, Silver Lake, Hollywood ou Eagle Rock, cujo deslocamento para a área costeira de Los Angeles levava mais de uma hora, às vezes duas, dependendo da crueldade do trânsito nas autopistas (hoje, com certeza, o tempo para tal percurso é muito maior). Mas com certeza este estilo de vida, de Malibu à Balboa, é um dos mais importantes para a imagem da cidade. E Banham relaciona este estilo de vida a dois exemplares de arquitetura residencial moderna: a casa Hunt, de Craig Ellwood (em Malibu), e a Lovell House, projetada por Rudolph Schindler, localizada no começo da península de Balboa $^{97}$. Banham fará então uma descrição das praias e portos, no sentido norte-sul, oeste-leste, descrevendo os "surfurbs", um lugar paradoxal, no qual se encontram o estilo de vida despojado da cultura de praia, com os valores da sociedade de consumo que toma forma nas diferentes tipologias de subúrbio Angelenas.

97 Idem, pp.21-22. 

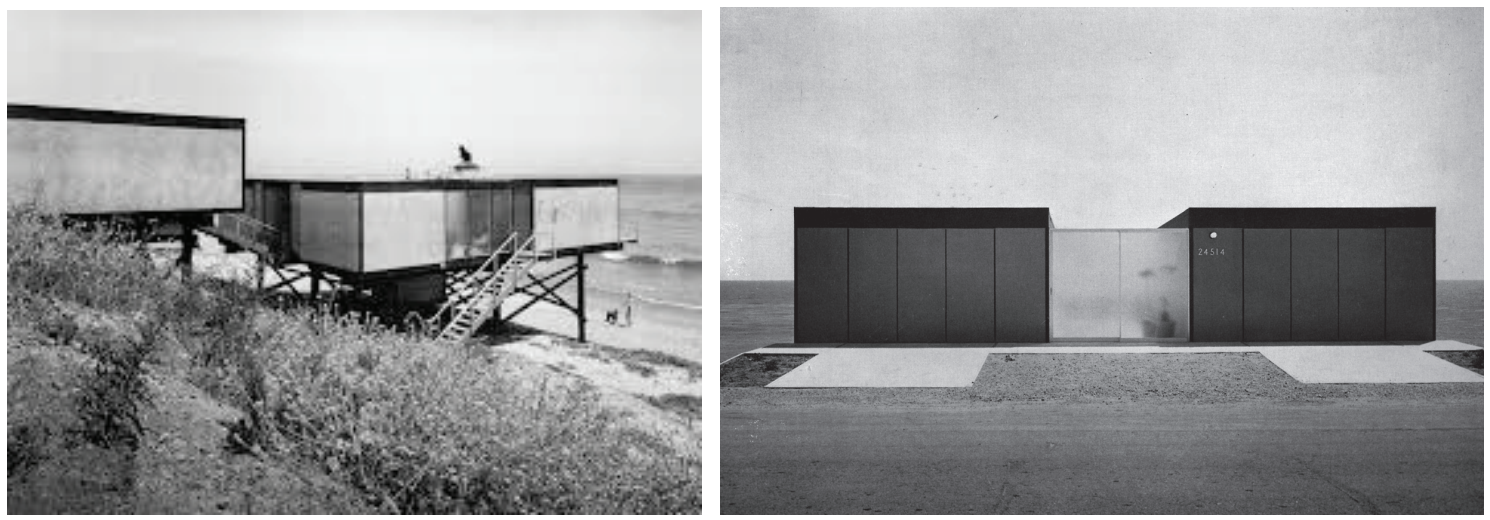

Craig Ellwood, Hunt House, Malibu, Califórnia, 1955. Foto: Julius Shulman

No caso de Malibu, lotes teriam sido vendidos entre a estrada e a praia, nos quais foram construídas casas, formando um renque intransponível: o acesso à praia, portanto, torna-se privativo por questões físicas, mais do que institucionais. Somente a partir de Santa Monica o acesso e usufruto das praias ganha ares públicos - talvez por conta das íngremes falésias da região. No topo destes morros, encontram-se o bairro chamado Pacific Palisades, no qual se foi construída a casa do casal Eames, que desfruta até hoje de uma privilegiada vista do cânion e do píer de Santa Monica ${ }^{98}$. Este cânion foi explorado para a tentativa de formar lá o principal porto de Los Angeles, o que não ocorreu, principalmente após o estabelecimento do Porto de San Pedro. De qualquer maneira, o advento da linha ferroviária permitiu a ocupação organizada e intensa da região de Santa Monica, que se tornou uma das mais urbanizadas praias da região.

Banham descreve o fracasso de locais como Venice - na época de publicação do livro, um empreendimento ainda decadente e fracassado, uma tentativa de reproduzir os canais de Veneza em uma parcela de terra destinada à loteamento e venda de imóveis residenciais. Hoje, uma renascença movida pela gentrificação e especulação imobiliária trazem novos investimentos a um antigo reduto da cultura 'hippie'.

No 'surfurbio', a viela entre a rua e a praia é a "artéria" da vida praiana. Fechada para automóveis, é o reduto dos sufistas, ciclistas e banhistas. Algumas casas abrem suas portas somente para essa viela; e é onde pode-se ver um dos mais interessantes artefatos da cultura praiana de Banham, a prancha de surf. Banham remonta historicamente a prática do surf, e aborda a materialidade do objeto com entusiasmo e excitação:

"A prancha de surfe é o principal artefato simbólico e functional dessas praias onde se começou a surfe na Califórnia. O esporte foi trazido aqui - como quase todo o resto - pela Pacific Eletric Railroad em 1907 quando, de modo a estimular o transporte em finais de semanas, trouxeram Geourge Freeth, o surfista pioneiro Hiberno-Havaiano para a praia de Redondo, para dar demonstrações de surf. O surf se manteve um

98 Idem, pp.26-27. 
esporte duro e restrito - em grande parte por conta das pranchas de madeira massivas - até o meio dos anos 1950, quando a versão moderna de prancha feita de plástico com fibra de vidro chegou ao surf, mais prática e mais barada (porque era produzida em massa) do que a prancha tradicional. O que aconteceu desde então foi - como dizem - história, mas alguns poucos episódios da história à beira-mar desde as invasões vikings foram tão coloridas. Debruçadas pelo passeio à beira-mar, ou fincadas na areia como monolitos de plástico, elas concentram praticamente toda a capacidade de Los Angeles em criar imagens decorativas, e fixar essas imagens nesta panóplia de técnicas visuais e materiais - e tudo isso, lembrem-se, no serviço da forma local preferida de nobre selvagem, com seus músculos nus e reações habilidosas contra toda a força do poderoso Oceano Pacífico." ${ }^{99}$

99 Idem, p. 31. Texto original: The surf-board is the prime symbolic and functional artefact of these beaches where California surfing began. The sport was brought here - like almost everything else - by the Pacific Electric Railroad in 1907 when, in order to stimulate flagging passenger traffic at weekends, they brought George Freeth, the Hiberno-Hawaiian pioneer surfer, to Redondo Beach to give demonstrations of surf-riding. It remained a tough and restricted sport - largely because of the unwieldy massive wooden boards - until the middle 1950's, when the modern type of board made of plastic foam jacketed in fibreglass hit the surf, handier and effectively cheaper (because mass-produced) than the traditional board. What has happened since is - as they say - history, but few episodes of seaside history since the Viking invasions can have been so colourful. Leaning on the sea-wall or stuck in the sand like plastic monoliths, they concentrate practically the whole capacity of Los Angeles to create stylish decorative imagery, and to fix those images with all the panoply of modern visual and material techniques - and all, remember, in the service of the preferred local form of noble savage, pitting his nearly naked muscles and skilled reactions against the full force of the' mighty hulking Pacific Ocean'. 


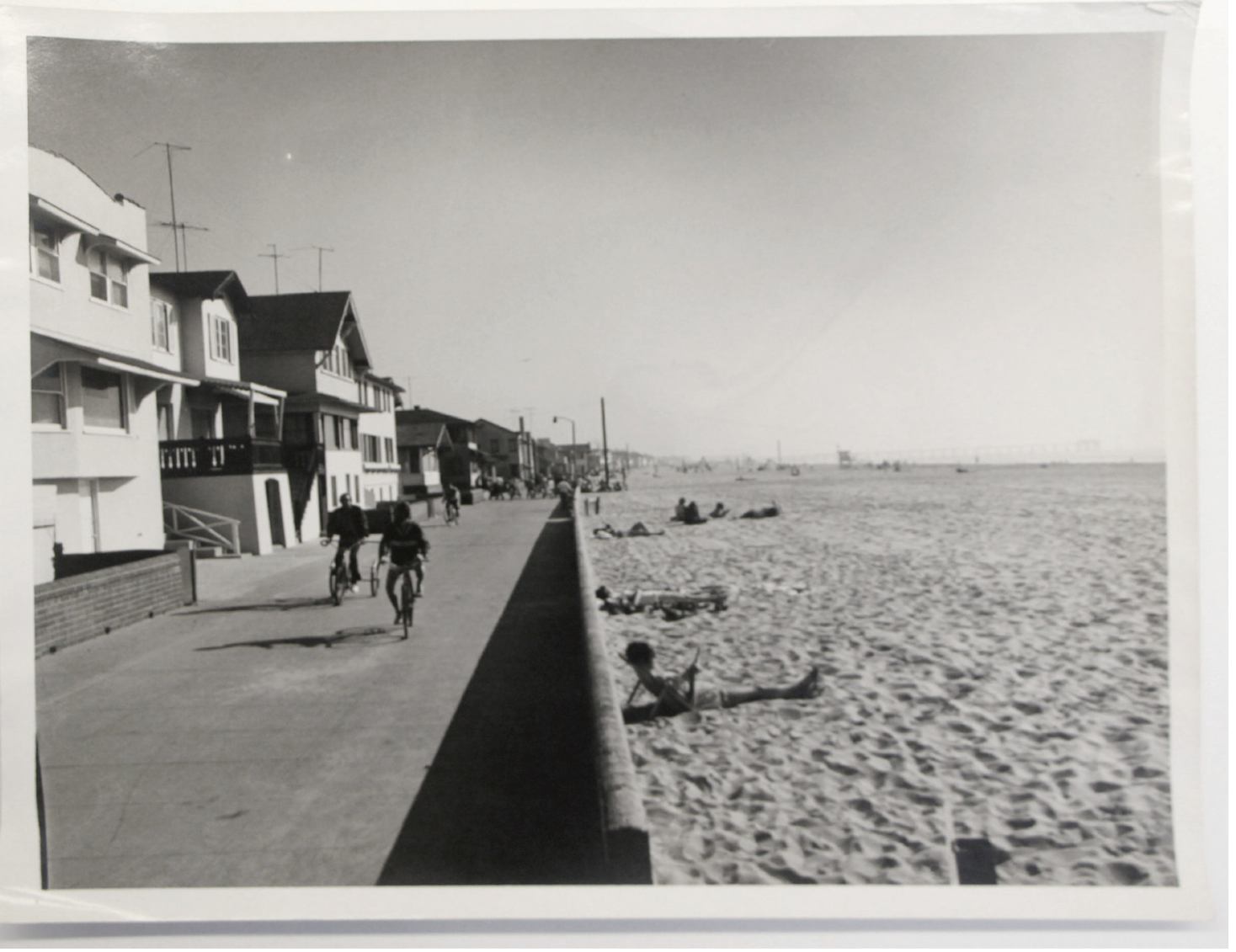

"Surfúrbio" em frente à praia de Los Angeles (provavelmente Malibu ou Venice), s/ Data. Foto: Steve Wilkings. Fonte: arquivo Getty.

No capítulo 5, "Ecology II: The Foothills" Banham descreve os princípios de ocupação dos pés de morro, no território do antigo pueblo de Los Angeles (fundado pelo governador Felipe de Neve), seguindo o curso do rio Los Angeles. Em seguida, ele cita o plano de extensão do Tenente Ord em 1849, em contraste à iniciativa dos cidadãos em ocupar a colina ${ }^{100}$. Os Heights, ou 'altos' ou 'outeiros', eram estas regiões da cidade, altamente adensadas, de característica predominantemente pedestre, malgrado estivesse inserida em uma cidade cujo contexto era desde daquela época motorizado.

Ao redor da década de 1870, teria se iniciado o desenvolvimento da região dos foothills angelenos, viabilizados pela proximidade do braço da linha ferroviária de Santa Mônica convenientemente próximo dos pés de morro de Hollywood Hills e a montanha de Santa Monica. Porém foram iniciativas tímidas:

“O total desenvolvimento de até mesmo essas eminentemente desejáveis terras seriam de esperar, como tantas outras coisas em Los Angeles, pelos bondes elétricos, e estes chegaram em com Pasadena, e Pacific Lines de Sherman e Clark, em 1895."101

100 Idem, p. 77.

101 Idem, p. 79. Texto original: The full development of even these eminently desirable lands would 
Os bairros novos que ocuparam as Colinas da região da cidade, tanto no oeste Hollywood, West Hollywood, Bel Air, Beverly Hills, Pacific Palisades - tanto quanto à leste - Highland Park, Pasadena, San Marino, Sierra Madre - representariam um lado do mapa socioeconômico da cidade: quanto mais alto se mora, maior é sua renda. Ao sul, no entanto, estão presentes os subúrbios mais abastados da cidade, onde se destaca o conjunto Palos Verdes Mountain - que continha Palos Verdes, Palos Verdes States, cuja posição geográfica e natureza cuidadosamente controlada trazia uma superioridade tremenda de visual. Estes dividem com os demais empreendimentos de alta renda as características urbanísticas cujo objetivo é separar-se da malha urbana convenciona, quadriculada, e fornecer mecanismos para isolar das demais populações da cidade, fossem elas negras ou mexicanas. São rua levemente curvadas, em desenho tortuoso, no lugar de cactos e outras plantas do deserto, uma fantasia de vegetação exótica graças ao solo fértil da região e ao extremo cuidado dos proprietários. A ideia seria cultivar espécies de vegetação densa, fechada, a fim de garantir uma privacidade instantânea.

Tais bairros forneceram à indústria cinematográfica de Hollywood material para ilustrar as fantasias dos filmes policiais (private-eye), filmes noir, enfim, gerar fantasias em torno da vida privada (e escala privada), onde detetivea se esgueiravam entre arbustos, passando por portas de madeira maciça e entrava por soleiras curvas no estilo Spanish-Colonial, passava pela lareira, a fim de buscar provas, ou suspeitos, ou frequentar essas casas durante o dia para encontrar clientes banhando-se em piscinas privativas. A indústria cinematográfica foi responsável por divulgar essa fantasia privativa para o mundo, criando uma notoriedade quase instantânea dessa ecologia humana, até então recentemente criada. No documentário da BBC, “Reyner Banham Loves Los Angeles" Banham se arrisca a reproduzir a encenação hollywoodiana.
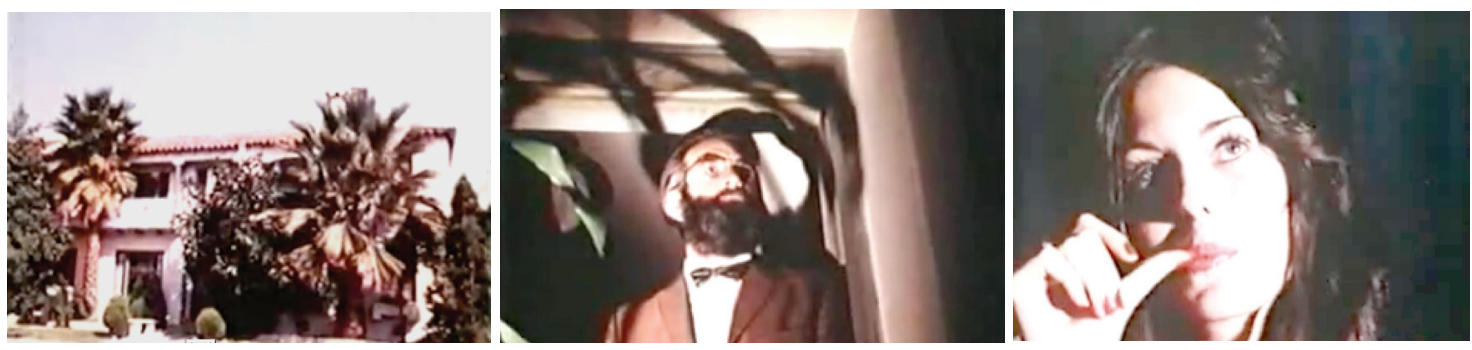

Cenas do documentário especial para televisão de 1972, “Reyner Banham Loves Los Angeles”, do canal Britânico BBC (21"34). "Dreams, domestic dreams, that Money can buy, but dreams like the dreams of Hollywood."Tradução: Sonhos, sonhos domésticos, que o dinheiro consegue comprar, mas sonhos como os sonhos de Hollywood.

Curiosamente, aponta Banham, a casa típica do angeleno, mesmo daquele que vive nas colinas, seria pensada como uma construção térrea. A tecnologia utilizada nos anos

have to wait, like so many other things in Los Angeles, for the electric trains, and these arrived with the Pasadena and Pacific lines of Sherman and Clark in 1895. 
1960 seria uma tentativa de satisfazer, valendo-se de qualquer meio possível, o desejo de viver em um terreno plano como em uma planície de subúrbio, ao invés de sentir-se num barranco, porém com os benefícios de vista desobstruída e espaço reservado:

"A solução comum por muito tempo foi criar uma subestrutura reticulada de alguma maneira, colunas e sapatas para trava-los no talude para impedir que tudo deslize barranco abaixo. A casa de Craig Ellwood no número 401 em Crestwood Drive é um clássico deste tipo de solução, porque a casa térrea é integrada com o sistema de suporte abaixo, uma estrutura metálica simples é uma continuidade da estética do sistema de pilares das caixas de vidro, deixando o espaço abaixo, entre casa e barranco, completamente livre. Uma solução mais ou menos equivalente em madeira, integrando a subestrutura com a arquitetura acima, pode ser vida na Casa Seidenbaum desde a Mulholland Drive projetada para Richard Dorman, e muito da suposta excentricidade da arquitetura residencial de John Lautner é rastreável à tentativa de resolver esse tipo de problema - sua famosa Casa Chemosphere (também a partir de Mulholland) estar erguida em uma única coluna de concreto é uma solução bem razoável e pensada, dada a declividade de 45 o do terreno.." 102

102 Reyner Banham, Los Angeles, p.83. Texto original: The common solution for a long time has been to create a framed substructure of some sort, with supporting posts and tiles and 'dead-men' to fix it back to the slope behind and stop the whole affair sliding. Craig Ellwood's Smith house 401 on Crestwood Drive is a classic of this kind of solution, because the flat-floored single-storeyed house is integrated with the supporting frame below, a common steel structure continuing the bay-system of his customary glass-box aesthetic down to the footings on the slope and leaving the space underneath wide open. A more or less equivalent solution in wood, integrating the sub-frame with the architecture above, can be seen in the Seidenbaum house off Mulholland Drive [41], designed by Richard Dorman, and much of the Supposed eccentricity of the domestic architecture of John Lautner is traceable to the attempt to solve this kind of problem - his famous Chemosphere house [42] (also off Mulholland) standing on its single concrete column is a very reasonable and well worked out solution, given the forty-five degree slope of the site 


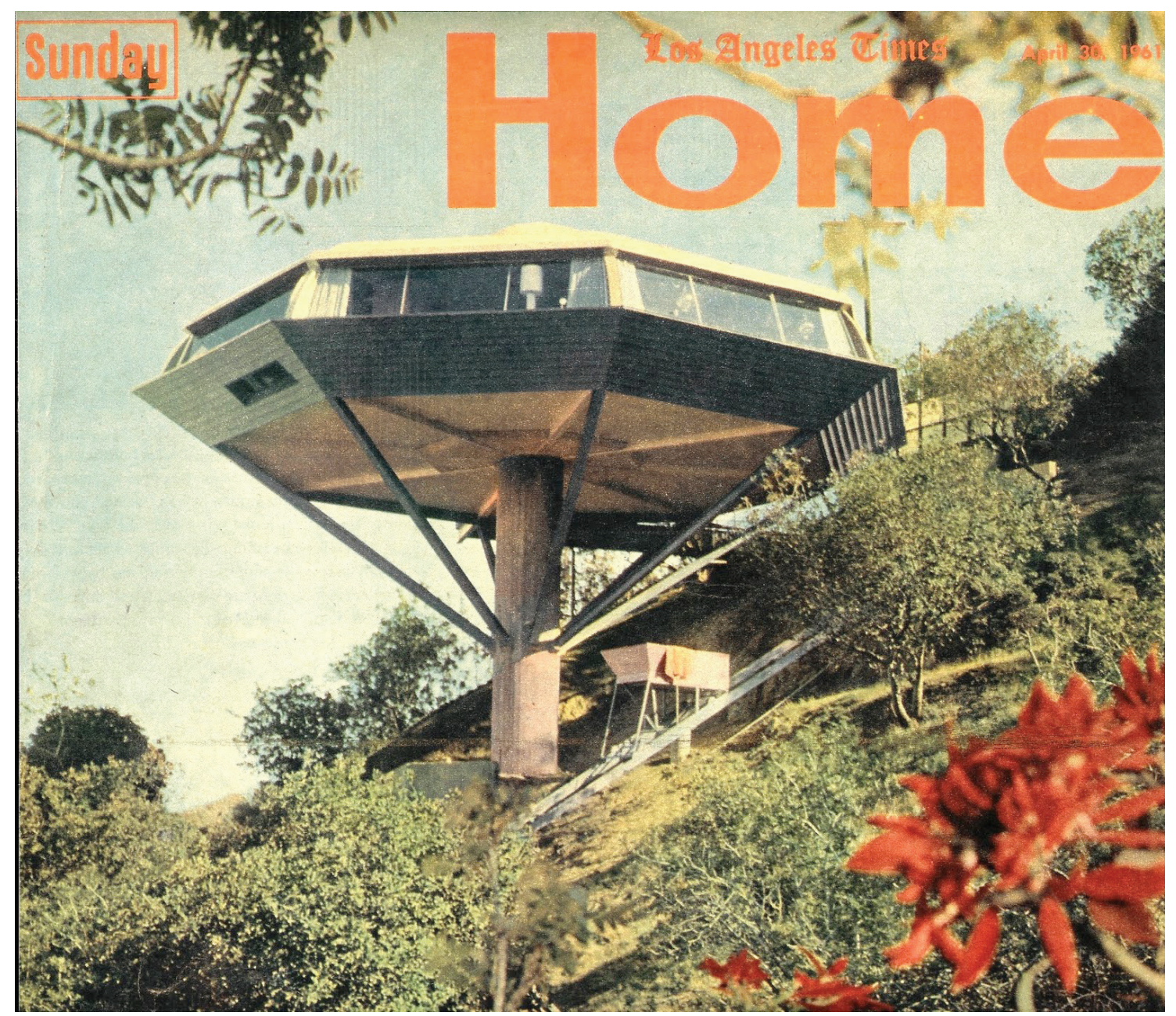

Capa da revista Los Angeles Time: Home, 30 de abril de 1961, destacando a residencia Chemosphere, de John Lautner. Seria para Banham esta residencia a herdeira do legado da Dymaxion House de Buckminster Fuller?

Completantdo a série de tipologias habitacionais da cidade, haveria o dingbat, tipologia residencial disseminada de maneira abrangente pela grande mancha suburbana reticulada das planícies de Los Angeles ${ }^{103}$. Mais adensados que o subúrbio tradicional americano, as planícies são povoadas por sobrados, geminados ou não, seja se apropriando de maneira inadvertida e sem intenções intelectuais de motivos da arquitetura moderna, das tradições do Spanish Colonial Revival, ou simplesmente da estética kitsch. Para Banham, essa tipologia construtiva seria a forma que melhor poderia resumir a arquitetura média angelena ${ }^{104}$. Seria a expressão do Id de Los Angeles, tentando ajustar a alta densidade com as necessidades de fantasia do cidadão suburbano, mesmo que modesta: de referências desde Rudolph Schindler, passando pelo estilo Cape Cod ao mediterrâneo, os dingbats simbolizariam os sonhos

103 Idem, p.117. O termo foi emprestado por Banham do professor Francis Ventre. Sem tradução direta, o dingbat significaria no caso uma simbologia reduzida de algo maior. No caso, outra tipologia construtiva. O dingbat é o conceito cenográfico de Hollywood e Disney transposto para a arquitetura residencial.

104 Idem, pp.117-119. 
suburbanos, a necessidade de transposição de lugar, de estar lá, mas em qualquer outro lugar. É um sentimento possível dentro da grelha suburbana, monótona e delirante.

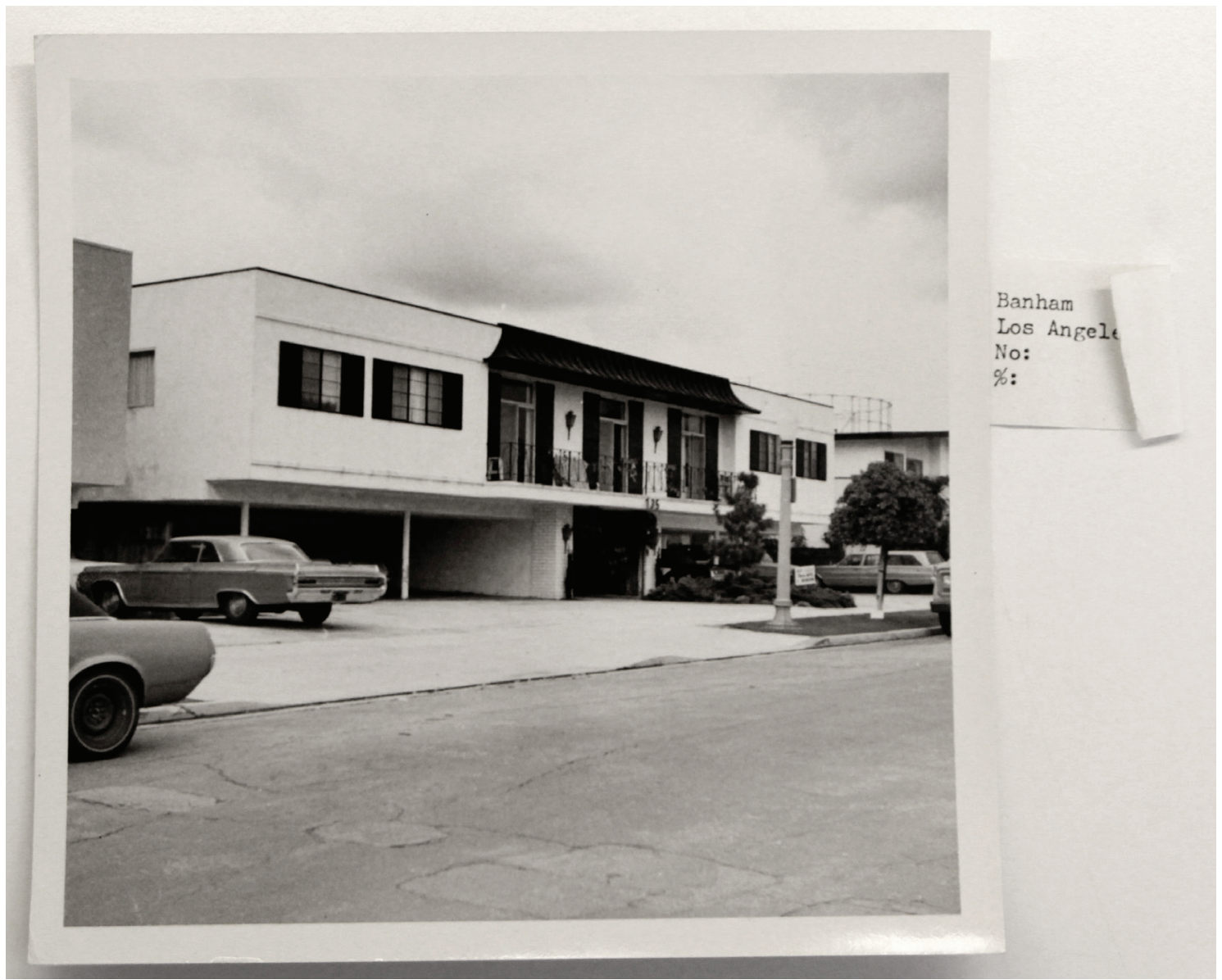

O classico dingbat Californiano, s / data. Fonte: arquivo Getty.

“Nessa grelha, não na águia de estrelas e listras, que é nosso verdadeiro emblema nacional. Eu acho que deve estar impresso no momento de concepção de cada criança Americana, a permanecer por toda sua vida como uma maneira de calcular não só espaço como também movimento." ${ }^{105}$

105 Ver Jackson, a Sense of Place, a Sense of Time, p.153. Texto original: I its this grid, not the eagle of stars and stripes, which is our true national emblem. I think it must be imprinted at the moment of conception on every American child, to remain throughout his or her life a way of calculating not only space but movement. 


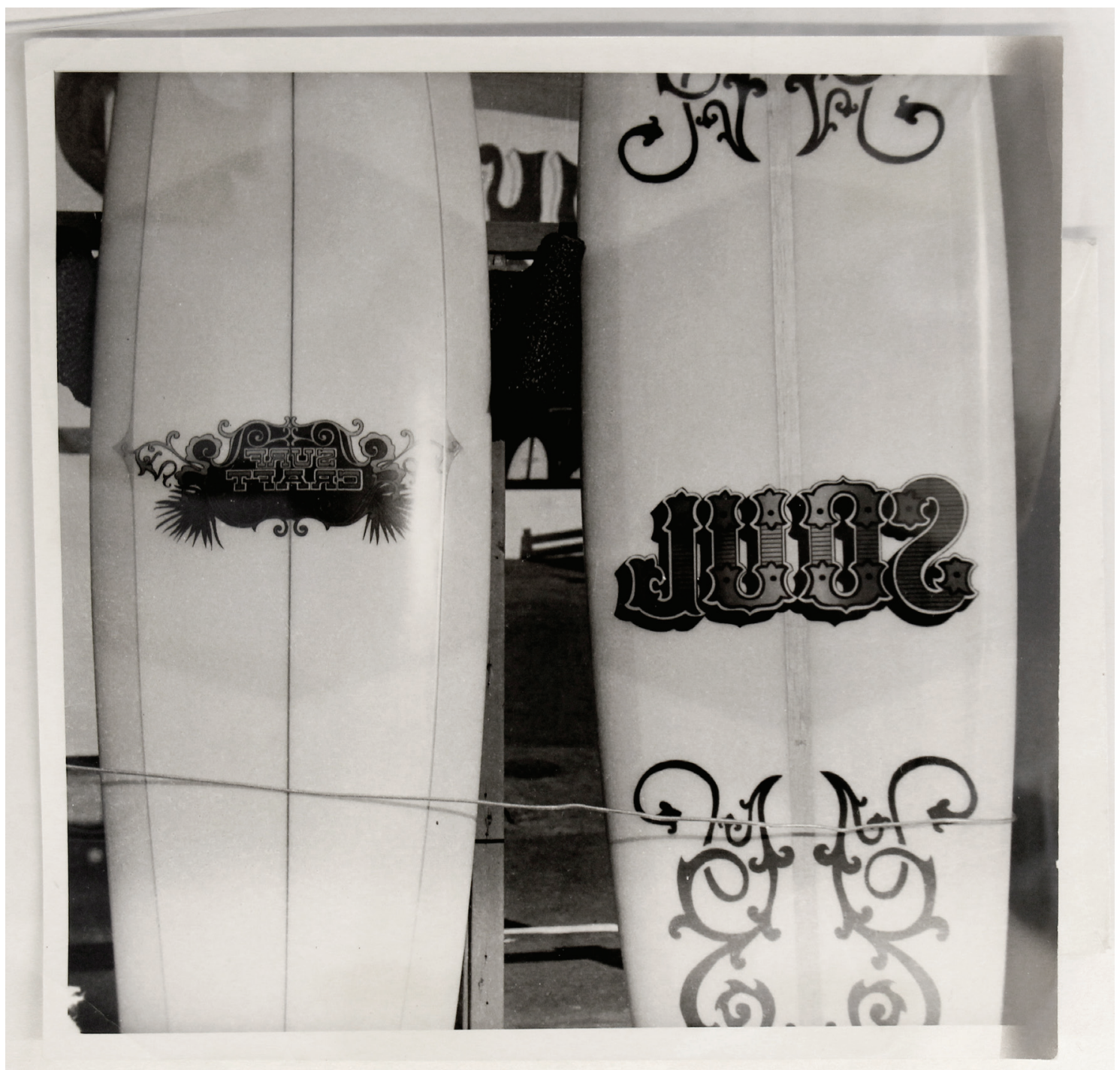

Pranchas de Sufe, s/Data. Fonte: Arquivo Getty. A imagem faz parte da série de fotografias sobre customização de pranchas de surf, publicadas no capítulo "Surfurbia”, em Los Angeles: the Architecture of Four Ecologies, p.30

Não foi novidade a perspectiva apresentada por Banham sobre expressão vernacular moderna, e sobre o amplo espaço conquistado na paisagem americana: o acesso facilitado aos meios de produção, seja por necessidade ou prazer, proporcionou ao americano comum - sobre quem patrulha do rigor estético não recai tanto quanto ao profissional da arquitetura - a criar uma paisagem customizada às suas necessidades, gostos, e ambições pessoais.

Para alcançar o patamar do 'fantástico', da ostentação e brilho que permeiam a história da arquitetura americana, no estado da California, desde a década de 1920, diversos grupos culturais desenvolveram expressões personalistas de objetos que compunham a paisagem cultural de cidades como Los Angeles, a capital da hipérbole 
americana, que não somente atraiu Banham, mas também americanos como Charles Jencks ${ }^{106}$ e Mike Davies ${ }^{107}$, e outros ingleses como Anthony Vidler, e os escritores Christopher Isherwood ${ }^{108}$ ou Tom Wolfe.

Wolfe, em especial, foi um dos principais interlocutores de Banham e um dos poucos citados diretamente em seus livros. Podemos notar as proximidades entre as narrativas de Banham e Wolfe, bem como perceber seu interesse mútuo pelos artigos produzidos pela cultura americana. No artigo "Kandy-Kolored Tangerine-Flake Streamline Baby," Wolfe traça o perfil dessa população que se envolve diretamente na produção e no consumo de objetos customizados na década de 1960, na Califórnia. É patente que as personagens reais do círculo de adolescentes e das culturas locais de apreciação do estilo e da velocidade preconizadas por Wolfe são emprestadas por Banham para a construção de sua narrativa sobre a cultura de "doing your own thing".

"A primeira boa olhada que eu dei em carros customizados foi em um evento chamado "Feira Adolescente"(Teen Fair), realizada em Burbank, um subúrbio de Los Angeles, depois de Hollywood. Esse era um lugar selvagem para se estar olhando para objetos de arte - eventualmente, eu devo dizer, você chega a conclusão de que esses carros customizados são objetos de arte, ao menos se você utilizar os padrões aplicados em uma sociedade civilizada." 109

Fica claro, aos olhos de europeus como Wolfe ou Banham, Vidler ou até mesmo Frampton, de que tais expressões de cultura popular como carros customizados em cores fortes, tons de neon e outras cores cítricas, carros em formato de cachorro-quente, pranchas de surf com grafismos rebuscados e outros eram, a primeira vista, objetos estranhos, frutos de um gosto e valores estéticos obtusos. Não se tratava apenas de ser uma cultura jovem. Tinha de ser uma cultura jovem como a dos Estados Unidos nas décadas de 1960: excêntrica, inclinada à favorecer expressões pessoais em detrimento de padrões estéticos, e com um grande aporte de dinheiro à mão. Wolfe afirma com facilidade que carros significavam mais para os jovens daquela época e região, do que arquitetura significaria para os europeus entre 1750 e 1850. Todos os principais valores

106 Charles Jencks, Heteropolis: Los Angeles : The Riots and the Strange Beauty of Hetero-Architecture. New York: Academy Additions, 1993.

107 Mike Davies, Ecology of Fear: Los Angeles and the Imagination of Disarter. New York: Metropolitan Books, 1998. Ver também Idem, City of Quartz: Excavating the Future in Los Angeles. London: Verso, 1990 108 Christopher Isherwood, A Single Man, publicado originalmente em 1963. Minneapolis: University of Minnesota Press, 2001.

109 Tom Wolfe, The Kandy Kolored Tangerine Flake Streamline Baby, publicado originalmente em 1963. New York: Bantam, 1999, p. 75. Texto original: The first good look I had at customized cars was at an event called a "Teen Fair", held in Burbank, a suburb of Los Angeles beyond Hollywood. This was a wild place to be taking look at art objects - eventually, I should say, you have reach the conclusion that these customized cars are art objects, at least if you use the standards applied in a civilized society. 
daquela cultura estavam lá: liberdade, estilo, sexo, poder, movimento e cor ${ }^{110}$.

“Eu passei por uma da cabines de guitarras, e lá estava um garotinho dentro, mais ou menos treze anos, tocando o diabo com uma guitarra. O garoto era chamado Cranston ou qualquer outra coisa. Ele parecia ser chamado Kermet ou Herschel; todos os seus genes eram um tipo terrível de Okie (vindo de Oklahoma). Cranston estava inclinado que nem um jovem galho de árvore sobre a mesa, aparentando estar gloriosamente entediado. Aos treze, esse garoto estava sendo fanaticamente cool. Todos eles estavam. Eles eram todos maravilhosos escravos da forma. Eles tinham criado seu próprio estilo de vida, e eles eram muito mais autoritários sobre reforçar isso do que os adultos. Não somente isso, mas esses garotos, mas hoje esses garotos - especialmente na California - tem dinheiro, o que, não é preciso dizer, é porque esses vendedores de calçados e guitarras, e a Ford Motor Company estavam na Feira Adolscente (Teen Fair) em primeiro lugar. Eu não ligo de observar que é essa mesma combinação - dinheiro mais devoção servil à forma - que conta para Versailles ou a Praça São Marco (Veneza). Naturalmente, muito dos artefatos desses garotos dinheiro-mais-forma produzem são terríveis. Mas também era maioria da parafernália que desenvolveu-se na Inglaterra durante a Regência."111

Outro grande elemento que uniria as narrativas de Banham e Wolfe era o estilo 'streamline'. Teria se formado na década de 1930, pelas mãos e criatividade de designers de objetos, carros, aviões e barcos (todos representantes da noção de velocidade). Curvas sinuosas e longas linhas retas simbolizariam visualmente este estilo. Segundo Wolfe, essa forma pode ser funcional para um avião, visto suas necessidades de aerodinâmica, mas para um carro não parecia oferecer qualidades ${ }^{112}$. Para Banham, a necessidade de se justificar tecnicamente não era real, visto que a estética da máquina da arquitetura moderna transitava entre o necessário e o fetiche com grande facilidade. O Streamline representava muito do que teria sido mitigado pelas narrativas da historiografia moderna: de Mendelsohn a Marinetti, do

110 Idem, p.78.

111 idem, p.70. Texto original: I went by one of the guitar booths, and there it was a little kid in there, around thirteen, playing the hell out of an electric guitar. The kid was named Cranston something or other. He looked like he ought be named Kermet or Herschel; all his genes were kind of horribly Okie. Cranston was slouched back with his spine bent like a sapling up against the table, looking gloriously bored. At thirteen, this kid was being fanatically cool. They all were. They were all wonderful slaves to form. They have created their own style of life, and they are much more authoritarian about enforcing it than the adults. Not only that, but today these kids - especially in California - have money, which, needless to say, is why all these shoe merchants and guitar sellers and the Ford Motor Company were at a Teen Fair in the first place. I don't mind observing that it is this same combination - money plus slavish devotion to form - that accounts for Versailles or St. Mark's Square. Naturally, most of the artifacts that these kids moneyplus-form produce are of a preety ghastly order. But so was most of the paraphernalia that developed in England during the Regency.

112 Idem, pp.83 
expressionismo ao futurismo, o estilo representava a tentativa humana de capturar a forma da velocidade. Tudo isso foi encontrado, não só por Banham, mas também por Wolfe, na Califórnia. Cunhado de "barroco moderno" ou de "barroco abstrato", o streamline foi solapado pela estética também cunhada por Tom Wolfe como estética "Mondrian": capas de revistas, caixas de lenços, caixas de fósforos, inclusive automóveis, tudo era 'Mondrian' para Wolfe. Mesmo a estética das montadoras de automóveis de Detroit teria se curvado à influência do abstracionismo bauhausiano, cujos princípios de cantos vivos, formas retangulares ou quadradas representava valores apolíneos. Já o streamline, de curvas sinuosas (e supérfluas) representava Dionísio. A juventude americana da década de 1960, por razões óbvias, tenderia para o streamline. Detroit, tendo cedido ao hermetismo abstrato, não poderia prover para tais jovens. Surgem figuras de fama local, como os artistas / mecânicos como George Barris e Ed Roth (ambos também citados por Banham, provavelmente através de Wolfe) ${ }^{113}$.

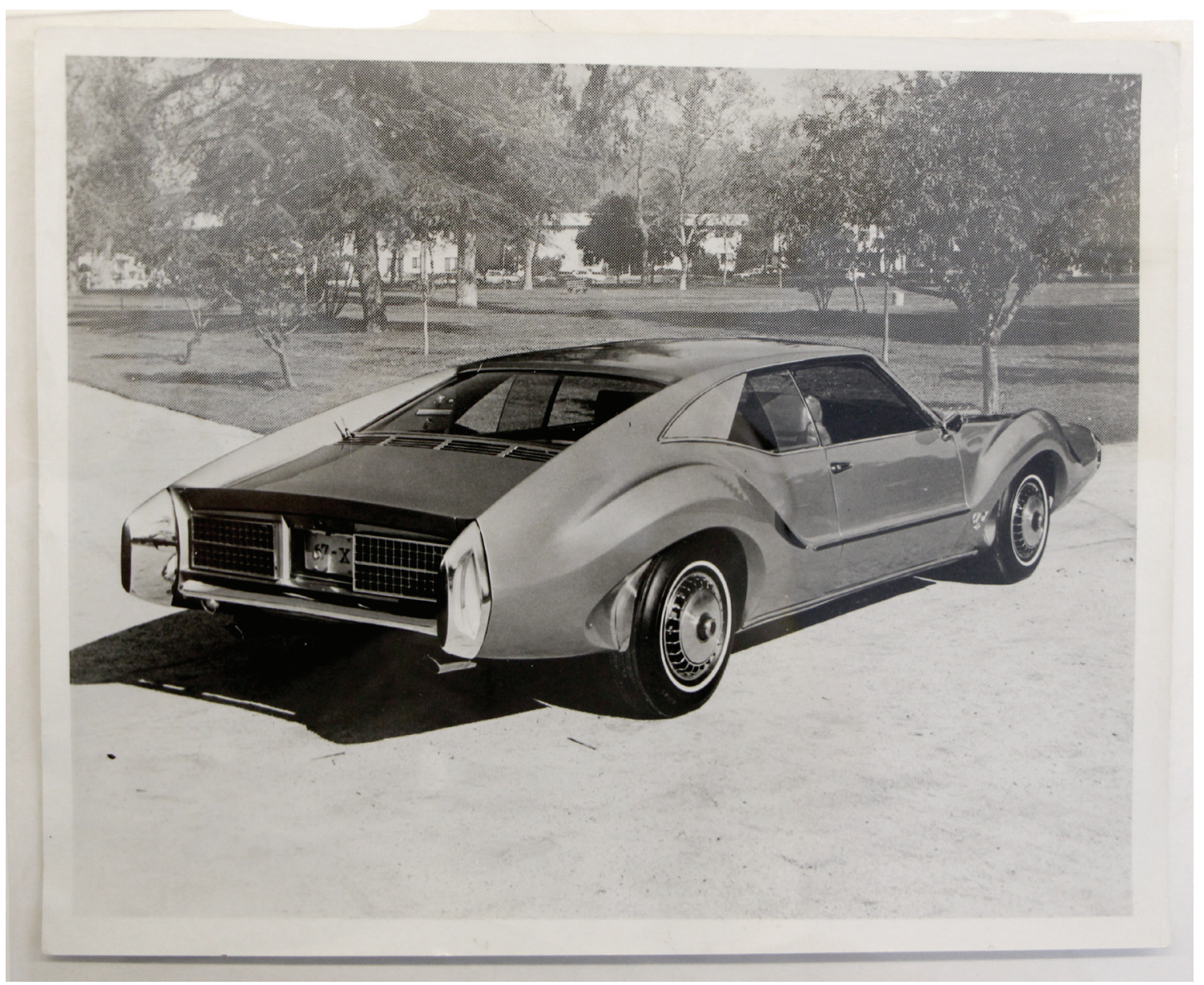

George Barris, automóvel customizado, s/ data. Fonte: Arquivo Getty. A imagem é muito próxima da imagem publicada por Banham em Los Angeles, apenas mudando a perspectiva do automóvel. Foi retirado também o fundo e destacado o veículo. Carros como o de George Barris, responsável pela criação do primeiro "bat-móvel" para o seriado de televisão Batman, estrelado por Adam West, poderiam ser rastreados, para Banham, à contrapartes mais 'eruditas', como o automóvel projetado por Buckminster

113 Tom Wolfe, pp. 83-84. 
Fuller, o Dymaxion.

Já J. B. Jackson traz o olhar local à questão, identificando também outros aspectos da relação entre o cidadão americano e o automóvel. Focando na juventude 'blue-collar' americana, a qual tinha menos acesso à recursos, Jackson via uma outra faceta da mesma realidade: a exploração da cultura de consumo de massa, mas dessa vez como logística reversa dos elementos descartados. Ferros-velhos, cemitérios de automóveis, pequenas oficinas mecânicas e iniciativas individuais de jovens economicamente pouco providos fecharia a esfera de customização de massa da cultura americana.

"Psicologia pop nos diz que os Americanos valorizam o carro como um símbolo de status, sexo ou poder. Esse é o ponto de vista da classe-média. Ele sugere que a maioria de nós dirige apenas carros de passeio ou carros esporte. Mas muitos americano colarinho-azul [termo referente a trabalhadores braçais, operários, técnicos ou não, e camadas salariais mais baixas do mercado americano - n.a.] pensam em seus automóveis em termos econômicos: ou é uma ferramenta de trabalho, essencial para seu sustento, ou é uma forma de capital. Isso é particularmente verdadeiro para os jovens americanos de baixa renda. Eles adquirem um carro velho em más condições, ou uma van ou pick-up, substituem seu motor, modificam seu chassi, pintam e os expõem - daí conseguem vende-lo com uma margem de lucro. Ou isso acontece, ou eles começam um pequeno negócio com o carro. No geral, para aqueles sem formação, e precariamente educados e jovens, não existe melhor maneira de fazer dinheiro do que ter um carro. Ele permite procurar por um emprego, e quando o encontra, o permite se deslocar ao trabalho diariamente; e se o carro é um tipo de veículo de carga especialmente um caminhão - este se torna seu parceiro." ${ }^{114}$

114 J. B. Jackson, "Looking into Automobiles", in A Sense of Place, a Sense of Time, pp.167-168 Texto original: Pop psychology tells us that Americans cherish the car as a status symbol or sex symbol of power. That is middle-class point of view. It suggests that most of us drive only passenger cars or sport cars. But most blue-collar Americans think of their automobile in economic terms: it is either a work tool, essential to their livelihood, or a form of capital. This is particularly true of young, low-income Americans: they acquire an old car in a bad condition, or a van or a pickup, replace its engine, modify its chassis, paint it, show it off - and then sell it at a profit. Either that, or they start a small service with it. All in all, for one who is unskilled, and poorly educated and young, there is no better way of making money than having a car. It allows him to look for a job, and when he has found it, it allows him to commute to work; and if the car is some sort of load-bearing vehicle - specially a truck - it becomes his partner. 


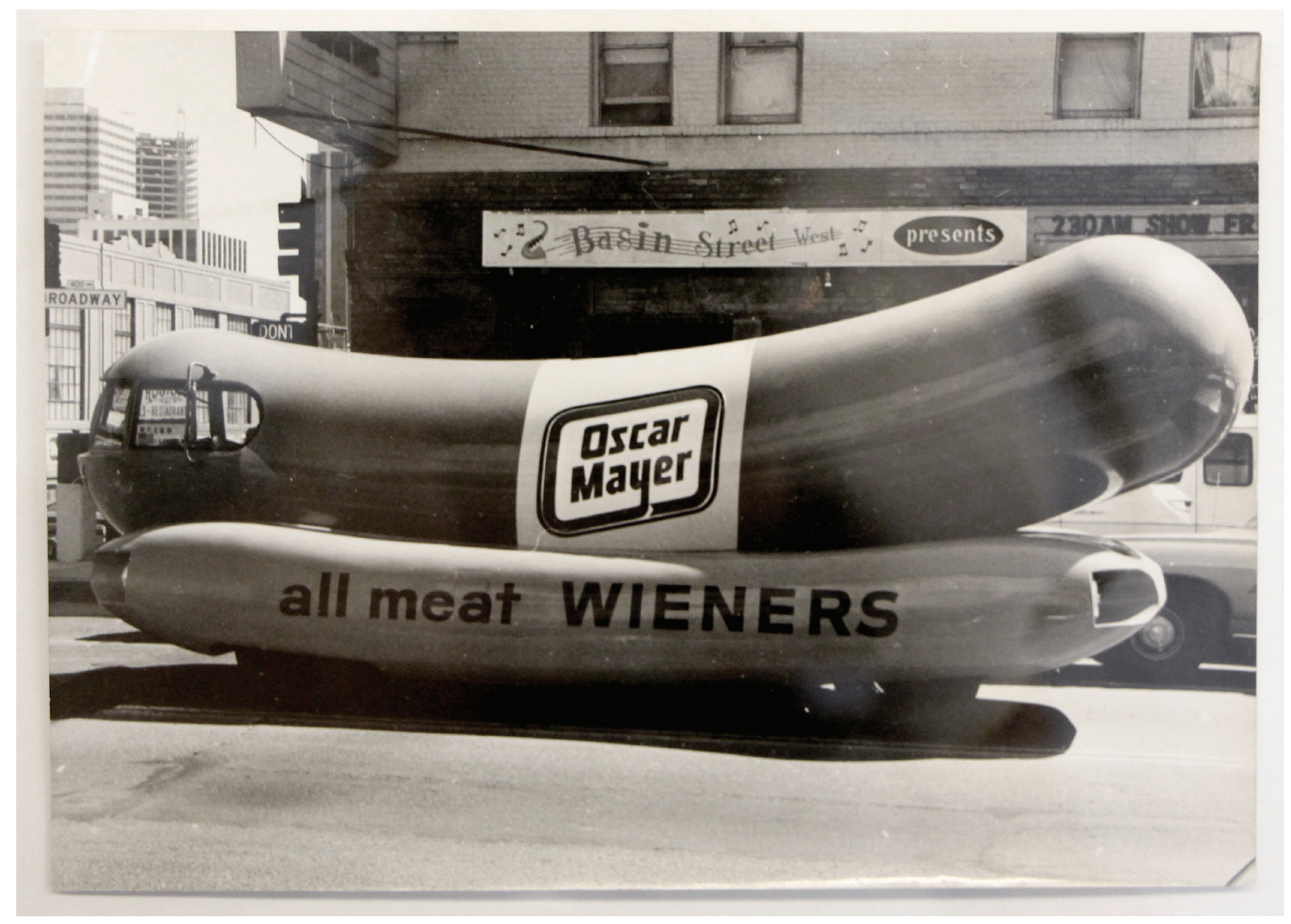

Automóvel customizado, s/data. Fonte: Arquivo Getty. A imagem faz parte da pasta referente à publicação de Los Angeles: the Architecture of Four Ecologies.

É importante fazer a ligação entre a imagem criada por Jackson do subúrbio residencial americano não somente pelas edificações inseridas em seu contexto, seu ritmo de assentamento e seus motivos arquitetônico, mas também com os espaços vazios ao seu redor: a rua, os quintais defronte a rua, e a vida cotidiana formavam o cenário para diversas classes sociais. Se os subúrbios primam pela repetição dentro do mesmo tema, podemos ver nuances da cultura que enriquecem esse cenário, visto pelo europeu como repetitivo e monótono.

“Toda vez que eu vejo homens brotando ansiosamente por baixo de capôs erguidos de carros arrebentados, estacionados na frente de suas casas, eu imagino que eles estão não somente disciplinando suas mãos e seus olhos, como também suas mentes, visualizando e ttentando recriar algum tipo de ordem. Eu não me arrependo de ver o lixo que eles espalham por todo o lugar, mas eles vêem valor que me escapa; um jeito de ganhar a vida." ${ }^{115}$

115 Idem, pp.167-168. Texto original: Whenever I see men anxiously peering under the raised hood of a beat-up car parked in the front yard of their house, I imagine that they are disciplining not only their hands and their eyes, but also their minds, and visualizing and trying to re-create a kind of order. I'm sorry to see the junk they scatter all over the place, but they seem some value in it which escapes me; a means of 


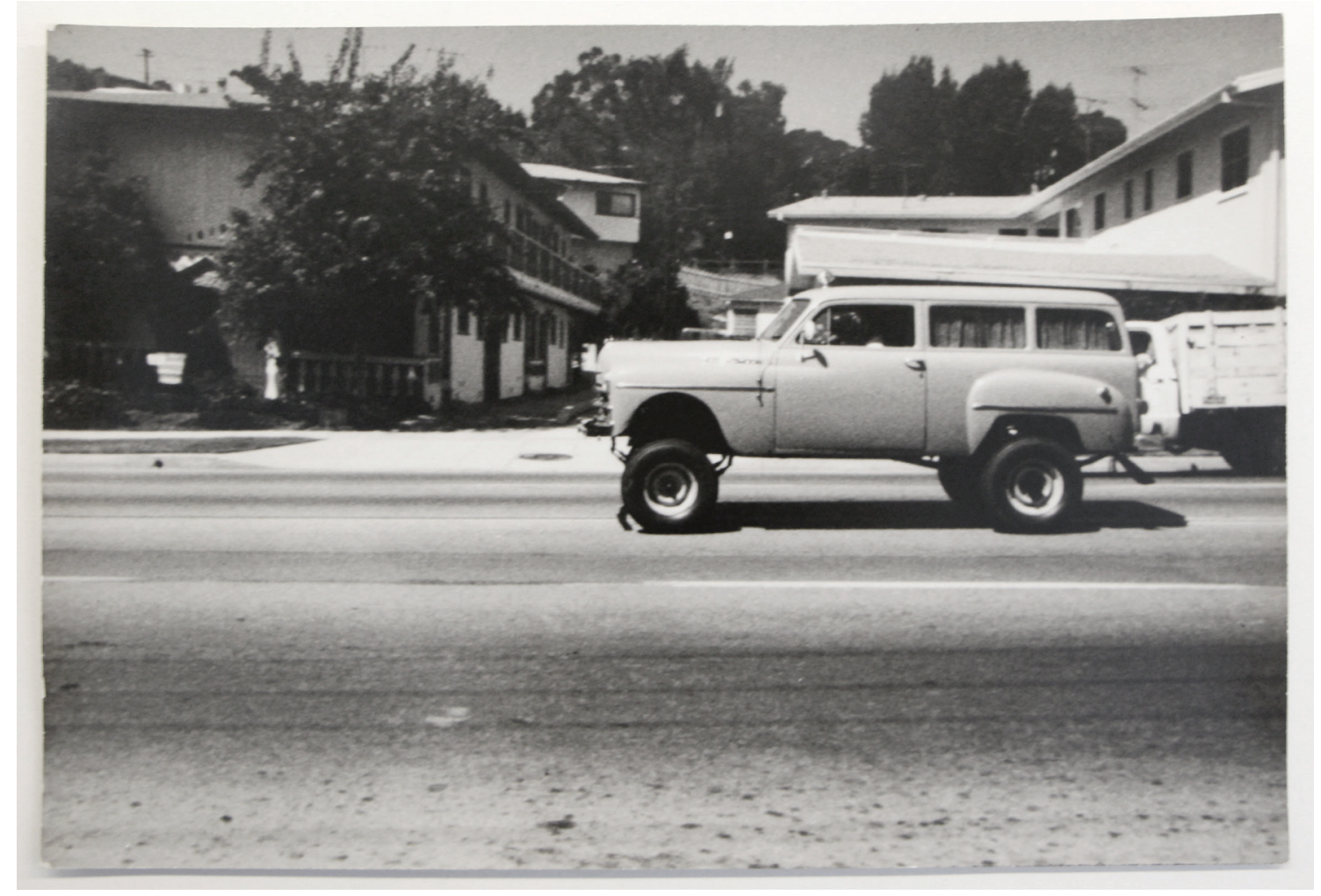

Automóvel customizado, s/data. Fonte: Arquivo Getty. A imagem faz parte da pasta referente à publicação de Los Angeles: the Architecture of Four Ecologies.

Outro aspecto a ser levantado é a noção de fantasia e cenografia da arquitetura e do design americanos: os antecedentes históricos de Conney Island e do Manhattanismo, e com o advento da indústria cinematográfica de Hollywood, e mais tarde com o império da fantasia e do fantástico permeada em várias cidades, a cultura construtiva comercial americana apostou, e aposta continuamente no 'fantástico', e no efeito visual para conquista a atenção dos olhos do mundo.

“Disney é talvez o conceito transcendente de Los Angeles, o sítio provável para a resolução do enigma da cidade. Para os Los Angelistas do mainstream, a Disneylandia em si representa um ideal de manipulação benigna, uma cripto-apologia da fantasia dos seus planejadores que não falta a nenhum arquiteto." 116

O símbolo de Hollywood, fixado no sopé da colina homônima, estabelece um padrão de simbolismo e manipulação da imagem (e paisagem) natural. Cenografia e

making a living.

116 Michael Sorkin, p.55. Texto original: Disney is perhaps the transcendent Los Angelist concept, the probable site for the resolution of the city's enigma. For mainstream Los Angelists, Disneyland itself represents an ideal of benign manipulation, the crypto-vindication of the planner's fantasy no architect is ever truly without. 
arquitetura se encontram na construção comercial em Los Angeles. A necessidade de recriar uma versão fantástica da realidade se transferiu da indústria cinematográfica para as expressões vernaculares modernas. Com os recursos à mão, a população explorou esteticamente os limites da customização e ilusão, da transposição de forma e material.
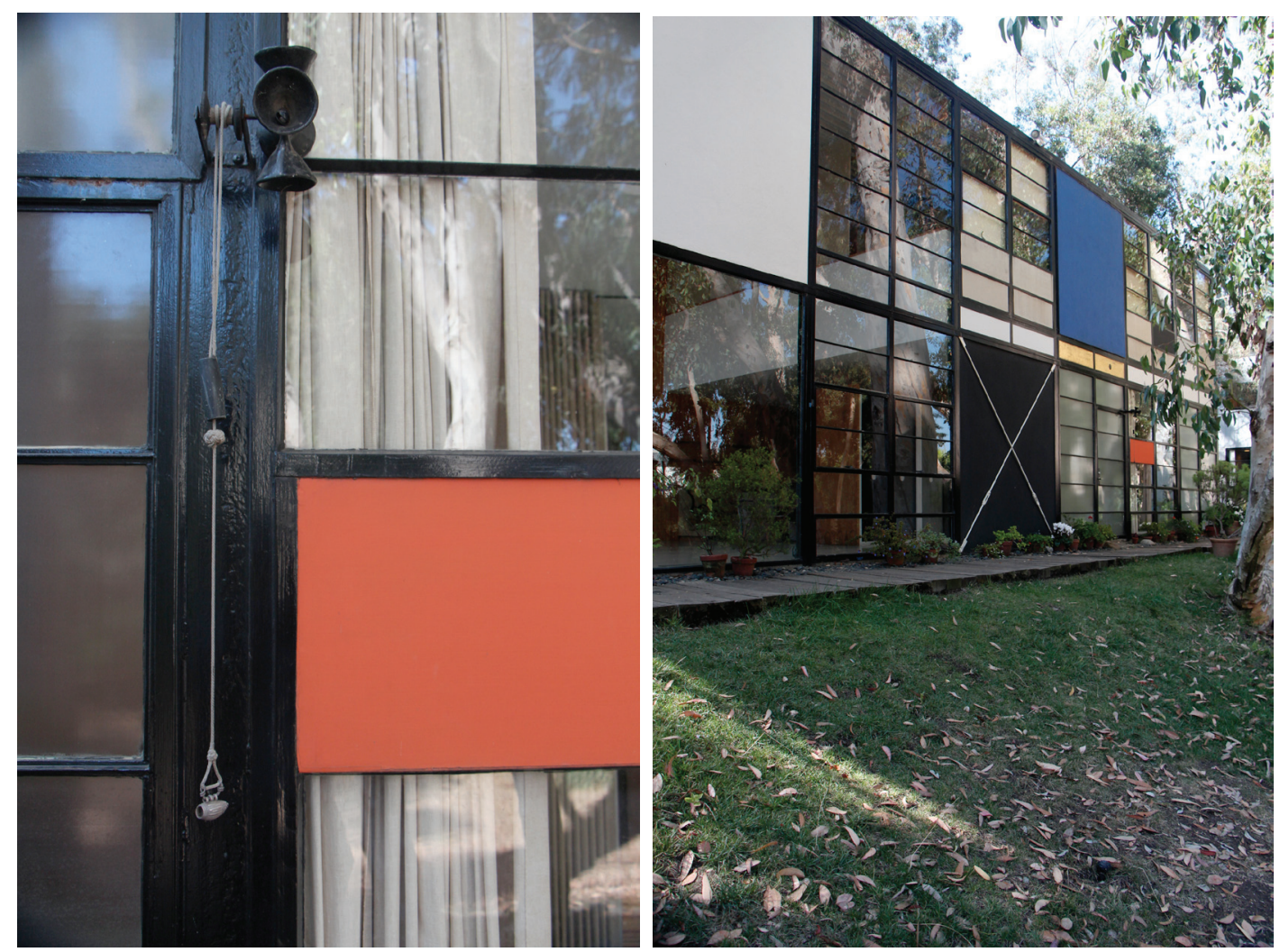

Ray e Charles Eames, Case Study House \#8, 1948. Foto: Luiz Florence, 2012. Destaque aos painéis préfabricados de esquadrias e as adaptações de objetos para uso em construção civil.

O conceito de espaço publico do complexo do parque temático de Walt Disney, segundo Sorkin, é mais do que um argumento sobre Urbanismo, e sim um argumento sobre estilo ${ }^{117}$. Sua legitimação, bem como as de toda a arquitetônica comercial americana, liberta o presente das amarras de coerência com o passado, e permite ao arquiteto se apropriar de qualquer fonte, seja histórica, seja de transposição de mídia, e amplificar sua carga simbólica. A construção da casa do casal de arquitetos Ray e Charles Eames quase que expõe, como em museu, componentes construtivos "offthe-shelf" (ou "direto da prateleira") em seu plano de fechamentos da edificação; as customizações de Ed Roth e George Barris na verdade são hipérboles das criações de massa de montadoras como Ford, Chrisler, Plymouth, General Motors e Buick ${ }^{118}$; as pranchas de surf em plástico e fibra de vidro, coloridamente customizada, são os

117 Idem, p.55.

118 Tom Wolfe, pp.77-79. 
veículos estilizados do estilo de vida de praia ${ }^{119}$; um dos melhores exemplos do tipo de vernacular moderno artesanal ligado à arquitetura é o monumento construído por um só homem, Simon Rodia, no bairro de Watts, em Los Angeles. As Watts Towers são verdadeiros monumentos da autoconstrução americana: uma colagem de elementos industrializados, ciclos industriais reciclados e ultrapassados, um símbolo da cultura americana, que se auto fagocita ${ }^{120}$. Anthony Vidler escreveu o prefácio da edição de 2000 de Los Angeles: the architecture of four ecologies, no qual descreve como Banham capturou a tradição de "doing your thing" embebida na expressão de cultura urbana da cidade. Nesta descrição, Vidler deixa claro que para Banham até mesmo uma obra façavocê-mesmo como a de Simon Rodia não poderia ser classificada como arte popular ou naifi21.

"Finalmente, Banham apresentou seu julgmanento sobre cultura popular em Los Angeles: sua tradição de "faça-você-mesmo" nas artes, das pinturas em motocicletas por Billy Al Bengston aos capacetes pintados por Von Dutch Holland no começo dos anos 60, e a onipresente decoração de pranchas de surfe em Venice, até aquele monumento a cultura faça-você-mesmo, as torres de Watts de Simon Rodia, o sublime do faça-você-mesmo. Essas "não eram naif ou popularescas, como alguns críticos europeus tentam sustentar. Sua estrutura é imensamente forte, e a decoração de suas superfícies são criativas e engenhosas." O mesmo é verdade sobre artistas pop contemporâneos como Ed Ruscha - seus "26 Gasoline Stations," seus "34 Parking Lots," seu "Every Building on Sunset Boulevard," foram todos eles, aos olhos de Banham, declarações que eram conteúdo do "do their own thing," nunca os julgando ou criticando". " 122

Não fica claro se é uma tentativa de elevar as torres de Watts a um patamar acima de arte popular, desqualificando o coletivo, ou se Banham cria camadas de qualidade, mesmo dentro da categoria de design popular. Mas isso é relativamente irrelevante neste momento. O que importa é entender como Banham advogou pela valorização do produto popular, e como criou um campo expandido de crítica de

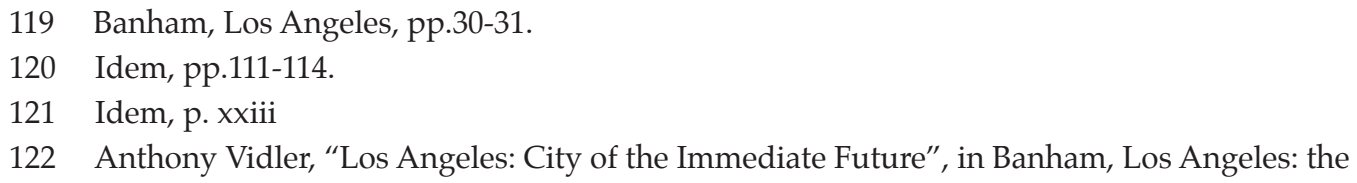
decoration down in Venice, to that monument to do-it-yourself culture, Simon Rodia's Watts Towers, the do-it-yourself sublime. These were "not, as some European critics seem to maintain in any way naïve of folksy. Their structure is immensely strong, the decoration of their surfaces resourceful and imaginative." The same was true of contemporary pop artists, like Ed Ruscha - his "26 Gasoline Stations," his "34 Parking Lots," his "Every Building on Sunset Boulevard," were all, to Banham's eyes, dead-pan statements that were content to "do their own thing," neither judging nor criticizing. 
arquitetura, cujo vocabulário deveria abarcar expressões populares, anônimas, comerciais e corriqueiras. Para isso, Banham se faz valer da personagem que representa o Americanismo em arquitetura. Se ele a encontrou na Califórnia, não significa que o estado é 'mais americano' do que as demais regiões dos Estados Unidos, mas por representar algo que a crítica europeia de arquitetura moderna ignora ou desconhece, e por desconhecer não criou mecanismos próprios para sua crítica de valor. Como foi dito anteriormente, no começo deste capítulo, "Los Angeles is the Middle West raised to the flash-point... ${ }^{123}$ "

Se podemos questionar os rótulos de "vernacular moderno", e questionar as áreas cinzentas do binômio vernacular-erudito, ou vernacular-acadêmico, ou até mesmo repensar o valor da contribuição da arquitetura comercial na paisagem americana, não podemos nos furtar a identificar o componente cultural que forma essa paisagem. Banham explora o consciente coletivo da sociedade de consumo americana materializada nesses mesmos objetos que a população americana produz e consome, concomitantemente. Carros, casas, roupas e objetos pessoais são passíveis de manipulação, e no caso especial da cultura dos Estados Unidos, o consumo é uma etapa previsível, e até mesmo planejada do processo criativo.

123 Ver Banham apud. Michael Sorkin, "Explaining Los Angeles", in Exquisite Corpse: writing on buildings. London: Verso, 1994, pp.54 
Conclusão: Banham, da Paisagem Cultural e Depois 
Durante os anos 1950, o termo paisagem cultural raramente apareceria impresso, resume Paul Groth em sua compilação sobre o legado de J. B. Jackson¹․ Isso seria verdade até mesmo quanto escritores precisavam de um termo para descrever a intrincada rede de espaços mentais, sociai, e ecológicos que ajudaram a definir grupos humanos e suas atividades. Nos anos 1990, contudo, o termo já havia se estabelecido em variados círculos profissionais e literários. Paisagem cultural, ou, mais frequentemente, a palavra 'paisagem' apenas, vieram a se referir a trechos de cidades, interiores de edifícios e até mesmo cenários virtuais, bem como a locações rurais.

Entre 1950 e 1990, pessoas estudando cultura, história, e relações sociais começaram a gradualmente se dar conta a importância do ambiente construído e da necessidade de traçar relações entre geografia, sociologia e arquitetura. Reyner Banham viveu em Santa Cruz e lecionou na universidade da California entre 1976 e 1988, justamente no período de maior intensidade de transformações, diálogos e produções acadêmicas na costa oeste dos Estados Unidos. Na Califórnia Ele encontrou não somente elementos dos mais eloquentes do seu vernacular moderno, mas também um grupo de intelectuais interessados em observar esses fenômenos. Pois foi especialmente nas universidades californianas que floresceramdos estudos da paisagem cultural nos Estados Unidos ${ }^{2}$.

Nesta dissertação foi apresentada a trajetória de Reyner Banham como uma das maiores contribuições para o amadurecimento do debate sobre o vernacular tecnológico e a paisagem cultural nos Estados Unidos. O tom crítico de Banham não se restringia à arquitetura moderna europeia: Apoiando-se no aporte de cultura de massa norte-americano, que já no segundo pós-guerra invadiu a Inglaterra e a Europa, Banham foi capaz de relativizar a cultura do alto modernismo, conferindo ares de universalidade a uma cultura americana que então punha em cheque a hegemonia européia. Para o autor, O principal fator dessa predileção era a naturalidade com a qual o público médio nos Estados Unidos se apropriava da tecnologia, de uma maneira supostamente bem mais intensa do que as promessas do Modernismo jamais lograram fazer. A investigação do estudo do dispositivo técnico anônimo e a construção da paisagem foi uma das principais atividades que resultaram dessa operação. Segundo Banham, Esse engajamento com a tecnologia teria tornado a produção cotidiana de arquitetura e a paisagem nos Estados Unidos um desafio para o próprio termo "vernacular": quais seriam as relações entre carros customizados, autopistas, restaurantes com letreiros gigante, e casas operárias, cabanas silvestres ou assentamentos aldeotas? Através da obra de Banham buscou-se entender o que poderia ser considerado local e autêntico em uma cultura de consumo de massa: conceitos

1 Paul Groth e Chris Wilson, Everyday America: Cultural Landscape Studies after J. B. Jackson. Los Angeles: University of California Press, 2003, p.1.

2 Na qual se destacam as universidades UCLA (University of California), com campi em Los Angeles, Santa Cruz entre outras cidades: Berkeley, na qual lecionaram Spiro Kostoff e J. B. Jackson; e a Sci-Arch (Southern California Institute of Architecture). 
de "customização de massa" e estética descartável" não são apenas um mote em seu discurso, mas sua bandeira. De fato, existiria uma nova tradição local em gestação na capital do mercado de consumo de massa, na qual originalidade, autoctonismo, e a ingenuidade pré-capitalista teriam dado lugar à energia, velocidade, luxúria e fantasia do vernacular moderno.

“Deste ponto de vista privilegiado, visto de cima para baixo, toda a arquitetura é vernacular, mais ou menos. É simplesmente uma questão de coisas parecerem diferentes desde perspectivas diferentes - em paralelo, existe ainda uma outra perspectiva, da qual a palavra 'vernacular' vem essencialmente sem sentido em uma visão democrática de arquitetura. Mas seguindo Marcel Vellinga, este é um próximo estágio: “É apenas quando o vernacular, como o moderno, o popular, o colonial e o informal, se tornar analiticamente obsoleto, que sua existência e importância será verdadeiramente reconhecida", e em acréscimo, assim que o conceito de vernacular se tornar obsoleto, será possível se debruçar sobre a materialidade e especificidade de edifícios em particular com uma visão renovada sobre o que os diferencia." ${ }^{3}$

Segundo Peter Guillery, os estudos a respeito do vernacular moderno na Inglaterra poderiam ser remontados a Revolução Industrial, mas seus antecedentes estariam tão enraizados na cultura arquitetônica inglesa que dificilmente poderiam ser separáveis da dita arquitetura "não-vernacular". Guillery aponta o caso da publicação de Nikolaus Pevsner, A History of Building Types (London, 1976), além de outras publicações com a finalidade de apontar para os caminhos da historiografia em direção ao tema do vernacular ${ }^{4}$. O que teria começado como um estudo de casos - construções industriais, casas operárias, abrigos, celeiros, igrejas - demonstraria a fragilidade mesma do termo "vernacular" do ponto de vista da historiografia contemporânea. Nesse caso uma indistinção entre vernacular e "não-vernacular" teria tornado o termo em si obsoleto. E de fato, na Inglaterra, o estudo de expressões da arquitetura vernacular se confundiriem com estudos de tipologias.

Vimos, especialmente no terceiro capítulo, que outros intelectuais americanos mantinhém a mesma bandeira de Banham. J. B. Jackson dedicaria sua vida a

3 Ver Peter Guillery, Buit from Below: British Architecture and the Vernacular. New York: Routledge, 2001, pp.1-2. Texto original: From this vantage point, seen from below, all architecture is vernacular, more or less. It is simply a matter of things looking different from different positions - parallax, there is also another perspective, that from which the word vernacular is essentially meaningless in a democratic view of architecture. But following Marcel Vellinga, that is a next stage: 'It is only when the vernacular, like the modern, the popular, the colonial and the Informal, has become analytically obsolete, that its existence and importance will truly have been recognized' and, it might be added, once the concept of the vernacular is obsolete, then it will be possible to turn to the materiality and specificity of particular buildings with a fresh view of what sets them apart.

4 Idem, p.3 
formatação do genius loci americano e a análise das paisagens culturais americanas ${ }^{5}$. Desde os anos 1970, A historiadora Gwendolyn Wright manterim constante interesse das diferentes perspectivas em relação à produção de arquitetura ${ }^{6}$, compartilhando alguma afinidade eletiva. com Reyner Banham. Seu orientador de doutorado, Spiro Kostof (1936-1991) foi professor da cadeira de Environmental Design em Berkeley de 1965 até seu falecimento, em 1991, e com Banham estabeleceu importantes relações acadêmicas. Segundo Groth, teria sido o próprio Kostof quem introduziu Banham no círculo acadêmico de Berkeley, onde atuava J.B. Jackson. Ali, Em encontros normalmente conduzidos pelos professores de arquitetura, geografia, sociologia e antropologia, estudantes e professores de arquitetura teriam entrado em contato com uma perspectiva e metodologia alternativas em relação ao ensino de arquitetura ${ }^{7}$. Nestes encontros, como vimos no primeiro capítulo, Banham teria encontrado não somente J. B. Jackson, como também Kostoff, Denise Scott-Brown (então professora visitante em Berkeley), entre outros.

Banham chegou a posição de especialista em arquitetura norte-Americana, um intelectual cuja pesquisa poderia se encaixar no que Jean-Louis Cohen denominou "americanista" - característica de uma atração às vezes fetichista pelas expressões de cultura norte-americana. Mesmo sendo um estrangeiro, ou exatamente por essa razão, ele se formou e se manteve como um especialista não somente sobre a moderna arquitetura dos $\mathrm{EUA}^{8}$, mas também em um entusiasta do estudo das estruturas vernaculares modernas na paisagem. Como disse Gabrielle Esperdy ${ }^{9}$, Banham tomou tempo para analisar os produtos da produção anônima de arquitetura sem uma agenda ligada à crítica de arquitetura moderna. Diferentemente de Robert Venturi e Denise Scott-Brown, que se apropriaram das comparações entre fenômenos da arquitetura comercial e vernacular norte-americana, como o Strip-Mall, o cassino, o letreiro luminoso (Billboard) e o estacionamento, para tecer críticas à produção moderna europeia ${ }^{10}$, Banham se preocupava essencialmente em encontrar parâmetros para se observar, analisar e criticar os fenômenos eles mesmos ${ }^{11}$. Existe aí uma diferenciação

5 Ver J. B. Jackson, A Sense of Place, a Sense of Time. New Haven: Yale University Press, 1994, pp.149164 para descrições de como a ideia de espírito do lugar - genius loci - se atrela à noção de tempo e memória afetiva.

6 Em Building de Dream: a Social History of Housing in America, ela abordou, por exemplo, a perspectiva das donas-de-casa na provisão de habitação nos Estados Unidos. Cf. Gwendolyn Wright, Building the Dream: a Social History of Housing in America. Cambridge: the MIT Press, 1983.

7 Conforme descrito em conversa com o prof. Paul Groth, em 2012.

8 Malgrado Banham não ter se dedicado em sua carreira nos Estados Unidos em abordar uma biografia de arquiteto específico, notamos no decorrer de sua obra descrições recorrentes sobre a obra de Buckminster Fuller, Frank Lloyd Wright, Charles e Ray Eames, entre outros.

9 Ver entrevista com a professora Gabrielle Esperdy, em anexo nesta dissertação.

10 Robert Venturi, Steven Izenour, Denise Scott Brown, Aprendendo com Las Vegas: o simbolismo (esquecido) da forma arquitetônica. São Paulo: Cosac \& Naify, 2003.

11 Nigel Whiteley atribui essa característica como um legado das dinâmicas internas ao Independent Group, e como seus integrantes entendiam q ue a produção da indústria de massa merecia ser criticada 
entre a relevância dada para as expressões populares entre Banham e Venturi. Sua crítica à historiografia europeia, dentro da qual se formou, fundamentava-se lo questionamento as omissões e ausências nas narrativas dos críticos precedentes Pevsner, Giedion, Sartoris, Zevi, Scully Jr. - em relação aos fenômenos mundanos, aos arquitetos que não se encaixavem na auto-narrativa modernaa; mas, principalmente, Banham questionavauas tentativas dos arquitetos modernos de criarem uma arquitetura pretensamente atemporal e eterna, acusando o seu fracasso e estilização.

De fato, A cultura de massa estadunidense não somente representou a vanguarda da apropriação da tecnologia,omas estabeleceu novos parâmetrosàde reprodução de iconografias populares , relações inéditas entre mídias. Cinema, propaganda, literatura, arquitetura e design, de Hollywood ao império da fantasia de Walt Disney, tais expressões desempenharam um papel fundamental e na reprodução global do vernacular moderno americano. Com o cinema de Hollywood, e posteriormente da televisão, as culturas locais não estavam mais resguardadas em seu território. Paisagens culturais de outros países foram invadidos pela proposta americana de cultura de consumo de massa. Em uma palestra de homenagem póstuma Banham, a historiadora da arquitetura Beatriz Colomina descreve sua experiência e contato comao auto $9^{12}$. Em seus anos de formação entre Valência, Barcelona e Nova Iorque, Colomina menciona a relação entre Banham e Frampton, e o desinteresse acadêmico de um em relação ao trabalho do outro. Ora, são estas as posturas que podem narrar a trajetória da cultura popular americana: de um lado, o desejo pela inclusão no quadro da cultura ocidental, como agenda da cultura americana desde o século XIX, e anseio principalmente difundido entre as elites econômicas da América Latina até hoje; e a defesa do radical regional-rural da cultura popular, negando os pastiches colonizatórios da cultura de massa. Essa segunda vertente, encorpada na teoria do Regionalismo Crítico de Frampton, é mais facilmente aplicável a culturas autóctones. e encontra alguns problemas na leitura do popular americano, já que a primeira leva de colonos europeus em solo americano já poderia ser configurada como um movimento anti-regionalista.

Colomina sugere que a experiência na Costa Oeste teria transformado o autor, o desviando do ramo intelectual da costa leste e de Columbia, instituição na qual Framptonrensinava, eaela mesma formara-so arquiteta ${ }^{13}$. Colomina analisa a referência de Banham para o trabalho de relação entre imagens e mídias - mais especificamente fotografias - e seu estudo da arquitetura moderna e historiografia. Colomina descreve como a ideia da imagem e do consumo pautaram a cultura americana, principalmente como resposta ao modo de produção comunista, durante os tempos de Guerra Fria:

segundo seus próprios critérios. Ver Whiteley, Reyner Banham: the historian of the immediate future, mais especificamente o capítulo "Popular Desires and Rough Poetry", pp.80-139.

12 Beatriz Colomina, "Enclosed by Images: Architecture in the Post-Sputnik Age”, in Aynsley, Jeremy, Atkinson, Harriet (Ed.), The Banham Lectures: Essays on Designing the Future. New York: Berg, 2009.

13 Idem, p.194. 
um dos exemplares mais curiosos seria o debate da cozinha, "The Kitchen Debate", realizado durante a Exposição Nacional Norte-americana, realizada em 1959 - entre os presidentes Nixon vs. Khrushchev - com a proposta de troca de experiências e entendimento mútuo de ambas culturas populares. Para Colomina, teria sido um dos exemplares da proposta americana de fomentar o fetiche do consumo. O limite entre a fantasia e o vulgar, no gesto de criar esta fantasia, são pautas discutidas pela academia, e nas quail Banham se destaca por defender a persistência de algo genuíno na intenção popular ${ }^{14}$.

Um dos principais objetivos desta dissertação foi buscar nas obras literárias de Reyner Banham localizar o estudo ta cultura popular nos EUA, a partir de sua cultura tecnológica e industria. Neste mesmo processo de pesquisa de mestrado, foram investigadas obras menos conhecidas e debatidas pela historiografia europeia, como suas obras relacionadas às múltiplas paisagens culturais americanas. Pretendeu-se, por exemplo, entender como em A Concrete Atlantis Banham se propôs a quebrar os mitos da técnica da arquitetura moderna a partir da própria história de contínua reinvenção da indústria americana, e consequentemente, de sua arquitetura. Não por acaso, Uma das presenças frequentes, ainda que sutis, do livro, é a noção da renovação industrial constante e da linha de produção, símbolo máximo do raciocínio produtivo naquele país. Foi fundamental, do mesmo modo, compreender como em Scenes of America Deserta, Banham confrontou os perfis de ocupação do território europeu e norteamericano à luz do contraponto entre duas figuras emblemáticas da modernidade neste país, o desertooe sua antítese,do arranha-céu, em flagrante dissonância comdas paisagens metrópolitanas dos EUA descritas por Jean-Louis Cohen e Rem Koolhaas; Por fim, em Los Angeles: the architecture of four ecologies, observou-se como Banham foi capaz de desafiar os limites da disciplina de história do urbanismo ao focalizar a cidade tida como a antítese do modelo urbano europee. A metodologia de análise do livro, baseada no conceito de 'ecologias urbanas' foi um dos principais legados de Banhame resuminde de maneira única a ideia do vernacular moderno.

Algumas lacunas permaneceram após a pesquisa: pouco se sabe sobre os 12 anos em que Banham permaneceu como membro do quadro da UCSC em Santa Cruz. Nos principais trabalhos bibliográficos, como os de Nigel Whiteley e Anthony Vidler, muito é descrito sobre a década de 1960, seus trabalhos e suas impressões como visitante nos Estados Unidos; sobre 1970 e especialmente sobre a década de 1980, pouco registro restou. Mesmo nos arquivos do Getty Research Institute existem apenas alguns documentos referentes à cursos e palestras ministradas em Buffalo e Santa Cruz ${ }^{15}$. Pelas descrições dos professores entrevistados para a dissertação, a informalidade seria uma das características deste ambiente. Muitos encontros

14 Ver o terceiro capítulo desta dissertação para informações complementares

15 Na caixa \#13 dos Banham Papers, arquivados na Biblioteca do Getty Research Institute encontram-se materiais referents à palestras e aulas, tal como o curso sobre arquitetura high-tech (ver imagem na mesma página). 
teriam sido marcados nas residências dos professores, nos quais eram discutidos elementos da arquitetura, meio-ambiente, cultura em geral. A academia californiana é conhecida por sua forte vertente de pesquisa em elementos heterodoxos da cultura ocidental: drogas, cultura hippie, estudos de gênero, raça e religião aplicados às artes e arquitetura, estabelecendo, entre outras questões, uma exceção ao 'europeísmo' típico das instituições da costa leste dos Estados Unidos. Dentro deste ambiente, Banham escreveu sobre experiências estéticas de maneira diferente de sua obra anterior, Theory and Design. Com efeito: Scenes of America Deserta é um livro que dificilmente podemos classificar como acadêmico, sem notas de rodapé, nem uma estrutura de análise clássica. É patente no livro, ao contrário,ua referência a guias turísticos como os de Karl Baedeker, mencionado por Banham no documentário da BBC “Reyner Banham Loves Los Angeles", de 1972. outra referencia é Tom Wolf, m seu deboche da cultura europeia, na verve fashionista e no aporte na construção de sua própria imagem, atitude esperada de um escritor excêntrico ou de um artista, mas dificilmente encontrada em um acadêmico.
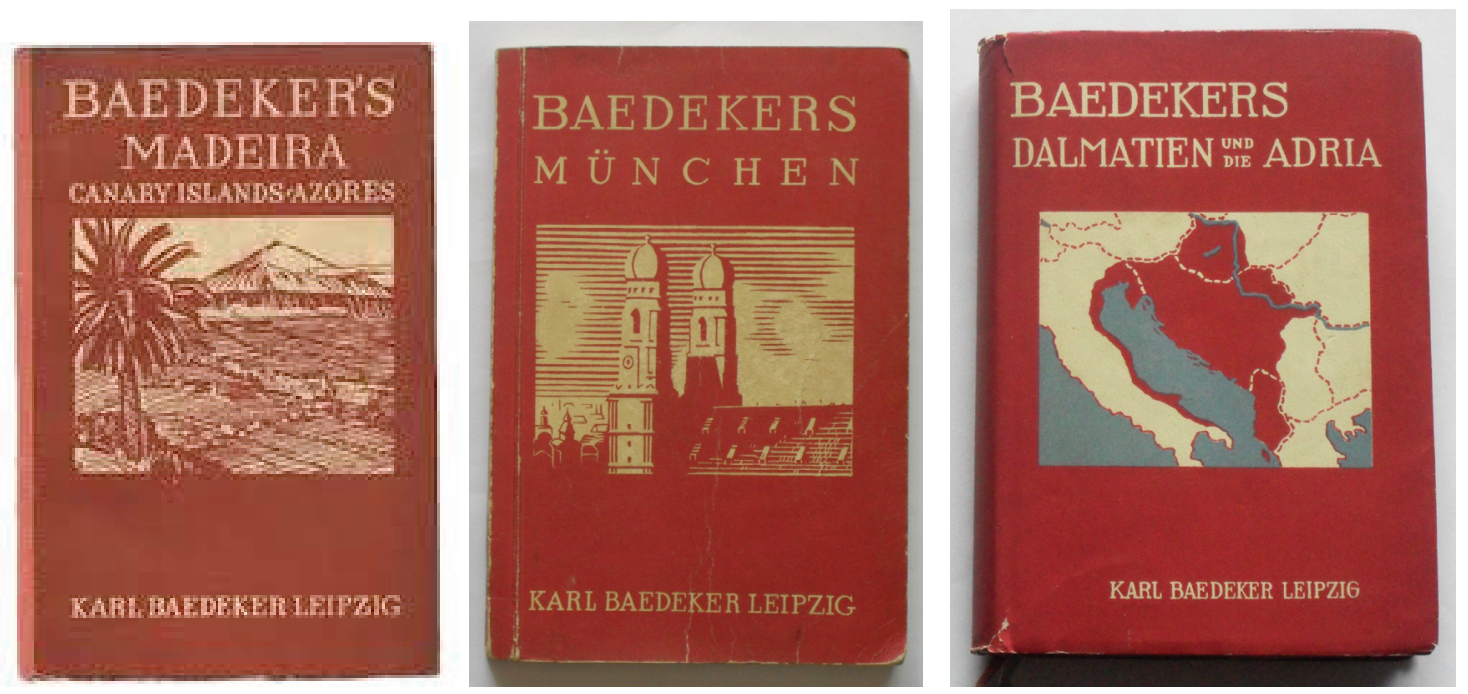

Capas dos guias turísticos de Karl Badeker, s / data. A referencia para a concepção da capa desta dissertação veio da diagramação destes livros, combinadas com a sequência de fotos tiradas por Banham, em uma de suas viagens ao Monument Valley, no Arizona. 


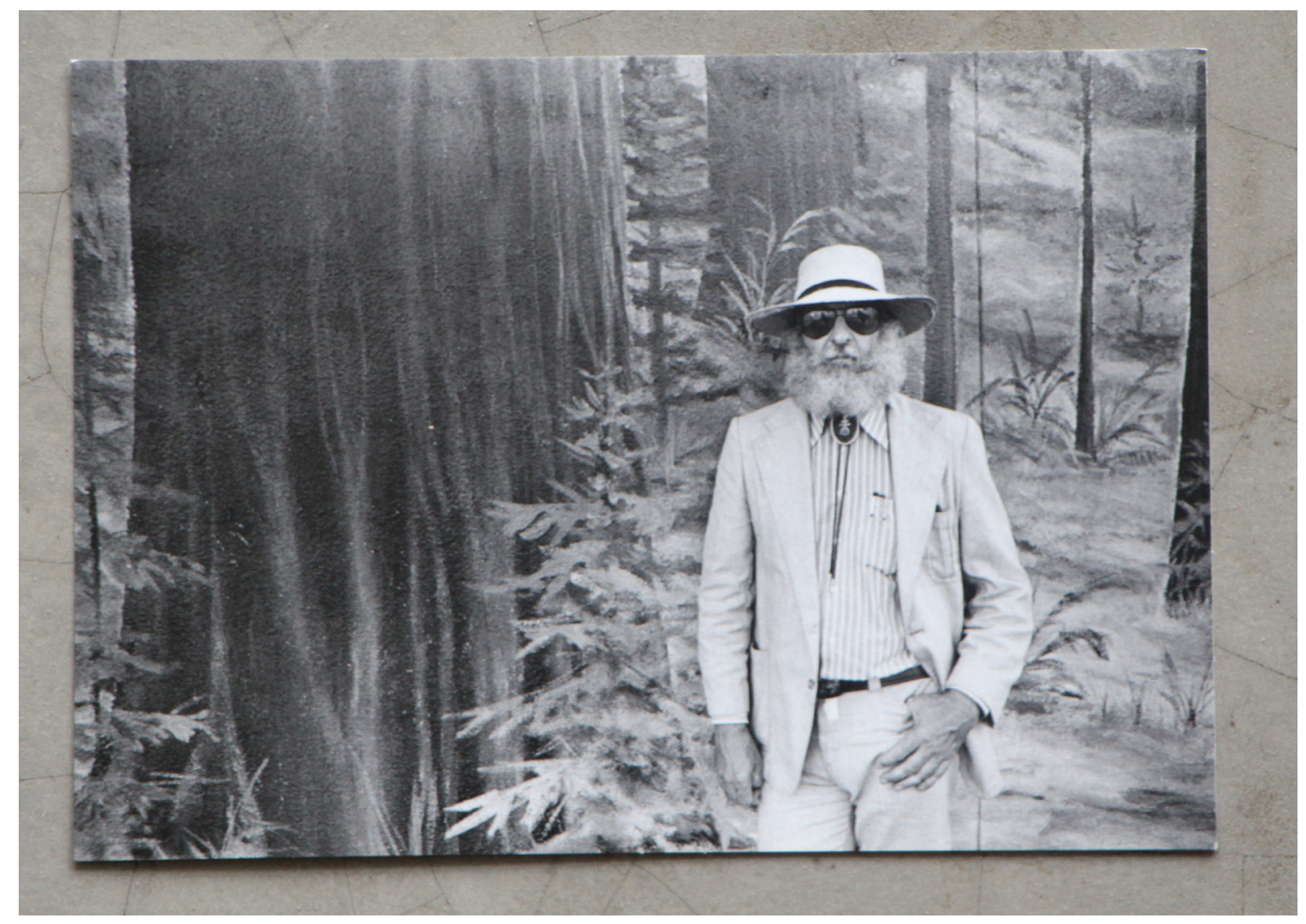

“Reyner Banham, cidadão inglês urbano, passou boa parte dos anos 1980 no mato. Pouco é sabido sobre os sete anos no campus da colina verde da Universidade da Califórnia, Santa Cruz. Não existe fotografia icônica de Banham andando por entre as árvores, como existem dele atravessando o deserto do Mojave numa Bickerton, ou se esgueirando através da selva de concreto de Los Angeles em um carro. Banham parecia preferir as planícies áridas do deserto a suas florestas úmidas e íngremes, e quando dada a oportunidade de posar entre sua folhagem, ele o fez - com toda a pompa - na frende do mural das floresta vermelha adjacente à uma intersecção movimentada de L.A. O crítico, generosamente barbudo vestindo seu terno chino, camisa listada, e gravata texana, seu chapéu buckaroo fazendo sombra sobre sua face sem expressão. Banham favorecia o artificial sobre o natural, mas sabia - como qualquer sartorialista sabe - que estilo atemporal é a combinação efetiva dos dois. Apenas árvores pintadas em paredes de massa corrida e uma cara envelhecida, adornados com óculos de aviador espelhados - acrílico e plástico - poderiam proporcionar uma perpetuidade estilosa." ${ }^{16}$

16 Revista Log, número 28, verão de 2013, “Stocktaking”, capa. Texto original: Reyner Banham, urbane Englishman, spent most of the 1980s in the woods. Little is known about Banham's seven years on the forested hillside campus of the University of California, Santa Cruz. There is no iconic photograph of Banham ambling among the trees, like there are of him traversing the Mojave Desert on a Bickerton or rumbling through the concrete jungle of Los Angeles by car. Banham seemed to prefer the state's arid flatlands to its damp hilly forests, and when given the opportunity to pose among the foliage, he did 
Contudo, a proposta de universalização da cultura moderna em Banham encontra seus limites nas bordas da cultura ocidental. Primeiramente, é inegável que sua rejeição ao reconhecimento do ornamento como qualidade presente na cultura popular limita suas análises. Ademais, em sua generalização do radical americano nos Estados Unidos, Banham não tem nada a dizer sobre nenhuma das outras versões do vernacular moderno do restante das américas e mundo afora. Podemos encontrar, observando da perspectiva brasileira, a polêmica universalização do termo "América". De fato, o conceito de "novo", e desprendimento da tradição não é privilégio nem monopólio dos Estados Unidos. Em diversos momentos, seu foco restrito à paisagem construída pelo homem branco, de ascendência europeia, o deixa perder facetas e episódios que poderiam enriquecer suas narrativas. É sintomática a propósito a maneira como Banham não consegue ultrapassar a superfície da questão do índio Navajo em Scenes of America Deserta, quanto o próprio J. B. Jackson, seu interlocutor, o propõe com maioredesenvoltura, em Sense of Place, Sense of Time. Também a polissemia das construções fabris em outras partes da América é reduzida à referência a apenas à uma fábrica em Buenos Aires e alguns poucos exemplares canadenses; Da mesma forma, o jeito como Banham comenta a cultura praiana angelena, sem qualquer alusão a outras culturas similares, como as mexicanas, caribenha, oe brasileiras, não deixam de revelar os limites de sua noção de vernacular moderno, circunscrito ainda a um eurocentrismo e a uma questão ao mesmo tempo historiográfica, cultural e existencial em torno dos centros hegemônicos do modernismo internacionais.

Não obstante, a contribuição de Banham paraeo amadurecimento crítico da historiografia, e principalmente para a ampliação do léxico da arquitetura há que ser reconhecida e valorizada. Através do conhecimento acumulado pela pesquisa aqui apresentada, surge o questionamento sobre o quanto de fato Banham tinha, em sua atitude entusiástica da cultura Americana, de ingenuidade em relação ao futuro da arquitetura. Ele via na cultura de massa, em sua proposta de se tornar a base de um estilo atemporal, democratizada de fato, uma saída para o dilema moderna. Descrente da imortalidade da arquitetura moderna, a partir de sua apreciação dos elementos da cultura de massa nos Estados Unidos, Banham parece sugerir ao seu leitor que se deixe envolver pelo que aquela Era da Máquina oferecia, já que esta, como todas as outras, teria vida curta. Como em um jargão americano, "sit back, relax, and enjoy the show".

so - prim and proper - in front of a mural of the redwoods adjacent to a busy L.A. intersection. The fully bearded critic dons a full chino suit, striped shirt, and bolo tie, his buckaroo hat casting a shadow over a stone-faced expression. Banham favoured artifice over naturalness, but knew - any sartorialist does - that timeless style was the effective combination of the two. Only trees painted on stuccoed walls and an aging face adorned with mirrored aviator sunglasses - acrylics and plastics - can convey cool in perpetuity. 


\section{Bibliografia e Fontes}

\section{Livros de Reyner Banham}

BANHAM, Reyner. A Concrete Atlantis: U.S. industrial building and European modern architecture, 1900-1925. Cambridge, The MIT Press, 1986.

. Los Angeles: the architecture of four ecologies. Los Angeles, University of Califórnia Press, 2001.

. Megastructure: Urban Futures of Recent Past. London: Thames and Hudson, 1976.

New Brutalism: ethic or aesthetic? London, Architectural Press, 1966. Scenes of América Deserta. Cambridge, The MIT Press, 1980. . Teoria e Projeto na Primeira Era da Maquina, São Paulo, Perspectiva, 1975. Theory and Design in the First Machine Age. Cambridge: The MIT Press, 1960.

. The Architecture of the Well-Tempered Environment, Chicago: University of Chicago Press, 1984.

\section{Artigos, ensaios e textos de Reyner Banham}

BANHAM, Reyner. A Critic Writes: essays by Reyner Banham. Selected by Mary Banham [et. al.]. Berkeley, University of Califórnia Press, 1996. "Art and Necessity: Inmos and the Persistence of Functionalism", Architectural Review, v. 172, dez. 1982, pp.34-41, 93-100. . “A Throw-Away Aesthetics". Industrial Design, v. 7, mar. 1960, pp.45-

58. . (Introduction). Foster Associates, London, RIBA Publications, 1979. . "All that Glitters is Not Stainless". Architectural Design, v.37, abr. 1967, pp.351-352. . "A Black Box: The Secret Profession of Architecture". New Statesman, 12 out. 1990, pp.22-25. "Buffalo Archeological". Architectural Design, v.167, 18 abr. 1985, pp.86-88.

. "Dymaxicrat". Arts, v.38, out. 1963, pp.66-69.

. "Encounter with Sunset Boulevard". The Listener, v.80, n. 12, 12 ago. 1968, pp. 235-236.

. "Fiat: The Phantom of Order". New Society, v.72, n.1164, Set. 1985, pp.86-88

"Fitch - Viewed from Marlboro / Indian Country". Architectural Design, v.43, Set. 1973, pp.601-603 . "Grass above, Glass Around". New Society, v.42, 6 out. 1977, pp.22-23. 
. "History and psychiatry". Architectural Review, v.127, mai. 1960, pp.20-

22.

. "The Historian on the Pier". New Society, v.17, n.436, jan. 1971, pp.66-

67.

. "A Home is Not a House". Art in America, v.53, abr. 1965, pp.70-79

. "Horse of a Different Colour". New Society, v.10, n.266, 2 nov. 1967,

pp.636-637

. "In the Neighborhood of Art". Art in America, v.75, jun. 1985, pp.124-

129.

. "L.A.: The Structure Behind the Scene". Architectural Design, v.41, abr.

1971, pp.227-230

. "Man, Machine and Motion". Architectural Review, v.118, Jun.1955,

pp.51-53.

. “Modern Monuments". New Society, v.78, n.1246, 14 Set. 1986, pp.12-14

. “New Brutalism”. Architectural Review, v.118, n.688, Dez. 1955, pp.354-

361.

. "Photography". Architectural Review, v.114, Dez. 1953, pp.259-261.

. "Roadscape with Rusty Nails". The Listener, v.80, n. 12, 12 ago.1968,

pp. 267-268.

. "A Set of Actual Monuments". Architectural Review, v.185, abr. 1989, pp. 89-92.

. "The Art of Doing Your Own Thing". The Listener, v.80, n. 12, 12 set 1968, pp. 330-331.

. "Towards a Million-Volt Light and Sound Culture". Architectural

Review, v.141, Mai. 1967, pp.331-335.

. “Unrecognized American Architecture: the Missing Motel”. Landscape,

v.74, Ago. 1965, pp.191-194

. "Who is This 'Pop'?". Art, v.10, set 1963, pp. 3-13.

. “1960 4: History Under Revision". Architectural Review, vol. 127, mai

1960 pp.325-53

. "1960 - Stocktaking of the Impact of Traditions and Technology on Architecture Today". Architectural Review, fev.1960, pp.93-100.

\section{Livros e artigos sobre Reyner Banhan}

AYNSLEY, Jeremy, ATKINSON, Harriet. Banham lectures: essays on designing the future. New York: Berg, 2009.

SPARKE, Penny. “Reyner Banham 1922-1988”. Journal of Design History, v. 1 n. 2, 1988, pp. 141-142.

WHITELEY, Nigel. Reyner Banham: the historian of the immediate future. Cambridge, The MIT Press, 2002. 


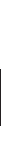




\section{Geral}

ANDERSON, Stanford. "Architectural History in the Schools of Architecture". Journal

of the Society of Architectural Historians, v. 58, n. 3, set 1999, pp. 282-290.

COHEN, Jean-Louis. Scenes of the World to Come: european architecture and american Challenge 1893-1960. Montréal/ Paris, Canadian Centre for Architecture / Flammarion, 1995. . Architecture in Uniform: designing and building for the Second World War. Montréal, Canadian Center for Architecture, 2011.

COLQUHOUN, Alan. Modernidade e tradição clássica: ensaios sobre arquitetura. São Paulo, Cosac \& Naify, 2004

CORNURBERT, Christophe (org.). Los Angeles: Stranger than Fiction. Amsterdam, Winter 2009/2010 - Berlage Institute Research report no.33

CRIMSON, Mark; ZIMMERMAN, Claire. Neo-avant-garde and Postmodernism: postwar architecture in Britain and beyond. New Haven, Yale University Press, 2010.

DAVIES, Mike. City of Quartz: Excavating the Future in Los Angeles. London: Verso, 1990. . Ecology of fear: Los Angeles and the imagination of disaster. New York: Metropolitan Books, 1998.

EISENMAN, Peter. Diagram diaries. London, Thames \& Hudson,1999.

FISHERMAN, Robert. Bourgeois utopia: the rise and fall of suburbia. New York: Basic Books, 1987.

FLEMING, Donald; BAYLIN, Bernard. The intellectual migration: Europe and America, 1930-1960. Cambridge: Harvard University Press, 1969.

FRAMPTON, Kenneth. História crítica da arquitetura moderna. São Paulo, Martins Fontes, 2008.

FRAMPTON, Kenneth; LATOUR, Alessandra., “Notes on American Architectural Education from the End of the Nineteenth Century until the 1970s". Lotus, 27, 1980, pp. 9-15.

FRAMPTON, Kenneth; FOSTER, Hal; ALLEN, Stan. “A conversation with Kenneth Frampton.". October, v. 106, 2003, pp. 35-58.

GIEDION, Siegfried. Mechanization takes command: a contribution to anonymous history. London, Norton \& Company, 1969.

Space, time and architecture: the growth of a new tradition.Cambridge, Harvard University Press, 2008.

GRAMSCI, Antonio, Americanismo e fordismo. São Paulo: Hedra, 2008

GROTH, Paul; WILSON, Chris. Everyday America: cultural landscape studies after J. B. Jackson. Los Angeles: University of California Press, 2003.

GUILLERY, Peter. Built from below: British architecture and the vernacular. New York, Routledge, 2001

HAMLIN, A. D. F. A text-book of the history of architecture. New York, Longmans, Green and Co., 1915. 
HAYS, Michael (ed.), Architecture theory dince 1968. Cambridge, MIT Press, 2000.

HERDEG, Klaus. The decorated diagram: Harvard Architecture and the failure of the Bauhaus legacy. Cambridge, 1985.

HINES, Thomas. The architecture of the sun: Los Angeles modernism 1900-1970. New York, Rizzoli, 2010.

JACKSON, John Brinckerhoff. Discovering the vernacular landscape. New Haven, Yale University Press, 1984. . Sense of place, sense of time. New Haven, Yale University Press, 1994. . The necessity for ruins and other topics. Cambridge: The University of Massachussets Press, 1980.

JENCK, Charles. Heteropolis: Los Angeles. The riots and the strange beauty of heteroarchitecture. New York, Academy Additions, 1993.

KENTGENS-CRAIG, Margret. The Bauhaus and America: First contacts 1919 - 1936. Cambrigde: The MIT Press, 1999.

KOOLHAAS, Rem. Delirious New York: a retroactive manifesto for Manhattan. New York, Rizzolli, 2001.

KOUWENHOVEN, John. The arts in modern civilization. New York, Doubleday \& Company, 1948.

KUBLER, George A. “What historians can do for architects?”. Perspecta, n. 9/10, 1965, pp. 299-302.

LE CORBUSIER. Vers Une Architecture. Paris, Flammarion, 2008.

LEWINE, Milton. “Rudolf Wittkower, 1901-1971”. Art Journal, v. 31, n. 2, 1971-197, pp. 236-237.

LIRA, José. “Da Forma-Lugar à Prática Reflexiva”. Desígnio, n. 11/12, mar. 201, pp.9-14

MASSEY, Anne. The Independent Group: modernism and mass culture in Britain, 1945-1959. Manchester, Manchester University Press, 1995.

MENDELSOHN, Eric. Amerika:Bilderbuch eines Architekten. Berlin, Nachdruck da Capo Press, 1976.

MILLON, Henry A. "Rudolf Wittkower, "Architectural principals in the age of humanism": its influence on the development and interpretation of modern architecture". Journal of Society of Architectural Historians, v. 31, n. 2, mai 1972, pp. 83-91.

MORRIS, William. News from nowhere. London, Penguin, 1994.

NESBITT, Kate. Uma nova agenda para a arquitetura: antologia teórica 1965-1995. São Paulo, Cosac \& Naify, 2008.

OCKMAN, Joan (org.). Architectural School: three centuries of educating architects in America. Cambridge: The MIT Press, 2012. . Architecture culture 1943-1968: a documentary anthology. New York, Rizzoli, 1993.

"Form Without Utopia: Contextualizing Colin Rowe". Journal of Society of Architectural Historians, v. 57, n. 4, dez. 1998, pp 448-456. 
OVERBY, Osmond. "From 1947: The Society of Architectural Historians". Journal of the Society of Architectural Historians, v. 49, n. 1 mar. 1990, pp.9-14.

PAYNE, Alina. "Architectural history and the history of art: a suspended dialogue". Journal of the Society of Architectural Historians, v. 58, n. 3, set 1999, pp.292-299.

PEVSNER, Nikolaus, Pioneers of modern design: from William Morris to Walter Gropius. Cambridge, The MIT Press, 1956.

REID, David (ed.). Sex, death and God in L.A. Berkeley: University of California Press, 1994

ROWE, Colin. The mathematics of the ideal villa and other essays. Cambridge: The MIT Press, 1987.

SAID, Edward , Orientalism. New York: Vintage Books, 1979.

SCULLY JR., Vincent. American architecture and urbanism. New York, Praeger, 1975. . Arquitetura moderna: a arquitetura da democracia. São Paulo: Cosac \& Naify, 2000.

SHANE, D. G. “Colin Rowe 1920-1999”. Journal of Architectural Education, v. 53, n. 4, mai 2000, pp.191-193.

SHERER, Daniel. "Fragments of the Modern: Alan Colquhoun - Modern Architecture". Art Journal, v. 62, n. 4, 2003, pp. 108-110.

SMITH, Elizabeth A. T. Blueprints for modern living: history and legacy of the Case Study Houses. Los Angeles, The MIT Press, 1986.

SNOW, Charles Percy. The two cultures and the scientific revolution. Cambridge, Cambridge University Press, 1965.

SORKIN, Michael. “Explaining Los Angeles”. In Exquisite Corpse: writing on buildings. London: Verso, 1994.

Variaciones sobre un parque temático: la nueva ciudad americana y el fín del espacio público. Barcelona, Gustavo Gili, 1992.

STERN, Robert. New directions in American architecture. London, Studio Vista, 1969.

SWENARTON, Mark. "The role of history in architectural education". Architectural History, v. 30, 1987, pp. 201-215

TOURNIKIOTIS , Panayotis. The historiography of the modern movement. Cambridge: The MIT Press, 1999

VAN DYKE, John. College Histories of Art. New York, Longmans, Green and Co., 1925.

VENTURI, Robert, IZENOUR, Steven, SCOTT-BROWN, Denise. Aprendendo com Las Vegas: o simbolismo (esquecido) da forma arquitetônica. São Paulo, Cosac \& Naify, 2003.

VIDLER, Anthony. “Art History Posthistoire”. Art Bulletin, v. 76, n. 3, set 1994, pp. 407410.

. Histories of the Immediate Present: inventing architectural modernism.

Cambridge, The MIT Press, 2008.

Eisenman, Peter (ed.). LOG, n. 28, summer 2013, "Stocktaking".

WEBSTER, Helena (ed.): Modernism without rhetoric : essays on the work of Alison and 
Peter Smithson. London: John Wiley \& Sons, 1994.

WHIFFEN, Marcus; KOEPER, Friederick. American architecture: volume 2 (1860-1976).

Cambridge, The MIT Press, 1981.

WHITELEY, Nigel: "Learning From Las Vegas... and Los Angeles, and Reyner

Banham". Visual Language, 37, 3, 2003.

. Reyner Banham: historian of the immediate future. Cambridge: MIT Press, 2002.

"Modern Architecture, Heritage and Englishness". Architectural History, v.

38, 1995, pp.220-237.

WOLFE, Tom. The kandy kolored tangerine flake streamline baby. New York, Bantam, 1999.

WRIGHT, Gwendolyn. Building the dream: a social history of housing in America,

Cambridge, The MIT Press, 1983.

. History of history in American schools of architecture, 1865-1975. New Jersey:

Princeton Architectural Press, 1990.

. USA: modern architectures in history. London, Reaktion Books, 2008.

\section{Fontes}

Acervo do Getty Research Institute - REYNER BANHAM PAPERS

24 caixas contendo material documental e manuscritos dos trabalhos americanos de Reyner Banham - setor de coleções especiais 
Anexo 1 - manuscritos de Reyner Banham no Getty Research Institute 


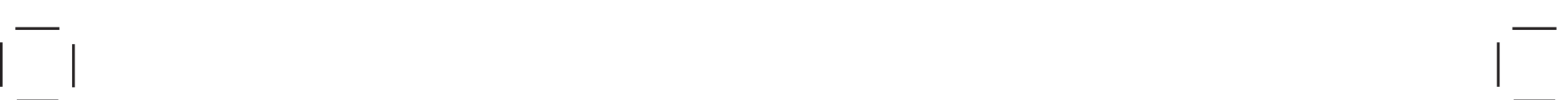




\section{Reyner Banham Papers - Nota de catálogo ampliada e traduzida 2012.08.21 - 2012.09.12}

O presente material foi baseado na ficha de bibliográfica original disponibilizada pelo Getty Research Institute. Os comentários à cada sessão foram inseridos pela pesquisa que culminou nessa dissertação, como também fez parte da contrapartida ao acesso irrestrito aos manuscritos de Reyner Banham. A lista de materiais em cada pasta foi revisada, corrigida e ampliada em seus detalhes, quando disponíveis.

No momento da pesquisa, o material encontrava-se ainda não processado fisicamente. A presente revisão do catálogo serviu como contribuição para rever alguns itens da organização. Por conta do processamento físico do material, o catálogo pode ter sofrido alterações. A presente nota de catálogo foi anexada às pastas de pesquisa presentes no arquivo da biblioteca do Instituto Getty.

Catalog review - Luiz Florence

The Getty Research Institute 1200 Getty Center Drive

Suite 1100

Los Angeles, CA 90049-1688

\section{Biographical/Historical Note / Nota Histórico-biográfica}

Reyner Banham (1922-1988) was a British-born architectural historian, critic, and educator. He taught at the University of London, SUNY Buffalo, New York University's Institute of Fine Arts, and the University of California at Santa Cruz. His writings and lectures influenced a generation of architects and historians of modern architecture. Banham's writings include reviews, journalistic and scholarly essays, and monographs. Of his many monographs, perhaps the best known are: Theory and design in the first machine age (1960), Los Angeles: the architecture of four ecologies (1971), Architecture of the well-tempered environment (1984), and Concrete Atlantis (1986). After his death, Mary Banham edited A critic writes, a compilation of Banham's essays (1996).

Reyner Banham foi um historiador de arquitetura, crítico e educador Britânico. Ele lecionou na Universidade de Londres, SUNY Buffalo, no Institute of Fine Arts da Universidade de Nova Iorque, e na Universidade da California em Santa Cruz. Seus escritos e palestras influenciaram uma geração de arquitetos e historiadores de arquitetura moderna. Os escritos de Banham incluem resenhas, ensaios jornalísticos e acadêmicos e monografias. De suas muitas monografias, talvez as mais conhecidas sejam: Theory and Design in The First Machine Age (1960), Los Angeles: the Architecture of Four Ecologies (1971), Architecture of the well-tempered Environment (1968 $\left.{ }^{17}\right)$, e A Concrete Atlantis: U.S. Industrial Building and European Modern Architecture (1986). Após sua morte, Mary Banham editou A Critic Writes, uma compilaçãoo de artigos escritos por Banham (1996).

\section{Administrative Information / Informação Administrativa}

17 Na versão dos arquivos Getty a data de publicação escrita, 1984, alude à revisão de Banham, publicada mais extensamente nos Estados Unidos, já quando Banham vivia na Califórnia, lecionado em Santa Cruz. 


\section{Preferred Citation / Citação preferida.}

Reyner Banham Papers, 1930-1990, bulk 1970-1988, Research Library, The Getty Research Institute, Accession no. 910009

\section{Acquisition Information / Informação de Aquisição}

O Getty adquiriu os documentos por Mari Banham em 1991. Ela enviou o material das conferências de design de Aspen em 1993.

The Getty acquired the papers from Mary Banham in 1991. She sent the Aspen design conference material in 1993.

\section{Scope and Content of Collection / Escopo e conteúdo da Coleção}

A coleção contém notas de pesquisa, manuscritos, e material impresso de oito dos livros publicados de Reyner Banham, de projetos não publicados, e diversos artigos e resenhas relacionadas à história da arquitetura e do design moderna e contemporânea. Estão inclusos notas e manuscritos para palestras públicas e suas aulas ministradas. Outros arquivos documentam sua participaçãoo em juris e seu trabalho de consultoria. Materiais impressos e relatórios da International Design Conference in Aspen (1950-1988) documentam seu envolvimento com a conferência de design de Aspen durante seus anos de formação.

The collection contains research notes, manuscripts, and printed materials for eight of Reyner Banham's published books, for unpublished projects, and many articles and reviews related to the history of modern and contemporary architecture and design. Included are the notes and manuscripts for his public lectures and his teaching. Other files document his participation on design juries and his consultation work. Printed materials and reports from the International Design Conference in Aspen (1950-1988) document Banham's involvement with the Aspen design conference during its formative years.

\section{Arrengement / Arranjo}

Organizado em 6 séries:

Série I: Manuscritos de Livros, ca. 1930-1990 (caixas 1-9);

Série II: Artigos e resenhas por Banham e outros, ca. 1930-1987 (caixas 10-11);

Série III: Conferências, palestras, simpósios, 1965-1987 (boxes 12-13);

Série IV: Consultoria e juris de projeto, ca. 1981-1989 (boxes 14-15);

Série V: Correspondências e documentos sortidos, 1976, 1987 (boxes 16-17);

Série VI: Conferência Internacional de Design, Aspen, 1950-1990 (boxes 18-24*).

Organized in 6 series:

Series I. Book manuscripts, ca. 1930-1990 (boxes 1-9);

Series II. Articles and reviews by Banham and others, ca. 1930-1987 (boxes 10-11); Series III. Conferences, lectures, symposia, 1965-1987 (boxes 12-13);

Series IV. Consulting and design juries, ca. 1981-1989 (boxes 14-15);

Series V. Assorted correspondence and papers, 1976-1987 (boxes 16-17);

Series VI. International Design Conference, Aspen, 1950-1990 (boxes 18-24*).

Indexing Terms / Termos de indexação 


\section{Subjects / Temas}

Architecture-California-Los Angeles

Architecture-Historiography

Architecture-United States-20th century

Banham, Reyner

Brooklyn Museum

Buildings-Environmental engineering

Concrete construction-United States

Herron, Ron

High technology

International Design Conference in Aspen

Nicholas Grimshaw and Partners

Piano, Renzo

Ransome, Ernest L. (Ernest Leslie), 1844-1917

Rogers, Richard George

Tennessee Valley Authority

Wright, Frank Lloyd, 1867-1959

\section{Geographic terms / Termos Geográficos}

Buffalo (N.Y.) - Buildings

Los Angeles (Calif.)—Buildings, structures, etc.

Los Angeles (Calif.)—Description and travel

\section{Genres and Forms of Material / Gêneros e formas de Material}

Blueprints

Correspondence

Draft writings, manuscripts

Negatives

Photographic prints

Photographs, Original

\section{Contributors / Contribuidores}

Banham, Reyner

Piano, Renzo

Price, Cedric

Rogers, Richard George

Waterhouse, Alan

Titles / títulos 


\section{Container List / Lista de Conteúdo}

\section{Series I.}

Manuscritos de livros, ca. 1956-1990

Inclui notas, rascunhos, material impresso, correspondência, resenhas e outros materiais de pesquisa, para Banham's Los Angeles: the Architecture of Four Ecologies (1971), Megastructure (1976), Buffalo: an architectural Guide (1981), Scenes in America Deserta (1982), Architecture of the well-tempered environment (1984), A Concrete Atlantis (1986), Visions of Ron Herron (1990), e "Making Architecture: the paradoxes of high-tech" (não publicado).

Book manuscripts, ca. 1956-1990 4.5 lin. ft.

Includes notes, drafts, printed material, correspondence, reviews and other research materials for Banham's Los Angeles: the architecture of four ecologies ( 1971), Megastructure (1976), Buffalo: an architectural guide (1981), Scenes in America Deserta (1982), Architecture of the well-tempered environment (1984), Concrete Atlantis (1986), Visions of Ron Herron (1990), and "Making architecture: the paradoxes of hi-tech" (unpublished).

Box / Caixa

1 Scenes in America Deserta, ca. 1970-1982

Relativo ao material arquivado sobre Scenes of America Deserta, dois diálogos são mais presentes do que do que muitos outros mobilizados na versão final e Reyner Banham. Primeiro, sua correspondência com as duas editoras, Gibbs M. Smith, da Peregrine Publishers, e Niko Stancos, da Thames \& Hudson. Esse material mostra elementos particulares do processo de publicação deste livro. Podemos sentir a complexa negociaçãoo e as tensões sutis entre uma editora de pequeno porte e uma editora notória como a Thames \& Hudson. Ademais, o impacto da viagem de Banham ao Lake Soda com o fotógrafo Tim Street Porter no próprio Banham é perceptível no conteúdo de seu próprio discurso. Especialmente pelo jeito como, durante a seleções de imagens, ele reitera sua apreciação da sessão de fotos de Porter durante essa viagem. Duas cópias em Xerox da viagem - uma dos dois entre seu meio de transporte (uma camionete típica americana) e a bicicleta dobrável de Banham, e outra, um close-up de Banham como um cowboy de bicicleta. Mais tarde, a Editora MIT Press utilizaria uma foto desta série para ilustrar sua edição deste livro.

Conforme lemos as primeiras letras, percebemos que foi de fato a conversa entre Gibbs e Banham que a idéia do livro surgiu, previamente ao material apresentado. Outro fato interessante é que Reyner Banham estava planejanto entregar o rascunho final de Scenes of America Deserta após terminar seu outro livro, já em seus planos, sobre construções industriais americanas e o Modernismo europeu. Mas, como a história nos mostrou, Banham na verdade publicou A Concrete Atlantis em 1986, enquanto Scenes of America Deserta foi publicado em 1982.

Outro aspecto interessante desta caixa é que, enquanto muito material de pesquisa parece estar ausente, Banham, manteve uma quantidade razoável de mapas. E muitos deles eram mapas turísticos, os quais podem pecar pela falta de precisão, o que seria normalmente necessário para um turista, contudo apresentam motivos gráficos populares notáveis.

Regarding the stashed material for Scenes of America Deserta, two dialogs are more present then the many others mobilized in Banham's final draft. First, his correspondence with 
the two involved publishing companies, Gibbs M. Smith, from Peregrine Publishers, and Niko Stancos, from Thames $\mathcal{E}$ Hudson. This material shows us particular elements of the process of publishing this book. We can feel the complex negotiation and the subtle tensions between a rather small publishing company and a notorious publisher such as Thames $\mathcal{E}$ Hudson. Also, the impact of Banham's trip to Soda Lake with the photographer Tim Street Porter to Banham himself is perceivable in the content of his own words. Specially by the way in which, during image selection, he reinforce his appreciation of Porter's photo shoot during that trip. Two Xerox copies of the trip - one of the two between their ride (a tipical U.S. off-road truck) and Banham's foldable bicycle, and another, a close-up of Banham, as a "bicycle cowboy". Later, the MIT Press would use on photo of this series to illustrate their edition of this book.

As we read the first letters, we realize that it was actually in a conversation between Gibbs and Banham that the idea of the book came out, previously to the material presented. Another interesting fact is that Reyner Banham was planning on deliver the final draft of Scenes of America Deserta after finishing his other book, already in his plans, about American industrial buildings and European Modernism. But as history showed us, Banham actually published A Concrete Atlantis in 1986, whereas Scenes of America Deserta was pulished in 1982.

One interesting aspect of this box is that, where much of the research material seems to be absent, Banham kept a good amount of maps. And most of them are tourist maps, which may lack precision, what would be necessary normally for a tourist, but displayed remarkable folk graphics.

Research materials, ca. 1970-1980, n.d. ca. 30 items Aztec Ruins tourist folder - National Park Service, 1976 Memos from SUNY Buffalo, n.d.; sketched map "south on Arizona Avenue (87/93)", n.d.

Business card with note - Willian M. E. Clarkson - 12-1-1980 6 color post cards with photographs, n.d. - Golden Canyon; Saguaro Cactus; Red Mountain; Hoover Dam (2); Ubehebe Crater

Walt Whitman bookmark from Aptos Bookmaker, Rancho del Mar center

Monument Valley tourist brochure from Goulding's Lodge \& Ranch

Memos on books - "Smithson: A Sedimentation. Art in America, 59 (Sept/Oct 1971); Anderson: American Sculptures on Rocks, $1975^{\prime \prime}$

Death Valley National Monument and Vicinity map 2 Xerox copies of photographs - P.R. Banham. Tim Street Porter and Banham's folding bike at Soda Lake; Banham riding the bicicle

Newspaper clippings - NY Times, May 11, 1980; S. F. Sunday

Examiner \& Chronicle, Mar 2, 1980

Xerox book chapter: “4 - Landscape, Violence, Poker (pp.100113)

Bind Xerox copy, n.d., showing photos and descriptions of desert buildings

Signed manuscript with note from Alan Ritch "The Exposed Landscape: Aesthetics and Evaluations of the Arid Southwest in the Nineteenth Century", 1970.

Hertz Albuquerque and Phoenix map 
Desert photographs and photograph roll, n.d.

Magazine clipping with Banham's picture, n.d.

Newspaper clipping: This Week - Radio Times (BBC) - June 28, 1979.

clippings, maps, photographs, some letters, and mss.

Manuscripts, n.d. ca. $30 \mathrm{pp}$

Manuscript for chapter, most likely "A Written Word", on John

Van Dyke's The Desert

Amex receipt for car rental, 07/20/81

2 copies of "First draft for chapter of Scenes of America Deserta, 7 pages

Note: list of chapters for unknown book

Xerox copy of a bibliography list with the latest book cited being from 1979

Manuscript written on yellow legal sized paper (8.5x14)

Manuscript written on green paper - preface description, n.d.

Copy of "Text for Arentz Photo of Spruce Tree House Care", n.d.

Scenes of America Deserta promo material, n.d.

New Society clipping, incomplete, May 6, 1970

Text copy "Viewing the Landscape on the Road to Culver, New Mexico", from 'Carolyn' to Peter (Reyner Banham), August 29 ${ }^{\text {th }}$, 1978.

Note on chapter organization, June 6, 1980

Notes, letters, mss, and printed materials, 1978-1982, n.d. ca.

20 items

Message to Mary M. Chrisney, AIA - June 26, 1980

Bind manuscript fot the letter and Chrisney's first letter, June 18, 1980

"Rose Pauson House site: its background and suggested course of action" memo, n.d.

Correspondence between Niko Stancos, Thames \& Hudson, Gibbs M. Smith, Peregrine Publishers, ca. 1979

First draft of part of a chapter - "Kelso", n.d.

Correspondence with Julian Cooper, BBC, about the program

"Desert Roads", November 21, 1978.

BBC standard contract fot the program "Desert Roads"

Outline of program, n.d.

Correspondence with Thames \& Hudson, 1980.।

Correspondence with Mr. Dennis Caselier, from Mojave

Publishing co.

Notebook with notes, n. d.

Call Messages

Letter from Photographer Tim Street Porter, n. d.

Southern Arizona Road Map, n. d.

Monument Valley Road Map, 1975

Correspondence with BBC staff

Box

Nesta caixa encontraremos material de pesquisa do ultimo livro publicado, 
A Concrete Atlantis: American Industrial Building e Arquitetura Moderna Europeia. Nesta caixa, podemos ver que diferentemente de America Deserta, este é um livro em que houve uma substancial pesquisa bibliográfica para somar às viagens observacionais feitas por Banham e Patricia Layman Bazelon, a fotógrafa de muitos dos retratos das fábricas americanas. Muito material sobre arquitetos e engenheiros de patentes pareciam interessar Banham. No começo, seu livro delineou claramente a vontade de dedicar espaço e reconhecimento à Ernest Ransome. Neste período, como podemos perceber por sua correspondência com outros historiadores e seu interessados em geral em edifícios fabris, ele declara que a agenda de seu livro vai além de erguer arquitetos aos seu merecido lugar na história da arquitetura.

Outro aspecto interessante do livro são as fontes de língua alemã da pesquisa. Sendo Banham praticamente fluente em alemão, como demonstrou em seu último livro, Teoria e Projeto na Primeira Era da Máquina, Banham é consciente das sutilezas dessa linguagem e como é o efeito sobre conceitos de beleza, indústria, artesanato e funcionalismo.

Ademais, há a carta da esposa de Walter Gropius para Nikolaus Pevsner, orientador de Banham em seu Ph.D., na qual Banham é mencionado, de maneira desagradável, na impressão de Gropius sobre seus escritos, chamados de "exercícios tortuosos". Banham parece ter grifado esse comentário com marca-texto vermelho, junto com outros trechos que chamaram seu interesse. Curiosamente, a carta é escrita em inglês.

In this box we will find the research contents of Banham's last published book, $A$ Concrete Atlantis: American Industrial Building and European Modern Architecture. In this case, we can see that differently from America Deserta, this is a book where there was substantial bibliographical research made to sum with the observational trips made by Banham and Patricia Layman Bazelon, the photographer for most of the pictures of the American factories. Much material about the patent architects and engineers seemed to concern Banham. At the beginning, his book outlines exposed clearly the eager to dedicate the proper space and recognition to Ernest L. Ransome. Then, as we can perceive through his correspondence with several other historians and overall interested people in factory buildings, he declare that the agenda of this book goes beyond raising architects to their deserved spot in architectural history.

Another interesting characteristic of this book is the German-spoken sources of research. As Banham spoken fairly fluent German, as he showed in his first book, Theory and Design in the First Machine Age, Banham is aware of the subtleties of that language and how this affects the concepts of beauty, industry, craftsmanship and functionalism.

Also, there is a letter from Walter Gropius' wife to Nikolaus Pevsner, Banham's tutor for his Ph.D., where Banham is mentioned, in a rather displeased manner, as Gropius found the writings of "Mr. Banham" to be "tortuous exercises". Banham must have underlined this comment in red marker, along with other matters that raised to his interest. Curiously, the letter is written in English.

21 Correspondence and research, 1980-1985 ca. 60 pp

letters, notes, ms proposal, and printed matter

Correspondence with Ms. Deborah Gómes, National Gallery of

Art, January 27, 1983

Correspondence with American Concrete Institute, Betty

Borschell

Correspondence with Leonard K. Eaton, April 14 1984

Charles B. Foster Indiana State Patent, Xerox Copy, May 5 ${ }^{\text {th }}, 1934$

Correspondence with Maria Grazia Dapia Conti, regarding the 
photos of Fiat-Lingotto factory at Milano, March 5, 1985

"Cooper Building" copy from Krop \& Woolling, Arch/Eng

Memo from SUNY Buffalo, n. d.

Correspondence with Alan Conant, May 25 ${ }^{\text {th }}, 1984$

J. Ardis Abbott envelope, no content, n.d.

Correspondence with Sandra L. Tatman from Atheneaum

(Philadelphia), Jun 19, 1981

Correspondence with Robert N. Gordon

Correspondence with Harvard University Art Museums, January

18 1985, regarding Gropius and Breuer material

Leonard K. Eaton: "Winnipeg: The Northern Anchor of the

Whole Safe Trade" Xerox copy, 1982.

Correspondence with Miles Lewis, Melbourne University,

October 271983

Correspondence with Jane Irene Atkinson, December 13, 1980

History of Contra Costa County", Xerox copy

Letter from Walter Gropius' wife to Nikolaus Pevsner, June 14

1963, Xerox copy, with post-it attached, saying: "JSAH Oct 82

Edgar K J Quinan"

Correspondence, 1982-1986 ca. 25 pp.

most letters regard publication, with some mss.

Abstract: "A Concrete Atlantis, by Reyner Banham" on Matrix

printer paper n. d.

Text dummies, n. d.

Correspondence with Debby Edelstein, October 27, no year

Correspondence with Patricia Layman Bazelon, photographer

23

Notes and rough drafts, n.d. ca. 60 pp.

NY University message from Linda Sullivan

Downtown Minneapolis map with notes, n. d.

Notes in German regarding the book: Die Entwickung Moderner

Industrialbaukunst, n. d.

Manuscript: "Reminder to Architects", 11 pp., n.d.

Xerox copy: "The Building Complex: Workshop, Office Block,

Press", 9pp.

Manuscript: Lingotto Factory, typed, n.d.

Translation to English from German: Faguswerk

Gemeingeschichte, 4 pp.

Xerox copy: "A Concrete Atlantis, an outline"

"A Concrete Atlantis: Index" on Matrix printer Paper

24

Manuscript, n.d. ca. 200 pp.

Manuscript: "reminder to architects", 10 pp. n.d.

Index of images for the book, 1 page, n.d.

Express Mail Jan $13^{\text {th }} 1986$ from Debby Edelstein, MIT Press

Inside first page from Technische Schönheit.

Final draft of A Concrete Atlantis revised from Banham to Debby

Edelstein on matrix paper ca. Jan 1986.

Checking proof guidelines from MIT Press 
The MIT Press letter from Debby to Banham

25

Reviews, 1986-1987 ca. 80 items

London Review of Books, July 24, 1986 pp.22-23

"From Grain to Gropius" - Review from John Coolidge - NY

Times book review May 4, 1986

"Modern Icons" - Review from Sutherland Lyal - New Society,

August 1, 1986

"Loving Buffalo" - Martin Pawley review - The Guardian

August 1', 1986

"Buffalo Wonders of the World" - Jack Quinan - The Buffalo

News, July 27, 1986 - with dedicatory "with Love, from Magda" (possibly Magda Cordell)

AIA Journal, Martin Fitch, n. d.

"Letting in the Day Light" - Nicholas Adams - Times Literary supplement, Oct 19, 1986

"The Last Laugh?" - Kent Williams - Illinois Gazette, n.d.

The Bookseller, London, February $8^{\text {th }}, 1986$

The Library Journal NY, April 15 ${ }^{\text {th }}, 1986$

Directions, Vol. 12, No 5, May 1986

“Where Modernism First Lit Up" - Colin Amery - Financial

Times, June $28^{\text {th }}, 1986$

The Wilson Quaterly, Autumn 1986

"Quella Atlantida di Cemento che Conquistò Le Corbusier" -

Mauro Calamandrei - Il Sole, July $7^{\text {th }}, 1986$

"Heavy Duty Scholarship" - Martin Pawley, n.d.

Le Promeneur, October-November, 1986

LA Times, September $14^{\text {th }}, 1986$

Bauwelt September $12^{\text {th }}, 1986$

The Midwest Review, n.d.

"Unravelling the 'Silo Dream'” - Architectural Design, 56, june 1986

"Industrial Romance" - Esther McCoy - L.A. Architect ,

November 1986

"Temple to the Dynamo" - Joseph Masheck - Art in America, January 1987

SIA Newsletter Vol. 15, No2, Sumer 1986

Archis (Nederlands) February 2, 1987

The Boston Sunday Globe, December $7^{\text {th }}, 1968$

Brighton Polytechnic, n.d.

Technology Review, Feb/Mar 1987

"Shaping the Modern American City" - George Kapelos -

Canadian Review of American Studies, Vol. 18, Spring 1987

Michael Stratton, Journal of the Construction History Society,

Vol. 3, 1987

Box

3 Concrete Atlantis, illustrations, n.d.

Na segunda caixa do livro A Concrete Atlantis, encontramos a maioria das fotografias selecionadas para a impressão final, publicada no começo de 1986. Podemos 
ver que a qualidade dos originais é refinada, e através de um processo simplificado de impressão pela MIT Press, parece que essa qualidade se perdeu.

Na caixa \#2 existe uma correspondência entre Banham e Maria Grazia Dapia Conti, relativo às fotos da fábrica Fiat-Lingotto em Milão. Nessa caixa, as fotos estão presentes, como solicitado por Banham.

Existe mais de uma impressão da maioria das fotografias, o que nos diz sobre a possibilidade de escolha aberta para o livro.

O material sobre este livro é de longe o mais substancial entre os demais manuscritos de Banham. Uma das razões para isso é, além do caráter da pesquisa do livro em questão, é a questão de tempo. Sendo esta sua última publicação substancial, é fácil entender que a maioria do material de Banham foi mantido intacto em relação às mudanças constantes do autor, e suas viagens. Como muitos de seus interlocutores e profissionais próximos, Banham, como um historiador observacional, preferia viajar com pouca bagagem.

In the second box of the Concrete Atlantis book, we will find most of Banham's selected photographs for the final print, released in early 1986. We can see that the quality of the prints are rather refined, and through the rough process of printing the MIT Press publication, it seems that this quality has been lost.

In Box \#2, there is a correspondence between Banham and Maria Grazia Dapia Conti, regarding the photos of Fiat-Lingotto factory at Milano. In this box, the photos are present, just as requested by Banham.

There is more than one print of most of the pictures, what can tell us about the possibility to choose the best print for the book.

The material regarding this book is by far the most substantial among the Banham's Papers. One of the possible reasons for this is, besides the character of the research demanded for the preparation of this book, is the question of time. Being this his last substantial published work, it is easy to understand that most of Banham's material was kept intact from the author's constant moving and travels. As most debaters and close professionals, Banham, as an observational historian, liked to travel light.

Photographs and photo list ca. 200 items

Fiat-Lingotto factory at Milano - 7 itens - circa 1970

Patent pictures

Patricia Layman Bazelon photos of Grain Elevators

Envelope with negatives

Unprotected photographs - 27 itens - Fagus Werk, Ernest L.

Ransome

MIT Press envelope with negatives

32

Photographs ca. 60 items

Envelope with the name "Kellog" written, containing photographs and slides of grain silos and day-light factories Proof photography - repeated from file 3.1 - most of them with notes in post-it, n.d.

33

Photographs ca. 50 items

Proof photography - ca. 30 items, n.d.

List of photographs in letter size paper, n.d. 
Box

$\mathrm{Na}$ caixa ${ }^{\circ} 4$, uma das caixas destinadas a $A$ Concrete Atlantis, encontramos a maioria do material sobre os arquitetos europeus que extraíram inspiração do parque industrial edificado nos EUA para a arquitetura moderna europeia. Os destaques são os croquis de Mendelsohn em seus 'sonhos de silos' de 1924, e o material sobre a fábrica Fia-Lingotto.

Ademais, há uma vasta pesquisa realizada no inventório do HAER (Historic American Engineering Record), arquivado na pasta 4.4. Esta é uma evidência da extensa pesquisa realizada por Banham sobre os 'arquitetos de patentes' e engenheiros, nos quais Ernest L. Ransome é elevado aos níveis mais elevados, no que concerne a historiografia. Isso pode explicar muito sobre a falta generalizada de detalhes sobre a obra de Albert Kahn, se o compararmos com Ransome, por exemplo, cujo material é extensamente investigado por Banham.

In Box four, one of the four Boxes destined to A Concrete Atlantis, we find most of the material from the European architects who drawn inspiration from American industrial built environment in the US to the modern architecture in Europe. The highlights are the Mendelsohn's sketches of his 1924 'silo dreams', and the material from Fiat-Lingotto factory.

Also, there is a vast research on the HAER Inventory (Historic American Engineering Record), which is stashed in folder 4.4. This is one evidence of the extense research performed by Banham on 'patent architects' and engineers, in within Ernest L. Ransome is elevated to higher standards, for what historiography in architecture is concerned. That could explain a lot about the overall lack of details on Albert Kahn's work, if you compare him to Ransome, by instance, whose material has been widely surveyed by Banham.

$4 \quad 1-3 \quad$ Illustrated material, photocopies and printed matter ca. 60 items Fiat-Lingotto section and plan in photographic print

Die Entwicklung Moderner Industriebaukunst hotographic print, $7 \mathrm{pp}$.

"Portmouth Shipyard" n.d. (xerox copy)

"The legacy of Albert Kahn", n.d. (xerox copy)

Architecture and Design, Vol. XVII, August 1953

"Lingotto: un problema di ristrutturazione urbana" (original, 4pp.) n.d.

Merrimack Valley Textile Museum Folder, n.d.

Lowell Offerings, Michigan, tourist guide,1984

"Oscar Eckerman: Architect to Deere \& Company - 1897-1942" Leonard K. Eaton, n.d.

"The Buffalo Sloped Bin Grain Elevator" - ABL Engineering Ltd, Feb. 1982

Hannibal, Missouri map, Sanborn Map Co., n.d.

Hennepin County History brochure, 1981

Buffalo City Plan - Sanborn Map Co., n.d.

Assorted Xerox copies

Niagara Wallpaper Co. images - 7pp., 1916

US Department of Interior Ecological Survey Map, Buffalo*

Member Warehouse Federal System Plans*

Cargill Eletric Grain Elevators photographs - Xerox* 
Eric Mendelsohn's sketches - Xerox*

Fagus Werk photos - Xerox

Gropius' Entwicklung der Moderner Industriebaukunst, Xerox*

Bethume Hall, SUNY Buffalo, photographs - Xerox*

Fiat-Lingotto photographs - Xerox*

Le Corbusier, Rappel a MMs. Les Archiects, Xerox*

*All non-dated.

$44 \quad$ HAER inventory, 1976 ca. $30 \mathrm{pp}$

photocopies of Historic American Engineering Record (HAER) survey records of buildings

Grain silos in America timeline, 1 page

HAER inventory, ca. 100 pages

Box

$5 \quad$ Concrete Atlantis, ca. 1974-1985

Na última caixa dedicada à Concrete Atlantis, há muitas publicações feitas por cidades e condados que expões seu orgulho local através da imagem de um passado distante de vigor econômico, dada ao passado de desenvolvimento industrial. Ao entendermos os desenvolvimentos contemporâneos da sabedoria industrial, em que muitas companhias manufatureiras enviam seu excedente à exportação intercontinental, o tempo dessas pequenas cidades dependentes da produção agroindustrial é há muito passado.

Muitos manuais e relatórios de construção em concreto dentro deixa caixa são válidos de menção. Existem parâmetros nos quais Banham poderia se amparar para analisar o valor da relação entre arquitetura e real estética fabril, o funcionalismo em sua verdadeira forma.

In the last Box dedicated to A Concrete Atlantis, there are many publications made by cities and counties that are exposing their local pride through the image of a long gone economical peak, due to the gone age of industrial development. As we understand the contemporary developments of industrial wit, where most of the highly manufacture-based companies had sent their production overseas, the time of these small cities dependent on agroindustrial production is long gone.

The many concrete building manuals and reports inside this box are worth mentioning also. These are the parameters through which Banham was able to value the interconnection between architecture and real factory aesthetics, functionalism at his true form.

$5 \quad 1-3$

Research material ca. 250 items

photocopies of articles and illustrations, printed materials, and mss.

Buffalo Archeological, n.d., pp.88-93

Archetype, n.d., ca. 1980-1983

American Machinist, May 23, 1907 - "Largest Concrete Machine Shop in the World"

The Atlas Portland Cement Co., ca. 20pp.

Minneapolis Map, 2 copies

"The Diffusion of Silos" Allen G. Noble, Landscape Magazine, Vol.25, No1.

“Basic Patents for Inventions Rationing to Reinforced Concrete 
and a Short Survey of the Early History of the Art"

The Brickbuilder, November 1902, pp.232-236

"Report of the Committe on Reinforced Concrete" - Sanford E.

Thompson - Proceedings, National Association of Cement Users U.S., 1909.

"A Century of Minnesota Architecture" - n.d., with correspondence with Adolf K. Placzek, Avery Librarian, January 18,1976

"Pacific Borax Co." - Ransome \& Smith Co., n.d., 4pp.

Clipping from American and Architect Building News, Nov 17 ${ }^{\text {th }}$, 1877

"Frank Lloyd Wright: a study towards appreciation" - in

German, 8pp. - translation (unidentified) 14pp.

Clipping from Journal of the Western Society of Engineers, Vol. V,

Oct. 1900, No. 5 - Monier Constructions

Clipping from "Reinforced Concrete Buildings" - Ernest L.

Ransome and Alexis Saubrey. New York, McGraw-Hill, 1912.

19pp.

Enclosed Booklet of Peavey Co. with letter from Debbie Word, n.d.

"Pacific Borax Co." - Ransome \& Smith Co. Concrete Engineers, xerox copy, 4 pp. n. d.

Clipping from "The American Architecture and Building News" November $17^{\text {th }}, 1877$.

"Frank Lloyd Wright: A study Towards Appreciation", handwritten, 14pp. Translated from German original, 7pp.

Clipping from "Journal of the Western Society of Engineers, Vol. V, October 1900, No 5 - Manier Constructions

Clipping from "Reinforced Concrete Buildings" - New York, McGraw Hill Books Co., 1912, 19pp.

Enclosed booklet of Peavy Co., with letter from Debbie Ward Clipping from Transactions, American Society of Civil Engineers, Vol. LXVI, March 1910

"The Grain Elevators of Buffalo" - School of Architecture and Environmental Design - "independent study for professor

Banham" Charles D. Carter, November $28^{\text {th }}, 1978$

Clipping from Industrial Buildings, 18pp., n. d.

"Final Report of the Joint Committee on Concrete and Reinforced Concrete" - July 1 1, 1916 , 63pp.

"General Description of Proposed Elevator for Eastern Grain Elevator - Buffalo, NY" - with notes

Clipping from Minnesota newspaper "Modern Fireproof Grain Elevator" - November $18^{\text {th }}, 1903$

Listings of industrial Buildings (inventory) - 12pp., n. d. Independent study "A Study of the Works of R. J. Reidpath" Susan Copley, April 8" ${ }^{\text {th }}, 1978$

Textile Mills - List of photographs of buildings by Aberthow, $n$. d.

Eric Mendelsohn's 1924 Amerika clipping

Draft manuscript of Ginzburg section on $3^{\text {rd }}$ chapter

Gropius and Corbusier clippings 
Clipping from Archetype, Vol. 1, No 4, winter 1980.

Clipping from Learning from Las Vegas, pp.92-93

"Modern Architecture and the Image of American Industry"

- Synopsis of a paper to be given by Reyner Banham to the

Colloquium L'Americanism et La Modernité, Paris, October 1985

Clippings of designs from Edoardo Persico (Fiat-Lingotto),

Walter Gropius (Fagus), and Le Corbusier (Vers Une Architecture)

Leonard K. Eaton: "Winnipeg: The Northern Anchor of the

Whole Safe Trade" Xerox copy, 1982.

Historical American Engineering Record (HAER) inventory, ca.

60 itens

Clipping from Progressive Architecture in America, September 1957

Clipping from Walter Gropius: work and Teamwork, New York,

Reinhold, 1954 (pp.20-24)

Documents on local Buffalo architects, ca. 40 pp.

Notes on Gropius publications in German, n. d.

“The Bemis Big Plant in Winnipeg, Canada" - Concrete

International

"American Buildings and Early Modernism" - Dale Peterson

(draft) January $17^{\text {th }}, 1983$, with letter

Clipping from Edoardo Persico" Tutte le Opere (1923-1935) - Giulia

Veronesi, Milan, Edizioni di Comunitá Milano, 1964

Ca. 20 pp.

Box

6

Assorted publications, ca. 1956-ca. 1990

Nesta caixa está o material sobre as novas edições dos livros de Banham, tal como The Architecture of the Well-Tempered Environment, novas colaborações e a revisão da nova edição do catálogo da exposição This is Tomorrow, realizada em 1956 na White Chappel Gallery, em Londres, que se resume a uma proposta inicial para uma nova edição da exposição, e uma cópia xerox do catálogo original.

Não é necessário dizer que esses não são materiais oriundos das publicações originais, com a exceção dos ensaios sobre Ron Herron, e um dos mais notáveis materiais desse pacote, o material sobre a publicação Megastructures. Sobre o que está disponível na caixa, existem muitos planos de palestras e listagem de slides, remontando os eventos de 1967, em Montreal, as quais foram vastamente investigados no capítulo do livro em questão. Isso pode dar ao leitor de Banham uma boa ideia sobre o começo desta publicação. Um aspecto interessante do método de Banham emerge dessa informação combinada. É bem possível que Banham tenha trabalhado em mais de um livro por vez, malgrado em alguns momentos tenha acontecido o processo de consolidação de uma ou outra publicação.

Uma parte substancial do material é focado no desenho da Bahia de Tóquio, projeto de Kenzo Tange, sobre o qual há uma longa apreciação na versão final da publicação.

In this Box there is the material regarding Reyner Banham's books new editions, such as The Architecture of the Well Tempered Environment, new collaborations and a review of the 
catalog of This is Tomorrow exposition, held in 1956 in the White Chappel Gallery, London, which, by the way, resumes in an outline of a new edition and a xerox copy of the original catalog.

Needless to say, these are not the materials from the original publications, aside the essays on Ron Herron, and one of the most remarkable materials, one exception among the reprints, that is the material on Megastructures. As for what is available in the box, there are many lectures plans and slide listings, tracing back to 1968. Perhaps the spakle, the inspiration for the book came from the events in 1967, in Montreal, which are vastly investigated in a chapter of the book in question. This can give the Banham reader a good idea about the very start of the making of this publication. An interesting aspect of Banham's method arises from this combined information. It is very likely that Banham worked in more than one book at a time, regardless of certain moments of closure for any given publication.

A substantial part of the material is focused in the Tokyo Bay design from Kenzo Tange, which had wide appreciation in final publication.

$6 \quad 1$

This is Tomorrow, 1956, $1987 \mathrm{ca} .40$ pp.

photocopy of catalogue, published 1956, plus ms. outline, dated 1987

IG This Is Tomorrow exposition catalog outline - This Was Tomorrow, 1991 re-edition, October $26^{\text {th }}, 1987$

Original 1956 exhibition catalog, xerox copy

62

Megastructure, 1976, n.d. ca. 20 items

proposal, bibliography, notes

"Proposed book on Megastructures: probable chapter headings"

- typed and handwritten

1973 book outline

Lecture manuscript, August $18^{\text {th }}$ no year indicated

"Kikutake: the Oceanic City

Notes on Lectures, ca. 1968-1975

Folder ofr the Raoul Waltenberg Lecture, April 1-2, 1975

Bibliographical research notes - Scott-Brown, Giedion,

Maldonado

Lecture material in Naples Architecture School, February 1973

"A Short Bibliography on Megastructures", by Ralph Wilcoxen,

n. d.

Letter from Guy Desbarats, University of Montreal, March $8^{\text {th }}$, 1974

Unidentified transparency

"Montreal, Laboratoire Urbain" de Guy Desbarats

Clipping from Architecture Canada, n. d.

Progressive Architecture, June 1972

63

Visions of Ron Herron, 1985-1987, n.d. ca. 50 items

photocopies, notes, letters

Correspondence with Ron Herron, February $12^{\text {th }}, 1987$

Correspondence with Maritz Vandenberg (Architectural Press),

regarding Japan Guide

Sketches from Ron Herron, Xerox copy, 8 itens

Ron Herron Biography and projects

"Ronthoughts", 3pp., n. d.

"The Drawings of Ron Herron"

Drafts - introduction and entire book 
Architecture of the well-tempered environment, n.d.

1 notebook of reading notes

Spiral notebook with notes for re-edition

n.d. ca. 30 items

Architecture of the well-tempered environment, 1982-1983,

material for illustrations: drawings, blueprints, posters, photos, photocopies

transparency with sketches on marker - "Robie House"

Notes and sketches on Belfast Royal Victoria Hospital

Correspondence between Mary Banham and R. J. Johnson

(Heating and Works Service Division)

Correspondence with Maritz Vandenberg (Architectural Press), 2

August 1982

Correspondence with Wendy Stathman and Tony Noarces -

Department of Health and Social Security (DHSS) - about Royal

Hospital of Belfast

Cavalera Drawings on blue paper, ca. 10 itens

Sketches on tracing paper pad, 9x12 in

Notes on Robie House

Box

Esta caixa contém as imagens do livro de Banham sobre Los Angeles - Los Angeles: the Architecture of Four Ecologies - e o material de Buffalo: an architectural Guide. Sobre o Guia de Buffalo, existem muitas repetições da fonte de pesquisa de $A$ Concrete Atlantis. O material da pesquisa independente de Susan Copley sobre R. J. Reidpath faz outra aparição, e parece que Banham à dá mais atenção desta vez. Um novo artigo interessante é um ensaio publicado por um estudante sobre elevadores de grãos, datado de 1984. Malgrado A Concrete Atlantis tenha sido publicado apenas em 1986, existiam já alguns artigos por Banham sobre o assunto. Nenhum foi citado pelo estudante.

Sobre o material de Los Angeles, encontraremos principalmente fotos, croquis e material recortado de decalques para mapa, apresentados na versão final do livro, publicado em 1970-71. Muitas imagens são do famoso fotógrafo de arquitetura de Los Angeles, Julius Shulman. Seu conteúdo cobre as Torres de Watts, de Simon Rhodia, os projetos construídos de Craig Ellwood, alguns exemplos de "arquitetura fantástica", arquitetura dos ding-bats, presente no capítulo sobre a ecologia das planícies, algumas imagens sobre a cultura do surf, pranchas customizadas e alguns bangalôs nas falésias das praias.

Alguns desenhos pessoais desta caixa foram apresentados na publicação de 2010 do Instituto Berlage, organizada por Christophe Cornurbert, Los Angeles, Stranger than Fiction. Nesta publicação as Torres de Watts são apresentadas, bem como os mapas desenhados em papel manteiga sobre os mapas de 1935 de autoria de Wanton Wagner, presente em uma das publicações que mais inspirou o livro de Banham, Los Angeles: Werden, Leben, Und Gestalt Der Zweimillionenstadt in Sudkalifornien.

This Box contains the images of Banham's Los Angeles book - Los Angeles: The Architecture of Four Ecologies - and the material of Buffalo: an architectural guide. Regarding the Buffalo guide, there is many repetitions from the source material from A Concrete Atlantis. The material from Susan Copley's independent research on R. J. Reidpath makes another 
apparition, and it seem that Banham gives it more attention this time. One interesting new paper is a student essay on grain elevators, dated from 1984. Even though Concrete Atlantis was only published in 1986, there were already some published articles about this theme by Banham. None is quoted by the student.

Regarding the material on Los Angeles, we will find mostly pictures, sketches, basic material cutted in craft-type paper for the maps shown in the final print and the photographs which formed the main body of images of the final publication, in 1970-71. Many pictures are from L.A. well-known photographer Julius Shulman. Their content covers the Rhodia's Watts Towers, Craig Ellwood built designs, some examples of "fantastic architecture", Dingbat architecture featured at the ecologie of the plains, some images of surf culture, customized surfboards and some bungalows at the beach terraces.

Some personal drawings from this box have been shown in a 2010 publication from the Berlage Institute, organized by Christophe Cornubert, Los Angeles, Stranger than Fiction. In this publication the Watts Tower sketches are displayed, as well as the drawn maps on sketch paper over 1935's Wanton Wagner's maps on the most inspiring publications for Banham's book, Los Angeles: Werden, Leben Und Gestalt Der Zweimillionenstadt in SudKalifornien.

Los Angeles: the architecture of four ecologies, n.d., ca. 1970 ca. 20 items

Postcards, n. d. - Constance publisher

Los Angeles Street and Vicinity Map - Chevron

Unidentified photographs, n. d. - authors: Julius Shulman, Steve Wilkings, James Ganzer photographs, negatives, maps, postcards ca. 60 items Los Angeles: the architecture of four ecologies, n.d.

notes, photocopies, maps, negatives, drawings

Watts Tower Sketches

'Foothills' list, n. d.

'Beaches' list, n. d.

'Plains' list, n. d.

List of Maps for the book

Map hand-drawn on sketch paper over Anton Wagner's 1935

map

Planes icons drawn on sketch paper

Envelope with negatives

Maps for the older part of Los Angeles - xerox copy icons cutted from craft-type paper, most likely for the maps photographs with negatives, ca. 36 itens

Los Angeles: the architecture of four ecologies, n.d. ca. 50 black and white photographs Photographs with negatives, ca. 50 itens Los Angeles: the architecture of four ecologies, n.d. ca. 60 black and white photographs Photographs with negatives, ca. 60 itens, mostly repeting the material in folder 7.3 research: photocopies of articles and illustrations, notes and mss. Clipping with aerial photograph from Buffalo River upstream, 1922 - published ca. 1980 
Clipping from Buffalo News, June $14^{\text {th }}, 1987$ - Xerox copy Independent study "A Study of the Works of R. J. Reidpath" Susan Copley, April $8^{\text {th }}, 1978$

"Achievement in Building Design" - George D. Wilson, Engineer, n. d.

Flyer from panel discussion: "The Past, Present \& Future of

Grain Elevators" - Anthony Bannon, Gusto, June 1', 1984

Student essay "Buffalo Grain Elevators" Richard C. Orogek, Jr., April $11^{\text {th }}, 1984$

Edoardo Persico: La Fiat: Operai, typed, 2pp., n. d.

List of Grain Elevators of the Buffalo District, n. d.

List of Buildings - Columbia University, Summer 1982

Clipping from Buffalo Industrial, 2pp. n. d.

Clipping from Egyptian Art - Wilhelm Worringer, London, 1928 with notes

J. R. Reidpath chronology, 2pp., n. d.

"Buffalo Archeological" - Architectural Review, Vol. CLXVII, No 996, February 1980

"History and Purpose of the Modern Movement" - JSAH, 1979

Notes and photographs, xerox copies, n. d.

Box

$8 \quad$ Hi-tech book project, ca. 1983-1987

Malgrado o material aqui exposto remonte apenas à 1983, é sabido pela correspondência e notas de que a idéia para esse livro já tinha sido delineada desde antes da produção de Scenes of America Deserta - ver caixas 1 e 2, correspondência com Gibbs M. Smith - mas foi apenas depois da produção de um artigo e de uma série de palestras que Banham chegou aos elementos chave das obras de Renzo Piano, Richard Rogers, Norman Foster e Cedric Price, material que constituiria o corpo central dos projetos a serem mostrados neste livro não-publicado.

Está claro que o tema deve tê-lo levado de volta ao estudo da arquitetura moderna europeia como protagonista, mais especificamente aos modernos ingleses.

Naquele momento, a construção do edifício Lloyd em Londres, comissionado a Richard Rogers, foi gatilho de uma série de debates ao redor da arquitetura high-tech, como podemos ver pelos recortes de jornal. É provável que Banham viu nisso um sinal da aceitação pública de seu livro por vir.

Nas correspondências com o representante da editora alemã, Axel Menges, da Ernst \& Sohns, é possível capturar a coincidência afortunada, conforme Banham tinha há tempos a ideia deste licro, e a editora alemã estava pré-disposta à suas ideias, ao invés do manual de arquitetura High-Tech, previamente planejado.

Even though the material here are traced back only to 1983, it is known from correspondence and notes that the idea for this book was already outlined since before the production of Scenes of America Deserta - see boxes 1 and 2, correspondence with Gibbs $M$. Smith - but it was only after Banham's article production and lecturing led him to key elements of the works of Renzo Piano, Richard Rogers, Norman Foster and Cedric Price, material that would constitute the main body of design to be shown in his unpublished book.

It is clear that the theme would led him back to study European Modern Architecture as a protagonist, and most specifically towards English moderns.

At the time, the construction of Lloyd's of London, comissioned to Richard Rogers, 
had triggered a series of debates around high-tech architecture, as we can see by the newspaper clippings. It is most likely that Banham saw in this a sign of public acceptance of his upcoming book.

In the correspondences with the German publisher representative, Axel Menges from Ernst $\mathcal{E}$ Sohns, it is possible to capture a serendipitous coincidence, as Banham had for long an idea of doing this book, and the German publishers were sympathetic to his idea, instead of a High-Tech manual, previously intended.

Hi-tech - research material, 1984, 1987, n.d. ca. 100 items photographs, photocopies of articles, printed materials "Geometry and Abjection" - Victor Burgin, AA Files, No 15, pp. $35-42$

Series of unidentified photographs on triplex paper, n. $d$.

"Astrological Automobiles of François Dalleget" - reprint from Automobile Quaterly, Vol. III, No 1, 1964

Casabella clipping "Renzo Piano" Lo Stadio di Bari e Sincrodrone di Grenoble", pp. 54-63, n. d.

Building Design, October 19, 1984

San Franscisco Examiner, Sunday, June 2, 1986

"Tecnica: the quiet game for designs by Renzo Piano"

Architectural Review, No 1087, pp. $72-79$

Clipping from The Times, February $4^{\text {th }}, 1985$

"J. M. Richards to receive Royal Gold Medal" Riba Journal, February 1985

Financial Times, February $6^{\text {th }}, 1985$

Clipping from "Redesign of Gallerie: Centre George Pompidou, Paris - Architect: Gae Aulenti" - by Charlotte Elias, n. d.

Architectural Review, Vol. CLXIX, No 1038, August 1983

"Norman Foster at the Whitworth Gallery, University of Manchester" - May $25^{\text {th }}$ - July $28^{\text {th }}, 1984$ - text with photographs of the exhibit

"Piano Rehab" - Architectural Review, Vol. CLXXIV, No 1041, November 1983

"Lloyd's of London" - Building Design, October $11^{\text {th }}, 1985$

"A Home is Not a House" - Reyner Banham, $A D$, No 1, 1969

"Corb: a Structural Rationalist" - Joyce Lawman, reprint from Architectural Review, October 1976

Photographs from old automobiles and from Herman Muthesius house, $n$. d.

"The Intelligent Responsive Building", n. d.

Correspondence with Foster Associates - regarding photos August 25 ${ }^{\text {th }}, 1983$

Response from Richard Rogers to The Times - Saturday,

June $9^{\text {th }}, 1984$

The Guardian, August 11 1984

"Un Bar a Montreal" - Domus, 1965

“The Age of Astro-Architecture: Buckminster Fuller" July $13^{\text {th }}, 1965$

"Richard Rogers and Partners: Architecture and the programe: Lloyd's of London

82 Hi-tech - correspondence, 1983-1987 ca. 40 items 
Correspondence with John Young, Richard Rogers Partnership

Ron Herron's letterhead paper

Correspondence with Axel Menges, Ernst \& Sohn Publishers,

Germany, about book on High-Tech

Correspondence with Alain Guiheux, Centre George Pompidou, January $24^{\text {th }}, 1986$

Correspondence with L. T. Papey, January $24^{\text {th }}, 1986$

Correspondence with Charles E. Basham, regarding Edison's

Huntington Beach Steam Station

Postcard from Axel Menges, May $2^{\text {nd }}, 1987$

"High-Tech Architecture: the beginning of an argument" outline for book, n. d.

Letter manuscripts, handwritten, n. d.

Correspondence with Kisho Kurokawa, May $7^{\text {th }}, 1986$

Correspondence with Vittorio Gregotti, June $5^{\text {th }}, 1986$

Correspondence with Axel Menges, n. d.

Reyner Banham's bibliography - in Germna - Helga Menges,

July $23^{\text {rd }}, 1986$

Correspondence with Stuttgart Publisher, DVA

Correspondence with Renzo iano, October $16^{\text {th }}, 1986$, regarding

publication of book

Notes, handwritten, n. d.

83

Correspondence with Paolo Cevini, December $10^{\text {th }}, 1986$

Hi-tech - draft outline, introduction, proposal, $1987 \mathrm{ca} .50 \mathrm{pp}$.

"High-Tech Architecture: the beginning he full argument for the book, 25pp., with letter, and a proposal: "Making Architecture:

the paradox of High-Tech" with introduction

Box

9 Hi Tech book project, ca. 1978-ca. 1987

Na segunda caixa do livro sobre High-Tech, encontraremos na verdade apenas o material enviado à Banham dos escritórios de arquitetura de Rogers, Piano, Foster e Price. Nesta caixa podemos visualizar o livro como focado em monografias específicas.

Existe sem dúvida uma grande quantidade de material sobre o trabalho de Renzo Piano, que inclui a caixa 17 - provavelmente devido à reorganização prévia à primeira indexação. Em seu primeiro esboço de manuscrito muito é dito a respeito da exibição itinerante da IBM. Isso nos leva a crer que sobre este projeto teríamos uma menção especial no livro. É também interessante relacionar à cópia do famoso artigo de autoria de Banham, A Home is Not a House, encontrado na pasta 8.1. Conforme este lida com o impacto da tecnologia na separação entre abrigo e construção, espaço e ambiente, o artigo poderia representar uma das características da visão de Banham sobre o High-Tech.

In the second box of the High-Tech, we will find actually only material sent to Banham from the architectural offices of Rogers, Piano, Foster and Cedric Price. This box may lead one to visualize the book as focused on specific monographies.

There is unmistakably a large amount of material from Renzo Piano's practice, which includes box 17 - probably due to reorganization before first indexing. In the firts draft of the manuscript much is said about the IBM's travelling exhibition. This leads us to believe that this 
design would have special mention in the book. It is also interesting to connect to the copy of Banham's famous article, A Home is Not a House, to be found at folder 8.1. As it deals with the impact of technology on separating shelter from construction, and space from environment, it could represent one of the characteristics of Banham's view on High-Tech.

Hi-tech - publications and promotional materials, ca. 1985-1986 ca. 20 items includes promotional packet for Nicholas Grimshaw and partners "Docklands Masterpiece: New York by Nick Grimshaw" Building, January $10^{\text {th }}, 1986$ Texas Architect, July-August 1985, Vol. 35 No 4 Architecture D'Aujourd'hui - "Verre et Acier" - reprint from AA No 2112, December 1980

The Advanced Engineering Bycicle" - Alex Moulton Bycicles Folder from Nicholas Grimshaw Partners, containing: Architectural Review, Vol. CLXXI No 1021, March 1982; RIBA Journal, September 1983; Architects Journal, 24 September 1980; Herman Miller project; Nicholas Grimshaw Partners Portfolio Hi-tech - Richard Rogers research, ca. 1978-1987 ca. 100 pp. photocopies of articles Richard Rogers information material and C.V. Magazine clippings from Richard Rogers Partners - Lloyd's of London Correspondence with Royal Fine Art and Comission, March 21 ${ }^{\text {st }}$, 1979

Clipping from Domus clipping, n. d. - on Piano's exhibition on Calder Architecture D'Aujourd'Hui, No 223, June 1984

"Beaubourg and Rogers in Milan" Hi-tech - Renzo Piano research - documentation 1, ca. 1978-1987 ca. 60 items photographs, printed materials, photocopies (see also Box 17) IRCAM - Institute of Research and Coordination in Acoustics and Music - photos and drawings FIAT VSS Experimental Vehicle - slides, prints and drawings Metro Station in Genova - model photos, drawings Stage for "Il Prometeo di L.Nono" - photos and drawings FIAT-Lingotto and Torino - drawings European Synchronaton Radiation Facility in Grenoble - xerox copy of presentation, clippings Hi-tech - Renzo Piano research - documentation 2, n.d. ca. 80 items

photocopies and photographs

Palaceto dello Sport in Ravenna, 1986 - drawings

Bari Stadium - drawings and model sketch

Vincenza Office Building - 1986

IBM travelling Exhibition, 1982-84 - drawings and photos CUSAGO-Milan-one-family-homes - drawings, photos Civic-Cultural Center of Palladio's Basilica at Vincenza clippings, plans and photos 
Hi-tech - Cedric Price research, 1985-1987 ca. 80 items

clippings, notes, letters and photocopies

"Cedric Price: a Summertime Brise" - booklet, n. d.

Call memo - Cedric Price, n. d.

Ian McCallum obituary - The Independent, November $14^{\text {th }}, 1980$

Clipping from Archithese, June 1987 "Die Supermaschine"

Clipping from Archithese, June 1987 "Der Boden Wird Steinig"

Building No 16, November $8^{\text {th }}, 1979$

"Cedric Price: some recent work" - exhibition November 1979

Magazine clippings, n. d.

“Cedric Price's Aviary" - Building Design, December 9"h 1983

Correspondence with Cedric Price and Sheila Read, December 1984-85

\section{Series II.}

Artigos e resenhas, por Banham e outros, cerca de 1930-1987.

A série contém notas, manuscritos, edições de revistas e artigos recortados por Banham, publicados na Casabella, Art in America, A+U, New Society, e outras publicações. Inclui também artigos e publicações por outros autores, coletadas por Banham para sua pesquisa.

Articles and reviews, by Banham and others, ca. 1930-1987 1 lin. ft.

Series contains notes, manuscripts, issues of magazines and tear sheets of articles by Banham, published in Casabella, Art in America, A+U, New Society, and other publications. Also includes articles and publications by others, collected by Banham for his research.

Box

10 Artigos sobre arquitetura e design por Banham, entre 1974-1987

manuscritos, folhas recortadas, e artigos completos em revistas.

Architecture and design articles by Banham, ca. 1974-1987

manuscripts, tear sheets, and whole issues of magazines

Nessa nova série, o leitor pode esperar não apenas uma diferença em conteúdo, ao passo que nos deparamos com publicações menores e em maior número, portanto menos imagens, mais correspondências e conversas, mas se pode sentir uma certa narrativa nestes fragmentos da produção de Banham, que existe um tipo diferente de discurso, mais direto, focado, porém não tão elaborado e prolífico quanto as publicações de grande porte.

Ademais, no decorrer dessa caixa, o leitor informado pode facilmente fazer as conexões entre o que estimulava Banham, e suas fontes mais difíceis e escondidas. Sparado dos livros que eles alimentaram com pesquisa e conceitos, podemos capturar as sutilezas e pequenas diferenças entre artigos e periódicos - e como Banham teve que em momentos adaptar seu discurso para leitores de certas revistas. Contudo, Banham manteve seus padrões de discurso quando negociava o conteúdo de seus artigos como se percebe, por exemplo, na correspondência com Vittorio Lampugnani, da revista Domus.

Sobre os arquivos do Getty, essa é provavelmente a caixa melhor catalogada de todas. É devido, talvez, à natureza do material e pela clara separação de temas em pequenas pastas, cada uma ligada ao seu artigo. Não muitas adições foram feitas aqui. 
In this new series, the reader can expect not only a difference in content, as here we face with more publications of smaller size, therefore less images, more correspondence and conversations, but if one could sense a sort of narrative from this fragments of Banham's production, there is in this series a different kind of speech, more direct, focused, yet not as much elaborated and prolific as the publications of greater size.

Also, through this box, the educated reader could easily make the connections between what stimulated Banham, and his most difficult and hidden sources to attain. Separated from the books that they fed with research material and insights, we can capture subtleties and slight differences between articles and periodicals - and how Banham had to adapt sometimes his speech for the readers of a certain magazine. Nonetheless, Banham kept his standards when negotiating the content of his article - as one can perceive, for example, in the correspondence with Vittorio Lampugnani, from Domus.

Regarding the Getty records, this is probably the best cataloged box of all. It is due, perhaps, to the nature of material and for the clear separation of topics in small folders, each one to its article. Not many additions were made here.

10

Notes for articles, n.d.

3 notebooks and a few loose pages, with handwritten versions of articles, including one on the TVA [Tennessee Valley Authority] Published articles (photocopies), 1974-1980 "Europe and American design," from Lesson from America, 1974; "A question of magic," book review, 1976 [ New York Times Book Review?]; "Buffalo Archaelogical," from Architectural Review, Feb. 1980; "Catacombs of the modern movement," from Archetype, v. 1, no. 4, Winter 1980

103 "Valley of the Dams," 21 July 1977 about the TVA, in New Society (whole issue)

104
"Ransome at Bayonne," 1983 typed manuscript in 2 versions, with notes, apparently written for the Journal of the Society of Architectural Historians (JSAH), 1983

105 Correspondence regarding Banham article, 1985 for article on "Modern Nomadism" (called "Domesticity of movement") for catalog of the 17 triennale di Milano with George Teyssot and Marco Cavallotti

106
"Most beautiful power plant in the world," Nov 1985 in California (whole issue)

$107 \quad$ "Art space angst," 24 July 1986 published article about the Lloyds of London building by Richard Rogers, in New Society (whole issue); see another article, in manuscript, about Lloyds building in Box 10, f. 19

108
"Modern monuments," 14 Nov 1986 in New Society(whole issue)

109
Interview with Reyner Banham, March 1986 in Progressive architecture (PA); several sets of tearsheets, plus whole issue correspondence, notes, Banham's manuscript and research for article about the De Menil museum for Art in America, June 1987; (see also folder 11) 
Correspondence with Amy Slaton and Elizabeth C. Barker, from Art in America, April 28, 1987

$10 \quad 11$

$10 \quad 12$

$10 \quad 13$

$10 \quad 14$

$10 \quad 15$

$10 \quad 16$

$10 \quad 17$

$10 \quad 18$

$10 \quad 19$

Art in America (whole issue), June 1987

Article about Elena Baskin Visual Arts Studios, May 1987

tearsheets from magazine, Architecture

Article about Renzo Piano, $1987-A+U, 1987$

2 copies of typed manuscript called "Making architecture," for

$\mathrm{A}+\mathrm{U}$ magazine, with letter from Banham to the magazine

Book reviews, 1987

manuscripts, for TLS ( Times Literary Supplement); with letter to the paper from Banham

Correspondence with Casabella, 1984-1987

letters from Casabella editors and Banham's carbon copy replies, regarding articles he is writing for the magazine - Reyner Banham from US - a series

Correspondence with Vittorio Lampugnani, Domus, 1986

Article for Casabella, 1987

manuscript of article on the Tennessee Valley Authority (same as lecture, Box 12, f.3?), with letters from Banham

Article for Casabella, n.d.

manuscript, "Museum: USA,"

Article for Casabella, 1987

manuscript, "End of Silicon Valley," and letter from Banham to

Casabella

Assorted articles in manuscript, n.d.

"New Lloyds of London"; "MIT Press Book Reports”; book review for JSAH; "Quality of modernism"; "Fagus and Fiat";

"The Becher vision"; "Grain elevators," an article proposal;

"A Black box: the secret profession of architecture" with handwritten note "unpublished article"

Box

11

Architecture and design articles, by others, 1930-ca. 1975

Em contraste com a caixa 10, esta caixa contém material sortido, sem organização específica ou conexão com algum livro ou artigo específico. Não obstante, essas publicações, muitas delas publicadas por outros, podem dar ao leitor uma ideia sobre o que Banham pesquisava, e quais eram suas fontes para livros publicados ou não.

Dos periódicos não-catalogados nesta caixa, a edição de Architectural Review da década de 1950 indica uma fonte interessante do americanismo em seu panorama inglês, e seus primeiros trabalhos durante a década de 1950 e 1960.

In contrast to box 10, this box contains assorted material without specific organization or connection to a specific article or book. Nevertheless, this publications, most of them published by others, may give the reader a sense of what were Banham's research sources for his unpublished - and also published - works.

From the non-cataloged periodicals within this box, the issue of Architectural Review from the 1950's indicates an interesting insight on the Banham's sources of Americanism in his English background and early works during the 1950's and 1960's. 
folder of tearsheets of articles (some photocopies); 6 publications about heating, ventilation and solar power, 15 other architectural journal issues

"Cycles of the Price Mechanism" - AA Files, June $7^{\text {th }}, 1984$

Edison News, January $11^{\text {th }}, 1985$

"The Development of Modern Industrial Architecture, 1913" -

Walter Gropius, Arts and Crafts Values, pp.53-55

"Horatio Court Apartments Pré-restauration Reception" invitation - March $25^{\text {th }}, 1973$

"Three Reminders to Architects" - Le Corbusier, Vers Une

Architecture, unidentified English translation

Clippings from books - M. Read, 1934-53; W. D. Teague, 1940

Out of folder:

Southern California Edison Co. - folder, ca. 1986

Eletric Power Research Institute - December 1981

RIBA Journal, September 1987

89 Arch+, May 1987

The Buildings Services Engineer, Vol. 39, December 1971

Image, October 1987

Degree Show, Bartlett School of Architecture and Planning, 1982

UIm 19/20, n. d.

The Arup Journal, April 1983

Solar One, folder, n. d.

Border Crossings: Magazine of Arts of Manitoba, 1985

$A+U-R . M$. Schindler, n. d.

9H, No 3, 1982

RIBA Journal, December 1985

The Architects \& Engineers, April 1935

9H, No 2, 1980

AM - Architect Minnesota, March-April 1982

Progressive Architecture, April 1987

Man Made America, Architectural Review special edition,

\section{Series III.}

Conferências, palestras, simpósios, entre 1965-1987

Inclui correspondência, material impresso e manuscritos relacionados à pesquisa sobre o projeto de Frank Lloyd Wright em Ocatillo, data: 1980; a palestra de 1980 no Museu Neuberger; uma palestra na conferência na Universidade de Delaware, 1981; L'Americanisme et la modernité colloquim, Paris, 1985; Conferência Open Spaces, City Places, em Tucson, 1987; e a conferência da Sociedade de Historiadores de Arquitetura (SAH) de 1987, cuja palestra realizada foi sobre o projeto da Tenessee Valley Authority em Knoxville, Tenessee. Também contém material de aulas e ementas de cursos ministrados por Banham na Universidade da Califórnia, Santa Cruz (UCSC). Material adicional de palestras sobre assuntos e ocasiões desconhecidas estão arquivados juntos.

Conferences, lectures, symposia, ca. 1965-1987 1 lin.ft. 
Includes correspondence, printed material and manuscripts related to research on Frank Lloyd Wright's Ocatillo project, 1980; a 1980 lecture at the Neuberger Museum; a conference presentation at the University of Delaware, 1981; L'Americanisme et la modernite colloquim, Paris 1985; Open Spaces, City Places conference, Tucson 1987; and the SE/SAH 1987 conference lecture (about the TVA) in Knoxville, Tennessee. Also contains teaching materials and course outlines from Banham's classes at the University of California, Santa Cruz (UCSC). Additional lectures for unidentified venues are filed together.

Box

Nesta caixa o leitor vai ter a oportunidade de ler algumas das últimas palestras de Banham, as quais ele não teve chance de apresentar. A palestra "A Set of Actual Monuments", a ser apresentada como discurso de posse da cadeira Sheldon H. Solow na Universidade de Nova Iorque, depois de Henry Russel Hitchcock. No momento desta pesquisa, sua posição era ocupada pelo professor Jean-Louis Cohen, que por coincidência está presente em algum material - correspondência, lista de simpósios na mesma caixa. Para Banham, este seria o retorno ao ensino de história de arquitetura, desde sua curta passagem ela faculdade de Buffalo, da Universidade Estadual de Nova Iorque.

Quem passou pelas primeiras caixas fará ligações imediatas entre o material apresentado em cada artigo e as últimas publicações de grande porte de Banham "Riders of the Empurpled Page" e Scenes of America Deserta; "Modern Architecture and the Image of American Industry" e A Concrete Atlantis; e seu artigo sobre galerias de arte contemporânea e seu livro em desenvolvimento sobre arquitetura High-Tech.

In this box the reader will have the opportunity to read one of Banham's last lectures, which he did not have the chance to present. The lecture "A Set of Actual Monuments", to be delivered at as acceptance speech for the Sheldon H. Solow chair at New York University, just after Henry Russel Hitchcock. By the time of this research, this position was occupied by Professor Jean-Louis Cohen, who is by coincidence present in some material-correspondence, and symposium listings - in this very same box. For Banham, this would be his return to teaching history of architecture since his short passage through SUNY Buffalo.

One who has passed through the first boxes will promptly make connections between the material presented in each article and Banham's last major publications - "Riders of the Empurpled Page" and Scenes of America Deserta; "Modern Architecture and the Image of American Industry" and A Concrete Atlantis; and his article on contemporary art galleries and his upcoming book on High-Tech architecture.

121 "A set of actual monuments," 1988

1 handwritten and 2 typed versions of lecture in manuscript, with heading: "An inaugural lecture which was not delivered on Monday Feb. 8, 1988 at the Institute of Fine Arts, New York University, by Reyner Banham, First Sheldon H. Solon Professor of the History of Architecture" 
Handwritten manuscript of image listing

Correspondence with accounting clerk of University of Tenessee

- Knoxville, plus contract

"Kunstchronik" - Wolfang Pehnt, September 1984

Panasonic Shiatsu Massage Lounger Chair ad

Tenessee area map (Xerox) 2 copies, $n$. $d$.

Travel Agency schedule, September 21, 1987

TVA lecture at SE/SAH, 1965, 1987

manuscript of lecture (1987), and transcript of interview (1965)

with architect of the Tennessee Valley Authority (TVA); see also

TVA article in Box 10

Ramada Inn Call Memo

Photograph - April 1977 - Reyner Banham and George Polo,

former TVA Engineer

Handwritten manuscritps, n. d.

“TVA: An Agency fo Regional Development" - info material, 1986

The Chattanooga Times, n. d.

"TVA: the engineering of Utopia" - Pratt lecture, on matrix printer paper

Correspondence with Lawrence Wodehouse, March 1987

Conference program, $2 \mathrm{pp}$.

Correspondence with Marian Maffett (University of Tenessee,

Knoxville) and William Lee (TVA) regarding photographs to

Casabella article

Interview with Roland Wank, TVA first chief Architect, August $6^{\text {th }}, 1965$

"The Development of the Architecture of the Tenessee Valley

Authority" - Walter L. Creese, 3pp.

"Looking to the Future: the Architecture of Roland A. Wank" Marian Maffett, 12pp., n. d.

Open Spaces, City Places Conference, Tucson, 1987

conference held Nov. 19-21; 2 copies of manuscript of Banham's lecture ("Riders of the empurpled page") with slide list, letters and printed program

Westward Look Resort folder

Receipt for Animal figures and rings, October 1986

Conference program

"Riders of the Empurpled Page" - Manuscript, 1987, 6pp.

Clipping from Frank Lloyd Wright's An Autobiography, pp.306-

321

Handwritten slide list

Correspondence with Judy Lensink, November $9^{\text {th }}, 1987$

Conference material, n. d.

Correspondence with Kathleen Damreuther

Tucson weekly map, n. d.

John Henry Irsfeld Curriculum Vitae - with letter

Travel receipts

125

Colloque L'Americanisme et la modernité, Paris, 1985

correspondence, printed conference material, manuscript of 
Banham's lecture, and notes

Lecture abstracts, n. d. - some in French

Card from Isabelle Gourney, handwritten, n. d.

Folder of Symposium, October 1985

Correspondence with Jean-Pierre Epron

Correspondence with Jean-Louis Cohen and Hubert Damish, 1984-85

Notes and memos, n. d.

Symposium abstract

126

Handwritten manuscript

University of Delaware conference paper, 1981

includes manuscript of lecture, slide list and correspondence

Pratt School of Architecture Lecture Series 1981 - Poster

Correspondence with Damie Stillman and Dennis Montagna,

University of Delaware, March 14 ${ }^{\text {th }}, 1981$.

Draft for paper, 8pp., two versions typed, one handwritten

$12 \quad 7$

Slide listing

Ocatillo project, 1980-1985

research on F.L. Wright's Ocatillo camp (for lecture?):

manuscripts (by Colin Flavin and Neil Levine), correspondence,

1 color slide of site

Loose slide

Correspondence with Colin Flavin, November 1980

Sketch on sketch paper

Correspondence between Colin Flavin and Frank Lloyd Wright

Foundation

"The Ephemeral Ocatillo" - Colin Flavin, May 28 ${ }^{\text {th }}, 1980,30 \mathrm{pp}$.

"Gonzo Notes on Architectural Archeology, or Fear and Loathing on the F.L.Wright Trail" - Lester Tobias, AH 199, 8pp.

Clipping from the Architectural Forum, January 1938

Clipping from The Architectural Record, August 1930, pp. 189-192

"Wright's Death Valley Project for Albert M. Johnson - 1922-

1925" - Neil Levine, with letter, August 31 ${ }^{\text {st }}, 1983$

128

Neuberger Museum lecture, 1980

manuscript of lecture and slide list

Correspondence with Suzanne E. Delehanty, SUNY Purchase,

April 1980

Handwritten manuscript

Book clipping, pp.208 - Moholy-Nagy, n. d.

Slide list, handwritten

Box

13 Assorted lecture material; University of California, Santa Cruz (UCSC) course material, 1970-1987

Esta é a única caixa da presente coleção que não contém apenas material de palestras, mas também uma bibliografia e biografias resumidas para alguns cursos ministrados por Reyner Banham na UCSC. Infelizmente, nenhum material da SUNY Buffalo tampouco de Londres foi arquivado aqui, dando ao leitor apenas uma visão estreita da metodologia e atitude de Banham como professor de história de arquitetura. Contudo, alguns trabalhos apresentam seu comprometimento com seus artigos e livros, 
e como estes foram transportados para debates e lições de casa. Uma leitura organizada sobre arquitetura High-Tech se destaca, por sua organização e imagens estimulantes.

A listagem de livros para o curso sobre arquitetura High-Tech pode dar ao leitor algumas dicas sobre quais foram as fontes de informação que Banham estava procurando e quais narrativas estava mobilizando para construir seu livro.

Na pasta de listagem de slides, se o leitor for paciente, pode-se encontrar boas pistas sobre o uso das imagens por Banham, como também sua seleção para muitos temas tradicionais, como por exemplo, vida e obra de Le Corbusier.

This is the only box in this collection that contains not only lecture material, but also outline and bibliography for some courses taught by Reyner Banham in UCSC. Unfortunately, no material from SUNY Buffalo or London has been archived here, giving the reader only a narrow view of Banham's methodology and attitude as a teacher of history of architecture. Nevertheless, Some works here shows us that his commitment to his articles and books probably have been transported to debates and class assignments. One organized reader about High-Tech architecture stands out, for its neat organization and estimulating images.

The book listing for the courses on High-Tech architecture can give the reader some insights of what sources of information Banham was looking for, and what narratives would he mobilize to construct his unfinished book.

In the slide listing folder, if the reader is patient enough, one may find good insights of what usage of images had Banham, and also his selection for many traditional themes for him, for example, the works and biography of Le Corbusier.

131

132

133

134

135
Notebook, n.d.

handwritten notes regard travel, lectures, research, and readings - 1985-1987

Various lectures, 1970-1986

IDCA talk, 1970 (photocopy), see also series VI for more IDCA; Berkeley chat, 1986 (notes); Ms. of lecture for SAH 1981 annual meeting; transcript of lecture at SUNY, Buffalo School of Architecture and Environmental Design, ca. 1983

Lecture at Concordia University - “The Persistence of Functionalism Correspondence with 'Sandy', from SUNY Buffalo, April 11 ${ }^{\text {th }}$, 1983 - regarding transcription of SAED

Slide listing, May $1^{\text {st }}, 1986$

Transcribed lecture

IDCA lecture - "The Education of the Environmentalist" - June $17^{\text {th }}, 1970$ (2pp.)

Bound reader of photocopied articles about palaces, n.d.

reader for students at UCSC (?)

Brochure with clippings, 5 articles

Hi-tech course, UCSC, Winter term, 1987

course description and preliminary material for teaching

"Art History 186: The Rise of High-Tech Architecture" - Winter

1987 - instructor: Reyner Banham - outline for course

Letter from Janey Benett to Mary (?) and to Roger Conover, regarding manual of Finnish architecture

Articles on Finnish architecture by Scott Poole

Hi-tech course, UCSC, Winter term, 1987

course reader (bound photocopied articles), books lists, other 
materials for course

"The Rise of High-Tech Architecture: a reader" - book of clippings, 90pp.

AH 186: The Rise of High-Tech Architecture: reserve book listing "Hitek reader", handwritten manuscript, n. d.

AH 186 outline, typed

"Art History 108: Architectural History Fieldwork" - Fall 1984, assignement

Enrolment checklist - UCSC, Spring, 1981

Course evaluation form - UCSC

"Eighteenth Century Elysiums: The Rôle of 'Association' in the Landscape Movement" - H. F. Clark, pp 165-189

"Lord Burlington and William Kent" - clipping, pp 115-132

Reserve book listing - AH 153, Winter 1985

136

Leichester book clippings, AH 153

UCSC slide lists, various, n.d.

\section{Series IV.}

Consultoria e juri de concursos, entre 1981-1989

O material remete ao concurso do Museu d Brooklin, 1986; recomendações para a renovação da Robie House de Frank Lloyd Wright, 1986; o a banca de juri do Progetto Bicocca, 1986; a proposta de exposição para o Museu da Imagem em Movimento; a exposição da exposição Blueprint for modern living, 1989, no Museu de Arte Contemporânea de Los Angeles (MOCA); e outros projetos.

Consulting and design juries, ca. 1981-1989 1 lin. ft.

Material relates to the Booklyn Museum competition, 1986; recommendations for renovation of Frank Lloyd Wright's Robie house, 1986; Progetto Bicocca jury, 1986; Museum of Moving Image exhibit proposal; Museum of Contemporary Art, Los Angeles (MOCA) exhibit, Blueprint for modern living, 1989; and other projects.

Box

$14 \quad$ Brooklyn Museum Competition, 1985-1986

regards a publication about the competition, and Banham's involvement

Essa caixa é inteiramente dedicada ao envolvimento de Banham em trabalhos de bancas de concursos e um artigo sobre o projeto vencedor e o processo de julgamento. Como apontado pela informação do material, especialmente pelos calendários e cronogramas na pasta 14.2, todo o processo tomou mais de um ano, desde organizer o programa para selecionar o projeto vencedor e seu press-release.

Este foi um concurso que interessou a Banham provavelmente porque estava relacionado à museus de design e galerias de arte, um tema de seu interesse naquele momento. Um aspecto interessante deste concurso é que mobilizou, entre 102 inscrições, quase todos os arquitetos de reputação internacional na época. O projeto vencedor foi desenvolvido por Arata Isozaki e James Polshek.

This box is entirely dedicated to Banham's enrolment to the competition jury duties and $a$ article about the winning design and process. As pointed by the material info, specially the schedules and timelines in folder 14.2, the whole process took more than one year, from 
organizing the program to selecting the winning design and processing the press release.

This was a competition that probably interested Reyner Banham because it was related to the design of museums and art galleries, a topic of interest for him at the time. One interesting aspect of this competition is that it mobilized, among its 102 enrolments, almost all architects of international reputation at the time. The winning design was made by Arata Isozaki and James Polshek.

141

142

143
Catalogue introduction (by Banham), 1986

manuscript and photocopies

"The Brooklyn Competition - Problems and Opportunities" Catalog and Introduction by Reyner Banham (2 versions)

Correspondence with Bailey Van Hook and Joan Darragh from The Brooklyn Museum, 1986

Newspaper clippings - New York Times, May 27

"Ada Louise Huxtable" - The New Criterion Special Issue 1986

The Brooklyn Museum Master Plan Competition Addendum, June $27^{\text {th }}, 1985$

Correspondence with Rena Zurofsky

Arata Isozaki / James Polshek model for competition, xerox with letter, November 1986

Reports on shortlist offices with model photographs

"Brooklyn Museum Announces winner of Master Plan design competition at board meeting" - Press release, October $16^{\text {th }}, 1986$

"The Brooklyn Museum Master Plan - Institutional History"

"The Brooklyn Museum Master Plan - Building Program

Summary"

"The Brooklyn Museum Master Plan - Design Guidelines" Correspondence with Robert T. Buck

The Phoenix clipping, n. d.

The New York Times clipping, October $17^{\text {th }}, 1986$

Daily News Clipping, October 1986

New York News clipping, October $17^{\text {th }}, 1986$

Crain's New York Business clipping, November ${ }^{\text {rd }}$, 1986

The New York Times, October $26^{\text {th }}$, by Paul Goldberger

The Philadelphia Inquiry clipping, October 1986

“Winner's Statement: Arata Isozaki \& Associates / James S.

Polshek

Correspondence and competition documents, 1985-1986

Brooklyn Museum drawings, n.d.

Correspondence with Robert T. Buck and Joan Darragh, 1986

Memo on first meeting agenda and review material, 1986

Shortlist draft, May $1^{\text {st }}, 1986$

"Recommended selection method and meeting schedules", n. d.

"Modern Redux" - event flyer and program with highlights

Request for Qualifications due April 15 ${ }^{\text {th }}, 1986$

List of nominations - 104 architects in total

"Silo Dreams: American Industry and the International Style" -

Columbia University Lecture

Proposal and Procedure for limited Architecture Competition

Design and Construction Timeline, 2 itens 
Director's Commentary, n. d.

The Brooklyn Museum - Master Plan Development

Travel Itinerary

blueprint architectural drawings (6) and photocopied

illustrations (2) of the Brooklyn Museum

Competition Schedule on large size paper, heliographic copy, $\mathrm{n}$.

d.

"Piano Nobile" plan, from the 5 short-list architecture offices, $n$.

d.

Box

15

Assorted projects, 1981-1989

Embora essa caixa não tenha tema particular para ser definida, existe uma congruência cronológica que se aplica a esse número de cartas, correspondências, inscrições para pedidos de financiamento e bancas de juris. Nesta caixa podemos ver algumas continuidades dentre a agenda movimentada de Banham na época, e sua luta contra o câncer que eventualmente tomaria sua vida.

Outro tópico onipresente foi sua nominação para a cadeira Sheldon H. Solow no Instituto de Belas Artes (IFA) na Universidade de Nova Iorque. De fato, seus últimos anos foram agitados, sendo ele um professor convidado na Universidade de Columbia em 1984, compareceu a diversos concursos como membro da banca e também como ensaísta, e por seu engajamento com a exposição e publicação que celebravam os 40 anos do programa das Case Study Houses. Em seu envolvimento, não apenas escreveu um artigo, como também ajudou o MOCA a preparar o pedido de verba para a National Endowment for the Humanities (NEH). Se tivesse vivido durante os anos 1990, ele teria participado também da exposição que relacionava a cultura do cinema e arquitetura vernacular, a ser apresentada em 1990 ou 1991.

Even though this box has no particular theme where to be defined, there is certainly a chronological congruence that applies to this number of letters, correspondence, grant applications and competition jury duties to perform. In this box we see some continuities along the rather busy schedule that Reyner Banham had, even during his struggle agains the deadly cancer that would take his life.

Another omnipresent topic of conversation was his nomination to take the Sheldon H. Solow chair at the Institute of Fine Arts (IFA) at New York University. Indeed, his last years were agitated, as he was a visiting scholar at Columbia University at 1984, attended to several competitions as a member of the jury and also a essayist, and for his engagement to the exhibition followed by a publication, celebrating the 40 years of the Case Study House Program. In this enrolment, he not only wrote an essay, but also helped the Museum of Contemporary Art - Los Angeles (MOCA) to prepare a grant application for the National Endowment for the Humanities (NEH). Had he outlived through the 1990's, he would have participated as well in the project of a exposition that would relate motion picture culture and vernacular architecture, to be presented in 1990 or 1991.

$151 \quad$ Blueprints for modern living: history and legacy of the casestudy houses, 1989 exhibit at Museum of Contemporary Art, Los Angeles (MOCA), 1985-1987

correspondence, most with Elizabeth Smith, regards planning the exhibit and related events; with printed materials about the project 
Riordan-Winerett travel itinerary

"Case Study Houses - 40 years" - budget list

Correspondence with Carter Manny, Grahan Foundation,

December 1987.

Correspondence with Elizabeth Smith - assistant curator,

September-October 1986

NEH grant application

"Case Study Houses - 40 years" committee meeting, November $3^{\text {rd }}, 1986$

Correspondence with Esther McCoy and Elizabeth Smith, 19861987

Thomas Hine abstract of essay, 8pp. January 1987

Letter for essayists, from Elizabeth Smith

Correspondence with Howard Singerman, about essay draft:

"Klarheit, Erlichkeit, Einfachkeit...and wit too!", February 1987

Correspondence between Carter Manny (Grahan Foundation)

and Richard Koshalek (MOCA)

Letter of reference to the Grahan Foundation, with

correspondence with Richard Koshalek

MOCA NEH [National Endowment for the Humanities] grant application, ca. 1986

for Blueprints for modern living exhibit and related events; 3

versions of the application

"Klarheit, Ehrlichkeit, Einfachkeit...and wit too!" ca. 1989

Banham lecture about case study houses, for MOCA, during

Blueprints for modern living exhibit, 4 versions

155

Grant application assessments, 1981

Banham's draft letters of evaluation for 2 grant applications:

Léon Ploegaerts study of Henry van de Velde, 1981; and Design

Communications grant, undated, to document the Doumani

house (Venice, Calif.)

Correspondence with Mary Jo Lynch - Research Council of

Canada - regarding Léon H. Ploegaerts grant, March 1981

Correspondence with Bert Kubli, March 1981

156

Progetto Bicocca jury, 1986

Banham manuscript, "BICOCCA '86" and correspondence and printed material

Correspondence with Donatella Moro, May 21 ${ }^{\text {st }}, 1986$

Report issued by the jury of the "Progetto Bicocca", 10 pp.

Copy of Reyner Banham's personal documents

Formal invitation and competittion info - with notes

"Bicocca '86" essay by Reyner Banham

"Progetto Bicocca" - competition folder, with notes

Robie house cooling and ventilation recommendations, 1985 correspondence and printed material

Correspondence with Burt Hill Rittelman Associates, November $14^{\text {th }}, 1985$

"Recommendations" - draft, November $8^{\text {th }}, 1985$

158

1986-1987

Motion picture design and vernacular architecture, proposal, 
printed material regarding Museum of the Moving Image;

correspondence with Donald Albrecht regarding grant

application proposal

Folder of the American Museum of Moving Image

Correspondence with Donald Albrecht, November 1987

Summary for NEH planning grant

Board of Trustees - list

American Museum of Moving Image - overview

Brochures, n. d.

News clippings, 1981-1986

\section{Series V.}

Assorted correspondence and papers, 1976-1987 1 lin. ft.

Correspondence with university colleagues and administrators, students, architects, people asking Banham to teach, lecture, contribute writings, read their work. Includes correspondence with Renzo Piano, Alan Waterhouse, New York University's Institute of Fine Arts (regarding the Sheldon H. Solon professorship), and with Columbia University (regarding teaching).

Box

16 Assorted correspondence, papers, 1976-1987

Esta caixa é difícil de emoldurar em um único tema, pois parece conter todo o material sortido que desafiava qualificação. Todavia, existem itens que poderiam facilmente estar em outras caixas, como a correspondência com as palestras - nas Universidades de Columbia e Concordia - e o material relacionado à palestra na NYU. Isto posto, existem alguns tesouros sutis nesta caixa, como uma nota escrita à mão com a citação de John Steinbeck que figura na introdução de A Concrete Atlantis; e alguns materiais crus das aulas de Banham em Santa Cruz, um dos poucos documentos que apresentam temas acadêmicos para além de sua escrita frequente.

This box is difficult to frame in a single topic, as it seems to contain all loose material that defied simple qualification. However, there are some items that could easily be in other boxes, such as the correspondence related to the lectures - Columbia and Concordia Universities - and the material related to the Sheldon H. Solow chair in NYU. That aside, there are some subtle treasures in this box, such as a handwritten note with Steinbeck's quotation that figures at the introduction of A Concrete Atlantis; and some course material from Banham's classes at Santa Cruz, one of the few documents in this collection which appeal to the subject of academic relationship besides his frequent writing.

$16 \quad 1$

162
Curriculum vitae, ca. 1984 - typed, 3 versions

Columbia University correspondence, , 1982 ca. 20 items regards teaching summer session

Columbia University - Graduate School of Architecture,

Planning and Preservation (GSAPP) - Spring 1984 lectures flyer

Correspondence with Marion E. Jemmott and Helene Farrow,

March-June 1982

Handwritten manuscript

Correspondence with David Rosand, GSAPP, December $21^{\text {st }}$, 1981 
163

1987 ca. 15 items
"Art History S4662 - Funcionalism: Beginnings and Ends" - Professor Reyner Banham - outline of course at GSAPP (3 versions)

Correspondence with Arlene P. Jacobs - assistant dean, August 1983

Correspondence with James Polshek, regarding Fall course Notes, memos, n. d.

Reserve reading list form - Columbia Libraries (S4662), n. d. "Art History S4662"- July 26 1982: Assignment 1 - The Raw Stock

Sheldon W.H. Solon professorship, NYU Institute of Fine Arts,

correspondence regards bringing Banham to NYU and includes material for his inaugural lecture; see Box 12, f. 1 for manuscript of proposed lecture

Correspondence with Donald Posner, January $1^{\text {st }}, 1987$

Correspondence with James McCredie, April 20 th 1987

Correspondence with Kenneth Frampton, January 23 ${ }^{\text {rd }}$, 1987

Banham's Institute of Fine Arts inaugural lecture - guest list Correspondence with David Cope - IFA-NYU, April 2 ${ }^{\text {nd }}, 1987$ Correspondence, 1987 ca. 40 items

Correspondence with M. Max Hershenow, Jr., AIA Northern Nevada Chapter, October 1986

Correspondence with Toshio Nakamura, A+U, December 1987, regarding Renzo Piano's article

Correspondence with Carla Garbado, publicist from Renzo Piano Building Workshop, June 1987, with Renzo Piano C.V.

Correspondence with Paul Overy, November 1987, regarding article " On Wings of Wonder", New Society

Correspondence with Sonder Williams, November 1987

Correspondence with Denise Sharp, August 26 ${ }^{\text {th }}, 1987$ - CICA

Presidency

Correspondence with Margaret Crawford, September 1987, regarding symposium "Car and the City"

Correspondence with Michael de Cossart, June 1987, regarding George Melhuish

Correspondence with Elizabeth Gray Kogen - Hagley Museum, January 1987

Correspondence with Ron Keenberg, IKOY, November 1987

Memo to Axel Menges (Ernst \& Sohn) and Roger Conover (MIT

Press) regarding (Stanislaus) Von Moos' “L'Esprit Nouveau: Le Corbusier..."

Memo from Carol Krinsky" 1988, regarding foreign tour to

Central England

Correspondence, 1985-1986 ca. 10 items

Correspondence with Elizabeth Gray Kogen, Hagley Museum, August $25^{\text {th }}$, regarding lecture on Industrial Architecture

Postcard from 'Sara', n. d.

Postcard from Catherine Cantalupo, 1985, from Taliesin West

Correspondence with Melvin Charney, regarding Frampton's

"Modern Architecture: a Critical View", February 1985 
Correspondence with Cerwin Robinson, January 1985

Correspondence with Serge Hambourg, April 12 ${ }^{\text {th }}, 1985$,

regarding Industrial Photographies

Correspondence, 1983-1984 ca. 20 items

Correspondence with Joseph Bower, February 1984, regarding

McGraw-Hill photos

Correspondence with Charles Merzbacher, USC, regarding the

Los Angeles Book, February 1984

Correspondence with Thomas Hoving, The Connoseur, August

1984

Correspondence with Arlene Jacobs, GSAPP, October 1983

Correspondence with Leigh Olson and Garet Wohl, MIT,

regarding lecture series, 1984

Correspondence with Ronald L. M. Ramsay, March 1983,

regarding Grain Silos

Correspondence with Alan Hollinghurst, Times Literary

Supplement, July 1983

Sarah Jane Kearns, Oxford Polytechnic student, February 1983

Correspondence with Naomi Miller, SAH, July $25^{\text {th }}, 1983$,

regarding Ernest L. Ransome article

Correspondence, 1976-1982 ca. 25 items

Memo from Louise Gross, March 1981

Memo from Nora (University of California), June 1982

Correspondence with Maritz Vanderberg, Architectural Press, October 1982

Correspondence and Postcard from Patricia Layman Bazelon, June 1982, with list of photos needed (from Reyner Banham)

Correspondence with John Rae, Bartlett School of Architecture, October 1982

Correspondence with Roger (Conover?) August 13 ${ }^{\text {th }}, 1982$, regarding Gilbert Herbert book

Correspondence with Patricio Villalba, with Colón Cifuentos,

Colegio de Arquitectos del Ecuador, Núcleo de Pichincha, 1982 invitation to Quito $3^{\text {rd }}$ Biennale

Correspondence with Sidney Slelov, Pratt, April 1981

"Recent Trends in Architecture Theories and PracticeSAH

Vancouver Chapter, 1980

Correspondence with Warren Anderson, Concordia University, July-October 1980

Correspondence with Julian Cooper, December 27th, 1977 , regarding the film "Fathers of Pop"

Correspondence with John Gross, New York Times, June $16^{\text {th }}$, 1978

Correspondence and assorted notes n.d. ca. 15 items

Correspondence with Roger (Conover?) n. d., handwritten

Note from Amfac Hotel at Minneapolis, n. d.

Quote from Cannery Row, John Steinbeck, Penguin 1979, p. 143,

handwritten

"Boxing Day" - letter from Roger Conover, MIT Press, n. d.

Business card from Bruce F. Paulo, EMHART Machinery Group

Correspondence regarding Marcel Breuer's works, n. d. 
Correspondence with Richard Ingersoll, Rice University, with "Le Corbusier and America: Travelling Exhibit and Catalog Spring 1988"

Miscellaneous papers, 1982, 1984, n.d. ca. 50 pp.

2 course proposals by Banham; printed material regarding the SAH (Society of Architectural Historians); photocopy of article from SAH journal; photocopy of draft historical survey report regarding the New York harbor; assorted notes

"Art \& Technology: the Elusive Synthesis" - proposal for a course

"American Values and the American Experience: the impact of industrial transformation 1880-1930" - Seminar Series

SAH - Alice Davis Hitchcock book award info - April 19 ${ }^{\text {th }}, 1985$

SAH National Meeting - instructions for speakers

Notes and Memos, n. d.

The Writers Directory entry confirmation, $\mathrm{n}$. d.

Charles E. Peterson Prize form - Historic American Builiding

Survey, Fall 1983

"The Independent Group: towards a redefinition" - Anne

Massey, pp. 232-242

"Cultural Resources Investigations in Brooklyn Reach 1 - New

York Harbor Collection and Removal of Drift Project - draft report, Raber Associates, May 1984

Alan Waterhouse manuscript, Aug 1980

"Architecture, urbanization and the state" - Alan Waterhouse, University of Toronto, August 1980

"Progress Report as of December 15 ${ }^{\text {th }}, 1980$, on SSHRCC research "The Effect of Architectural Commodities on Land Use Patterns" - Alan Waterhouse, November 1980

Application for research grant - Social Sciences and Humanities Resarch Council Canada

Box

1 loose drawing (reproduction) and 4 spiral-bound volumes of drawings and text (photocopies)

Palazzo dello sport, Ravenna Oct 1986

Building workshop S.R.L.

General report, 1987

Extension IRCAM: construction report, Paris, 1987

Bercy Commercial Centre, 1987

Drawing of unidentified Turin building, n.d.

reproduction of (1916) drawing showing elevation and sections

\section{Series VI.}

Conferência Internacional de Design em Aspen, 1950-1990.

(esta caixa não foi investigada na presente pesquisa)

Correspondência, relatórios e material impress, incluindo papéis da conferência, relacionados ao envolvimento de Banham com o IDCA, bem como seu projeto de 
documentar a história da conferência em sua monografia The Aspen Papers (1974)

International Design Conference in Aspen, 1950-1990 3 lin. ft.

Correspondence, reports and printed matter, including conference materials, relate to Banham's involvement in the IDCA, as well as his project to document the history of the conference in his monograph The Aspen papers (1974).

Box

18 IDCA - correspondence and printed materials, 1950-1990

181 Correspondence regarding Aspen Papers (book project,

published 1974) with friends, colleagues and publishers, ca. 1969-1973

182 Manuscripts, Nicholas Pevsner talk at IDCA, 1963

183 Manuscripts and correspondence, Arthur Cohen talk, 1962

184 Assorted correspondence regarding IDCA, 1950-1954, n.d.

185 Manuscript, William Lynch talk, IDCA, 1965

186 Manuscript, John Allpass and Peter Eisenman interview at

IDCA, 1968

187 Portions of manuscript (by Banham?) about the 1st and 2nd

Aspen conferences, n.d.

$\begin{array}{lll}18 & 8-12 & \text { Aspen Reader, manuscripts, n.d. } \\ 18 & 13 & \text { IDCA committee lists (most photocopies), 1951-1972 } \\ 18 & 14 & \text { IDCA chairman and speakers lists, 1951-1968 } \\ 18 & 15 & \text { IDCA assorted papers, most in manuscript, n.d. } \\ 18 & 16-17 & \text { 28 photographs of speakers and panalists at IDCA, ca. 1965- }\end{array}$

$1968 ?$

1818 IDCA assorted printed material, including memorial booklet for Eliot Noyes, n.d.

$1819 \quad$ Printed material about IDCA, ca. 1985-1990

includes New York Times Sunday Magazine with article about

Aspen, 1990; photocopies from other publications

IDCA lists of participants, other printed material, arranged by year, $1951-1971$

191951

1921952

$193 \quad 1953$

$194 \quad 1954$

$19 \quad 5 \quad 1955$

$19 \quad 6 \quad 1956-1957$

$19 \quad 7 \quad 1960$

includes some correspondence, printed material

$198 \quad 1960$

clippings and ephemera

$19 \quad 9-11 \quad 1963$ speakers biographies and statements

$1912 \quad 1964-1968$ lists of participants

$1913 \quad 1969$ list of participants

$1914 \quad 1970$ list of participants

$1915 \quad 1971$ list of participants

Box

20

IDCA printed materials from the conferences, mostly annual reports, arranged by year, 1951-1960 


$\begin{array}{lll}20 & 1 & 1951-1954 \text { attendance list. } \\ 20 & 2 & 1951-1960 \text { annual report } \\ 20 & 3 & 1951 \\ 20 & 4 & 1952 \\ 20 & 5 & 1954 \\ 20 & 6 & 1955 \\ 20 & 7 & 1956 \\ 20 & 8 & 1957 \\ 20 & 9 & 1958 \\ 20 & 10 & 1959 \\ 20 & 11 & 1960 \\ 20 & 12 & 1960 \\ & & \text { PRINT Magazine, dedicated to IDCA }\end{array}$

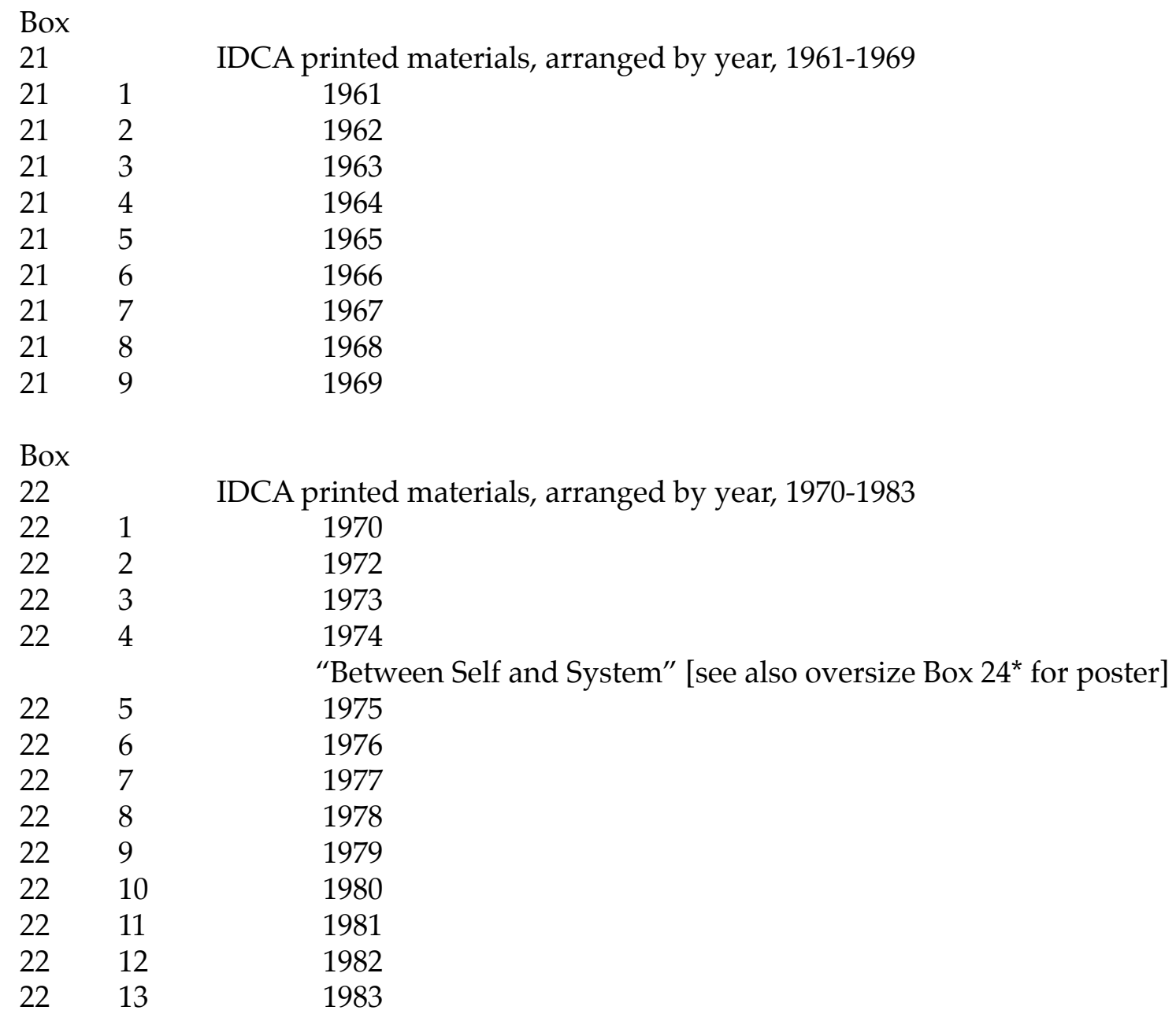

Box

IDCA Printed materials for the conferences, arranged by year, 19841988

$\begin{array}{ccc}23 & 1 & 1984 \\ 23 & 2 & 1985 \\ 23 & 3 & 1986-1987 \\ & & \text { Design Quarterly } \\ 23 & 4 & 1986\end{array}$


$23 \quad 5$

236

Box

$24^{*}$
1987

1988

Poster for ICDA, 1974

with envelope, see also related material in Box 22, f.4 
Anexo 2 - entrevista com Kenneth Frampton - Agosto 2011 


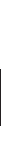


Interview Kenneth Frampton

July $27^{\text {th }} 2011$

Revised transcription (added with original questions)

2011.10.20

\section{ENGLISH IN AMERICA}

Luiz Florence: During the 2nd World War and immediately afterwards, it is possible to recognize a migrating movement of European intellectuals and professionals towards USA. Many of them English, otherwise through England's intellectual milieu. Within the 60's and the 70's, when you, Reyner Banham, Colin Rowe, Anthony Vidler and Alan Colquhoun are among those who settle in America. What motivate them? What allures them? And what circumstances did they find once there, and what are the differences in perspective in the academic milieu did they introduced?

Kenneth Frampton: Among the English architectural intellectuals in the United States between 60's and 70's, and you mention these names, are Reyner Banham, Colin Rowe, Anthony Vidler, Alan Colquhoun, Robert Maxwell and myself. What brought them to the United States? I think it was quite complex. These figures came to the States for different reasons and at different times. The first person to be intensely involved with the US was Colin Rowe. I think he first came in the late fifties, and taught in the University of Texas. He was part of a group, known as "The Texas Rangers", who worked in Austin, Texas, under the dean of the school, Harwell Hamilton Harris. Harris was a Southern Californian architect who took over the State University School of Architecture. (And there he employed young people directly, among the so-called Texas Rangers was John Hejduk, who would later be the dean of Cooper Union. Another key figure was the German émigré Werner Seligmann, who would later teach at Cornell, and Robert Stlutzky, who was a painter and a pupil of Josef Albers, who would also teach with Hejduk at Cooper Union. Rowe began his work in the States, in Texas and returned to England and taught for a very brief period at the Cambridge University School of Architecture. He came back to US and taught at Cornell University until the end of his career in the States.

Rowe had been a protégé of Rudolf Wittkower in Warburg school in London. He had also taught in the Liverpool School of Architecture at the end of the Second World War, when James Stirling was studying there. Rowe's most decisive contribution was his seminal essay "The Mathematics of the Ideal Villa," which was a Wittkowerian analysis of Le Corbusier's Ville Garches based on Wittkower's book Architectural Principles in the Age of Humanism. "The Mathematics of the Ideal Villa" would have an enormous influence in US; above all, on Peter Eisenman, and the so-called New York based Five Architects: Eisenman, John Hejduk, Michael Graves, Richard Meyer, John Hejduk, and Charles Gwathmey. I think the English were invited and drawn to the States because the American universities were wide open and salaries were much better than that in England. This surely applied to Rowe, and then to Vidler and myself when we came to Princeton. Eisenman had met me in London and Vidler in Cambridge, where he studied under Rowe.

Vidler and myself would soon receive professorships in Princeton. Other followed, like Alan Colquhoun and Robert Maxwell, this last eventually became the dean of the School of Architecture at Princeton. Colquhoun, teaching in Princeton, would deepen the doctoral program there, with which I had been involved at the beginning when it had a different character. Speaking for myself, the States had the effect of politicizing me. Only when I lived in the US was I able to recognize capitalism at its full power. As another English emigrate architect Mike Gilkman once said to me "in England, the 'claws' are hidden, but in America they are visible". What is interesting 
here is that Colin Rowe would remain an 'apolitical' figure, even a reactionary person. He was critical of the Modern Movement, of course, but also of social democracy. Anthony Vidler and myself were more to the left and Alan Colquhoun would become increasingly so, in the US. The interesting figure in this regard is Banham, who later taught at the State University School in Buffalo. He was invited to Buffalo by John and Magda Cordell McHale, Buckminster acolytes who had been with Fuller in Carbondale before moving to SUNY Buffalo. Later Banham would go to Los Angeles, and finally back to New York, to a professorship in the History of Fine Arts department at NYU. But at that very moment, however, he became mortally ill with cancer and died before he can really takes up the position. Politically speaking, Banham was a populist thinker and ultimately anti-Marxist until Vidler, myself and Colquhoun who, while we were not dogmatically Marxist, all three were decidedly on the left.

Would you affirm that this relationship between England and the USA is somehow traditional? Does it goes further back in time? How does it take place in architecture? Do you agree with concepts such as Englishness, picturesque, and the proto-industry brought into debate? Would it be possible to assert on a tradition of British critical history in architectural schools in America? If so, how where such values transplanted here? Recalling your recent interview with professor José Lira, could you say more about the British input in American architectural history?

There is no doubt that I was indebted to Banham's Theory and Design in The First Machine Age of 1960. However, I don't make it sufficiently obvious at the beginning of Modern Architecture: A Critical History (1980). What is very impressive about Banham's book is that he allows the protagonists to speak for themselves. I found this quite exceptional. In the main, those protagonists, who were fully engaged at the time after the First World War, their voices become fully manifest in Theory and Design. If you take Arnold Whittick, who wrote a general history of modern architecture around the same time the presence of these figures were less explicit. In that regard Banham, I think was a major influence on modern architecture critical history.

How do you evaluate the critical work by Reyner Banham after that book, mainly his books regarding historical issues of the American built environment? In the early sixties, Banham's work as a member of the staff of Architectural Review, and his presence in groups such as the Independent Group allow us to witness his path throughout that period of time in England. How is your appraisal regarding the academic "temperature" in England at that time? Furthermore, how do you value the first works made by Banham following immediately after that, such as The Architecture of the Well Tempered Environment, taking that background as cornerstone?

How would you analyse Banham's trajectory as an architectural historian, post his settlement as member in the faculty of the American Universities?

Concerning the differences between the Universities on the West and East Coast, and also between public and private schools of architecture, how do you value the change from SUNY Buffalo to the University of California, within the framework for architectural history and criticism?

In the sixties and seventies, as analysed by professor Beatriz Colomina, there were several editorial ventures, small periodic publications, discussion collectives, in Europe and the United States. Apparently Reyner Banham privileges another sort of periodic, better related to a broader, more commercial bias, such as Scientific American and New Statesman. The impression I have is that Reyner Banham draws a strategy of intervening more intensely in the public debate rather than the academic. Do you agree with this assertive? Why would he predispose to such a path? Do you believe in a broader field in media? 
Banham's participation in the public debate was populist rather than the academic. He was a brilliant writer, as all his articles in the New Statesman and New Society bear witness. His essays in these publications were very accessible, very topical, and direct. Why would he be predisposed develop in this way? That's an interesting question. You see, Banham's initial formation, was as an aeronautical engineer, before he shifted to art history at the Courtald. In that sense he was always interested in industrial technology, aeronautics, etc. as in art. I think when he began to write his primary interest was art, rather than architecture. In fact, some of the earliest writing of Banham appeared in the British newspaper Art News, which was published by a certain Dr. Gainsborough. Some of my earliest writings also appeared in this publication. So, in this respect, Banham and I paralleled each other. Banham was a pupil of Nikolaus Pevsner, and his research work under Pevsner on Italian Futurism at the Courtald was particularly original. Apart from the chapters of Futurism, Theory and Design in the First Machine Age of 1960 is unquestionably a masterwork. Nothing that he published thereafter would quite equal that book. Not Megastructures, nor The Concrete Atlantis, nor The Well Tempered Environment came to this level. The Architecture of the Well-tempered Environment is a an interesting book because it does draw attention to the question of sustainability, early on and in that sense it is a path-breaking book. The other writing of Banham, which is of the highest quality, are all the essays he wrote for the Architectural Review. The book New Brutalism comes out his work for the AR. In my view, Banham's critical intensity diminishes as a result of his experiences in America. It is still populist but not as aggressive as his earlier work. I find the book on the four ecologies of LA alright, but not as penetrating as before. For me, both of Banham's appraisals of Los Angeles, and Venturi's Learning from Las Vegas are populist postmodern arguments, bordering on the reactionary. They are, in their respective ways, apologia for the American megalopolis. For them, the consumerist megalopolis is just fine. The Concrete Atlantis is more objective, historical, in technological sense, as with the book on Megastructures.

You ended with this question concerning vernacular motif in Banham's work. Well, I think the term, vernacular, has to be more precisely defined. A true vernacular is ultimately related to agriculture, it is in that sense deeply pre-industrial. The whole megalopolian landscape of Las Vegas, Los Angeles, etc, is categorically post-industrial and consumerist. For me, this is not vernacular at all.

You have referred to Banham as an anti-Marxist. Do you think he was always as so, or did he became one, once in America?

He was always aligned with that British popular tradition, liberal, but not in any sense politically radical. The Smithsons were very much like this also with TEAM X in general with the exception of Shadrach Woods and Giancarlo di Carlo. Backema is really in the middle and Van Eyck and the Smithsons are not really "of the left", you know. Van Eyck is more of anarchic than the Smithsons, of course. But Banham is closer to the Smithsons and to their liberal view. If we take projects like Golden Lane by the Smithsons of 1952, it is very sensitive about British working class culture, that is true. Maybe more sensitive than Banham, and also perhaps more nostalgic than Banham, regarding British working class culture, going back to the $19^{\text {th }}$ century, as something authentic, but in the end, they are still not politically radical. And I think what one must understand is that the British Communist Party barely existed in the trajectory of the $20^{\text {th }}$ century. There was a Communist party, but it was quite small. There were one or two Communist members in the British parliament at the time of the Socialist government at the end of the Second World War. Banham's anti-Marxism is not so much spelt out, but you can sense it in his writings all the same. 
Anexo 3 - entrevista com Gabrielle Esperdy 


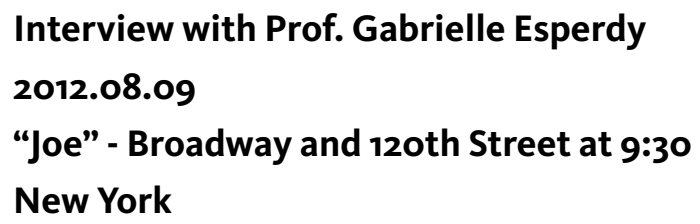

Luiz Florence: As I have been reading your web-based project, American Road Trip, and a term rose above others - "ordinary, non-heroic buildings" The process of reading itself has raised one recidivist question about not only Reyner Banham's view itself, but furthermore, a way of describing United States built environment. This attractive, mass-consumed yet customized type of building, brought to my attention through reading Banham works were the first main subject of research for this dissertation. Among them are specially Scenes of America Deserta and the Los Angeles book. As an American historian, familiar both to Banham's method and to the subjects of his research, would you say that this was a real agenda for him, or this is insight is reserved a younger generation of his readers?

Gabrielle Esperdy: One of the things I find is interesting about is its possible to, and he does it intentionally, is the way he separate the chapters - the chapters about LA architecture, with a capital " $\mathrm{A}$ " and he kind of traces that history. But of course is interwoven what his analysis of what would it be considered anonymous landscapes. And even if he consciously separates these things out, the fact that they are present in a single book is extraordinary. We have to thank him for that moment: to allow you to think - "Hum, Its possible to write about Greene \& Greene, Neutra and Schindler, and at the same time I'm looking to the Jack-at-the-Box and the freeway, and beautiful downtown Burbank, and all these other things". He dealt with all these levels, and made it possible, frankly to the next generation of historians and critics to consider those things at the same time. To in fact not distinguish between what we conventionally call "high-style" and "everyday". He is certainly not the first person to do it, but he is certainly the first one to do it in a what we can call a "strictly historical anthology", and that what was really important. Certainly that's what was really important for me, he is clearly influenced by someone like J. B. Jackson. And Jackson is interested in ordinary landscapes. And maybe if Banham had lived longer and had actually taken his post in the Institute of Fine Arts we would see a very different trajectory of his straight criticism in the United States because he would have educated a generation. I mean, I would have gone to the Institute [laughs] and I have a number of colleges who with, by the time we decided to get our PhD's we would have come to the Institute to study with him, but at that time he was already dead.

It's interesting because in America Banham writes mostly about this kind of architecture. His upcoming book was to be about High-Tech architecture, what I find very funny because he goes back to a canon of modern architecture... 
But I wonder though if that was a sort of a "coming back", or is it possible to think that his interests and his enthusiasms were always going in these different directions. And as for anyone who is both an academic and a critic certain things have to take priority over others. I don't see the high-tech project as coming back to say, more "high-style concerns". Is that he was focusing at that moment. And it takes us back to my disagreement with Nigel Whiteley: when Banham is writing about a ponderous steakhouse in upstate New York, I don't believe that in that moment he is not writing about high-style architecture, or not interested in it. Rather, his subject matter at that point is shifted, and that he brings the same concerns, and that's pretty much what makes it interesting: is him bringing the same concerns, weather he's looking at a building by Norman Foster, or an anonymous bicycle shed.

At the same terms...

Absolutely, and that he refuses to argue that there should be different tools. And one of those tools are formal analysis, another tool is an investigation on infrastructure, but it doesn't matter: the same tools were useful in different contexts, and that's what was new. That was also what distinguishes him from someone like Venturi and ScottBrown, who are looking at Las Vegas scene graphically, but not actually looking at them as buildings, whereas Banham, had he written a Las Vegas book, would in fact have looked at them as buildings, and wouldn't bother to find out what was being done there as a designer, not just assuming that it is that product of a spectacle of consumption. That he uses tools like these to study a building. It is also very different because Venturi and Scott-Brown are not actual historians, and Reyner Banham was an historian, and a critic. If you think about all of them acting as critics and theorists, Banham was doing it as an historian who was also a critic and a theorist; Venturi and Scott-Brown were doing it as architects and urban designers who were also critics and theorists. And that's a very, very different perspective. I think it is an important one, and at the same time, it was also the moment when everyone was having comparable conversations. And there was the same kind of siloing of historians, critics and theorists that one witnessed more recently in the academies, certaingly in the United States. That has to do with the influence of critical theory, gradually moving away from what I may think of an "historical project" in architectural histories.

Nigel Whiteley wrote about the comparison between Scott-Brown and Banham, and I have to agree that whereas Venturi and Scott-Brown are proposing a criticism on modern architecture and a new way to look at high cultured architecture, Banham is just saying that we should take a look at it and see beyond modernism, in a spectrum of different features of architecture. That shows that Banham was not only interested in Modernism but he was always trying to make a defense statement for it. Perhaps that's why he was writing about high-tech architecture. For him, it's a survivor. 
Yes, I think again it has to do with his generation. He was combative about modernism. That's why he freaks out in the 1960's and call them "the ballet school". He was so upset about the Italian regression, he was sort of dismissive of Philip Johnson's work in the 60's. It's because he was such a defender of Modernism, and if he had looked at Johnson's work at the New York State Theater, the work that Banham criticizes as the "Ballet School", if he looked at that with the his criticism "ad-on", instead of his Modernism "ad-on"... this is what makes him such a interesting figures, because when he is looking at pop buildings and everyday buildings it is no problem bringing his methodologies of a historian of modernism to manner them. But when it's reverse, when he has to deal with high-style buildings he has more difficulty seeing to what degree to which they are influenced by other sensibilities. And so his complete dismissal of the more decorative work of the 60's and the early 70's. I think it is related to that. He is such a defender of Modernism that he can't get beyond all these crystal chandeliers, whereas now, 30 years on, we can look at that work from the 60's and think it's fabulous, because we are more catholic in our taste about what modernism means. And even though Banham opened the door to the idea of the multiplicity of modernisms - he's the guy who made it ok to say no to Modernism as a monolith, and to say there was many modernisms - but he couldn't quite swallow that once he opened it up. And he certainly would not have thought that it was fine for this first generation to explore, but now it is a recess. Because for him ultimately, and that's why in Theory and Design in the First Machine Age, in the last chapter where he introduces Buckminster Fuller. The technological line is going to win... So the decorative work that is so fascinating to many scholars of my generation, Banham could not deal with it. Because it seemed to him to be a retreat from that technological line. Even tough much of the decoration was made possible through the use of technology, it was mass produced.

Perhaps it has to do with the fact that Banham was very upset by the fact that Modern architecture had transformed the view on technology. So it shaped a view of technological fetish distant from real pragmatism.

I would agree with that. I also think that this is not fully articulated. Some people started to write about this kind of tension in criticism and discourse when a kind of heterodox position came into contact with a sort of the beginnings of the articulation of a kind of homosexual aesthetic, and Banham was really uncomfortable. He was such a straight guy from the middle of the $20^{\text {th }}$ century, that I wonder if he was not uncomfortable with these decorative sensibilities. And this is not fully formulated but I have done a lot of work on Morris Lapidus, and that critique of the decorative, and Tim Rowan, who writes on Paul Rudolph, has articulated this really well... I think it was an article that he published perhaps a decade ago, where he talks a lot about this 
sort of masculine anxiety and disgust of decoration, in cold war period. I think Banham is caught up in that. He was a sexist, he couldn't help being sexist, it was so clear in his writings. But does that mean he was more of a sexist than the next guy? I don't think so, he was a product of his generation. And I think it sort of influences the way he acts... there's a kind of "macho" embrace of technology in the same way that there is a "macho" distrust of decoration.

Still on the impact of Banham's writing, what could you say about the relationship between your generation of historians and architects and Banham's work, regarding the blow that struck him as well as many tech-enthusiasts, during the oil crisis, the demonization of the machine and the consumption culture? Many of his contemporary Marxist historiographers understood Banham as a populist historian, including Kenneth Frampton. What was the reception of your generation?

On one hand, as I already mentioned, there's a opening of a possibility that there not a monolith version of Modernism. Even if Banham had not written another word after Theory and Design in the First Machine Age, which was his dissertation for PhD... [laughs] we should all be that fortunate in writing such kind of "game-changer". That in itself was the first major impact. Certainly for my generation of historians, in the tail-end of the "baby-boom" generation - I'm 47, so I am more in the next generation than the "baby-boom" - but I would align myself, in terms of intellectual formation to that generation. We were trained by the people who were trained by Pevsner and Giedion. There were the historians made up the history of modern architecture, and then there was a generation trained by them. Banham was in that generation. But because they were completely trained in the methodologies of Modernism and in the historiography of modernism, the Party lines: from William Morris to Walter Gropius. Initially, you taught that line and it seemed to make perfect sense. And suddenly you read Banham. For my generation, who were fed by Pevsner and Giedion, but then we would immediately critique that through Banham. Because again, when I first went to school people were still reading Pevsner and Giedion as textbooks, not as historical documents. There's a really important distinction. But when I went to graduate school we were still reading then, but in order to understand what was problematic about their narratives of modernism. The first thing that pointed to explain why that was too narrow was Banham. So I that's would be the first major impact: that he made it possible to see multiple modernisms. And then for me personally, and this again has to do with my own training, as I went study with Rosemary Bletter in the CUNY Graduate Center, who was an historian very much in the Banham mode: that she was a critic and a historian at the same time. And also was involved, just as Pevsner and Giedion were with modernism two generations before, to the writing of the history of what we now call Postmodernism. So she was a very early historian / critic of what Venturi and Scott-Brown were. What that meant for me, regarding Banham's polemics, 
is that you continue to open up the ideas of multiple modernisms. Instead of just becoming more expansive in terms of what qualifies as Modernism, or, it was possible to think "up" and "down" in hierarchy, and that you could also look at everyday landscapes and start to think about them as different products of modernization. So I would say that even if I came at that initially through a kind of simplistic reading of Venturi and Scott-Brown - you know, the first time you read it, and you are not quite aware of the polemics you just say "wow! Las Vegas!" - and I think I was still at college when I read it for the first time. So if you want to look at this stuff Banham will give you a methodology for actually doing that. Again, I am not sure on how wide the generation is and how many people have approached him on that, but I think the impact was there. To described it would be [gesticulating] first you would open up this way [arms stretched open], and then he started opening up in this way [doing up-anddown signs]. It's both horizontal and vertical in terms of expanding not a canon, but what is appropriate to look at, historiographically.

Returning to the American Road Trip project, you dedicate an independent section to the photos. Both Nigel Whiteley, author of Banham's most prolific biography, and photographer Mark Haworth-Booth, in posthumous The Banham Lectures have acknowledged this facet of Banham as an observational historian. Is there a reference of Banham's usage of the photograph in your method?

That's interesting. Though you should know I gave up on the photography page of that project [laughs] because it was too time-consuming! So that is the snarky answer. I think yes, but there a couple of ways to answer that. On the one hand, I would say yes, being an observational historian I am always amazed on what difference it makes to literally get out of the car, get on a plane and go somewhere and observe that building, and understand that things completely change once there. So I would think that I was influenced by Banham, but I also have to give credit for Rosemary Bletter for that, because she would choose canonical views of the building that have been published, and then she would show us her views, which were always from the parking lot, the back door to something, the way you actually go visit the building. In terms of representation, I wonder... that's an issue where... I was from a generation who started shooting slides, so I have a collection of $35 \mathrm{~mm}$ slides, but since 2001 I have been shooting digital, and that really changes the way that you take pictures. When shooting in film, eventhough you were taught that the film was cheap, you say "yeah, the film is cheap, developing it isn't". So I wonder to what extent that would be related to Banham's influence. But I would say when thinking about the representation of buildings in images is absolutelly something that pays attention to.

Also on photographs, how do you understand the effect of the new medias in the work of the historian and critic? Is it unavoidable for the next generation of critics to engaje in this sort of 
language?

I would say it's probably a couple of things: one is that as the history of and criticism of architecture continues to evolve, it's only natural that we would turn from the buildings to representation of the buildings, so I think this is very clearly a generational shift, and a lot of that has to do again with interest with structuralism and poststructuralism, in which we were all trained in the 1990's: that we moved beyond, that in refusing to accept any building as something which has a fine art interpretation, and one of the key ways you look at how it exists and to understand its cultural representations. So images are a key part of that. Banham never articulated that anywhere...

He never used a representation of the building. He would always put on photos...

Again if I think about his relationship with the Smithsons, who were so into that. There was Alison Smithson's famous quote: "now we collect ads". Ads are representations of something, they are not the thing itself. One thing I like about Banham is how you know when he's taking the pictures, and that goes back to what you mention about him being an observational historian. But at least you are aware that this is a view that he took, because he wanted to reveal this particular thing about this detail of the building. And so there is notion of him sort of having an experience.

A sense of viewing and reviewing in it.

Absolutely. I remember when I gave a lecture in Berkeley a couple of years ago, the first time since I came from the Banham archives at the Getty, so I kind of digesting any of this. They wanted an image for the poster, so I dug up a photograph that I have taken a few months before, from when I was driving across the country from the Ames Monument in Wyoming. It's this Henry Hobson Richardson big pile of granite that used to be right in the railroad tracks, and once the railroad moved you have to drive in order to find it, even though it was a big monument. So I drove to the Ames Monument and took plenty of it, but as we were driving away, I was obsessed with taking a picture of it from my rear-view mirror, which to me was more compelling than the actual pictures of the Ames Monument. That was definitely influenced by Banham in the Los Angeles book, when he's talking about the rear-view mirror. So ok, part o that is just a trope, but what does it mean to take a picture from your rear-view mirror? When you look at something as it is retreating... So maybe one could argue that Banham has influenced the way I take pictures, but not the way I that he would have done it. But we are free to use it and misuse it. 
to both Banham and Tafuri, which represent different opposing canons of historiography in the 1970's and 1980's. Can we expect more echoes of their narratives in your work?

Probably it will be interesting to see, because Banham would figure it, Tafuri less so. I have to admit I just thought it was a cute title... And yet, when I start thinking about it, it actually became very valuable, because it is a project about discourse. And it's a project that looks in the ways in which the commercial landscape has been envisioned for lack of a better way of putting it, by historians, critics, the popular press, architects, designers, and so on. So the articulated conscious agenda of each of those different players is key. Is where I would argue that Tafuri is going to be there, subliminally speaking, whereas Banham would be one of the players. He is going to be a key figure. And yet, the article that i wrote for the Design Observer... I actually thought that there was a whole book called "Banham's America". I tried to pitch that for publishing, but nobody seems to care about it... [laughs]. "You should write about that on your blog"... So I managed to produce one article, and I mean in fact there could be a larger book, that is about Banham's America, that ends up being about cultural history in the United States in a certain period, that would look at what America constituted for him, but that's not the point. For me, Banham would figure in this book some essence in the way that he looks into American landscape and found value in it, as something to be investigated, both critically and historically, at the same time. And not just in the terms of an archeology of modernism, although that's a part of it, but I think it is something that can be taken in its own terms.

Still on Architecture and Autopia, you mention the examination the ways in which architects, writers and critics explore the topic of road sprawling and car culture. Do you see value in investigating such foreign, literary works, such as fiction, to describe landscapes in America?

I think that, weather it is "foreign" or just an outsider perspective, there is value because quite often it points towards something that otherwise would fall under the radar. I think Banham did that successfully, as a Brit coming to America, as an architecture historian looking at everyday landscapes, and as architectural historian looking at Los Angeles, for instance. It's a privileged position, to be able to notice something that others would not notice. It also allows you to overlook things, as many of the critics who would take exceptions, Banham would say "it's fine to love Los Angeles, but I never had to live here" or it's fine to romanticize a traffic jam, but not when you have to deal with it every single day. And yet he certainly gave us the ability to look at Los Angeles seriously. And all you could do is look at the school of Michael Dear and Mike Davis: they all kind of created a geography, and when they talk about Los Angeles they point to Banham as being almost like a godfather, somebody who said: "ok, this is serious work", and again, this sort of outsider perspective is essential. And for me it is so different that his perspective as an outsider versus, say, Venturi 
/ Scott-Brown perspective. For them it was essential to maintain critical distance, as they would say "we are looking down, we are not refusing our elite position, we are in fact embracing it" whereas Banham wasn't interested in that elite position, he was just reveling on everything that he saw, what again doesn't exactly make him a populist, but it certainly makes him an enthusiast. There was the difference: he was genuine in his enthusiasm.

And he was pretty much criticized by that...

Absolutely. But also I think it has to do with these polemics of intellectuals. That's where he makes Frampton uncomfortable. But them Frampton is also British. I am American, I don't have a problem with America. I mean, I can problematize it, but I don't feel that I have to defend or rationalize why I write about commercial landscapes, whereas within the academy, even in the $21^{\text {st }}$ Century there is still an elitist, high-style, Eurocentric bias. And there must be a lot of people who think I should defend or rationalize what I research, I don't know.

You have mentioned in your article for the Design Observer about the genius loci of America as captured by Banham. Could you describe what, in your understanding, was Banham's view of the American built environment and its idiosyncrasies?

I think he was interested in multiple examples, there wasn't actually just one. How could it be otherwise, in such an enormous place? But I think he was particularly interested in that he could never get beyond the fact that he had an Eurocentric bias. He really wanted to understand what was the meaning of space in "this place, at this moment". I can't help but think that J. B. Jackson is a real influence there, because you see a shift in Banham's work from this kind of distant understanding of the United States to suddenly being in the place. Weather the place is the Desert, or the Los Angeles freeway, or a strip-mall.

He doesn't mention J. B. Jackson at all in his texts, does he?

No, not at all, but who does he mention? That's the other thing...

He does mention Anton Wagner's work in Los Angeles. And Esther McCoy, also.

Yes, but he mentions it as a "good historian". But as for Esther McCoy, for me there was a duty of a historian, to mention these kind of sources. In Los Angeles acknowledges he mentions the work that has been done, but not the ones who have influenced him. This things written about McCoy, which he is very generous about the fact that she was the one who started to take Los Angeles architecture seriously, and made it possible 
for folks to follow her footsteps, but it is different then arguing two things: one is subject-matter, and the other is methodology. So he can be generous about those who influenced his subject-matter, but he is more quiet about his other sources. It's probably a generation thing. My generation, because we were trained in historiography, and instead of method courses we had historiography, we are really more comfortable with historiography. There has been an explosion of publications dealing with historiography, and studying the production of history as an important aspect of Modernism. So we are more comfortable doing that. And who knows? How would he describe the influence of Jackson? For me, the simple fact that he wrote for landscapes is essential. It's funny because I went to New Mexico, in the Jackson archives, and investigated his unfinished book, that was to be about roads, and going through that, the notes, manuscripts and stuff, I would think "what Banham would have find?" It seems that it could be an interesting conversation, an ongoing conversation about the significance of the road and the highway as a defining landscape. The difference of course is that Banham is fascinated by the road as an environment, but he is also interested in the architecture, as an architectural historian, whereas Jackson is not. For Jackson the house is simply an embodiment of culture, for Banham it is a thing in itself, that's an important distinction. And to go back to the notion ot Genius Loci, Banham was interested in exploring that in as many ways he could possibly do it. What does a building tell us? What does a car tell us? What does a sign tell us? All of those thing were contributing factors to the nature of the place. I think his hability to hold all of those balls at the same time. It's certainly where lies the power of the Los Angeles book. The ecologies for him, where the place, that's why they are not simply an ecology in a natural landscape. They were cultural ecologies. His usage of that word was clearly of the Zeitgeist, because it was a word that was in use at the time. So he made it sexy...

But wasn't at the same time a mockery?

I wonder tough: was it a mockery, or was it an extension? Saying "hey, you got an ecology, I got an ecology too." Because I don't see Banham as cynical, so I wouldn't see his use of ecology as mockery. Yes, maybe he was kind of poking a little bit those he saw as far too serious. Specially East Coast, he loved making fun of East Coast liberals. But I also think it is a more enthusiastic notion of defining a place, and a more universal way of defining a place.

Still about your article, you focus much of the reading of Banham on one of his least studyied yet interesting books, Scenes of America Deserta. What are the reasons for your choice, and why do you believe that book has not yet got much attention from foreign scholars? In Brazil, for example, Banham is vastly known only as the author of Theory And Design in The First Machine Age. 
It is his strangest book, the one that doesn't fit in any category. It's not a historical study, not strictly travel writing, it's not about one place. It's very personal. It would have made an excellent blog. It was not published by an academy publisher. You have an MIT edition, but initially it wasn't published by MIT, it was published by somebody, whatever. So I think for all those reasons, it was just ignored. It didn't fit comfortably into any of these categories. So that's one reason. I chose to focus on it because it affected me profoundly. I was reading it while traveling in the desert. You see, I knew Banham's work, and I only stumbled upon it, because nobody ever talked about it. I was trying to find something else, and there is a site called Abebooks, that aggregates all these bookstores, and often I research there, because there's these obscure books which you never heard about, so there was when I first met him. "What book is this?" We didn't have it in our library, so I bought it sight on scene, and read it in one time. The original edition is so peculiar, I should show you the cover, it looks like a $19^{\text {th }}$ Century album that you would put photographs on. This is so sexy and slick [pulling up the 1990 MIT Press copy] I noticed it's cataloged under travel literature, but this is a total repackaging. The original packaging is so of its moment...

\section{Its like Charles Doughty's...}

Yeah, absolutely, and it was meant to evoke that. So those were the obvious reasons why it was overlooked. Also because he writes about places that at the end of the day are still in the unknown. You have to be a desert freak, you need to be someone who is interested in driving out of Los Angeles, out of Las Vegas, and exploring this back-end of America. It's hard to get through it, and yet, one of the things he ends up revealing is... even though a lot of the landscapes that he describes have been pulled into the National Park system, so they are national monuments, or just preserved, and you can pick up those beautiful brochures that can describe them, etc, etc... but without this book, I think I would have miss a lot. I am still interested in driving into the desert just because of what Banham described as a desert freak, although I wouldn't consider myself one, like in the terms of the book, but this is the closest that he comes to obsess fully describe an American place. He keeps going back and back again and again. Because it's the most distinctive for him, it's the most distant landscape from the "New England Village", which is far more familiar to him. It's slightly different, but it follows the same predicates. The desert is something else.

\section{Perhaps entirely American?}

Yes. I mean for his point of view it certainly is. And so that's why he is so interested in exploring it in the context of the "Arabian Desert" because it when you have a "Laurence of Arabia" image of the desert, and that was certainly my case. I didn't go 
to the middle-east until I was an adult, so my first-hand experience of that desert came only from images, so when I came to experience the American desert, it didn't looked like the desert, because I thought the desert looked like that childhood image. Even though there are lots of examples of that kind of desert in Colorado and New Mexico, in most cases it looks like this [pointing on the picture of the Soda Lake canyon and Reyner Banham. And it got mountains, and trees, canyons, and all these different scenes. It also has a lot to do with one's understanding not so much about American geography, but American geology inside there. I think part of what he comes up with the book is how all this comes together to a single understanding and a place, which is essential. It's one of those things: the United States are so big there are so many different ecologies, if you will, both naturally and culturally. And they are bound. Until you get on the other side of the Mississippi, and the other side of the Mid-West, and drive through the desert, you just cannot understand the peculiarities of that place. And I think because of its distinctiveness within American cultural landscape he found it so fascinating. Not only that, but it was the way in which though millions of years, humans had attempted to transform it, and he is putting it as always unsuccessfully. They would live their mark, and then it would be abandoned. They would create ruins.

\section{Modern ruins?}

Yes. And it would have been interesting if Banham had gone to Detroit in the 90's. It would have been interesting to see what he would think about our contemporary obsession with modern ruins, and I think he would the skeptical the way we romanticize all those ruins. And you get to that when he's driving through Bayonne. Or he doesn't actually see them as ruins yet. In fact it wasn't, right? Even the factories, even though they were not occupied the way they once were, clearly he was not romanticizing them as ruins. He sees them as artifacts that need to be interpreted because they hold keys to a certain place and a certain time.

What would you say particularly about Banham's contribution to American history of architecture? Unlike his compatriots, such as Kenneth Frampton and Anthony Vidler, a large part of Banham's research and debate field was staged in the West Coast. What in this milieu could have lured Banham? Which differences between East and West Coast architecture schools are key to understand the academic insertion of Reyner Banham?

It's interesting though, because in terms of architecture schools, to be sure, Banham wasn't teaching in an architecture school in Santa Cruz. He was teaching in the art history department. And the position he was to take in the Institute of Fine Arts here was again in the Art History Department. It was only in Buffalo that he is really in an architectural school. And at that moment he is in the milieu of Cornell, and one can't help but wonder if his almost aggressive interest in Grain Elevators and Day-Light 
factories is in opposition to Colin Rowe's formalism. I don't recall exactly the dates and all of that, but it must be something of that there. Even though there is a kind of preexisting impulse in Banham's work, that it was sort of inevitable that Banham was looking at those artifacts. But I don't know if I would really see an East-Coast / West-Coast subject. Banham's work on the west coast was funded by the Graham. They financed him to go to the West Coast. It was not an academic position. You know, he was from a different generation, whereas Rowe and Banham were such a subject matter. And Frampton is older than Vidler... I would see Frampton pretty much uninspired by Rowe's approach... Frampton is not a populist. Vidler is not a populist. It's just accidental that... wait, what are all this Brits doing here? Why is America so interesting? [laughs] I mean, it is a funny thing. There is a real difference. We already touched upon this, is that kind of Eurocentric purview, and a distrust and a distaste with anything that touches upon a kind of populist purview. I think it runs through all of their work. Unless of course it is distant. Its fine for Vidler to write about the messianic traditions and their influence on enlightenment in architecture because there is the safe critical distance. I have to go back and re-read the Banham chapter in Vidler's book on historians, but he tends not to explore what we call as "populist interests".

I read the book in search of a connection on British migration but what I came up with less than a cohesive, regardless of the role of Colin Rowe, along with Eisenman to bring the other Brits to America. When you see the rejection by Peter Eisenman of Banham's view so strongly...

But again, how much of that is his about own intellectual trajectory? When Eisenman was much younger, when he first gets on the board of the Architectural League here in New York he actually defends a populist viewpoint. When there was great controversy, when the league was showing the works of Morris Lapidus the old guard was furious about it. "Why we seem to be validating the work of this populist hack?" as far as they were concern. And Eisenman was saying "why would we not put this show on? We need to investigate all the aspects and implications of architecture as to be practiced at this moment time. It is for sure the last person you would have thought to come out in defense of an exhibition of Morris Lapidus. But again it has to do with Eisenman's America. And maybe in some ways he is more comfortable with an exploration of everything. It's like his obsession with football. He can be an intellectual and also be obsessed with American football, that's ok. Those two things are not mutually exclusive. Eisenman likes to come across as an everyday guy, despite the fact that he is also an intellectual working in an extremely dense point of apprehension. For people who are still working it is difficult to pin them down and tell what their work is. It is easier when the work is now done and you can begin to assess it. Except in Frampton's case, he always had a discomfort with what he sees as "The" popular. 
When I brought this subject of modern vernaculars, Frampton was so resistant to that idea, perhaps because of the fact that he comes from a rural landscape in England, and for him vernacular is a counterpoint for the metropolis.

And I would argue that this is entirely wrong. My first book was about exploring how modern vernaculars could in fact be constituted. Suddenly, in the industrialized society the vernacular would cease existing? That's absurd. It's just that it transforms itself. I think Banham understood that in some way. Even though he didn't pulled architecture into that, Banham understood that the products of mass production were there. It's not that he couldn't get around to that. Its because for him "design"... And this is another problem I have with the Whiteley's book and a lot of people who think they can separate Banham's writings on design from his writing on architecture. I think it is a real problem. We do that at our peril, in terms of any kind of criticism. But it's not surprising for me that Frampton would reject that, because of his problematic approach to critical regionalism: it is predicated on this notion of the vernacular that is not modernized, and not industrial. That somehow, regionalism itself taps into some other notion of authenticity, that is entitled to a pre-industrialized place. It's the way he ends being just as elitist as the next guy. Any intellectual project can be structured as elitist, but I think Banham would have understood a notion of a modern vernacular that embrace architecture. Well, that's where he's getting at, in chapters of the Los Angeles book that looks at this other architecture. Doesn't matter if he does not describe it as 'architecture' in the same way as the Case Study program. I think he was beginning to understand that.

Banham has been historically misunderstood as a prisoner of the first machine age and its idiosyncrasies, and the enthusiasm towards technology. Even Anthony Vidler, while evoking Banham's inventiveness an ingenuity as a writer, rejects this assertive, nor Nigel Whiteley, Banham most competent biographer, as he depicts Banham as an "historian of the future" - a rather anecdotal character - he induces to reinforce that same image. Do you agree with them?

I think I partially agree, but I wouldn't say 'prisoner', maybe 'volunteer prisoner'. I think in some ways it was inescapable that his enthusiasms and optimisms, particularly about technology, the promises of Modernism and the promises of modernization would get in the way of his critical faculties. But that's inevitable, right? We all have preconceptions and biases that influence the way we see the world. It is easy for us now, with wide sight to see what was problematic about his blind enthusiastic appraise of technology. I think probably it was less easy to see it forty years ago, or fifty. So I would say I agree with them to an extent, but I don't see it as problematic as they do. I don't think it puts limits for what we can learn from him. I don't think it devalues his importance. Corbusier and Wright misinterpreted the value of the automobile, and I don't see anyone saying that we should disregard them, just because they were too 
optimistic about that. It's the same thing. The car for Corbusier and Wright was like technology in general for Banham. You have to take it in its context. 
